
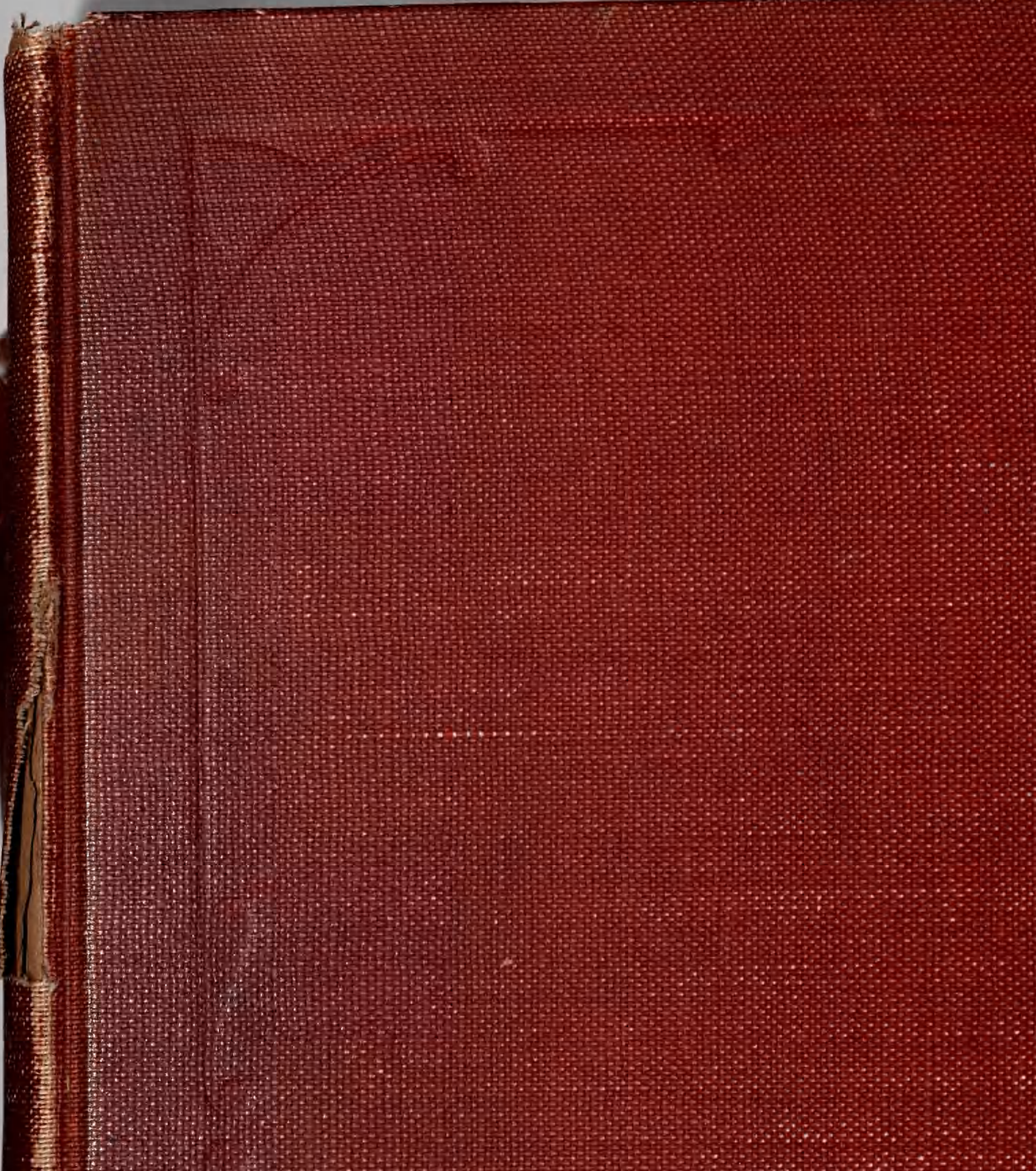

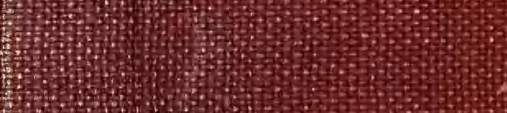

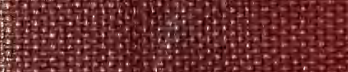


FOR THE PEOPLE FOR EDVCATION FOR SCIENCE

\section{LIBRARY}

of

THE AMERICAN MUSEUM

of

NATURAL HISTORY

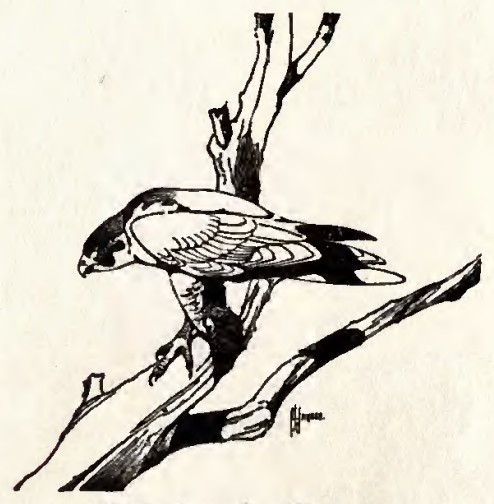

LIBRARY DEPARTMENT OF BIRDS $\cdot A \cdot M \cdot N \cdot H \cdot$ 
$k-2$ 




WHITNEY SOUTH SEA EXPEDITION

$59.82(9)$

of

THE AILUICAN MUSEUN OF MATURAL HISTORY

Extracts from the Journal of

ROLIO H. BECK

$$
\text { wot I. Sent } 1920 \text {. June } 1923
$$


September 14, 1920.

Left San Francisco with Mrs. Beck and E. H. Quayle for Papeete, Pahiti, to collect for American Muserm of Natura.I History. Few Sooty Shearwaters few miles out; 3 phalaropes seen in the afternoon, also 2 terns and 3 blacifooted albatrosses. Fogey inshore but clearing, and clear outside.

\section{September 15}

Nice weather, Iight wind 32-51 I, 125-17 $\mathrm{W}$. Quayle saw 2 terns and 2 blue herons; I noted 2 blackfooted albatrosses.

\section{September 16}

$27-49 \mathrm{~N}, 128-13 \mathrm{~W}$. Single blackfoot gooney seen.

\section{September 17}

22-39 N, 130-38 W. A shore bird, surf bird probably, flew about steamer few mimutes in forenoon. 


\section{$\ldots-$}

\section{- ose 1 a redinester}

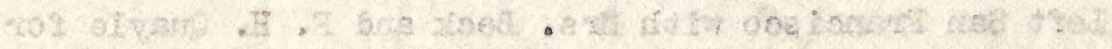

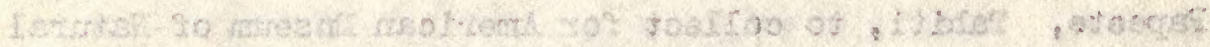

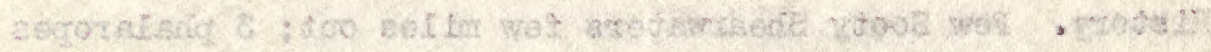

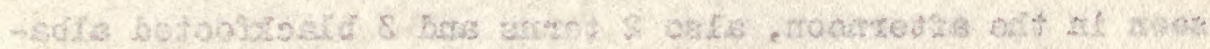

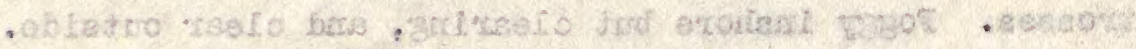

\section{Be sudhostree?}

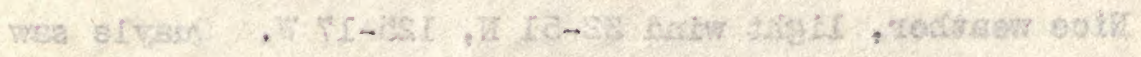

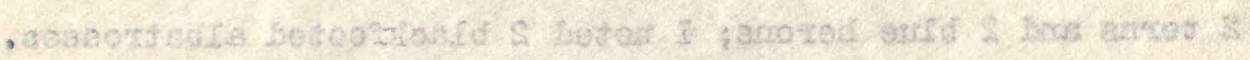

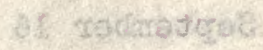

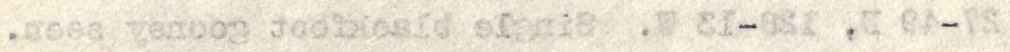

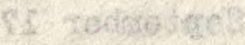

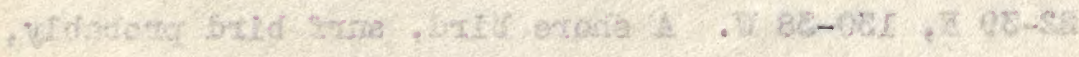

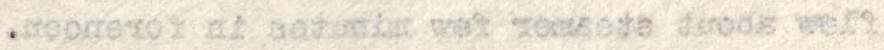


 \\ September 18}

17-28 N, 133-14 W. Six red-billed tropic-birds and few aestrelatas size of phaeopygia, 1 light-backed and others dark-backod; flying-fish plenty.

\section{Soptembor 19}

12-22 N, 133-4I W. Two small black petrels trifle larger -- Wilsons? Half dozen dark-backed, medium sized, whitebreasted aestrelatas seen.

\section{September 20}

Three or four dark-breasted cuneatus (?) seen. Birds salled along close to water, occasionally flapping wings. Few white-breasted aestrelata, two tropics and a half dozen frigate birds,--one tropic on the water. Heavy rain at 8 o'clock. Iight breeze from south-east in P. M.

\section{September 21}

Sma1l grayish Aestrelata seen at long distance, half a dozen seen. Strong breeze from south-east all day.

\section{September 22}

$2-37 \mathrm{~S}, 142-59 \mathrm{~W}$. Not a bird noted all day. Good breeze. 


\section{6. mox methes}

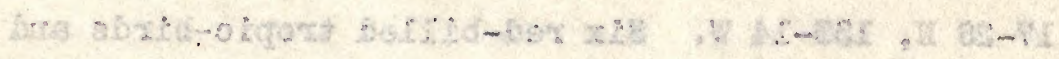

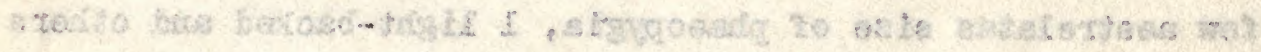

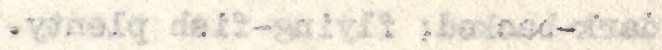

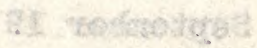

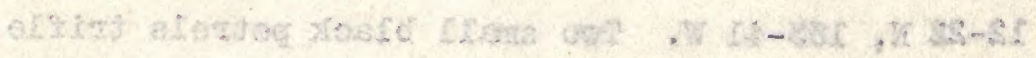

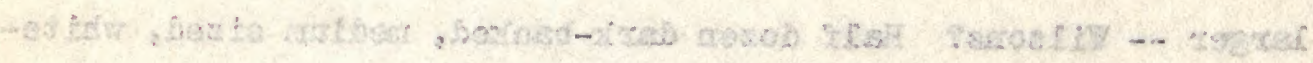

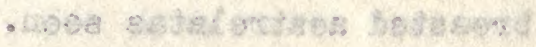

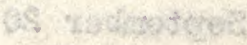

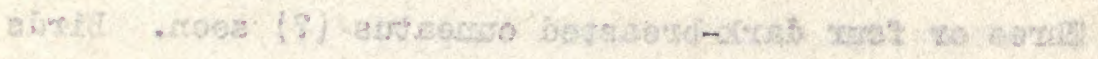

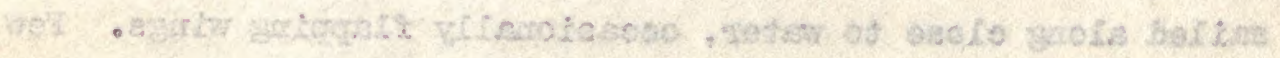

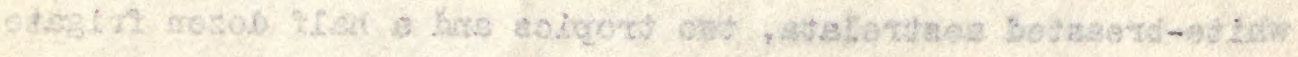

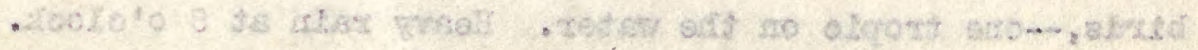

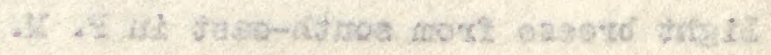

\section{so soving thos}

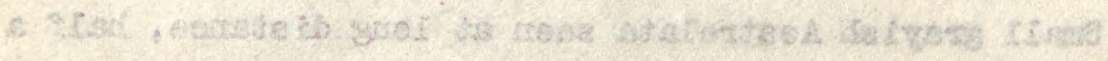

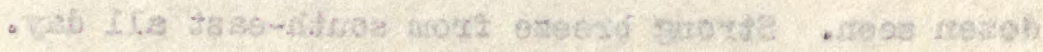

\section{Ste rachetigef}

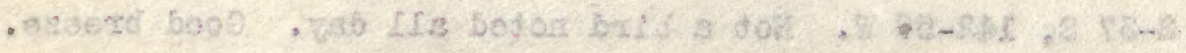


September 23

7-59 S, 145-8 W. Good breeze all day. Couple grayback aestrelata and couple sooty terms seen.

September 24

No birds noted.

\section{September 25}

Reached Papeete 9 A. M. Passed Tetuaroa Island after daylight; no birds seen till entering Papeete when a single tropic-bird was seen in distance.

\section{September 26}

In Papeete minah birds are common about the town like English sparrows in cal. towns; they light on tables in hotel. Fights between pairs of blrds are common on the ground. Two birds grab each other's feet and hold on. One usually lies on its back and the other sits on its own tail, keeping upright by holding to other's feet or legs.

\section{September 27}

Three or four gygis terms fly over town or high in air toward hills; a pair of them lit in tree close by Governor's residence. A pair of wandering tatlers and a reef heron seen 


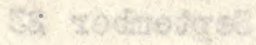

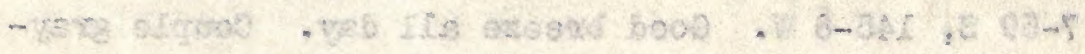

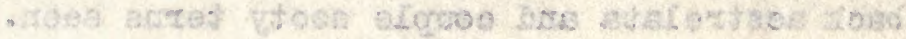

AS recireduge

- bejog anis iv of

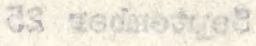

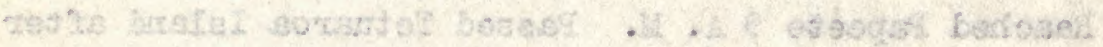

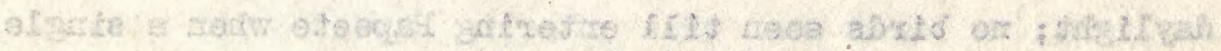

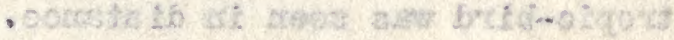

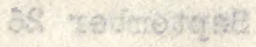

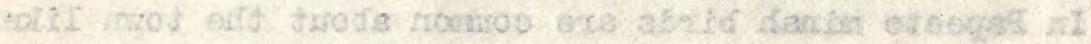

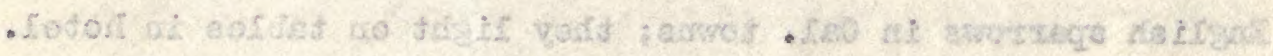

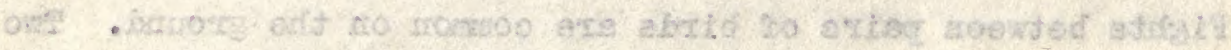

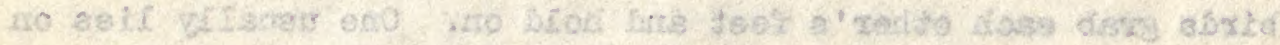

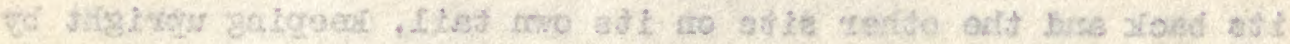

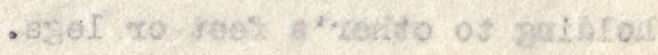

\section{TS sechastices:}

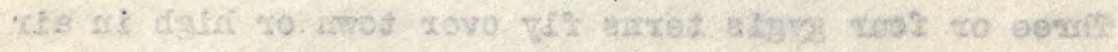

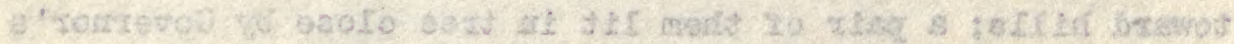

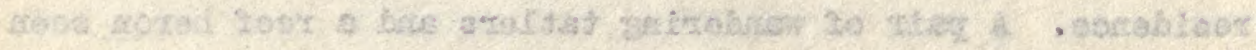


a few handred yards from mouth of Papenoo river. Several small flocks of weaver birds seen along road to Papenoo. Minahs often call like blue-fronted jays.

\section{October 2}

Waiting shooting permits. Quayle went to Fau-Taa water-fall and saw tropic-bird fly to nest on cliff. Also saw two kingfishers, two swifts (?) and wandering tatlers. I saw a reef heron fly along water front and light near consul's home. Hinahs building nest under eaves of house in town.

\section{October 6}

Permits to bear arms and to hunt have been granted to Quayle and myself. Today we went out Mission valley. Minahs were only birds noted along bottom of canyon, being seen principally about cultivated ground, though several were about cattle in a cocomat grove. We spent three hours climbing through brush up onto a ridge that led into the higher part of the 1sland. Two or three tropic-birds were seen in the distance sailing along rocky cliffs or over the canyon. A hawk sailed high overhead calling, but returned to heights farther inland. We were fagged out after getting through the brush, so returned down the ridge to town, seeing only the three species. 


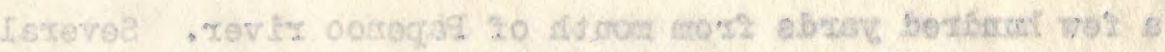

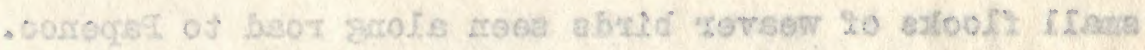

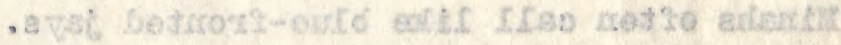

S rovostoo

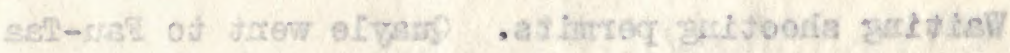

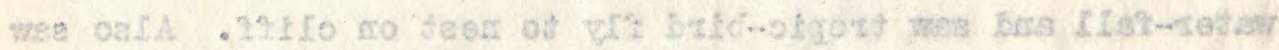

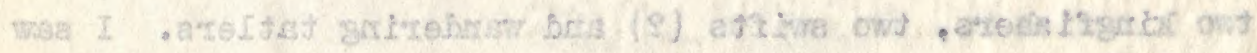

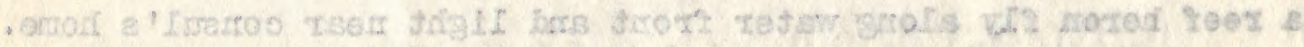

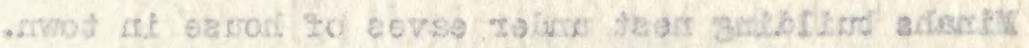

2. rociogol

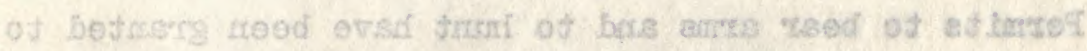

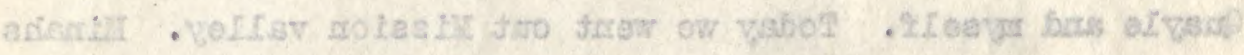

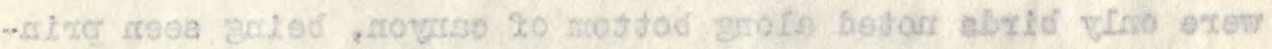

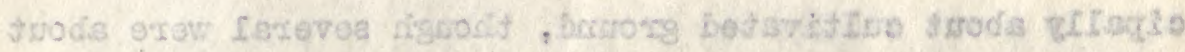

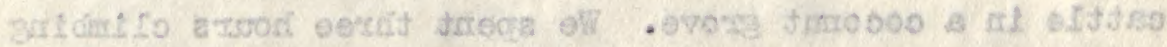

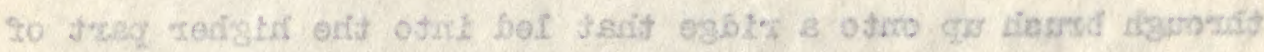

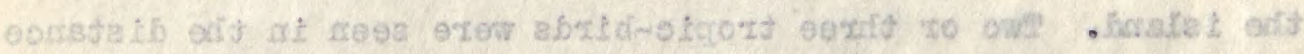

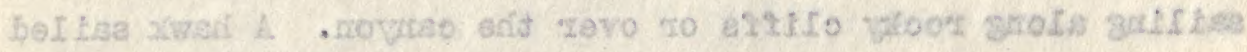

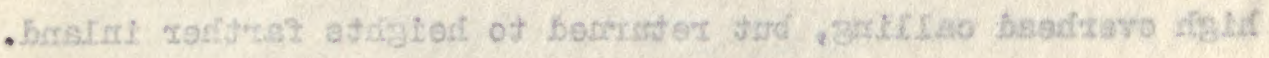

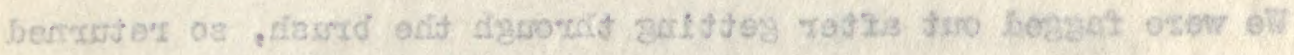

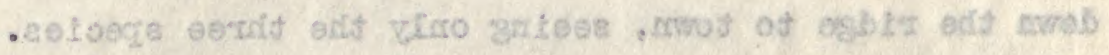




\section{$-5-$ \\ october 7}

Quayle went up same canyon as yesterday, following trail in bottom of canyon up to water, where he secured four kingfishers. I went along road to the west and got a large tern, the only one seen (rectirostris?). It was fishing close to shore. Wandering tatler in worn summer plamage and a reef heron (one of three seen) were secured. Minahs were common and several weaver-birds were seen feeding on seeds of weeds near a house. A pair of gygis terns sometimes fliesalong shore or light in trees near our cottage. Minahs noted nestbuilding under roofs of two houses.

\section{October 8 and 9}

Getting ready to go up the Punaruu river.

\section{October 11}

Left Papeete with outfit and provisions for two weeks and met our two men at mouth of river. They made four packages of the material and tied them to a couple of strong poles. Fach shouldered a pole and we traveled for three hours up the river bed, stopping at $110^{\prime}$ clock for lwnch. After eating wo began climbing up a steop trail rising one thousand feet in a mile. Rain began at noon and continued three hours. Thoroughly soaked 
Y 7060000

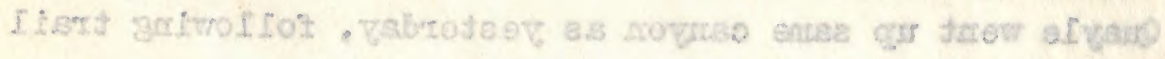

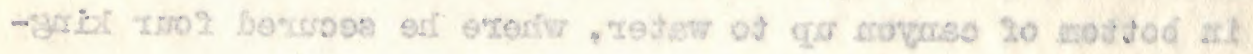

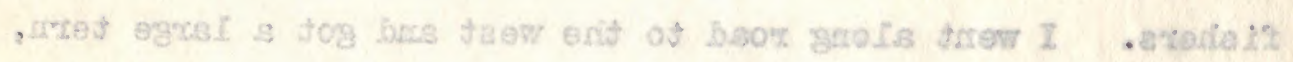

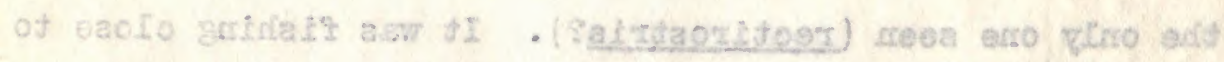

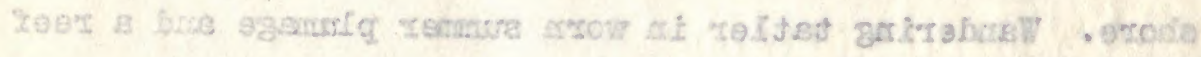

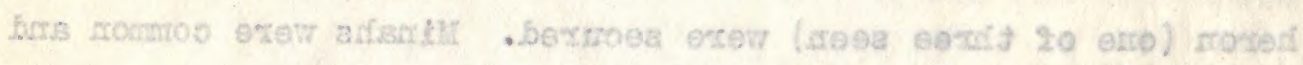

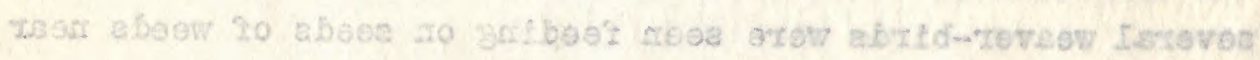

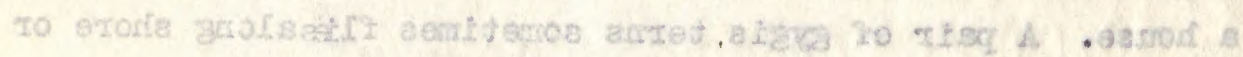

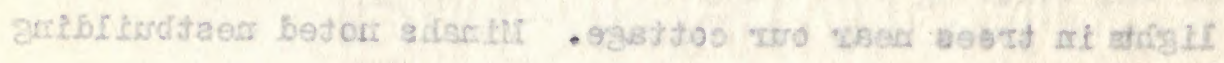

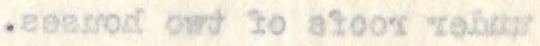

\section{e bess 8 rodoto}

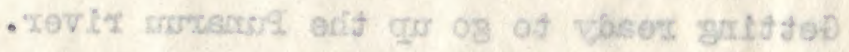

\section{IL. "redoto 0}

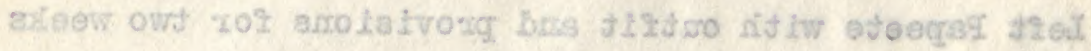

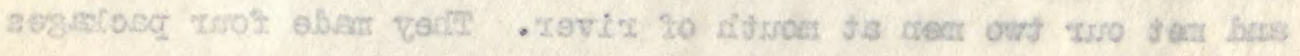

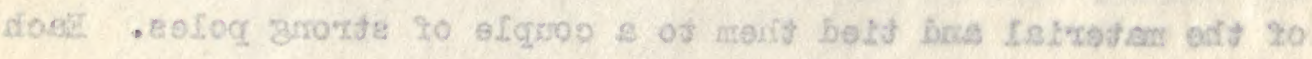

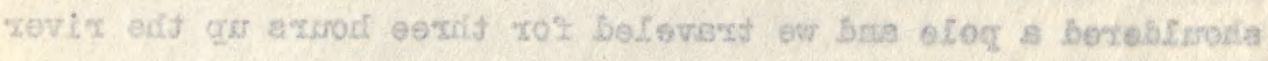

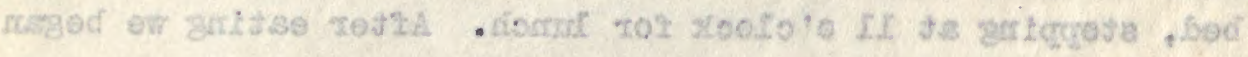

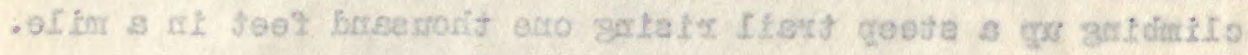

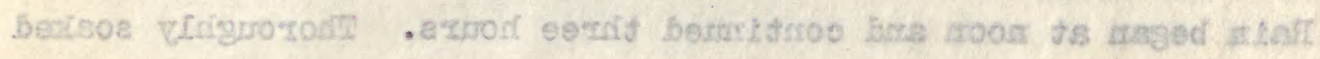


we made camp at 4:30 near a spring and pat up our canvas sheets for a tent. I shot a dove and Quayle shot a swallow and Kingfisher.

\section{October 12}

Sunny, and hounting near camp got three kingfishers. Quayle got three doves with aid of guide who called them. Yesterday passed a depression of three acres with a little water in center and twenty golden plover there. Shot one and rest circled out high and left. Quayle saw three more and shot a swallow over the water (only one seen). Kingfishers call a lot, pairs set together at times; they dart out after insects like flycatchers. Minahs (two to six) in companies about the forest calling and singing. Two or three weaverbirds hoard and seen. Fropic-bird flying along cliff and hawk flew around where I called for small birds. Minahs pay no attention to calls and leave when I call in squealy tones.

\section{October 13}

Out with Tafia, the guide, along base of cliffs where trees are tall. Heard doves calling and secured four. Two or three came when I called to them. Call is a prolonged coo coo to begin and gradually quickons; usually ten or more coos. While eating oranges under a wild orange tree a 


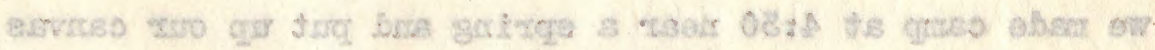

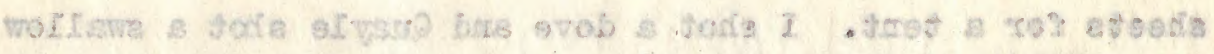

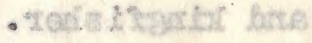

\section{St textojoo}

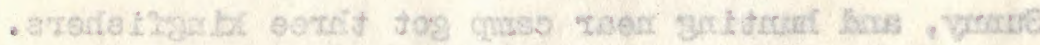

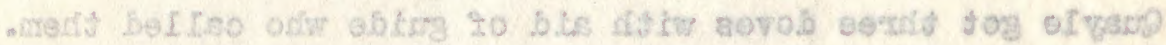

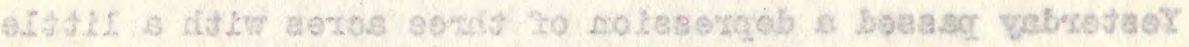

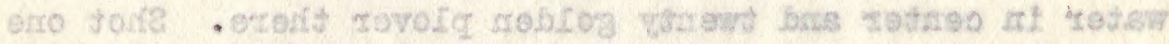

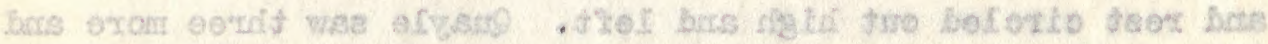

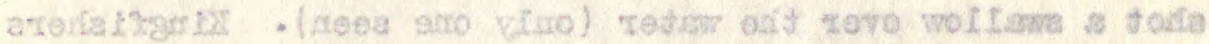

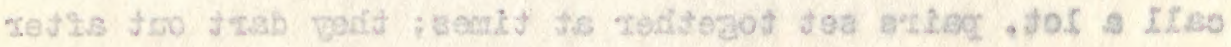

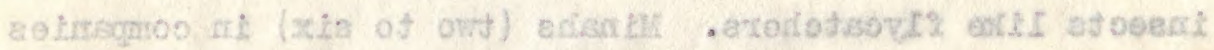

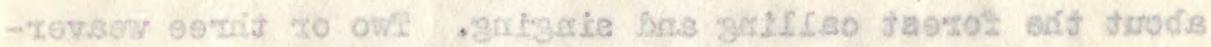

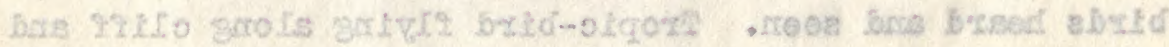

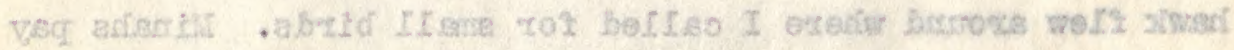

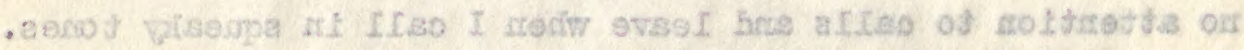

\section{EI redotod}

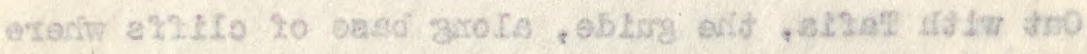

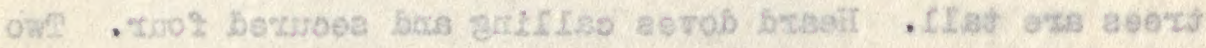

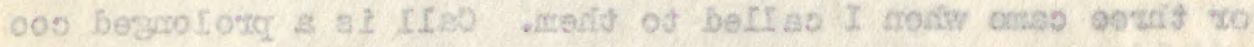

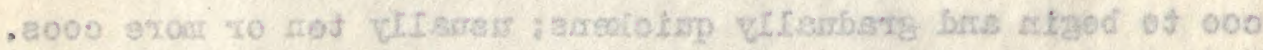

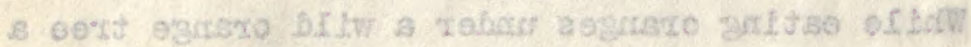


wild pif showed up and I shot her. Tafla built a fire, heated some lava rocks, scraped the hair off on the hot rocks and took it to camp, cooking it there Pahitian style with hot rocks and green leaves. I skinned the birds in the P. M.

\section{October 14}

hain began at daylight and continued till after 3 P. M. Quayle went out with guides in rain. Minahs sing in forest and a lingfisher heard a couple of times,--the only birds heard today. Minahs in town gather in trees and sing like blackbirds just before dark. Gather in prblie market, especially about the butcher shop: while in forest they are wary, flying out of tall trees when noticed by a person. They make many different sounds, being mistakon for other birds. First camp at 1,700 feet.

\section{October 16}

Queyle up trail with guides and returned with three doves and guides with two bunches of faees. In evening Tafia went down to creek in the rain and came back in an hour with two bif eels over two feet long; boys caught a few shrims in the brook just below camp. 


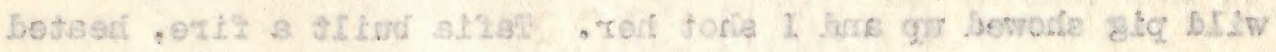

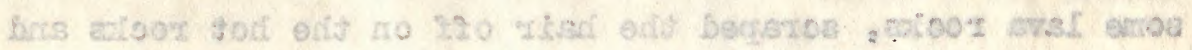

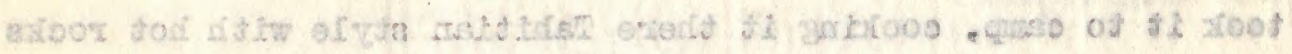

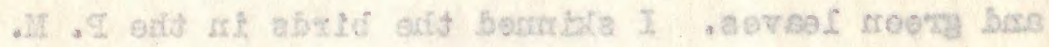

\section{A1 revojod}

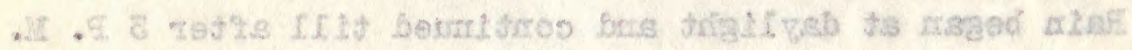

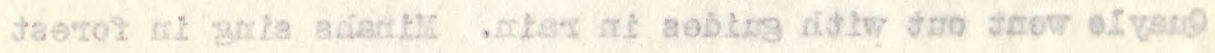

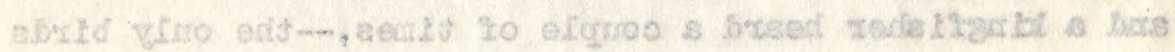

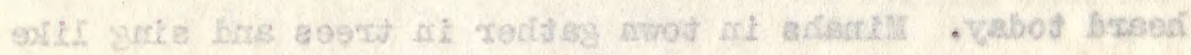

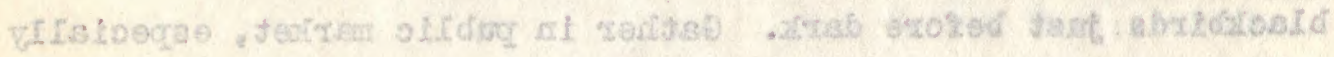

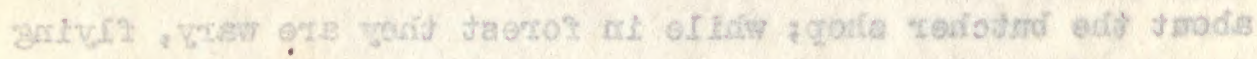

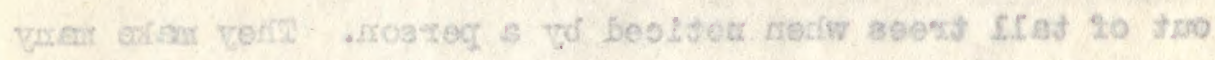

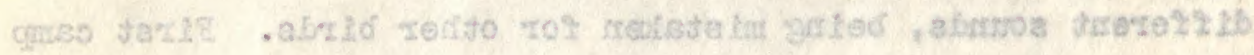
- $5002.007,5$ in

\section{aI sedotop}

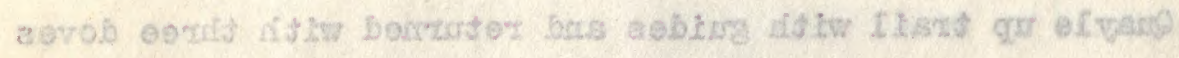

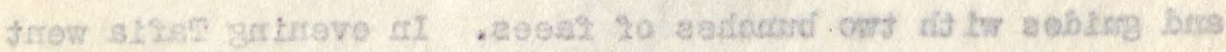

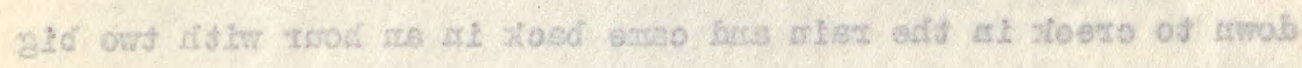

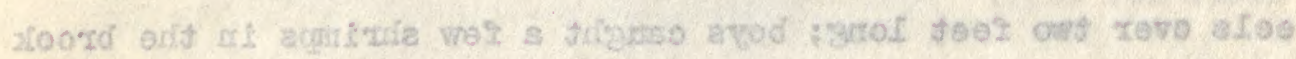




\section{October 17}

sundey. Guides made a fire, heated stones, cleaned, and wrapped the eels in green leeves, pat on hot stones, covered With stones and leaves and left an hour to cook. Fine eating. Rain every day so far. Wost places hard traveling except on trail. Camp 1,200 feet. Pictures of mountains taken at 1,700 feet.

\section{October 18}

Hove camp to $3 / 4$ mile from Diadem which lies east by north. Went up to base of cliffs 2,800 feet, following dangerous pig trail for a mile and saw but one possible shearwater nest which might have been used last year. Pigs may dig out many that nest below cliffs. No birds heard at night.

\section{October 19}

Quayle out with guides to look at other cliffs. I went down trail a couple of miles and heard only minahs, two or three doves, and kingfishers. Finally shot one dove and one kingfisher. Quayle returned at 5:30 having located five or six old shearwater burrows by the cliffs under the Diadem. He worked on cliffs where one guide had to climb a tree to direct movements of Quavle and other guide. At times the two 
Fi. zedotod

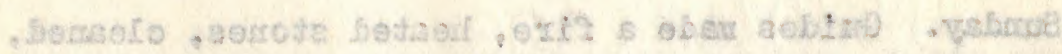

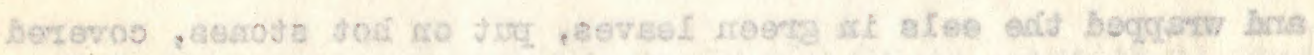

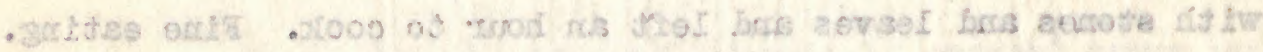

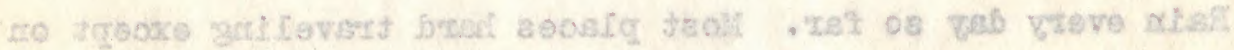

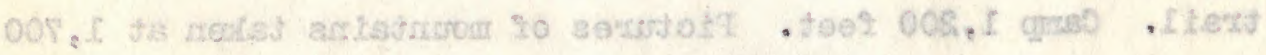

- tees

\section{8. ratiotop}

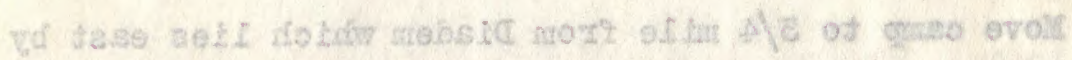

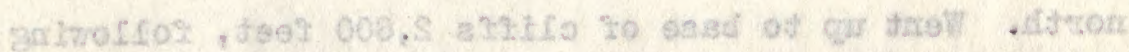

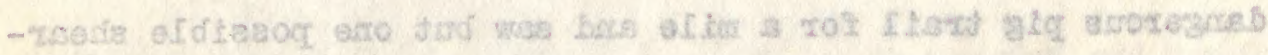

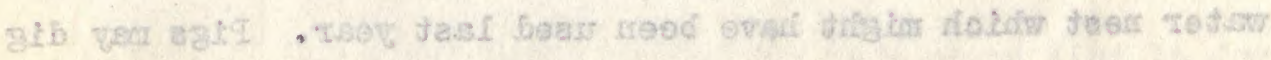

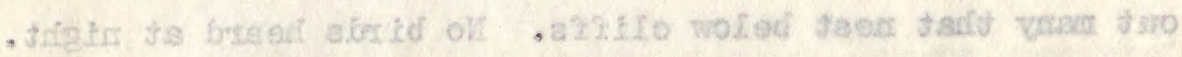

\section{er zodotoo}

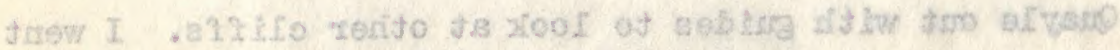

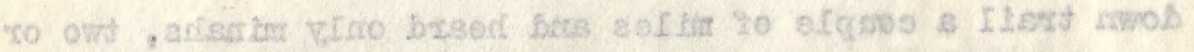

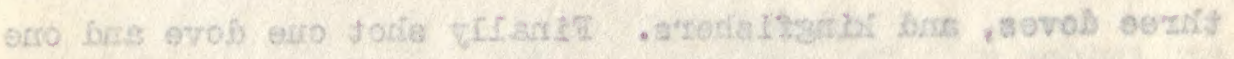

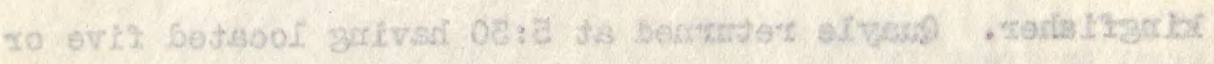

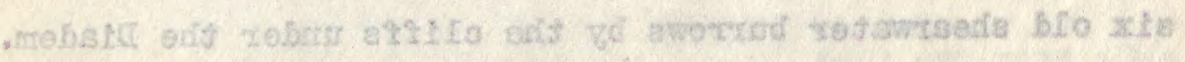

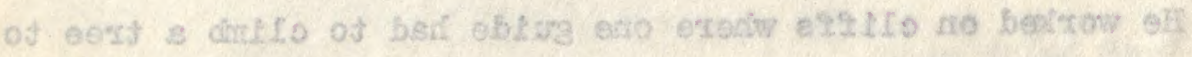

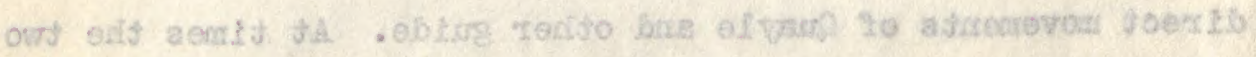


had to use a rope to lower therselves from dangerous cliffs. A rod-bill tropic-bird wes Ilushed from tho nost but spot was unapproachable. The steep mountain tops are surrounded by cliffs and the sides are too steep to climb with safety. The old shearwater nests were dug in the soll on short steep ridges close under the clifis on the mein mountains. The pigs perhaps unoarti quite a few of the birds, but judging by the one nest I saw under a tree root some birds would go too deep for the pigs.

\section{October 20}

Packed up, and, cutting trail, worked across toward head of Punaruu caryon to stop at two o'clock on southeast side of main stream just as rain began. Built a camp in the rain, covering it with largo leaved ferns wich shed water perfectly, though perhaps a heavy downpour would work through. Two swallows flying over and along a ridge were noted and one secured. A hawk was seen and two or three kingfishers heard.

\section{October 21}

Quayle and guide went to top of ridge east of us, reaching 4,000 feet and seeing swallows, kingfishers and doves, while I went up the stream about three miles till going becamo too 


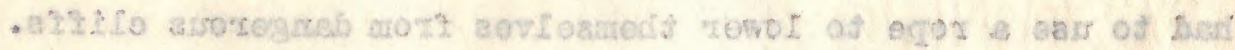

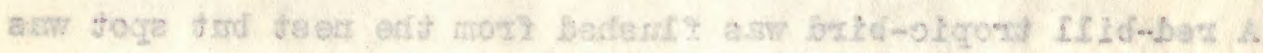

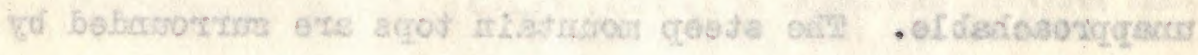

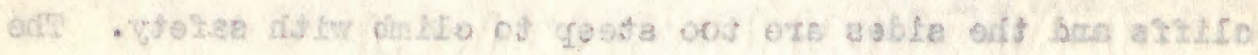

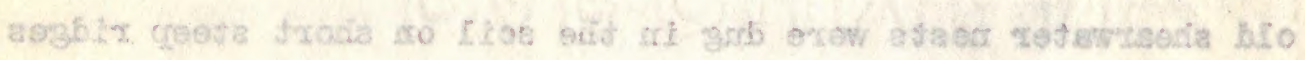

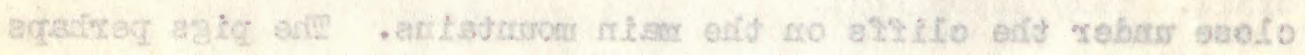

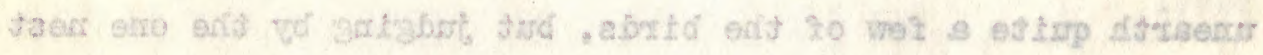

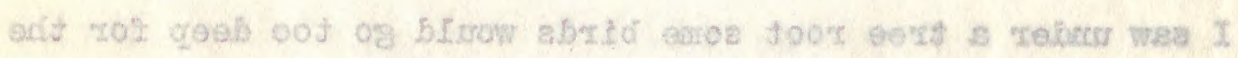
- angles

\section{os rectotod}

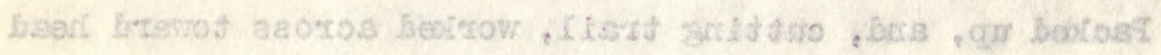

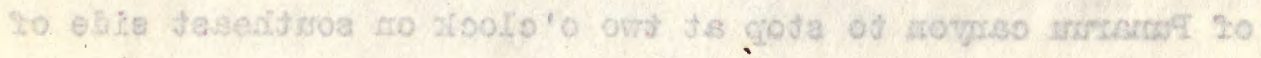

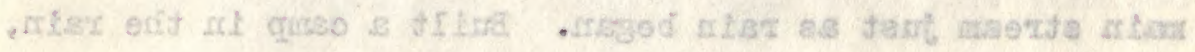

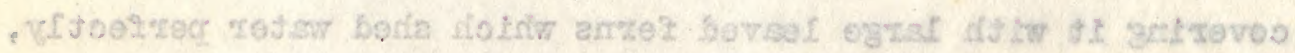

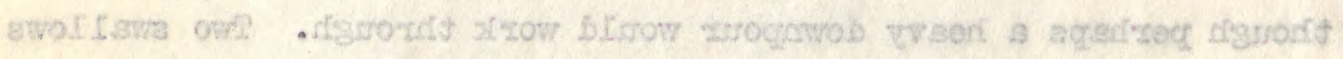

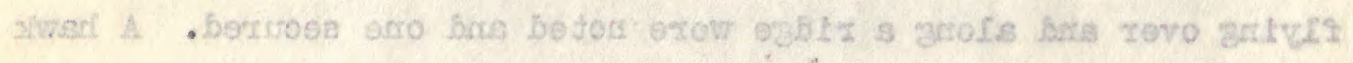

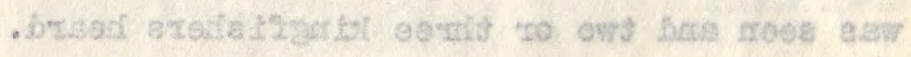

LS redoto0

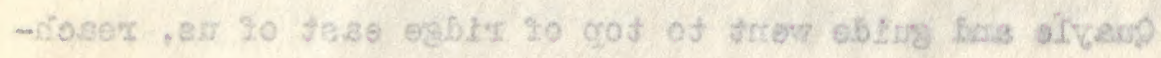

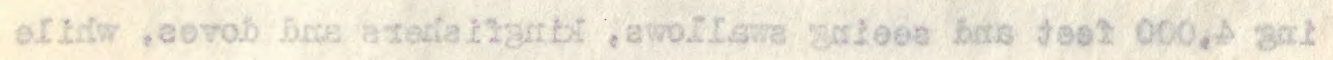

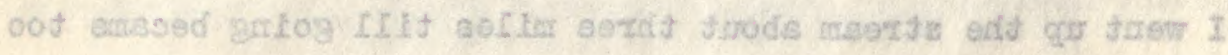


rough. Cliffs and steep, dengerous mountainsides run up in places 4,000 feet to tops of peaks and in ridges. The ridges sometimes have oliffs 20 to 100 feet high on their tops, thus preventing contimous approach to the highest peak. Elevation of last camp 2,300 feet, present one 1,300 feet.

\section{October 22}

A stick ran into my foot through the sandal yesterday P. M. and it is very sore today. I discarded all weight, and with the aid of two sticles made the roadside at mouth of Punarua canyon by fire o'clock in the evening, traveling eight and one-half hours. Reached Papeete at nine P. II . as motor car ran out of gas two miles from town and chauffeur had to walk in to get a can. The trip of twelve days jielded thirtynine birds, which is less than half as many as I heve collected in one day alone at Juan Fernendez Island which lies some hundreds of miles to the eastward of Tahits. The swallow, kingfisher, and dove were the only native birds seen, and they were not plentiful. Minahs were common in the hills, but weaverbirds were fow.

\section{October 24}

Sunday. 


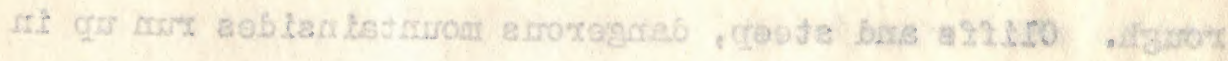

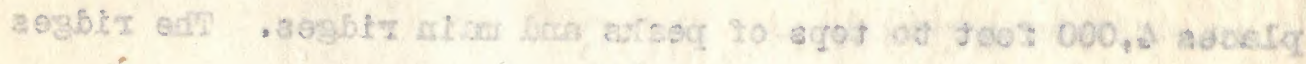

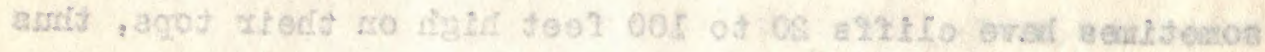

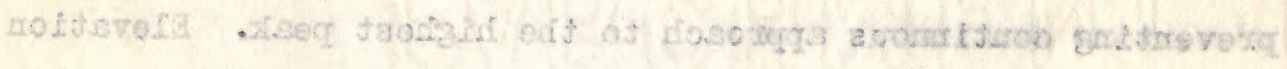

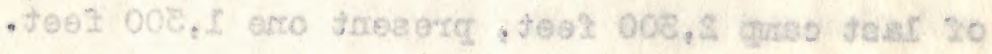

\section{Sas redoto}

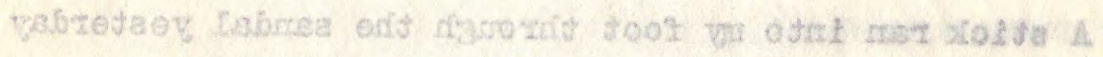

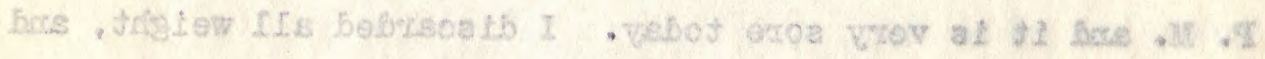

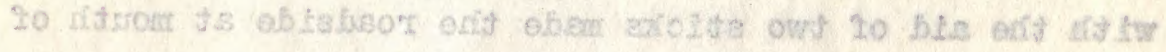

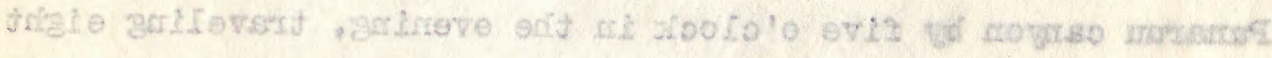

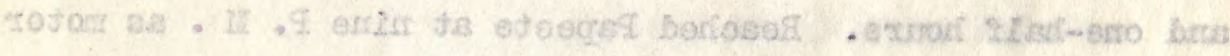

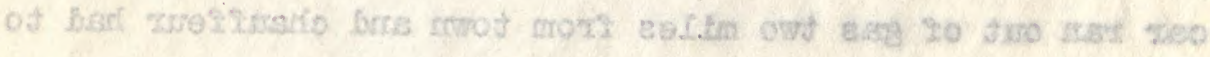

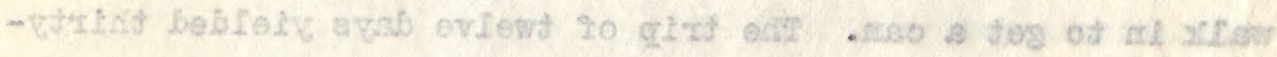

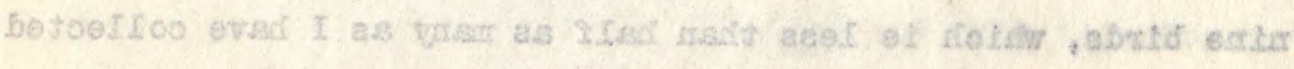

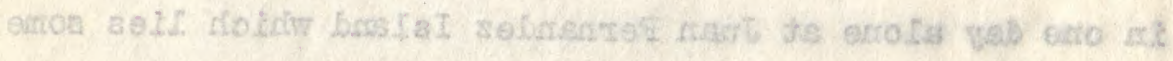

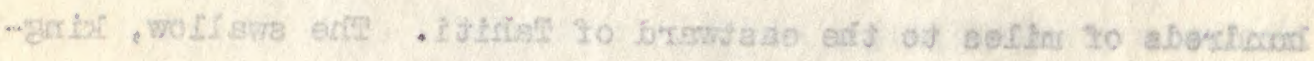

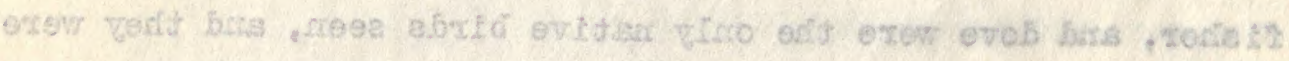

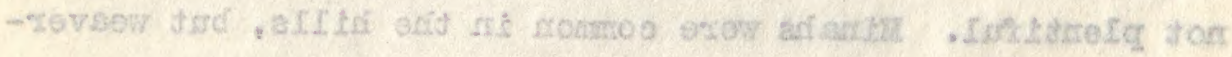
- wot exevi eibukd

AS redote?

- vestersate 
October 25

Quagle left at five A. H. to go up the Faa-Tea creek and returned in evering with a dove and a kingfisher.

\section{october 27}

Quayle stayed out in hills last night and returned with one reef heron, two green herons and a hawk. The latter looks like a marsh hawik and was shot in the bottom of a canyon as it flew over Quayle's head toward the ocean.

\section{October 28}

Quayle went to Pt. Vernus. Stayed all night.

\section{October 29}

Quayle back with two doves.

\section{October 30}

Quayle out on lagoon; back with gygis and yellow-bill terns.

November 1

Quayle to rice fields and got a dozen weaver birds, 2 rinds.

\section{November 2}

Quayle to rice fields and got about fifty wearer-birds, 
U. 1000000

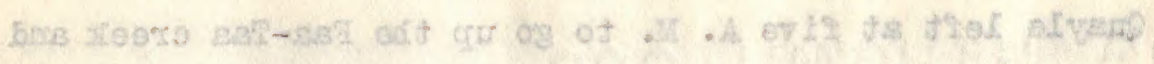

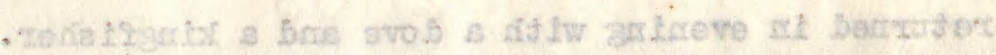

IS secotol

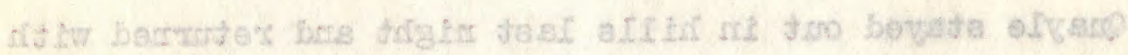

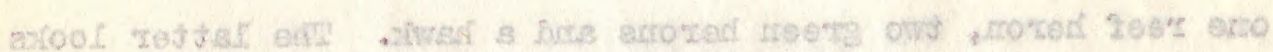

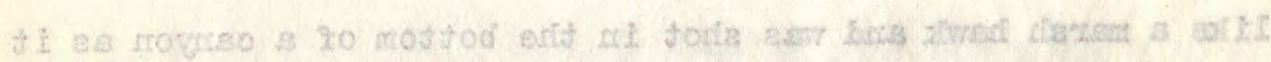

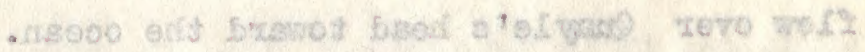

\section{BS zedotsoo}

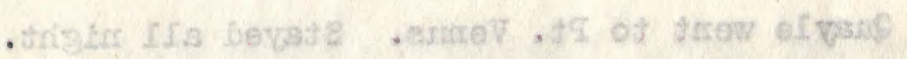

esi modotoo

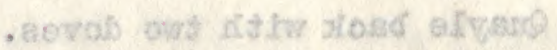

03 rediotal

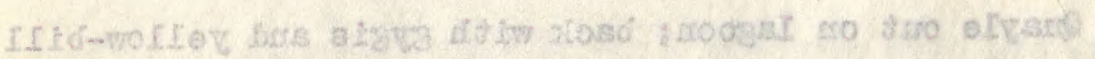

.

I. rocidevoll

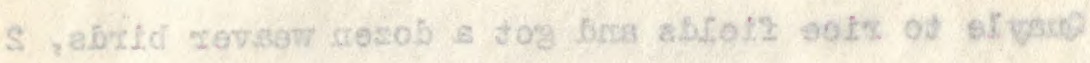

- e barsint

S. zoónovoll

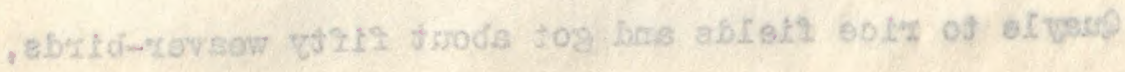


three kinds. I skimned twenty-five of them, the rest being too ripe.

Novomber 3

Quayle along shore, got two terns, three tatlers, and one golden plover.

November $4,5,6$.

Quayle into mountains with guide and found few shearwater nests unoccupied. He heard one bird, he thought.

\section{November 8}

Quayle out to Maaea, shot and sent in to me one dove and eight noddy terns. I sirimned the lot.

\section{November 9 and 10}

Quayle got few noddies; they soem to be nesting by organs. Three gygis terns $f l y$ around cottage here and light in trees over the cottage.

\section{November 11}

Quayle back with several rotten rectirostris terns and a sore knee scratched in crawling through brush while hunting ducks. 


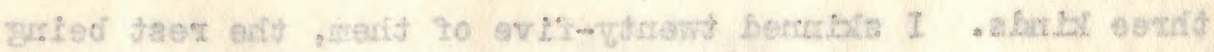
- ox 275004

\section{t5 sodimevolf}

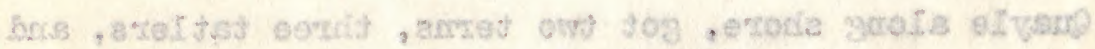
- xevola mobiog ono

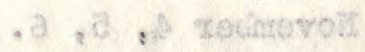

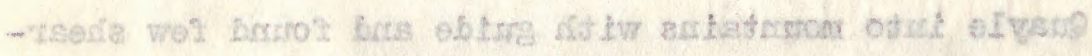

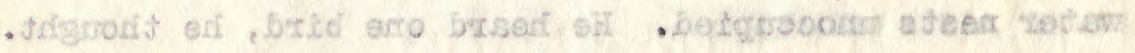

\section{Q rediturati}

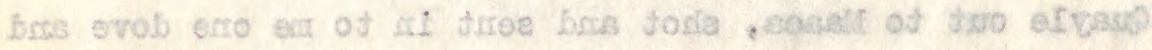

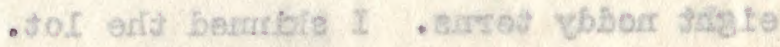

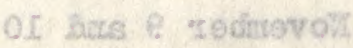

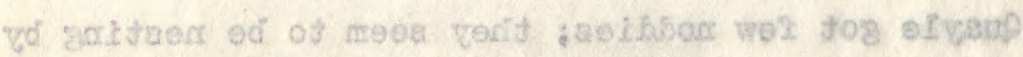

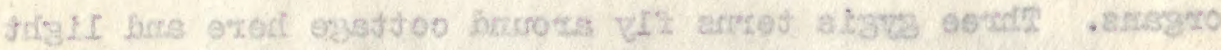

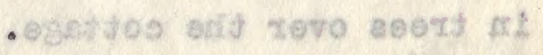

\section{If. sechovoli}

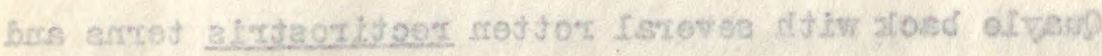

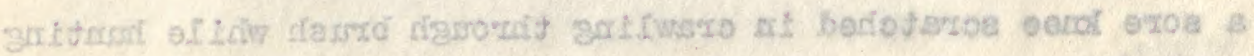
. actorsb 
November 12

Doctor orders Quayle to stay in bed. Why foot still sore.

November 16

I visited Doctor's office, the first time in my life for medical assistance. He cut the sore place open and said to keop off till healed. Quayle still in bed.

\section{Notember 18}

Doctor dressed quayle's knee. A pair of gygis terns seem to be nesting about a block from here, as they often call during day and night,--"Koek, keok, keok!" is the call. Minahs were introduced to combat a large wasp that frequents the houses in town. Though I have watched the minahs getting food for their young have seen no wasps captured, though they were flying about the minains while the latter were hunting small worms in the bark of a tree in front of our house. Have recognized calls of several California birds in singing of minahs. Two or three people have said but one pair of minahs was brought here from seven years ago to over twenty years ago. They are now comnon up to 3,000 feet. The California cuckoo, Galifornia and blue-fronted jays, yellow-breasted chat, and western robin have notes that are duplicates of sounds uttered by the minahs. A peir raised a brood in a coconut tree twenty 


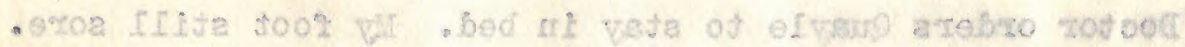

\section{if. socmevoti}

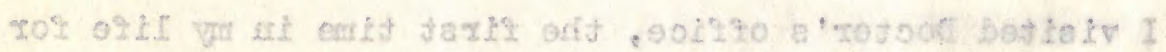

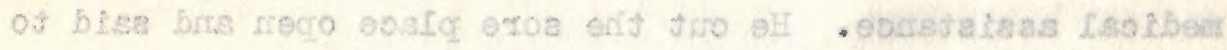

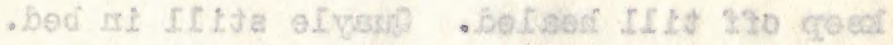

\section{SI 7ecisevoth}

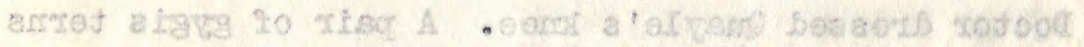

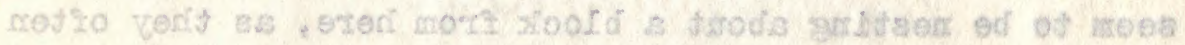

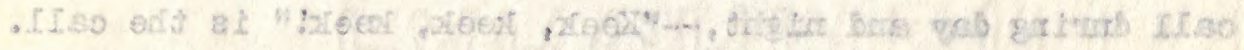

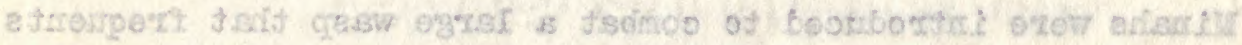

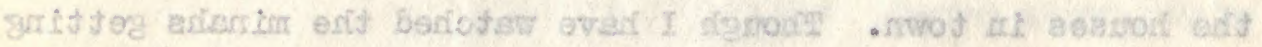

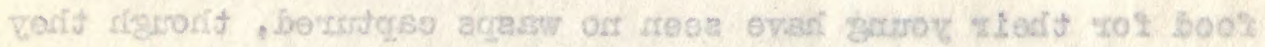

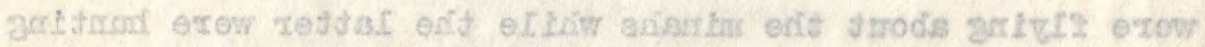

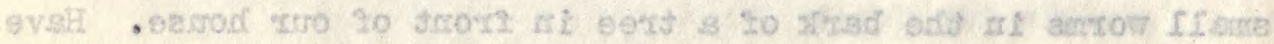

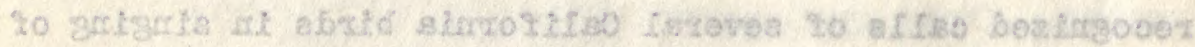

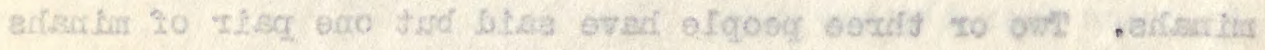

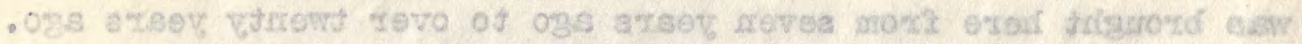

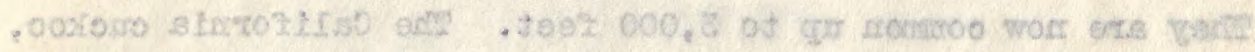

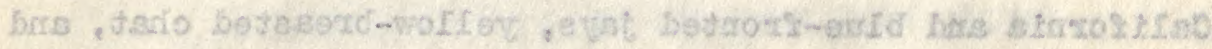

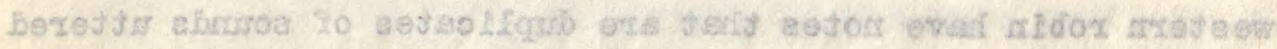

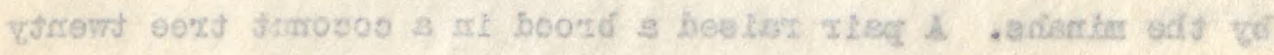


yards from where I am typing this. The young are still following their parents, flying down in our back yard to eat scraps with the noighbors' chickens.

November 23

Quayle out again and got few minahs, reef heron and rectirostris term.

November 24

Quayle shot four tatlers, one with fow sumner feathers in breast.

Hovember 20

Five fresh minah eggss received from Mr. Yerex at Maaea; the nest was under eaves of house roof.

November 30

Quayle went to Papenoo River to $g 0$ into mountains.

\section{December 1}

Quayle sends back letter saying thrushes (warblers), swallows, doves and green herons are present five kilometers from roed. 


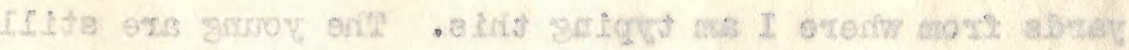

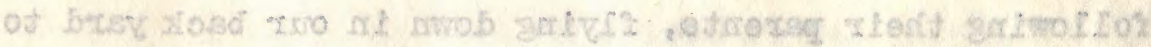

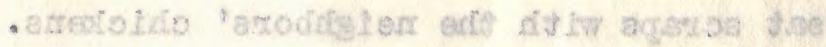

\section{as redrevor}

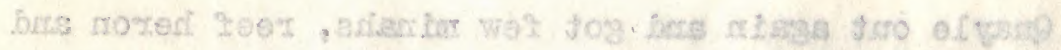

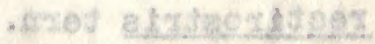

AS redoseyot

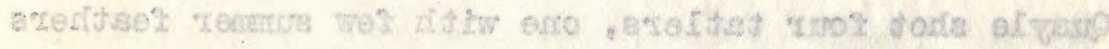
whesesed its

l08 ropinovort

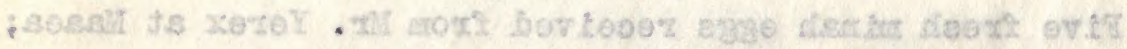

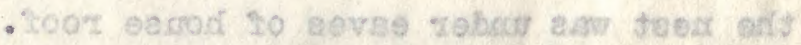

Oङ xecinovo:I

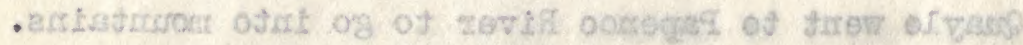

\section{I rechiseode}

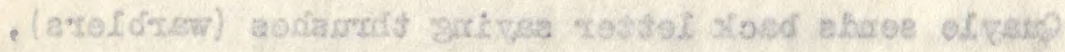

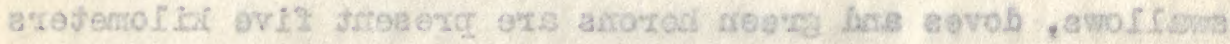


December 7

Quayle returned from Papenoo with over 12 warblers, 2 swallows, several green herons and lingfishers,--35 birds. Water was waist deep in sane of the fords and he was stormbound two days in a cave. Food gave out before he could go over the top of the ridge.

\section{December 6}

Doctor cut foot open again with shears for second time and a $\log 15 / 16$ of an inch long came out of the carity.

\section{December 9}

Quayle starts for Papenoo agrin. Hy foot healing rapidzy.

\section{December 23}

Quayle returned from Iake Vahirla today without shearwaters, though he heard several. Ho got a young rall feathered, though primaries not fully grown. He also had a black flycatcher,--the first we have seen, and several more warblers, doves, ldngfishers and swallows. The nests he thought were swifts' nests last trip up Papenoo he now thinks are swallows ' as he got birds from one of them this trip. I still walk with stick in hand. 


\section{8 zediuber}

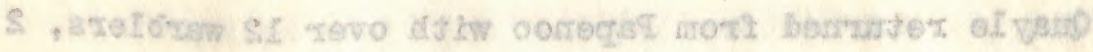

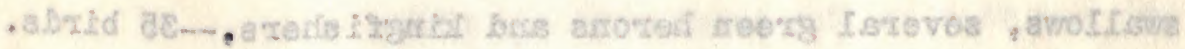

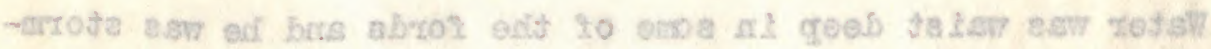

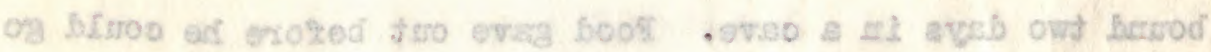

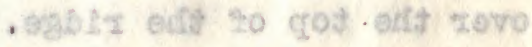

\section{d redmeoph}

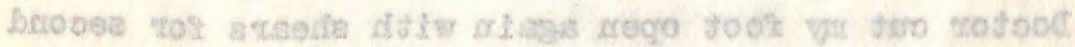

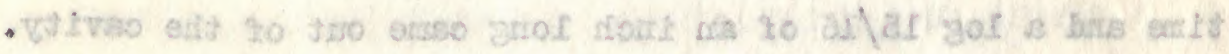

\section{Q sodictosect}

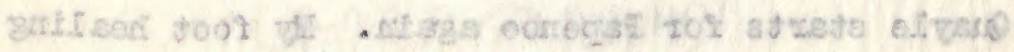

- tribsegsa

\section{ES sodmosolt}

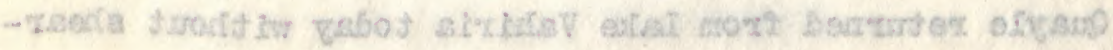

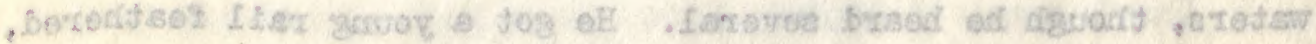

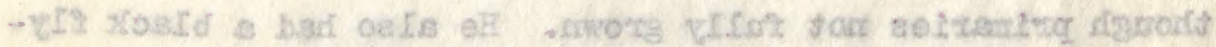

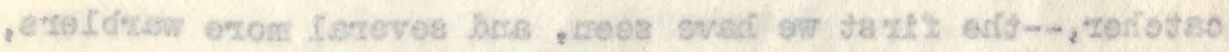

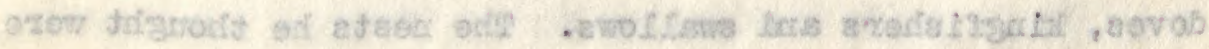

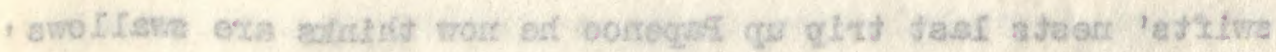

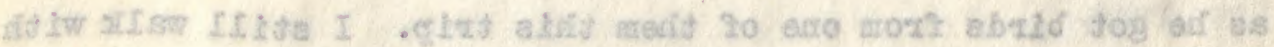


December 26

Quayle put on diet by Doctor,--dysentery the cause.

\section{December 27}

I hired a launch and went out on ocean and saw flocks of noddy terms, a few gJgis, and five Iunatus terns. Redfoot boobies were in flocks fishing; most all were gray birds, though a fow were white-tailed and not one was in the white plumage out of the 200 seen.

\section{December 30}

Quayle went to the rice fields and got a few weaverbirds, one young of the red-bellied kind and several young of Je110w-rump.

Papeete, Jamuary 7, 1921.

Left on schooner "Moana" for Christmas Island via Marquesas with Quayle at 4:30 P. I. Outside the reef a few noddy and a couple of sygis terms were fishing. Also 2 or 3 boobies.

\section{Jamary 8}

In P. H. sighted Tahiti 20 or so miles to the southward. A single ${ }^{\prime}$. cuneatus and a single white-breasted shearwater noted. Few red-footed boobies, few noddy terns and gygis seen. 


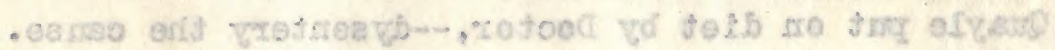

\section{FS rotinasoc}

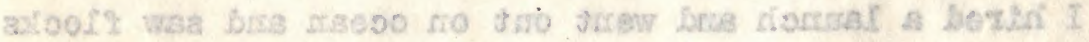

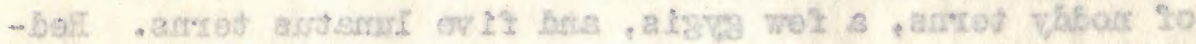

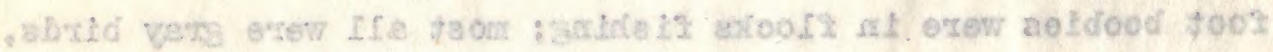

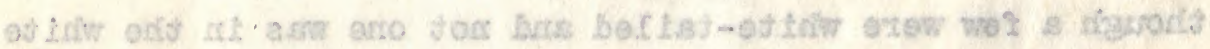

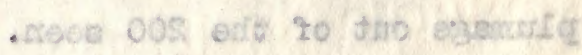

\section{of roultisosa}

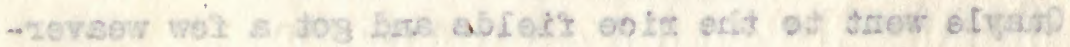

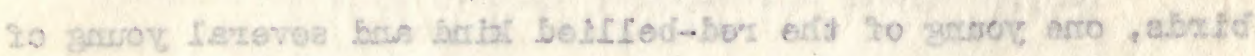
- conat-iotiez

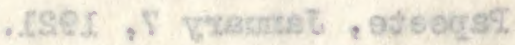

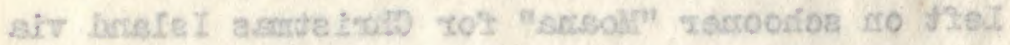

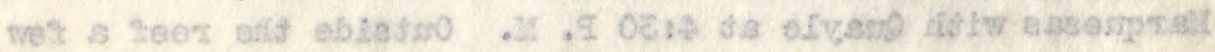

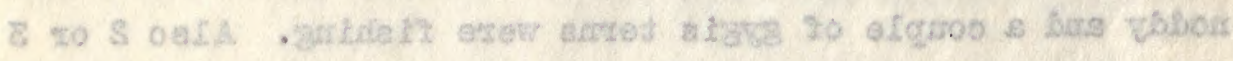
-. aldipod

\section{8 resarasale}

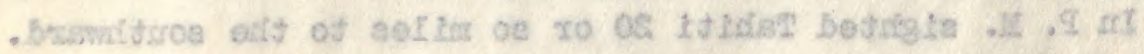

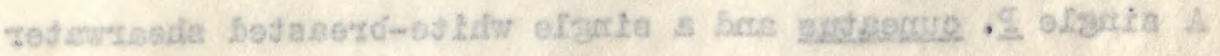

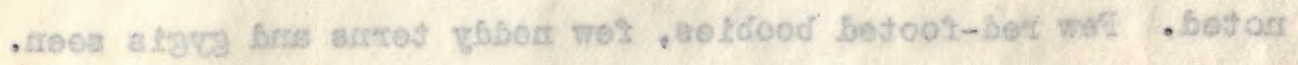


Passed a sloop bound for Tahit1. Ilttle rain in $P . M$.

\section{January 9}

Salling MVe all night and at four P. H. off the Phosphate Company's wharf at Nakatea Island. A fow noddies, red-footed boobies and gygis terns seen fishing before and after passing the islend. A wandering tatler seen alighting on shore and as we left tho island several common boobies (S. I. plotus) flew near the ressel. A single sooty tern was seen few miles to north of island and three white boobies seen flying together may have been S. cranops. Nakatea is 200 feet high on the western end with cliffs rising straight from the water.

\section{Jamary 10}

At six A. M. Rangiroa Island sighted ahead and we beat to the eastward close along shore till three-thirty P. H., when we passed the eastern point. Patches and clumps of trees and mary barren coral rocics were visible from the ship. Cocomat . treos were plenty. Patches of sandy beaches were seen inside the reef at the easterm end. Two or three hats signted but no persons. Noddy and gyols terns and four frigate birds fishing near east ond. A single young plotus booby in flock of fishing birds was seen in morning. Along the N. E. shore coconuts and low bushy trees extend as far as the eyo can see. A light wind 


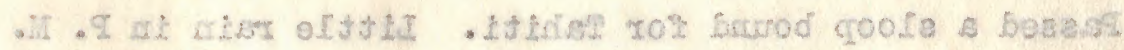

।

e vorestisist

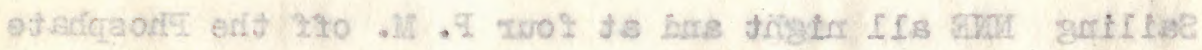

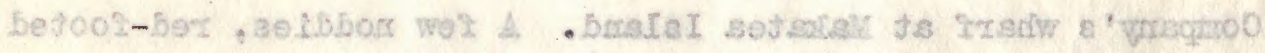

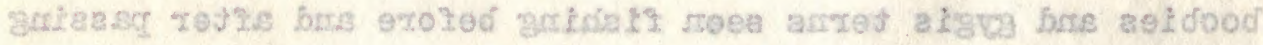

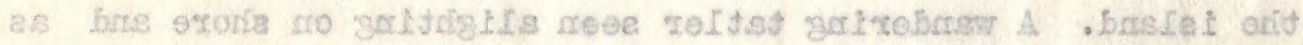

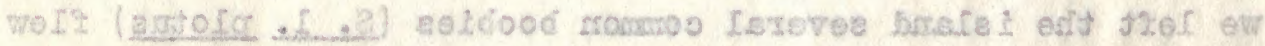

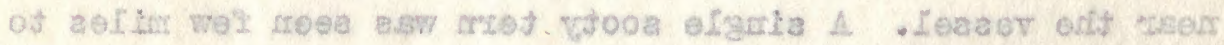

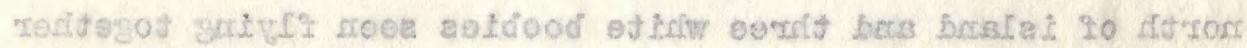

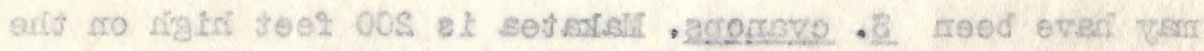

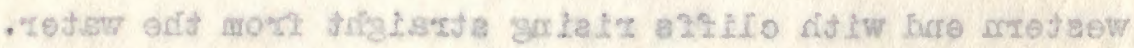

\section{O5 viserent?}

toed ow bra bseris bojtigls bratel aorlgraf . M . A xha tA

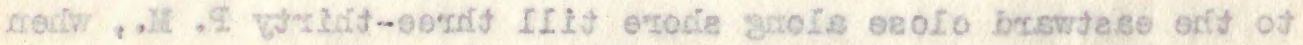

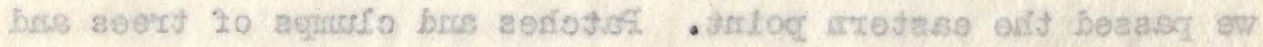

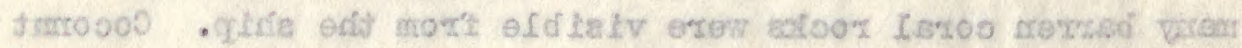

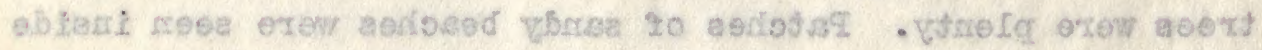

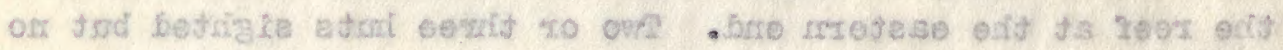

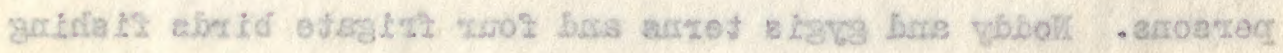

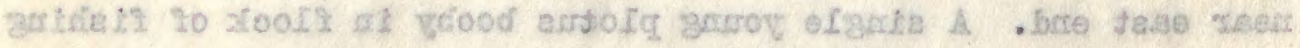

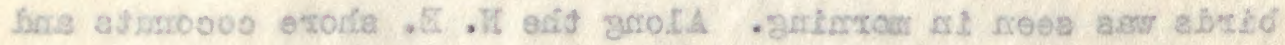

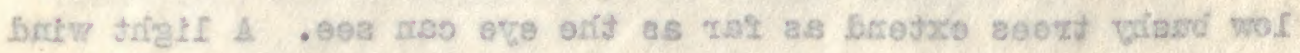


a.1 day and the motor was started at daylight.

At sunset several small flocks of sooty terns seen flying toward Arutua Island. Most fly close to the water, but sometimes a bird was higher in the air but would descend to join others flying low.

\section{January 11}

At sunrise a few miles north of Arutua. Sooty terns wero flying northward fishing bound, a dozen or so in two parties. Sailed close along west shore of Arutua last night after dark. Smooth sea, little wind. Stopped engine in night brut started at five in the morning. Terns fly higher in morning than at night when returning to island. Fine weather, no coat on since starting. Quayle and priest discuss French lesson while crew in cockpit smoke cigarettes.

Takapoto is sighted at $4: 30$, a long line of trees on the horizon reminding me of the line of trees along a river banic in the San Joaquin seen at a distance on a hot day. Few sooty and lesser (?) noddies during day, but not a tropic-bird seen yet. Sallors fish with bone hook, barbless, but catch nothing. Iffelike tail of hair tied to tail of hook.

Jamary 12

Fair breeze all day, heading NNE, only half dozen birds 


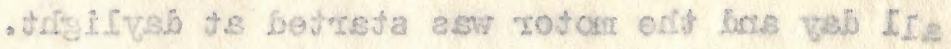

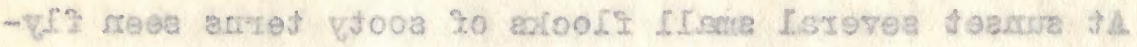

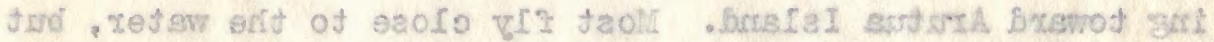

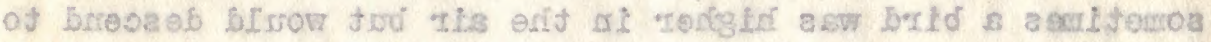
- wol arivita amorto miol

\section{Trasscust,}

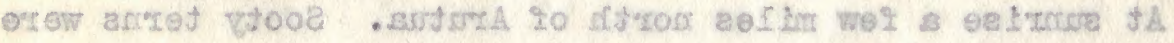

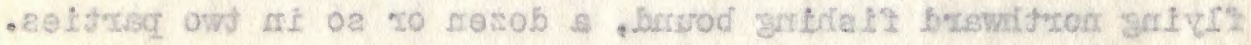

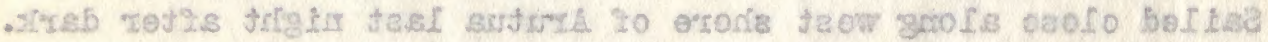

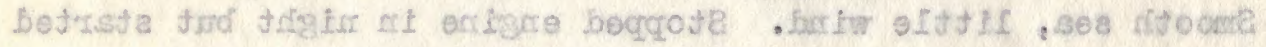

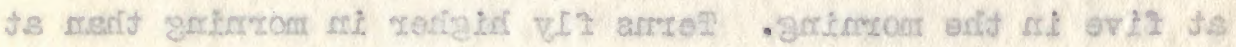

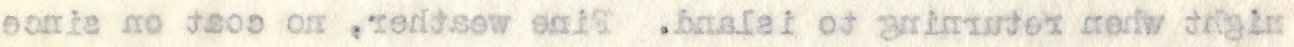

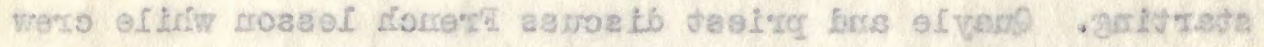

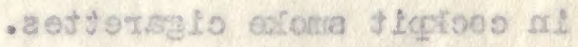

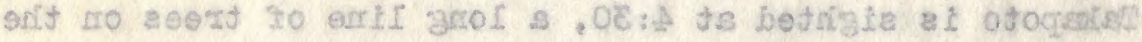

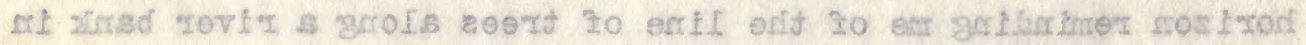

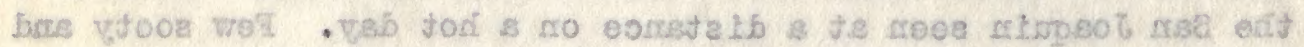

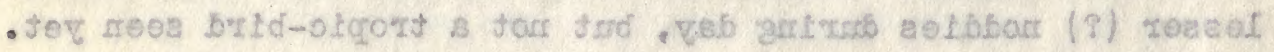

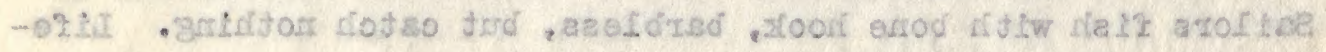

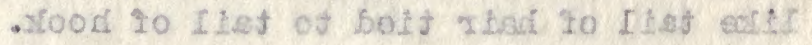

\section{S1. Whartst}

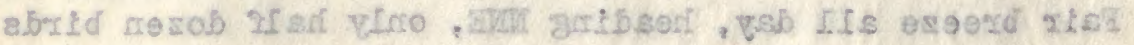


seen, sooty and gygis terns.

\section{Jamary 13}

Some wind all day. Made 112 miles about MNE. About 300 miles from Varquesas in straight line. One sidipjack caught by Captain, lost two others by breaking pole. Dozen or more sooty terms and couple gygis seen in evening, all woriking toward windward, possibly toward island 170 miles away in that direction (Napraka).

\section{January 14}

Several sooty terns, a single or two and three yellowbilled tropic-birds during day; also one white-breasted and two small blacir shearwaters, the last two Bulweria (?). The last one in the evening darted about something like a nighthawk for a short timo and then evidently flew away close to the water like the first one seen, for both disappeared suddenly as though they might have lit on the water. Iowered sails in P. M. and started motor as wind light and. nearly straight from our destination. Made fifty miles since yesterday noon $N$ by $\mathbb{W}$ and our port is about NE by $\mathrm{g}$.

\section{January 15}

A couple of Jellow-bill tropics around ship at daylight, 2

and at eight $0^{\prime} \mathrm{clock}$ an old and young red-bill cane around. 


\section{1. veresinst}

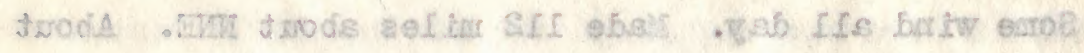

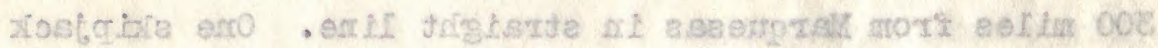

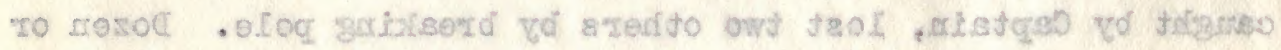

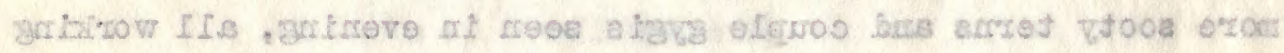

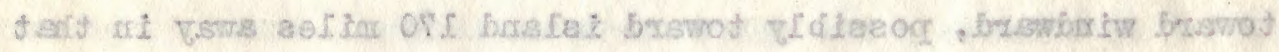

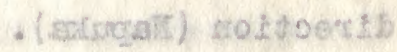

\section{I veremriat:}

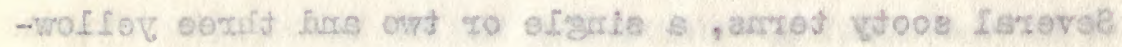

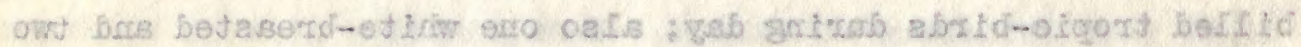

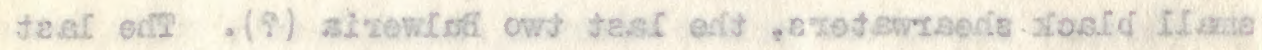

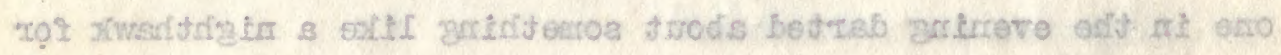

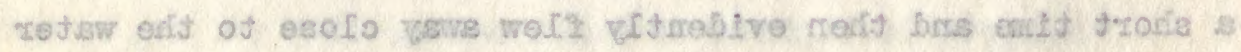

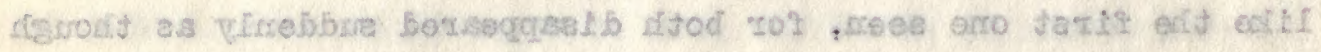

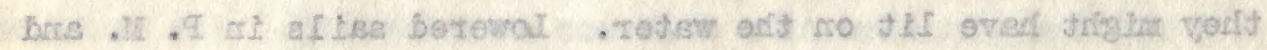

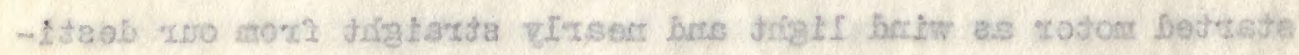

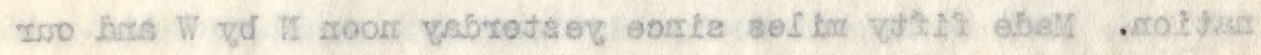

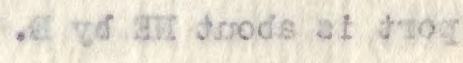

\section{2) Tamast}

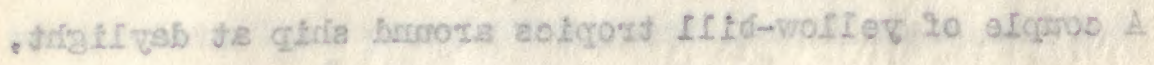

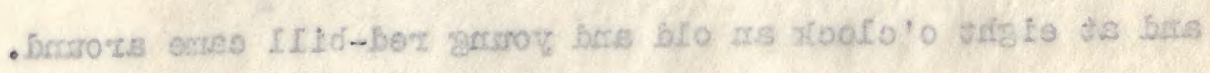


They drifted off and three white terns joined them for a couple of minutes. A sooty tem also flew past and a small shearwater seen in distance. Good sailing breeze in morning; motor went wrong last night, so sails spread at eight o'clock. Crew holystoning deck with fire bricks and cabin washed out.

At three o'clock three frigates, three or four sooty and several white terns seen fishing, two or three Bulweria (?) also seen. The latter fly more like petrels than Pterodromas, keeping close to the water in the strong broeze. No noticeable difference in color on the upper part of plumege could be seen in flight, though good view had several times. Three frigates sailed high over the fishing birds and a red-footed booby came up astern a mile past them. We are just about 200 miles to the SW of Huapu Island, the nearest land in the Harquesas. Quite a school of flying-fish flushed shortly after passing the birds. Position 11 South, 143 West.

\section{January 16}

Sunday. Strong breeze this morning and quite a number of birds seen by 6:30. Three frigates, one yellow-bill tropic, one bulweri, one brown or gray red-footed booby, one large, heavy, gray-backed, light-breasted fulmar-like bird seen at a distance, several fairy and several sooty terns; also two shearwaters that looked like puffinus, white-breasted. 


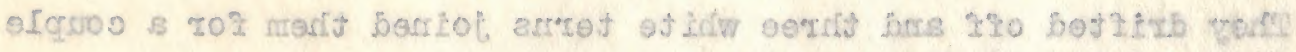

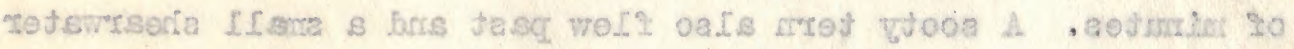

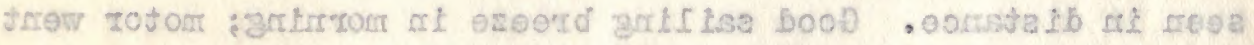

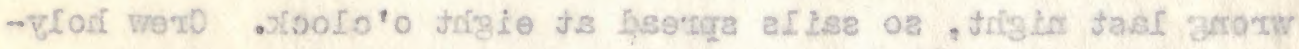

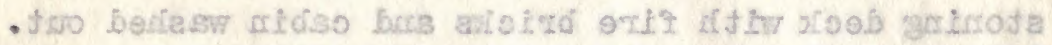

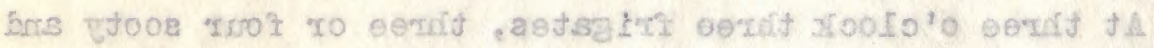

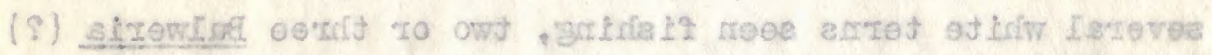

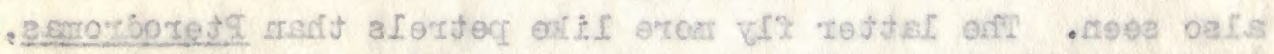

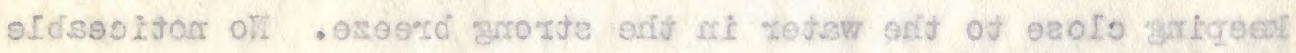

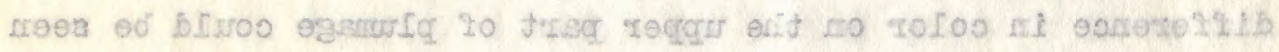

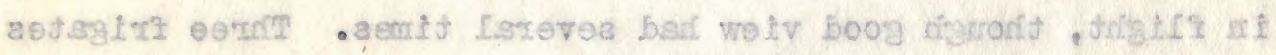

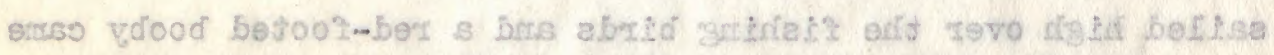

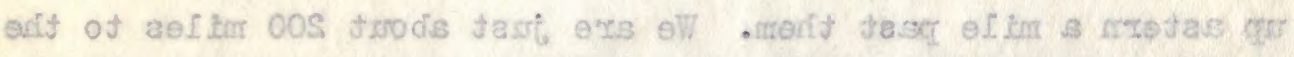

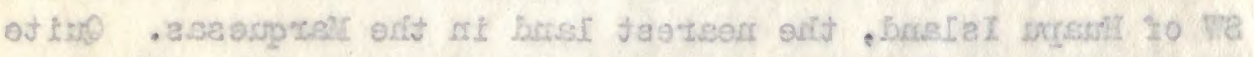

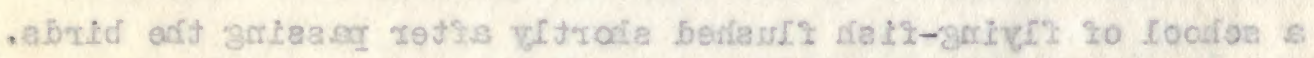

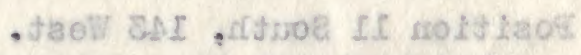

\section{Thasust}

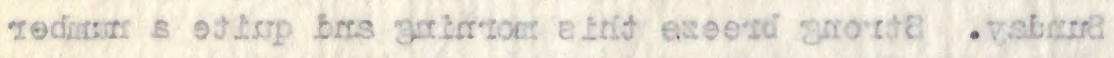

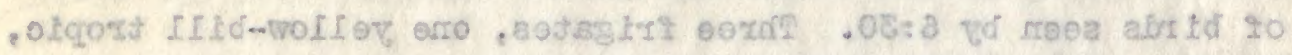

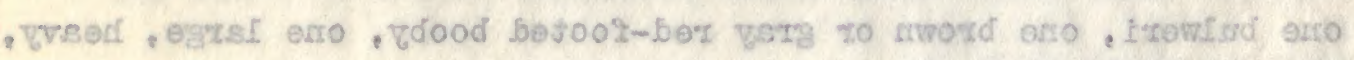

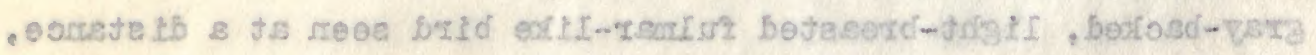

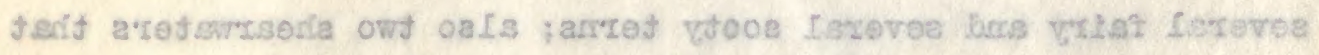

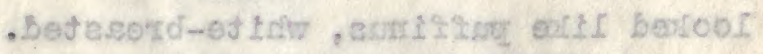


Later saw a booby two or three times that may have been the heavy shearwater. Small flock of fairy terms and a couple of sooties. Two bulwerias seen at one time, but hours of watching the ocean frequently reveals not a single bird. Wind not so strong in the evening. Hade 120 miles since jesterday.

\section{Jamary 17}

Good breeze 2.11 day and two or three squalls in the evening. First rain for three or four days. Couple of small puffims seen in $\mathrm{P}$. M., black back and with below. One large shearwater dark, possibly dark cuneatus, also three or faur bulweria. One showed brown band on wing. Few white terns and many noddies, also red-foot boobies in small parties and singles and four frigates. In evening birds were working toward island. of Eiao some thirty miles to windward, supposedly, though we can't see it at twenty miles at six P. M. No white red-foot boobies out of seventy-five seen. Some had whitish breasts and a couple had white tails. A single plotus booby seen also flying alone.

\section{Jamary 18}

light wind during last night, but breeze started at sunrise and motor started also. Sooty terns frequent and at eight o'clock other birds seen; a flock of terms, sooty and fairy seen 


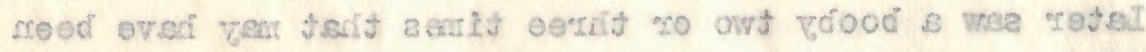

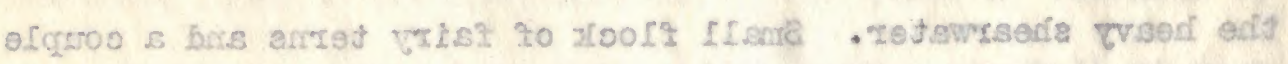

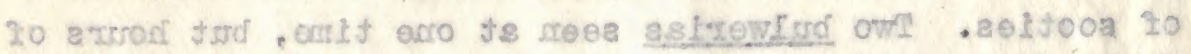

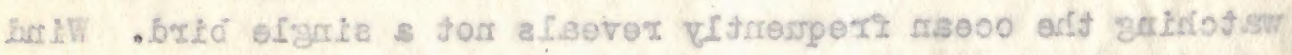

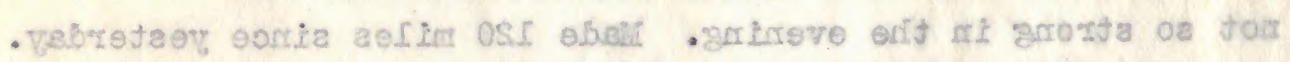

\section{PI. vigumst}

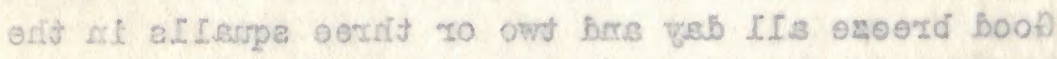

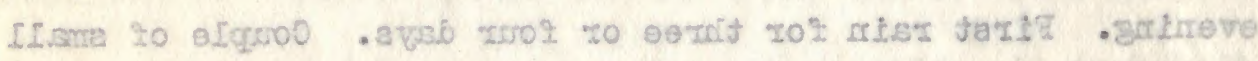

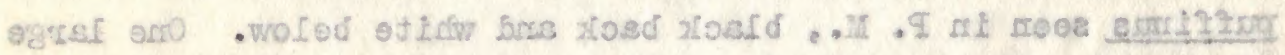

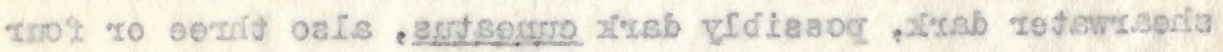

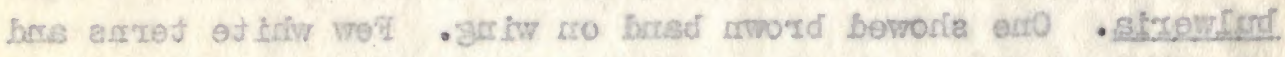

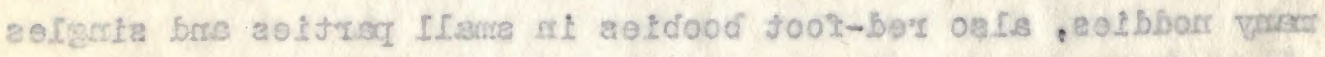

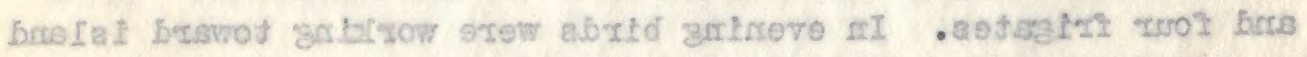

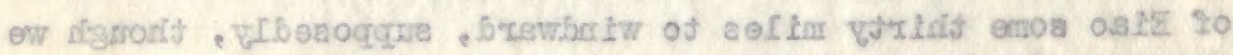

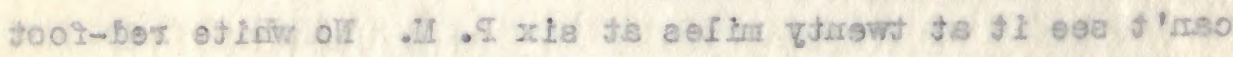

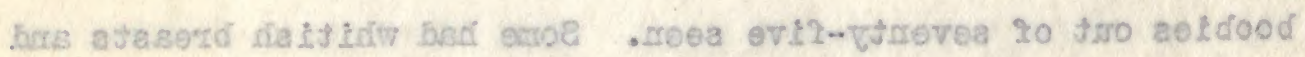

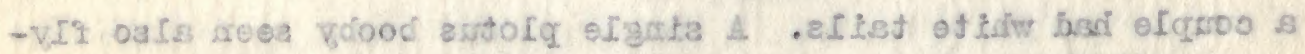
- enols zat

\section{1 tranmet}

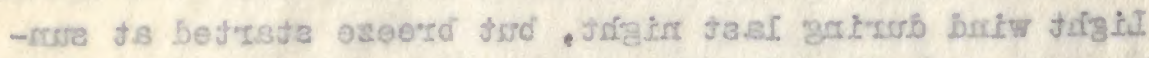

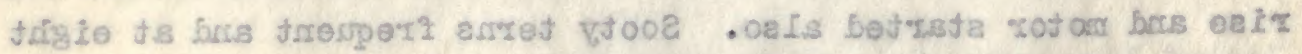

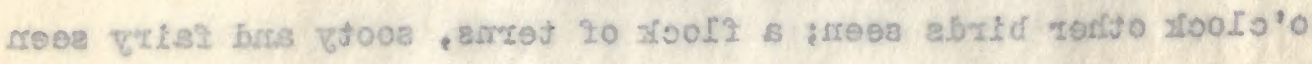


and a little later a flock with several puffings and a couple of crneatus shearwaters and a single white-rumped petrel resembling Wilson's in size and flight. Couple of plotus boobies and a couple of red-footed, also one or two bulweri. Couple of red-billed tropics, old and young; single frigate noted. During the day several plotus boobles seen and half a dozen red-feet, several small petrels, couple seemed larger than wilson's, but could see no white on underside. Saw two larger terms than sooties with slower wingbeats, flight similar to gull. Sooties and fairy terns a.ll day.

At five the Captain sighted Hupu Island about 25 miles awry and 12ter Nuhathiva. Huapr showed the tops of two pinnacle peaks, the highest over 4,000 feet.

\section{January 19}

light wind all night and motor busy; sails down but foresail up. Smooth sea in morn and light wind. Hruapr Island 15 miles to NW at daylight and Hivaoa 40 miles or more ahead. Few birds,--a sooty or two, red-foot boobies and plotus boobies (a couple) and one or two each of Bulweri and Puffinus auricularis. Nearing Hivaoa fairy tems were the comonest birds some miles off, with frequent red-foot boobles, but when near the SW end flociss of noddy and lesser noddies were fishing with frigates and the fairy terms were all along. Sailing close 


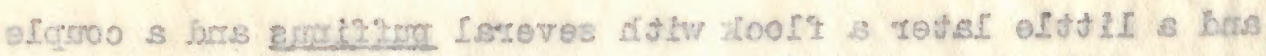

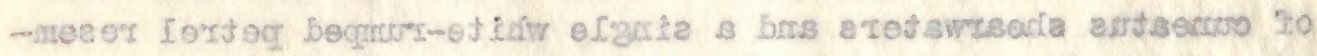

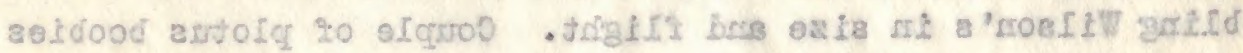

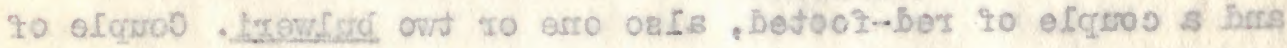

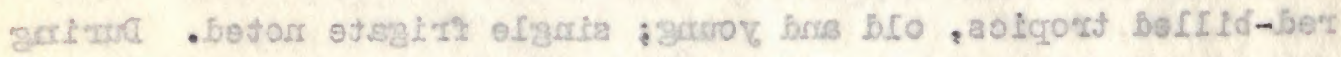

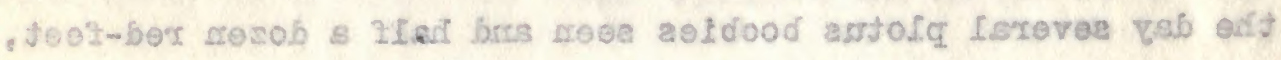

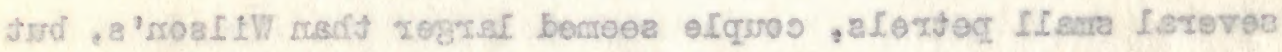

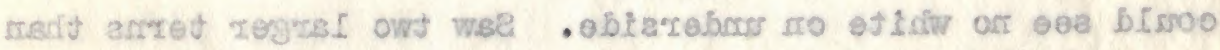

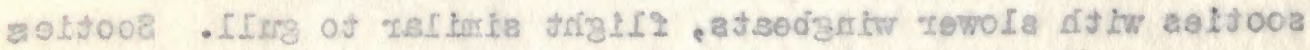

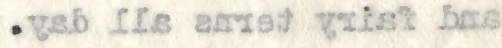

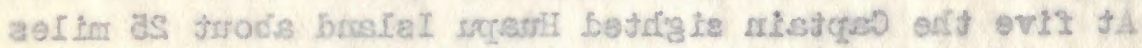

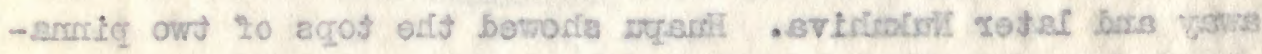

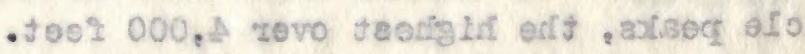

\section{PI Tracrosets}

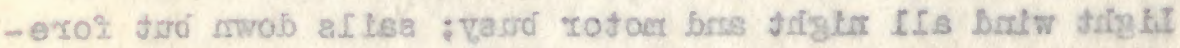

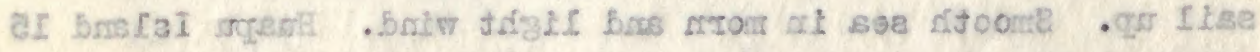

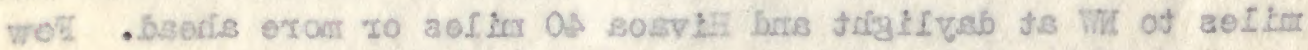

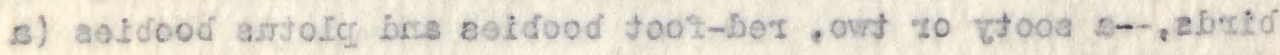

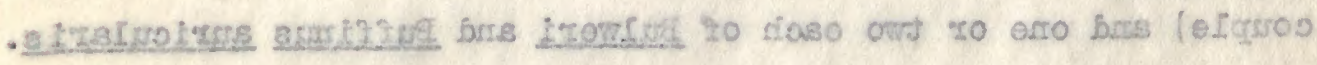

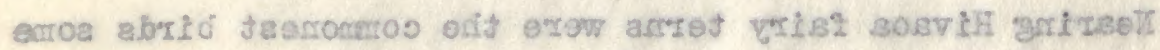

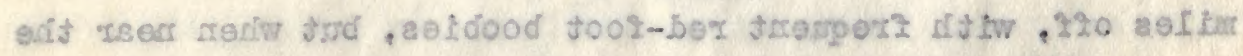

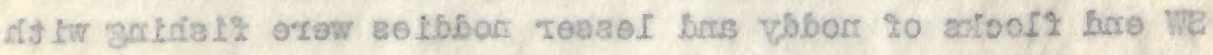

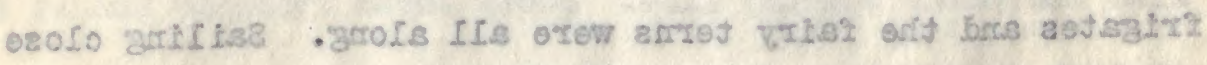


along shore with motor several small gray terns were seen fishing and a reef heron and several wandering tatlers were noted on the rocks. Trees were white at the base of steep cliffs with guano from red-foot boobies and frigates. Entering the bey many fairy and noddy terns were seen and a warbler wes heard singing as we anchored at five $P . M$.

\section{Jamuary 20}

Ashore in morn and met Mr. and Mrs. Hanly and Mr. Linton here for Bishop linseum of Honolulu after anthropology. Hr. Hanly introduced mo to the Administrator who gave us permission to collect. After lunch went ashore and got several flycatchers, a warbler, a dove, and a kingfisher. Heard several doves and warblers, the latter in coconut trees usually.

\section{January 21}

Ashore at six $0^{\prime} c l o c k$ and up stream several miles, passing three or four old tombs built of rocks about 8 by 12 feet and four to six feet in height among big trees and brash. A few doves were heard, but the flycatcher was the only land bird seen beyond the cocomats where several warblers sang. Fairy terns were sailing about clear up the canyon and several noddy terns were also seen five miles up sailing about cliffs. A pair of tropics were seen at one cliff. Wandering tatlers 


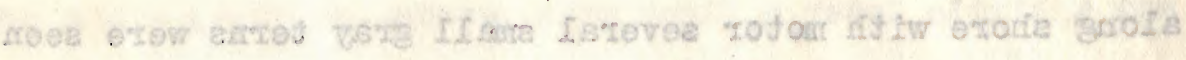

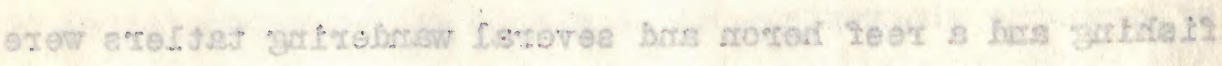

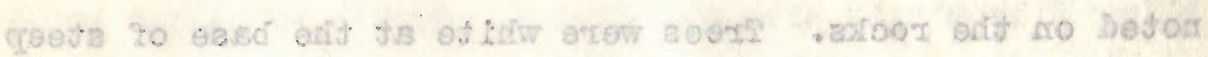

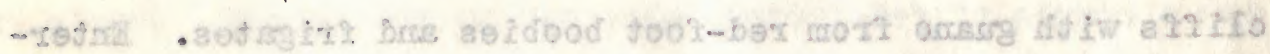

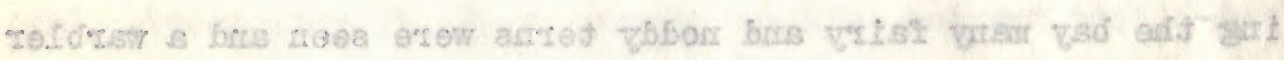

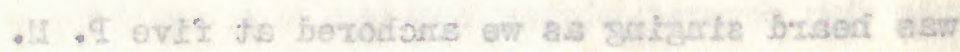

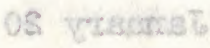

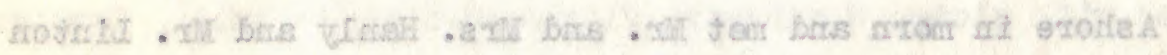

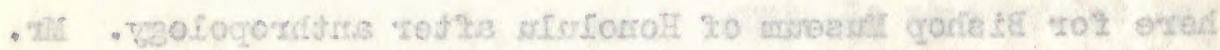

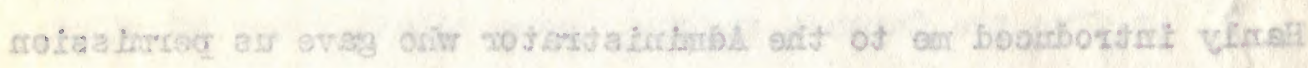

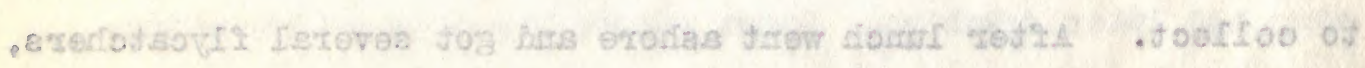

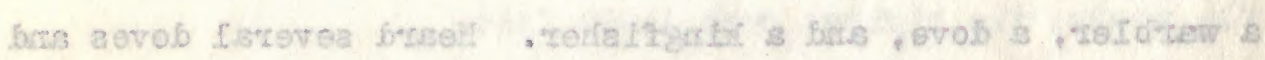

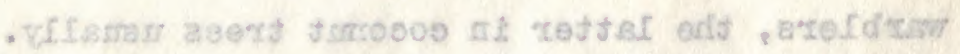

\section{3 vasmet}

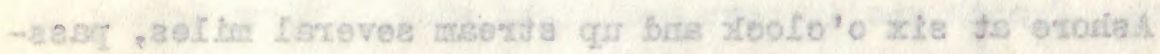

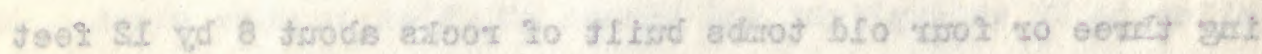

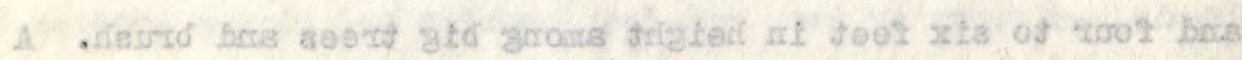

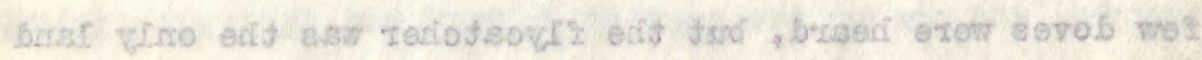

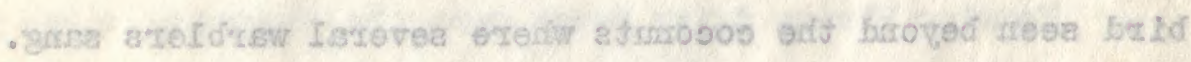

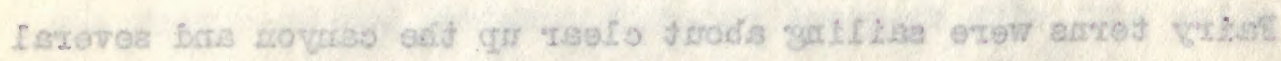

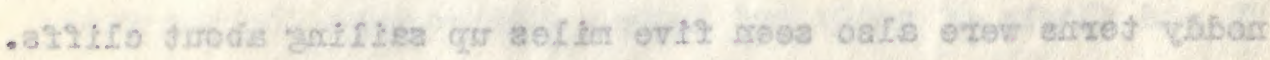

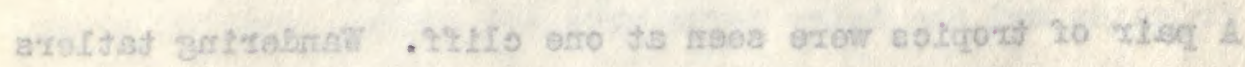


are common along the rocks on shore and reef herons also occur. Minahs were brought here three years ago,--sixteen birds my informant said, and now there are a thousand. A red-crown as well as white-crown dove occurs, but we have only taken the white so far.

Skinned birds with two lanterns and four candles giving poor light watil 9:30 P. M.

\section{January 22}

Skinned birds a.l day. Quaylo up to plateau for the night. He sent down several birds by Linton which I skinned in evening.

\section{Jamary 23}

Sunday and I took few pictures ashore. Quayle back with few blrds same as collected near shore.

\section{Jamuary 24}

I went up onto the plateau and on up to Mt. Ootua several miles to the eastward, and around its base saw several redcapped doves of which three were secured. They were as reported, found near the heads of canyons and usually seen when flying to or from the canyon where the stream of water was flowing. As I stood on the top of the ridge with a brisk breeze sweeping over, 


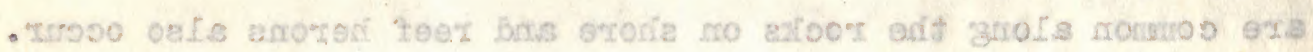

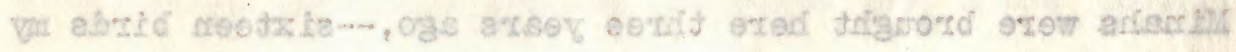

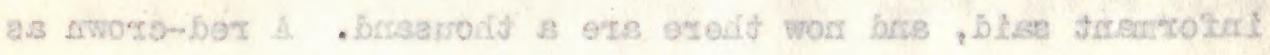

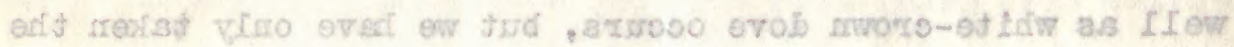
- xast oe stidim

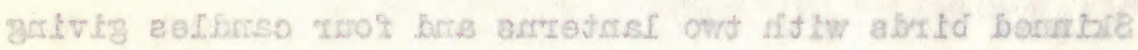

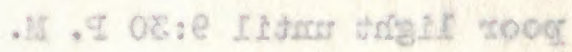

SS visumet

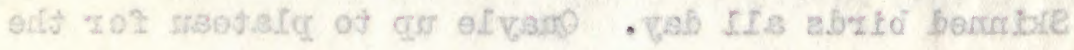

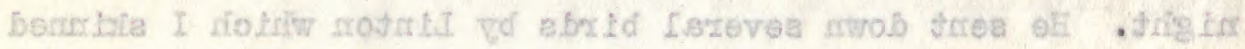
- artiowe st

es zramat

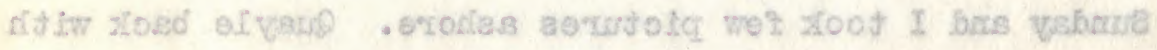

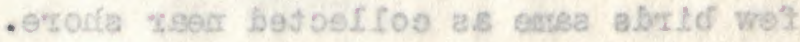

AS versonsto

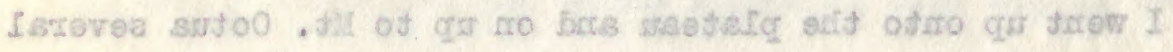

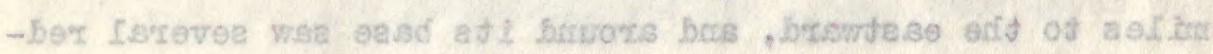

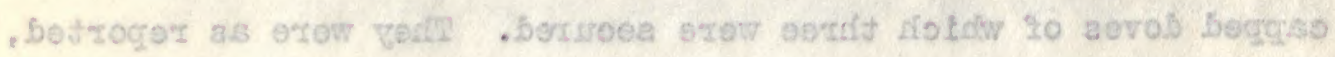

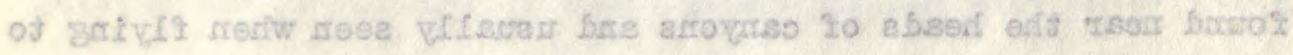

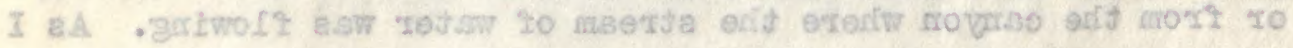

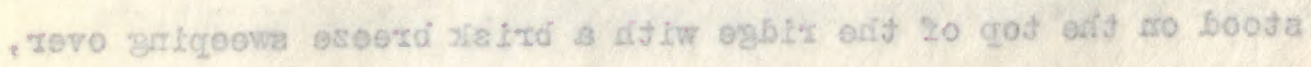


one flew back and forth to windward of me several times looking at me. Their call notes did not seem to have the half dozen rapid "Coos" at the end of the cooing as does the whitecrowned and the Tahitian species. The white-crowned seemed to be very mich like the Jahitian bird in its call. The redcrown would come to my calling occasionally, but in the thick forest would fly past or light unseen. No white-crowns were seen where the reds were found, but they occurred just below thom. The warbler and flycatcher were not as conmon as at lower levels, but two pairs of noddy terns were slying about and lighting on the tops of rocks near the highest peak. Fairy terns were seen everywhere, sailing about and alighting in trees, and several swifts were also feeding along the trail. Signs of cattle, pigs and horses were observed, and a small rat was seen in the trail at the watering place.

Quayle went with guide to look for red-crown doves but struck none. He got three or four swifts and guide promised to take him to cave where they nested if he would promise not to touch the bones or relics of dead men placed therein. I shot a couple of swifts in the evening along trail returning to the vessel.

\section{Jamuary 25}

Quayle up to caves and got a number of swifts while I 


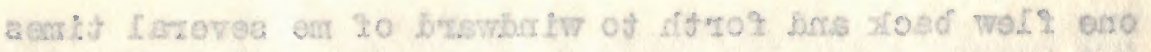

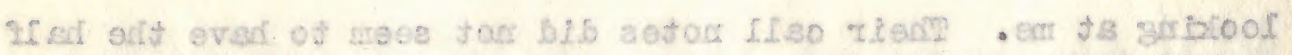

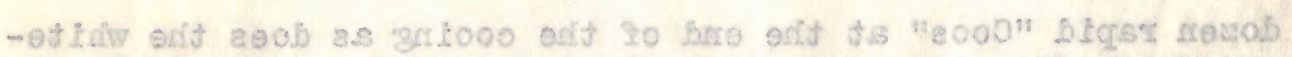

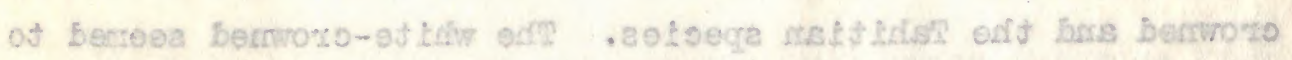

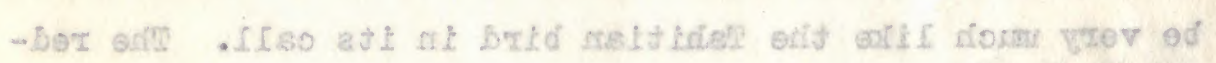

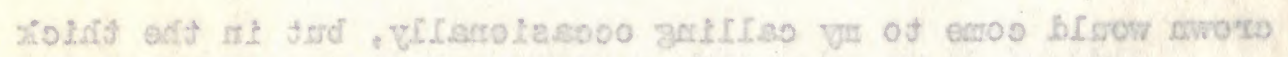

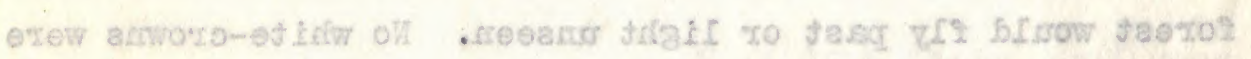

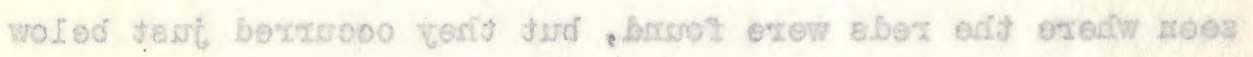

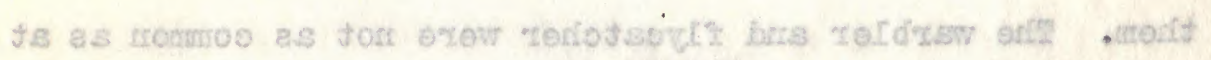

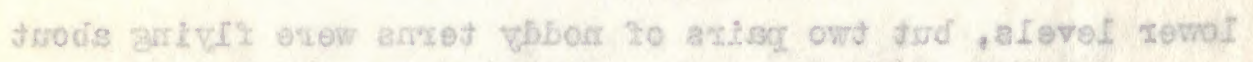

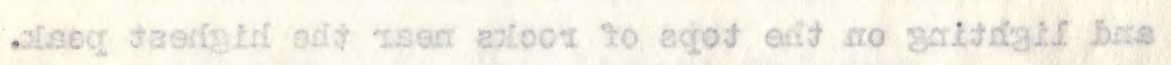

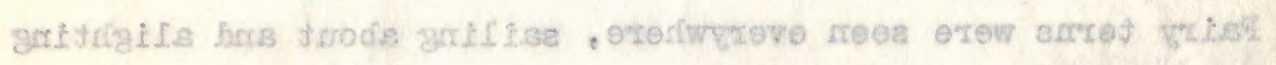

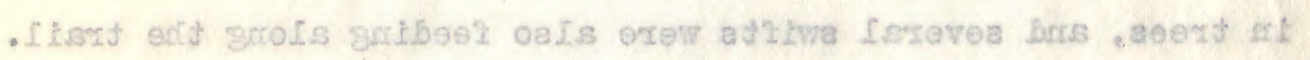

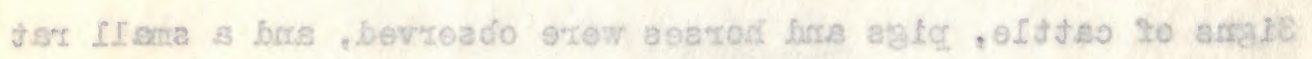

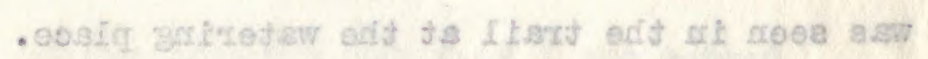

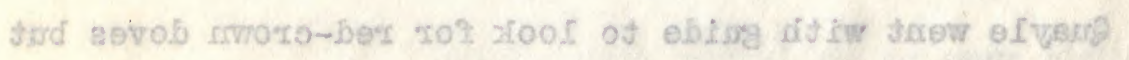

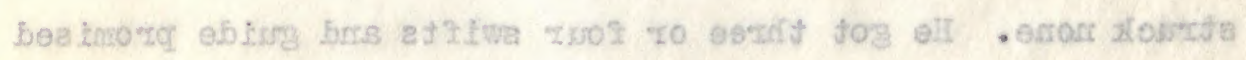

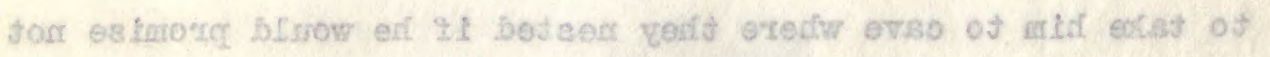

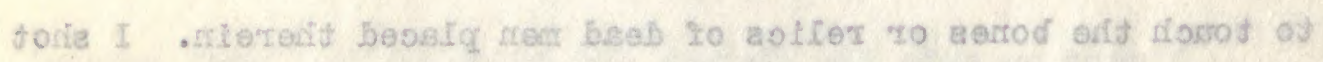

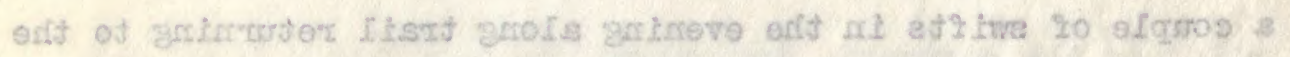

\section{cas gramete?}

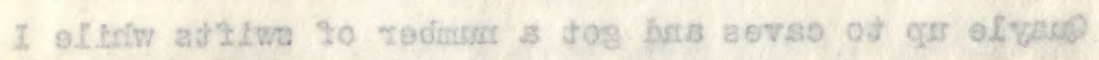


sxinned birds in forenoon and went out in P. M. and picked up a few. The warblers in the valley live largely in the cocomut trees, while on the uplands they live in the pandanus trees, singing throughout the daytime. The flycatchers were commonest near the stream; one nest supposedly of this species I noticed in a hibiscus tree twonty feet up by a trickle of water near IIt. Ootuna. Quayle got a couple of nestling swifts and a newly hatched kingfisher. Kingfishers are mch wilder and scarcer than at Tahiti, but warblers and doves much commoner.

\section{Jamary 26}

Quayle with sore lmee stayed aboard and skinned birds while I went ashore and got a few birds, including two plotus boobles shot at head of bay as they circled around fishing.

\section{Jamary 27}

Left about ten A. M. for Christmas and saw fewer birds fishing in channel than whon wo entered.

\section{January 28}

Light wind all day and at daylight to westward of Huapu. Island with Nuiahiva farther out to west. A few sooty terms and few red-foot and couple of plotus boobies flying around fishing. Ono very grayish backed sooty tern seen. In ovening 


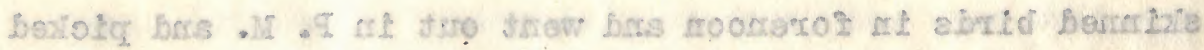

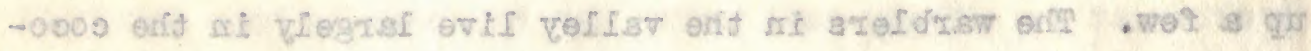

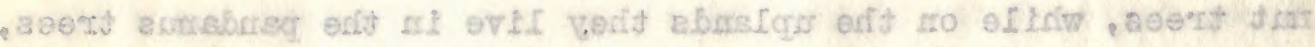

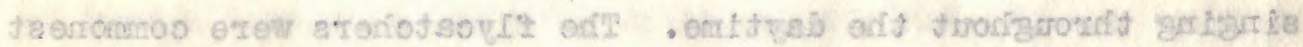

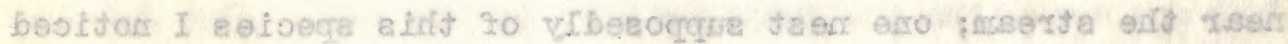

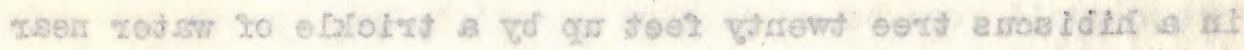

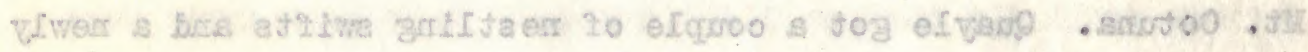

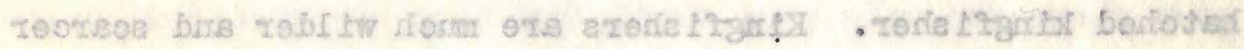

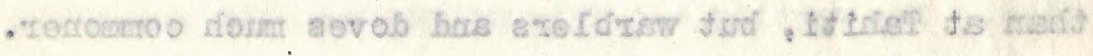

\section{dS vromist}

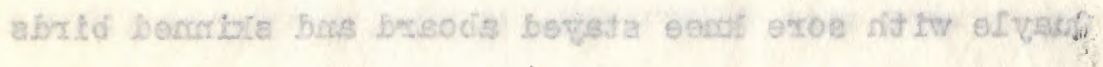

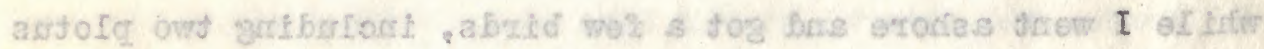

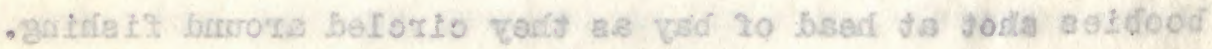

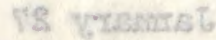

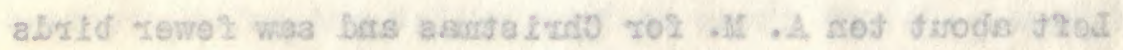

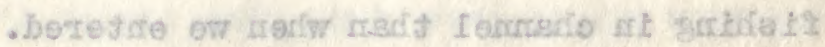

88. vermat

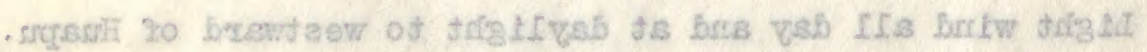

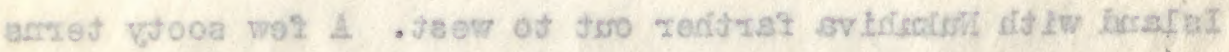

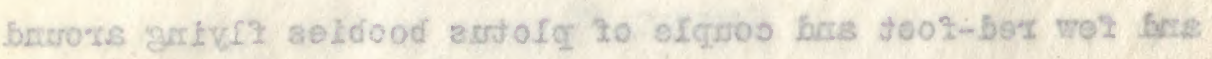

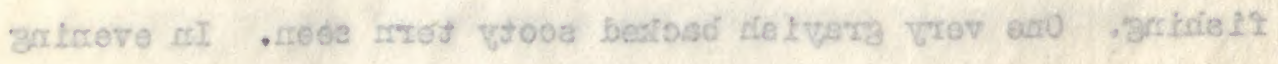


flock of 300 or so lesser noddies and some sooty terns fishing fifteen miles, more or less, off Hergest Rock; the thirty or so red-foot boobies all headed for Nuiruiva Island in the evening, while the plotus birds, a half dozen, are headed for Hotu Itu or Hergest. A cuneatus (?) and a single auricularis were seen.

\section{Jamary 29}

A few red-foot boobies and sooty terns, four prigates, two fairy terns and a couple of white-ramped petrels with no discernable white on under parts seen to leeward of north island of Ilarquesas group. In P. 政. with fair breeze birds are scarce.

\section{Janzary 31}

A day lost somewhere. 120 miles $I_{\text {. }}$. of the northern Marquesas at noon. At four P. M. a couple of redfoot boobies swung past toward thom. Three or four sooty terns seen singly during the day. Four or five petrels noted; part of them whiterumped, but no white below seen. A single auricularis flushed from water at a distance; after we passed it flew. It seemed heavier and shorter than a booby, like a skua. Good breeze all day. Petrels do not follow in wake of vessel as wilson's often does; two or three flew along in our direction a hundred jards 


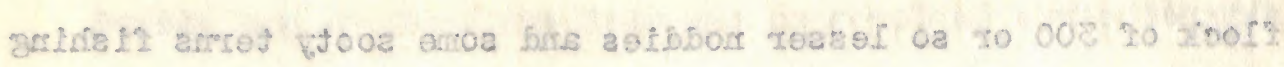

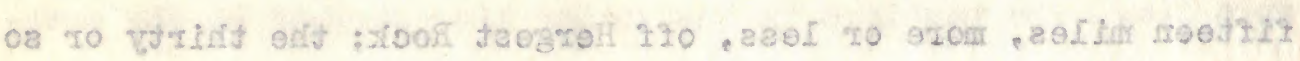

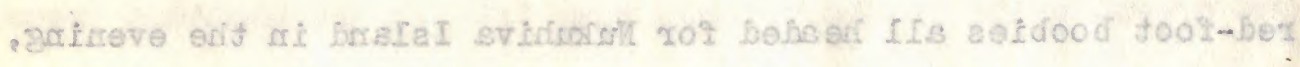

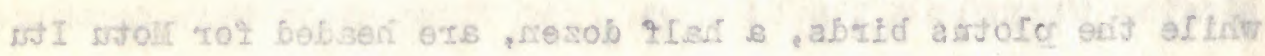

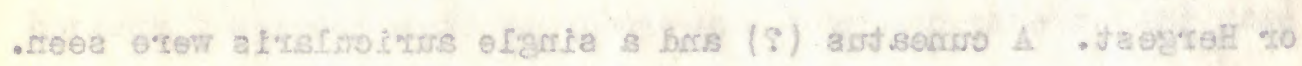

es vianasts

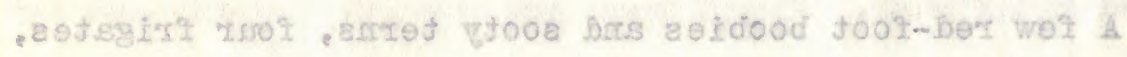

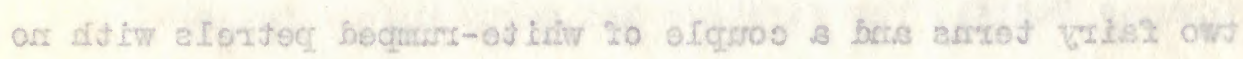

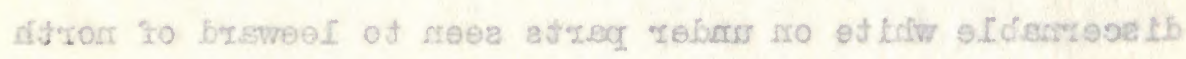

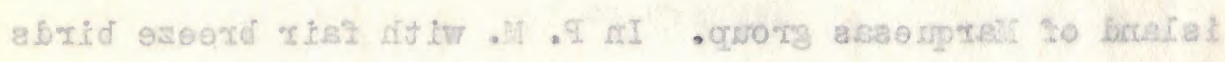
- eorave exso

I6 viassast

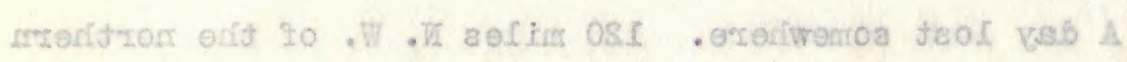

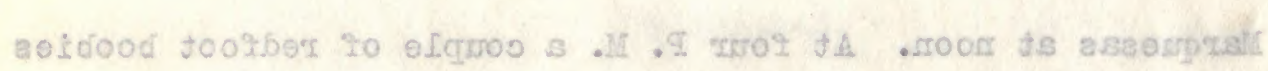

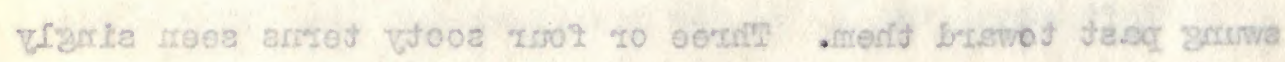

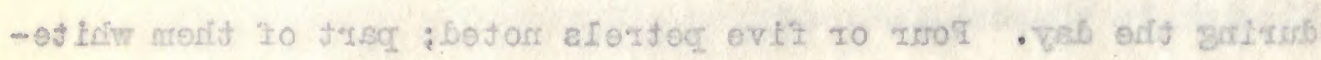

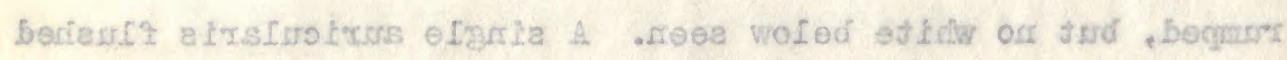

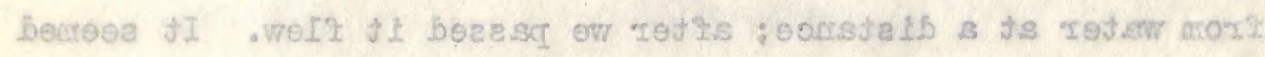

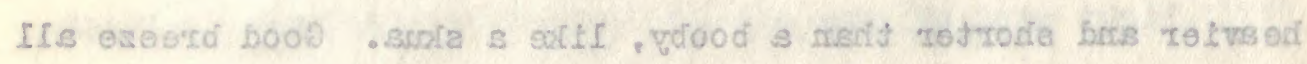

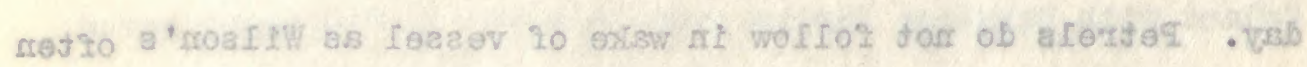

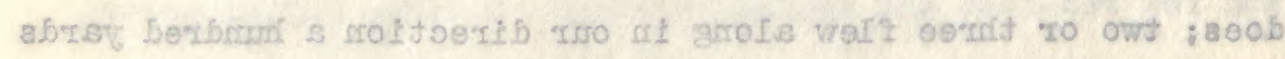


to leeward. Somotimes two were seen together; once a pair was seen on the water but flew when neared. Three redfoot boobies and a frigate bird were seen about dark, but bound nowhere in particular. A fairy tern seen at dusk.

\section{February 1}

A single booby and frigate were the only birds seen today, though the ocean was watched for hours. One Bulweria in evening.

Febraary 2, 1921.

$3^{\circ} 26^{\prime}$ S., $147^{\circ} 33^{\prime} \mathrm{W}$.

A Irigate bird working along to windward only bird seen. Light wind and smooth sea, plenty of flying-fish last couple of days, schools of twenty or so being flushed at times; these are usually small ones of four or five inches in length. A half dozen porpoise passed in the forenoon. A small petrel and a shearweter similar in color but larger than auricularis were seen in the evening at a distance.

\section{February 3}

$2^{\circ} 15^{\prime} \mathrm{S}, 150^{\circ} \mathrm{W}$

A single fairy term and several sooty terms noted in the morning; the sooties were straggling along to the $\mathbb{N}$. $\mathrm{E} .$, possibly following a school of fish, though flying close to the water rather than as usual well up in air. A redtail tropic flow 


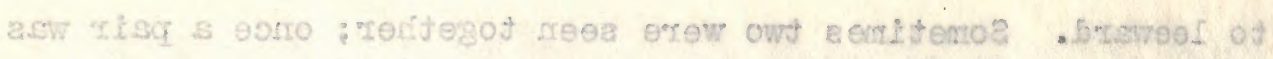

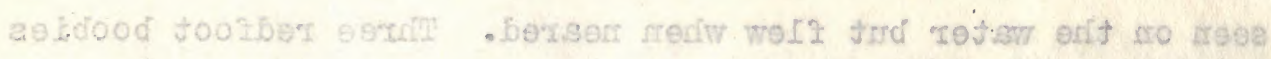

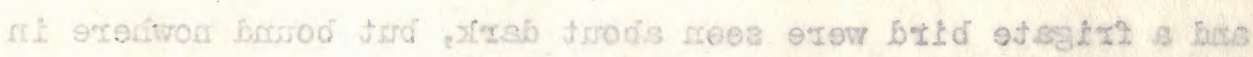

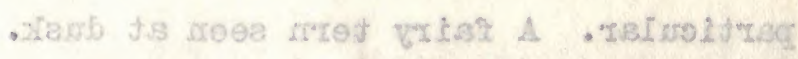

\section{I thascroder}

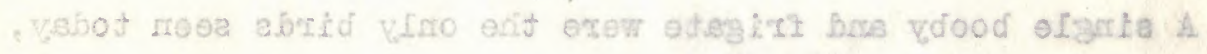

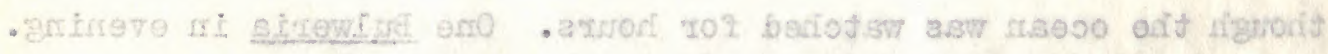

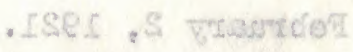

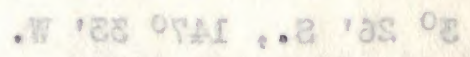

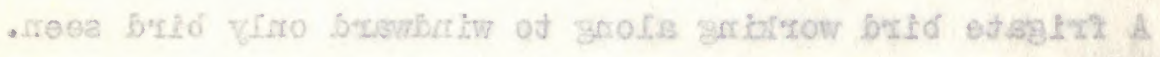

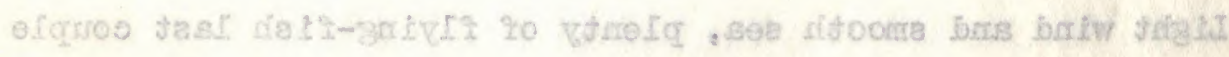

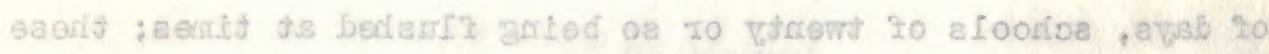

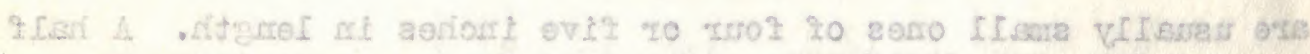

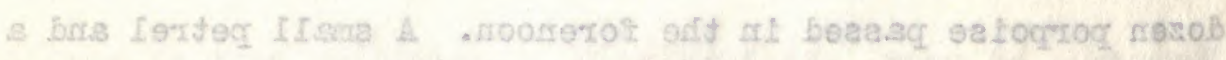

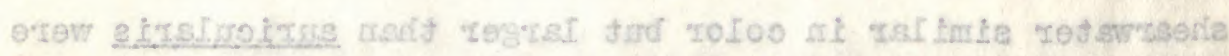

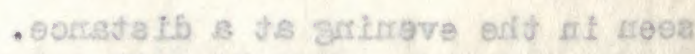

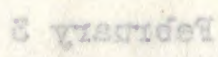

$$
\text { . WOar ..2 dor Os }
$$

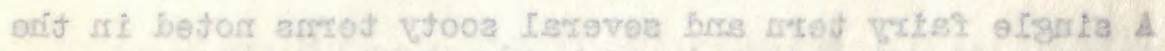

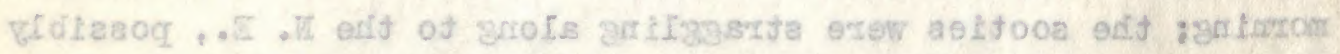

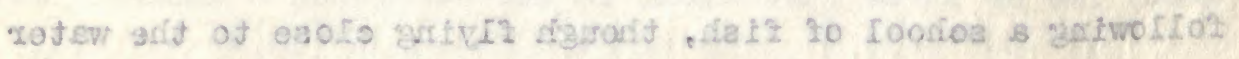

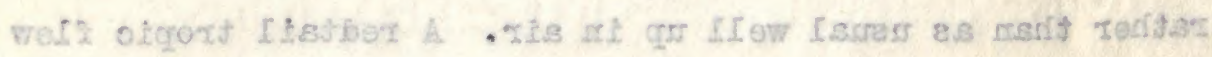


around ship and I shot it. It circled around and lit ahead. of the ship and was picked up, slinned in the afternoon, and eaten at suppertime, being relished by all.

Malden Island, the nearest lend, is 300 miles to the $\mathrm{S}$. W.

\section{February 4}

$1^{\circ} 15^{\prime}$ s., $150^{\circ} 53^{\prime} \mathrm{W}$.

A sooty tern in the morning and a cuneatus (?) in the afternoon. Iight wind and cloudy most of day. Few, hardly any fish. Blackbacked and whitebreasted and shorter tailed than cuneatus is shearwater as seen the second time later, possibly a trifle larger. Seen some distance away. A redtail tropic and a petrel seen in evening.

\section{February 5}

12 S., 152 \%

Sooty terns several times during the day seen fishing. A redtail tropic came near the vessel and a petrel and a shearwater were seen at a distance. Fair ISE wind. Little rain in early morning.

\section{February 6}

Sooty terms were cormon in the forenoon, over fifty being in one flock; they were usually worings to windward and nearly 


$$
-e s-
$$

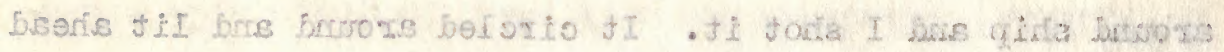

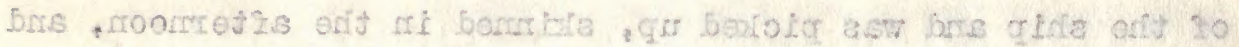

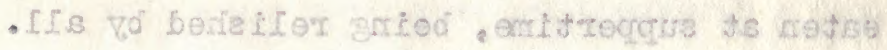

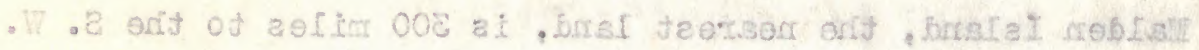

A thaxno's

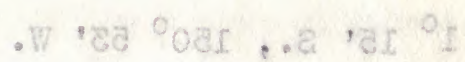

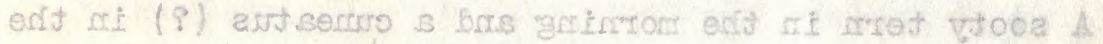

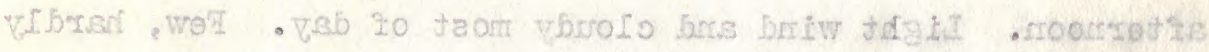

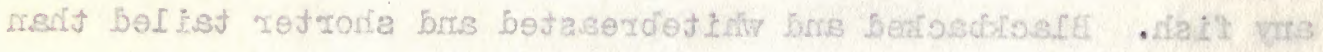

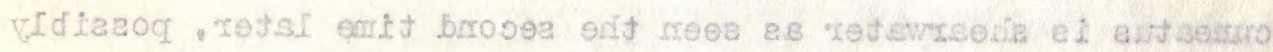

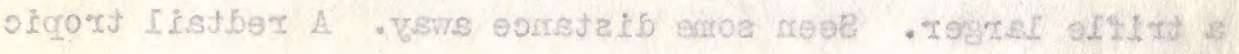
- guierevo ni roor lezjog es bris

c) resistocios

$$
\text { - } \sec . .881
$$

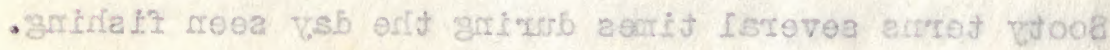

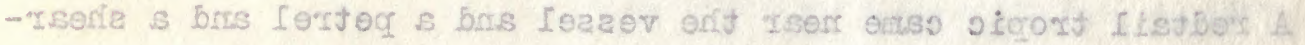

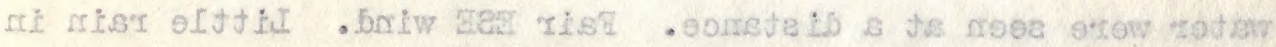
- ger imstorr firso

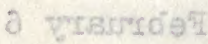

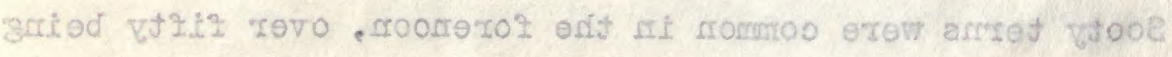

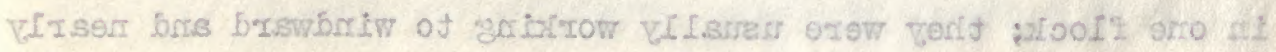


always flying close to the water, although a few were up in the air. One that came up astern was nearly black on the breast and probably was a young bird. Five frigates drifted across in front of a squall and a redtail tropic flew about the vessel several times in the forenoon just before a heavy squall. Shot a redtail tropic, dropping hin on deck just before dinner; he had a nice red feather in his tail which one of the sailors pulled and stuck under a box before Quayle could traverse half the length of the ship, but Quayle secured the feather finally. Four whiterump petrels feeding together on the water at one spot, and later two more were seen. Saw brown wing coverts on a couple. In P. M. a cyanops booby flew around and swang off toward Christmes 250 miles away. The tropics seem to head that way too.

$$
\begin{aligned}
& \text { February ? } \\
& I^{\circ} 30^{\prime} \mathrm{M} ., 155^{\circ} 48^{\prime} \mathrm{W} \text {. }
\end{aligned}
$$

Bluefaced boobies and sooty terns all day. 75 or so sooties seen fishing a couple of times with several boobies. One cuneatus (?) and one dark-headed, white-breasted, darkbacked shearwater seen in forenoon. Strong breeze from east. One hundred miles east of Christmas at noon. A single gygis seen. 


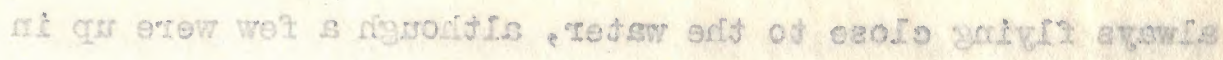

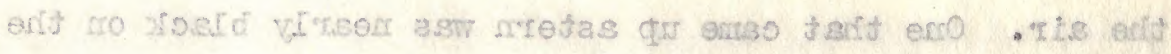

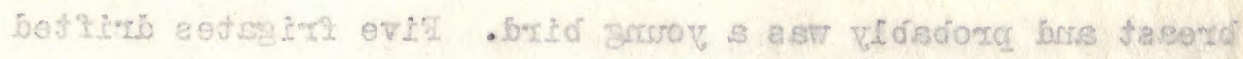

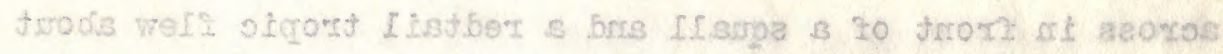

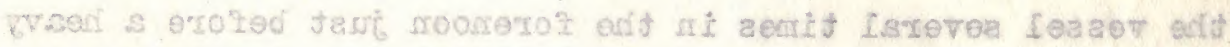

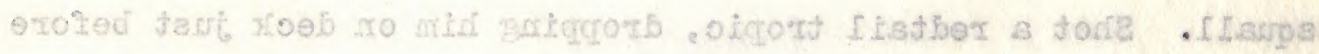

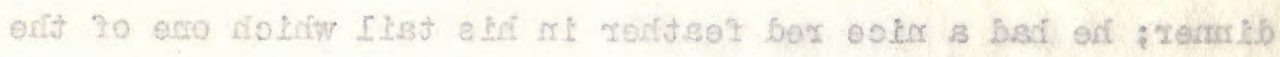

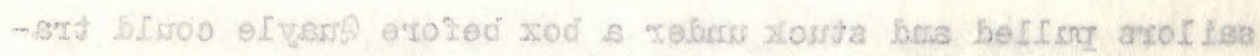

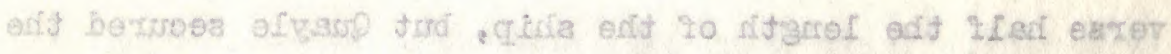

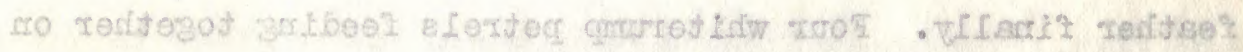

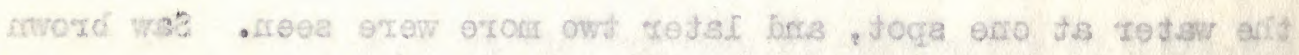

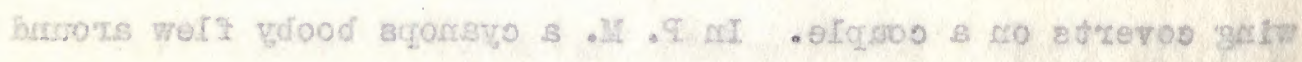

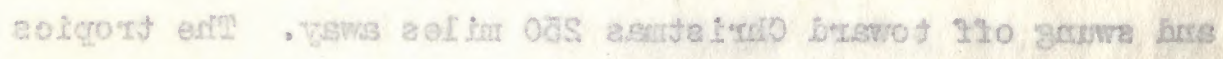

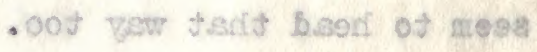

\section{It vesurdot}

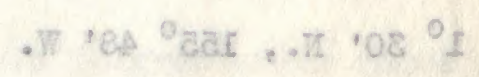

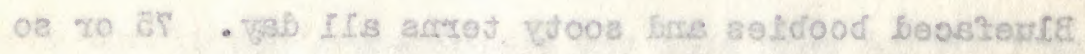

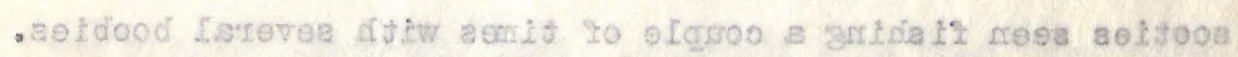

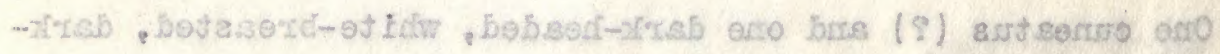

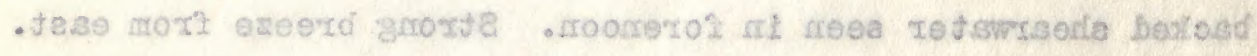

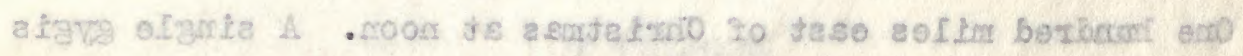




\section{February 8}

$1^{\circ} 47 \mathrm{~N}, 157^{\circ}$ 界.

Blue-faced boobles conmon and sooty terns abundant.

Several black-headed, white-breasted shearwaters during the day and nativitatis common in the afternoon fishing with sooty and boobles. Some looked like cuneatus and one showed whitish axillaxies. In P. M. blrds abundant and Christmas sighted at f1ve P. H. with sooties flying to windward and retuming all the time in P. M. A few plotus and redfooted boobies seen and frigate birds were chasing sooty terms. Three or four small brownish or grayish terms came around the ship. A single term thet looked $11 \mathrm{ke}$ rectirestris flew about. Redtall tropios were common, sometimes three at once circling the ship. Wo salled into eastern bay and headed out at dark. Two or three gygis terns seen.

\section{Fobruary 9}

\section{Christmas Island}

Arrived here at eleven o'clock. Island out of sight in morn till eight o'clock. Sooty terns, nativitatis and a few parvirostris shearwaters about vessel fifteen miles off. Many cyanops and a few redfooted and two or three plotus boobies also. Near anchorage one or two gygis and a couple cerula terns seo n. frigates . Ashore after Iunch and saw twenty or so rectirostris terns on edge of lagoon, young and old. Several of the 
8. एousutcied

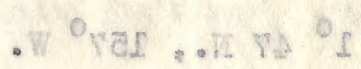

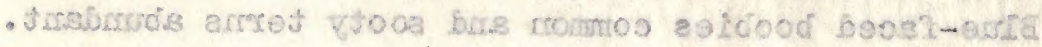

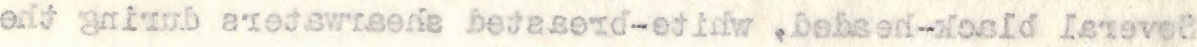

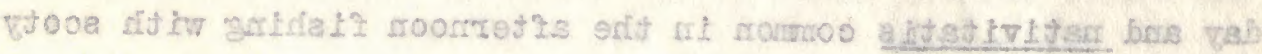

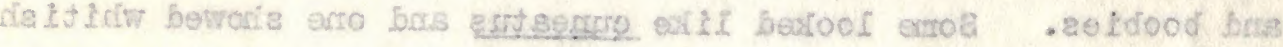

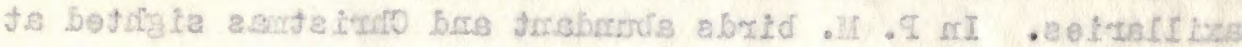

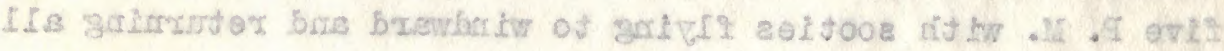

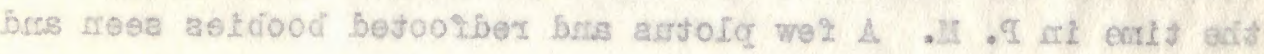

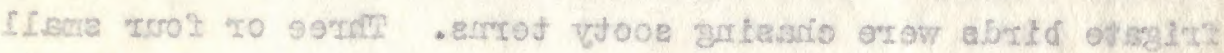

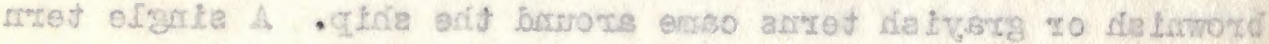

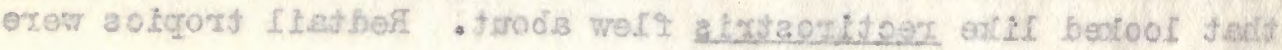

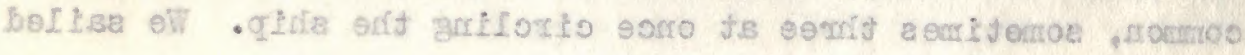

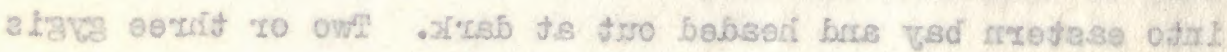
- Irege antol:

\section{e raserde?}

\section{brsalez asita livio}

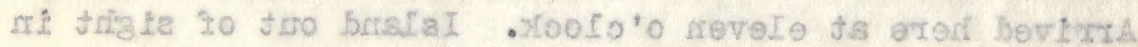

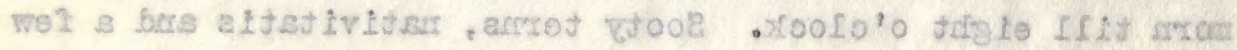

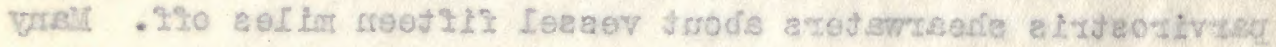

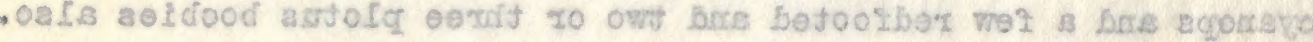

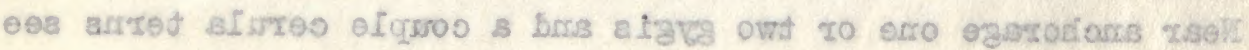

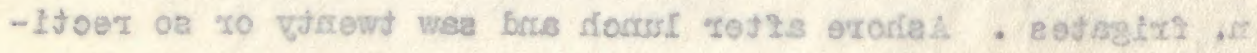

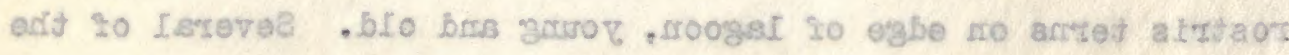


little gray warblers seen in bushes. Several parvirostris flew over land toward islet in lagoon where they nest. Sooty terms also fly across land to nests on east side of island.

\section{February 10}

We hired a boat, two boys and a man and sailed ort to Hotu Upoa where $\underline{P}$. nativitatis, $\underline{P}$. cuneatus and $\underline{P}$. parvirostris were found nesting under cocomat leares, gress roots and other cover. Several pairs of birds were seen in some nosts without eggs. Redtail tropic-birds were nesting comonly with eggs and young, and two or three young gygis terms were taken and one egs from nests in low trees. Whether the nests were built by the gygis or by lesser noddies which were plentiful about the nests I was uncertain. Some noddies were present also, but not nesting. Several redfoot boobies and frigates were sitting in bushes or trees and on the plats surrounding the island golden plover and wandering tatlers as well as a couple of bristlethighed curlew were seen. The shearwaters had eggs or small downy young as a rule, except the cuneatus, of which only three were taken. Warblers were common and a number were secured as they were very tame.

\section{Fobruary 12}

Ashore for awhile in morning and got a fov rectirostris 


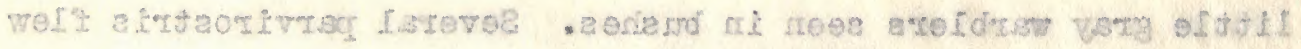

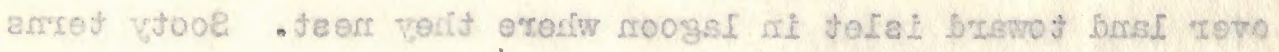

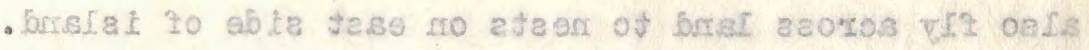

\section{Of Versmot}

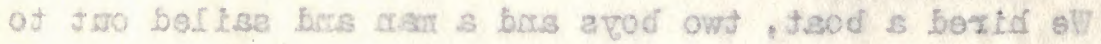

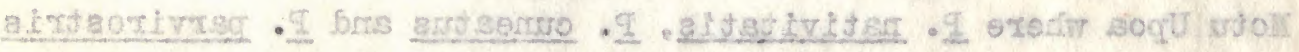

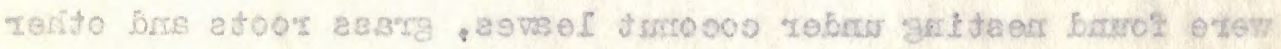

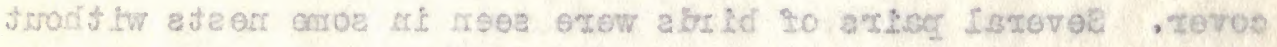

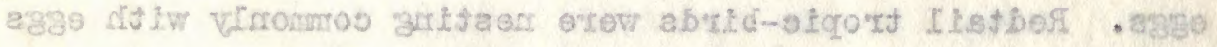

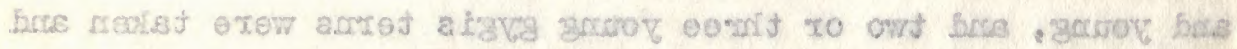

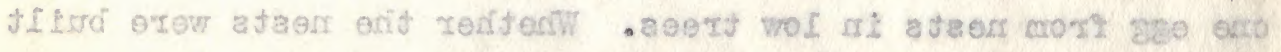

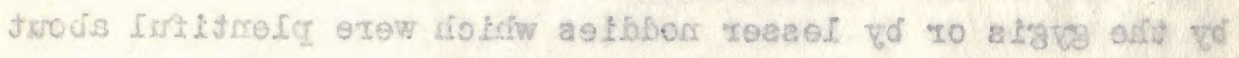

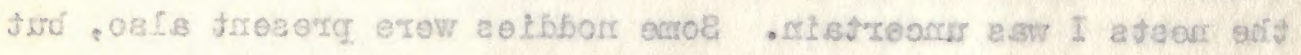

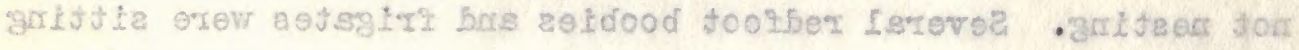

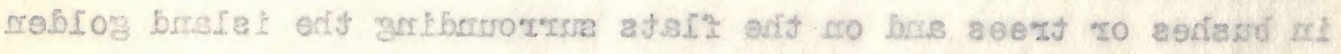

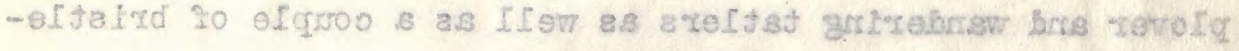

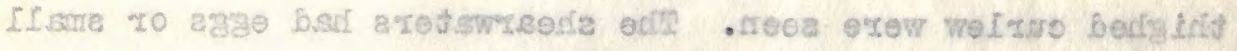

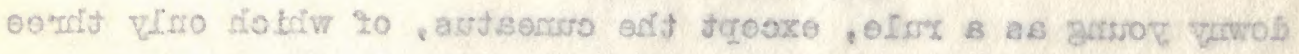

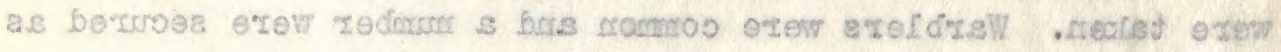
- encus riter exew react

\section{SI zrsarader}

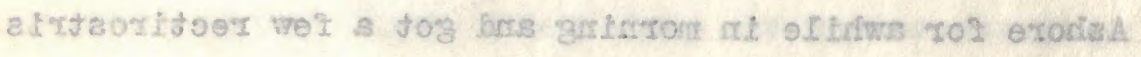


terns and saw a couple of red turnstonos with some plover and several bristle-thighed curlew seen and a couple shot.

\section{February 13}

Sunday. A shore at eight $0^{\prime} c 10 c k$ with Captain for lunch with manager. We took the Ford and drove out to end of coconut grove where a large colony of sooty terns were nesting, passing several nesting redfooted boobies on the way. The boobies had nests in trees from four to twenty feet high with incubated eggs in most cases. The terns had their nests on the ground in the grass and thick bushes where they found it difficult to rise into the air very often. Twenty or more fluttered ahead of mo in the trail at one place, reminding me of rockhopper penguins in the Falidlands. The young were just hatching and either laid flat on the ground as we walked near or tried to hide under anything convenient. Old birds were returming to the colony from all directions and a flock was circling above it all the time. Quayle stayed at the colony in preference to returning for lunch.

\section{February 14}

Took the Ford and went twenty miles down the island, seeing golden plover and bristle-thighed curlew flush along 


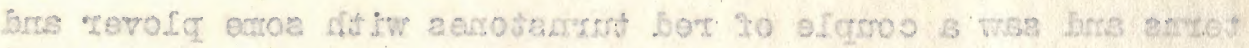

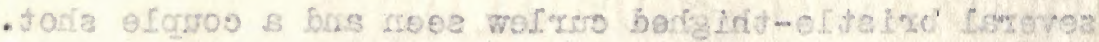

\section{EI verescióe}

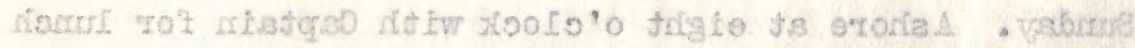

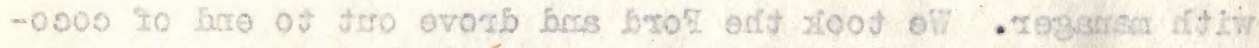

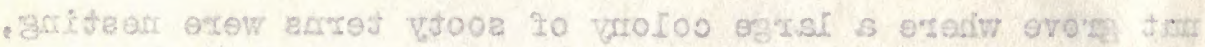

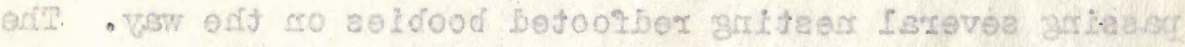

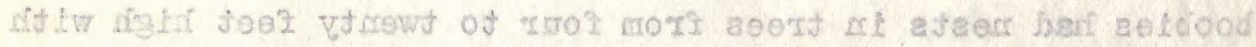

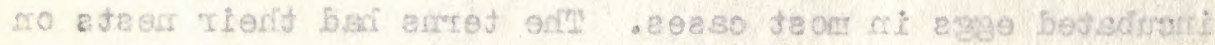

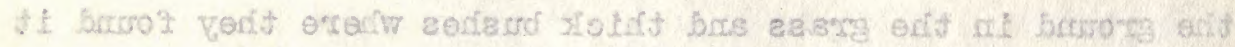

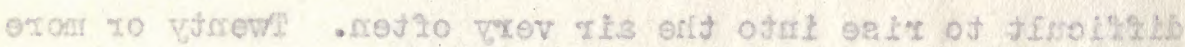

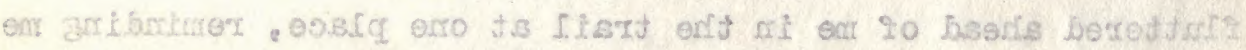

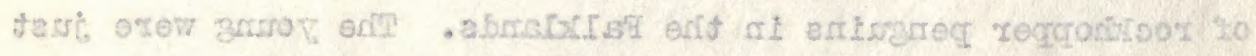

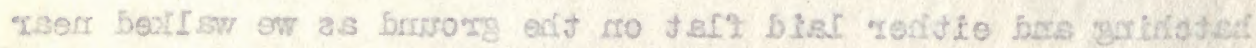

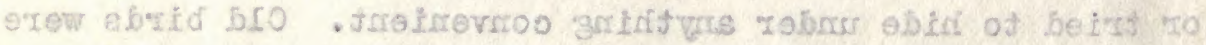

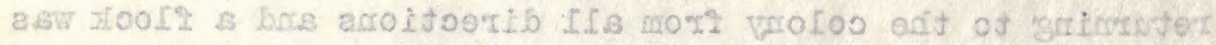

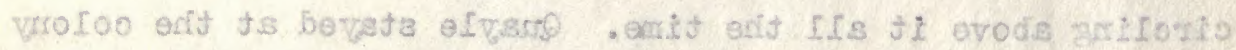

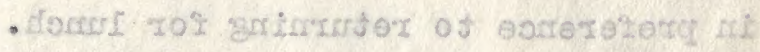

\section{AI KTseTicos}

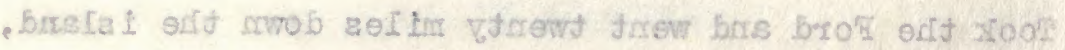

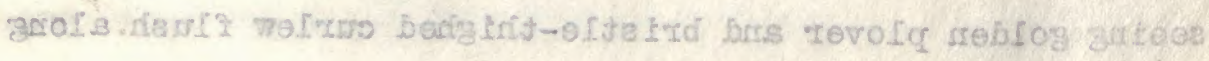


side redfooted and bluefaced boobles and frigate birds' nests. On an islet where wading lmoe deep for a hundred yards to reach it was required, a number of parvirostris were nesting under the bunches of grass and Quayle shot a red-legged turnstone that lit near us on a point. Wany red-pouched frigates were sitting in bushes and a few were on nests. Three or four bluefaced boobles were standing at nests, but most of this species probably nests nearer shore. Shot a black cat scared from a thick bush. Shot $\not$ six curlew along road. Not meny warblers seen, though a few.

\section{February 15}

Skinnod birds on board all day.

\section{February 16}

Took sailboat and three boys and went to Motu Tabu where owner of island reported unidentified shearwater nested under leaves of coconut trees. We finally found a young bird and one more by offering five francs to finder. When no more were found I offered ten francs and crev got busy, resulting in eight or nine birds being located. Some were under grass roots like the many nativitatis and parvirostris and several cuneatus shearwaters found nesting. Nativitatis were sitting in places under bushes along shore, while the parvirostris favored the 


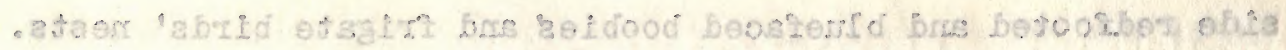

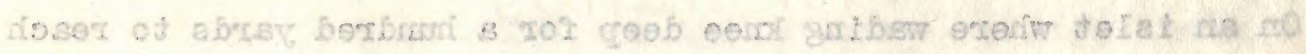

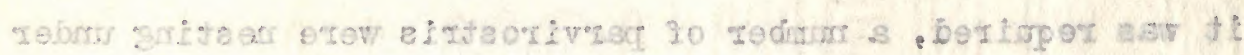

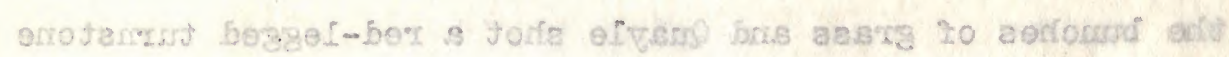

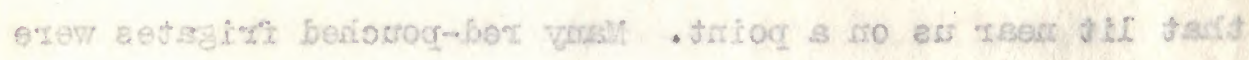

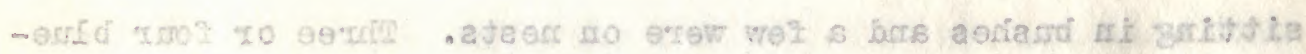

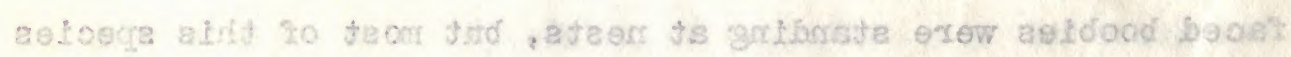

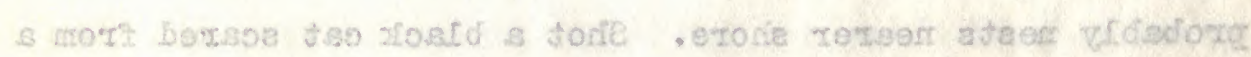

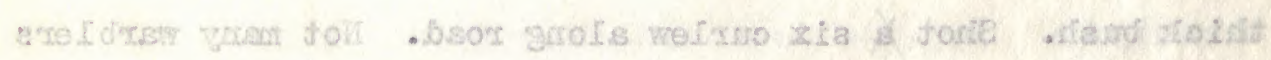

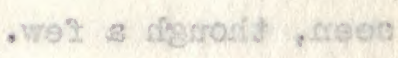

dI kasuréed

- vab Ifle brsod tro abrid bocur ixte

\section{af vesersiet}

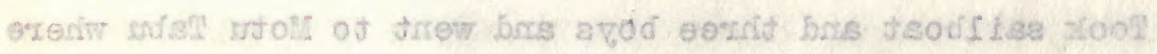

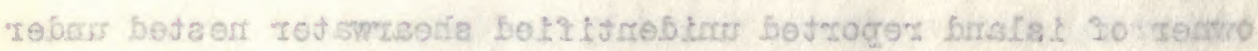

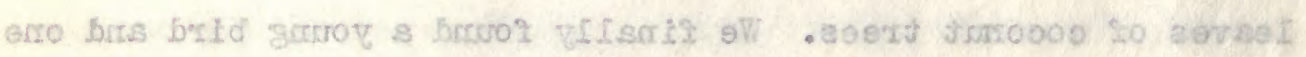

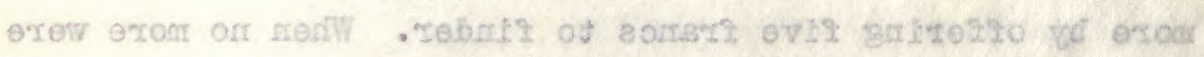

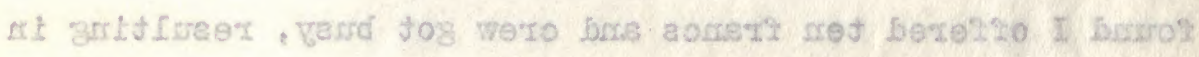

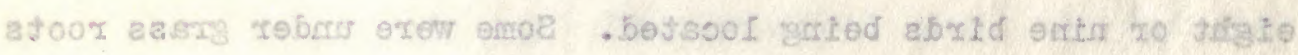

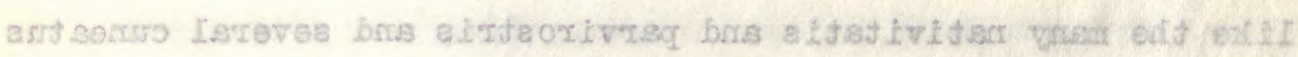

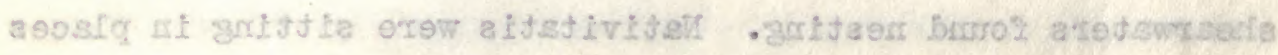

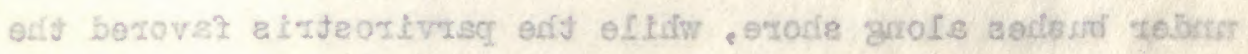


grass roots for nests and the cuneatus usually dug a burrow in one part where the soll was sandy. Two or three gray terns' nests were found on the ground under grass stalks, and two or three noddy nests with eggs seen under bushes. Fropic-birds had fresh eggs and young in all stages and lesser noddies have finishod nesting.

\section{February 18}

Ashore and found sail-boat broken by heavy sea this morning and motor boat also out of commission, so finally took ship!s boat and with load of fresh water aboard went to Cook Island. Found rectirostris, sooties, noddies, lesser noddies, gray and gygis terms, the young noddies being lighter below than the old birds. Iwenty or more joung tropics were under bushes and small trees, and a few old birds were also sitting around and several were taken. Iwenty or so redfoot boobies were sitting in trees, and a couple of eggs of gygis were seen on limbs of trees with no nest but bare wood. Sooties were sitting in flock in grass. Quayle shot a tatler and I saw a curlew on the island. Three hundred or more lesser noddies sitting on trees in flociss; a fow nativitatis seen but very little grass on island to hide under.

Ashore in P. M. and said good-bye. Fook a dozen of the natives whose contracts had expired and sailed about three 


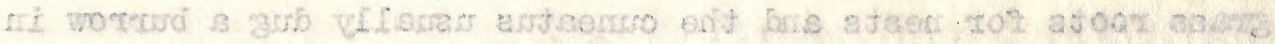

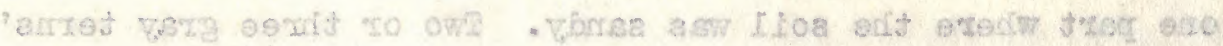

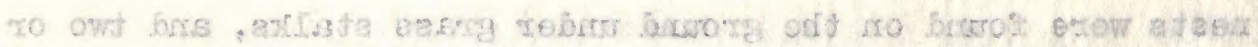

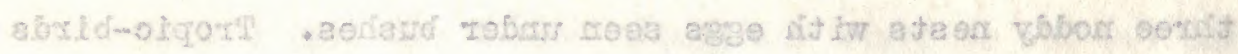

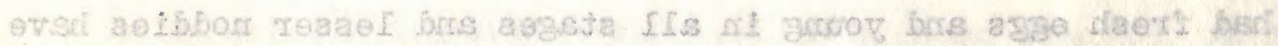
- ger iłaer seria in?

\section{3. veserciet}

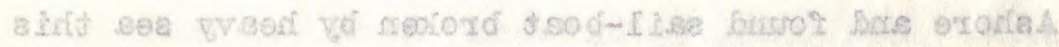

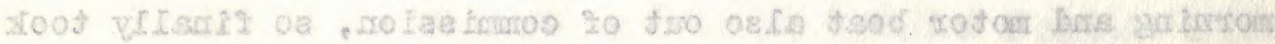

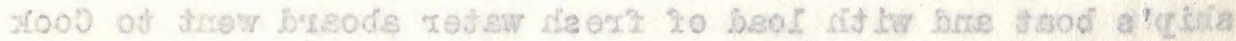

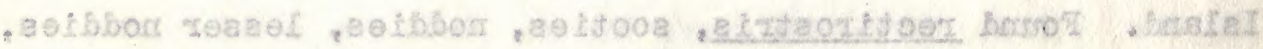

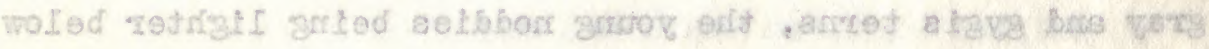

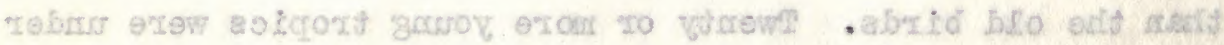

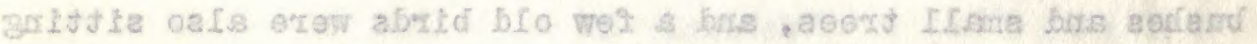

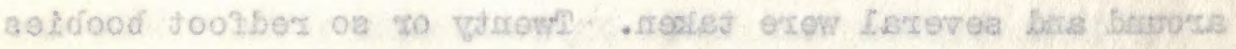

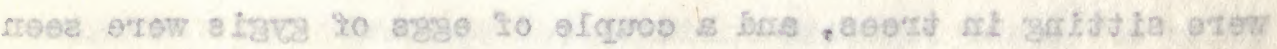

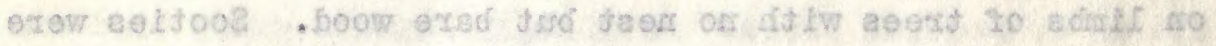

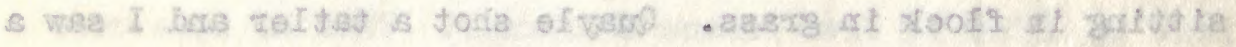

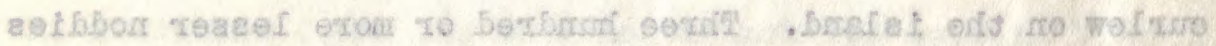

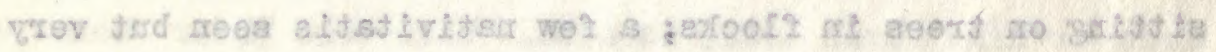

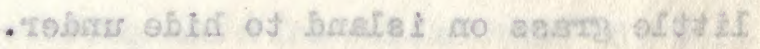

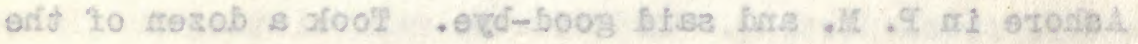

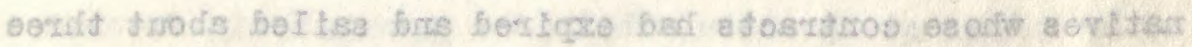


o'clock down the west side of the island. A few miles from the lagoon entrance another bif flock of terns was seen circling over shore, indicating another rookery there.

\section{Fobruary 19}

Skinned birds all day, having over 250 from this island in eight days, but the Captain and engineer skimed quite a few for us and we made up most of those they sirimed.

\section{February 20}

120 miles south of Christmas Island, heving left day before yesterday. Sooty terns frequent, several blue-faced and red-footed boobies, two cuneatus, one redtail tropic, and one white-throated petrel recognized and several other petrels seen. Heading about SEI/2S. Iittle drizzle in evening. Birds either heading toward or from direction of Christmas. One parvirostris seen in evening.

\section{February 21}

Jib-boom carried away and mainsail dropped to deck this morning at ono o'clock in a squall, but mainsail hoisted at eleven o'clock again. Two or three kenas or blue-faced boobies and a sooty tern or two only birds seen. I slimned four small birds after lunch. One gygis tern was very thin, but two downy 


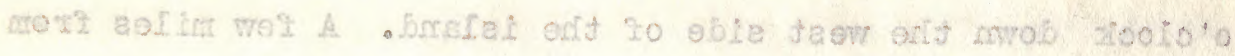

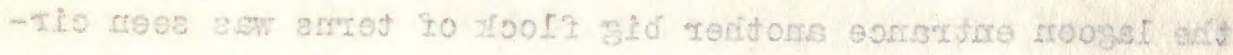

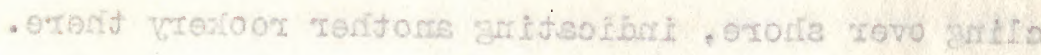

\section{et. vorsurdote}

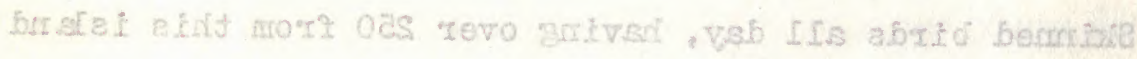

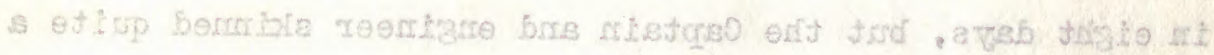

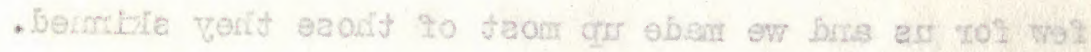

OS pusircoler

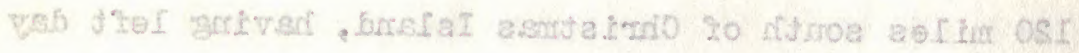

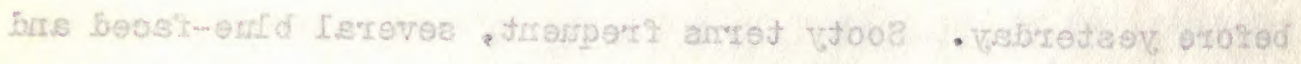

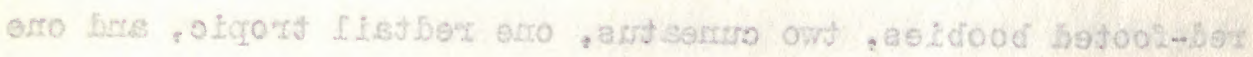

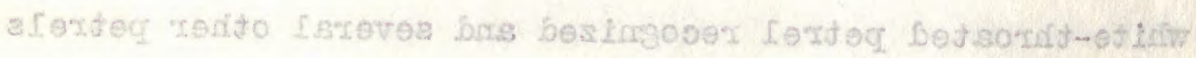

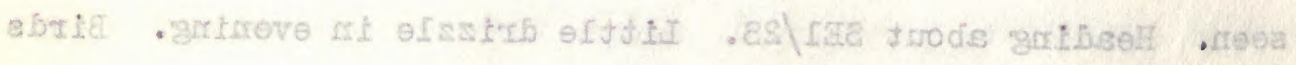

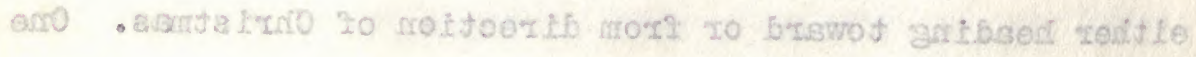

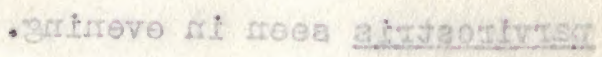

\section{IS krsivide}

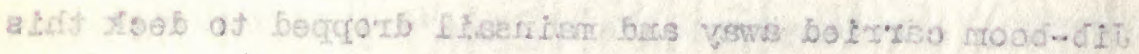

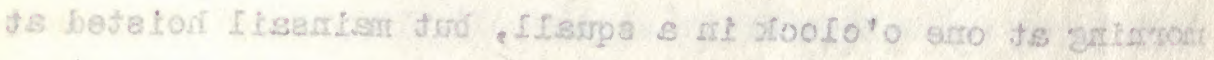

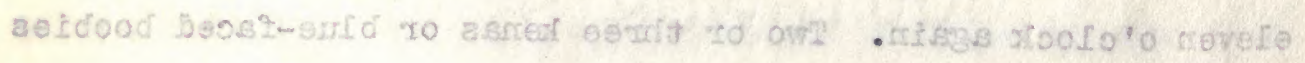

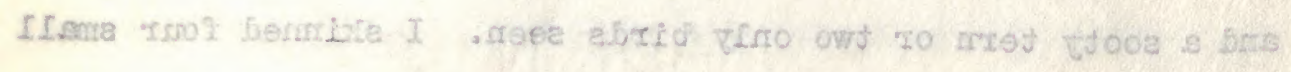

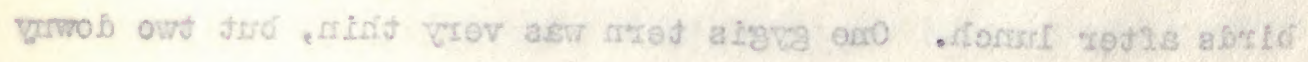


parvirostris were very fat, much fatter than a downy nativitatis. All these were taken five days ago on Motu Mabu. "Wahou, wahou!" is the call of nativitatis, while "Kik, kik, kik!" is usual call of parvirostris,-weak resemblance to call of duck hawk. Strong wind in morning but lightenod and light at sunset.

\section{February 22}

Fair breeze but lightening in evening. Motor going all day, maing a little better than south but far to west of Malden, though heading SE. A half dozen sooty terns and a single frigate were birds of day.

\section{February 23}

Saw a single aestrelata, dark grayish on back and dark below seemingly at a distance. Sooty terns all morning coming from ahoad, and at eleven o'clock I saw Starbuck four miles or so to the west. Low sandy,--no regetation showing. Sooty terns, a frigate and one young plotus booby were only birds seen.

\section{February 24}

Flock of sooty terns, three hundred or so, seen in morning, and smaller flocks seen all day fishing. Eighty-five miles south of Starbuck at noon and at five o'clock over a hundred and terns heading that way at sunset. Three sygis terns seen at four o'clock 


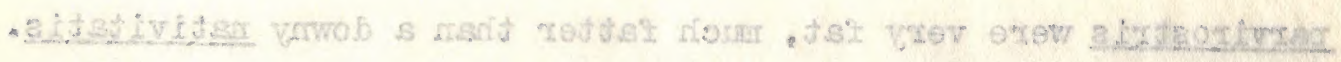

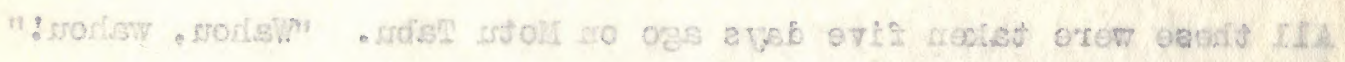

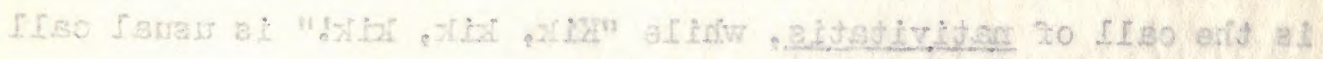

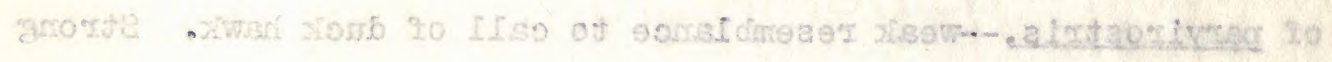

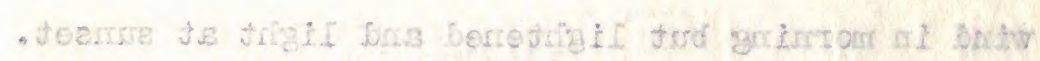

\section{SS Vtosumcte日}

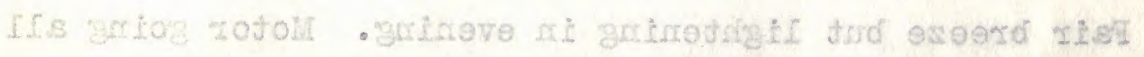

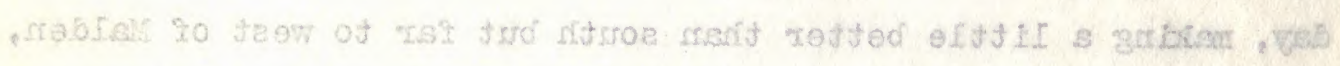

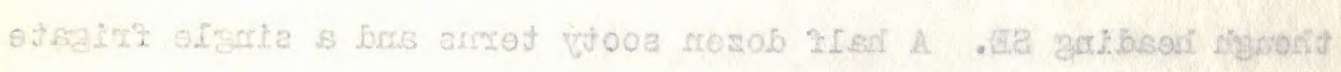
- Veb to ebrid geser

ES Xasurciol

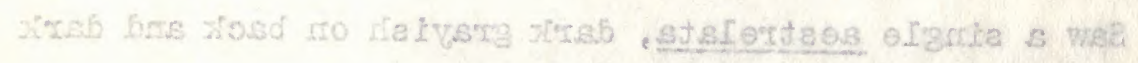

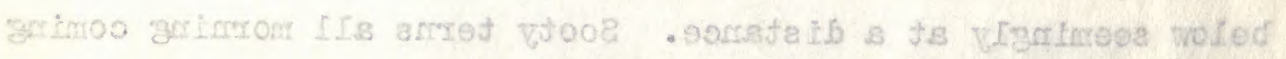

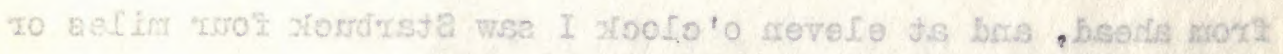

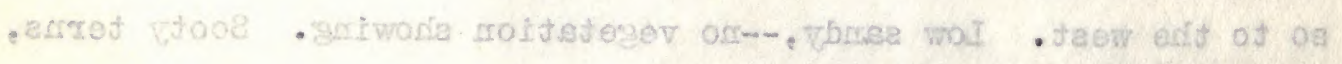

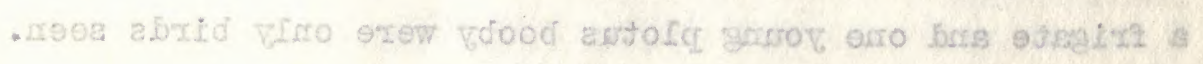

AS. Zasuruto:

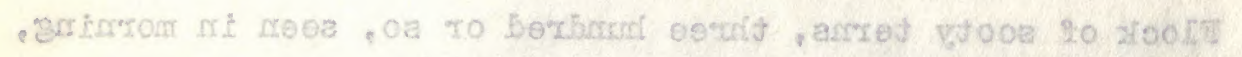

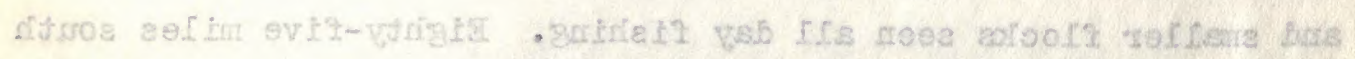

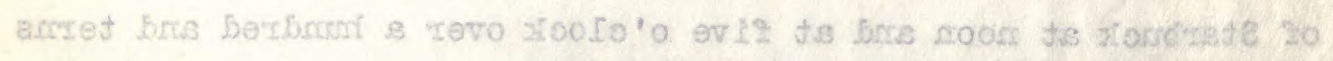
zisotolo $200 \%$ t. 
fishing with twenty sooties and a couple of frigates seen in morning with flock of terns. A bonita ceught in P. M.

\section{February 25}

$9^{\circ}$ S., $154^{\circ} 30 \cdots$.

Dozen or so sooty terns in morning heading back toward Starbuck 150 miles astern. In P. M. a gygis term, a yellow-bill tropic and a dark red-foot booby around vessel. These work off ahead and probably come from Penrhyn or possibly Vostok, as we are nearer them than Starouck.

\section{February 26}

Several flocks of sooty terns during day and gygis terns seen. One flock, four or five boobies, two frigates, and a shearwater or two. In P. M. a couple of bulweri flew across bow and I shot one of them, the first of the tubinares to be secured in the South Pacific this trip. A white-mump petrel and a cuneatus (?) seen also in P. M. Light wind and calm.

\section{Fobruary 27}

$$
12^{\circ} \mathrm{S}, 153^{\circ} \mathrm{W}
$$

A couple of dark shearwaters and a dark red-footed booby were the only birds seen today. Iwenty bonita were caught last night at five o'clock in a few minutes, two being in air at one 


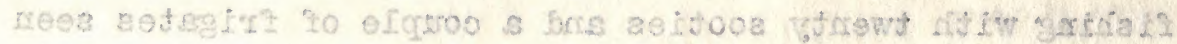

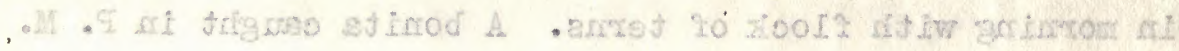

as vessmocist

$$
\text { -W " }
$$

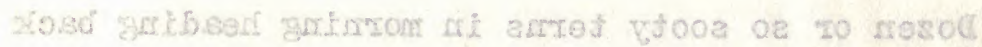

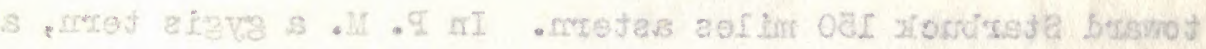

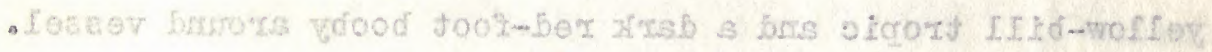

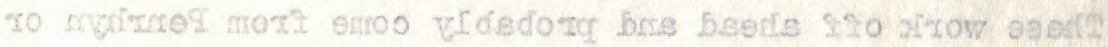

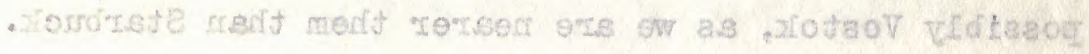

\section{dS Trisurede}

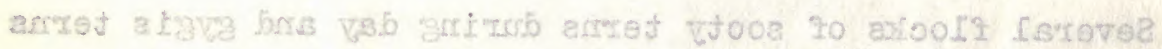

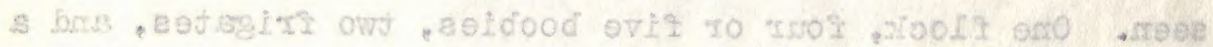

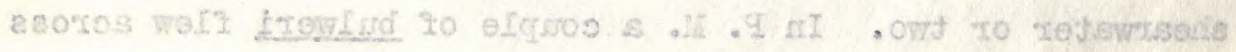

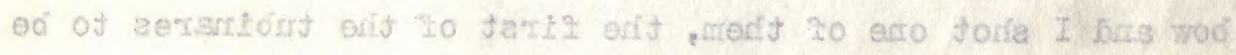

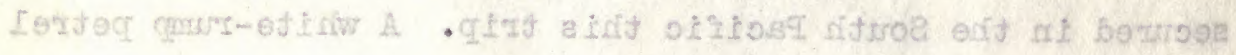

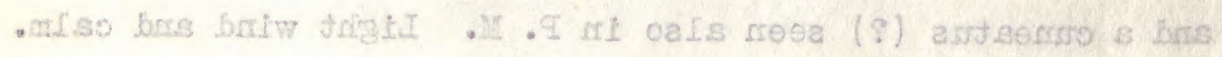

\section{is vescriodod}

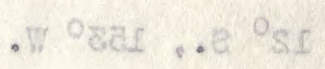

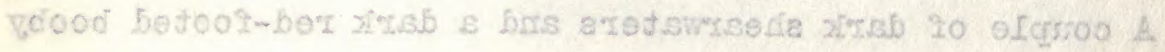

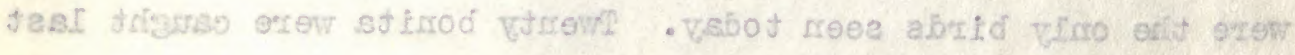

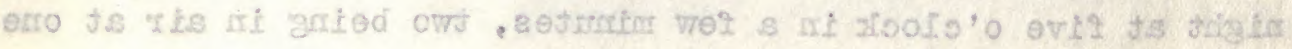


time on the barbless native hooks. Fight handred miles west by south of Flint Island and four hundred to Iahiti. Very light wind a.1 day, but only gasoline for two days' steaming, so will save it till a little nearer port.

\section{February 28}

Light wind from north for awhile today, but started motor at three o'clock. Very few birds, a gygis, noddy and a couple of sooty terns, a redfoot and an old plotus booby, and a shearwater or two. The noddy was a joung ono with several fish in crop and was farther from land, a handred miles further soutinwest of Flint Island than I remember seeing this species before. It was in company of a sooty tern.

\section{Varch 1}

Variable and no winds today, and motor going all the time.

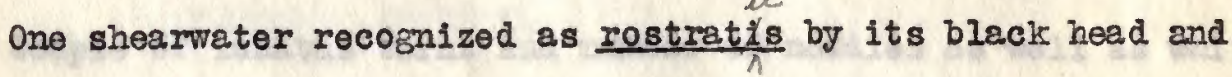
white breast and larger size than pervirostris. A black shearwater of same size scared from water in P. H. Three or four sooty terns, a frigate and a booby or two were the birds of the day. 240 miles from Tahiti dead reckoning. Ho sun.

\section{March 2}

Fair breeze part of day, but motor going most of time. 


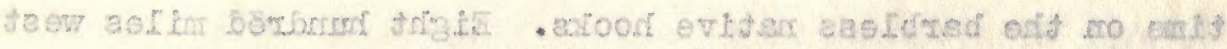

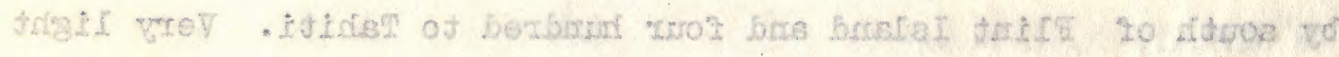

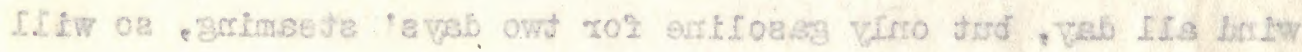

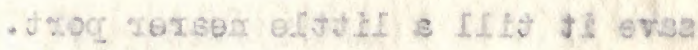

\section{$8 S$ trestrotos}

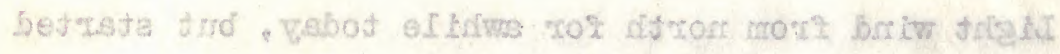

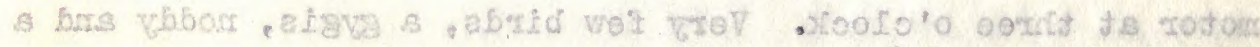

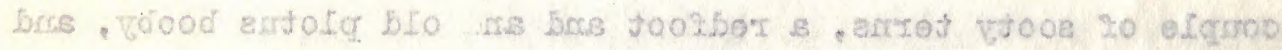

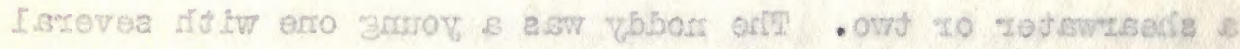

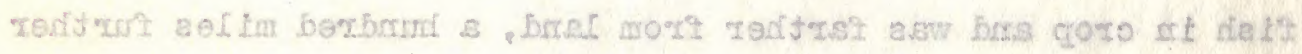

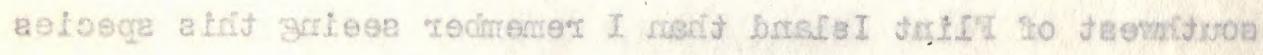

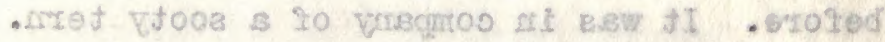

\section{I diorisi:}

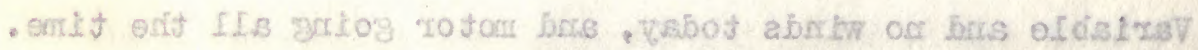

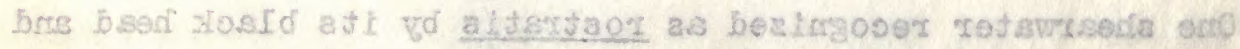

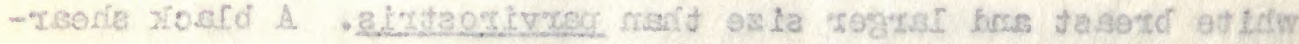

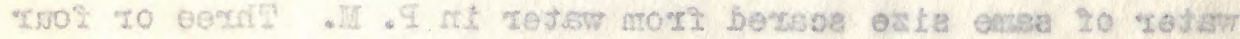

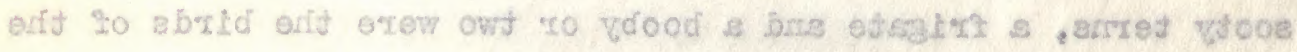

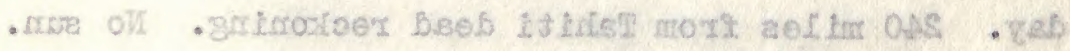

\section{S fioveslit}

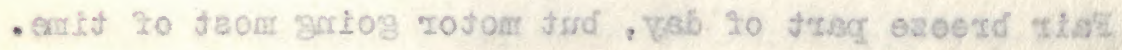


Captain thinks he can make Papeete tomorrow night, as we are but 150 miles. Several dark and rostrata shearwaters seen. Dark ones littlo larger than cuneatus and shorter tailed. A lunatus tern came up to vessel in A. M. and I shot it, the Captain obligingly circling back for the bird as it dropped oat of reach of the not. Three or four dark red-footed boobies were noted and a couple or so sooty terns.

\section{March 3}

Made Papeete by six $0^{\prime}$ clock, but Doctor kept us on board all night as we came from a foreign port. Beat along the west coast of Hoorea for several hours in strong breeze. Quite a few redfoot boobles close to reer and only one seen as white as Christmas birds. Practically all had wite tails and some were whitish underneath. A couple of auricularis shearweters as well as several rostratas seen off Noorea in the strong breeze. Couple of lunatus terns and mamber of noddies as well as white ones.

\section{March 7}

Quayle went up in hills to look for shearwaters again and returned on the sixteenth with a single P. rostrata which he got in a burrow. Iwo other burrows had been entered lately, but the birds were away. I packed birds and shipped them and 


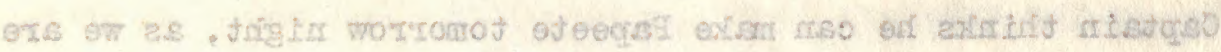

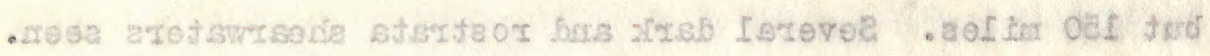

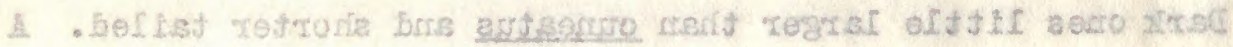

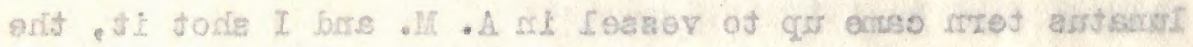

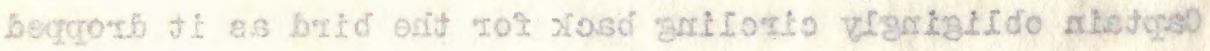

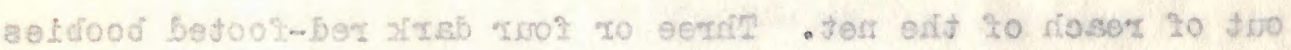

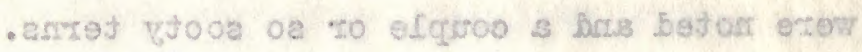

\section{8 frorent}

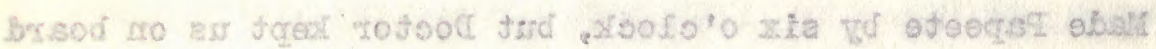

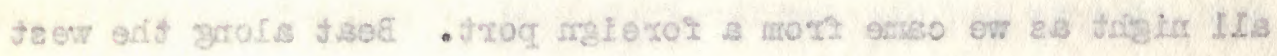

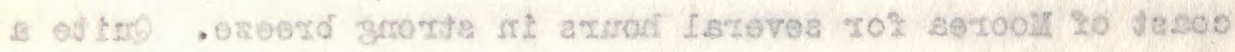

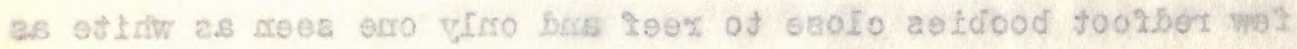

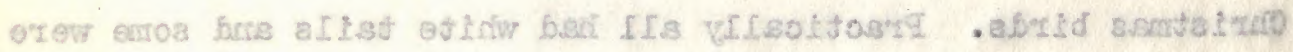

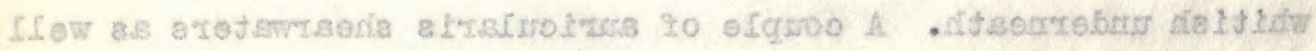

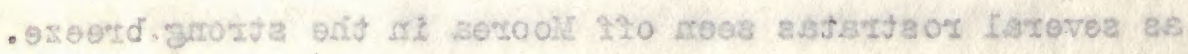

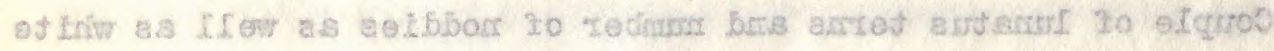

\section{Ioxed}

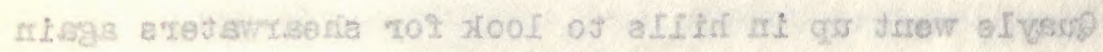

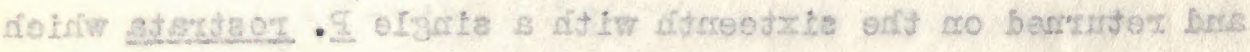

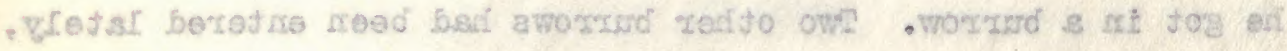

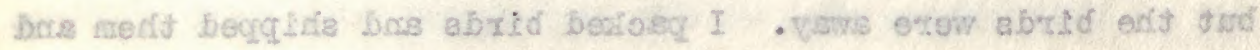


developed pictures.

March 18, 1921.

Started for the Austral Islands and Rapa Island at five o'clock, but didn't get the anchor up till eight $0^{\prime} \mathrm{clock}$, as anchor of "Moana" and anchor of a small sloop were tangled up with the anchor of the "Pro Patria", our boat.

\section{March 19}

Tahiti far in the distance at daylight and very few birds about. A sooty tern and a half dozen shearwaters noted; ono pterodroma passed far off,-looked white-tailed or ramped, dark abdomen. Iittle wind and smooth sea. Heading south. $150.20 \mathrm{~W}, 19.04 \mathrm{~S}$

\section{March 20}

$150.40 \mathrm{~W} \cdot 20.28 . \mathrm{S}$

Calm or light wind all day. Engine started at daylight. Pair flying and a single tropic on water; a sooty shearwater flew past to north in P. M. and one other seen in forenoon. 120 miles from Rarutu at noon, motor stopped during night last night but going all the other time.

\section{Narch 21}

Saw Rurutu at daylight, but motor trouble kept us back, so arrived at noon. Saw three or four shearweters twenty miles 


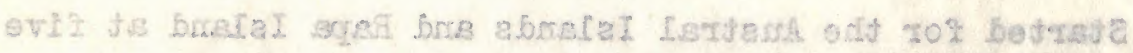

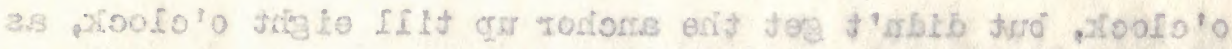

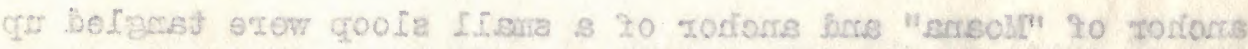

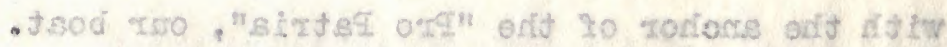

\section{e. fioralt}

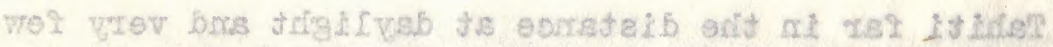

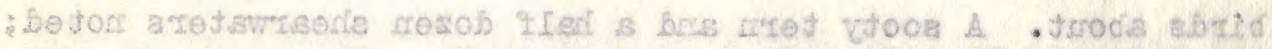

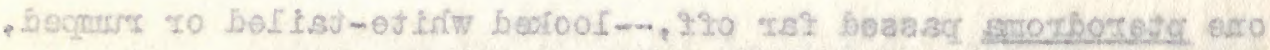

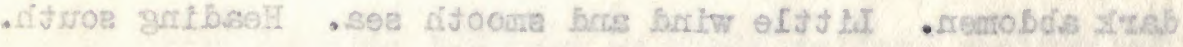
.8 DO.eI, a.W OS.OEI

OS ciorgent

$$
.2 .85 .05 \text { - OS. OAI }
$$

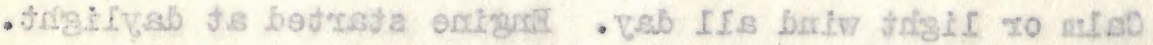

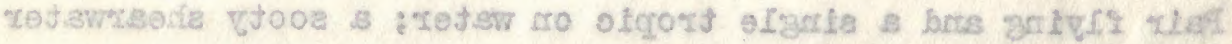

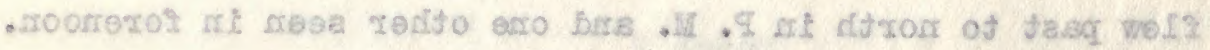

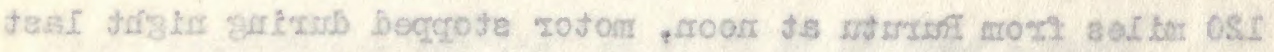

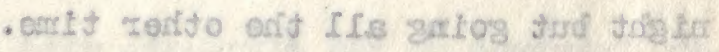

\section{IS ISTakm}

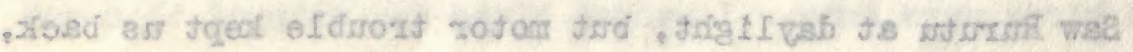

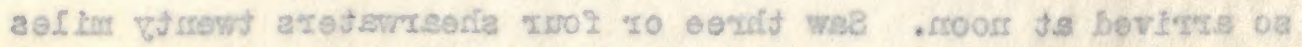


off, but none noar the island,--dark breasted the size of auricularis or little larger. Two or three sooty shearwaters, singles, flew past to north yesterday evening. Ashore this P. I. and got permission to collect. Saw a cuclsoo just before reaching the Administrator's house, but saw none after. I went up into the hills in the rain but saw no land birds, though about the village were a few minahs. A few gygis terms and several noddies were about and along shore were tatlers and reef herons.

\section{March 22}

Ashore at six $0^{\prime}$ clock in the morning and around several miles through coconut and ranilla plantations. Few mango and orange trees seen. Cliffs at one place three hundred or more feet high,--coral up a good way if not to the top. Couple of redtail tropics seen at the cliff and noddy and gysis terns were along shore as well as reef herons and tatlers. Quayle shot one of several golden plover seen and blew a yellowbill tropic bird to pieces in a cave, of which there were many in the face of the cliffs.

The island has trees principally in the canyons and along shore, ferns covering the upper part of the island and these are frequently bumed. One old man said shearwaters used to be taken and the eggs and young eaten, but not now. Iromwood is 


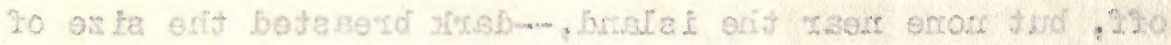

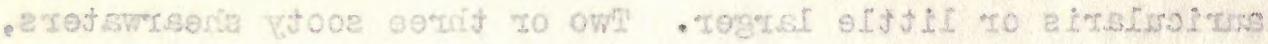

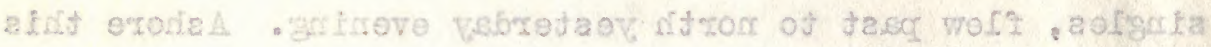

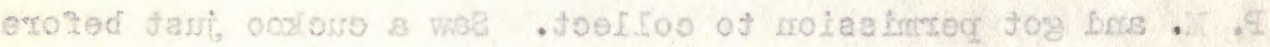

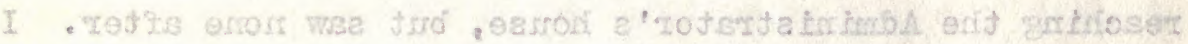

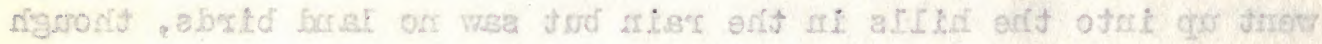

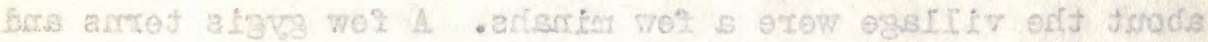

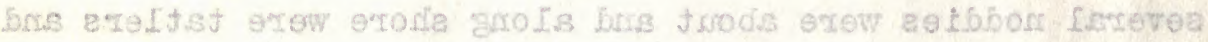
- amoved roos

\section{SE dioresith}

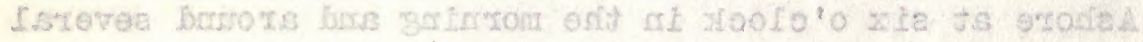

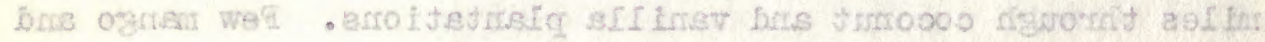

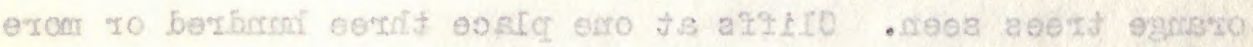

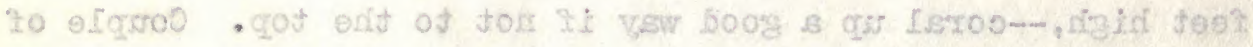

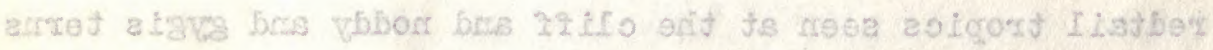

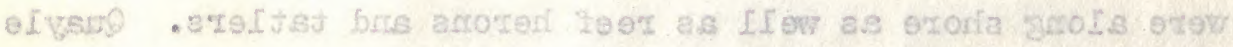

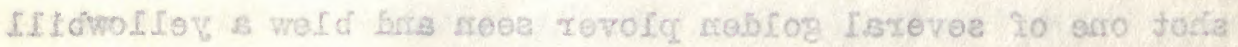

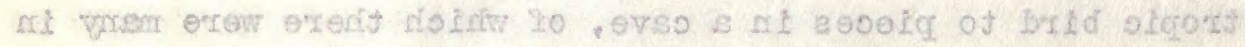

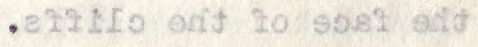

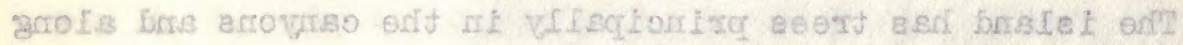

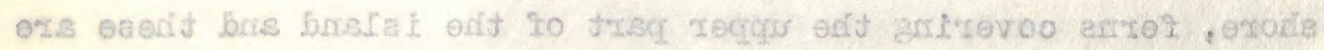

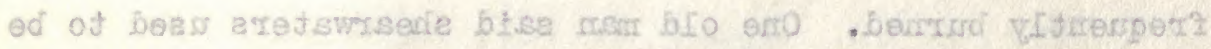

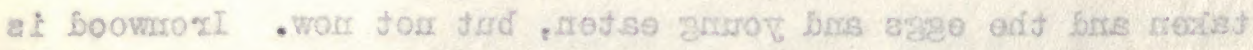


the principal tree on the hills; scattered trees on some ridges; many pandanus trees were close to shore. Coconuts did not look plentiful, but many young trees were seen.

March 23

Expected to leave this village at nine A. I., but at noon we are still here. Got away at two and went to other side, picked up a little cargo and left for Rimitara after dark.

March 24

Reached Rimitara at three $0^{\prime} \mathrm{clock}$, seeing only a noddy and a couple of gygis terns on the say. A low island 1300 feet) wooded along shore but few trees on higher part. Ashore in P. IT. and found warbler and parrakeet common and cuckoo rare. Shot one cuckoo and several warblers and parrakeets. Wandering tatlers seen in taro beds in mud. Oranges not quite ripe and mangos nearly gone; bananas plentiful, cocomits all round island on lower parts.

\section{Iarch 25}

3

Went to top of island, winich is only, miles or so in diameter. Clump of trees on top and ferns cover ground above one mandred feet; clumps of pampas grass near top. 


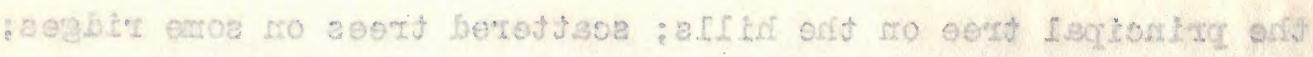

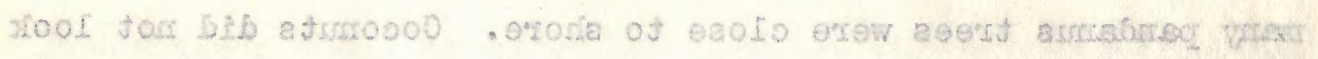

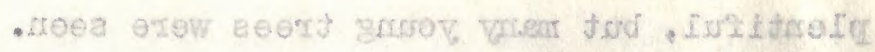

8. rionsid

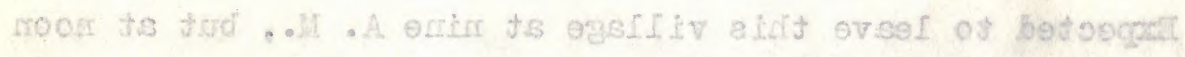

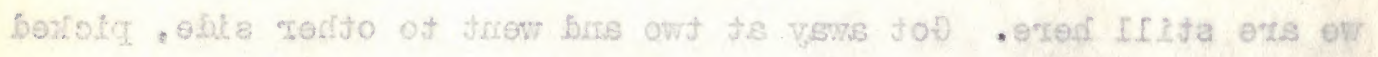

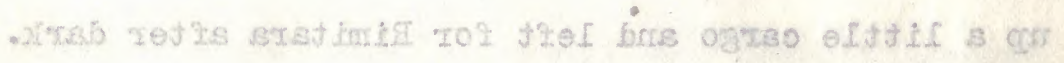

\section{As forall}

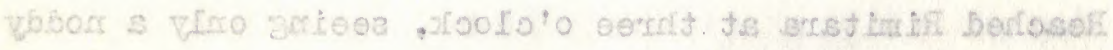

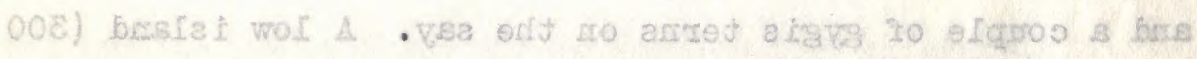

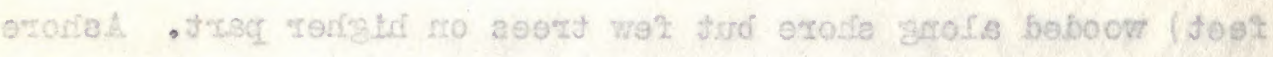

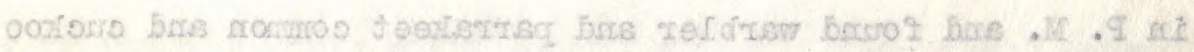

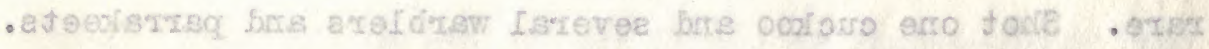

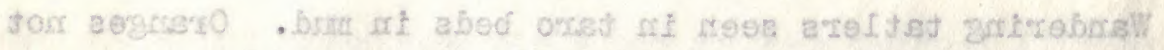

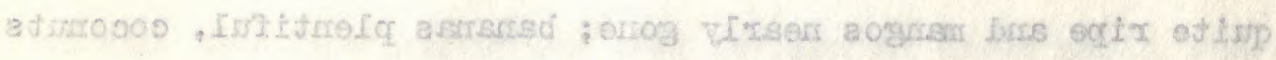
- atrag tevol, ro besial bonot ifs

des somali

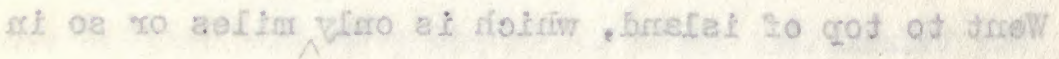

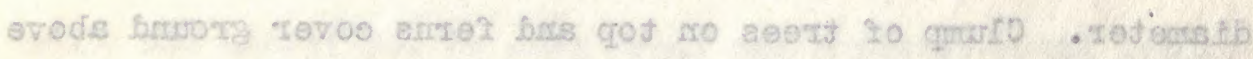

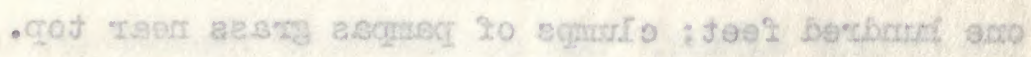


March 26

Few birds taken and skimned. Nany of the adult warblers show albinistic tendencies in greater or lesser degree.

Narch 27

Sunday and ashore awhile and got few photos.

Marcin 28

Few ducks seen; they seem to spend the daytime on the dry hillsides above the taro fields where the water is found. Noddy and gygis terns seem to be only sea birds here at present, one handred or so of each being noted in a day.

March 29

Quayle got three ducks today out of twelve seen and I skin birds.

March 30

A mile off shore at nine A. II. a crekoo seen fifty yards above water flying toward the island from the west. A flock of terns fishing in the direction he came from, but not unlikely a migrant from the Cook group.

Yesterday took some copra from the east side of island, but boat nearly swamped and as engine not in good shape Captain 
aS Aors'th

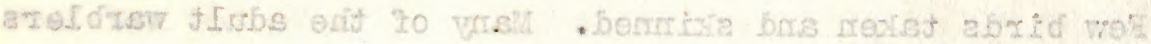

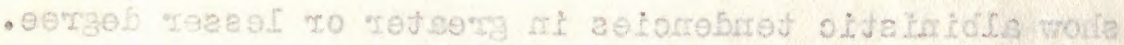

res forsit

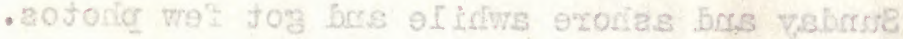

85 storsis

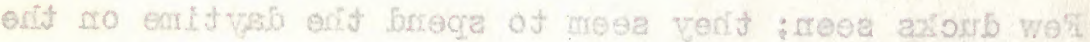

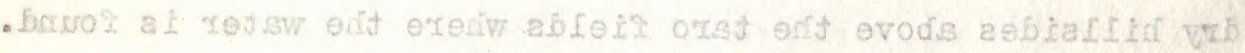

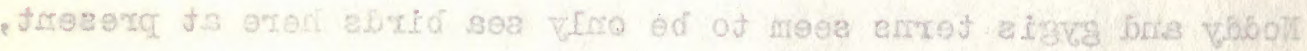

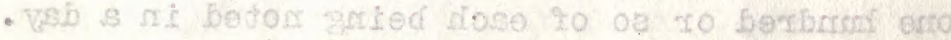

\section{es rionsith}

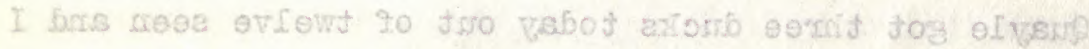

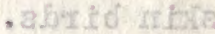

\section{of romill}

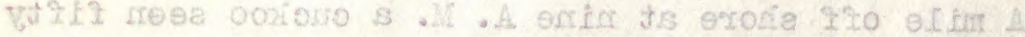

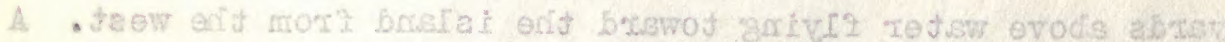

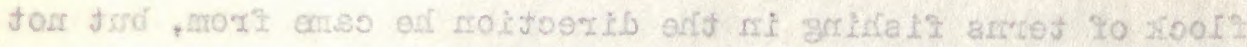

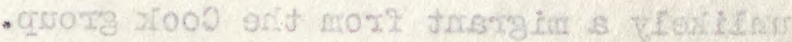

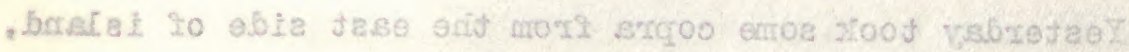

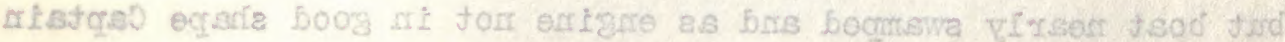


decided to work only from the lee side where the channel is not wide enough for men to use oars when tide rans out.

Apri1 1

Left the island at five P. H. for Tubuai with a dozen or more passengers for Tahiti.

April 2

At dayligint fifteen miles or so from Rimitara heading SE. In P. M. a few dark shearweters seen, one aestrelata light-breasted and grayish backed and another larger seemed white-headed, dark-backed and white-breasted. The dark birds looked mach like sooties, but appeared a little heevier. The dark birds were mostly headed north.

\section{April 3}

Gygis tern and several shearwaters and couple sizes aestrelata seen.

\section{April 4}

Four gygis terns and no shearwaters seen today. Tubuai about fifty miles to eastward. A couple of shearwaters seen last night were probably sooty, as the axillaries were whitish as they swang away from the sun. Nany of the others seen last 


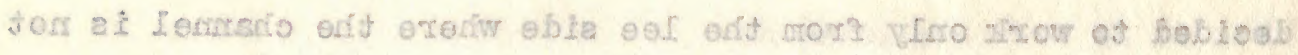

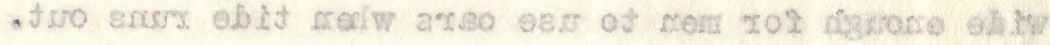

\section{I I g}

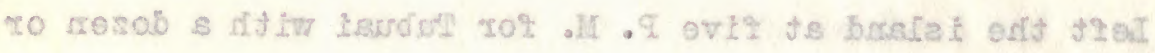
- Attrian rot atregreassg orail

\section{S I I rog $A$}

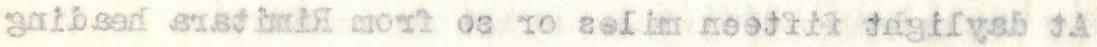

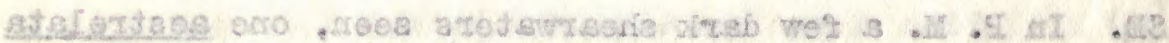

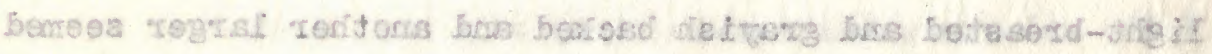

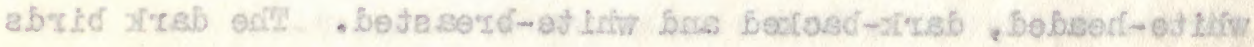

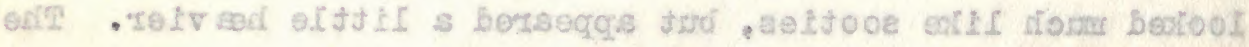

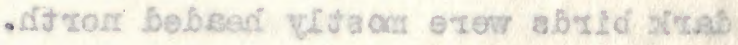

E I.req

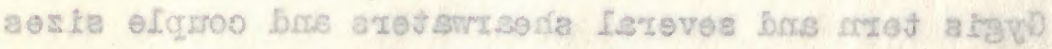

- mpos atsfortase

\section{$\$ \operatorname{lig} \mathrm{A}$}

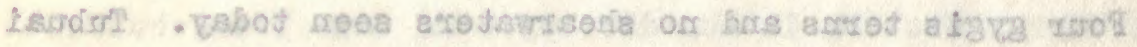

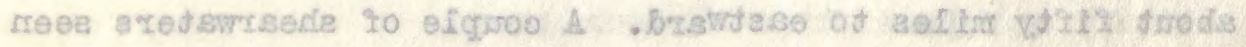

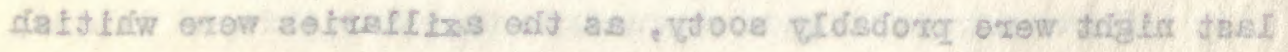

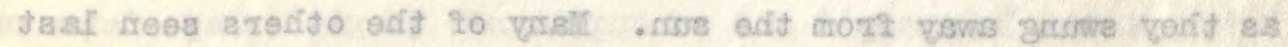


two days were likely sooties also, though two or three kinds of Pterodroma were seen too. Wind today has been from the IT. E. which possibly accounts for the shearwaters yesterday.

\section{April 5}

Falr wind this morning and we reached lubuai at noon. Shot a redtail tropic a few miles off shore and a flock of fishing noddies and gygis terns seen five miles off.

Went ashore in P. M. and went above the trees of the lower part of the island, seeing a cuckoo and several minahs as the only land birds. Quvyle went in another direction and saw no land bird but minahs which seem to keep about the house.

\section{April 6}

I took the small boat and with a sailor went to two islets on the reef three miles off shore. A half dozen frigates left before I landed, but a dozen noddy and a hundred or more gygis terns were flying and lighting in the trees, and when I shot a term a cuckoo flew to a tree above the wounded bird and was taken. On the next islet a number of lesser noddies were sitting in the trees and on nests. I climbed one tree with several nests in it, but found no egg's and the nesting season is evidently pest. No signs of shearwater nests were found, though a native said they occurred. A small higher islet five 


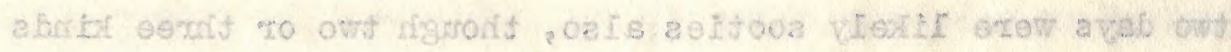

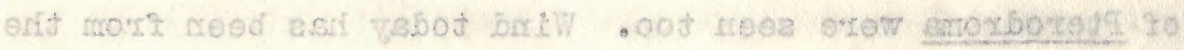

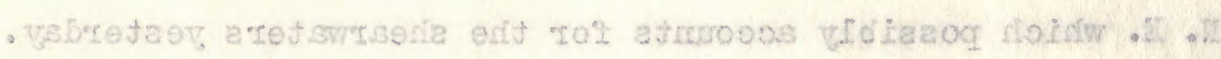

\section{atregs}

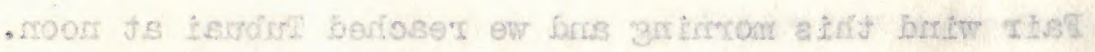

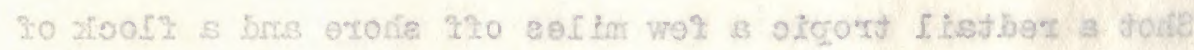

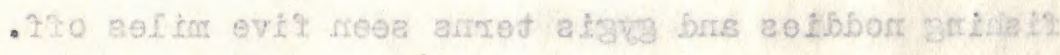

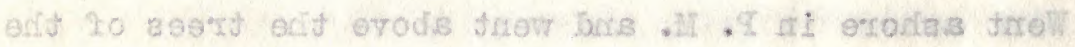

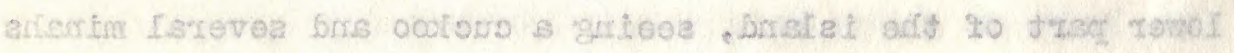

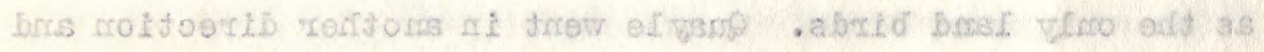

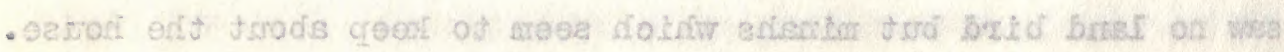

\section{IIIqA}

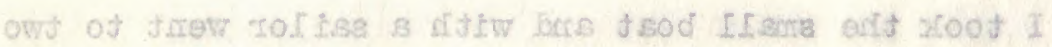

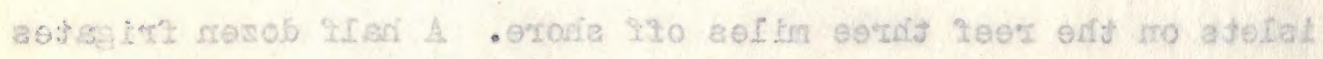

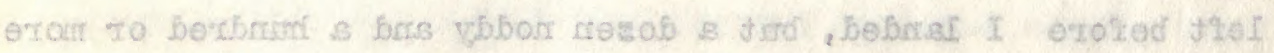

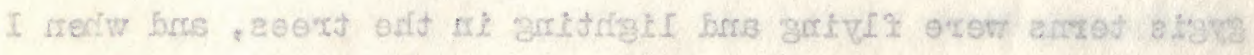

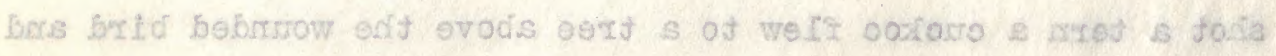

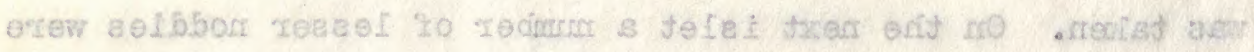

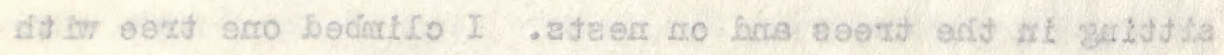

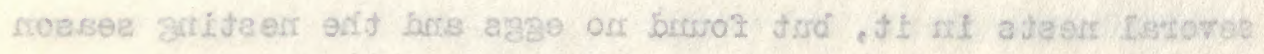

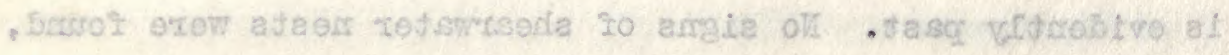

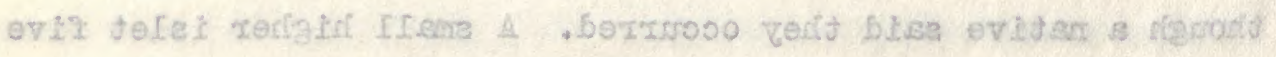


miles farther down the reef may be a more likely spot for a few to nest, but none were seen as we neared the island the last day. Quayle got a couple of ducks and two cuckoos going to the top of the island, but no other land birds noted. The natives say a bird the size of minah is found in grass in marshy places and is probably rail or gallinule.

\section{April 7}

Quayle stayed ashore to $100 \mathrm{k}$ for the rail last night and this morning, but could see no sign of them. A native said it was in very rainy weather when they were best seen. We were supposed to sail today and the two pilots came on board, but the two engineers failed to get the engine going properly by noon when the tide had lowered, so sailing is delayed till tomorrow. I skinned birds in forenoon and Quag le waited at outer village till two P. M. Then I went over and got his couple of ducks and a heron, leaving him to look for rail and ducks tonight and tomorrow morning.

\section{April 8}

At 9:30 time for pilot to be aboard and the Captain and ongineer are so busy fishing over the stern for small fish that it is probable we may fail to catch this tide out. Four small dolphins have been caught in the first hour and a few needle 


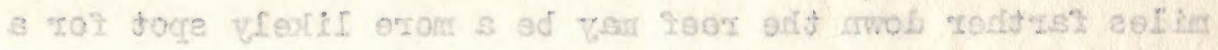

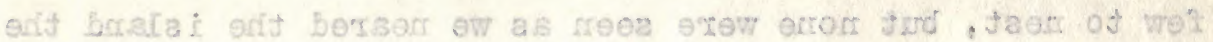

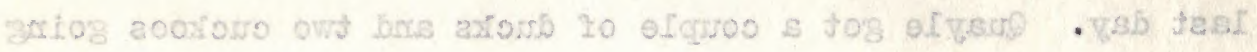

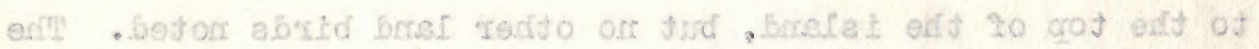

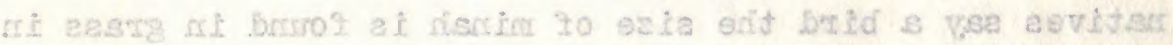

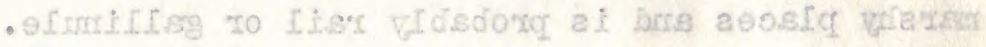

\section{$\Gamma \operatorname{ing} A$}

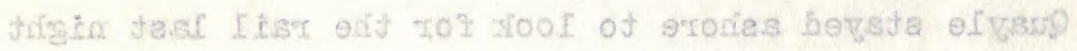

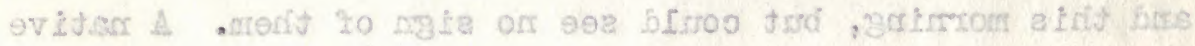

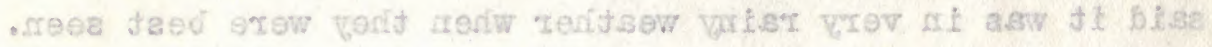

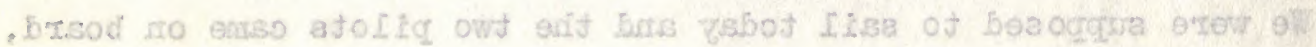

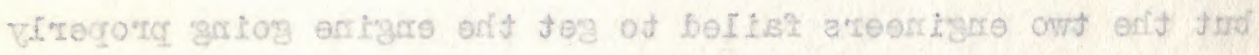

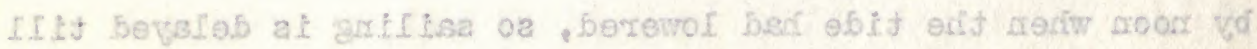

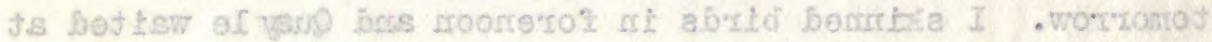

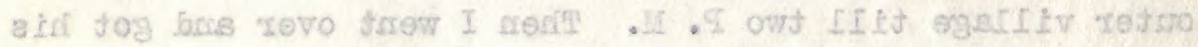

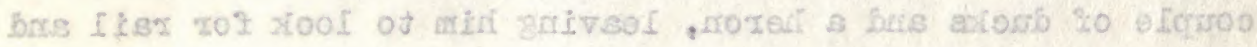

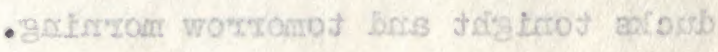

\section{I Irga}

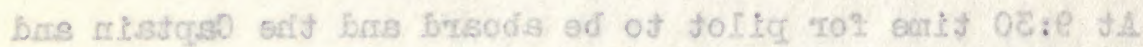

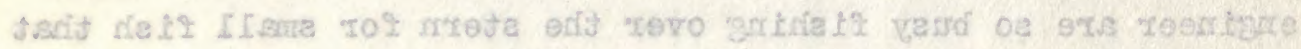
Ifeme woot. of

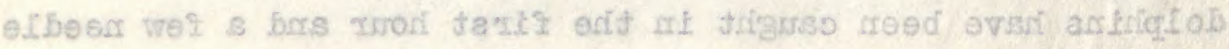


fish (?). The boat returning with a load of water is waved far off to one side as it approaches so the school of fish won't be scared.

\section{April 9}

A sygis term and a half dozen shearwaters, two or three of which were Iikely sooty, and one large white-breasted seen.

\section{April 10}

Perhaps a dozen shearwaters all daris above and one of them white-breasted were noted during day. Some rain and cloudy all day. About 130 miles from Tubuai, heading east by south part of time.

\section{Apri1 11}

Five gygis terns and a couple of redtail tropics were seen before noon, but no shearwaters. Calm till noon, when a Iight breeze began.

Apri1 12

Couple of redtall tropics and an occasional shearwater. Strong wind from west, mainsail taken in at dark.

\section{Apri1 13}

Weather fine with light wind. Fifty miles from Rapa at 


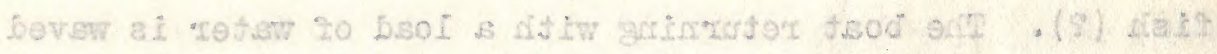

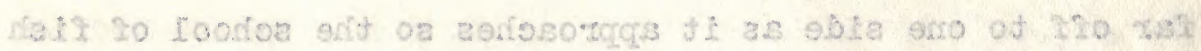
- Sigecsua of thew

\section{e Ligg $A$}

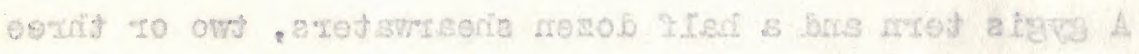

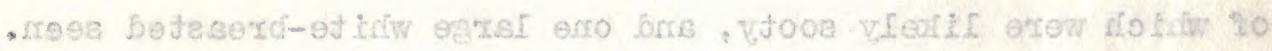

\section{of tirge}

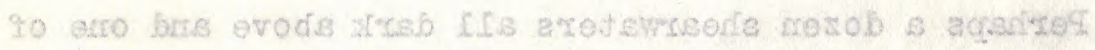

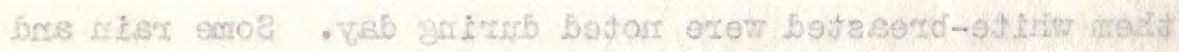

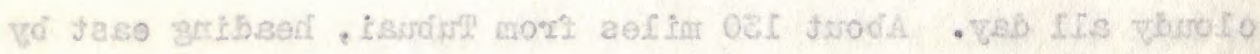
- extif to stracg altinod

\section{If Iixegh}

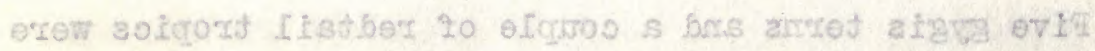

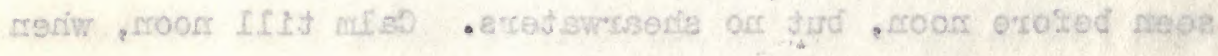
- rsged exeard the if a

\section{SIf IITgA}

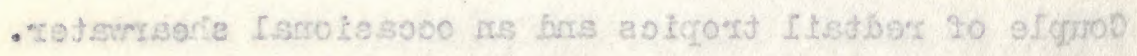

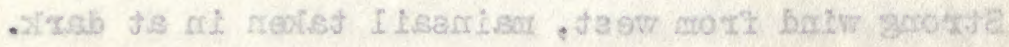

\section{EI I Irgh}

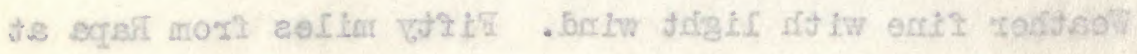


noon. A sooty shearwater and a white-breasted ono seen also. A noddy and a little gray term came around the boat in A. $\mathrm{U}$.

\section{Apri1 14}

A grallaria petrel and a few neglected shearwaters as well as noddy and gygis terns seen as we approached land. Native in canoe came aboard as pilot five miles off bay. Steep cliffs hundred of feet high line the coast with tropicbirds and gygis terns sailing along thom.

Ashore in P. M. and around bay to head of it and up on hill. Shot four ducks, and a pigeon up in the trees near top of ridge; also got a rail in a taro patch in the evening, and saw several wandering tatlers along shore and in the taro.

\section{Apri1 15}

Ashore at sunrise and over hills a.ll day, getting but two doves, though dropped two more in the thick forest where they were 1ost. Quayle got a neglected shearwater and egs and a couple of others; also a cuckoo and a couple of rail.

\section{April 16}

I stayed on board and skinned birds while Quas le spent night ashore looking for rail. 


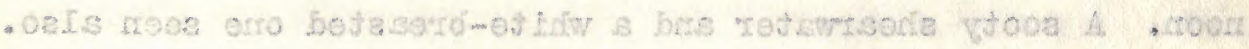

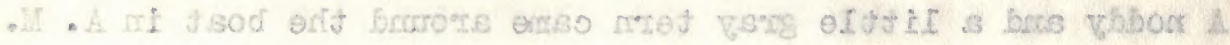

\section{AI Iisga}

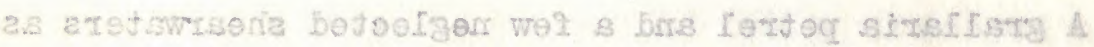

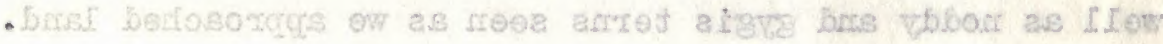

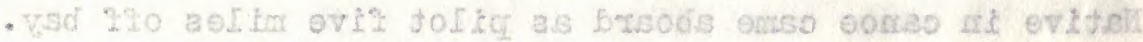

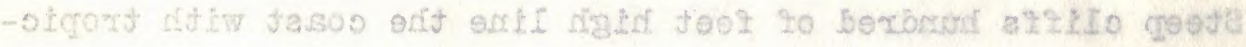

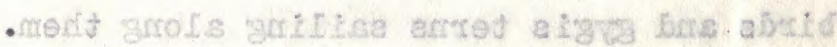

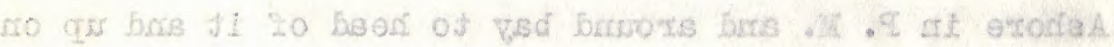

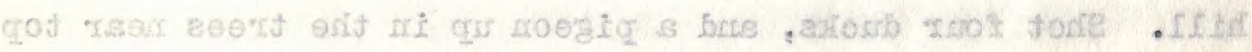

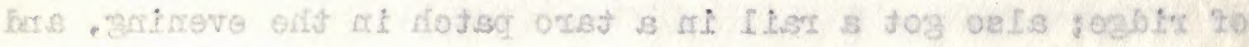

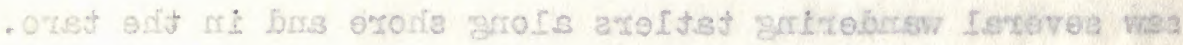

\section{c. $1 \pm \sec A$}

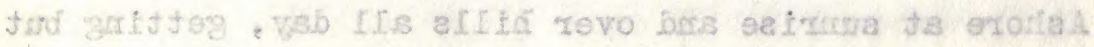

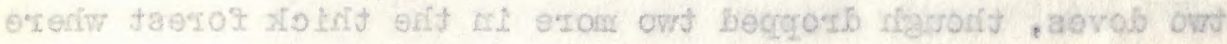

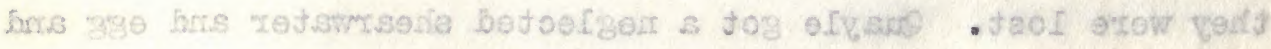

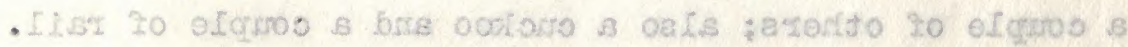

\section{$\partial I$ IresA}

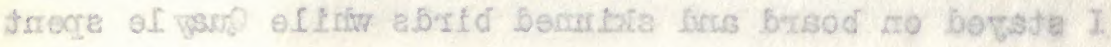

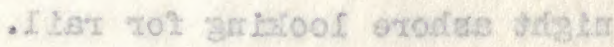


Apri1 17

Sunday. Took a few pictures ashore.

Apri1 18

I got native crew and went around coast five miles to islets where shearwaters nest. Native jumped into water and got ashore on islet and found two downy and ono old grallaria petrel nests in grass on top, or near top. Went on to point of Repa, 2,000 feet high, where neglected shearwaters were flying about cliffs. In rain and wind we jumped ashore and formd under a young pandanus bush a pair of birds, the nest having a few green leaves in it for lining, no others being found. Back into boat and lay off point awhilo shooting a few neglected shearwaters, a noddy tern and a redtail tropic. From the rabbit island the orew of a native boat brougint in a Solanders (?) shearwater and Stephen, a passenger, got one in a hole on Rape while hunting doves. Two or three or more gray terns flying about the coast and a large flock of noddy terns and one redfoot booby seen at a distance. Back to rabit island and ashore in rain and wind to look for birds, but found none and returned to ship against heavy wind and rain, having to bail frequently. Two of crew were boys fourteen years old.

Apri1 19

Ashore early to photo a duck's nest found by Stephen a 
PI isgat

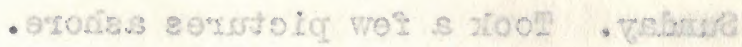

\section{I IxaA}

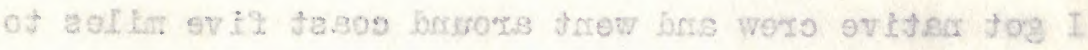

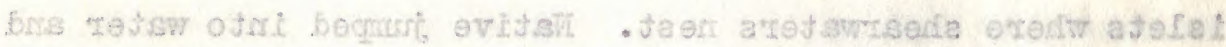

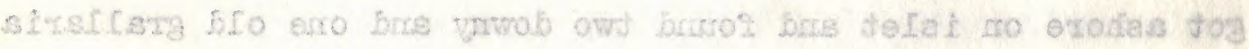

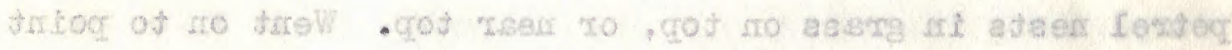

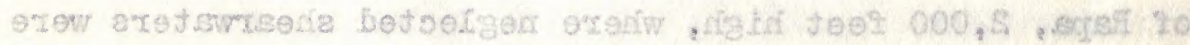

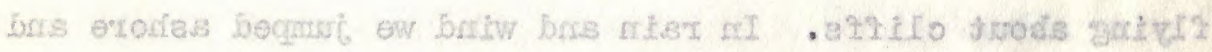

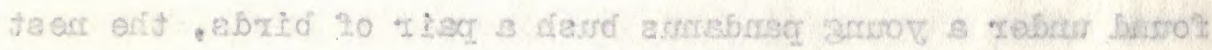

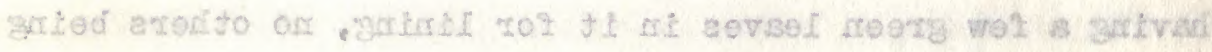

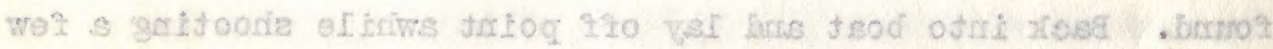

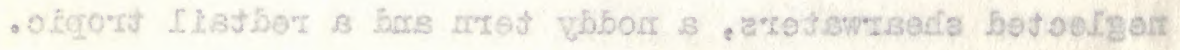

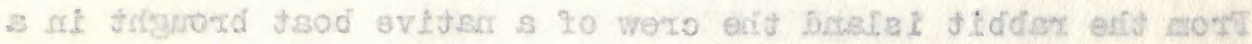

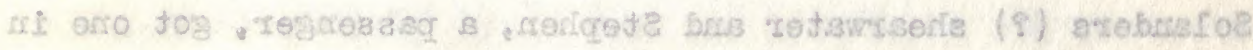

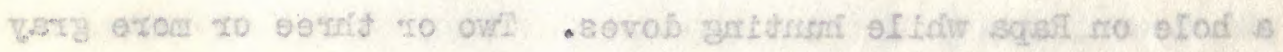

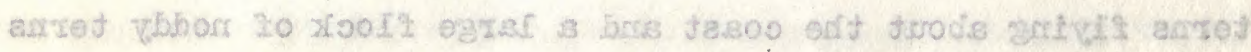

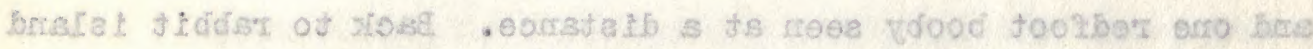

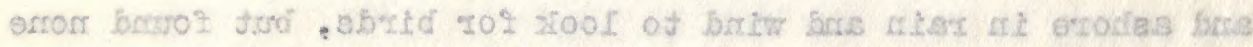

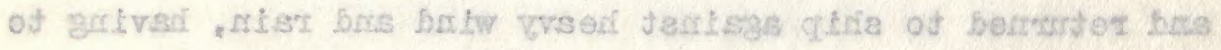

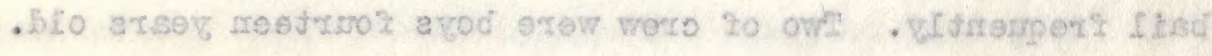

\section{eI SIrqA}

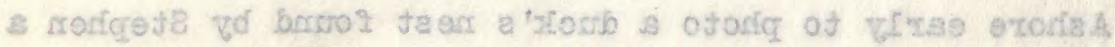


couple of days ago. Boy to guide me and found it deserted. Got photo and took eggs and back on board at eleven, but storm was too heavy to go out and wind terrific in P. M., overturning the pilot's boat tied astern and dragging both anchors so we drifted toward shore; but wind slackened towerd evening and we anchored in better holding ground.

\section{April 20}

Got away at on $0^{\prime}$ clock and with fair wind lost sight of island before dark, seeing a wandering albatross about thirty miles north of Rape, which swung astern of us from the west and sailed off to the eastwerd without stopping. One grallaria petrel and a number of neglected shearwaters noted a few miles from island.

\section{April 21}

No birds seen in A. H., but a couple of gray terns in P. M. and two tropic-birds 150 miles from Rapa and same from Ravaiva1.

\section{April 22}

Tropic or two and three gray terms kept about vessel all afternoon, probably driven off Rapa during blow other day. 


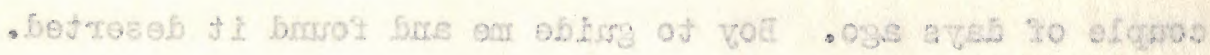

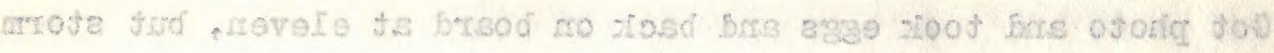

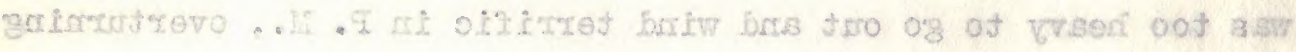

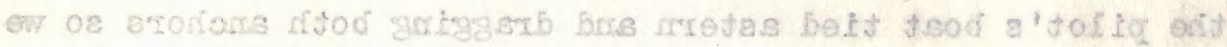

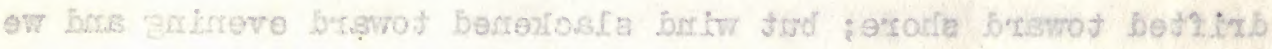

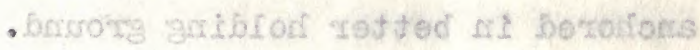

\section{OS 11 ra $A$}

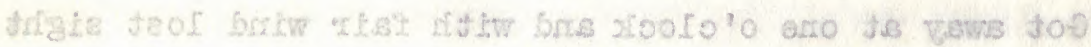

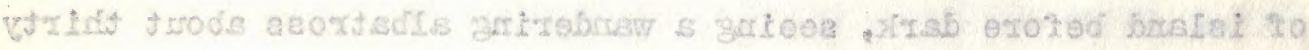

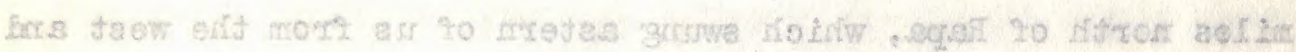

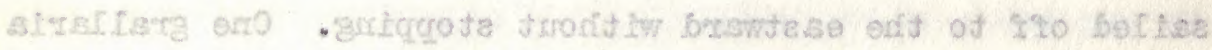

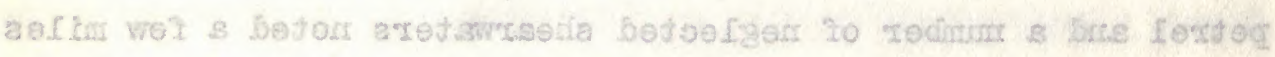
- batelaz motat

\section{Is Itive}

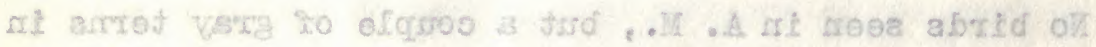

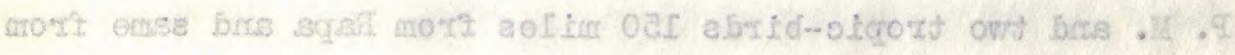
- Isviswast

\section{$\operatorname{sis} \operatorname{Lise} A$}

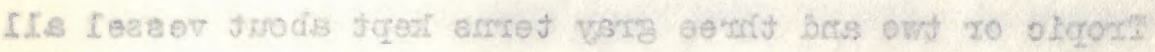

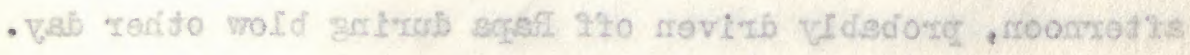




\section{April 23}

An albatross, darikish above but white-breasted flew about schooner few times in P. M. and Quayle shot him astern, but on account of rolling of vessel and light wind the Captain couldn't pick him up. A noddy tern seen in P. H.

Ravaivai seen tonight about ten o'clock.

\section{April 24}

Anchored at ten $0^{\prime}$ clock and ashore in P. H., seeing only a cuckoo in land birds but several redtail tropics about cliffs and few noddy and gygis and one gray term; also two white and few reef herons and several wandering tatlers. The tatlers were in marshy places along trail and a couple ran ahead of me in the trail for some rods. Pair of ducks within twenty feet of trail and a frigate flew over island along cliffs.

\section{April 25}

Went to half dozen of islets on reef at eastern end. Dozen noddy and a fer gygis terns and four or five reef herons, one spotted. I got and saw two white ones and two pairs blue ones. Rain more or less all day. Stephen got a couple of white herons I saw yesterday. 


\section{$-8 \mathrm{c}-$

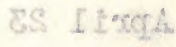

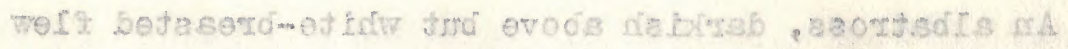

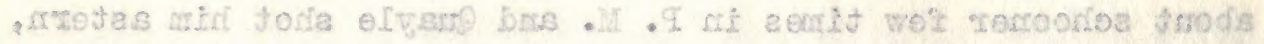

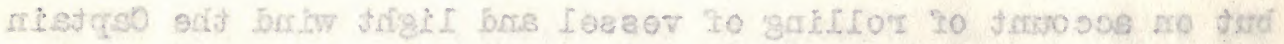

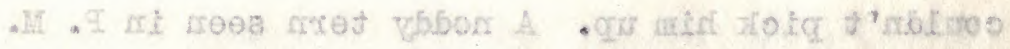

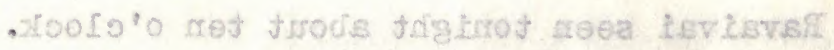

\section{AS ILTA}

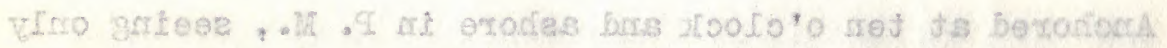

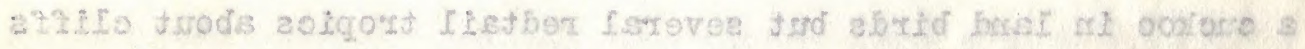

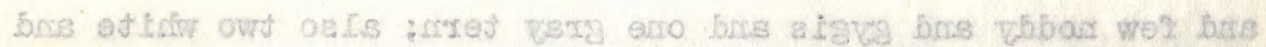

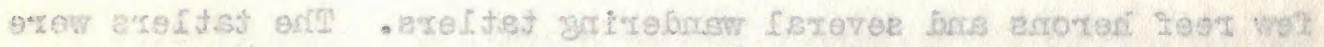

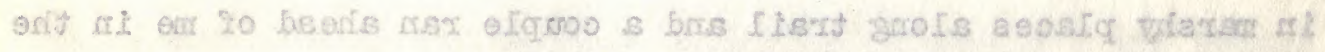

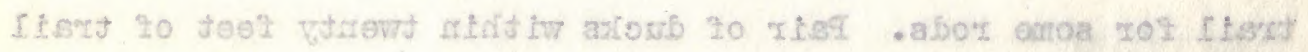

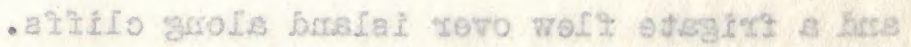

\section{CS Ifres}

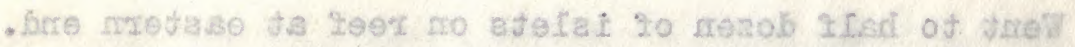

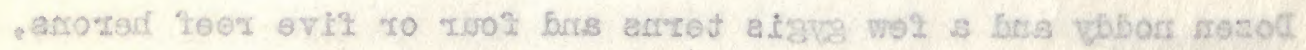

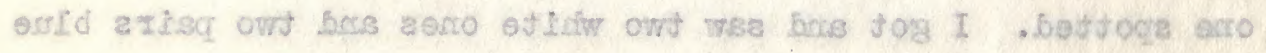

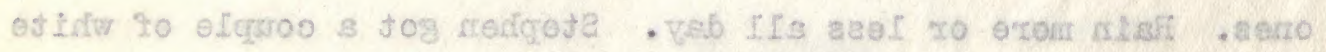




\section{April 26}

Quayle shot a couple of yellow-b111 and red-tail tropics. The yellow-bills went over cliff; I got a couple of cuckoos and a duck. Wandering tatlers common and red-bill tropics common along cliff. A plotus booby sailed along over lagoon yesterday and today fishing; only one seen. Quayle got egg of red-tall tropic. Ieft at three o'clock for Tubual with light fair wind.

\section{April 27}

Ravaivai astern about twenty miles at daylight. A little gray tern flow around ship awhile before seven $0^{\circ} \mathrm{clock}$. Breeze freshened at nine o'clock.

\section{Apri1 28}

Rain, fog and light hoad wind all day. Mwo gygis terms seon.

\section{April 29}

Rain, fog and light head winds all day. Six gygis terns at one time in the afternoon fishing near ship. Two or three shearwaters seen in distance during day.

\section{Apr11 30}

Tubuai about thirty miles to windward at daylight SW by W. 
as It:CA

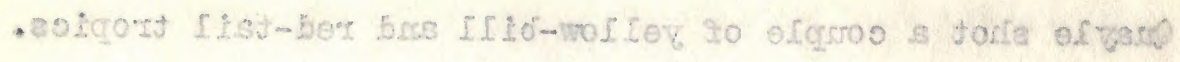

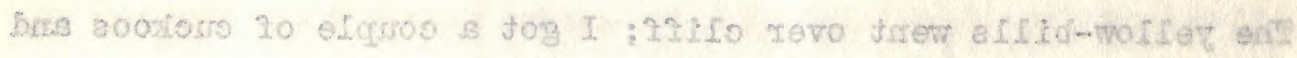

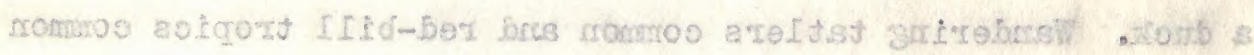

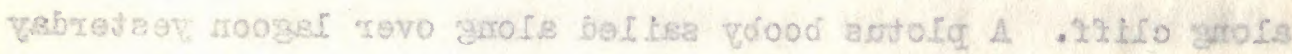

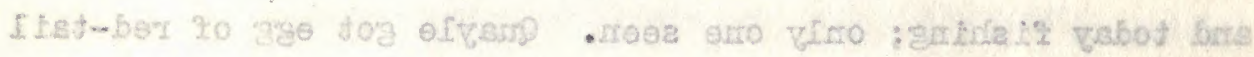

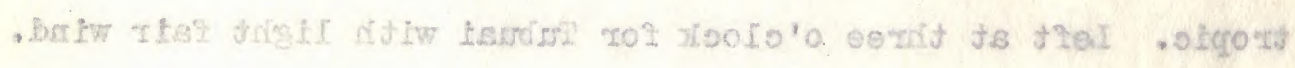

TS $I \operatorname{lrg} A$

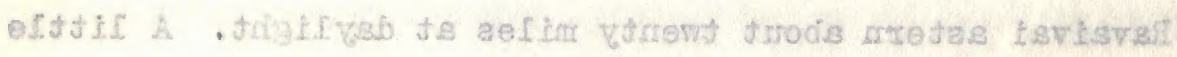

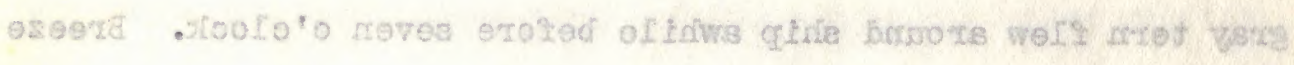

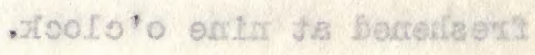

8S Ilog 1

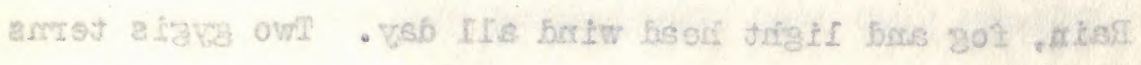

- resea

es IIIgA

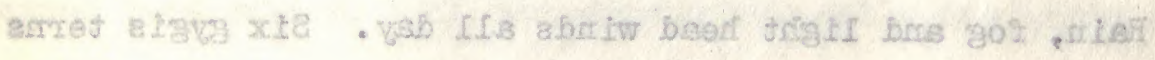

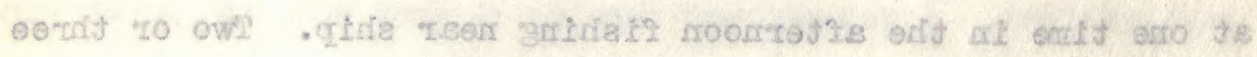

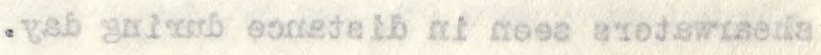

\section{of It:Th}

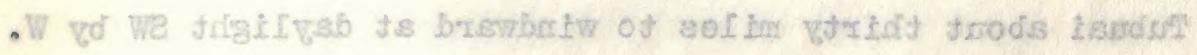


May 1

Island fifteen miles to windward at daylight, but at ten can see flagstaff and houses. Gygis term or two fishing.

\section{May 2}

Ashore and through center of island and up to near peaiss, but heard no chickens. Sew a flock of one hundred ducks near some small ponds of open water, and going to it got five. Probably most of birds on island in the flock. Steve in evening got a rail and Garyle heard some, but didn't get any.

\section{Nay 3}

Seven tatlers flew around in a flock and climbed well up into air as we entered harbor.

\section{May 4}

Sailed at five o'clock for Papeete.

\section{May 5}

Gygis term and sooty (?) shearwater seon at a distance.

\section{May 6}

Rainy and birds rare; a red-tail tropic and a noddy tern seen. 


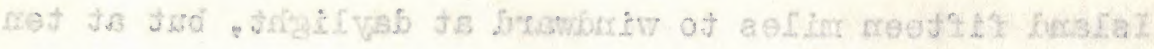

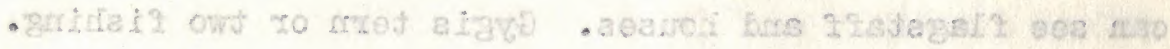

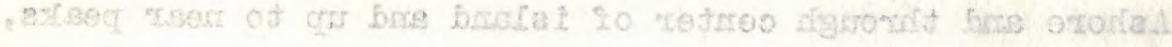

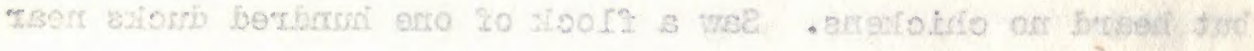

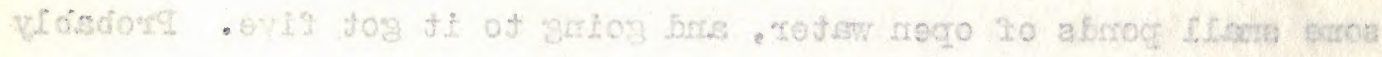

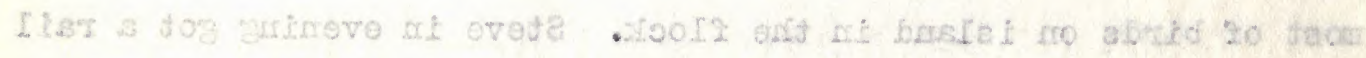

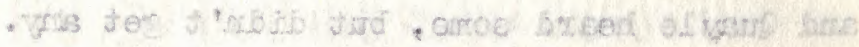

\section{Vsit?}

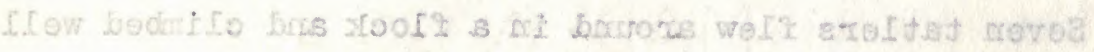

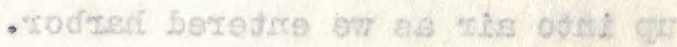

\section{A vell}

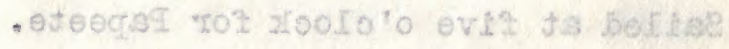

\section{C paly}

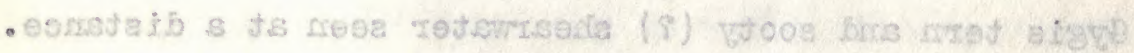

\section{d) VRII}

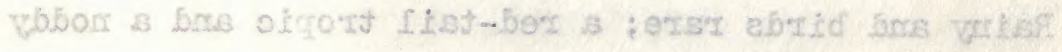




\section{$-55-$}

\section{May 7}

Tahiti in sight at daylight, and reached harbor at four P. M. Only two or three rostrata seen as we neared island. and one auricularis seen south of Moorea.

\section{May 8 and 10}

Quayle getting ready to go to Lake Valheria, but Taria, the guide, cannot go till next week, so quayle goes after swifts.

\section{IIay 15}

I spend week drying birds ready to pack and get ready to visit Moorea to collect. Rain first of week.

\section{May 14}

Quayle returns with a series of elycatchers but no swifts. Flycatchers were all in one canyon and none in carvons on either side.

\section{May 16}

Quayle starts for Iake Valhoria with guide and packer.

\section{May 18}

I go to Taravao for a weel waiting for lodgings at Moorea. Get one rail and hear several, but they are in high, 
5 VEST

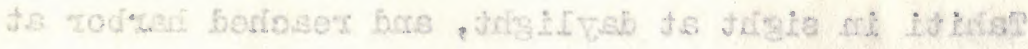

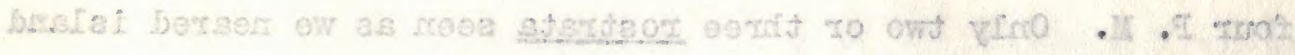

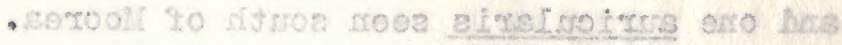

\section{O. Done 8 theth}

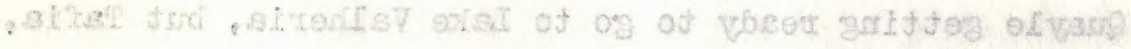

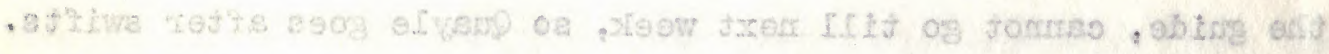

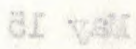

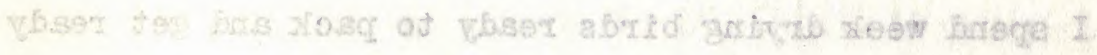

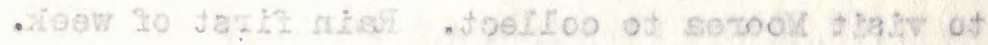

A. KG:

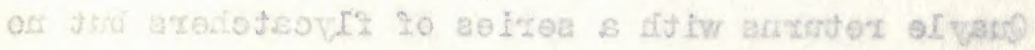

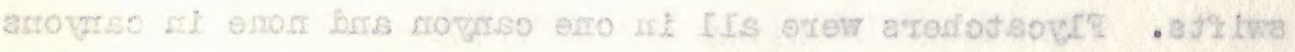

- obla tocifle ko

at: vests

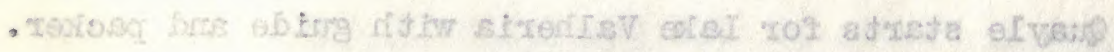

\section{5. vers}

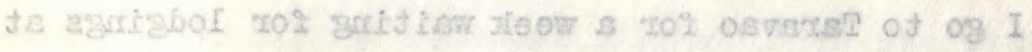

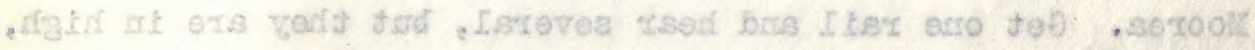


thick ferns and hard to secure. Fow wild chickens heard and three taken. A golden plover seen and taken on the 3lst. No pigions found though we went far inland to about 3,000 feot.

June 2

Return to Papeete and pack boxes for shipment.

June 11

Went to Hoorea; in P. M. up the valley and hear doves, kingfishers and chickens.

June 13

Up a long canyon to base of highest peak and got threo doves, two kingfishers and saw a hawk. Quayle out before daylight for chickens and got a couplo.

\section{June 14}

Skin birds and out in P. M., but get nothing.

June 15

Out all day and get nothing but a rat. See fire yellowbills.

June 16

Quay lo goes to other side of island for a couple of days. 


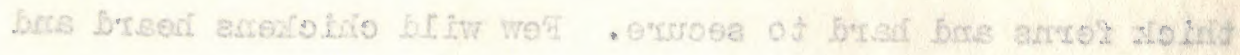

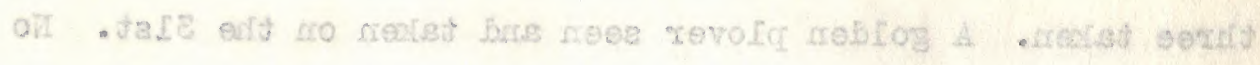

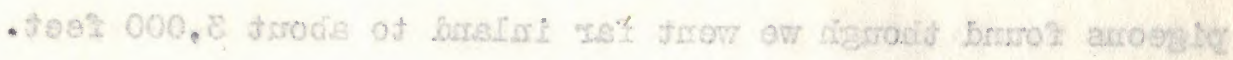
$S$ excesto

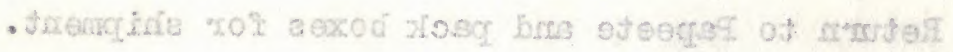

I. exrsts

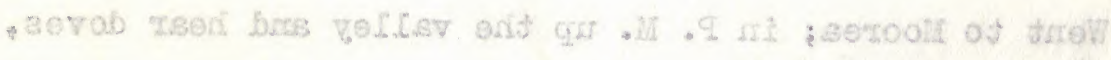

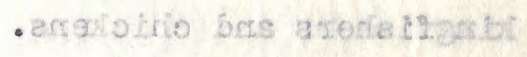

Bif errest

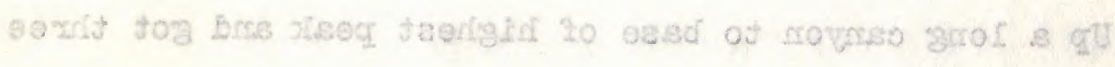

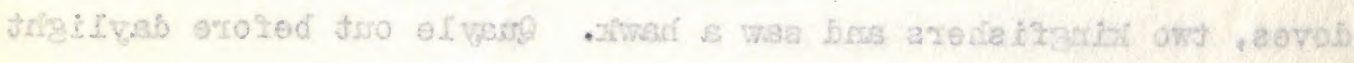
- eloupo s jog bres amexiotio mot

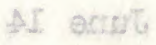

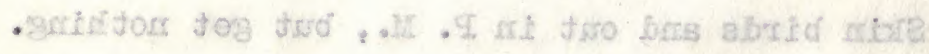

\section{er antil}

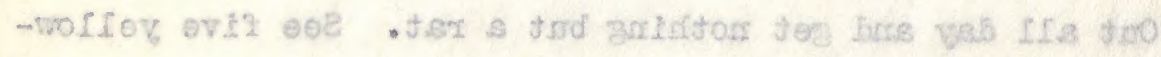

\section{dic arsart?}

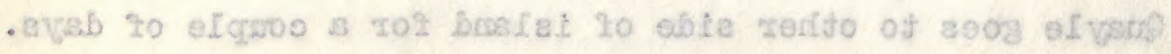


I go to Nateia and hear a lot of chickens and get three in wild country where a few pig muters are the visitants. No pigeons or warblers heard.

June 17

Skin birds and out awhile. Noddy terns come in after darik and roost in trees about village. Rain nearly every day.

\section{June 18}

Out in rain till P. M. and get one dove.

\section{June 25}

Quayle got three Nohas on Plerced Peak near top in burrows. He saw three warblers on other side of island, but weak auxiliary shells prevented capture, in each case a mere fizzle being emitted from gun. I got three chickens. In the forests they very often fly up into trees to spend the middle of the day, and fly down to feed about three $0^{\prime}$ clock in the P. H. The roosters crow several times a day for periods of a fer mimates. The chickens fly up and feed on the ripe bunches of feis and bananas that natives do not pick, though they feed principally on the ground. When disturbed suddenly some run away, while others may jump into the air and fly off through the trees. Only one white one was seen out of a goodly number noted. 


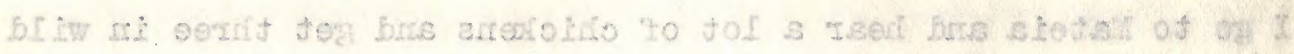

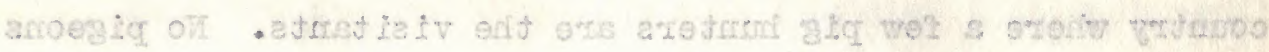

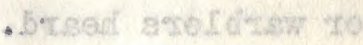

VI. ansto

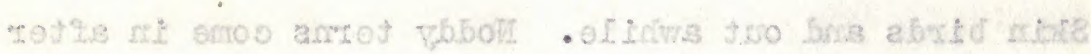

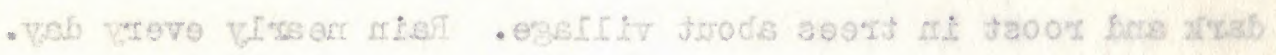

\section{I erut}

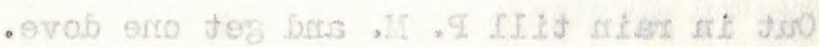

¿s. enst

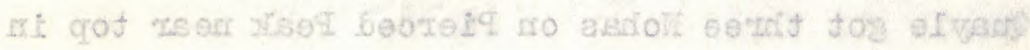

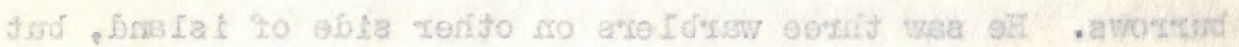

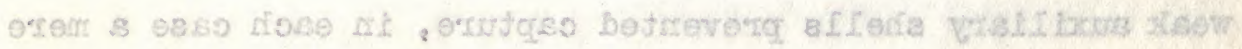

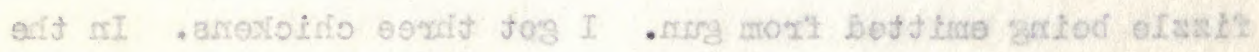

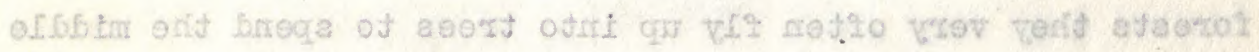

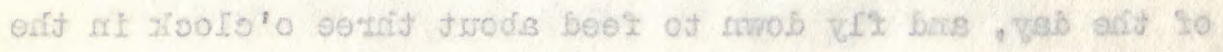

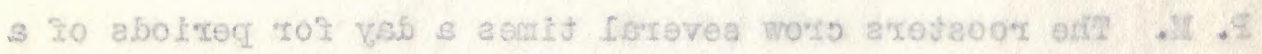

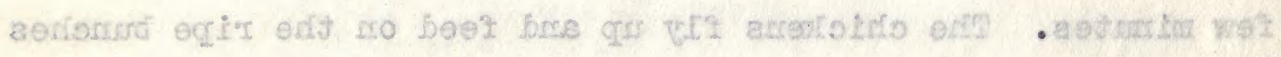

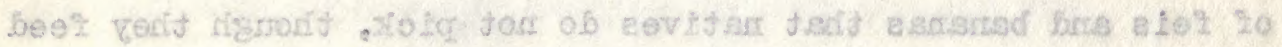

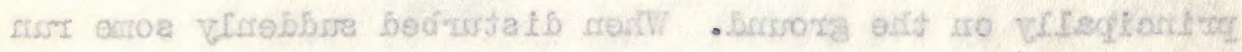

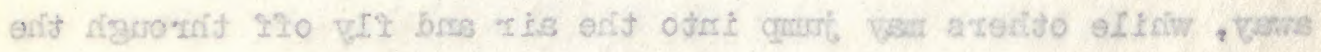

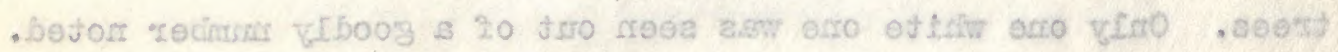


The natives catch many roosters by entangling them in a long string tied to the leg of a tame rooster which is carried up to figint the wild birds.

\section{June 27}

We move to Temai by the lake and I get one duck and. see about fifty others. Pairs and three, four or more fly along the hillsides, the males chasing females; a heavy rain in the evening the cause of the evolutions probably. Five hundred or so weaver-birds in rice fields feoding on rice and weed seeds, a few minahs feeding with them; the ducks como into the rice at dark and I seldom saw them flying in the daytime. A hawk seen flying along hillside hunting chickens (?).

\section{June 30}

Quayle back from a two day trip after Nohas with three birds,--no warblers. I see seven golden plover and get two; they lreep out on a small is let in the lagoon a few yards in extent. I went yesterday up the trail for warblers but heard none. Got a goat that proved good eating. Iantana is very bad and in many places one can't get far off the trail.

\section{July 3}

A boy brought in an emaciated dead . parvirostris which he got a couple of miles from here on the beach. It seemed a young bird. 


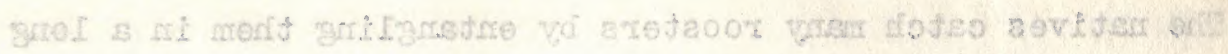

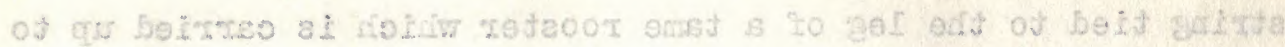

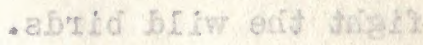

MS erset

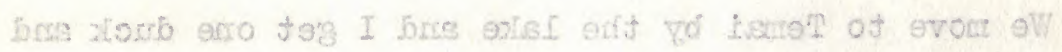

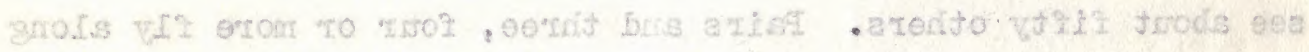

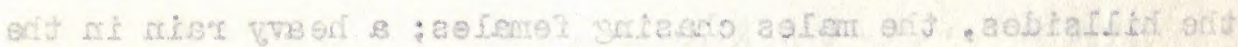

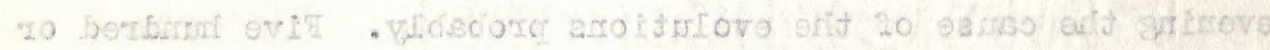

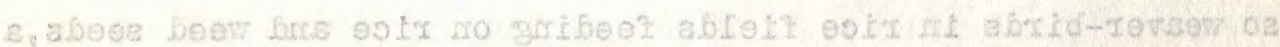

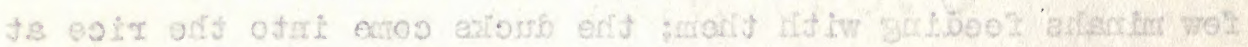

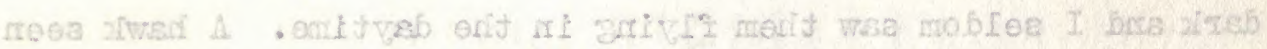

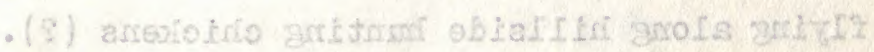

OE errets

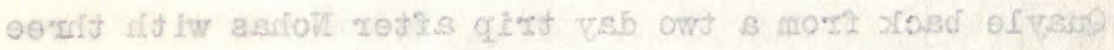

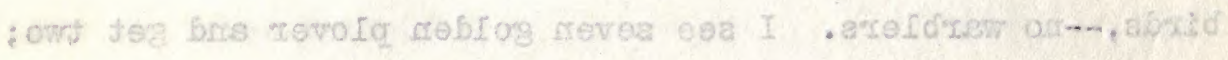

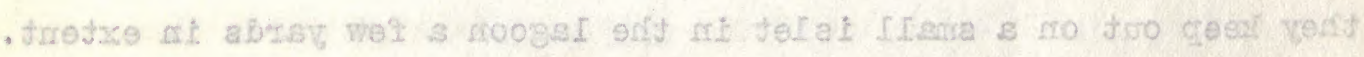

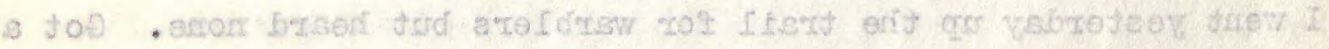

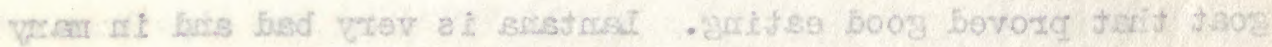

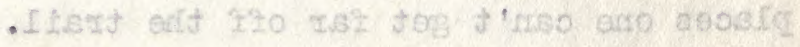

Q $\nabla \sin$

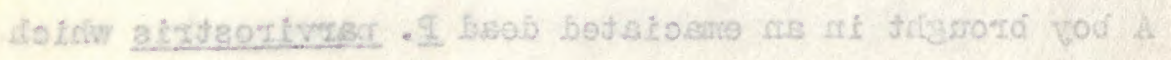

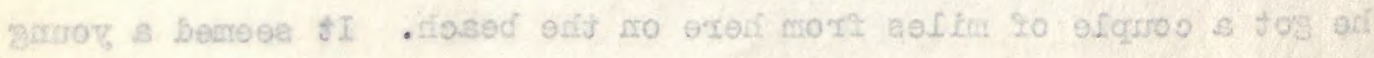


July 4

I went to Mapita and went up a ridge, striking a goat trail at 1,500 feet and at about 2,500 feet found four burrows of P. rostrata, taking two birds from each of two holes and a fema lo from another. A couple showed very slight enlargement of sezaal organs, the others practically none, thougin a male and female were found in the sarie hole. One hole had a few leaves for lining, the others had none. The nests were just below top of ridge with only a small spot of probably three feet diameter for landing place through the low trees, the landing place being six feet or so below the top of ridge; three of the birds were not three feet under the trail, though the trail was seldom used by the goats. The nests or end of burrows were in five or six feet from the entrance and in two of the holes the burrows ran under rocks where pigs could not have followed by rooting had they been so inclined. Wild pigs probably range through mountains of Moorea where the birds nest, but they do not seem to bother the birds in any one of five colonies examined. A little excrement was noticed at entrance of one hole. A hundred yards below along the ridge a rail was heard in the forms and bushes but impossible to see it, though heard several times in answer to my insistent calling. Four hawirs seen about this vicinity and one of them got a load of sixes in his tail when he unwittingly flow too close in crossing the ridge. 
$\$ \operatorname{Tin}^{2} \mathrm{C}$

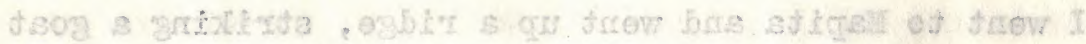

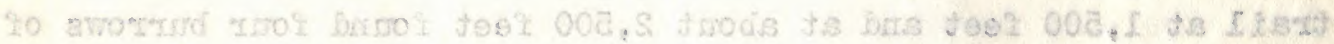

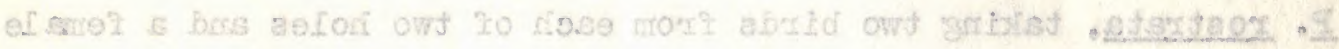

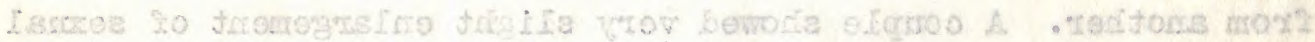

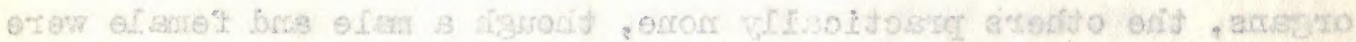

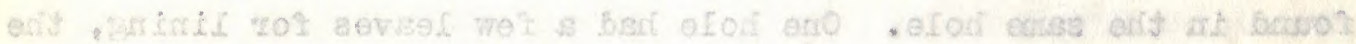

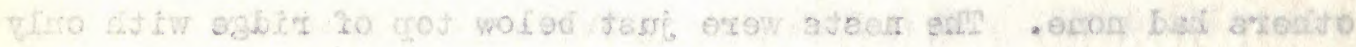

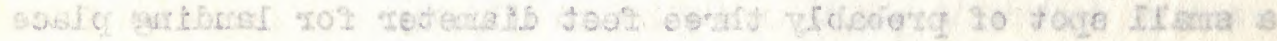

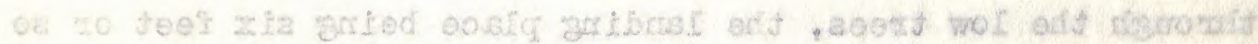

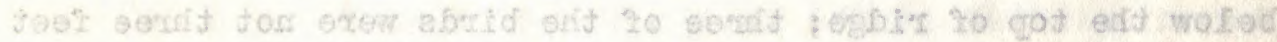

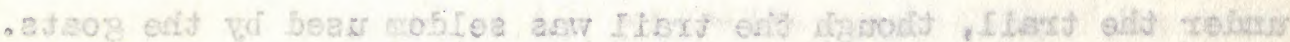

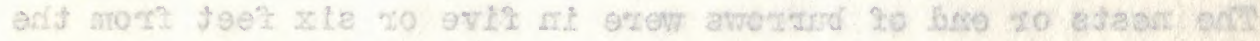

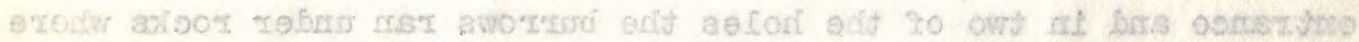

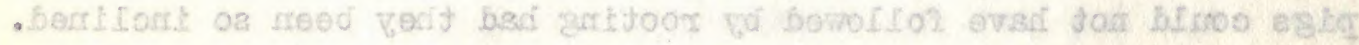

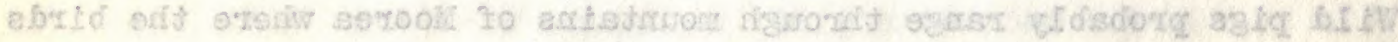

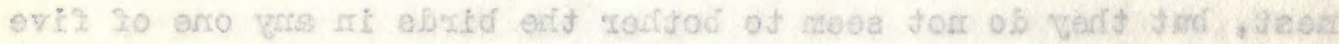

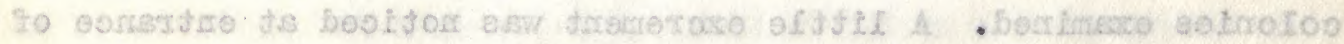

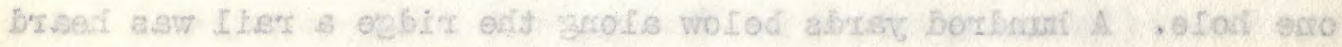

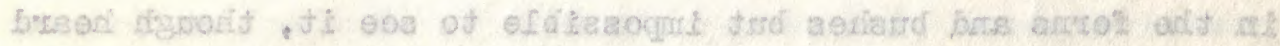

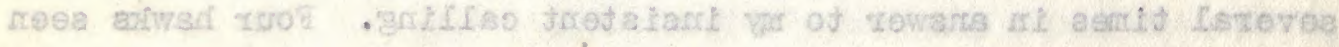

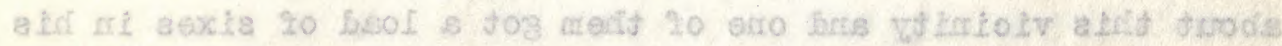

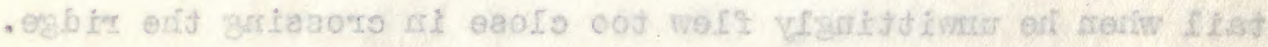


Quayle went into Cook's Bay section for a week in search of warblers and pigeons. I heard roosters crowing a half mile or so below the shearwater nests in thick jungle.

$$
\text { July } 6
$$

Return to Afearito and look for warblers again, but find none.

$$
\text { July } 11
$$

Return to Papeete, but Quayle stays till I arrange another trip.

\section{Ju. 1 y 14}

Holidays till 18 th and no business possible.

\section{July 18 to 30}

Two owners to see me about schooners which I ara considering, and that with cabling Masoum prevents leaving Papeote. Quayle visits motu off Hoorea and finds red-foot boobies roosting and a couple of shearwater burrows, but no shearwaters; also heard the auricularis type about cliffs in Cook's Bay, but could not reach nests.

\section{August 1}

Awaiting cable from linseum re schooner and discussing 


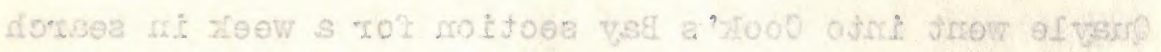

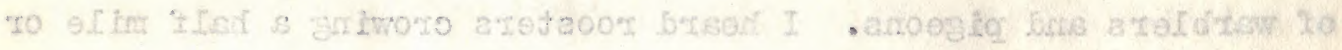

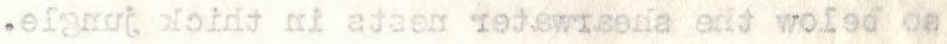

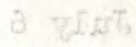

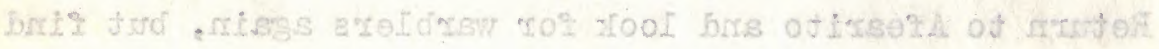

\section{If Vint,}

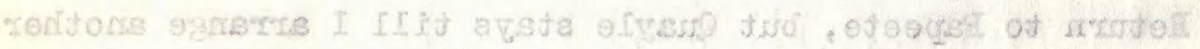

\section{Af $\nabla f \in t$}

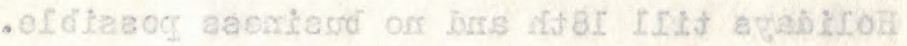

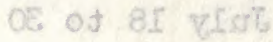

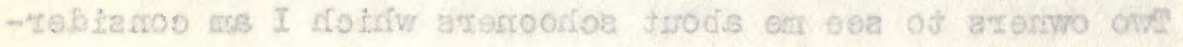

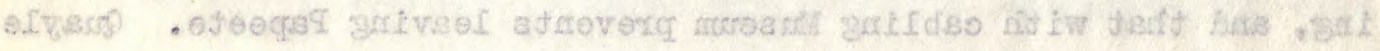

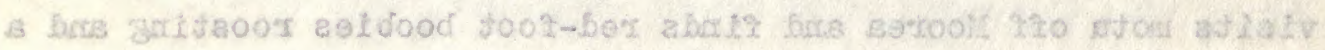

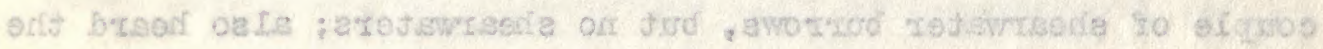

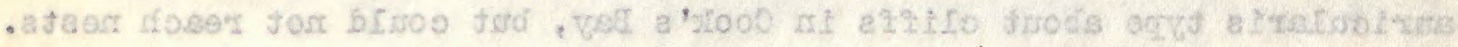

\section{I. taimgsi.}

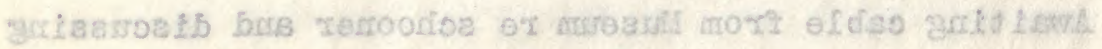


with mail company here regarding chartering the boat.

\title{
August 12
}

Quagle back a couple of deys ago without rail from Hoorea, though he heard them often near camp. The dense cover prevented securing any. We go to Papiere and in P. M. $g 0$ up canyons and I strike warblers, frequently getting several in bamboo thickets. Heard three at one spot and got one melanistic one,--the second we have taken from this island.

\author{
August 15 \\ night \\ Heavy rain last $\Lambda$ and wo go on to Taravao where Quayle gets
}

a fine plumaged rectirostris tern.

\section{August 16}

To Hitia and up canon where pigeons reported, but find none, though hawks were present and several warblers were heard.

\section{Augast 17}

On to the villago, arriving at dark and see a pair of swallows about the church and several others during our stay.

\section{August 18}

Up canvon but found nothing of interest except the 


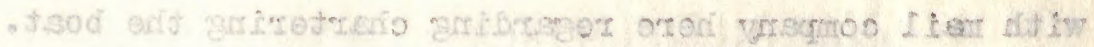

SI deisegA

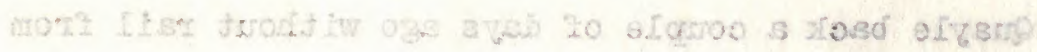

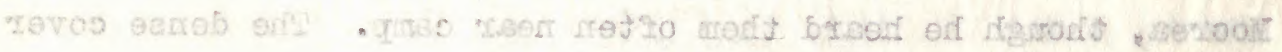

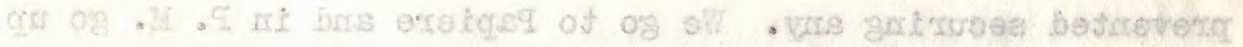

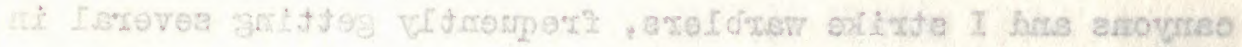

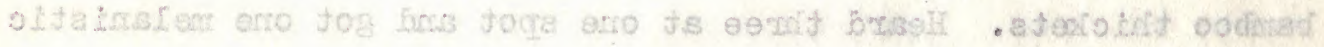

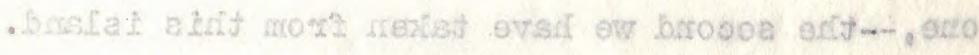

dit tespesth

trigitir

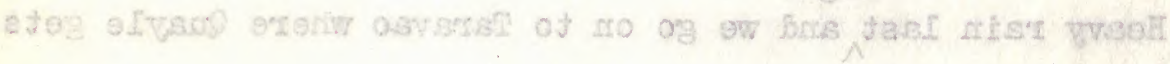

- cret abrtaoritoer bogsiustiq orth a

of $3350 \mathrm{gen}$

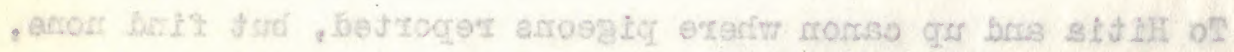

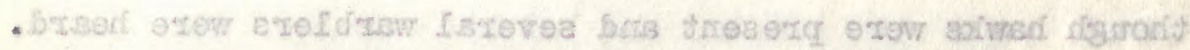

\section{II takises}

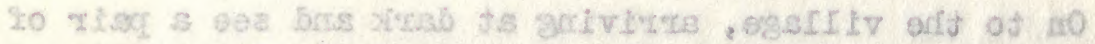

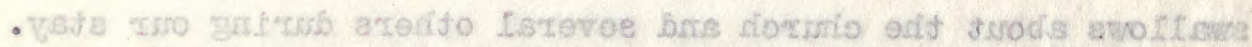

8I. Jesterk

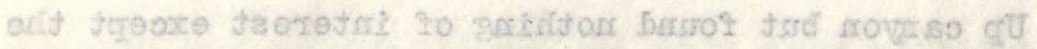


absence of warblers about the bamboo patches. In P. M. around to Wahaena district and up river and back.

\section{August 19}

We took camping outfit and went up the Mahaena River. I went far up river while Quad le stayed near camp and hunted, but he saw nothing till cutting bamboo for water carrying when he heard a pigeon noarby and succeoded in getting it after calling it and having it fly around him. I saw green and reef herons and three wandering tatlers far up the stream.

\section{August 20}

Hunted all day, but no sign of pigeons. Saw three or four warblers in bamboo patches and green herons up smell streams. Rain in P. M. and we return to Hitia. I saw three yellow-bill tropies up river.

\section{Augrast 21}

Sunday.

\section{August 22}

With Quayle again up another valley in Mahena district, and when calling for pigeons a hawk swoops over hill to investigate. Fire gun in likely looking places, but no pigeons seen. Got a white 


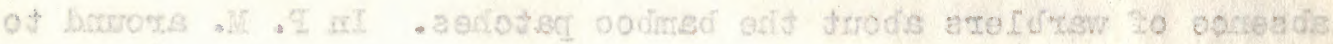

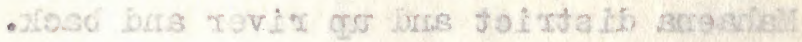

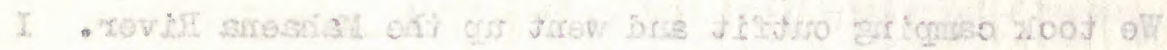

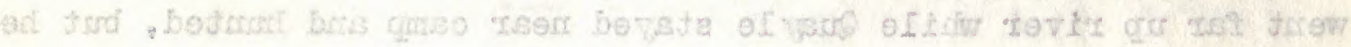

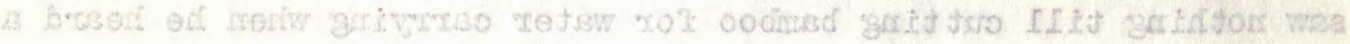

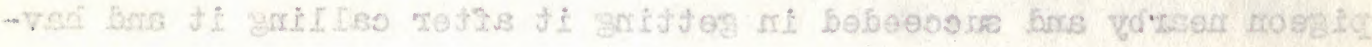

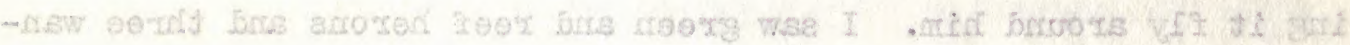

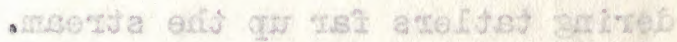

os testand

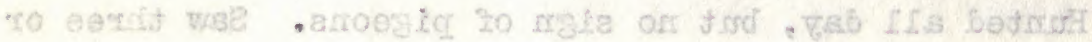

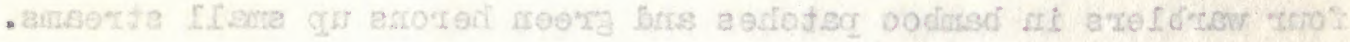

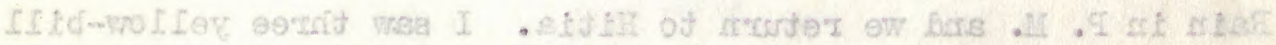
- Tevly qus aoluost

IS jaspion's

- vesporcura

She tangers

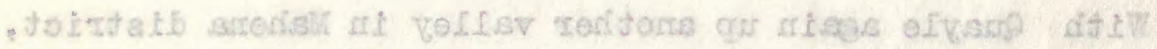

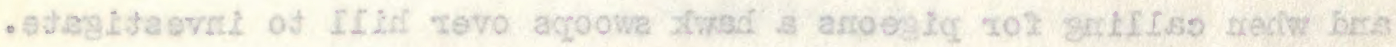

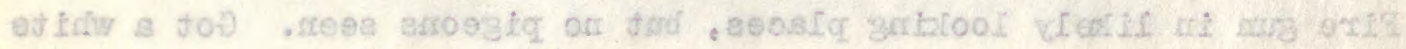


reef heron well up stream several miles from ocean.

\section{August 23}

Up stream again and see yellow-billed tropic flying around. A hawis was flying high over the canon circling so he could see the whole valley.

\section{August 24}

Follow guide around Lowlands back of village for pigeons, but found none so he showed mo a trail up onto tho hills and I went up into the feis. Saw no pigeons, though a hawk flew over me as I called for them. Heard warblers in bamboo thickets up in hills, though could hear nono lower in tho canons wille at Paperi. They were not very far up the stream. Saw four kingfishers fly into air at once. Quayle went out with another guide in different direction and saw four pigeons, getting three of them. Whey were in small canons but a short distance from shore.

\section{August 25}

I return to Papeete, leaving Quayle to search other canons as grunstock is cracked and unsafe to use.

\section{Argust 30}

Go up the Panare and spend night, looking for swifts but 


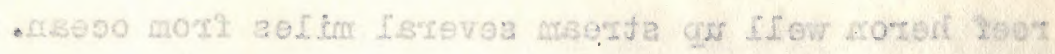

\section{GS Jassase}

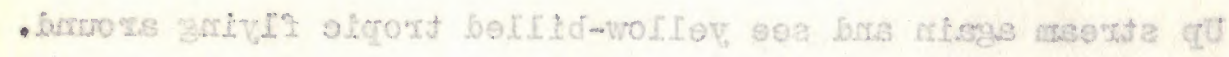

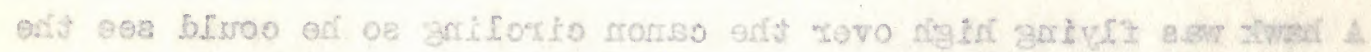
- ZeLfar a Loriw

\section{AS secoser.}

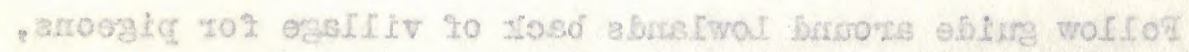

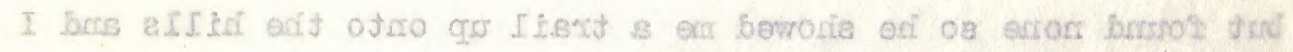

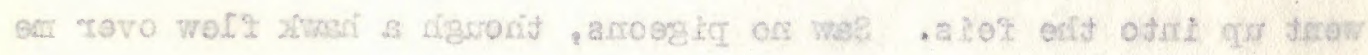

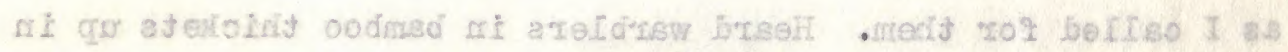

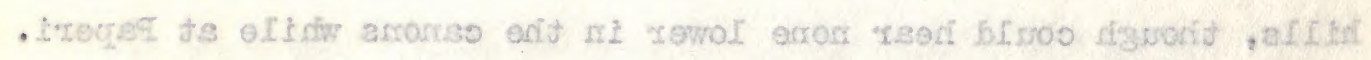

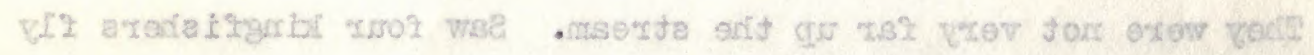

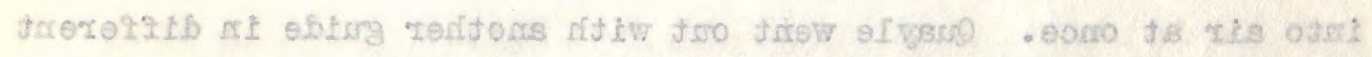

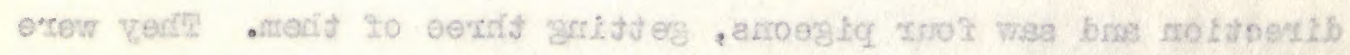

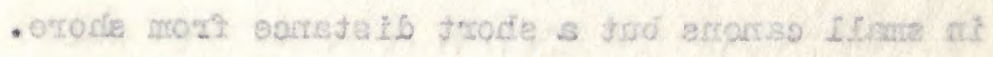

\section{as tasrgut}

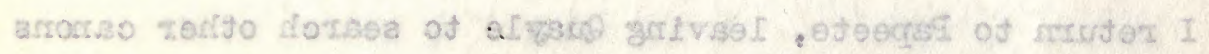

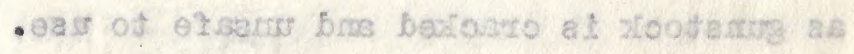
$\cdot 08$ tagertA

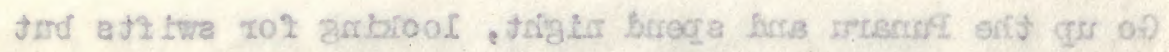


find none. Got two yellow-billed tropies of half a dozen seen. One went into hole in cliff and after I shot at entrance and called awhile it came out and was captured. Another lit on a ledge and scurried back to a nest, but though I shot four times at rocks over its head I could not get it to leave.

Shearwaters were heard at night coming in, and in the moming just before daylight they were calling about clifs. At daybreak I saw three or four circling about, all of then seeming

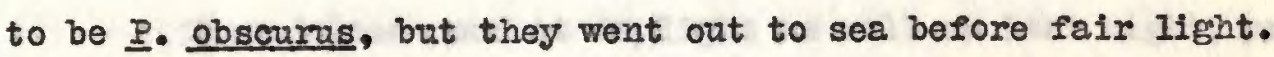

\section{August 31}

See a blacir-bellied golden plover along beach near charch in Papeete, and in P. M. go up Hission Cañon, hearing wild chickens and seoing minahs high up in hills.

\section{September 9}

Fail to hear from Quayle who changed his plans about meeting mailcoach, so leave for a trip with Mrs. Beck to Harquesas and Thamotus for six weeles. Three or four obscurus shearwaters seen at dusk a couple of miles off reef just after leeving Papeete.

\section{September 10}

A red-foot booby and a couple of $\underline{P}$. rostrata only birds seen. 


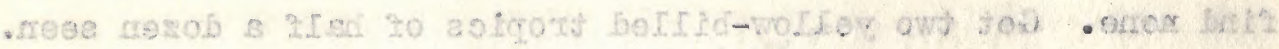

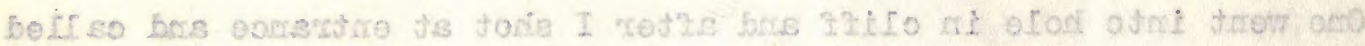

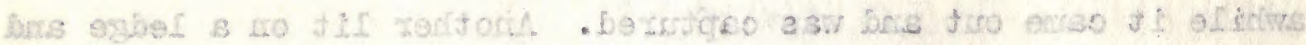

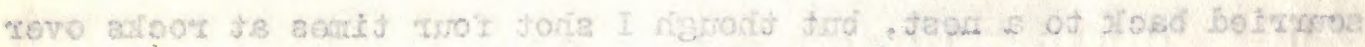

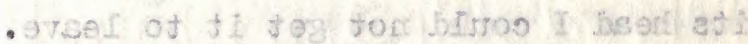

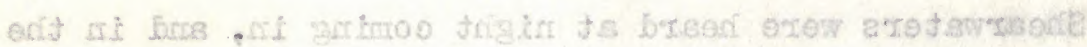

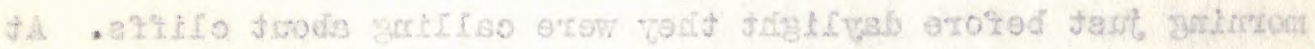

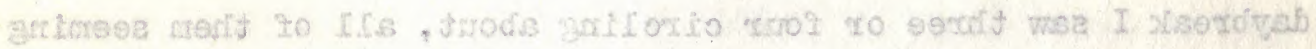

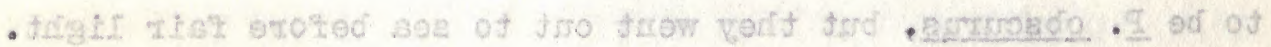

\section{8 tamgra}

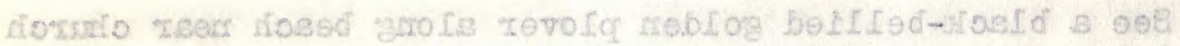

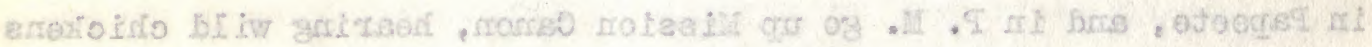

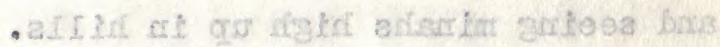

\section{e reoimotgel}

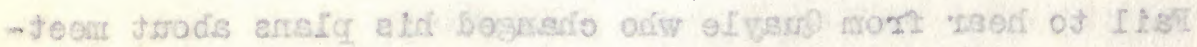

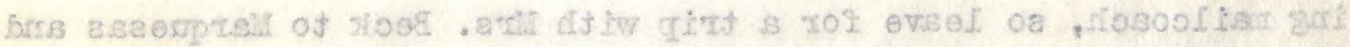

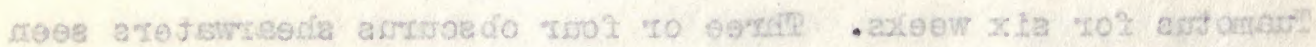

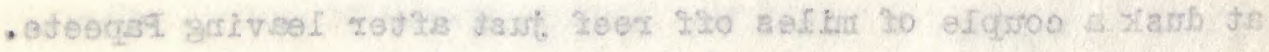

\section{OL "rocinestgea}

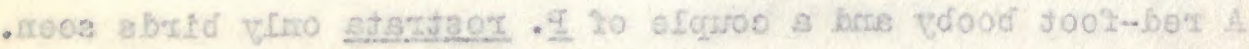


September 11

Light breeze and no birds seen before three when this is written.

\section{September 12}

Few ghost terns and two or three sooty seen during day.

\section{September 13}

Hian Island seen at daylight as well as last night, and salled along the lee shore and up to village where landing is made by running boat in onto reef and sailors jumping out and hauling up a few yards to beach. Not a bad place with a strong boat. A flock of lesser noddies and a fow ghost and noddy terns fishing off lee shore and one plotus booby with them.

On landing three dozen people went along with me to show the birds of the place. Wo soon saw a dove in a tree a few yards from me, which was missed, but later others were taicen, most of them being called up as they were in thick forest growing on rough coral. Three or four killed had pint berries in their crops. Kingfishers were not uncommon, as several were heard and a half dozen secured. They perch most often in the coconut trees, but three or four were seen low down in the bushes. Warblers were singing about the houses of the village as well as in the forest. They 


\section{I. redintefré}

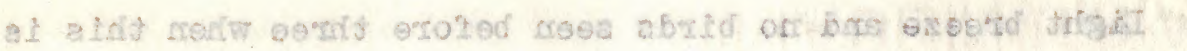

$\cdot \cos 0 \sin x$

\section{S. zoderotge}

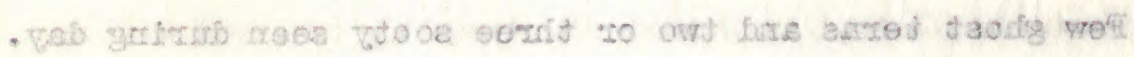

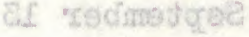

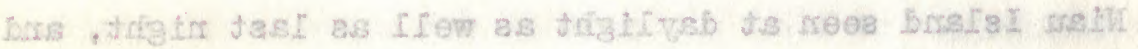

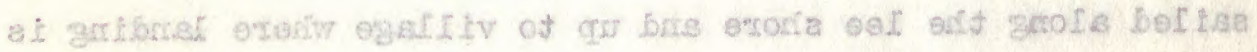

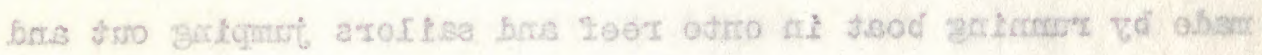

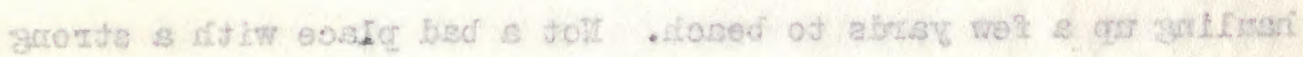

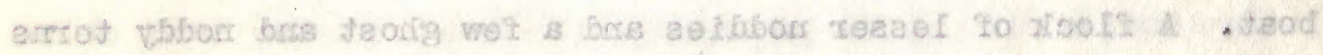

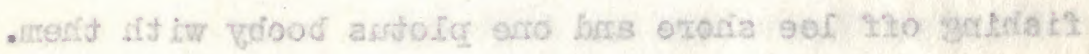

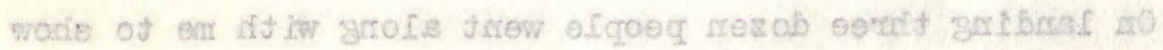

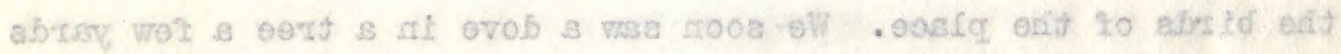

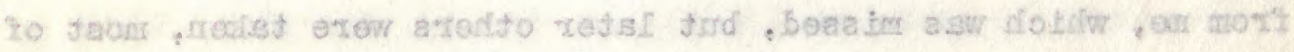

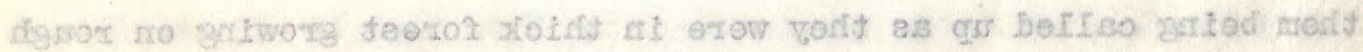

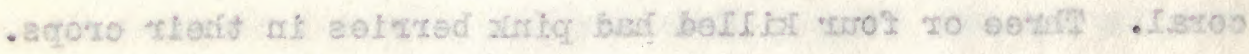

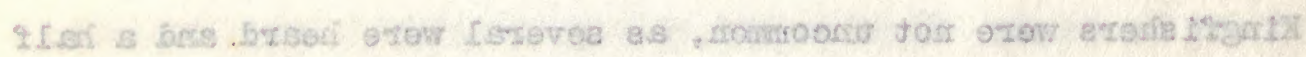

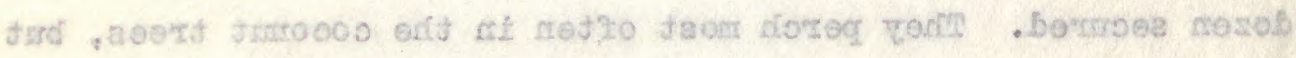

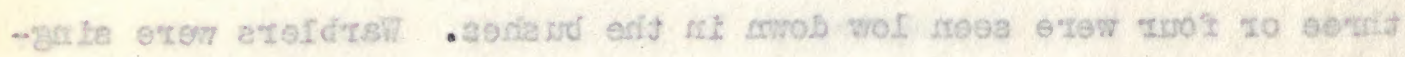

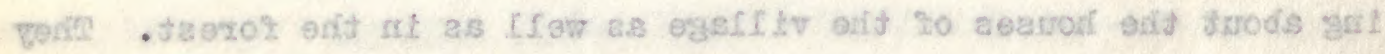


were the commonest bird of the three land birds seen. Paroquets were not heard and the natives did not know of them. A reef heron was feeding in a marshy spot near some houses, and a wandering tatler flew from the same place as we approached and two other tatlers were seen near the landing place. A frigate bird was noted sailing high over the island. Several sailing boats were on the lagoon, but as I had but about five hours ashore I did not get a chance to go far from the settlement. All the birds taken, 25 in mumber, were secured within a half mile of the village. A dozen or more geckos were taken from under the bark of a dead coconut tree and several eggs were also taken from the samo spot, the se probably belonging to the geckos, though they might have belonged to lizards of the skink species as a couple of that kind were taken under the same bark. We left about five for Fakarava 35 miles to the eastward.

\section{September 14}

A breaking reef ahead at daylight but no land in sight. Tacked off and after dinner saw Fakarava, but light wind and current make progress slow. Toau Island ahead at eleven, a small brunch of cocomats and a long reef marking it. Ran into lagoon of Fakarava Island about $8: 30$ in the evening and anchored in front of village. Bright moonlight. 


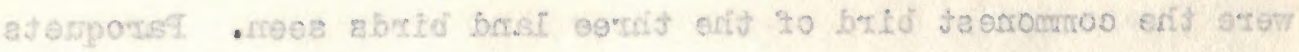

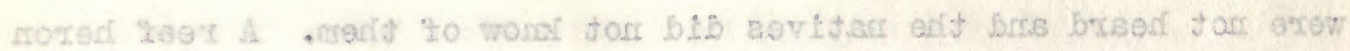

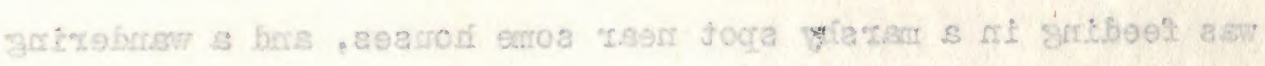

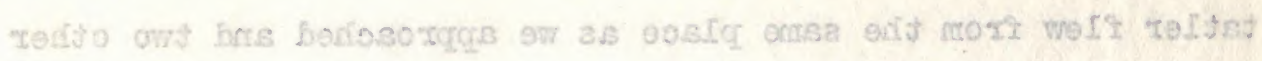

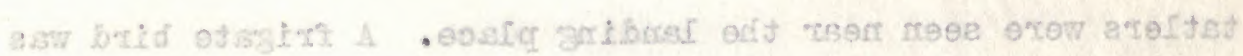

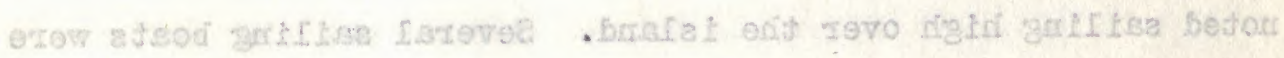

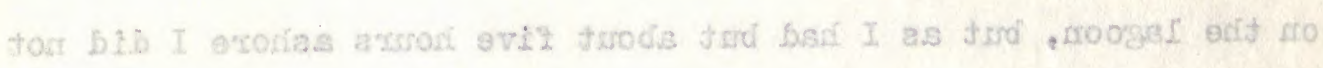

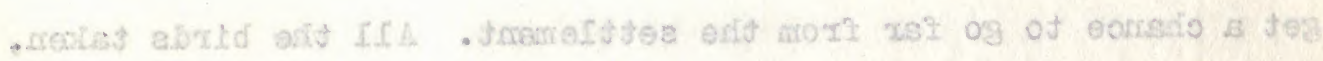

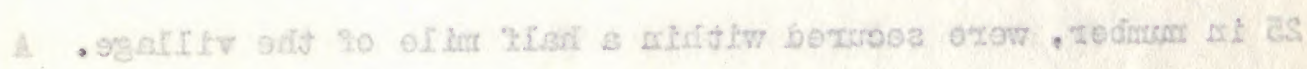

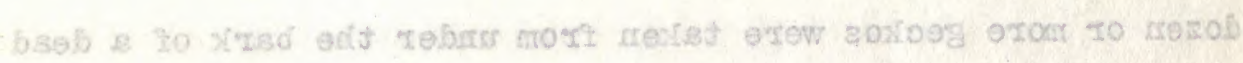

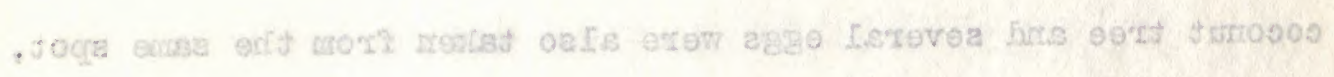

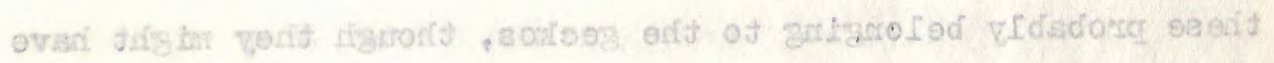

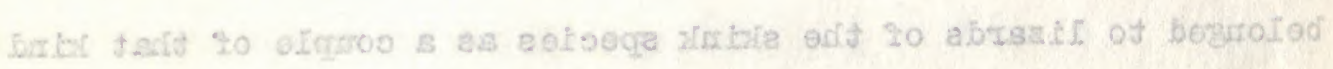

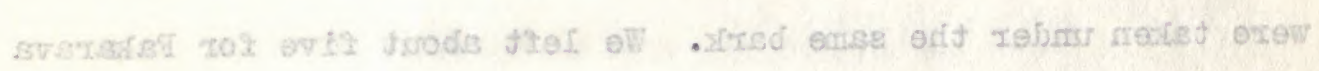
- bessutase oxit of aeline d8

\section{A. zobrtedgoe}

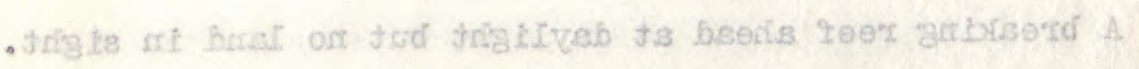

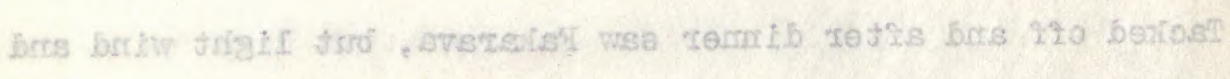

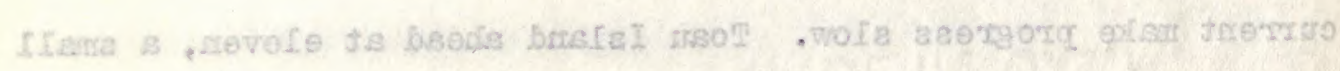

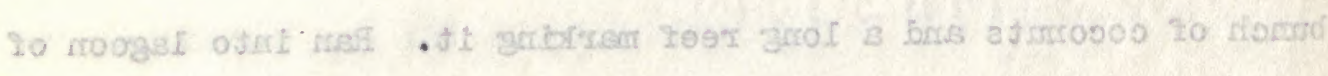

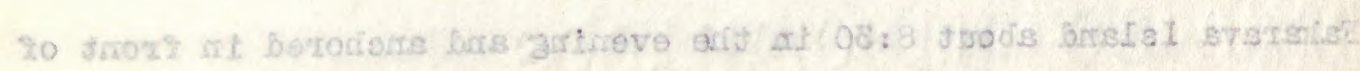




\section{September 15}

Ashore at Faikerava at six in the morning but had only a couple of hours ashore to collect, for a boatload of copra and a few loads of water were soon taken aboard. Farblers were the only land birds seen and they were not plentiful, though a dozen were seon or heard in a two mile walk. They were all either in or near pandanus trees except one singing about the administrator's house. The bushes were very thick in places and I had to crawl over the top of one patch to look for a warbler shot; seemingly a good place for ground doves, though cats have probably cleaned out those that lived near the village. A white and a dark reef heron, a gray-backed and a couple of yellow-billed terms were seen near the village on the lagoon. The terns were fishing back and forth close along shore and one fine plumaged yellow-bill was secured as he flew along within a fev yards of the shore.

As we sailed out of the lagoon a plotus booby flew over the lagoon, and outside noddy and lesser noddies were seon. Few rain squalls in the P. M. Sailed up to Aratika at sunset and along it for several miles, seeing a flock of plotus boobies lighting on one little patch of green and a flock of noddies (lesser) and a few large going to another. Sooty terns flew along coast and a tatler and reef heron lit on edge of reef. 


\section{af. isderetcoe}

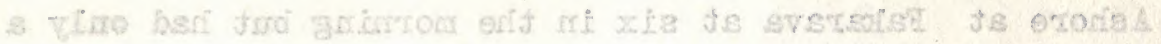

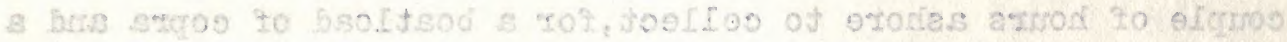

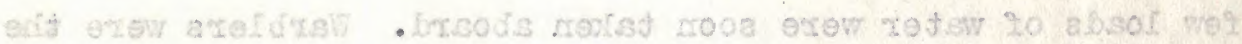

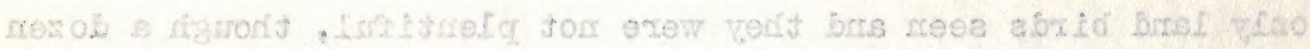

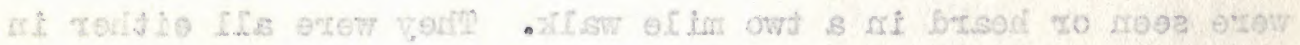

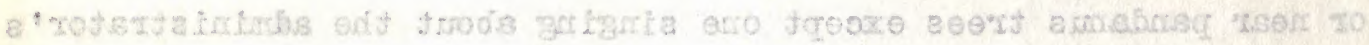

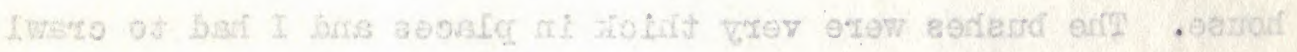

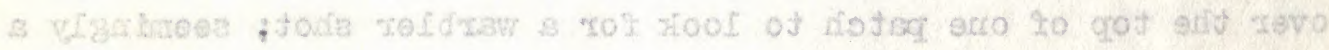

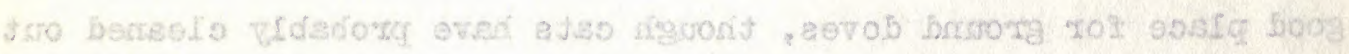

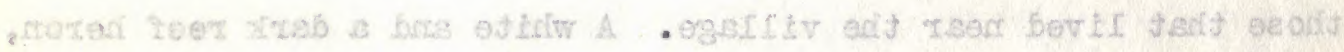

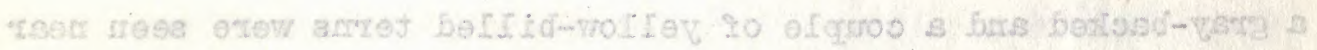

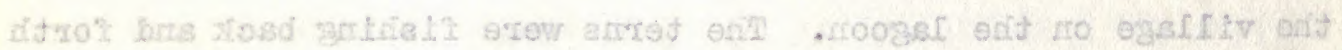

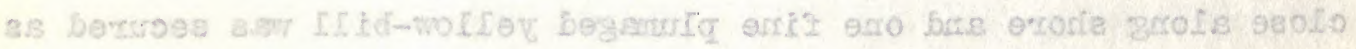

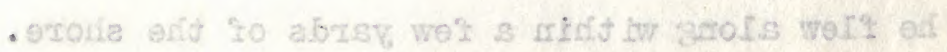

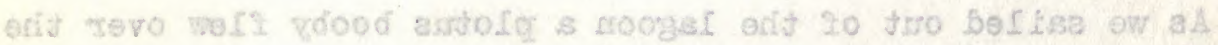

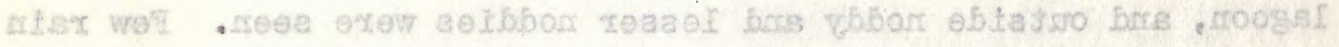

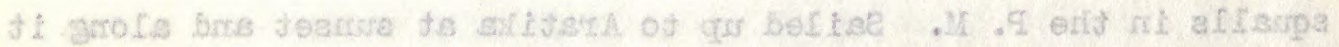

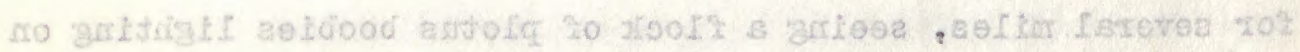

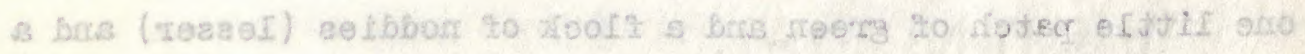

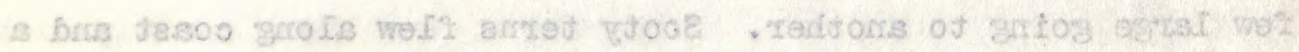

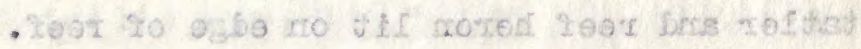




\section{September 16}

Sailed along Takapoto Island after dimner with engine going, trying to get to Pakeroa before dark. Saw three cutters in lagoon of Takapoto over the two foot shoreline where harricane in 1906 swept the lowest part of the island clear of vegetation the same as it did on Aratika. A red-teil tropic camo alongside for a mirute in morning and a few noddy and yellow-bill terns are flying along the reef as we sail along.

\section{September 17 Jalbarob}

Got in here last night and today went several miles along shore to the north, but failed to find a land bird, though heard a cuckoo. Saw a couple of witte reef herons and got one. Tatlers were common, several being along the reef and a couple of rectirostris terms as well as a half a dozen noddy fairy terns were noted.

\section{September 18}

Took a few pictures.

\section{September 19}

Out over same ground as Saturday, as I have to be back at two P. H. A couple of terms were the only birds taken, though I saw two or three white reef herons. Big 2,000 ton iron ship 'County of Roxburgh' on reef where it was thrown in hurricene of 


$$
\text { aI redmejoges }
$$

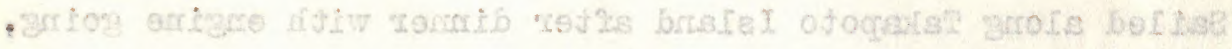

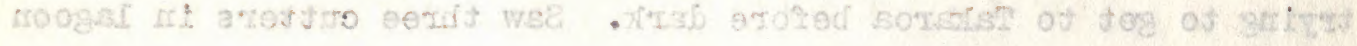

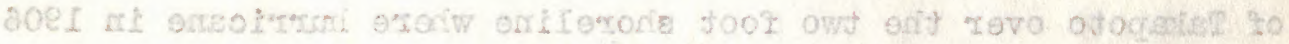

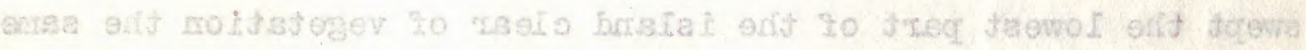

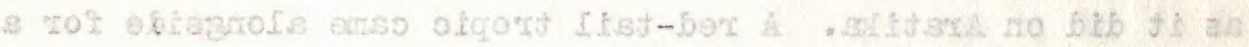

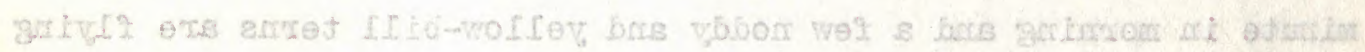

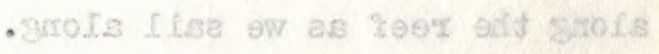

\section{is nedrotuee}

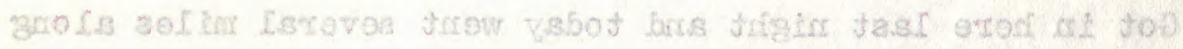

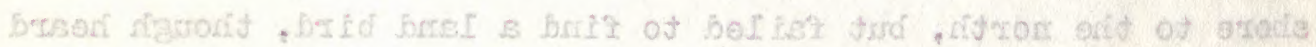

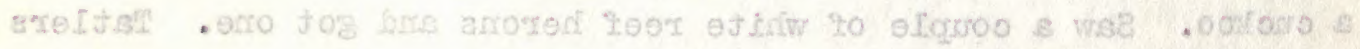

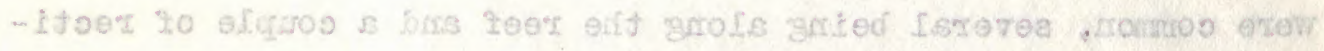

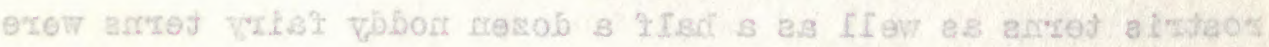

$.0030 \mathrm{set}$

\section{1. zedretqo'}

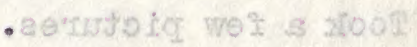

\section{e1 redirejerea}

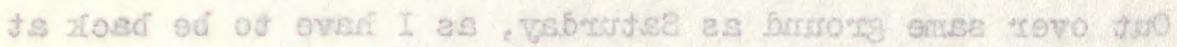

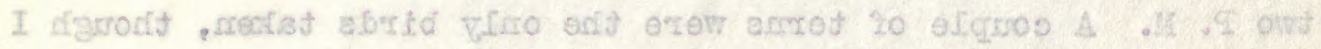

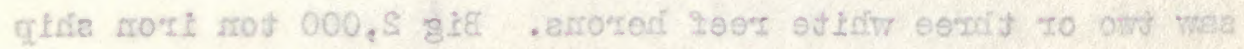

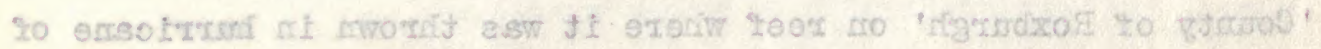


1906.

September 20

Got away at 11 A. M. and sailed for Marquesas.

\section{September 21}

Flock of dozen sooty and ghost terns fishing and a couple of shearwaters seen, one of the birds flying like a sooty shearwater.

\section{September 22}

Flock of a hundred sooty terns with a half dozen frigates and several ghost terns fishing at one place, and severa.l dozen terns and a single frigate and a tropic seen later. A couple of red-foot boobies also seen.

\section{September 23}

Couple of small flocks of sooty terns and several ghost terns and red-foot boobies as well as three or four Brewster's boobies seen. A Brewster's booby came aboard and was caught by a sailor and skinned. Three red-footed flew about the ship at dark.

\section{September 24}

Two pair, three sooty terns and a couple of ghost terns were seen as well as three yellow-bill tropic birds in a group, and 


\section{IS redinetgę}

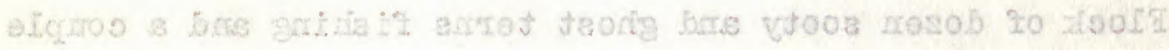

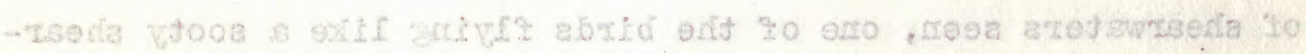

$-20+5$ ism

\section{$\operatorname{SS}$ recketrs?}

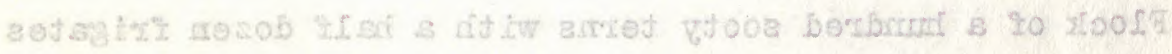

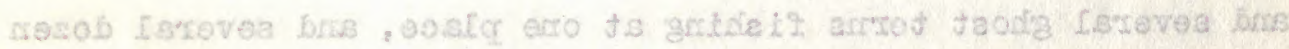

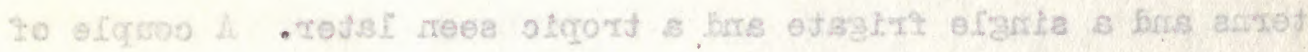

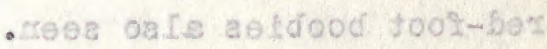

\section{Ses. redmetgee}

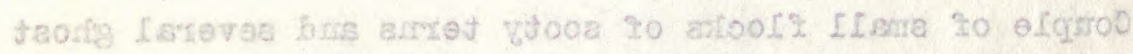

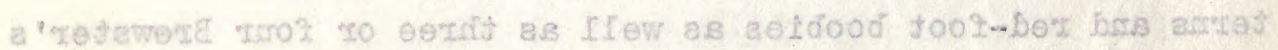

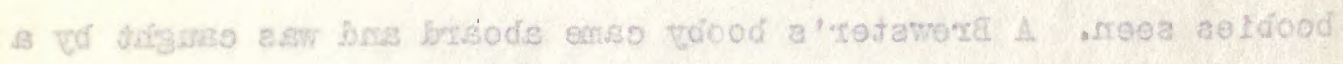

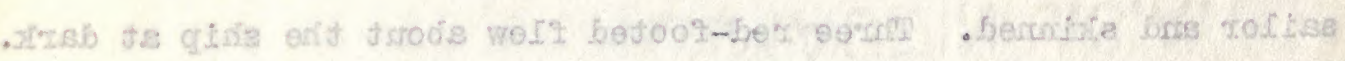

\section{AS nedinotored}

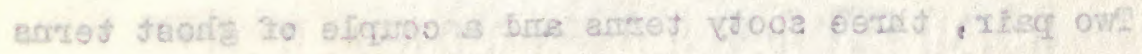

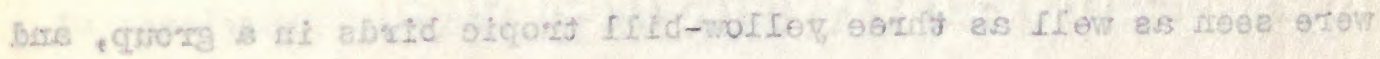


a larger tropic. A couple of small gray-back aestrelata came near the vessel, one at least having dark head marling. Wind getting light and we are about eighty miles or so SW from Mritahiva.

\section{September 25}

Three Bulwer petrels, one cuneatus and one $\underline{P} \cdot \underline{\text { obscuras, }}$ one plotas and several red-footed boobies, several yellow-bill tropics and a couple of red-tails, as well as a number of sooty terns and a dozen or more fairy were seen during day.

\section{September 26}

sooty and fairy terns all day and several boobies and three or four frigates. Several lesser noddies fishing in the P. M. Several red-tail and yellow-bill tropics also. A dark shearwater a little larger than cuneatus seen and ono obscurus. A little gray tern flew alongside and was secured at dark last nigint. Fine weather and island forty miles to windward all day supposedly, but unseen yet.

\section{September 27}

Eaio Island ahead at daylight, so bouted ship and headed St, seoing Nurahiva at twelvo-o'clock. Few sooty and wite terms and a half dozen lesser noddies in a flock noted. A red-tail 


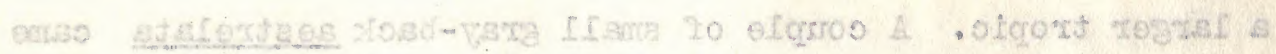

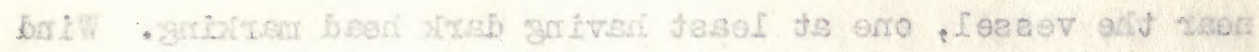

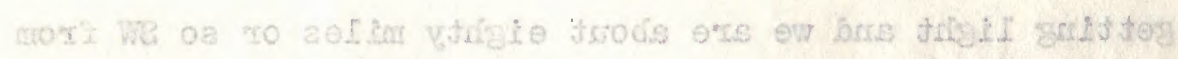

- sviofictistint

\section{¿̇ zedmestcrę}

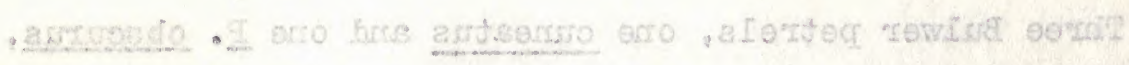

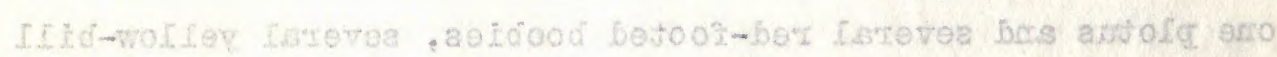

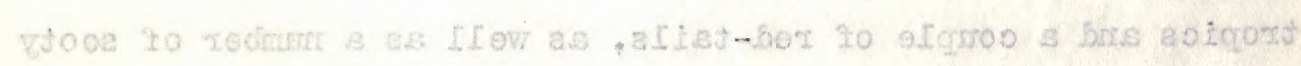

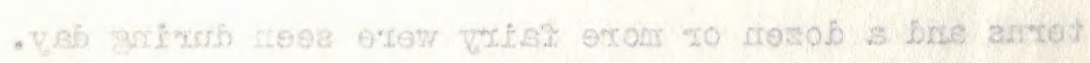

\section{9 recingtogé}

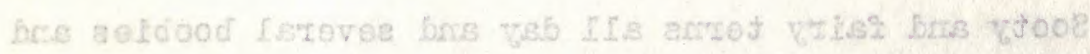

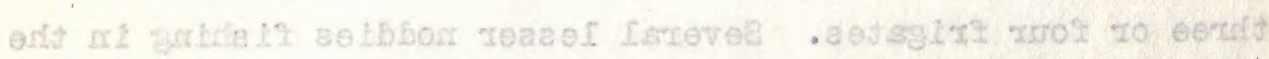

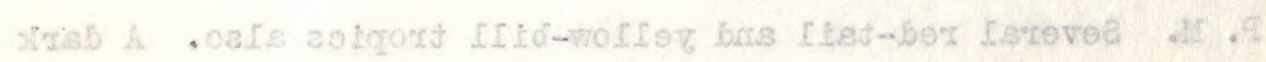

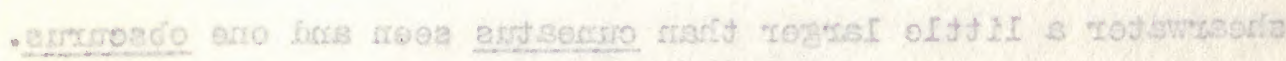

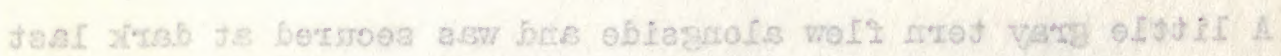

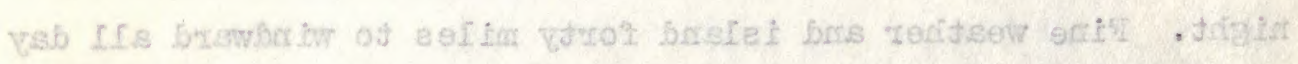

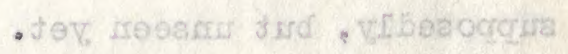

\section{is zodinetgei}

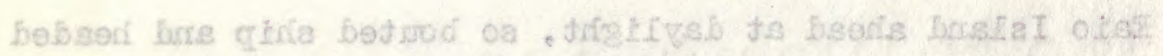

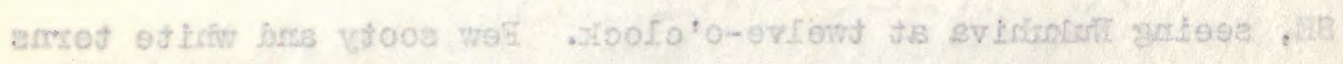

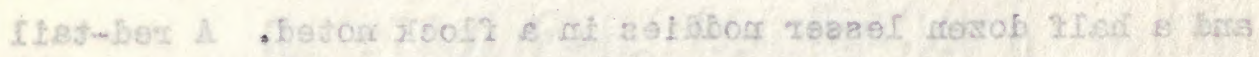


tropic or two, several frigates and a few red-foot and plotus boobies. The plotus show yellowish bills, whereas the small brewsteri taken a couple of days ago had a bluish bill and was decidedly smaller.

September 28

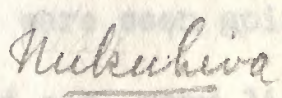

Started ongine last night, but it was four P. M. before we anchored as engine is not powerful and there was a head swell. West side of island dry looking with trees in canons and in higher parts near shore dry grass and some clumps of trees. Few plotus boobies on cliffs at one place and a couple of small gray terns flew along near them. Sooty terns were flying along close to shore but there was a big colony on an islet at east side of bay we entered. Sailors went over and brought back a couple of young nearly ready to fly. In bays on south side the mountainsides were greener than the west side of island. Several rain squalls passed along the coast as we approached bay, but night was clear.

\section{Septemier 29}

Ashore at six o'clock and up trail to 2,000 foet or so. Several heavy rain squalls lasting a few minutes each came along and soaked me, the trail being nearly a rivulet in pleces. Then not raining, warblers sang all over the hillsides and two or three 


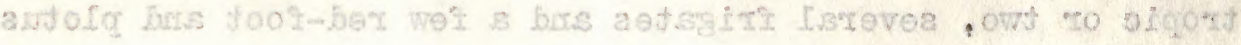

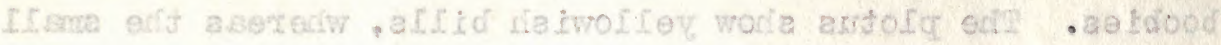

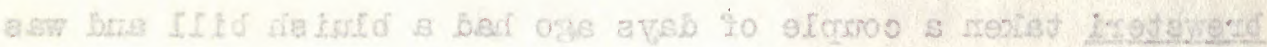
- rofirma visesiogl

\section{BS redinetope}

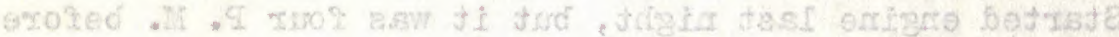

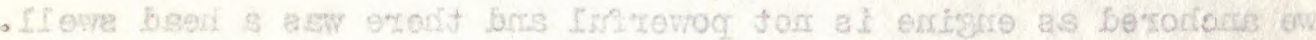

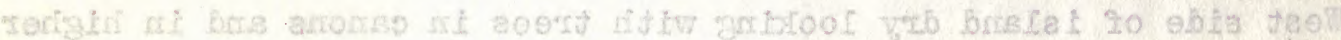

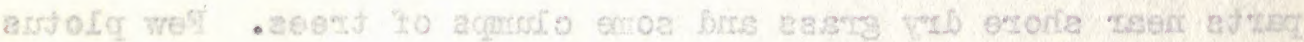

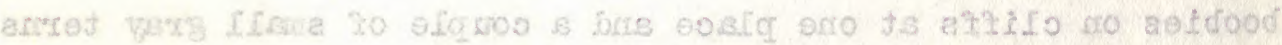

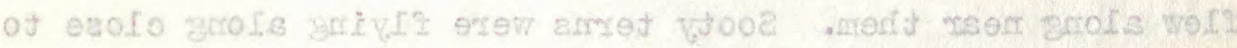

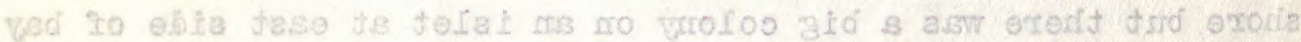

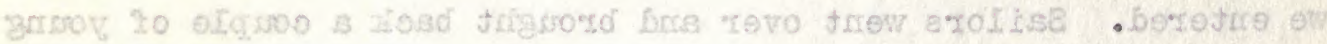

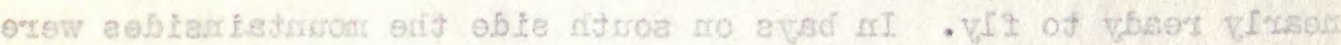

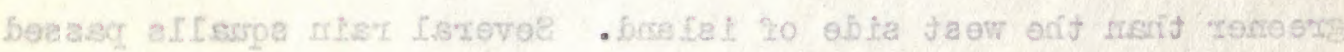

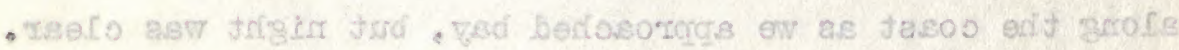

\section{es rocingteré}

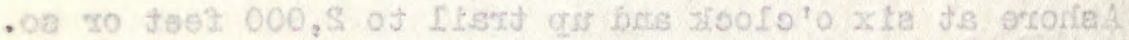

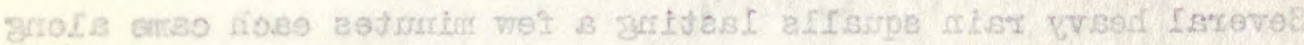

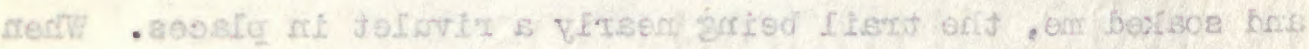

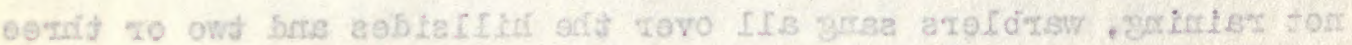


doves were heard, and after the rain cleared for a couple of hours a dozen flew up high in air and went to various parts of the hillside, probably having had certain trees to foed in. Iack of time prevented my hunting for them, as I returned at noon and we sailed at one P. M. for Hivaoa. Several noddy terns were noted along high cliffs at top of ridge and a couple were seen going there. Fairy terns were comon over the land and sea, many lighting in trees in canons, and when we left a couple of small flocks of lesser noddies vere seen flshing a couple of miles off shore in the rain. Wandering tatlers were seen and a reef heron taken.

\section{September 30}

A couple of grallaris petrels and a bulwers seen during rainy and windy forenoon; several nohas a.lso noted. A few miles west of Huapr Island at daylight and work slowly toward Hivaoa where we are tarding the Administrator and then returning to Nukahiva.

\section{October 1}

Got into harbor at Hivaos at two $0^{\prime} \mathrm{clock}$ this morning, and before six I was ashore and had started up the trail toward the center of the island. The day was without rain and warilers were singing full blast from the pandamas trees. A half dozen minahs were noted near shore, but they do not seem to go into the 


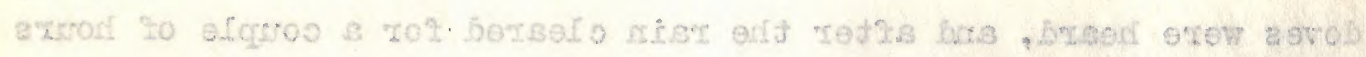

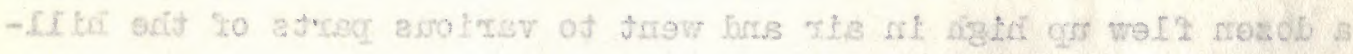

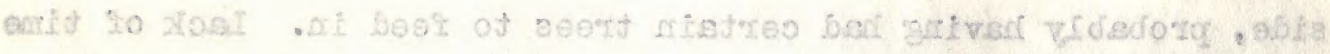

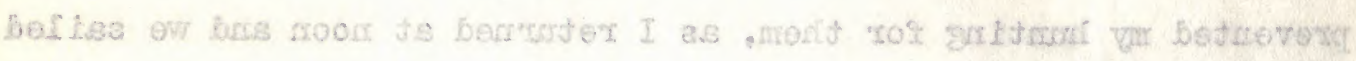

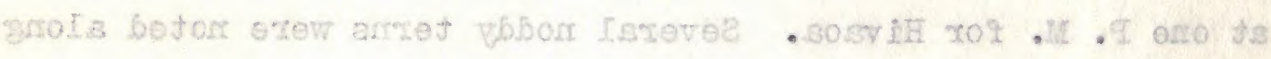

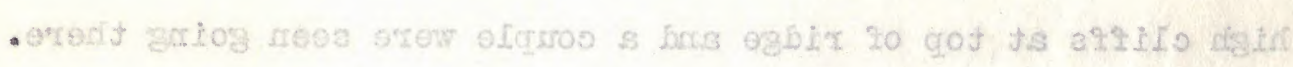

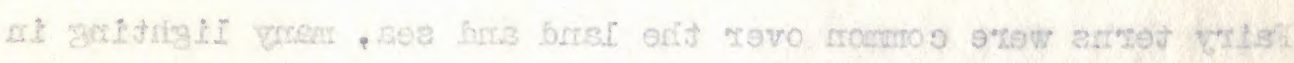

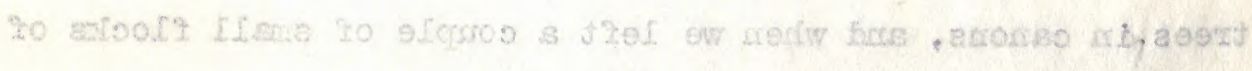

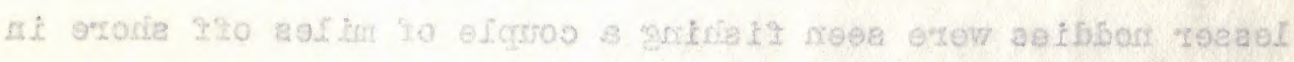

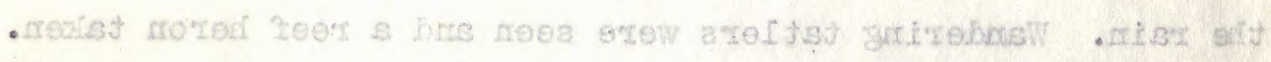

OE tedrutged

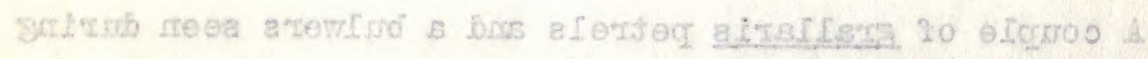

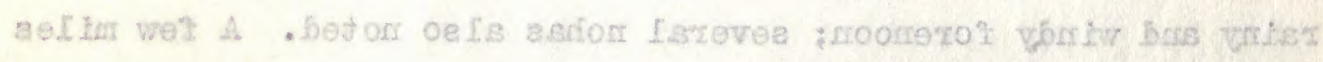

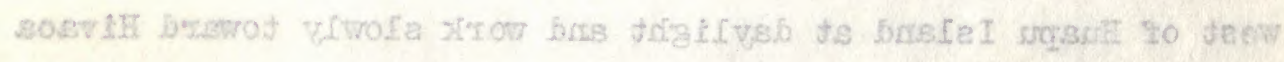

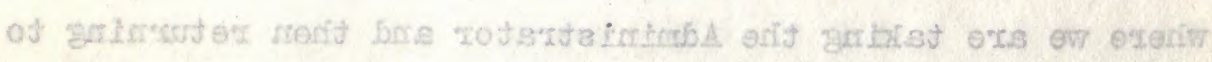
- svicixoisath

\section{I t9dotoo}

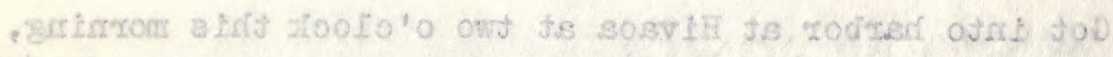

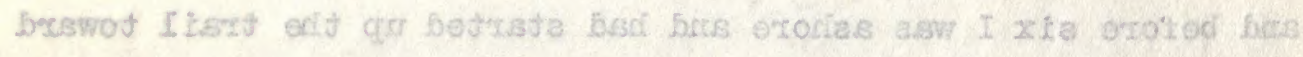

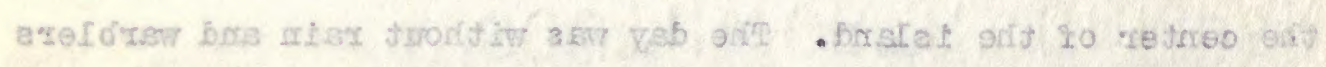

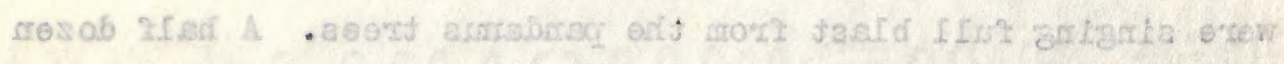

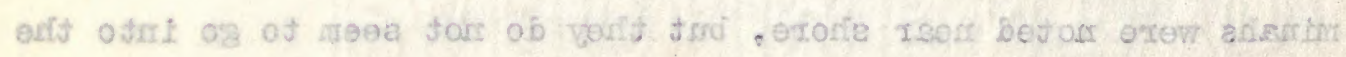


mountains as in Tahiti, the few birds here probably finding enough to eat about the shore.

In a small valley at 1,500 feet doves were cooing and the nest of a kingfisher was found with young bixds a day old. Parts of the eggshells were in the nest and were white, showing no markings on either end. The nest was in an old rotten pandams stro six feet from the ground and hed two entrances a couple of inches apart. The holes were about an inch and a quarter in diameter, and there were several others higher up in the stub, which was only ten feet high. The tree was nearly ready to fall and I lifted it up and placed it against a bush to photograph the nest in the sun. All the holes above but one had been merely started, but the lowest might possibly have been used last season. One of the birds came up with a bug in its bill while I was at the nest and perched but a few feet away, but usually they seemed wilder than any of the other land birds. Fairy terms were flying around and lighting in the trees, and several noddy terms were. seen flying high, likely coming from cliffs in the hills. Returned to shore at two and boat sailed at four for Huapr Island.

\section{October 2}

Huapu Island in sight at daylight thirty miles off nearly, but with fair wind we arrived at three P. M. Many Bulwers petrels and several grallaria petrels, the latter showing a black stripe 


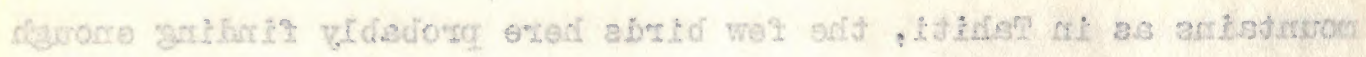
- szonia orif terodis diso of

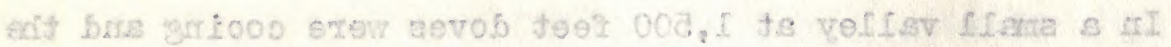

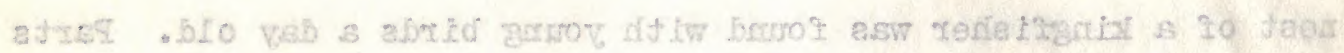
on grtwons , oj

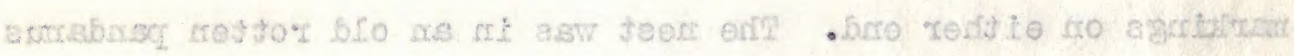

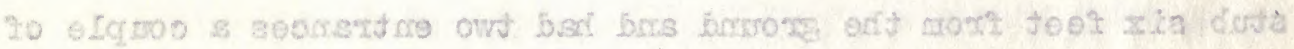

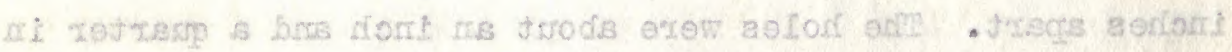

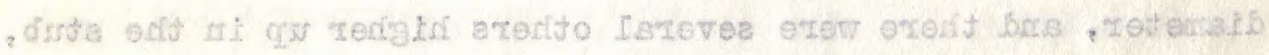

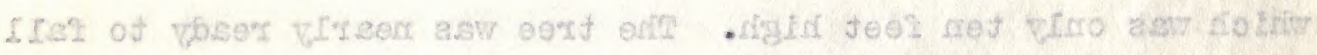

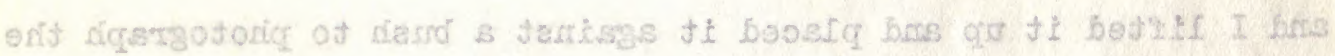

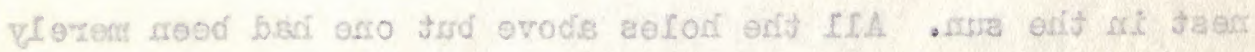

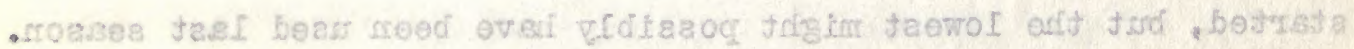

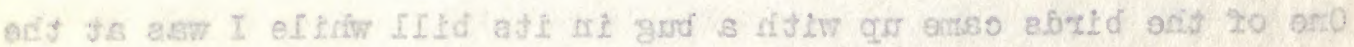

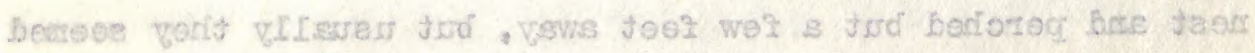

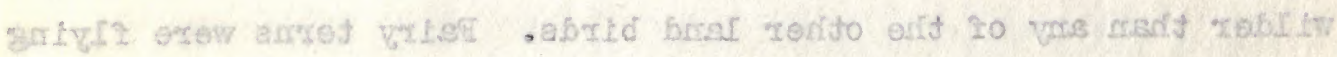

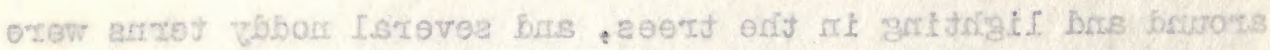

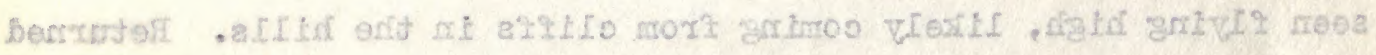

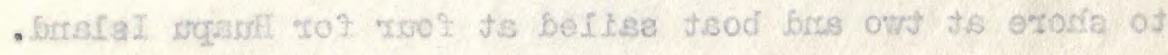

\section{S redojpo}

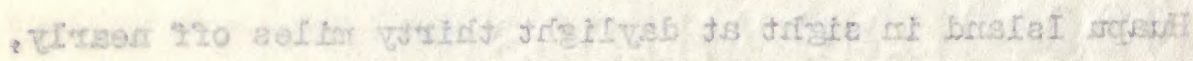

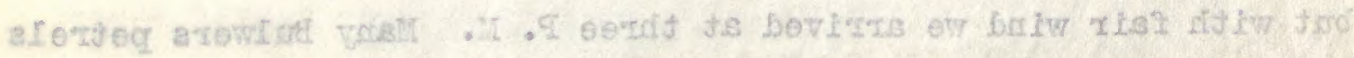

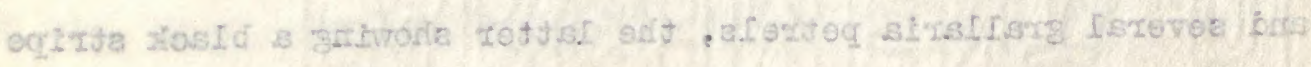


across throat but chin seemed white; none oame very close. Negelcted petrels also were common a fow miles off the island. Lot of young plotus boobies came around schooner as we neared land. Fairy terns were common all along, and a half mile from shore several small gray and lesser noddies were seen fishing. Sooty terns had a colony on island off north point of Huapa, and three or four frigates were sailing overhead. A sanderling was scared from beach when we landed, the first I have seen on the trip. It flew out along the cliffs out of the small bag. A single paroquet flew from the settlement as we approached. Warblers were singing and several were seen in the hour ashore. A young sooty tern was seen flying near the colony, and several noddies also seen.

\section{October 3}

Ashore early and up trail into hills through forest. Saw paroquets a mile inland, feeding on flamboyant blossom, it seemed. They were in companies of three or four or sometimes a half dozen. Single birds frequently flew high in air the same as doves and sailed around the ridges or across cañons, though the dores seemed to enjoy it most in a high wind. Doves were cooing in the higher part in big trees and along the higher canons $\mathrm{fly}$ catchers were found, usually near stream. Warblers were singing and three nests seen, but none had eggs, and one brood had 


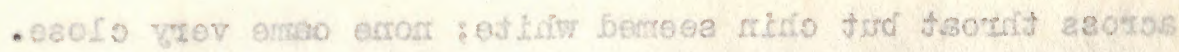

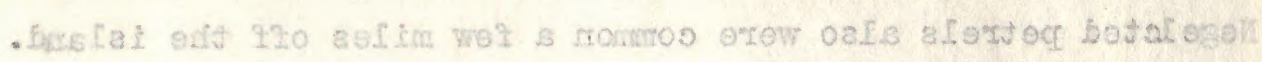

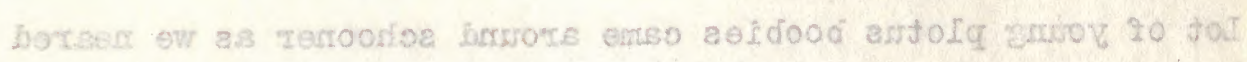

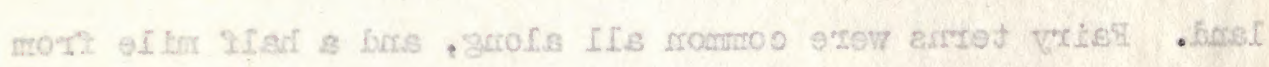

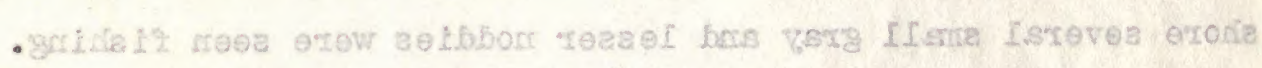

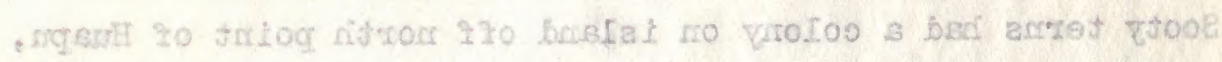

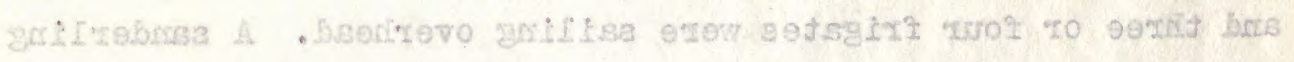

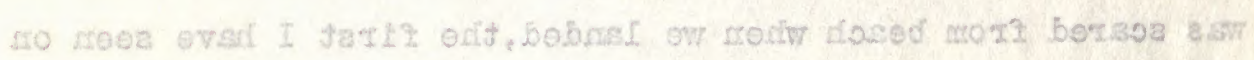

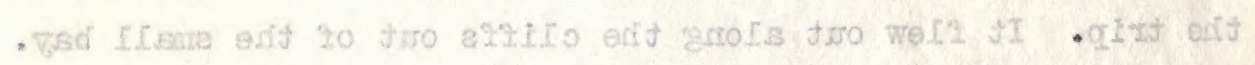

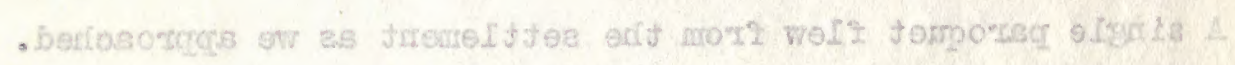

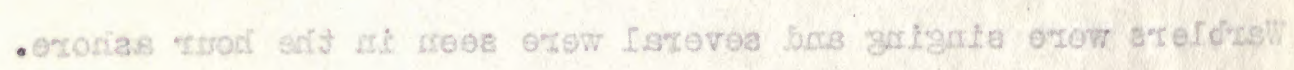

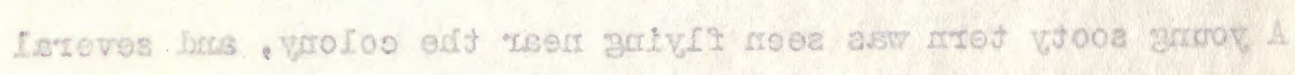

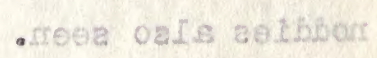

\section{E rodosto}

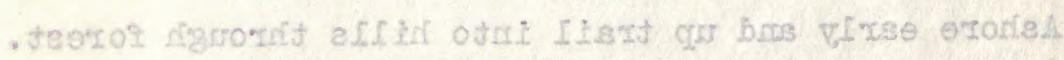

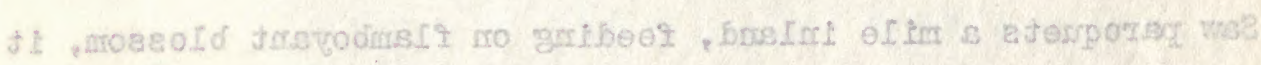

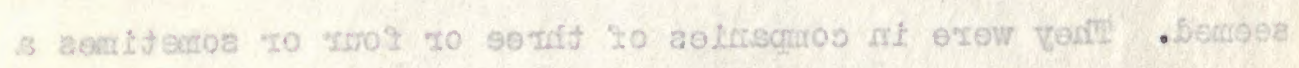

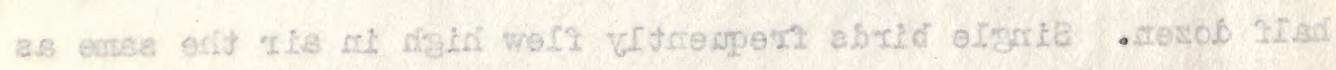

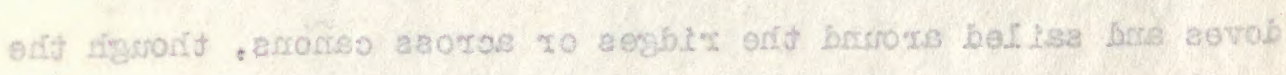

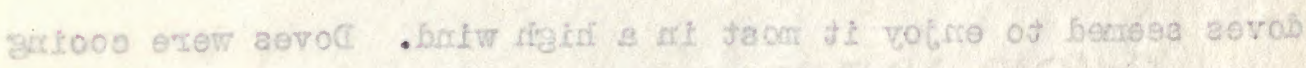

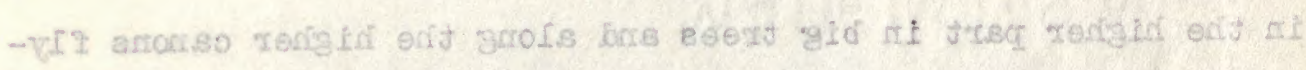

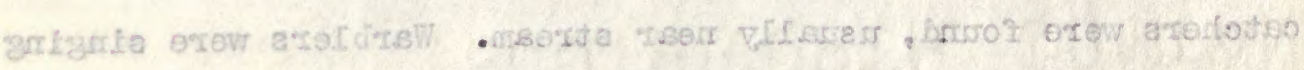

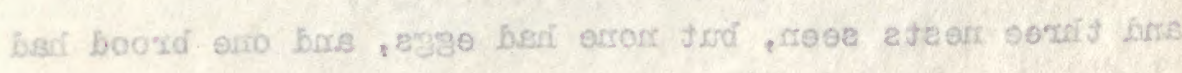


recently left nest, as well as several broods seen a little older.

A neglected shearwater or two flew around a peak and there may have been several flying around a pinnacle peak a mile away from trail. Sailor shot a couple of frigate birds flying over pond just back of beach. Two sanderlings flew out from beach as we neared shore, but could not get a shot. Fairy terns wero common about the forests and a noddy seen sitting in a cocomat tree way up in hills. We left for Nuluhiva at five o'clock, arriving at twelve $\mathrm{P}$. $\mathrm{H}$.

\section{October 4}

\section{Nububiera}

Took lot of birds from Huapu Island ashore and skinned them on porch of Brown's house (the botanist from Honolulu). Heavy showers occurred several times during forenoon, and I went aboard in P. M. and sirinned a couple of boobies and packed some birds.

\section{October 5}

Left at two o'clock this morning and anchored early at Taipe Bay at southeast end of island. Hice warm day and I went up a stream, getting a wild hen and ono small chick. Taxblers were taken, but only one dove seen at a distance. Couple of swifts seen and fairy terns were common. Left in evening for north side of island. 


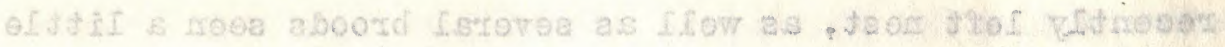

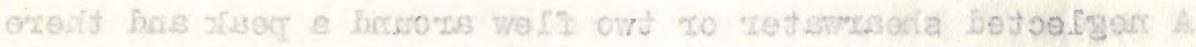

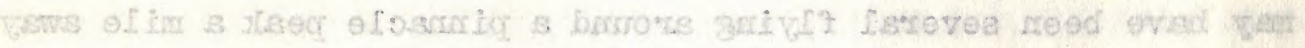

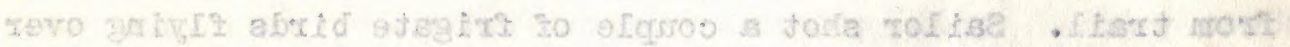

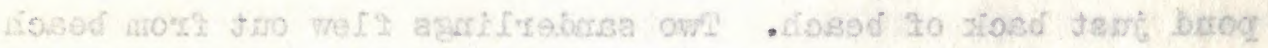

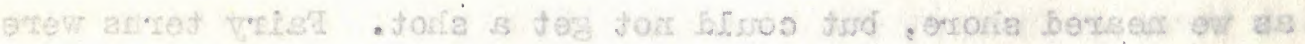

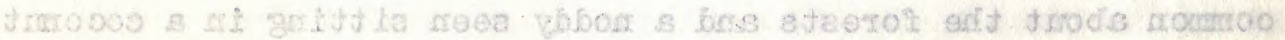

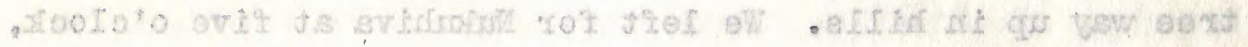

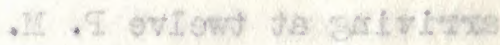

\section{A redotoc}

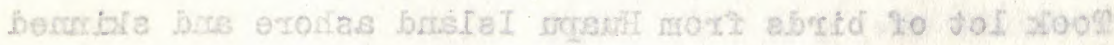

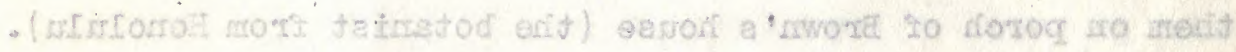

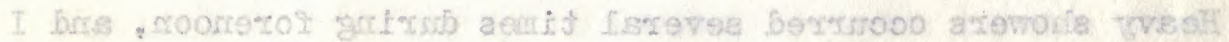

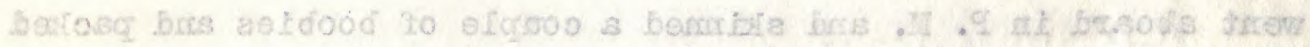
- ebsios encoa

¿ zedeso

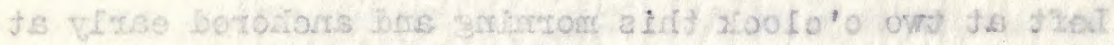

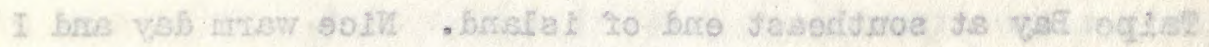

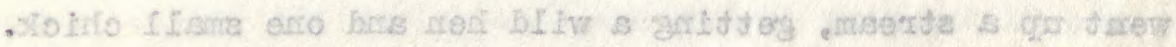

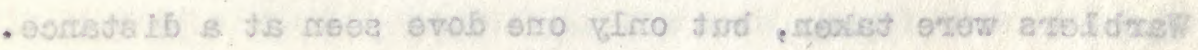

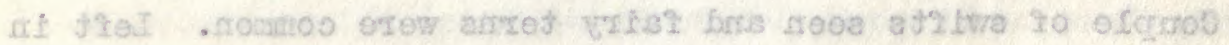




\section{October 6}

Got into Hatiher Bay late last night and ashore early. Wont up the trail that crosses to Taipe Bay. Two or three showers passed over, soaking everything, but I went to top of ridge and looked down the steep canon on the other side. Right on top of the ridge two rails were heard, but I could not see them, though I climbed a tree and called for somo time. Fairy terns crossed the ridge, often going to higher altitudes, though the pass is over two thousand feet. A noddy tern just clears the roadway as it crosses to Taipe side, and yellowbill tropics circle overhead, often three birds together. Doves coo along top of ridge and try to locate me as I call to them. A couple of swifts fly about for a mimate and then pass on.

\section{October 7}

Move around coast to small Hakapa Bay to get a couple of tons copra. Get several doves in trees where the birds are feeding in cakions and watch birds fly from one side ridge to other, emalating the terns in soaring feats at times. Several lesser noddies seen flying about trees as well as fairy terns.

\section{October 8}

Left the small bay last night and came into Anaha Bay, where are a half dozen houses and a couple tons copra. I 
a $\operatorname{xoc} 0 t 00$

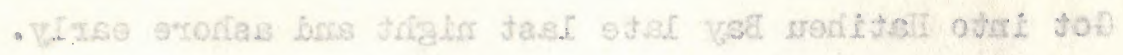

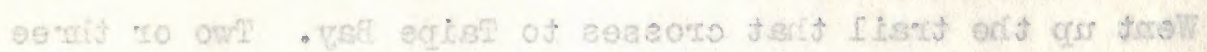

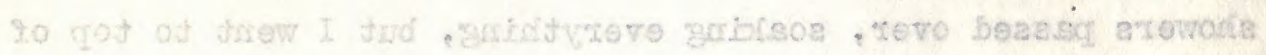

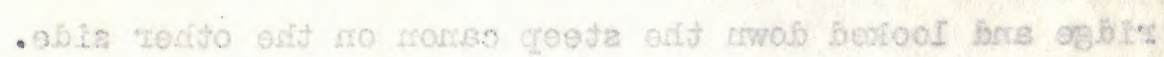

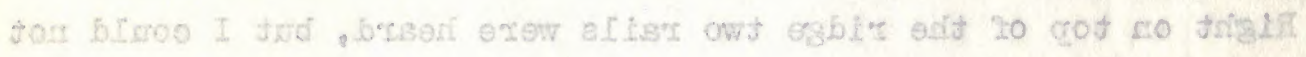

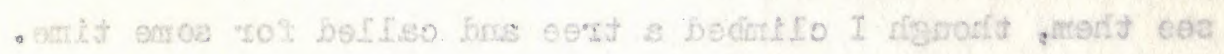

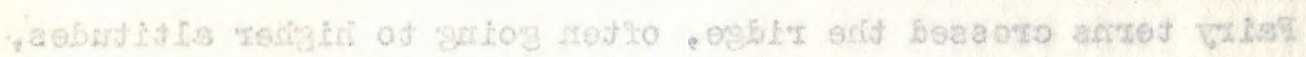

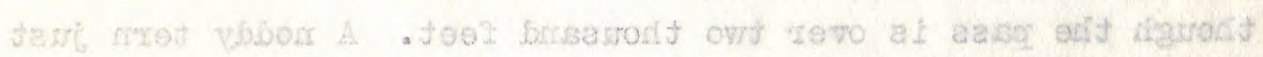

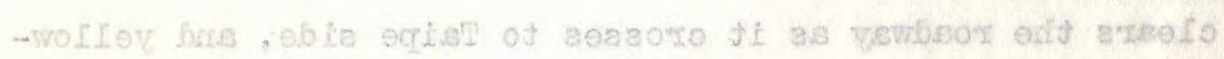

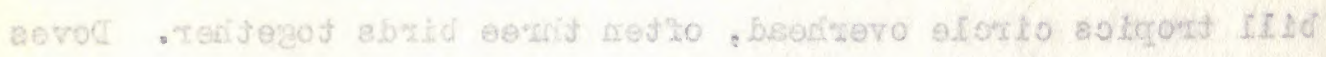

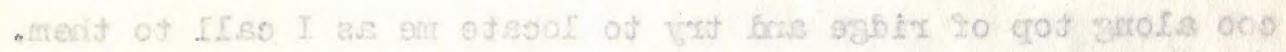

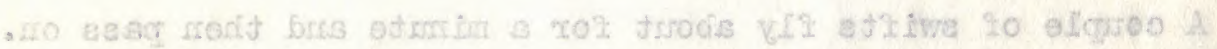
5 sediotso

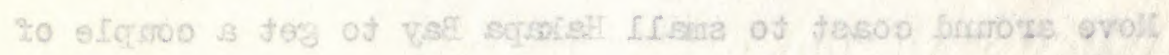

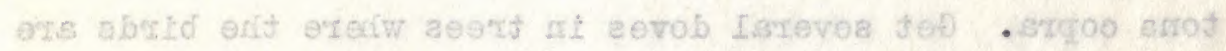

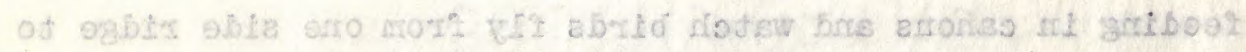

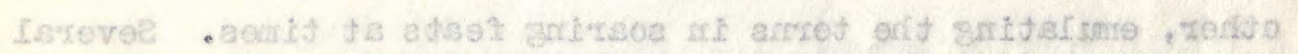

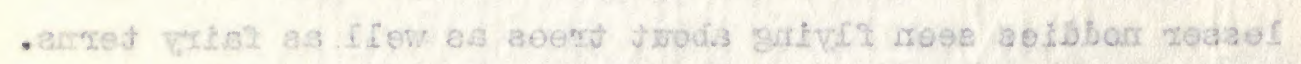

\section{$8 \operatorname{sedot} 00$}

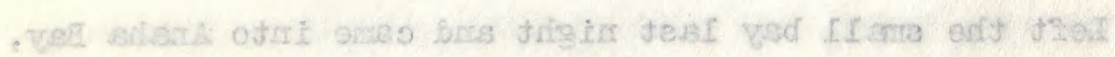

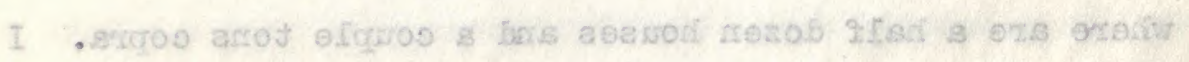


crossed a small ridge to head of Hatuatua Bay on east side of island. Warblers and doves taken and a swift shot but not found.

A dozen lesser noddies were roosting in trees a mile inland and one nest seen in a nearby tree that belonged to this species. Fairy terns were common and wild chickens heard and seen. A sanderling was shot on a sandy beach, and another was seen later in the day on another beach.

\section{Cctober 9}

Arrived at Uahuka Island at four A. M. and lay off an hour till daylight, then ontered the hole in the cliffs called Vaitake Bay. Pigeons were lighting on the cliffs, but they were from a house on the beach, but being mostly blue reminded me of the wild ones on Juan Fernandez Island off Chile.

It being Sunday I took the camera ashoro and took a fow pictures. There was a small Catholic and also a Protestant church where services wore held. The finest example of tattooing yot seen was exhibited by an old man whose face and body as well as legs were covered with designs in bluish ink. Cocomat trees were in the bottom of the canon for two miles inland from the beach, and in places they were well up on the hillside. Oranges, limes and breadfruit were plentiful, and guavas were also ripe, though not as largo as the fruit at Aneha Bay and Nuluhiva Island. 


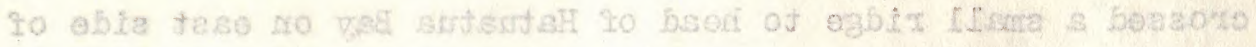

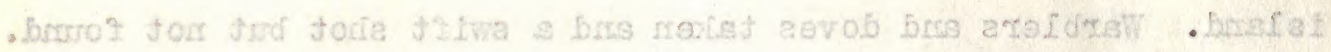

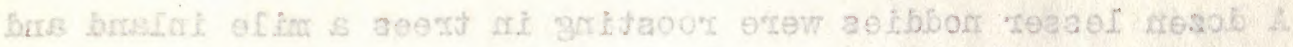

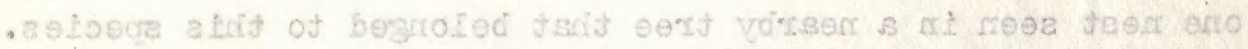

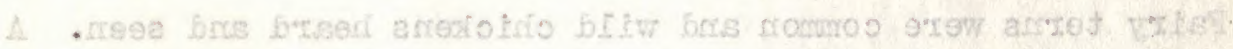

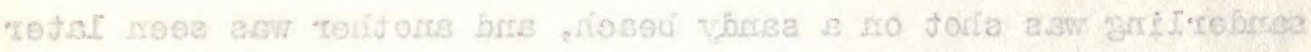

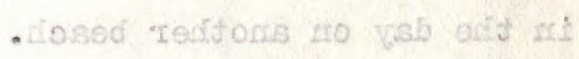

e. rodiotso

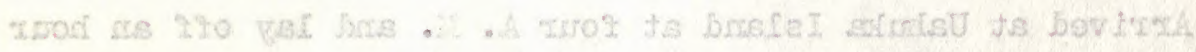

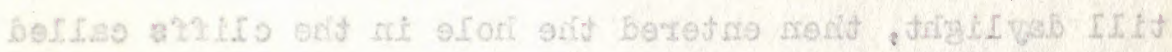

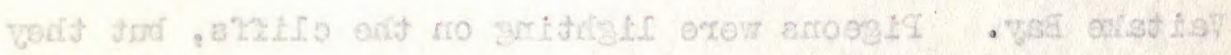

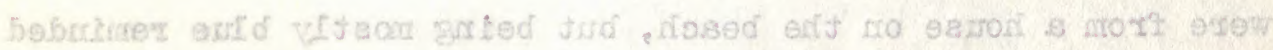

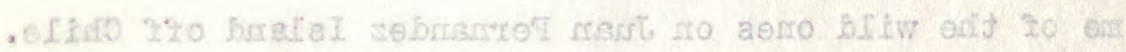

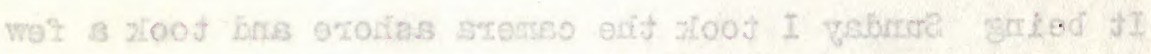

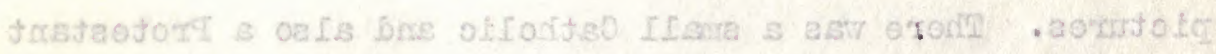

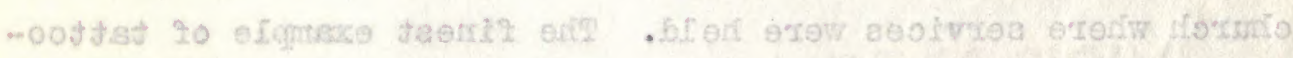

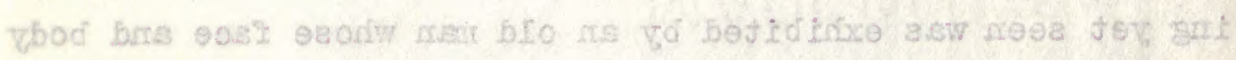

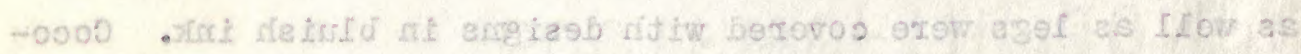

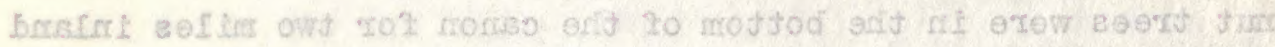

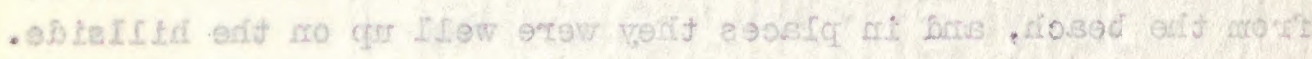

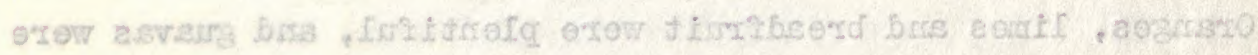

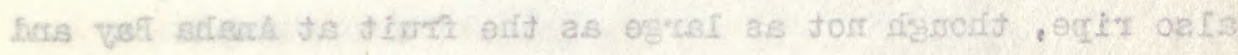

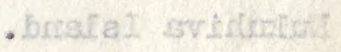


October 10

Inland a way and found warblers common, as well as flycatchers, the latter being on the open ridges as well as in the thicker forest. On Hivaoa and Huapu Islands they were found in the bottom of canons usually. Several swifts were flying along top of cliffs in morning, and one was shot and lost in bushes later. Seven curlews flew over boat as we were ready to leave the anchorage and the natives told me they were cormon on some of the drier ridges. The island is dry looking on the north side but wooded on the higher mountain. Sooty terns are probably nesting on the island at north side, as we heard them as we passed in the night.

\section{October 11}

Left yesterday noon for Hivaoa and reached here at nine A. M. this morning. I took a trail to eastward and went toward top for a few miles. Doves were quite common, feeding in small trees having a ripening berry on then. Some doves were noticed sweeping down from the higher parts of the island and a number of green-crowned birds were taken, though a couple of breeding males were also shot.

A couple of wild kingfishers were seen at a distance in a canon, but flew at approach. Fairy terns were circling about the forest in some canons and settling in the trees. Two male 


\section{Of zedotol}

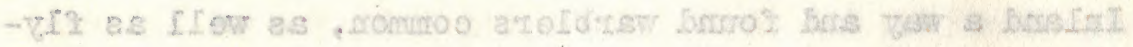

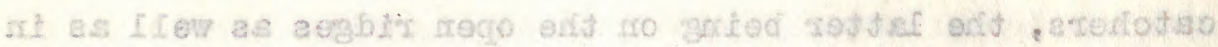

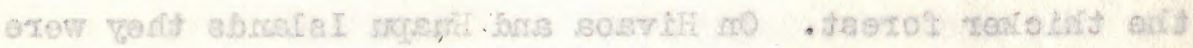

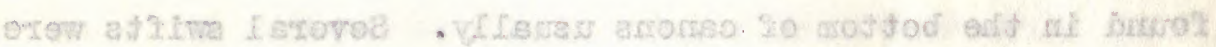

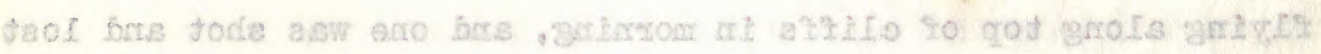

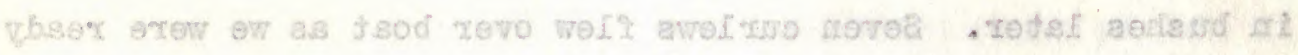

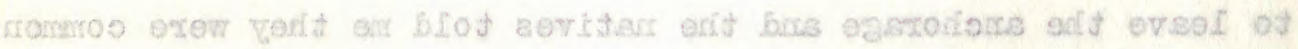

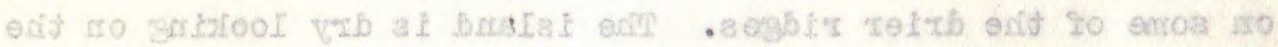

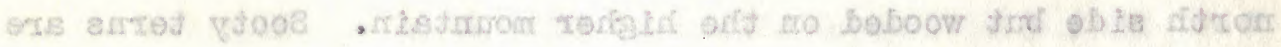

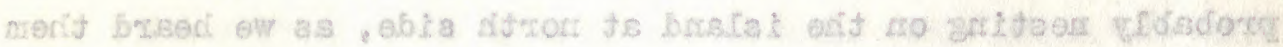

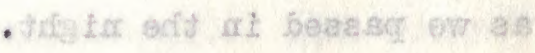

\section{If. Tedos}

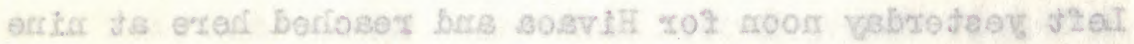

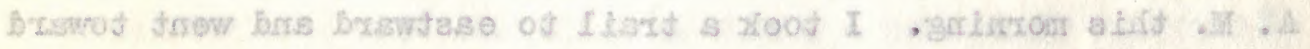

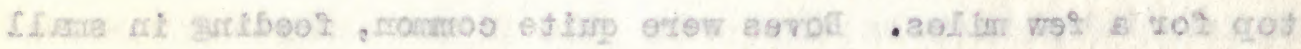

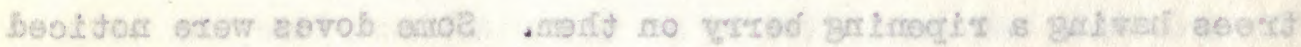

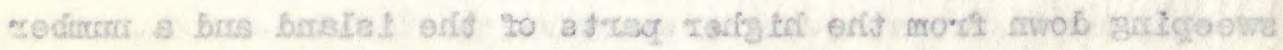

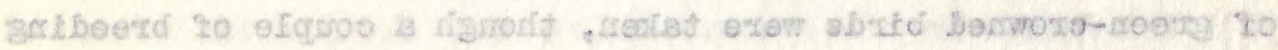
- toris oels etow aelear

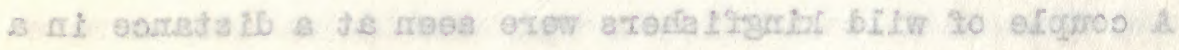

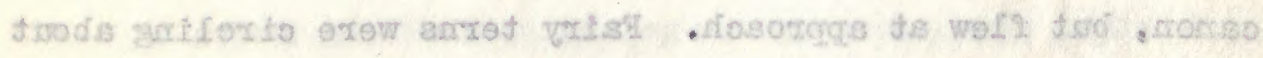

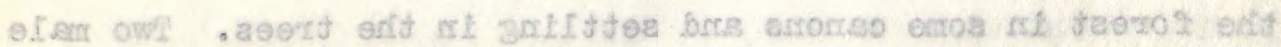


Plycatchers were secured in the bottom of a canon, and at the beach a couple of reef herons sat and a frigate bird circled around in bay fishing. We sailed at six in the evening for Fakahina Island in the Tramotus.

\section{0 fulliva? October 12 \\ Off Fakihiva at daylight and kept in sight all day, as} the wind was light. A bulwer petrel and a few sooty terns at sunset, and a little gray term was flying along with five redfoot boobies toward Fakihiva at sunset, two miles away.

\section{October 13}

A yellow-bill tropic about vessel in mornine and a couple of red-foot boobies, as well as several sooty tems flying about fishing. Calm all night with some rain. Three red-bill tropics flew around about noon and sooty terns were seen several times, as well as a bulwer petrel.

A couple of bonitas were caught by the Captain and shortly after noon a fair wind came up and we moved onward.

About four P. M. a flock of sooty terns and several redfoot boobies pessed ahead fishing and several small pterodroma were fishing behind them, the latter having darik upper wing marking, though lighter on the back, and the head appeared to 


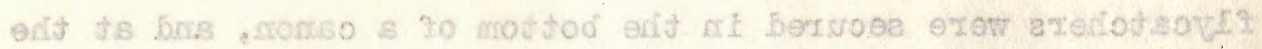

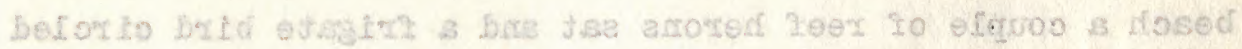

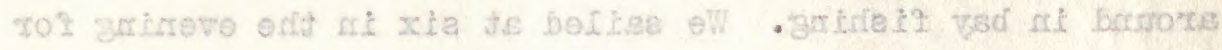

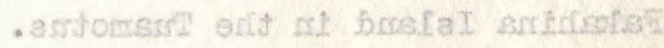

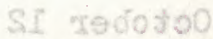

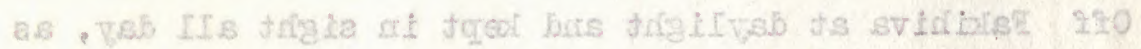

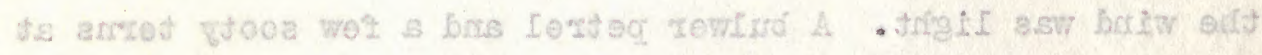

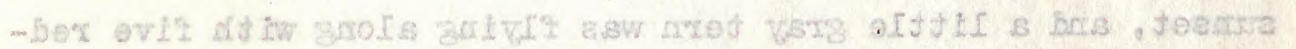

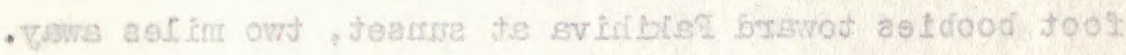

\section{al redotod}

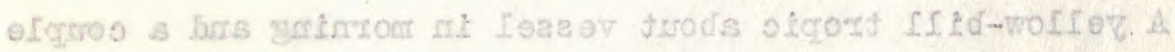

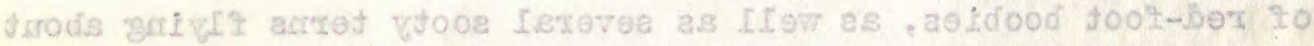

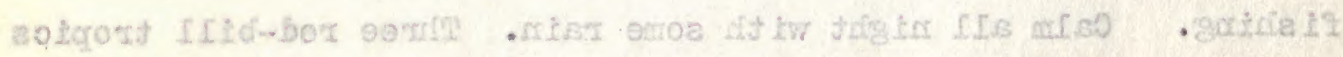

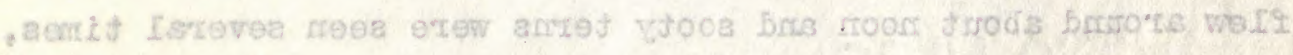
- Iorteg tem lud is as LIOW GS

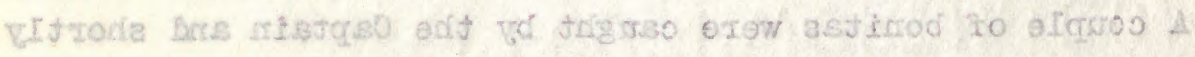

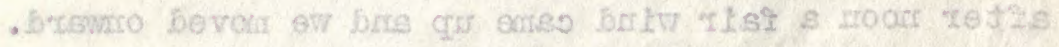

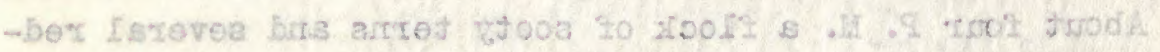

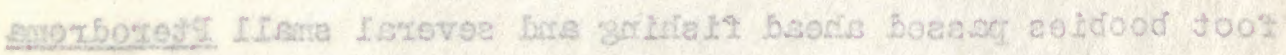

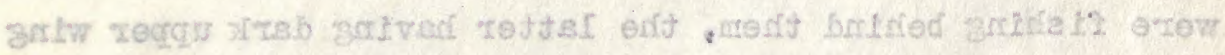

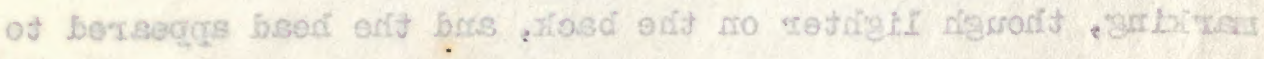


be marked with black, white below. A single fairy term was with them. A Bulwer petrel or two was also seen.

\section{October 14}

Fine breeze all day. A dark shearwater, possibly cuneatus, pessed and a couple of red-foot boobies as well as several yellow-bill tropies.

\section{October 15}

Reached Faishina at noon and ashore for four hours, finding a half dozen warblers in the coconut trees and seeing a few fairy terns in some tall trees near the village. Several rectirostris terms were on a point of land in the lagoon and a couple of wandering tatlers were shot there. A flock of noddy terms was seen circling about some trees at the east end of the island, and a reef heron was shot in the cocomat grove just as he carght a lizard and others were seen in his stomach, which was preserved. We left at four P. M. for Hao Island.

\section{October 16}

Island in sight soon after daylight and we sailed along the north side, seeing clumps of cocomut trees as well as single trees and $3,4,6$ etc. together, with barren coral between. No 


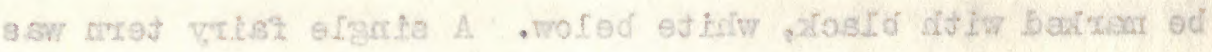

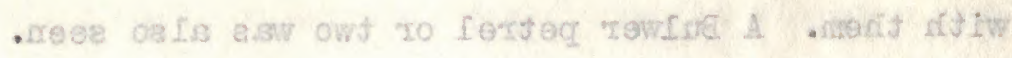

$$
\text { A. redoto }
$$

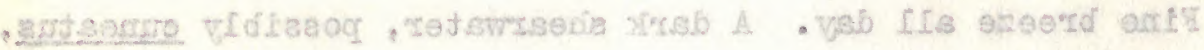

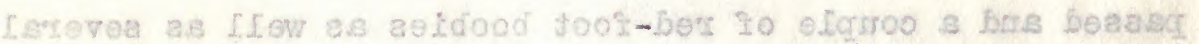

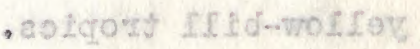

\section{EI. "rodotoo}

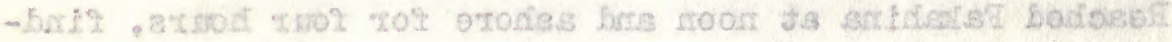

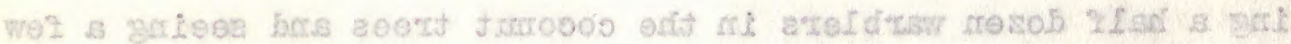

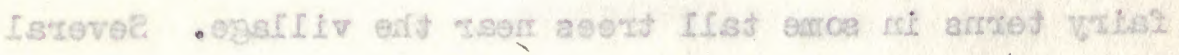

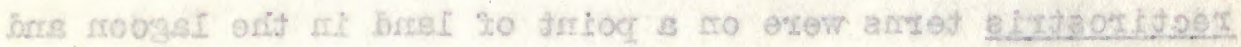

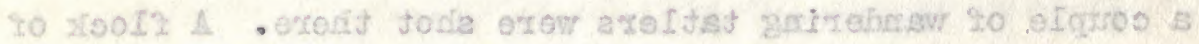

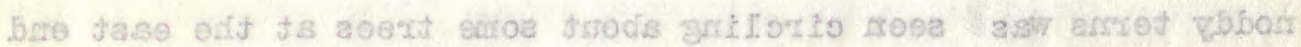

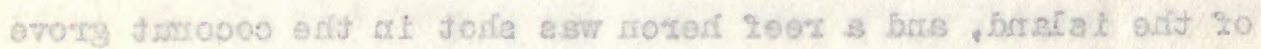

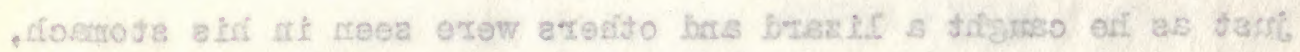

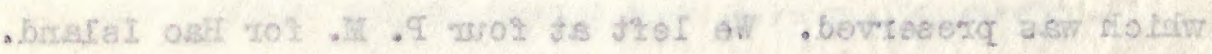

\section{a). 1000400}

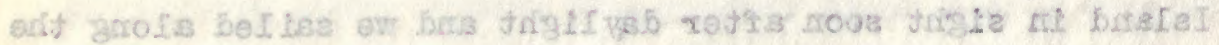

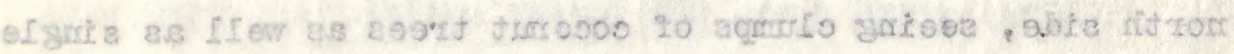

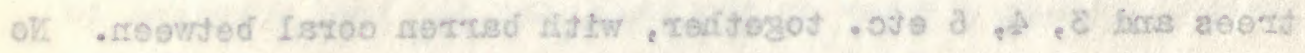


birds this morming as we sail along, and only a fairy term was noted as we approached Fakihina yesterday. Reached Hao Island at 2:30 P. M. and ashore for an hour, but saw only a couple of tatlers and did not hear a warbler or other land bird. A couple of dozen houses along the water front and lots of coconut trees not near as high as the trees of the Marquesas. Houses are mostly frame covered with galvanized iron roofs. Quite a few broken off cocomuts show effect of harricane. Most houses are raised a few feet from ground on coral rock usually.

\section{October 17}

Ashore before sunrise and went several miles down the coast, but a dozen warblers were the only land birds seen. A couple of white reef herons were noted. A caple of rectirostris terns were taken, one of which was flying over a pond with water a fow inches deep and containing fish. Wo left for Hakemo at three P. H. and saw no birds after leaving island.

\section{October 18}

Tekokota Island seen at seven in the morning and three or four sooty terns. Hao Island yesterday had but few bushes or trees other than cocomats and all vegetation seems but a few years old, whether burned off or swept by hurricane or both is uncertain. Reached Nihiru Island at three P. M. and ashore 


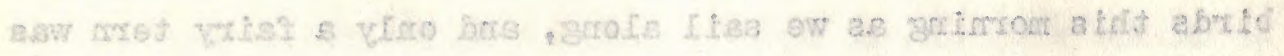

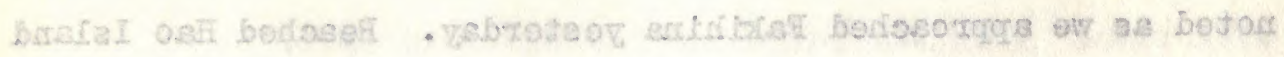

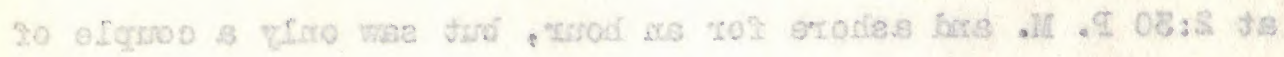

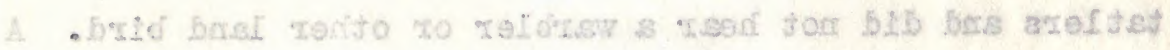

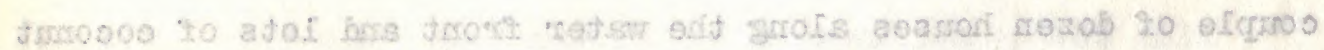

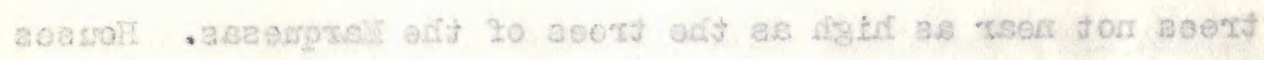

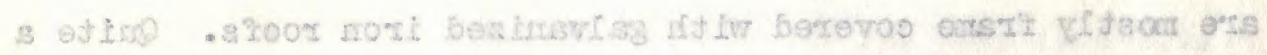

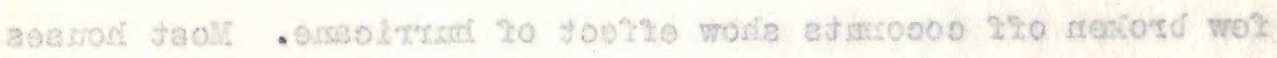

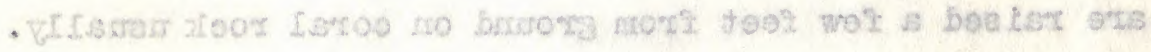

\section{एE I0dotoo}

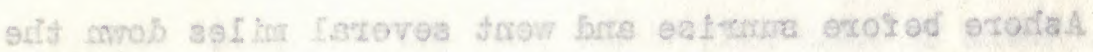

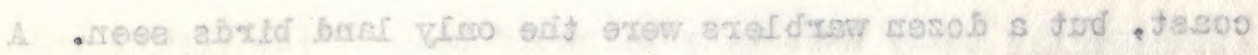

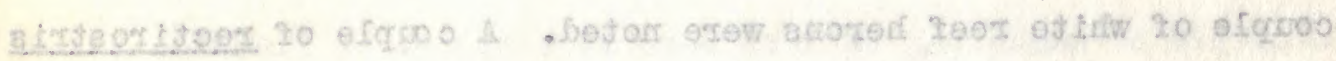

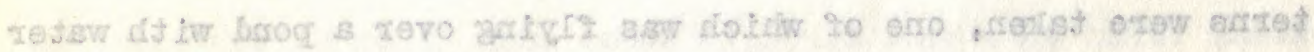

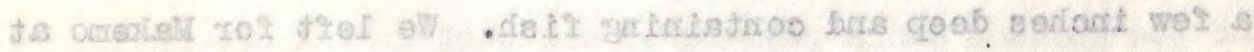

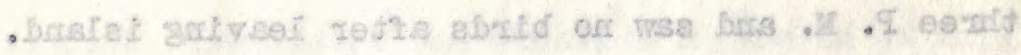

\section{5 sedoto}

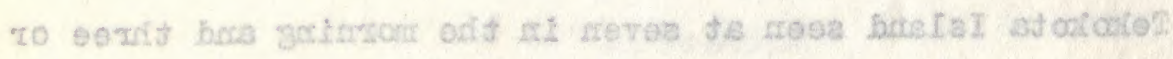

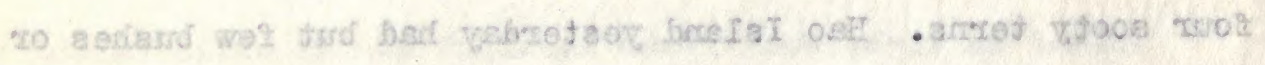

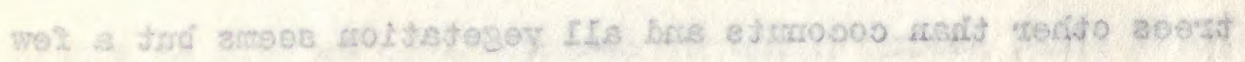

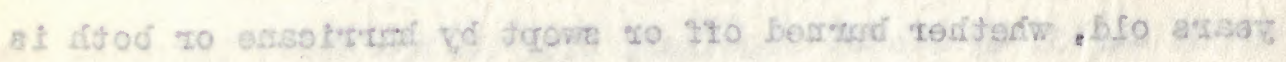

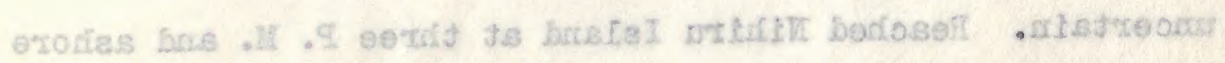


till six P. M. and got one warbler, the only land bird seen. Wandering tatlers were common, and a couple of golden plover were seen. A couple of white reef herons seen and several rectirostris terns. I bought a couple of the latter Irom a native. They were both young birds unable to fly and were taken on this islet.

\section{October 19}

Got a couple of white reef herons and a yellow-bill tern. Sailed for Hakemo at $9: 30$ and are now sailing along the shore of Makemo and will go in pass pretty soon. Speared two and caught one fine dolphins just as we left Nihiru.

Ashore at Makemo for a couple of hours and went about three miles along through patches of brash and cocomats. Heard and obtainod but one warbler after leaving tho villago. Heard one in the village singing in a coconut tree, but did not try to shoot him. Lesser noddy terms were flying along over the island to windward and to a colony probably to the eastward. A golden plover and several tatlers were seen, and when we struck the east ond of the island fairy as well as noddy terns, frigate birds and a few red-footed boobies were fishing and flying over and. near land. Red-footed boobies tried to catch flying-fish, but I did not see any succeid, but the persistency 


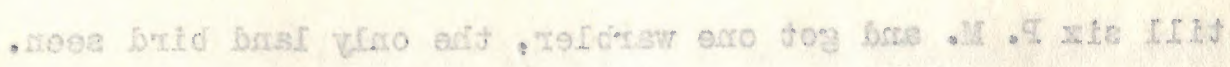

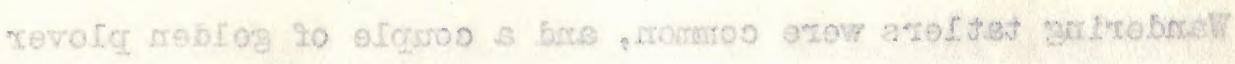

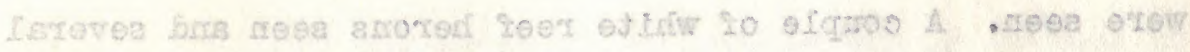

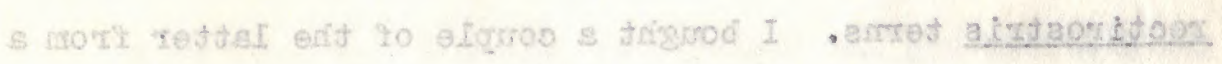

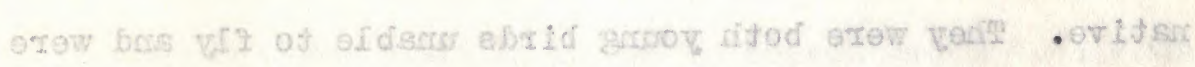
- telei aldit ro gentst

ef rediotso

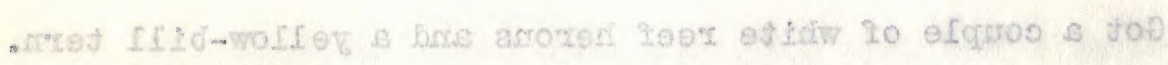

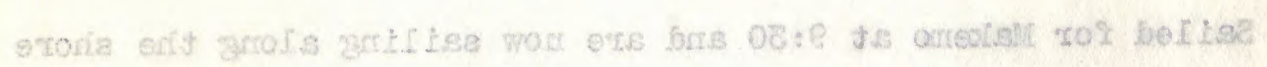

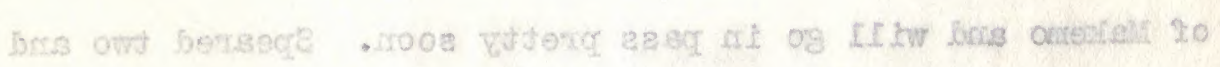

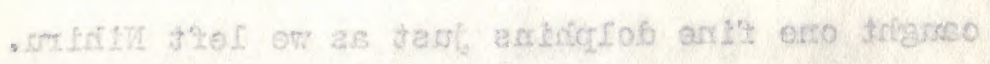

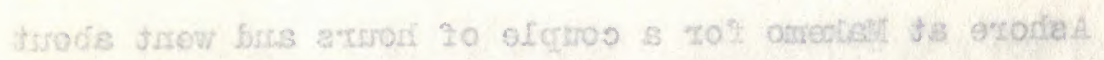

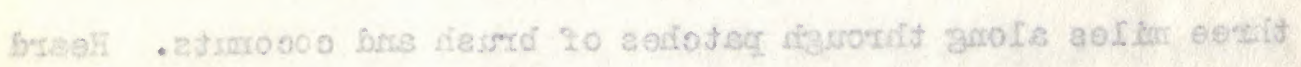

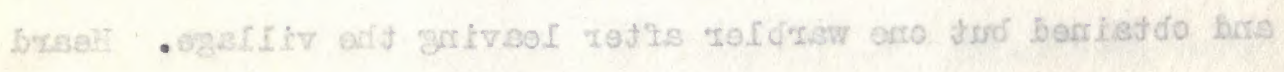

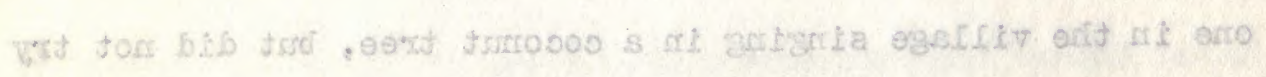

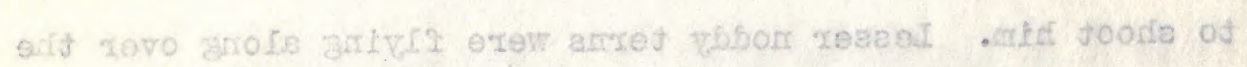

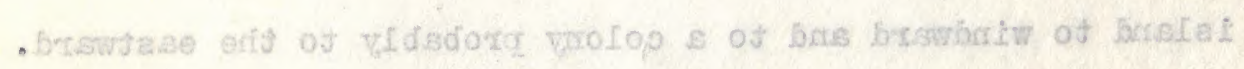

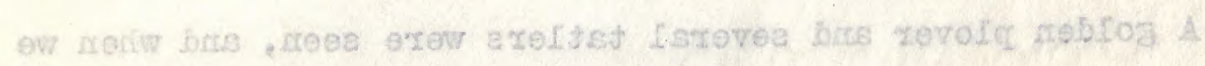

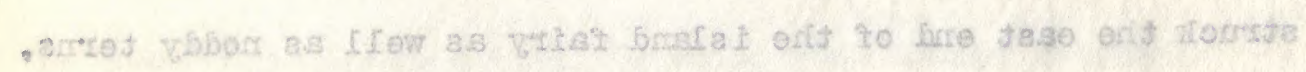

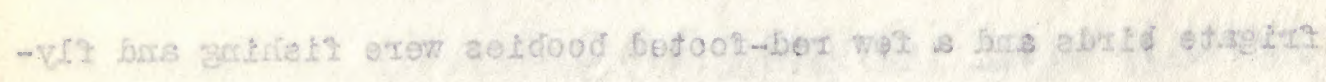

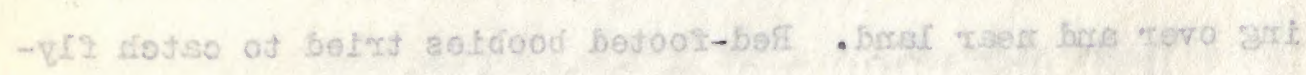

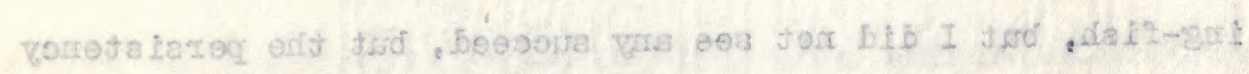


shown indicates that they must frequently catch fish by following them in the air.

\section{October 20}

Left the anchorage at five A. M. and sav the 'Moana' nearing the pass as we left. The 'America' and the 'Sophie' were anchored as we left the lagoon. Patches of brush with clumps of coconuts and stretches of barren coral where hurricanes have swept all vegetation are the features of the north coast, while on the south coast but very little vegetation can be seen as we head out to the southward. A few noddies fly about over the trees at the west end.

Reached Hiti Island at about noon and ashore for four hours, finding fairy terns common and many noddies. Two fairy terns were seen on nests, bare limbs of trees about four inches in diameter. One on pandanas limb other buro? Birds sat on nest till I was within few yards and other birds sat till closely approached. A young red-footed booby was seen in a nest near the beach in a tree about ten feet up, about a month old. Doves were seen in shade of low bushes along beach and a pair were sitting in the open near on the ground near the lagoon shore. Warblers were not common and did not favor the pandemas trees and kept in low bushes very often. A bristle-thighed curlew was shot, as was a golden plover in open bushes near lagoon. A sandpiper flev up to mo and was missed flying with the 


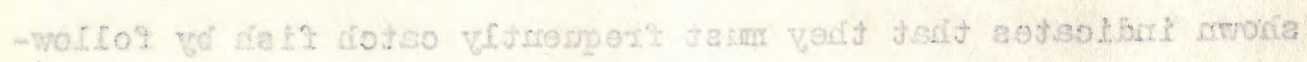

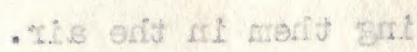

OS พอdojo

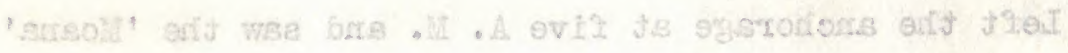

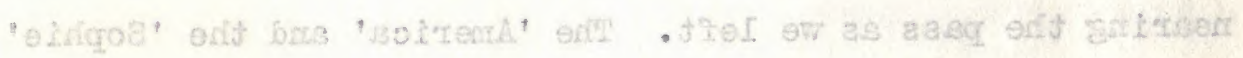

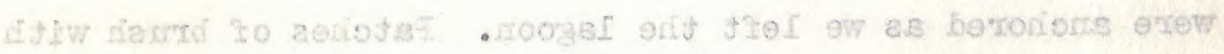

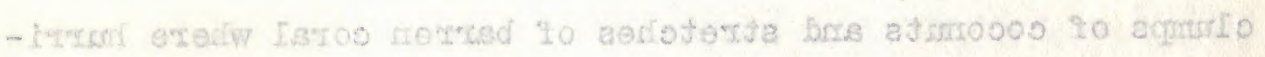

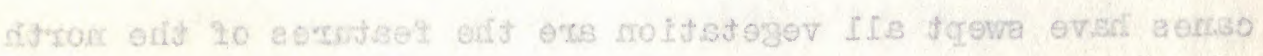

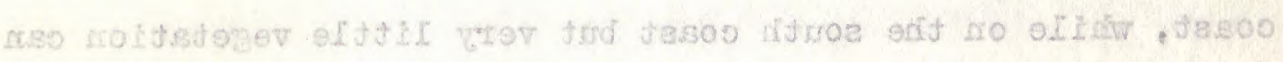

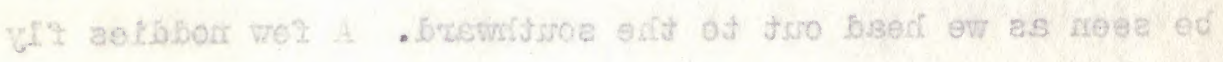

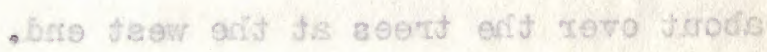

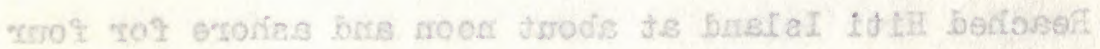

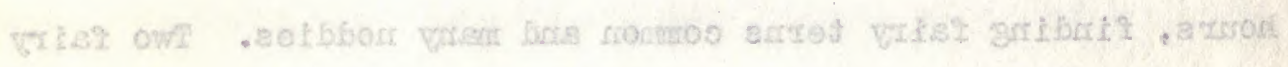

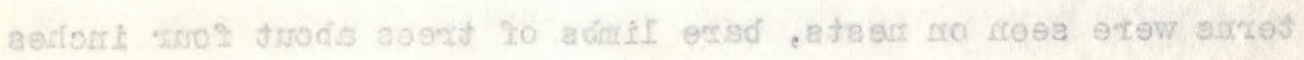

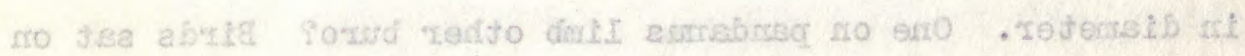

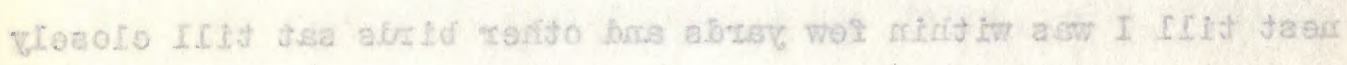

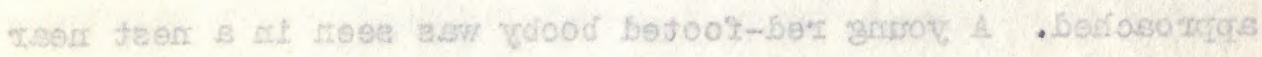

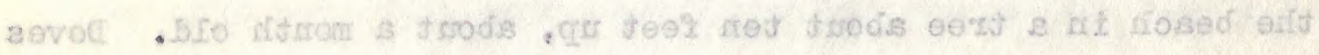

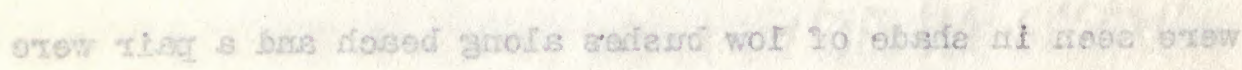

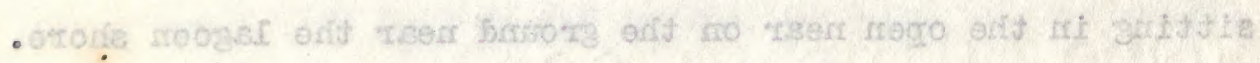

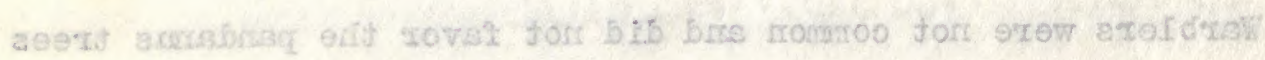

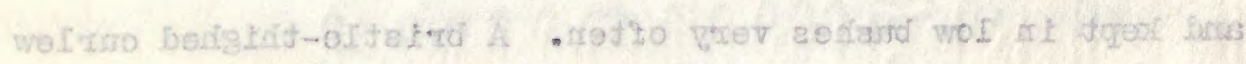

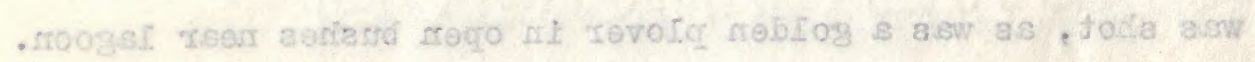

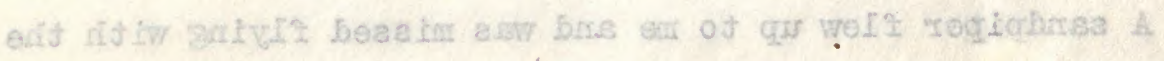


auxiliary but came right along and lit on a bare limb about eight feet from ground. I backed off to get shot with heavy load of tens, but bird flew toward me before I stopped to shoot and lit on ground near me. I ran back again and the bird ran toward me but stopped behind a bush and I shot it. Similar experience was reported by sailor to whom I loaned gan. He saw four birds and shot two and the engineer got one other,-a.1 that were seen at this point. They were all in open ground with patches of bushes scattered around a few rods back from lagoon shore. We worked but a mile of the several miles of similar ground and the mete tells me they are common on two other islands where no one lives. A couple of rectirostris terns were flying about the lagoon shore and as we left I shot a gray-backedtern fishing just off the reef. Sailors speared a lot of fine fish on reef, one weighing about fifty pounds. Several frigates flew around and likely as did a number of red-foot boobies have nests. We left at four for Anaa Island.

\section{October 21}

Reached the island at eight A. M. and wo got a few warblers, but they were not plentiful. Three or four tatlers were seen but no other birds, making this island the poorest in sea birds that I have seen on the trip. We got away at 


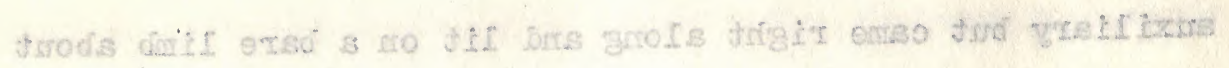

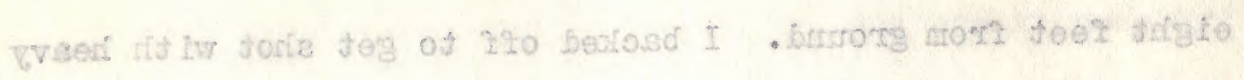

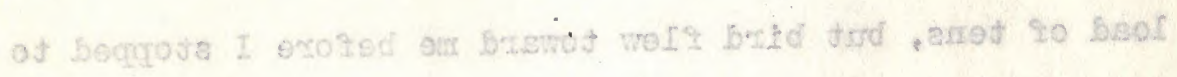

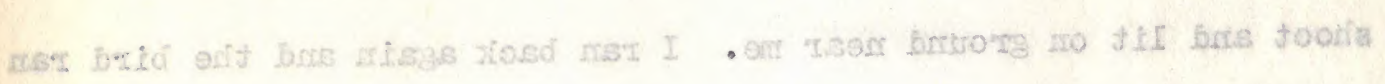

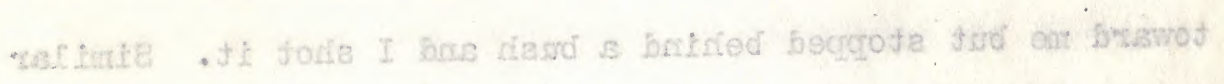

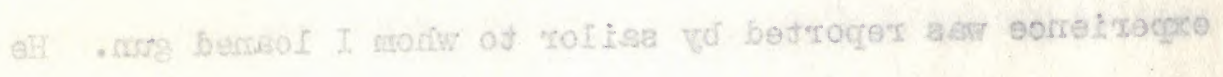

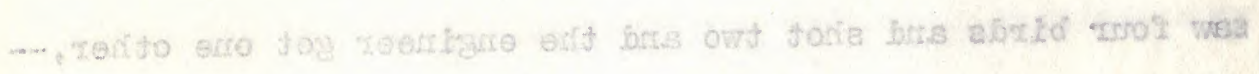

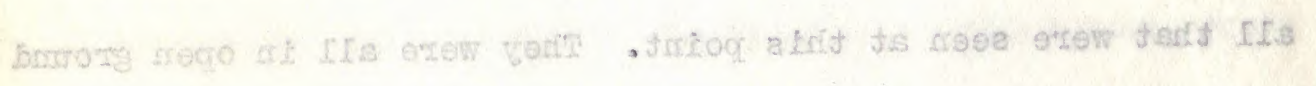

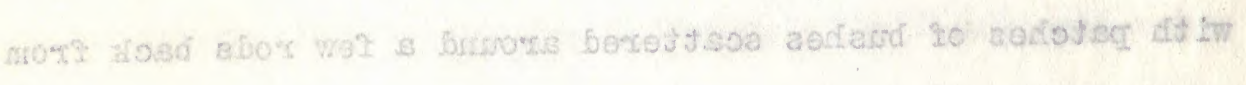

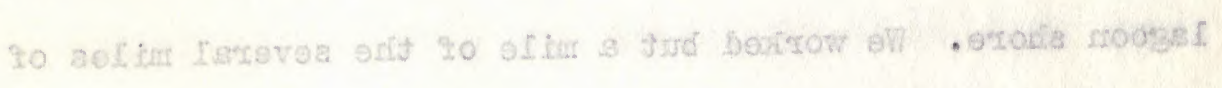

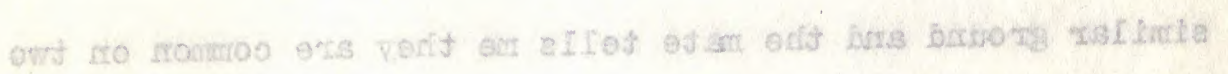

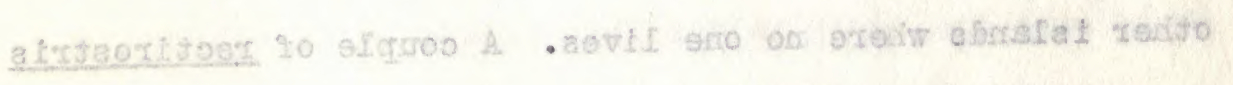

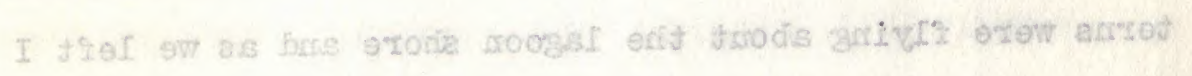

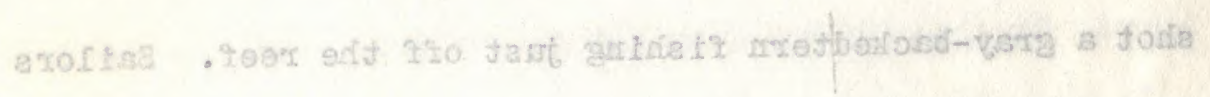

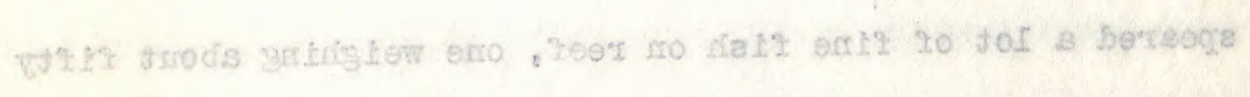

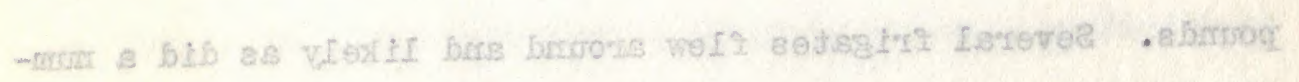

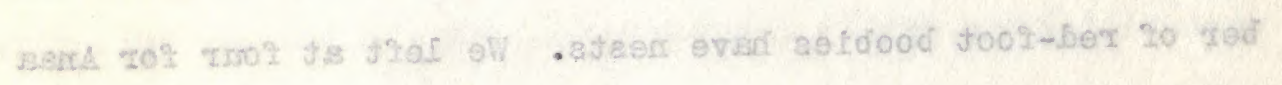
$.5 m i f a l$

\section{IS redetop}

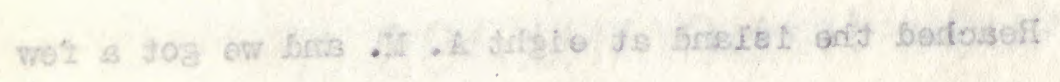

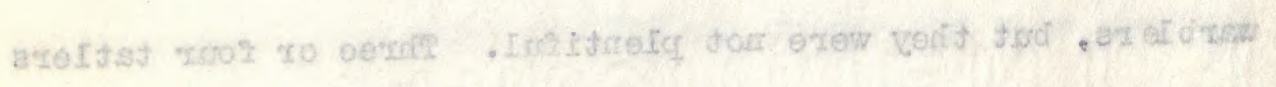

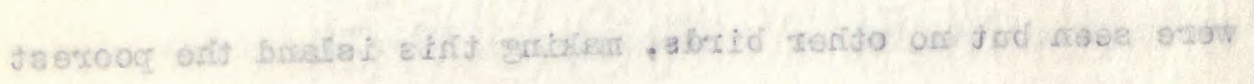

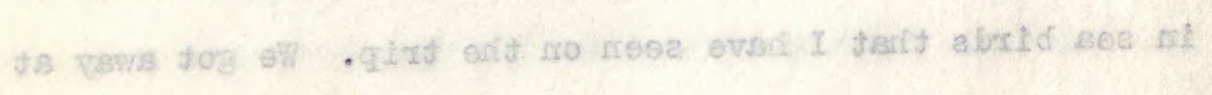


five P. M. for Papeete, but light wind and calm with lack of gasoline makes progress very slow.

\section{October 22}

Calm all day. A red-tail tropic sailed about vessel in morning.

\section{October 23}

Breeze picked up in morning and we sighted Pt. Venus at sunset, and in dim distance saw island to eastward of Tahiti.

October 24

Reached Papeete at sunrise and found Quayle just in from Varaio with some plants and a few birds.

\section{October 26}

Quayle left for Hoorea hearing of warblers singing.

\section{November 14}

Quayle back last week with one warbler and three cuneatus shearwaters which are coming in to the little island off the west end of Moorea to dig holes under the pandanus trees. He marked several trees to visit again. He is now putting up minahs and the like while the dentist is holding him 


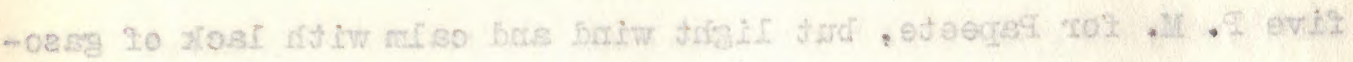

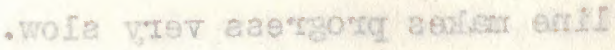

\section{SS "todoto}

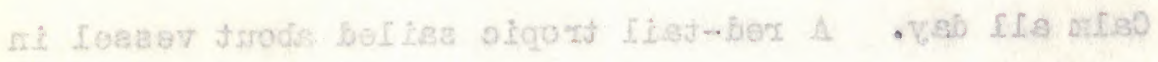

- satisercous

xh recotoo

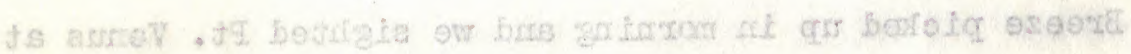

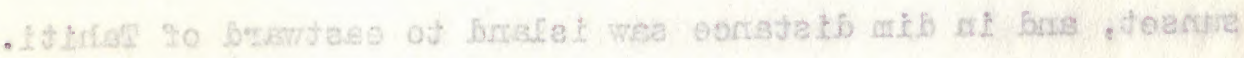

\section{As rectotol}

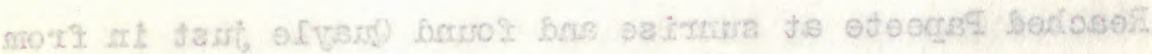

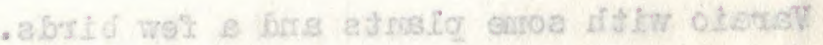

\section{DS xecoto0}

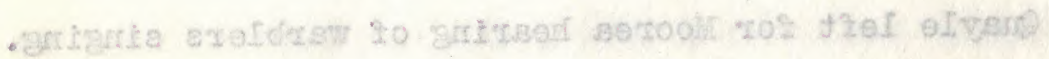

\section{AI rechovoti}

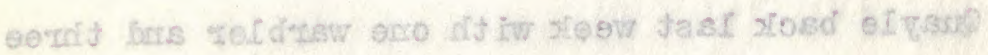

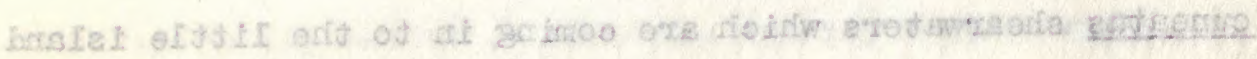

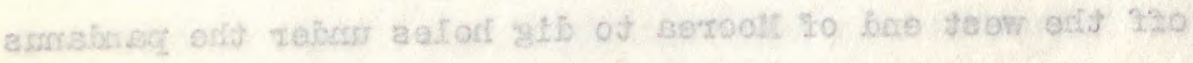

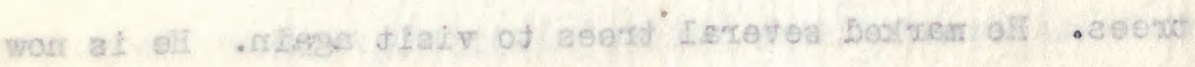

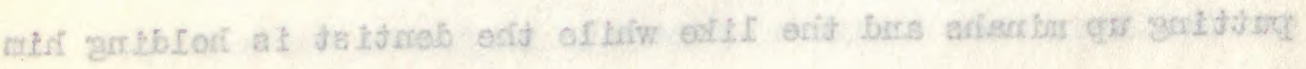


in tow to get his teeth fixed up.

I packed up all material on hand and shipped it last weex. Went out of the pass a mile or so yesterday and today, getting a gray-back tern and two red-foot boobies in tho two trips. One booby was all winte but the wings; they passed occasionally flying east or west, single birds mostly. The gray-back tern was inside the reef fishing and a couple of others were seen outside also. The wind starts about eight in the morning, preventine a long trip outside.

I am now trying to get a boat, but the several looked at have grave defects according to the opinions of the various mariners consulted. Wone are very satisfactory to me, but may charter one for a few months if can do no better.

\section{November 17}

Quayle up Fatau valley for the fourth time and shot a couple of swifts, seeing two or three others. He has taken swallows there on previous visits. In collecting a nest of kingfishers he broke the three eggs it contained. They were fresh. Several young minahs are seen about town and their call for food is often a duplicate of the call of the crossbill as heard in Alasia. Out a couple of times beyond the reef and one day got two boobies, a half dozen terns, and two or three 
- aps bexi? niteat aid ter of mot at

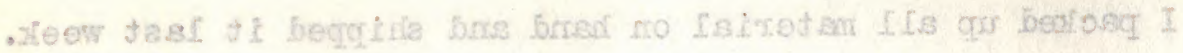

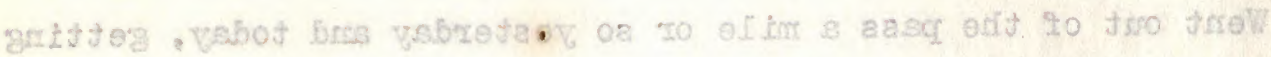

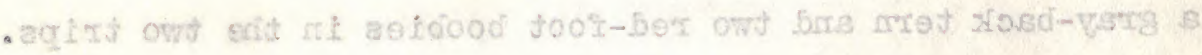

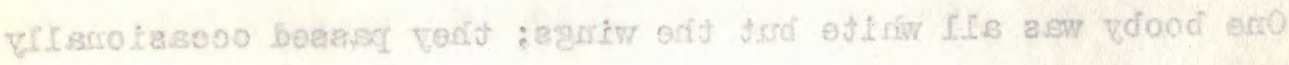

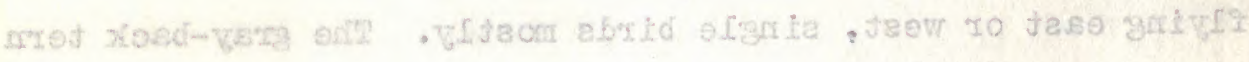

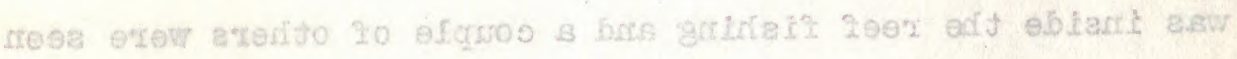

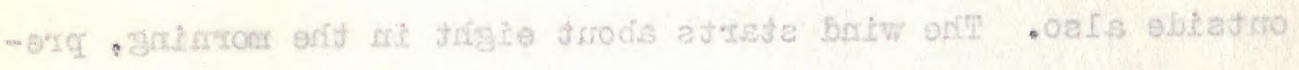

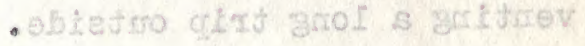

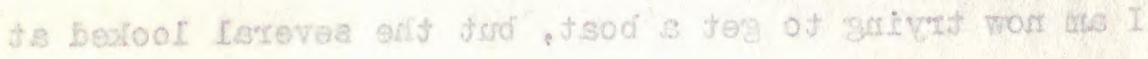

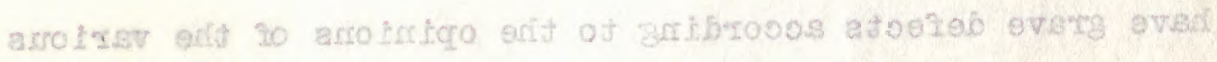

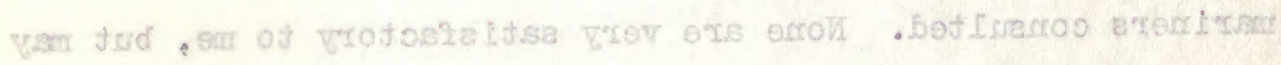

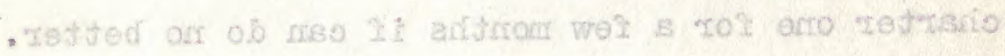

\section{5i redmevoll}

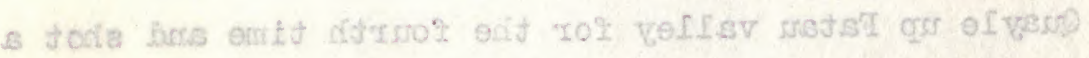

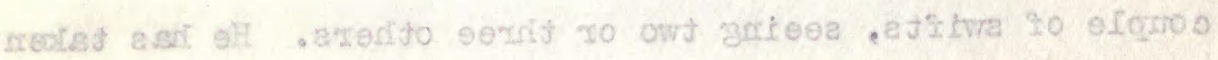

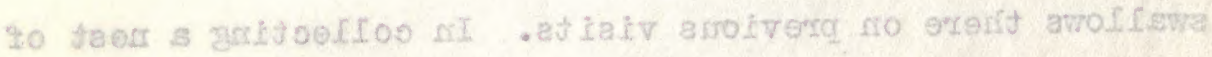

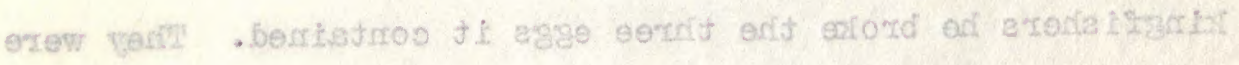

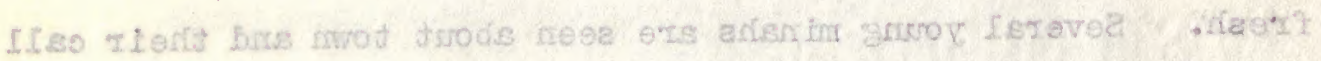

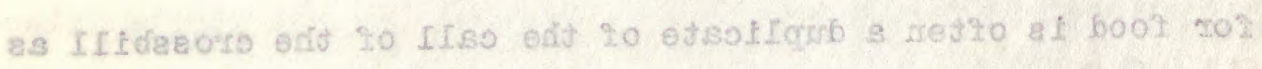

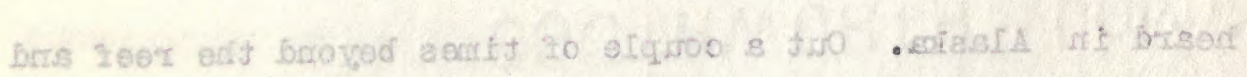

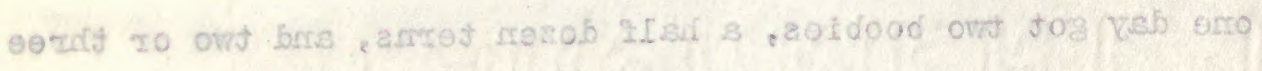


yellow-bill terns, the others being graybacks. Fairy terns fly out to sea and back frequently, but do not come near the boat.

November 20

Quayle went to Tetiaroa Island finding noddy terms nesting on the ground and in cocomt trees. Noddies, lesser noddies, red-foot boobies, frigate birds, reef herons and fairy terns were resident species, while tatlers, curlew and golden plover were noted as migrants. No land birds were encountered, but he did not visit every patch of vegetation as the party he went with remained one day being engaged in fishing.

\section{November 22}

Quayle went into hills for a couple of days and I finishod up the remainder of the Tetiaroa birds.

\section{November 23}

I went up Mission canon and shot a couple of roosters far up the canon and shot a downy chicken, one of three that flew up into trees when I approached them. Eight yellow-bill tropics were seen at one place circling about the cliffs, but all stayed too high to shoot. A kingfisher's hole was seen in a dead stump but was not ready for eggs. 


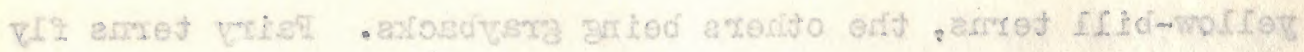

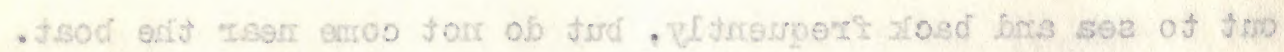

OS reditevoli

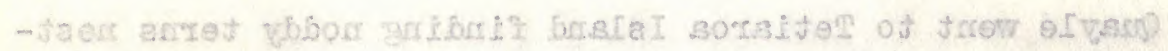

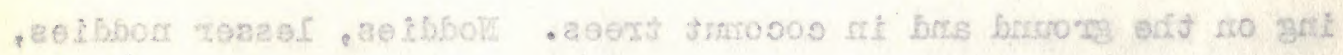

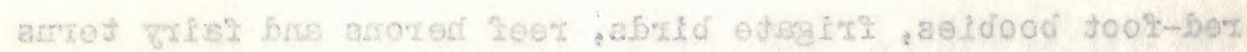

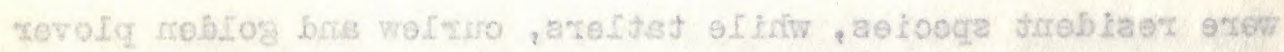

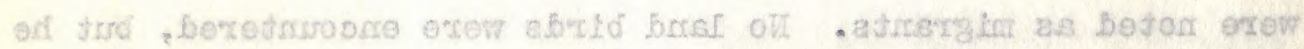

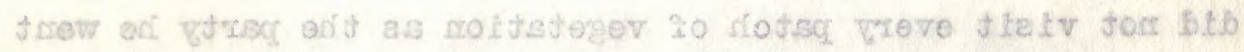

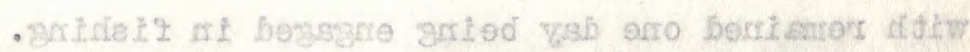

\section{SS rediseroT}

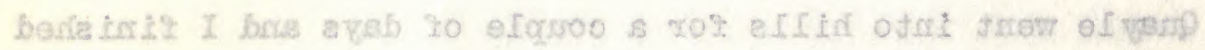

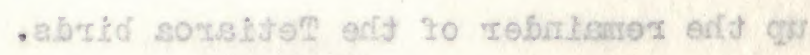

\section{ES redenovis}

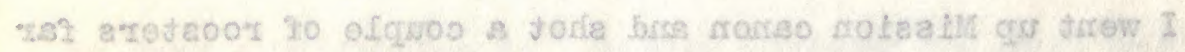

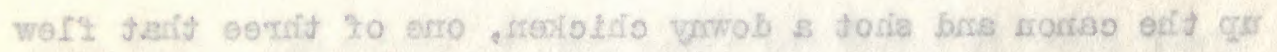

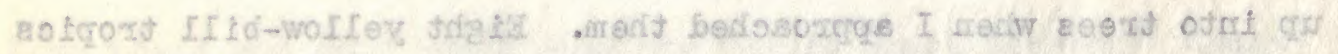

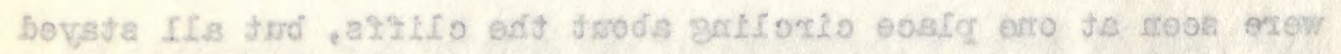

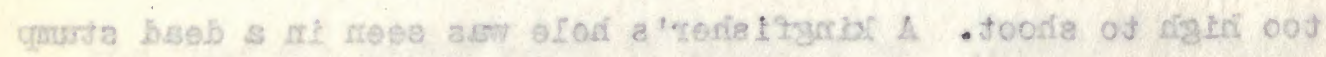

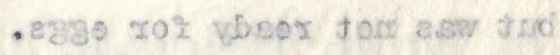




\section{November 24}

Out about three miles beyond pass and got a couple of gray-back terns, also one yellow-bill, one fairy, three lesser noddies and a couple of boobles. Saw a single obscurus shearwater. Strong current in pass running out made return slow with the heavy surf on the reef.

\section{November 28}

Up canon to end of it. In a side canon shot a rooster and a hen. The latter had at least two chickens a month old with her. They were at the head of the canon, or rather at the base of a cliff where progress upward was blocked. Shot a swallow here also, sitting on a limb of a small tree. It flew bacis and forth a couple of times before lighting, and a yellow-bill tropic bird flew around high above the cliff a few times. A few days ago two or three pairs were flying here. Farther up the main canon a pair of yellow-bill tropics were flying around another cliff, flying far out and above the cliff and darting down to some likely ledge and fluttering before it for a few seconds before turning away and repeating the performance. Doves were seen and heard several times and another kingfisher's nest found in a dead tree about forty feet up. One bird wes seen to enter.

In another dead tree thirty feet up a nest was located, but could not climb to it on account of rotten mood. The bird perched 
$\Delta S$ xedmevoli

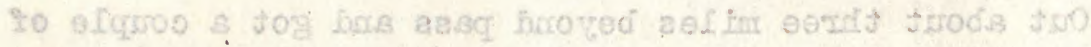

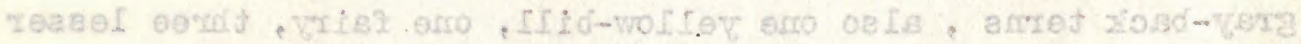

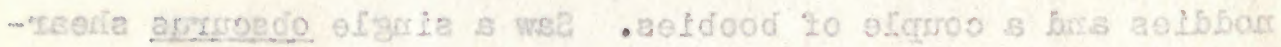

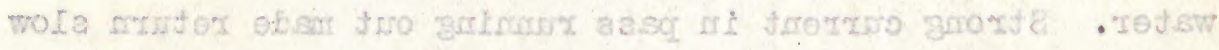

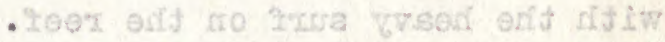

BS redmevoli

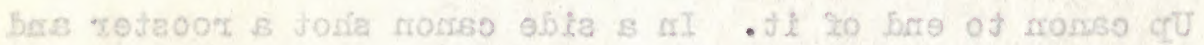

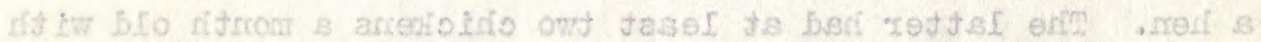

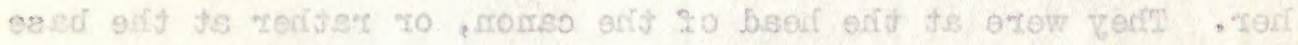

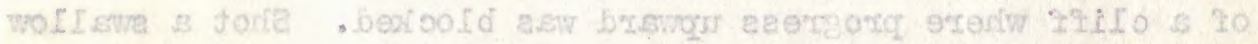

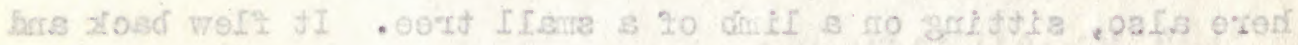

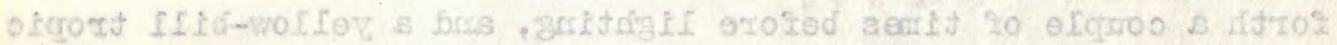

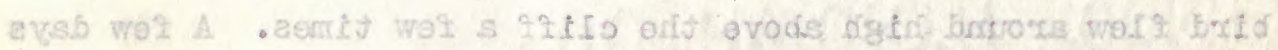

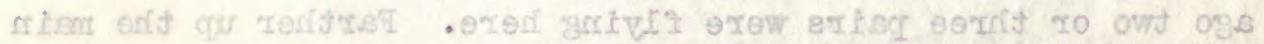

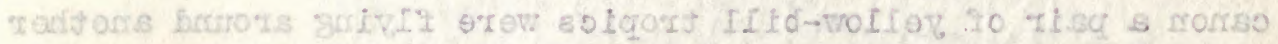

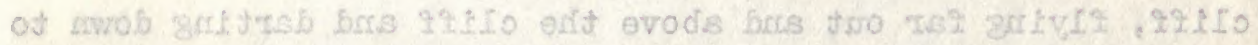

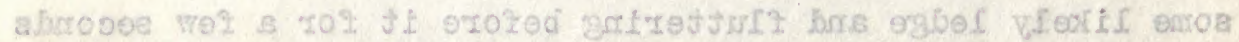

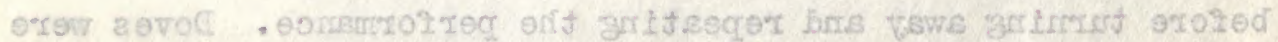

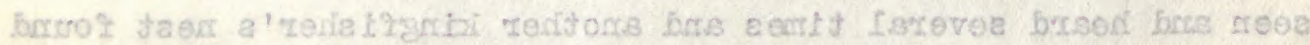

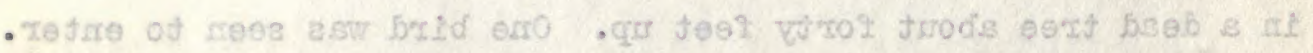

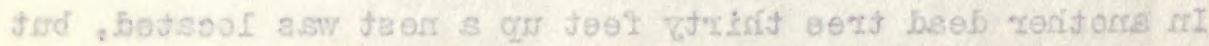

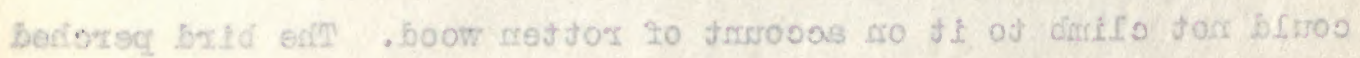


nearby and held tail dowaward like a woodpecker. The kingfisher is very likely the woodpecker of early writers, for it digs holes in dead trees in which to lay its eggs and frequently digs several in the same stump or tree, though using but one of them as a nest. The quail spoken of by an early writer as occurring on Christmas and possibly other islands was probably the native sandpiper, as it resembles a quail when running on the ground and a merchant here toid me the other day of quail on Scilly Islands which he is patting into coconuts.

\section{November 30}

Up with Quayle to kingfishers? nests and Quaylo goes up and gets three eggs in the hole in dead tree in bottom of canon. Bird darted at Quayle several times while ho was in tree, which was but a few yards from the stream in the bottom of the canon. Coming back we heard another bird near an old building and I saw the nest in the center of a fine avacado tree, a rotten limb in the midst of fine green leaves being pierced near the top with the small hole dug by the birds. I bought a wedgetailed shearwater from a boy up town who said it had been dazed by a fire at night and came to the ground and was picked up next morming. It had recently lost a leg. Quayle leaves in the morning for Papenoo to work the country from there to Hitia. 


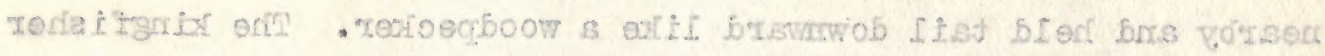

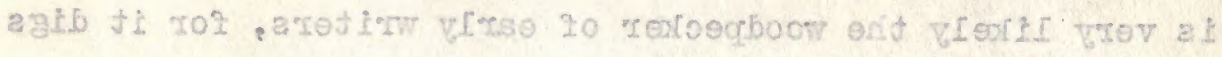

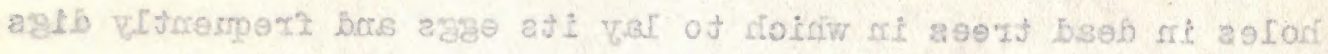

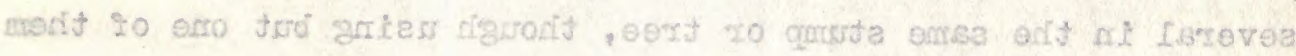

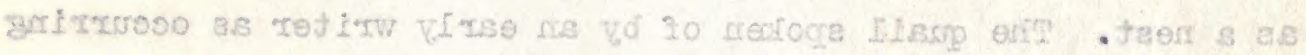

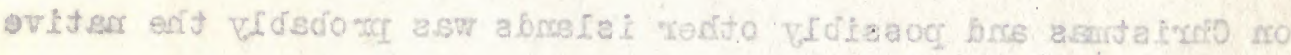

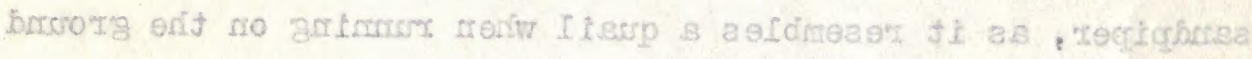

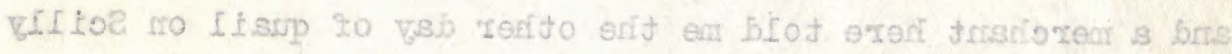

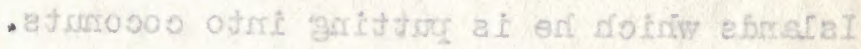
Os redmetoti

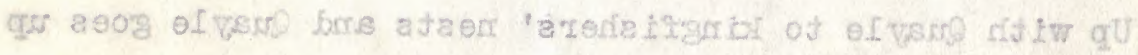

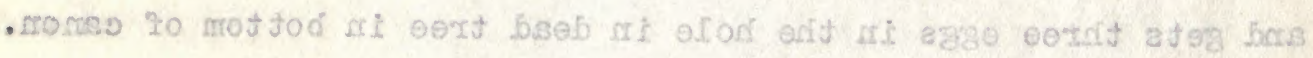

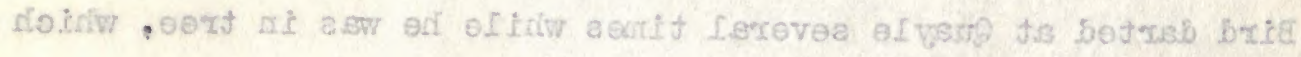

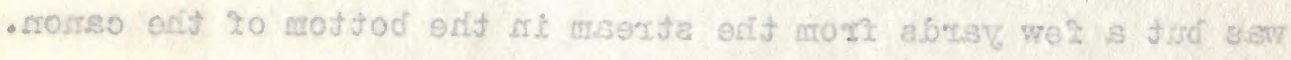

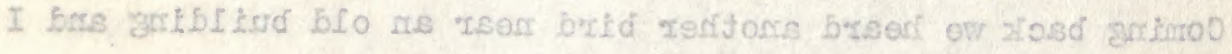

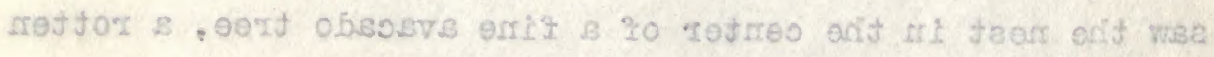

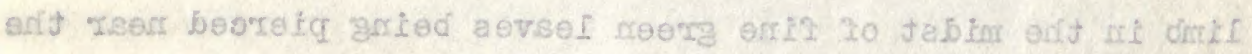

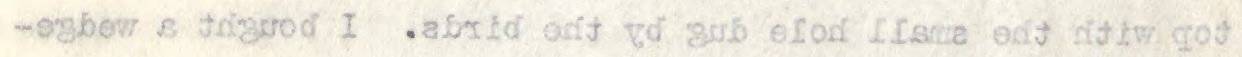

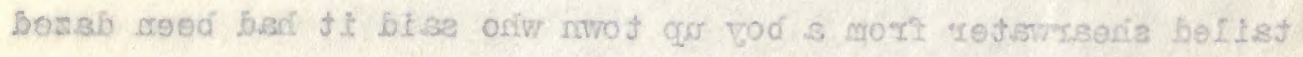

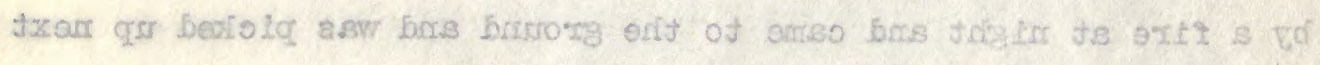

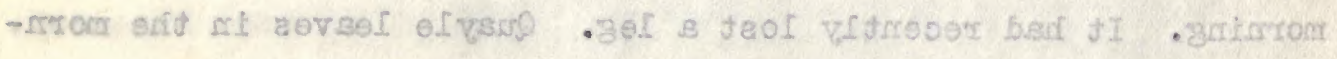

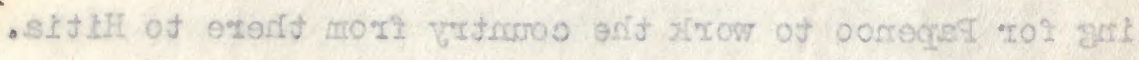


December 2

Went out about three miles and saw two or timree grayback terns and one came up the boat when I called as the terns were calling. I secured it and a Parasitic Jager followed the bird, seeing it fall, and I shot the jager. Am not sure but I have seen one or two before near the Marquesas, but always a good distance from the schooner. Got a dozen red-foot boobies; most of them seemed to be coming from Tetiaroa way, though a few single birds were flying north. All shot had empty stomachs. A couple of yellow-bill tropics were pulled down from high in the sky. One had a squid in its gullet.

Quayle missed the stage, or the driver would not stop for him, and the next day the same, so he went another direction for a couple of days, working a canon not visited before. The dog routed out a rostrata shearwater which had gotten sick or disabled and could not fly from its retreat.

On the thirtieth we went out and got a couple of lengfishers' nests back of town in the hills. Both were in rotten limbs of trees not far from the water in bottom of canon.

\section{December 6}

Quayle leaves for Mopelia and Scilly Islands for a month or so while I wait around town working on the vessel deal. 
S redinesed

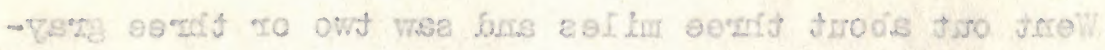

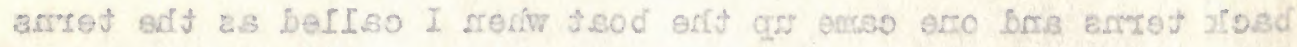

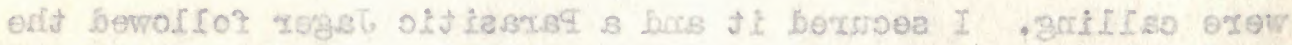

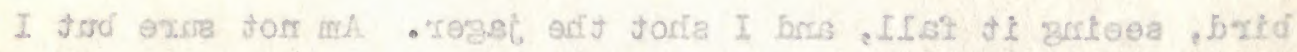

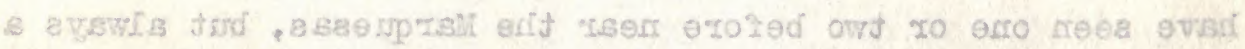

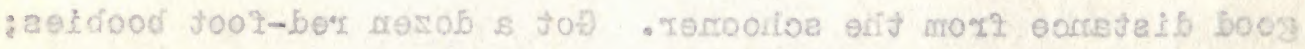

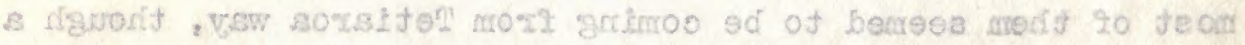

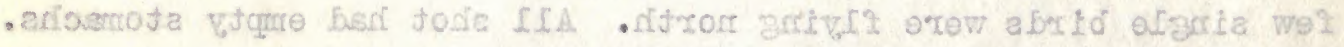

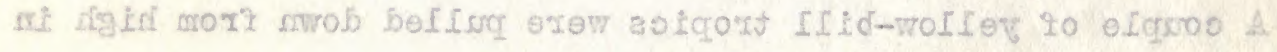

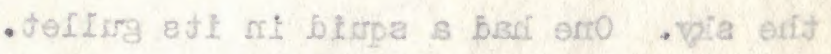

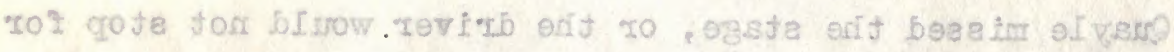

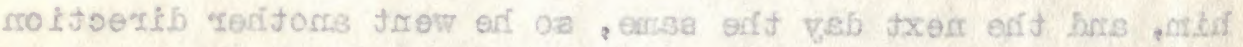

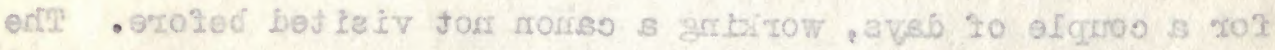

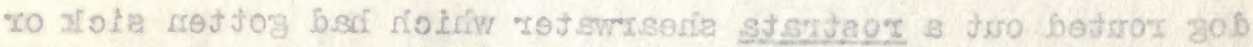
- tceztez. edt mori kf? for biroo bets befdselb

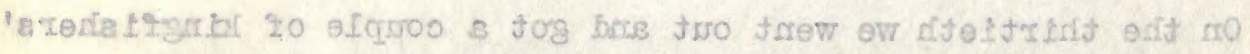

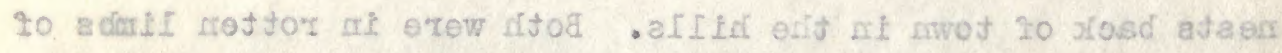

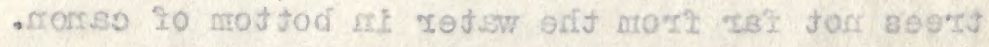

\section{a redmeoed}

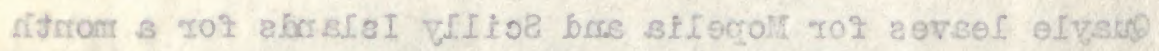

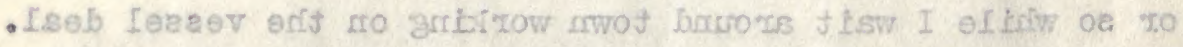


December 10

Back in hills to get a kingfi sher nest, but find the sturmp has fallen and the birds gone. Farther up in the canon saw three kingfishers sitting close together, and thinking they were young birds shot and secured two, but these were breeding birds and the female had an egg ready to lay tomorrow and the next two of good size. Four yellow-bill tropics flew around a cliff a few minutes and then went back to sea.

\section{December 13}

Start for ocean but cross currents just outside the pass do not look good, so I workod along a couple of miles inside the reef, getting nothing but a single yellow-bill and a grayback tern, one or two of the latter being seen fishing along the foam streaks inside the reef.

\section{December 14}

Stormy looking and went in morning up in hills a couple of miles to take and photo a minah's nest from a tree that I took eggs from a couple of weeis ago. The four eggs this time were on the opposite side of the tree from last nest, being placed just above an old nest in a lower limb. A few green leaves were used for lining, as in the last one. The nest was only twenty 


\section{QI recinesed}

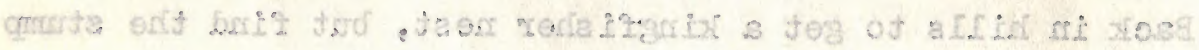

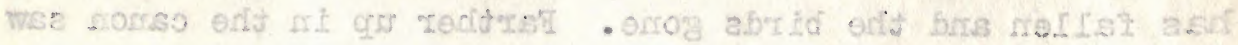

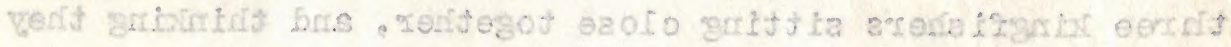

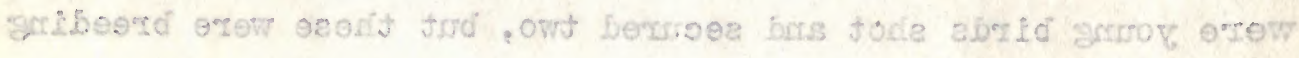

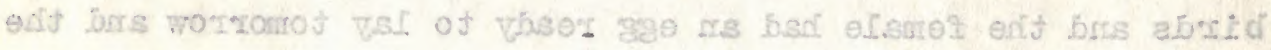

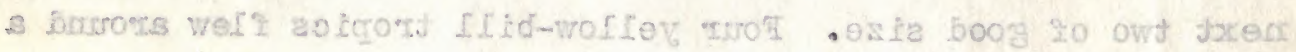

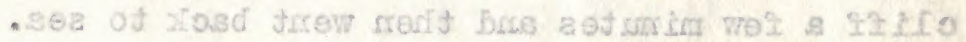

\section{El recirreoed}

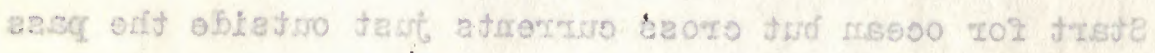

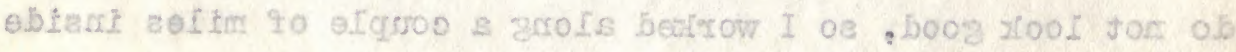

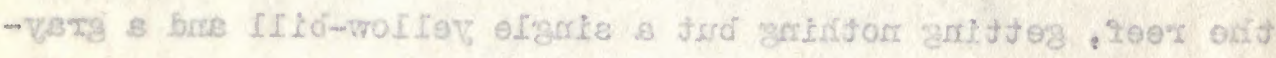

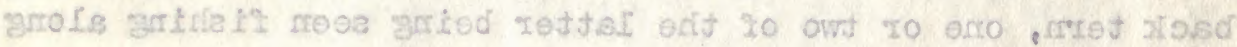
- 2eer enid ebiami extegrta musoz enta

\section{AI rocirrepeI}

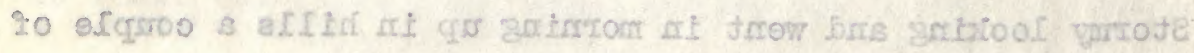

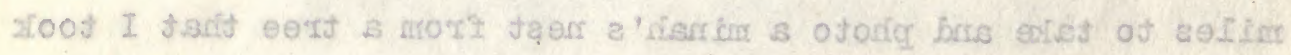

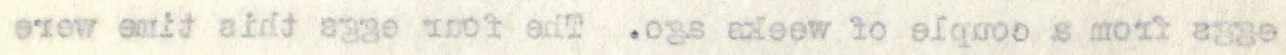

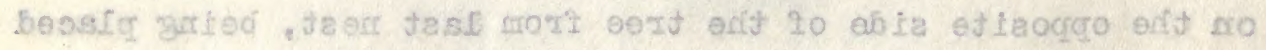

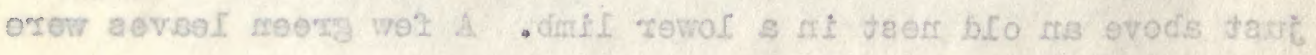

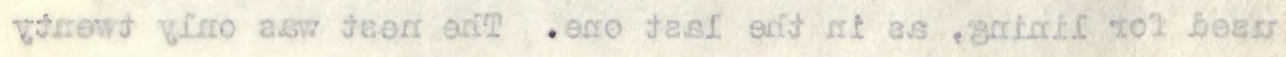


feet up behind a stem and was sheltered from the sun by a piece of ary bark.

\section{December 16}

Out a short distance and sot nothing.

\section{December 17}

Calm or light wind all day, so go out five miles and get a parasitic and pomarine jager, both of them flying up to the boat when I dropped a booby from a flock fishing. No shearwaters and but one gray-back tern seen, though well out.

\section{December 31}

Last two weeks have been trying to get the schooner deal through, but unexpected repairs take timo, although in a few days the purchase should be completed.

\section{2}

\section{Fëruary 1}

Started for Rapa this P. M. in the 'France', having spent the last month in getting things in shape and getting the supplies. Have a young New Yoricer with us (C. C. Curtis), who goes for 200 francs a month to see the islands and serves in any capacity that I desire. 


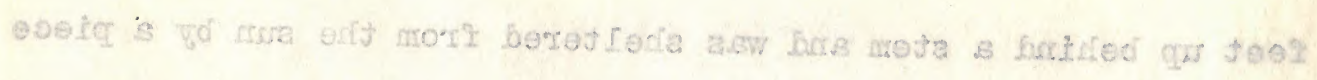

- xixed vấ 20

\section{of roofseogd}

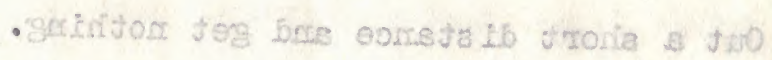

\section{Yi redimeged}

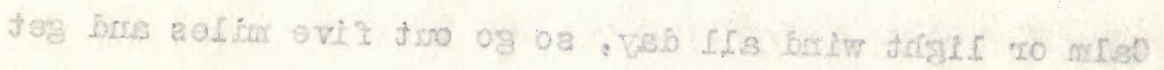

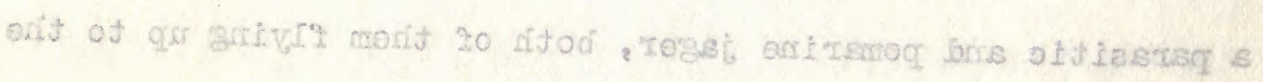

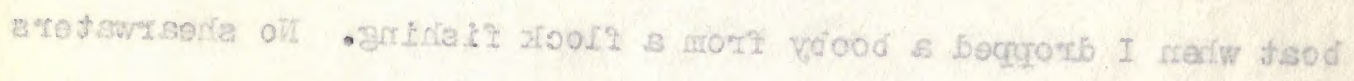

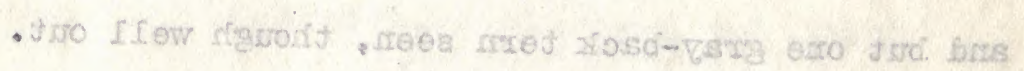

I8 redínood:

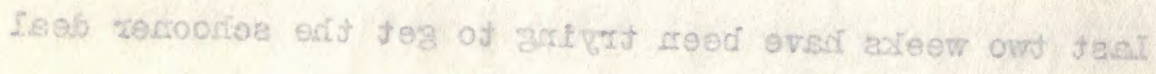

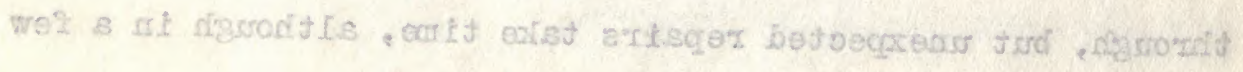

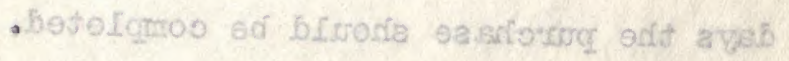

\section{I. vesestiog}

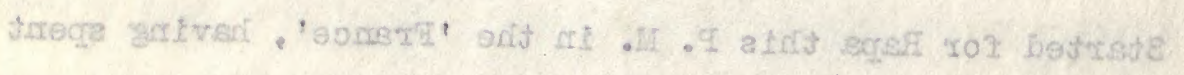

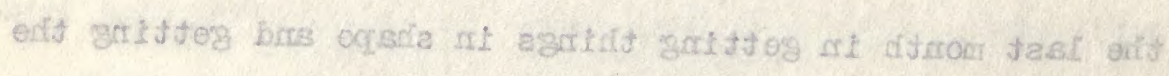

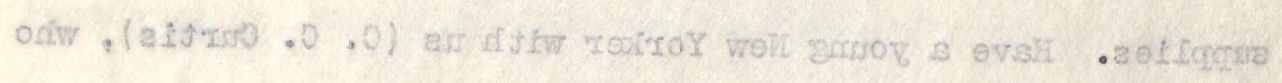

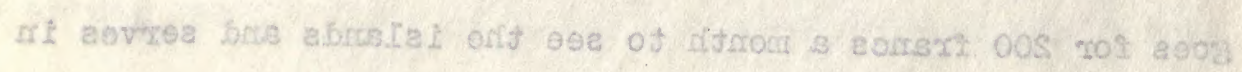


A pomarino was seen shortly after getting outside the pass, being the second jäger of this species recognized for certain. In the evening I saw what I took to be a parasitic. A couple of auricularis were seen and several rostrata as well as a number of red-footed and a single plotus booby.

\section{February 2}

Rain most of day and light wind. About 25 miles to $\mathrm{S} \mathrm{B}$ of peninsula we passed a spot in the water that looked light colored exactly like shallow water, but the light wind prevented our turning back to investigate.

\section{February 3}

An occasional tropic bird and one or two shearwaters, one in the evening being an aestrelata by its flight, were noted. Weather fair with light wind from north.

February 4

A sooty tern flew from water and a tropic or three seen in A. M.

\section{February 5}

Iight wind and two or three.tropics only birds seen. 


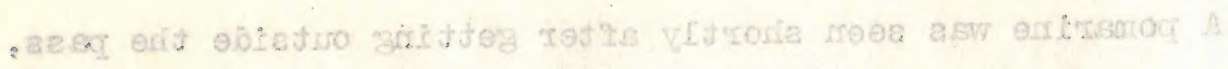

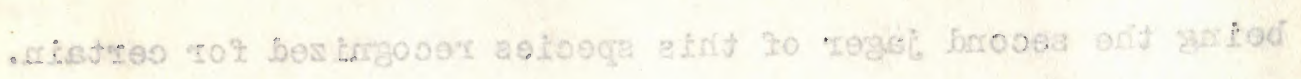

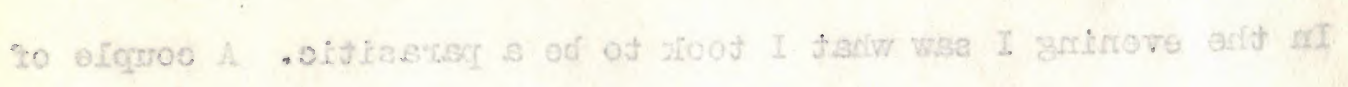

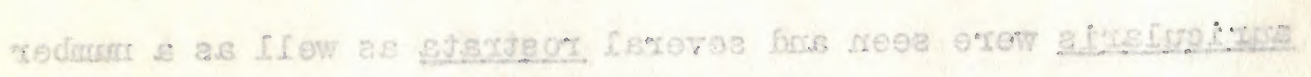

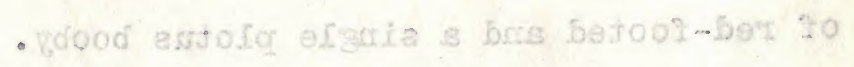

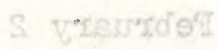

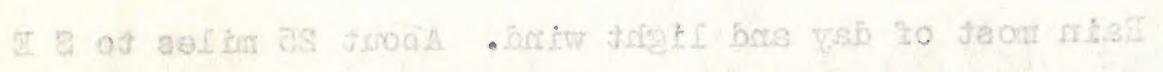

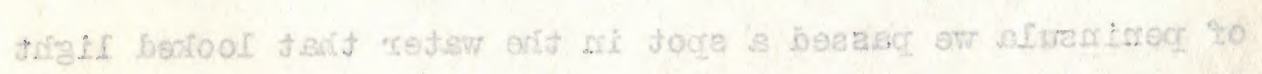

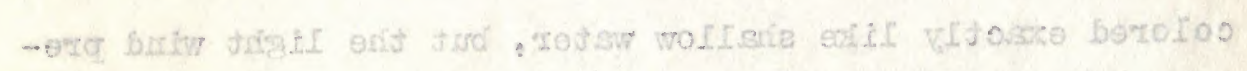

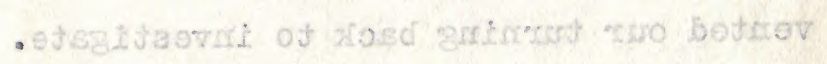

\section{8 vxsitider}

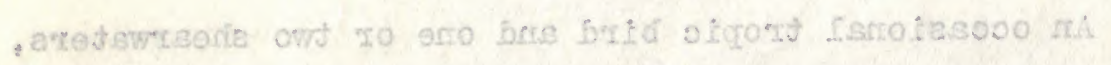

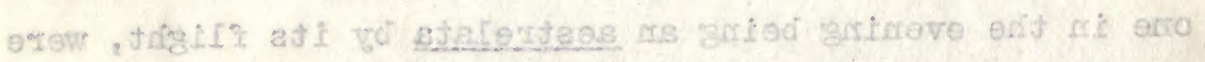

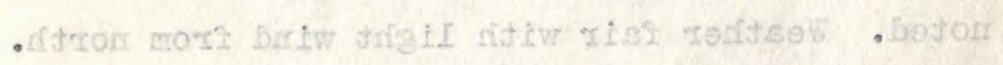

\section{A Vetsurdor}

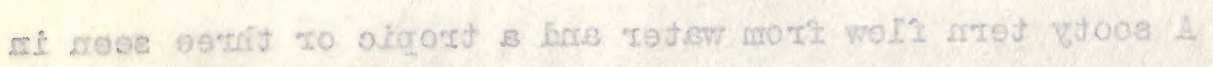

\section{C vesurdot}

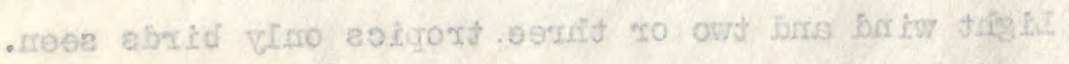


February 6

Quayle got a red-tail tropic in mornine and not a shoarwater seen 211 day. Wind light from MWW one handred miles to Ravaivai.

\section{February 7}

Ravaivai sighted at noon. Practically no birds about.

\section{February 8}

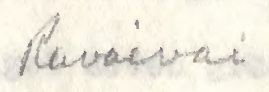

Noddy terns and several fairy and a couple of gray ones seen going out fishing as we nearod the island at davlight. Anchored at eight A. M. and ashore to spend the morning with Mr. and Mrs. Stokes who arrived last weok from Rapa by the 'Vahine Tahiti". Quaylo wont on top with Curtis and got a few birds and plants, three gray terms being taken along cliffs.

\section{February 9}

I took boat and went to motus, finding eighteen frigates sitting on trees along the water's edge, but they flew before I reached them and went to sea. Noddy and fairy terns were resting on small motus, but no young seen. Quayle found young of noddy, lesser noddy and fairy terns on other motus. He spent the night on top of the island, getting one each of neglected 


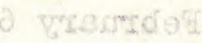

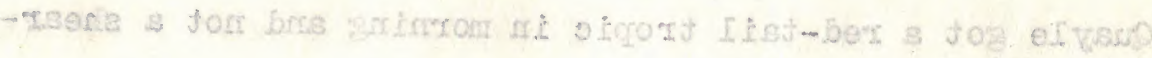

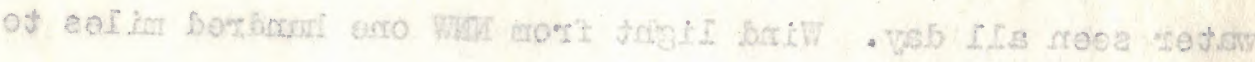

- isvistse

\section{5 vasande}

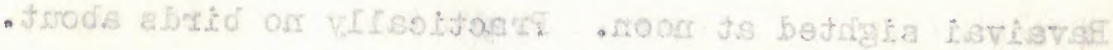

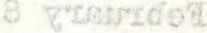

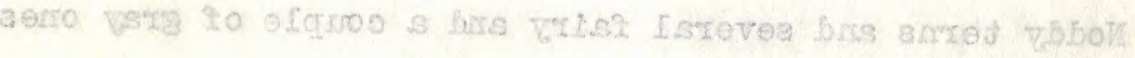

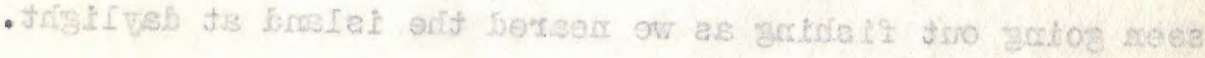

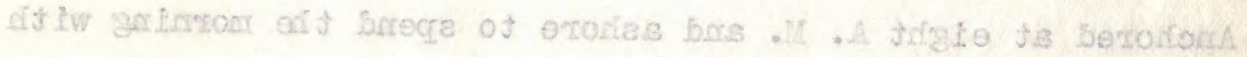

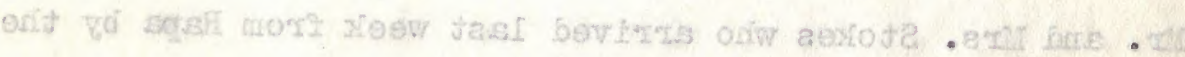

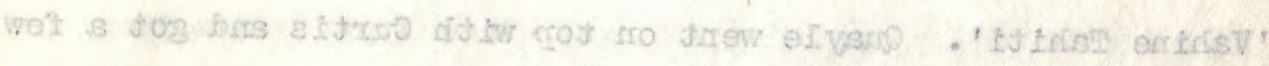

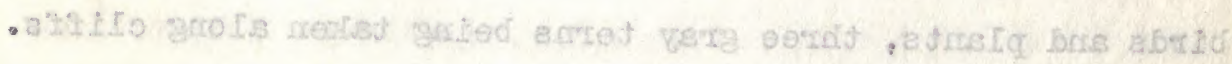

\section{e vesionóp}

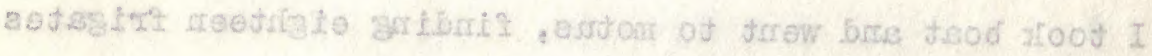

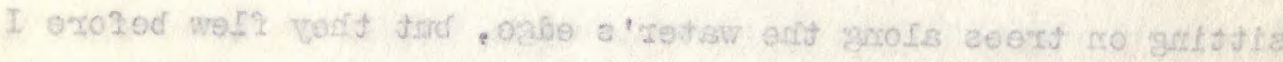

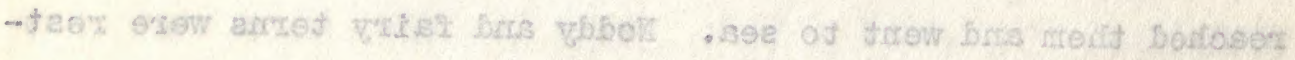

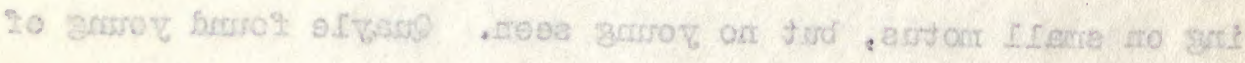

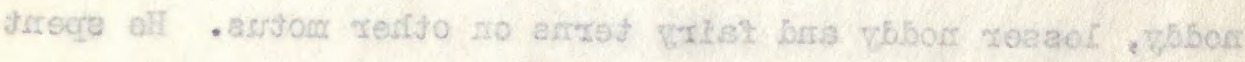

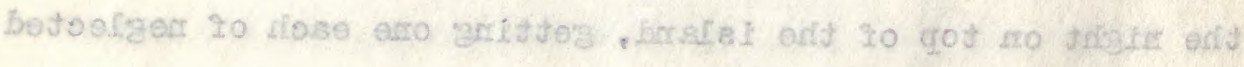


and wedge-tailed shearweters and three gray terns, as well as two downy wedge-tailed shearwaters. A yellow-bill tropic and egg wes also secured.

\section{February 10}

Left the island at nine A. M. and made slow progress all day, as wind was light. Noddies and feiry terns were seen often a few miles to the eastward of the island fishing, and several wedge-tailed shearwaters seen also. I got seven gray terns at base of cliffs last night about six P. M. as they flew about, evidently coming in to roost. Also saw a neglected shearwater fly along the cliffs and several noddies were resting and $f l y-$ ing around, while the fairy terns kept to the trees in the forest below. Cuckoos were heard several times, but none could be seen.

\section{February 11}

Light wind and three or four feiry terns and a couple of pacificus shearwaters seen, as well as three or four tropics, red-tails.

\section{February 12}

Shot a red-tail tropic in evening and saw a neglecta and 


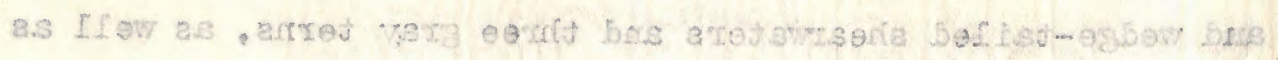

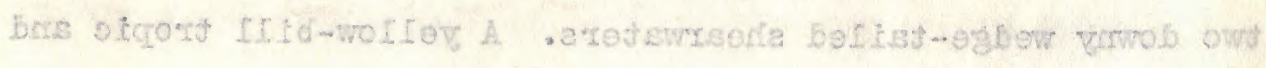
- botroper orlis and ges

\section{Of jusprociot}

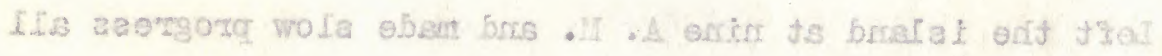

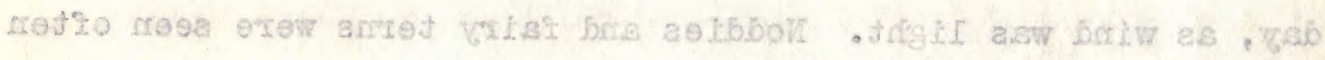

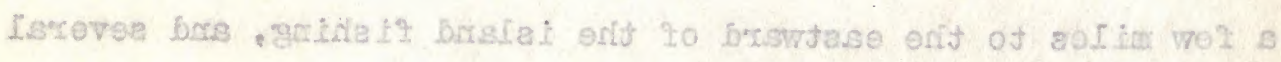

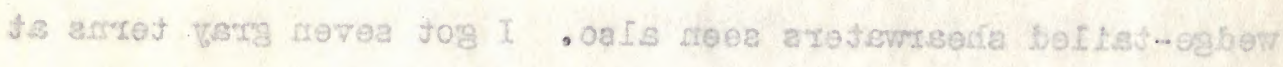

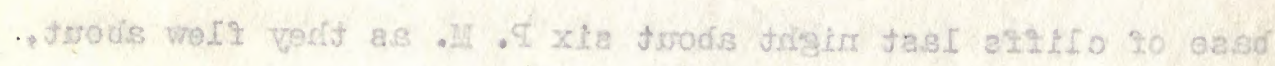

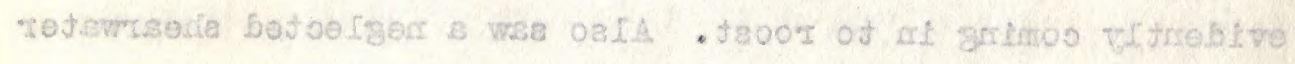

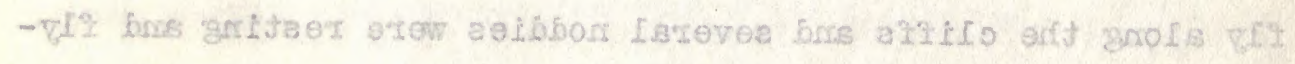

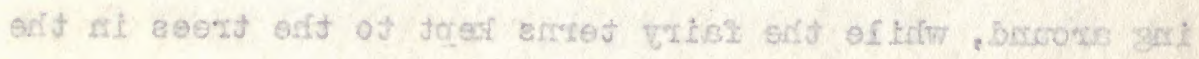

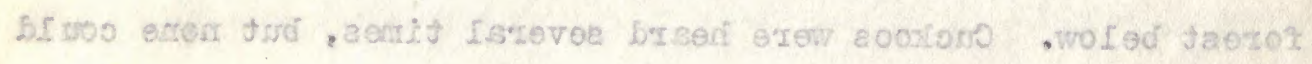
- rreaz $\theta$ dí

\section{If च'surdor}

20 elcuroo s bris anxet txist eno? ro gexis bre bnivr thight

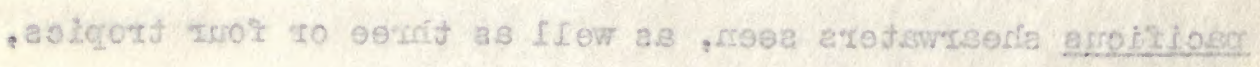
$.25 i s j-60 \%$

\section{SI prestiol}

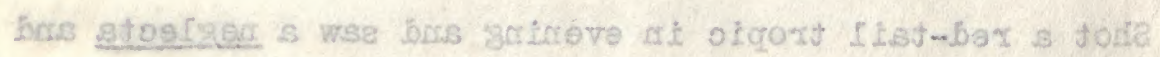


a pacificus shearwater. Good wind from eastward started.

\section{February 14}

Good wind and got a red-tail tropic at noon, $145 \mathrm{w}, 26 \mathrm{~S}$.

\section{February 15}

Rapa in sight at daylight twenty miles off and at eleven we were sailing along the shore on west side and went around the south side, seeing many red-tall tropies sailing along cliffs. At one islet on the south side a large colony of noddy terns were circling and three or four shearwaters were seen; also a half dozen gray ternlets and a few falry terns. One shearwater seemed to be the rare kind and one or two were seen this morning when nearing land. A few noddies and gray terns were noted flying to northward at sunrise to fish, and last night at fifty miles off a couple of gray terns were seen, also a couple of neglecta shearwaters.

Barometer 30.30 with good S E wind.

\section{February 16 to 27}

At Rapa, ashore in P. M. of 16 th and got a rail or two. On the 17th a boatload of natives came alongside with a lot of grallaria petrels and several young tropies which I bought for 


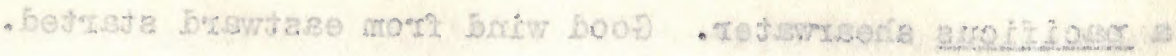

\section{A. Yroverdor}

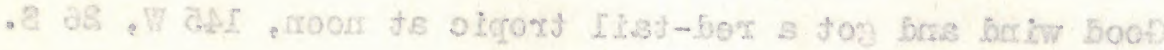

\section{cI veserisdo?}

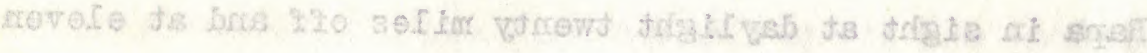

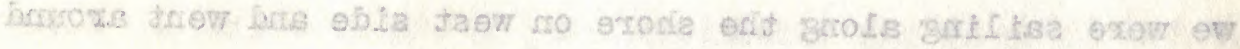

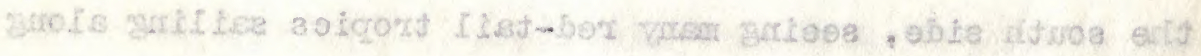

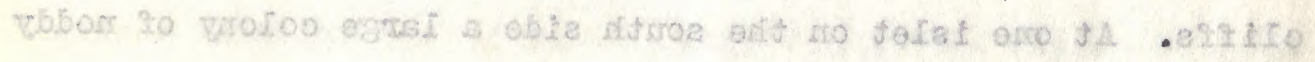

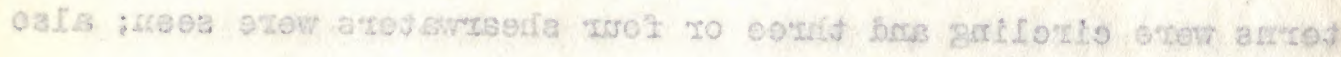

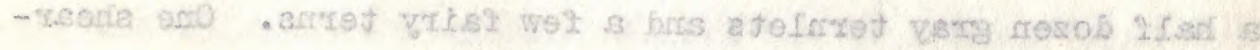

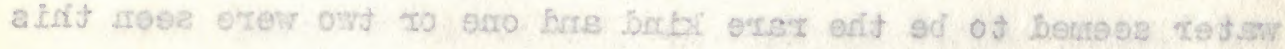

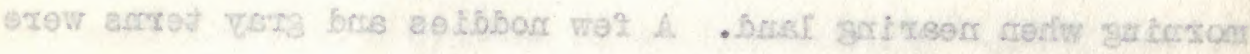

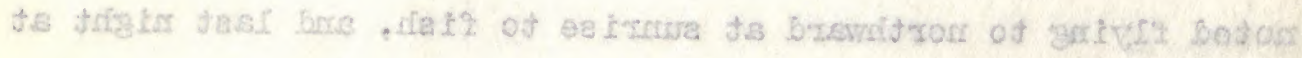

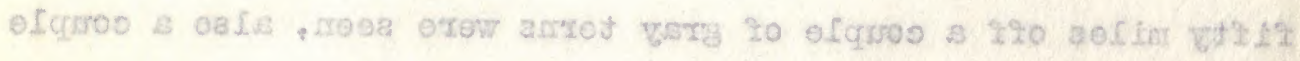
- arojewrsedia stoolpger To

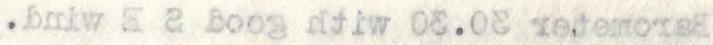

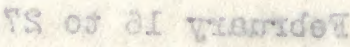

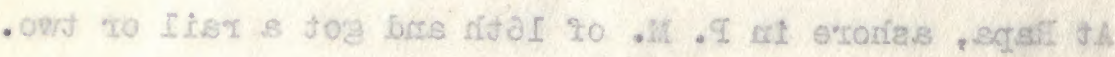

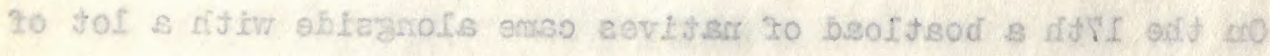

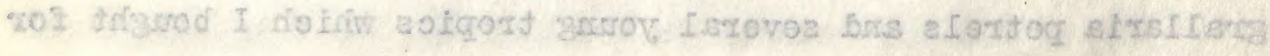


forty francs. A lot of the birds were alive and tied with strings, having been taken from their nests on a near-by islet. I skinned the birds the next day and Quayle got a fow doves and a couple of rail. The natives visited another islet and got a lot of young birds of which I secured a couple of downy neglecta shearwaters. Sent Quayle around in boat to visit islets while I skinned birds. He got a couple of puffinus shearwaters, and Monday he went back with traps and set them in the holes where he got his young purfinus and got two old $\underline{P}$. nativitatus. I took a boat and went to the islet where the natives caught their petrels and found another lot nesting under rocks all over the islet. Most, if not all, of the nests had a little lining of dried grass stems or leares in them.

$$
\text { February } 20 \text { to } 27
$$

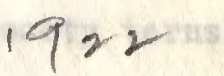

\section{Rape Island}

Wost of the petrel nests examined had fresh eggs, but one held two birds. Nests were found wherever the birds could find a suitable place nearby to alight and take wing. Several young noddy terms, and a number of little gray terns were seen, as well as a few red-tail tropics.

I made several trips around the taro beds, getting rail on nearly every trip. Several young birds were taken and quayle heard a cuckoo or two during our stay. Though hunted for not a 


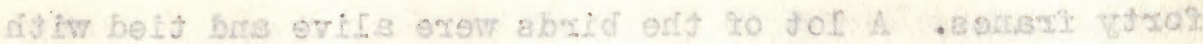

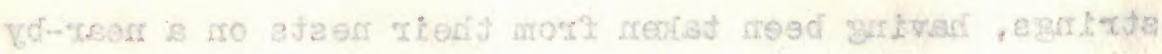

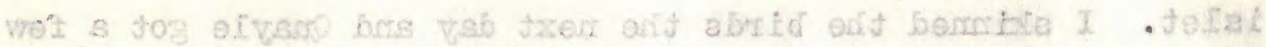

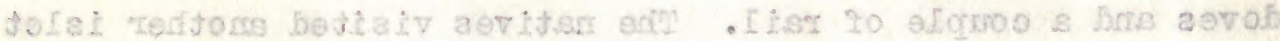

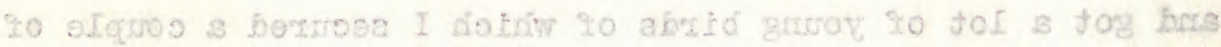

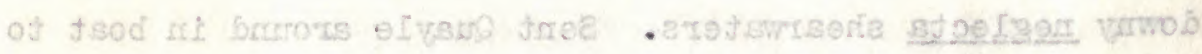

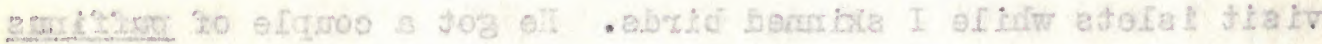

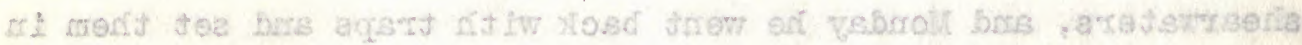

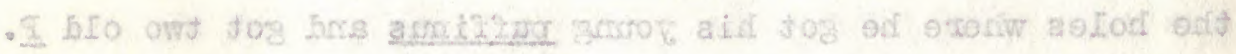

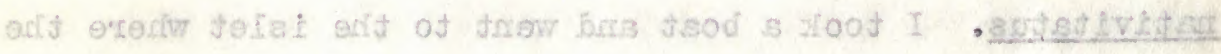

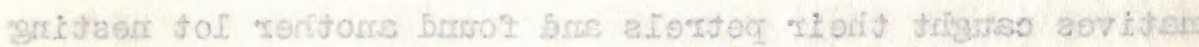

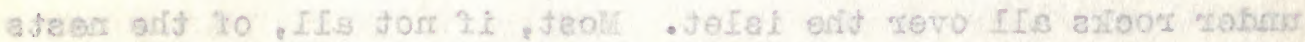

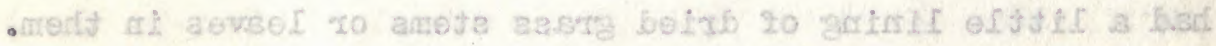

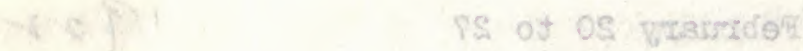

\section{bocheraI sogit}

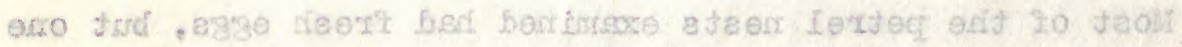

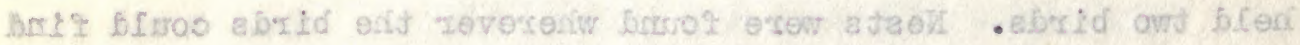

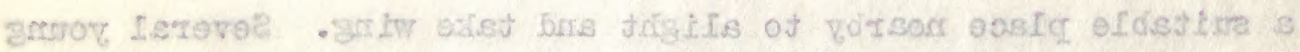

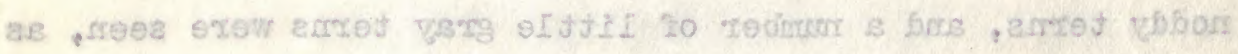

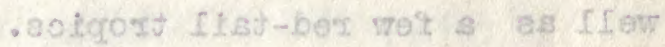

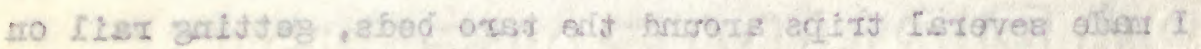

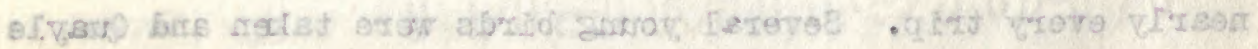

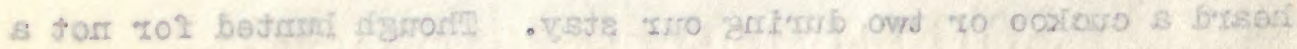


single one of the blue petrels or shearwaters were found. Neglected were sailing around the highest cliffs, and I sav one or two birds sailing over the village and along the shore of the bay. The little gray terns were not nesting. In return for a can of biscuits, a can of kerosene and a couple of hundred coconuts the natives gave us forty-five bunches of bananas and several inundred pounds of taro when we left.

\section{February 27}

In a rough choppy sea we put out the boat at Bass Rocks at six o'clock on the leeward side, and at eleven o'clock returned to the schooner, having about sixty-five birds, finding the blue shearwater common and nativitatus not rare. A small Pterodroma was seen a half dozen times and three birds were taken. A couple of adult and three or four young sooty terns were observed, and I shot one adult and a couple of young. The sea was too rough to attempt landing, though the blue shearwaters were nesting. A few fairy and flocks of gray tems were fishing off the islets, and quite a few noddies were about the rocks. No Erallaria petrels or neglecta shearwaters were seen about the islands, these two species evidently living at Rapa forty miles to the westward. 


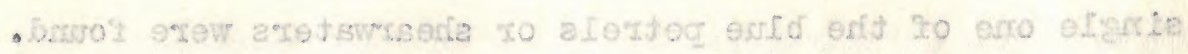

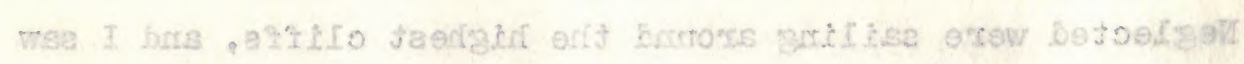

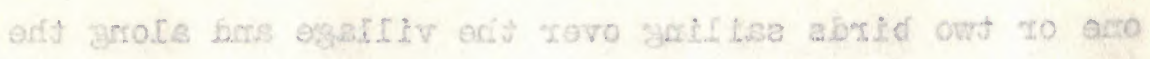

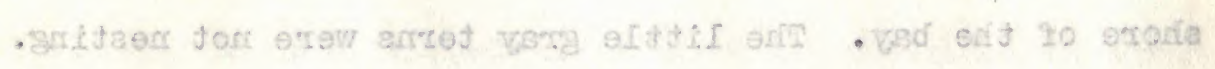

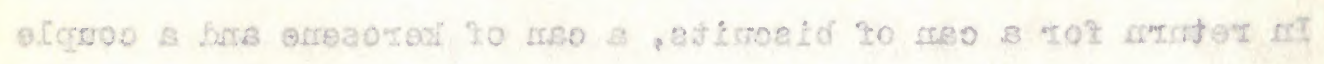

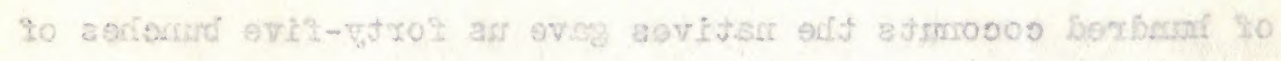

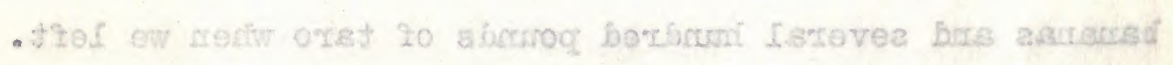

PS krestodot

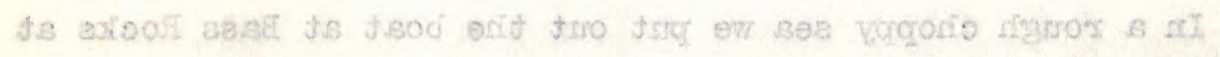

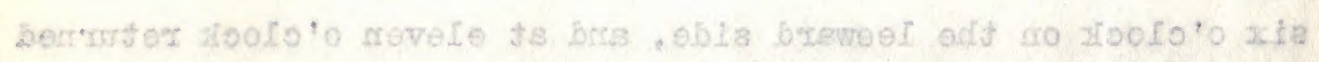

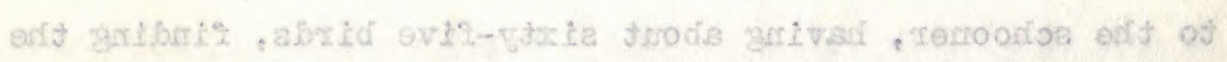

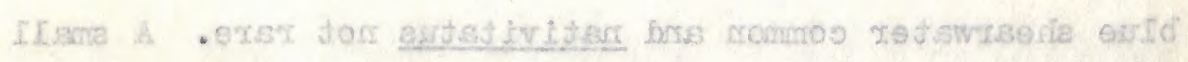

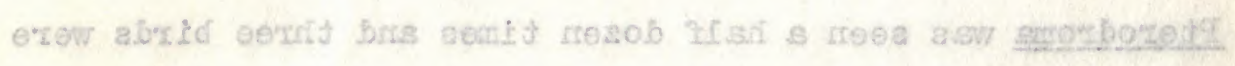

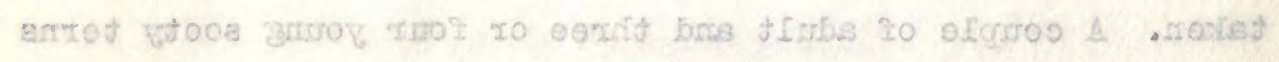

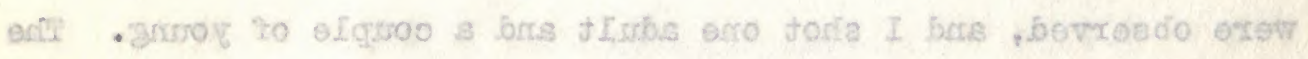

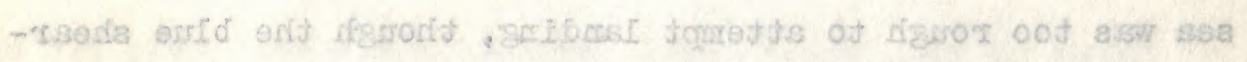

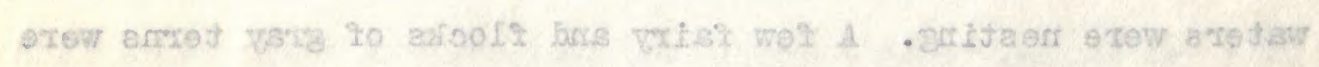

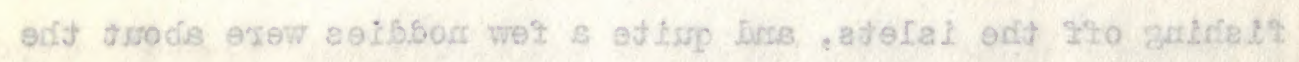

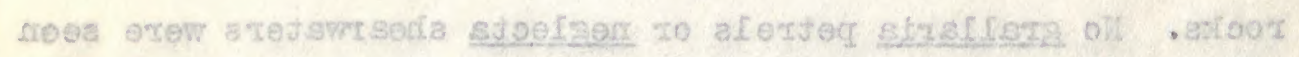

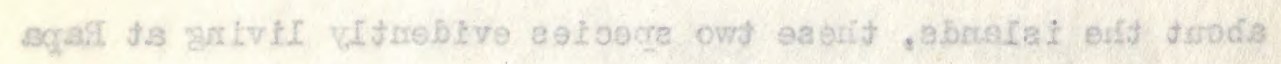

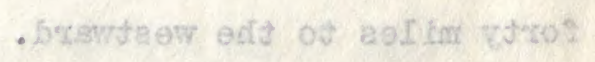


February 28

A gray tern seen following closely a nativitatus shearwater fifty miles off the islands. Also a couple of tropics.

\section{March 1}

A large, dark, long-tailed sheorwater seen at a distance.

\section{March 2}

A good-sized shearwater, white-breasted, flew past, as well as a fairy tern and a pair of red-tail tropics came along, and I got ono. Iight breeze from eastward.

\section{March 3}

A white-bellied petrel and a couple of red-tail tropics, as well as neglected shearwater seen during day.

\section{Narch 4}

Pair of red-tail tropics only birds seen. A small whale passed and the wind came light from the southeast in P. H.

\section{March 5}

A gray tern, one grallaria petrel, and a couple of tropics.

March 6

Iwo or three red-tail tropies and a blue shearwater today. 


\section{S vessowe?}

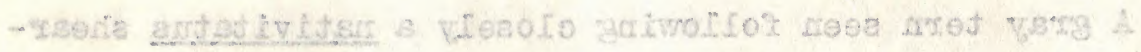

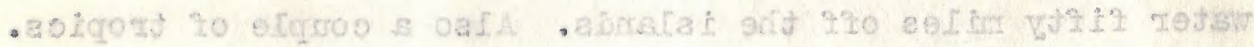

\section{1. rigeralt}

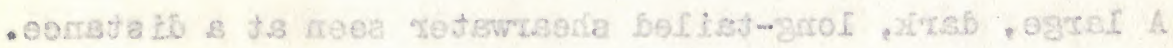

\section{$\mathrm{S}$ nions}

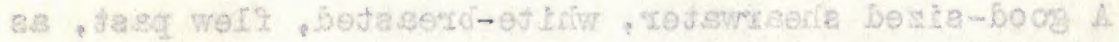

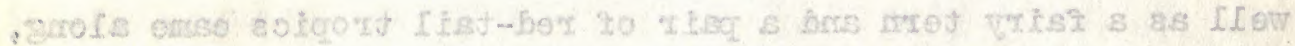

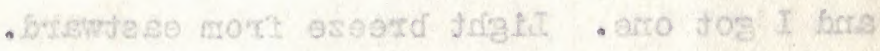

\section{E foronsth}

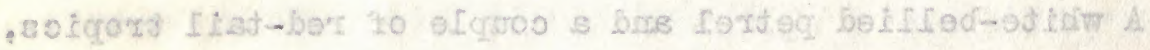

- vab anirub lroge rejewrisería bejoelzer as Ifory as

\section{A Nored}

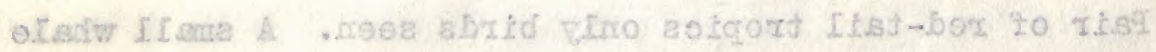

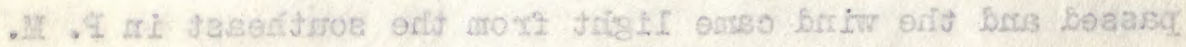

\section{है Iroxsilt}

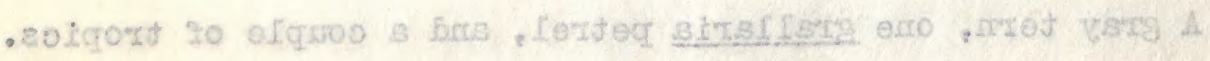

\section{2. riorels}

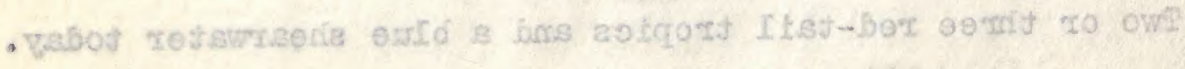


$\operatorname{March} 7$

Red-tail tropics and a neglected (?) shearwater. Wind east.

\section{March 8}

Propic or two about and in afternoon I pat out boat for four hours and kept ahead of the ship a mile, picking up a single neglected shearwater and seeing three or four others, and I thought a couple of sooty shearwaters. Iight wind from east and two mundred miles from Pitcairn to the southwest.

\section{March 9}

A single neglected shearwater and a tropic came around three or four times during day. Iight wind making ints.

March 10

A yellow-bill tropic came up in morning alongside, and later a redbill was shot. A neglected shearwater seen in A. M.

\section{March 11}

Light wind and started motor in P. M., heading for Pitcairn. Harch 12

Pitcaim in sight in P. M. but wind freshened and we stopped 


\section{$y^{2}$ moxollt}

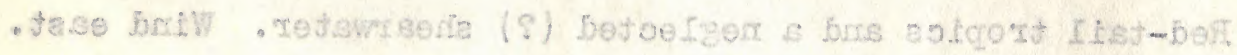

\section{8 noxe?}

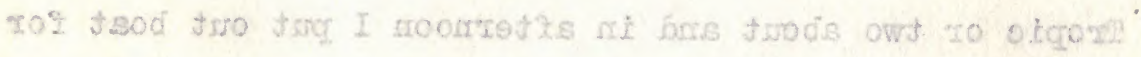

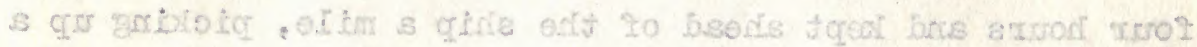

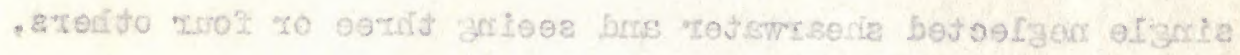

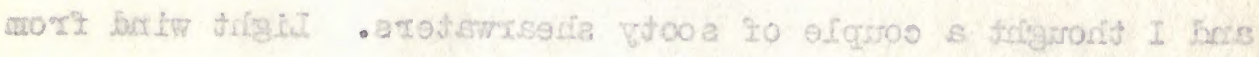

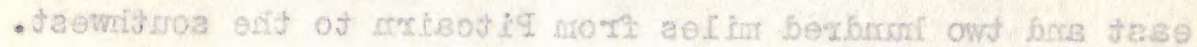

\section{Q. gorsill}

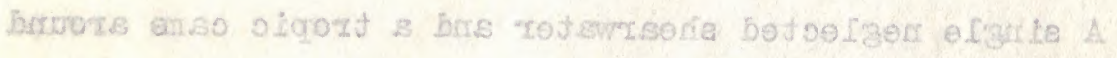

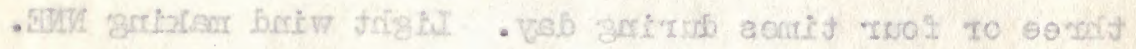

\section{OI. Iotall}

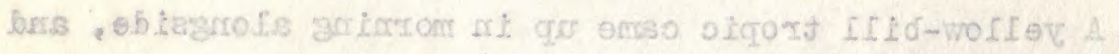

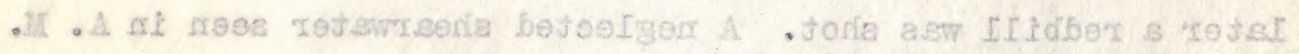

\section{If notsil}

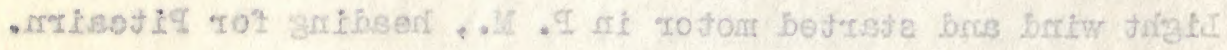

\section{SI sioxsif}

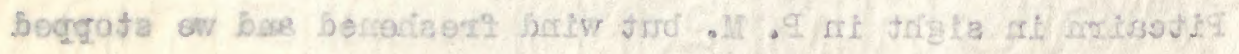


motor, expecting to make island in morning. Couple of fairy terns seen and one or two neglected shearwaters.

\section{Varch 13}

Approached island at daylight and sighted steamer nearing island also. Arrived together and three boats from shore went to steamer with bananas and wermelons, and after an hour aboard selling and trading goods the steamer dropped them and left, the boats coming' alongside the 'France' and I asked permission of the Governor, Mr. Christian, to collect, which was granted and we went ashore, finding the warbler common about the village and a few fairy terns flying about.

At seven in the morning a dozen or two gray terns were noted flying out along shore bound fishing, while but a half dozen noddy terms were seen around the island. These four species were all the bird.s seen, but the shearwaters were likely present in small mambers along the cliffs. Goats were seen on the hillsides, and a single horse is kept. Rain had been scarce and for our water the natives took their wheelbarrows with ten gallon tins and went over the top of the island to a spring from which they wheeled the water over a mile down to the beach. Wo bought a dozen and half chickens at a shilling and a half apiece and a goat for four shillings. 


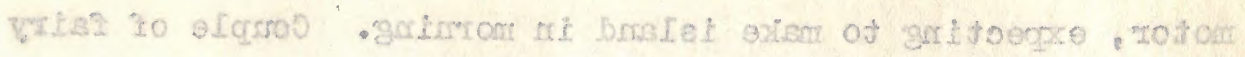

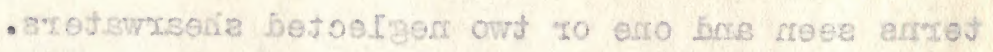

\section{of roralt}

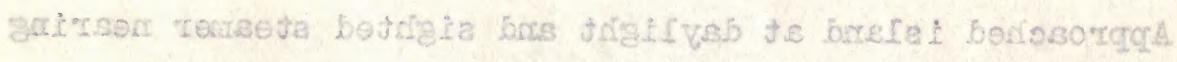

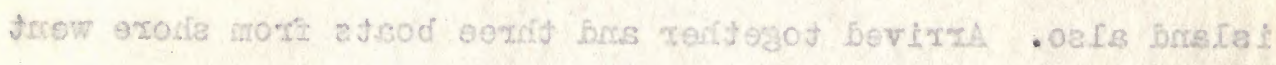

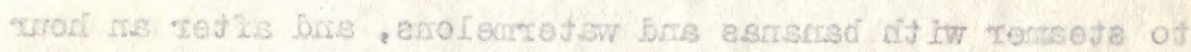

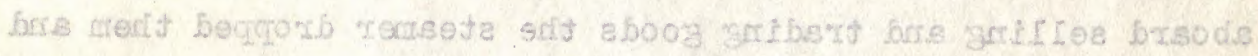

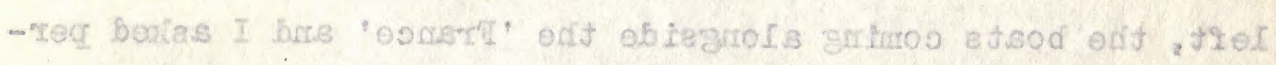

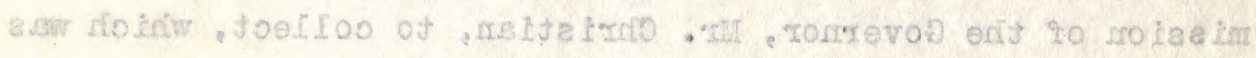

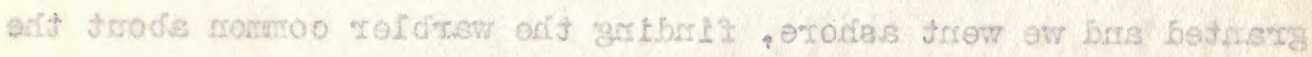

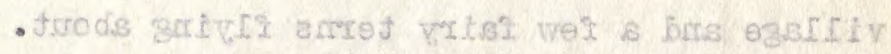

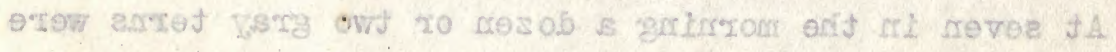

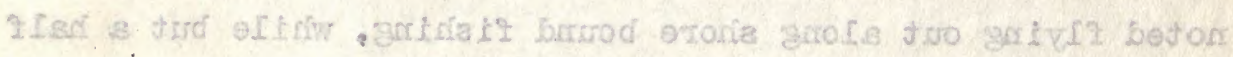

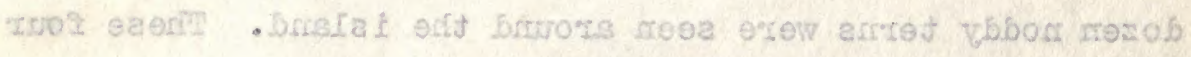

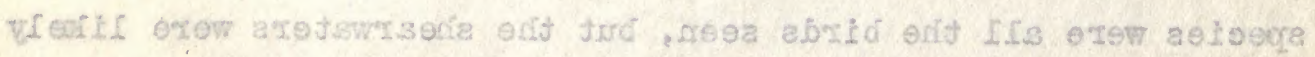

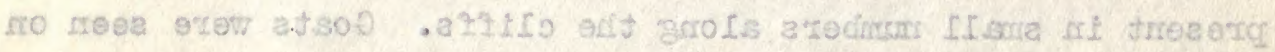

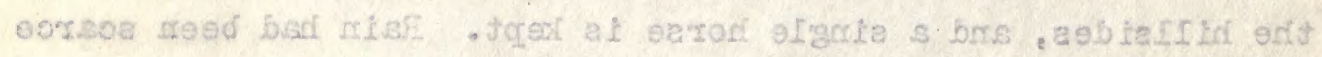

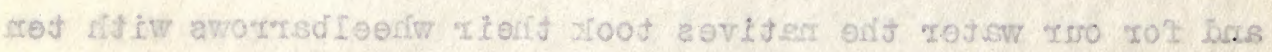

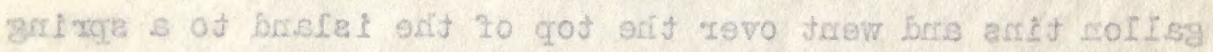

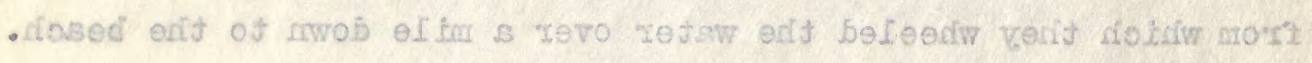

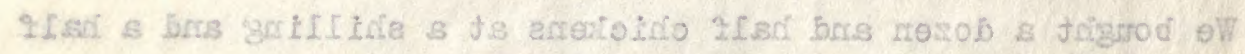

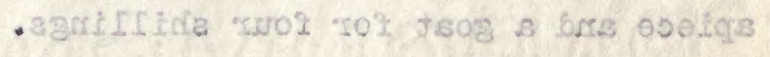


March 14

A fair breeze from the north blew today, and at three o'clock we sallod for Ducie Island.

\section{March 15}

A neglected shearwater seen a couple of times and two or three wedge-tailed (?) also.

Narch 16

Put out boat in P. H. and I shot several Henderson shearwaters, as well as a neglected, and got a couple of fairy terns winlch have white feet instead of the regular blue-toed which have been everywhere from Pitcairn to Narquesas and Christmas. Wind got light and at two A. H. tomorrow start engine and head. for Fenderson, thirty miles north.

Anchored on east side of Henderson Island at eight A. M. and went ashore, finding the top of the island rough, sharp coral rock very hard to travel on. Frigates and fairy terns were common and a few noddies were noted. Along the cliffs on top tropic birds were nesting, several nests being seen with eggs and one or two with egrgs. Frequently a neglected shearwater flew across the island. Warblers were common in the trees, many of the old ones showing wite feathers particularly in tail 


\section{AS IIJTal}

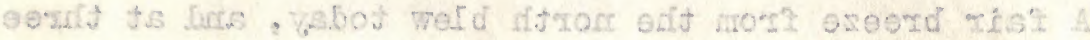

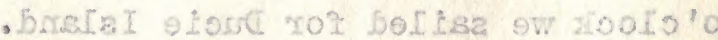

\section{E. niomell}

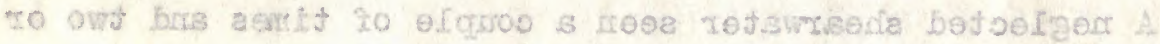

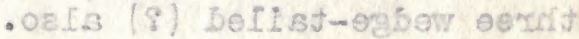

\section{If oreit}

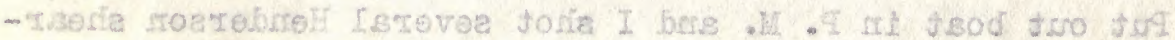

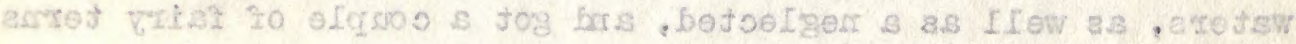

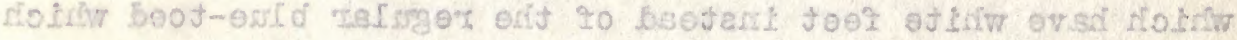

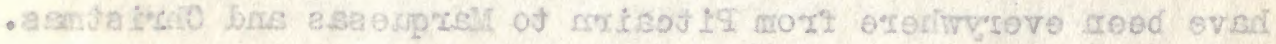

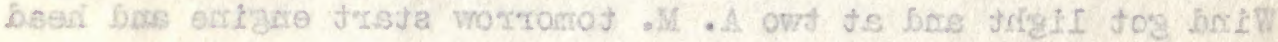

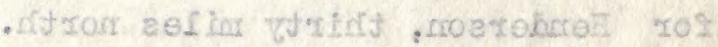

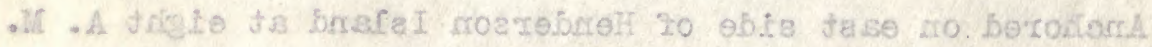

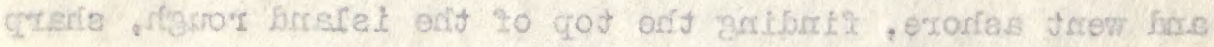

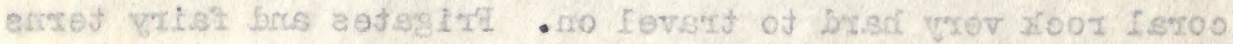

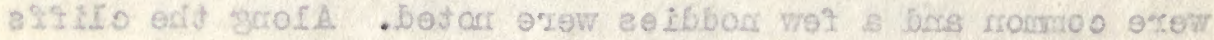

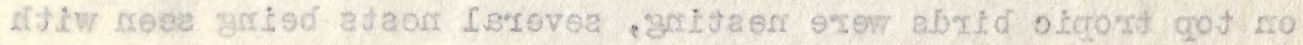

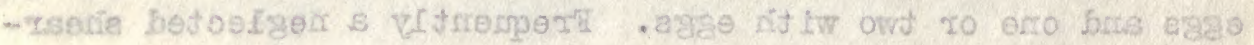

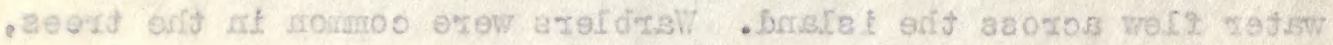

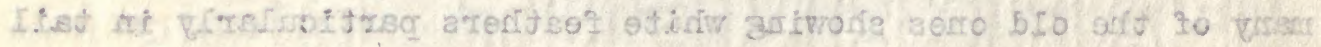


and wings.

\section{March 17}

Hoved to north side today as swell coming in heavy on east. Quayle and Curtis ashore while I skinned birds. Quayle got a few paroquets and a couple of doves and one rail near the beach. In evening I pat out boat and shot a dozen of the Henderson shearwaters, a hundred or so flying and feeding around some bodies of tropics and frigates thrown over. Shot four or five whitebreasted out of the hundred seen, the great majority being blackbreasted. An infrequent neglected flew by and a single wedgetailed came along and was secured. Heavy rain in P. M. and wind changing to north. Quayle ashore for the night to try for rail.

\section{Harch 18}

Quayle aboard at nine with several neglected shearwaters shot along the cliffs last night, but no more rail. He got three gray terns which were roosting on the cliffs and we saw a flock off the northeast point of the island fishing yosterday morning. As wind is good from $N$. W. we head for Drcie and will finish this island when returning.

March 19

Good wind since yesterday and meking seven miles with 


\section{7. ageste}

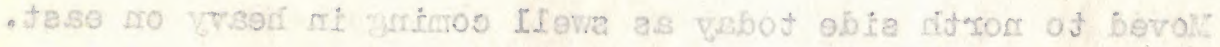

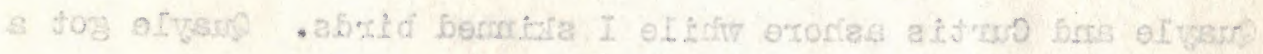

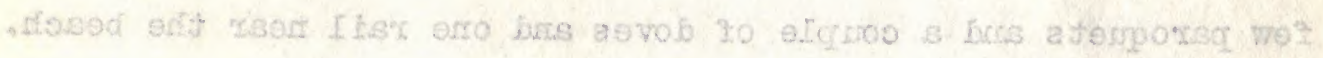

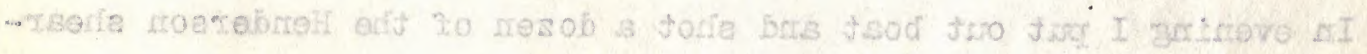

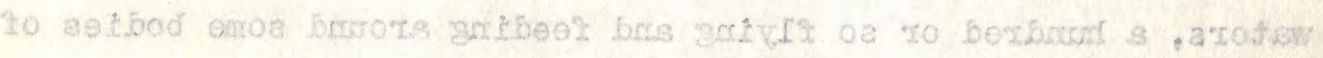

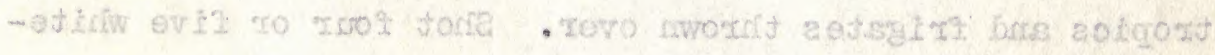

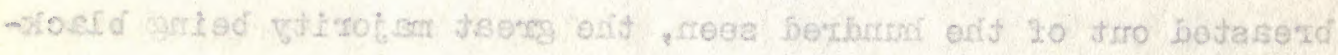

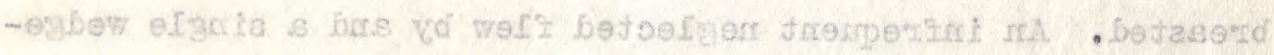

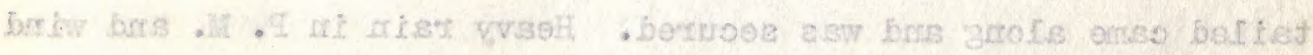

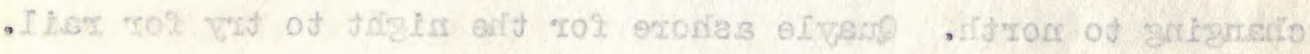

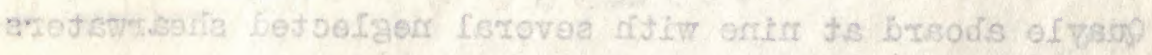

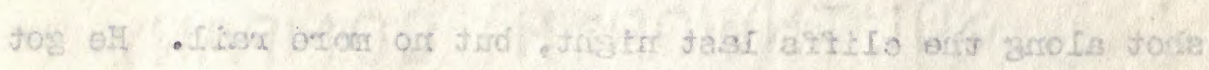

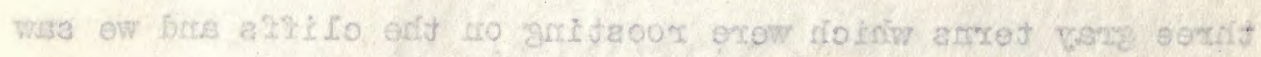

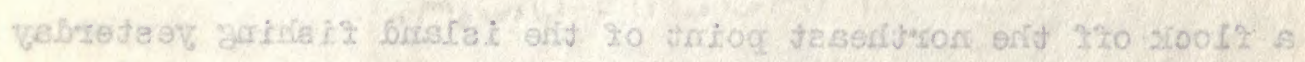

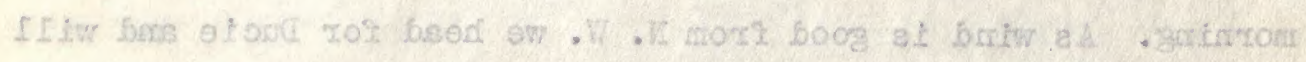

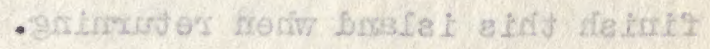

\section{eI dereil}

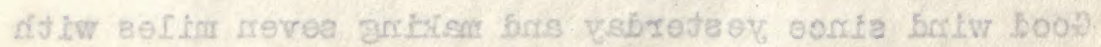


mainsail reefed and jib down. Forty miles and more from Ducie the neglected shearwaters were comon, and twenty-nine off a couple of fairy terns seen and later a red-foot booby, and five miles off a cyanons booby seen as island appears ahead.

\section{$\operatorname{March} 20-1922$}

Ashore and found neglected and Henderson shearwaters common under the bushes, most in pairs, though a few had eggs. A couple of nativitatus were discovered, young birds nearly ready to fly. At one place red-tail tropics were found under the trees or bushes setting on eggs and shearwaters near them in many cases, while in a few trees red-footed boobies had nests.

Blue-faced boobies were sitting in pairs along the beach and several young flying birds were with thom. Fairy terns were sitting in the trees and three or four eggs were found and a young bird also, while a single lesser noddy nearly ready to fly was taken from a nest of dry leaves about eight feet up, and noddy terns were sitting along the beach. A few frigate birds were seen, but one young nearly ready to fly was only sign of nesting. Two curlew, several tatlers, and a single sanderling were seen and the latter taken.

March 21 to 30

At Ducie working on birds, putting up four hundred in the 


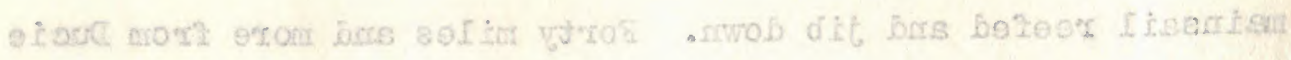

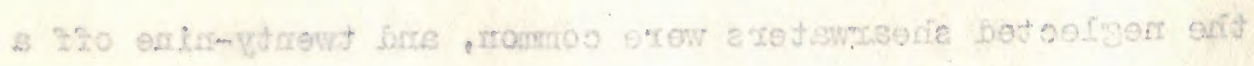

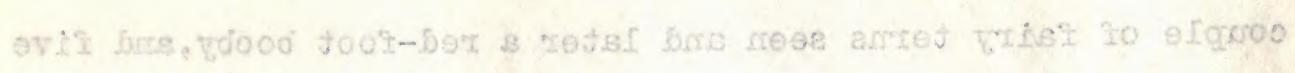

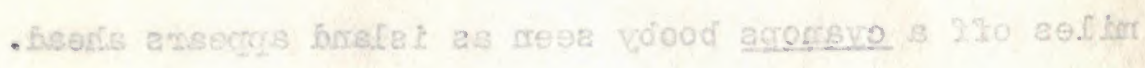
OS dionsit

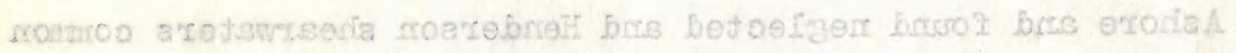

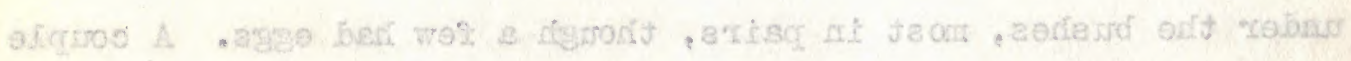

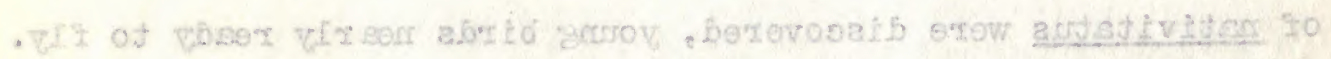

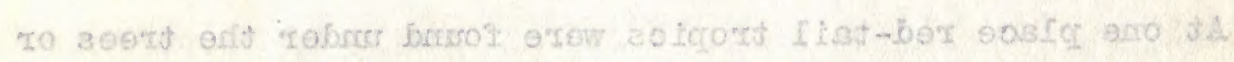

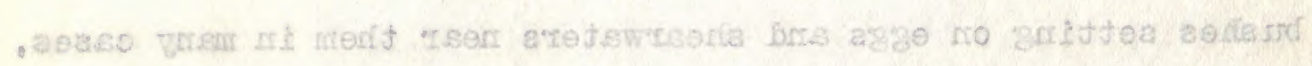

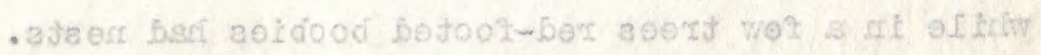

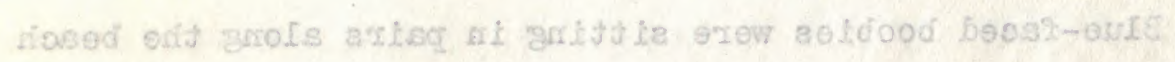

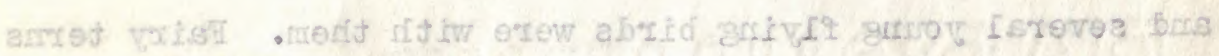

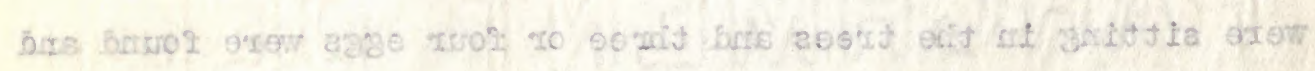

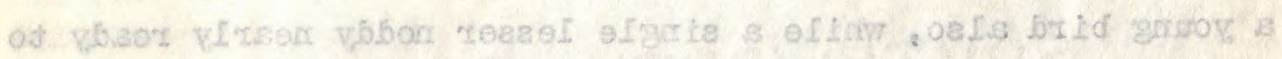

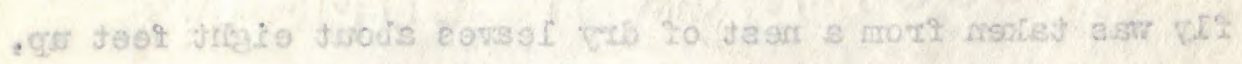

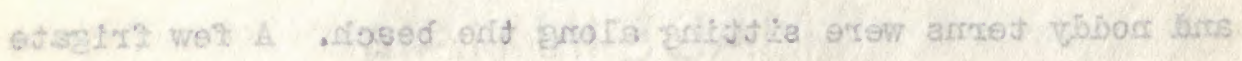

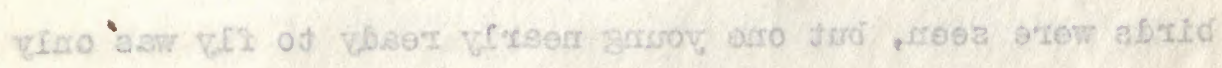

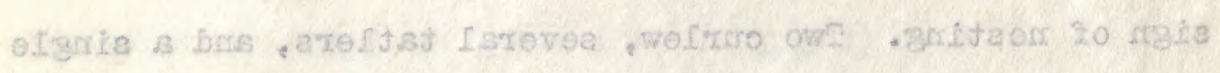

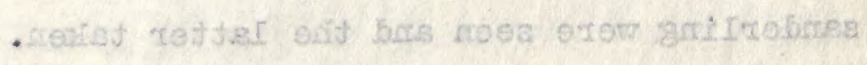
o8 of is forge?

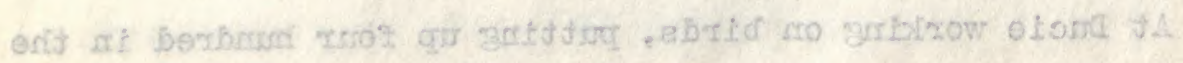


two weeks. The shearwaters come in to the island in greatest numbers about five P. M., flying around over the colony and the pairs circling high into the air frequently. A few birds were noted going to sea in the evening, but there were not a great number of incubated eggs and only four young birds were seen in the two weeks stay. The birds often climb up a tree trunk and into the tips of the small branches to get a place to start flying. They were often seen sitting on a tree trunk or limb, some feet above the ground. The nests are hollowed out by the bird's slowly pushing out her feet behind while resting on her breast. The two species often form little colonies close together, or rather groups in which one or the other will be the predominant breeder, while a short distance away another group may be largely of the other kind. I collected thirty birds of the small spocies in a radius of fifty yards when leaving the island, and counted seven nests under one fallen tree, each within six feet of another nest, while often a root or 108 separates a pair of birds. Sometimes a neglecta would be found nesting close to a tropic bird's nest, the tropics as a rule keeping close to the outer rim of bushes, while the shearwaters went all over the wooded parts.

1 fresh influx of tropics seemed to come in the second. week of our stay, and at two $0^{\prime}$ clock or thereabouts in the day 


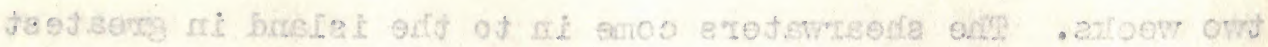

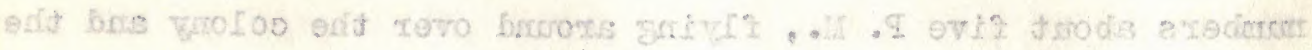

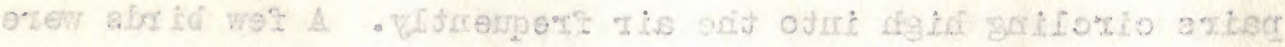

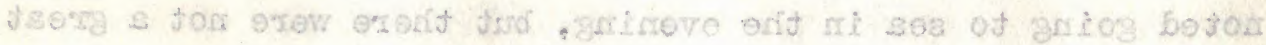

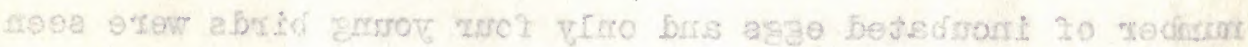

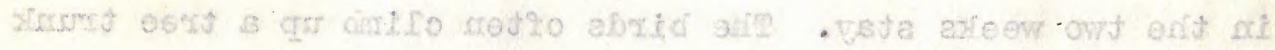

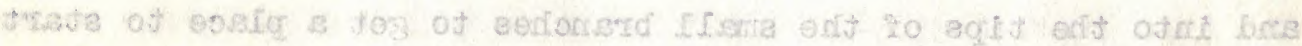

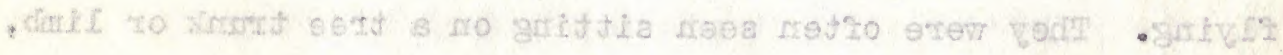

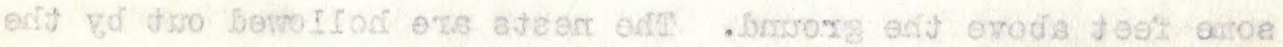

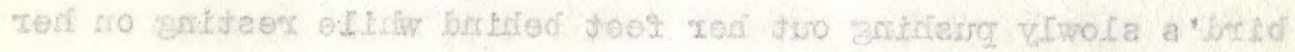

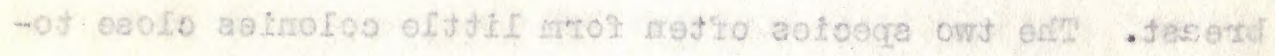

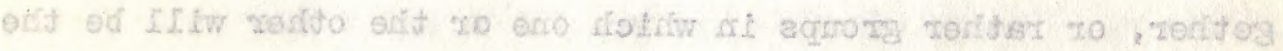

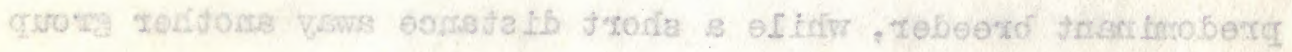

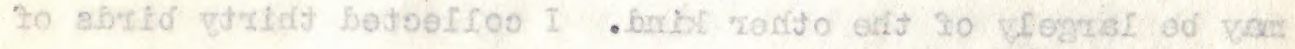

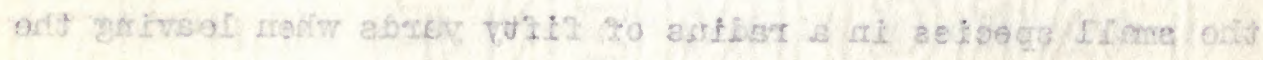

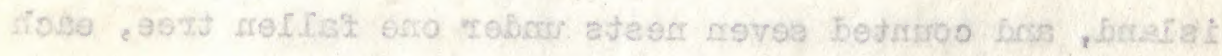

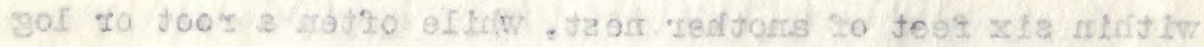

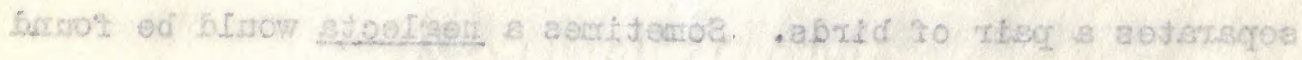

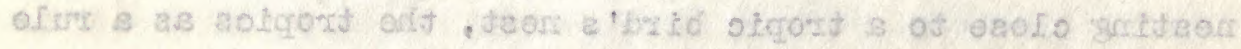

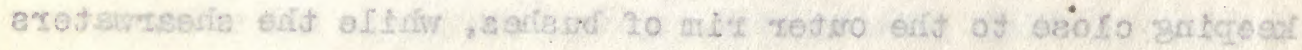

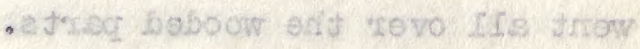

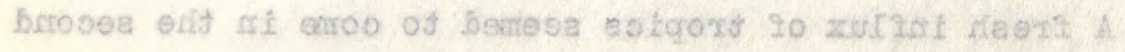

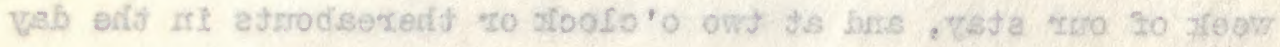


one might count forty or more flying around calling and dropping down to crawl under the bushes. Many had fresi eggs, while a few young birds were seen in downy stage. Gray terns sometimes lit in the trees as well as on ground. Collecting about fifty birds to work on across to Henderson, we left Thursday and amived at Henderson Sundey morn.

\section{$\Delta$ pril 3}

Ashore on the west side of island and find a few coconut trees at beach. I peck birds wille Quayle takes camp outfit to stay at night. Paroquets and warblers are taken and one of the sailors goes with him to cut trail into center of island. They cut a short distance to a strip of open rough, jagged rock, finding no rail in the jungle, though one was heard.

\section{April 4 to 9}

I went ashore the 4 th and along the coast a short distance and into the rough rock a half mile in, finding a couple of doves and a couple of paroquets, the latter being flying birds called around as they passed overhead in pairs. Fairy terns, noddies and shearvaters as well as boobles passed overhead going farther into tho island, and one noddy was seen sitting 


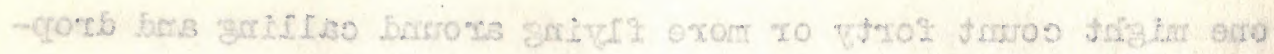

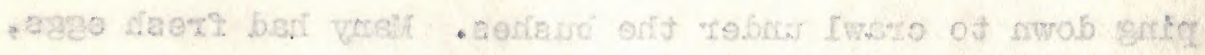

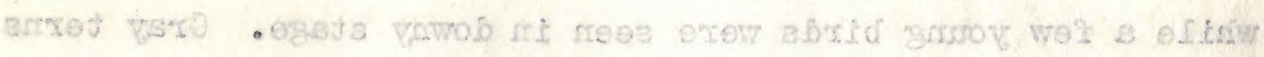

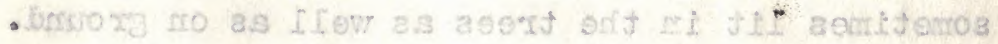

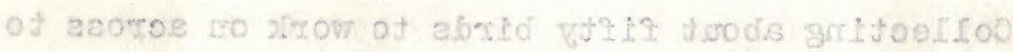

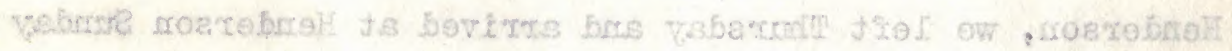
- rreas

$$
\text { E. ISTA }
$$

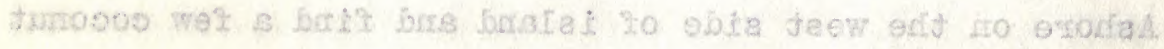

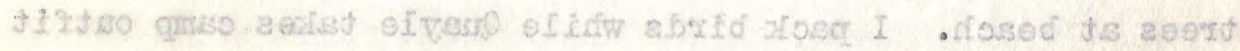

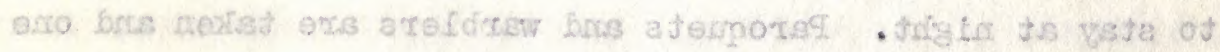

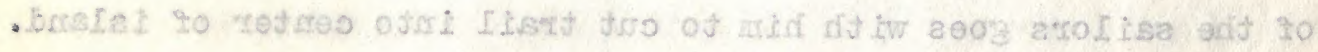

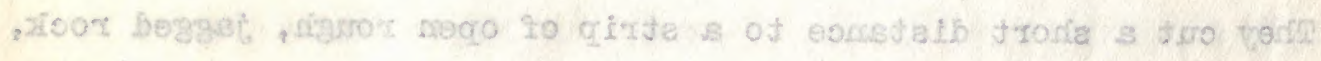

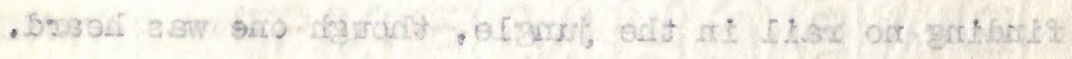

\section{e.os: ILTaA}

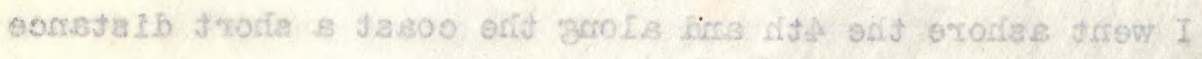

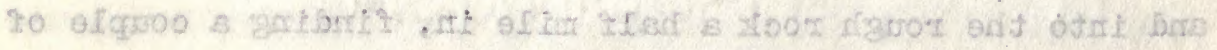

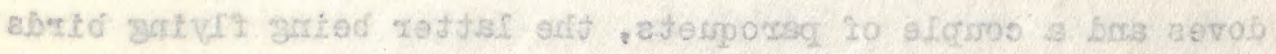

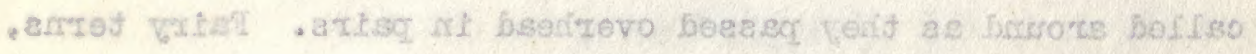

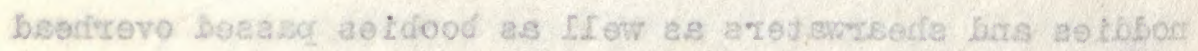

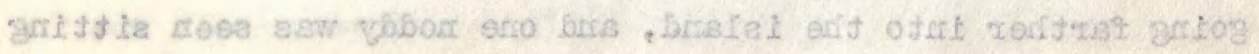


on a pandanus tree. Several rats were seen and a few wild lizards. Mropics flew along the eliffs as they did on the east and north sides, and the sailors found several nests. A single white reef heron was seen before we anchored, but kept away from the beach along the cliffs where approach was impossible. A couple of curlew were seen and one very fat one was shot.

Quayle went in over the rough ground and found the rail not uncomon, getting eight the first time he crossed. They were tame, coming up bohind him in most cases. Though chased by the dog on one or two occasions none flew, and their wings hardly appear sufficiently strong for flying. Though many of the shearwaters appear to be nesting, no eggs were found, though a pair of birds were taken a couple of times. I shot about thirty a half mile off the island after supper on three different evenings as they were coming into the island. All were dark birds, but Friday I went out at four P. M. and got a couple of light-breasted ones,--the first seen of two hundred or more that were closely looked at. The day of leaving the island for Ducie I shot three or four out of a couple of hundred that were the only white-breasted ones in the flock attracted to some feed. A couple of white boobies were seen, but the major part of the older birds show white tails and 


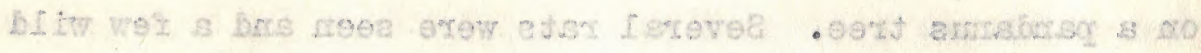

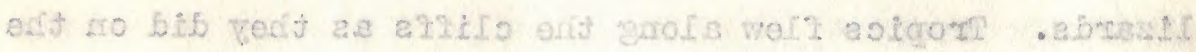

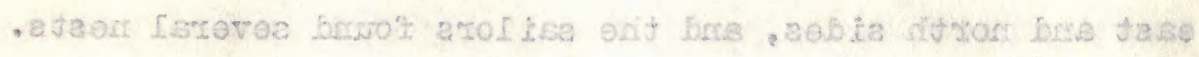

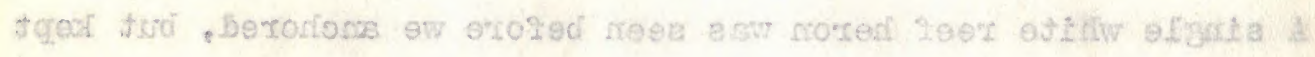

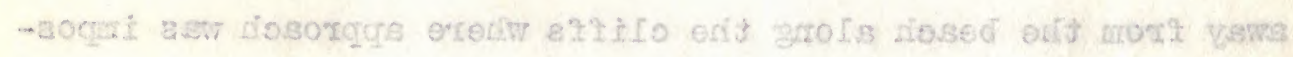

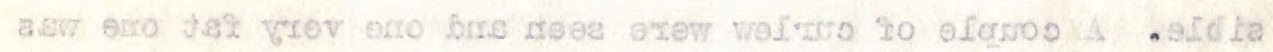
- torfa

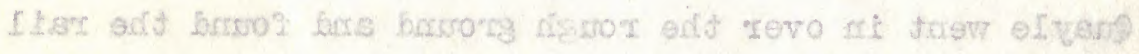

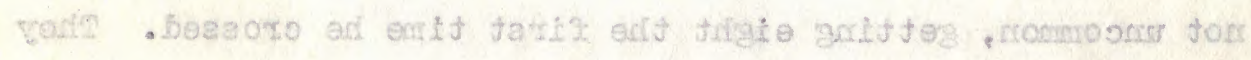

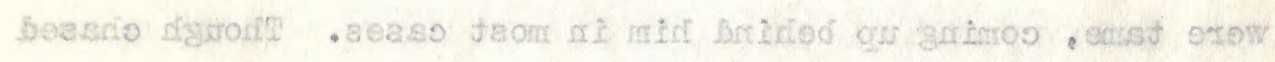

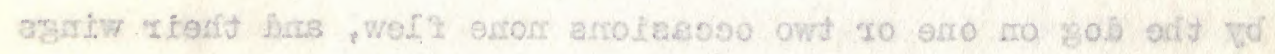

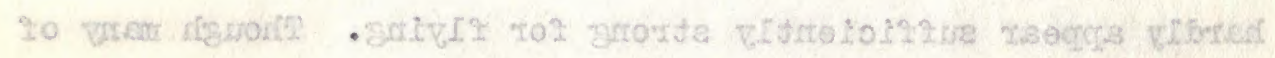

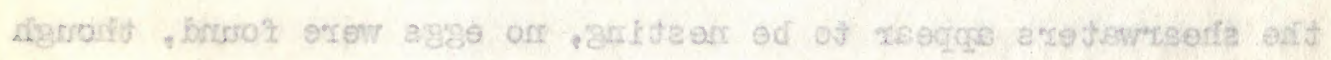

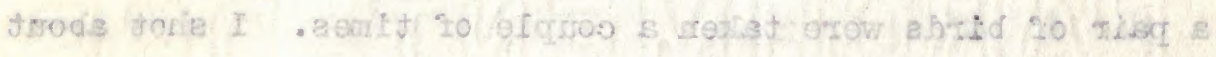

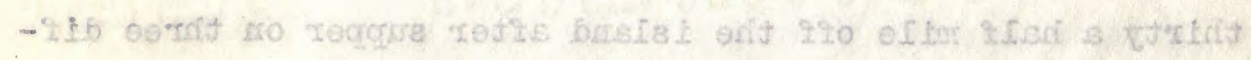

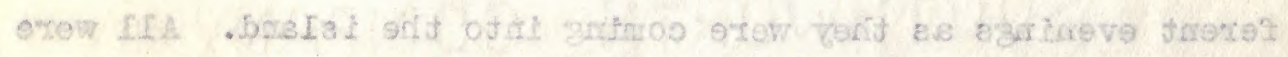

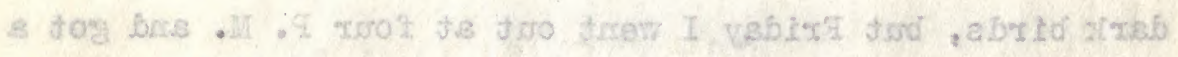

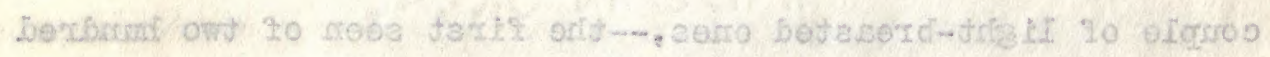

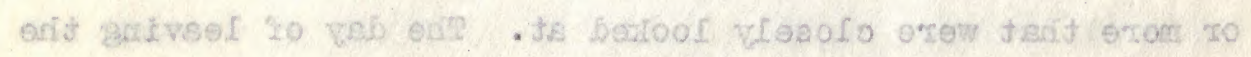

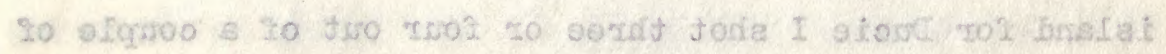

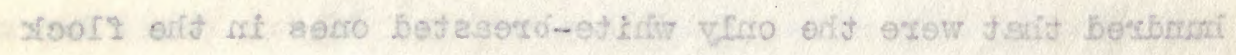

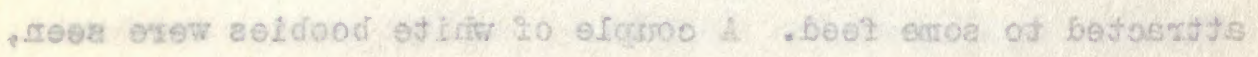

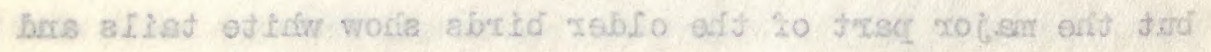


perhaps little white on the after parts. Not many are seen, but a few come in every day at dark, while a few noddies and shearwaters and fairy terns are seen going to sea, though most of the birds are coming landward. We anchored to the reef for four days, but a light breeze from the west Friday determined. us to lay to that night.

Apri1 10

Quayle ashore on west side to go after rails and doves while I went around to north end to try for terms and paroquets. A couple of blue ternlets (called gray terns previously in our notes) Ilew along the cliffs and lit once but could not be shot as they kept over brush where finding them if shot would have been unlikely. I could not find a noddy dropped thirty jards away, the brush was so thick. Frigates were sailing along the shore and lighting in the bushes along the beach, one male being noticed waving his red pouch to whom it might concern. With the Captain who had one of the guns, I returned to the vessel with a dozen paroquets, four frigates and a couple of bristle-thighed curlew,--the only curlew seen, and tatlers also are now scarce. Quayle got four rail and same of doves, and we left island when he got aboard at 5:30 P. M. A small steamer passed a mile off toward the west as we were leaving, 


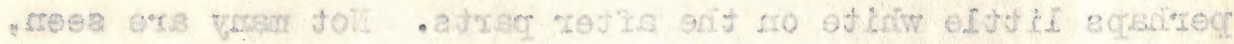

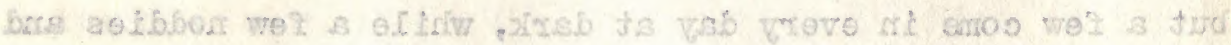

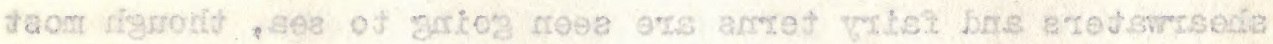

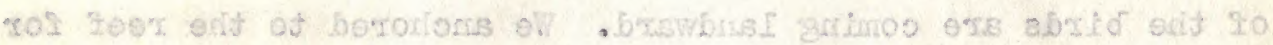

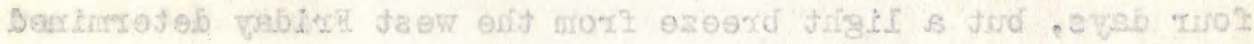

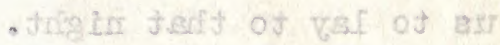

\begin{abstract}
or ItregA

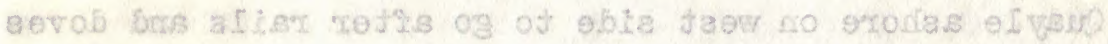

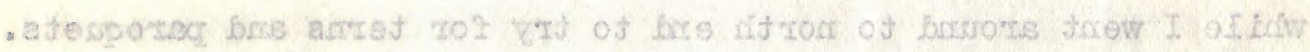

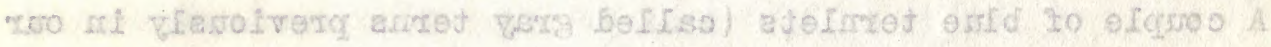

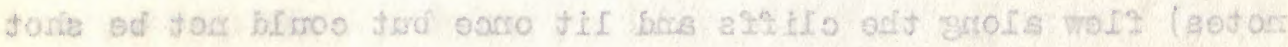

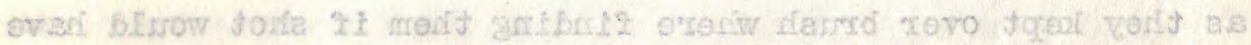

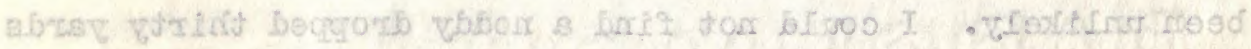

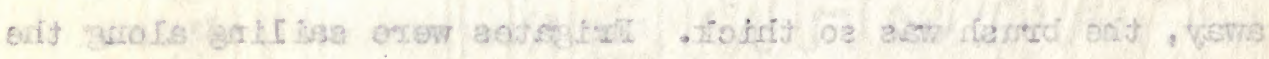

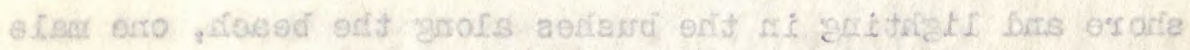

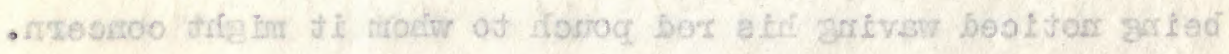

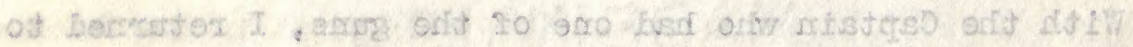

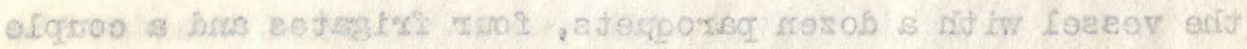

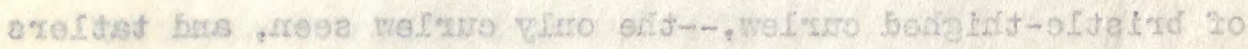

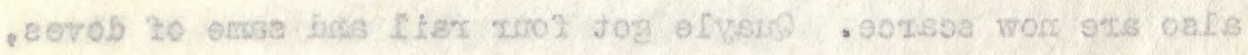

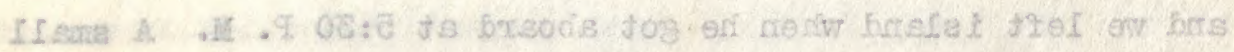

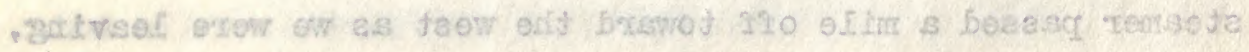


and a large one was seen yesterday bound the same way.

Apri1 11, 12, 13.

Sailing with light wind for Oeno Island. The twelith didn't see a bird a.ll day, and the thirteenth when nearing island saw a yellow-bill tropic, and at dark three miles from the island five sooty terns and a blue-faced booby went by to the island higher in air than boobies are often seen. A fairy tern wes seen in morning and a conple of dark shearwaters during day.

April 14

Laid off Oeno Island last night and this morning eqayle and Curtis went ashore while I finished up eSg datas and packing. Ihey came back with report that the Pitcaim men had left a few days before and had eaten a lot of birds, leaving the feathers near carnp. Propics were the common birds, with a few sooty as well as fairy and both noddy terns. A few blue shearwaters as well as neglected and Ducie birds were present, the latter in no numbers.

\section{April 15}

I went ashore, leaving Quayle to skin birds as he had not brought enough to keep us busy all day. Very few birds are 


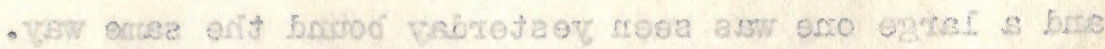

$$
\text { -EI ,SI , II ITECA }
$$

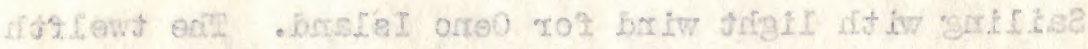

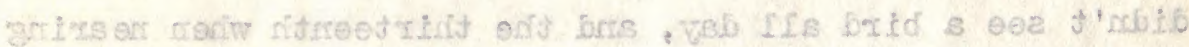

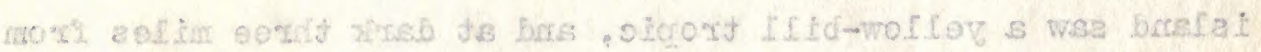

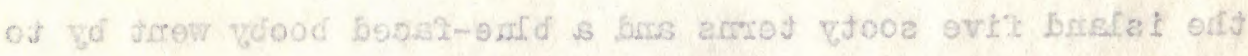

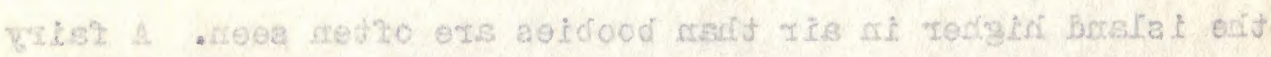

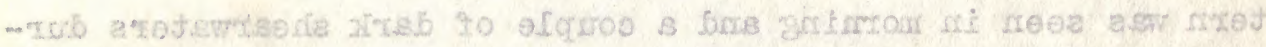
- vess gart

\section{AI Irret}

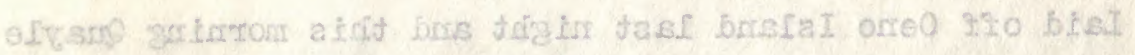

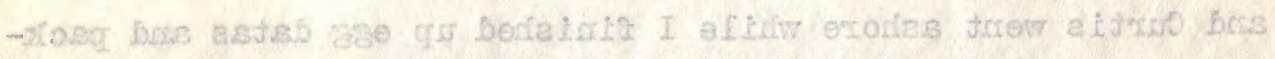

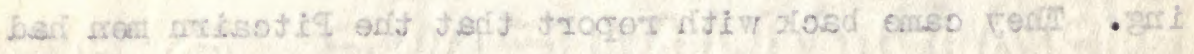

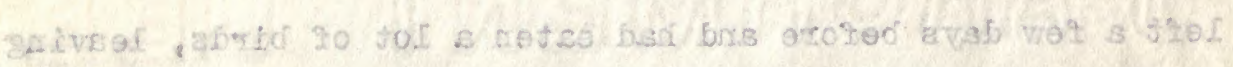

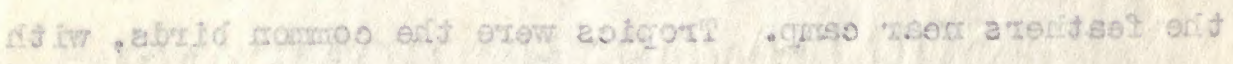

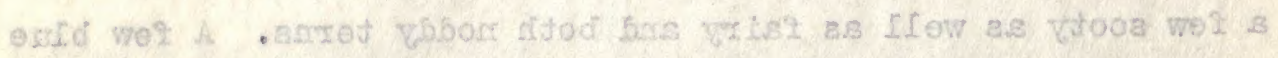

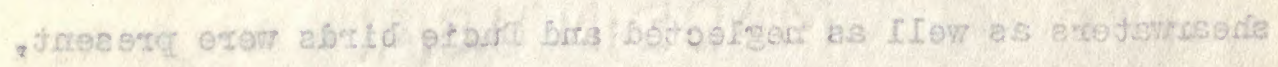

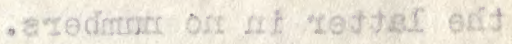

\section{de Iloce}

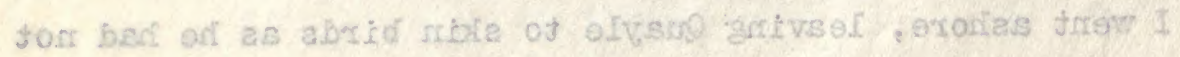

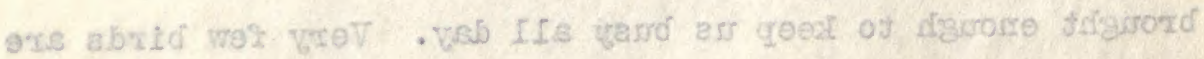


seen outside the reef,--an occasional sooty term or possibly a tropic. Few coconuts were growing, but all the nuts had been taken by the Pitcairners who came up here to get some lumber from the wreck that lies on the sandy island near the wooded one. Iumber of various kinds lies around the shores in worm conaition. This makes the eighth wreck that has been recorded on this island. The reef being nearly a mile from the low island makes it doubly dangerous.

Blue-faced boobies were standing around in the shade of low trees and often standing on low limbs, in the center of the island instead of on the beach as on Dracie. The only nest with an egg was seen under a tree, though many nesting sites were seen with birds by them in open places in the interior, which is about a quarter of a mile across and a mile long, this comprising the wooded part of the island. One redfoot booby nest with young was seen and many birds not nesting were sitting in trees. Iesser noddies' nests with young nearly ready to fly were noted, but most had left their nests. Propics were nesting under bushes all over island, many small young being noted, but the shearwaters were just beginning to lay. Three pairs of blue birds were hunting sites and were sitting near the beach in probably nests, but one pair left when I neared them as they were with a couple of feet of the open, rocky beach. Another pair crawled from their site in the ferns 


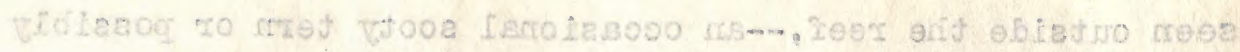

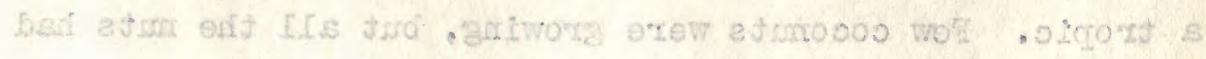

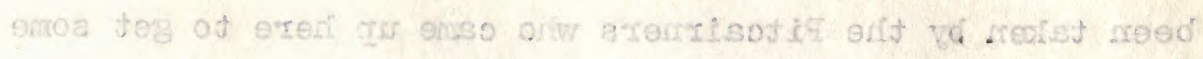

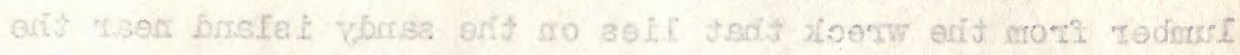

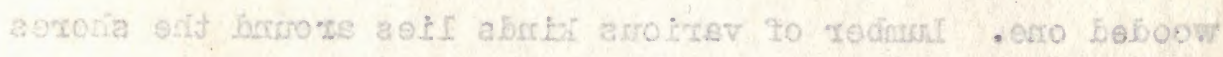

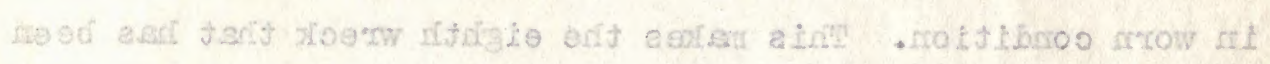

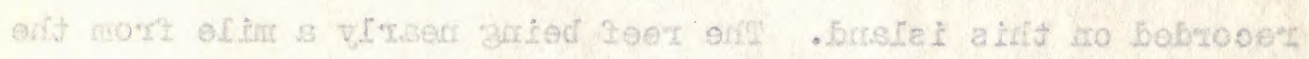

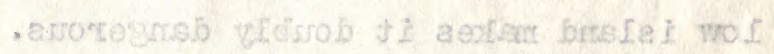

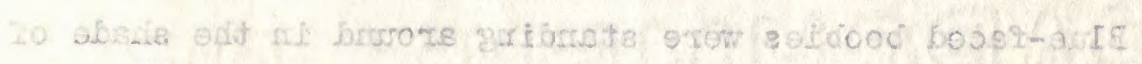

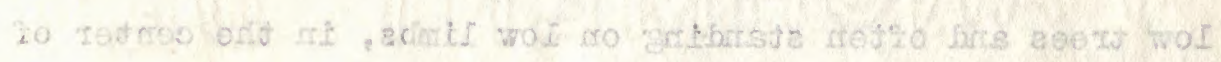

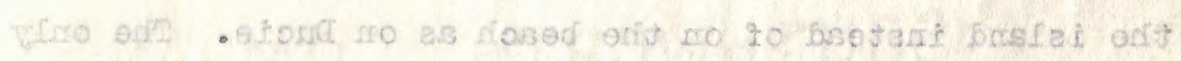

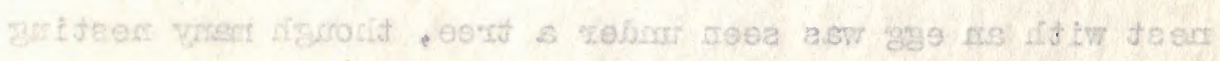

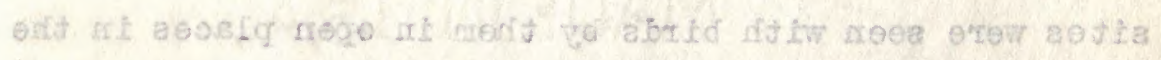

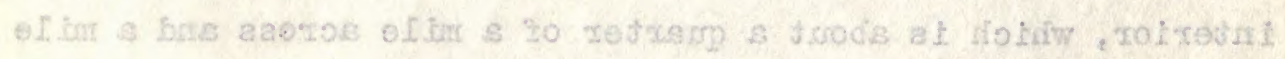

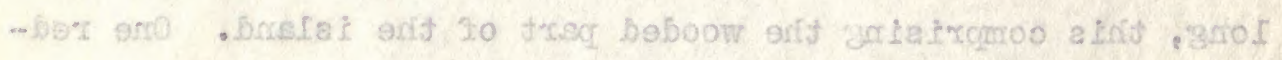

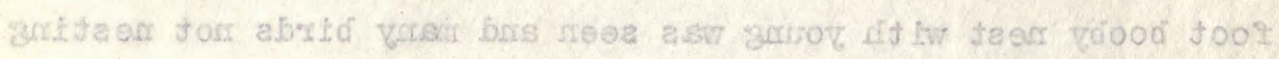

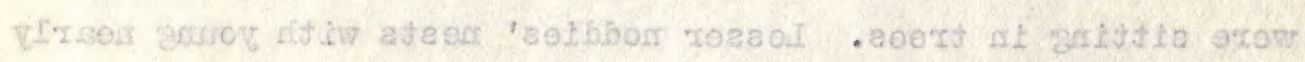

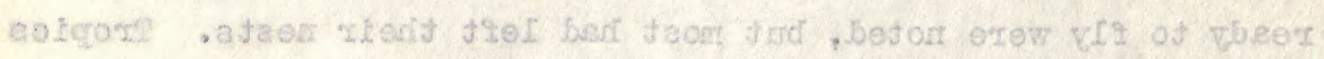

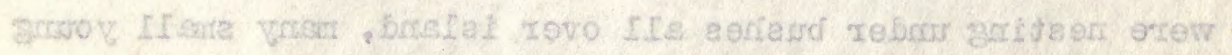

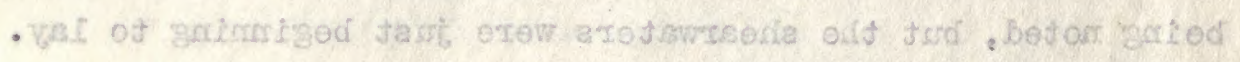

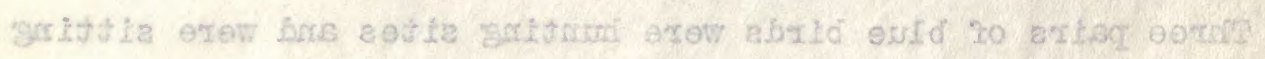

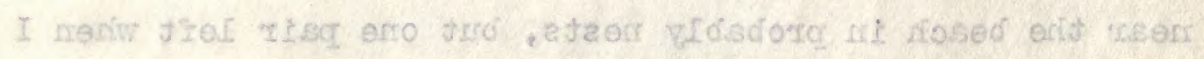

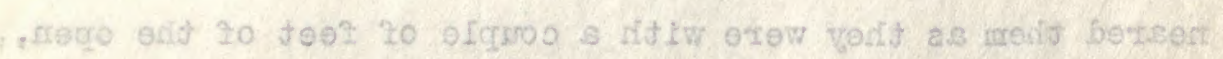

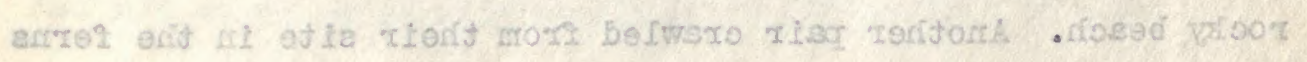


to shelter of a hollow tree while I went for the camera. I saw but one pair of Ducie birds, though Quayle got six yesterday. I saw one white heron as we sew one on Henderson. A curlew and a couple of tatlers were noted. White terns seem to have blue toes here. Few frigates here, but one young able to fly seen resting on bush. Two blue-faced young seen flying and the sooty terns kept high in air over one place but no nests seen.

\section{Apri1 16}

Sunday and stay on board.

\section{April 17}

Ashore with Quayle, and as he picised up a dead rail that had been dead a day and had been eaten by crabs (?) he stayed ashore to look for them and I took the birds aboard and with help of engineer sidinned them.

\section{April 18}

Skinned birds all day, finishing yesterday's as boat brings another lot from Quayle.

\section{April 19}

Calm day and sent boat after brealfast at eleven for 


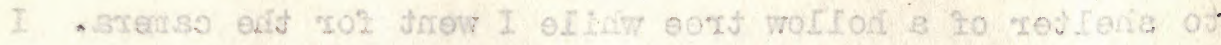

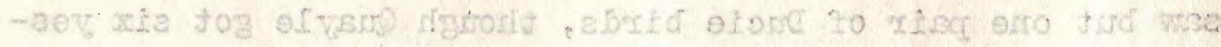

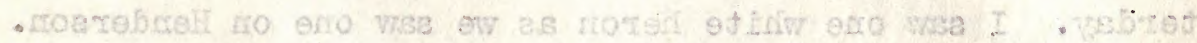

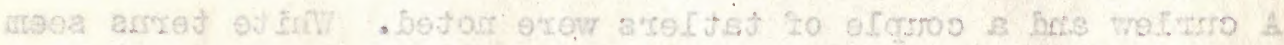

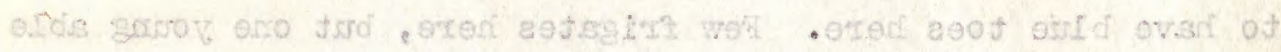

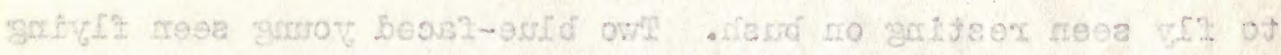

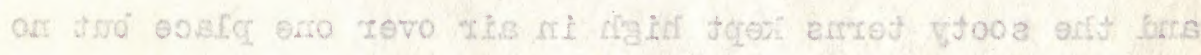

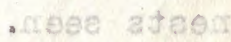

af $\cos A$

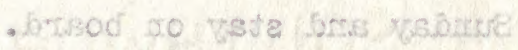

\section{Itecti}

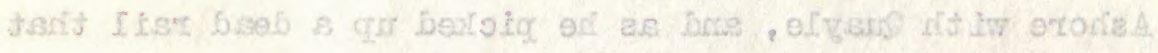

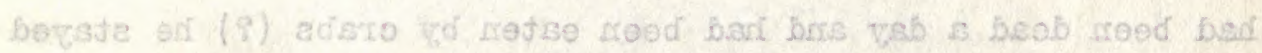

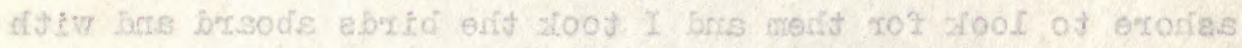
- molis bermitia zeontare to qutert

\section{3f Iivet}

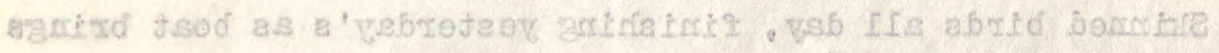

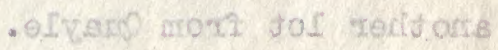

\section{e. I. Ster.}

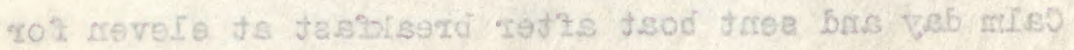


Quayle. I went on deck as usual to watch boat cross reef, but Captain said pass was caln and I returnod to work in the hold. But the smooth water on reef made the sailors careless and they steered in by another route than the one usually taken, resulting in their being on the reef as a periodic swell came along. This was so heavy that it overturned the boat as it broke and the four men were dumped in the water in the breakers. Being good swimmers they tried to work the boat shoreward, but an outgoing current set them back into breakers and they had to woris out to sea, where we picied them up three hours later when we ran in to receive them from the island. The boat was practically submerged all the time, being heavy, but sharks were Iuckily not around. After hoisting the boat to bale it out they were sent in again, and taking the right pass had no trouble, though Quayle said on coming out good-sized swells were encountered. The Captain of one of the wrecked ships was drowned when his boat was capsized here in trying to get out into the sea, and our experience demonstrates the necessity of having a good and careful boatsteerer and an easier handled boat than the one we have, for many of the islands can only be landed on by going in on a swell and landing on the reef. Queyle brought off about fifty birds and we left for Timoe at dark. The blue shearwaters appeared to be coming in searching 


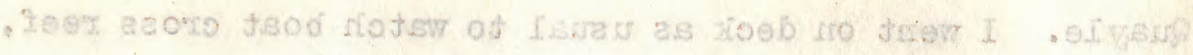

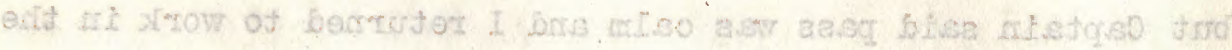

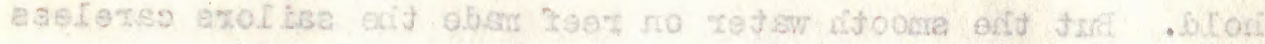

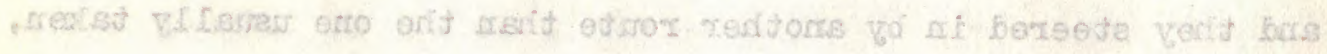

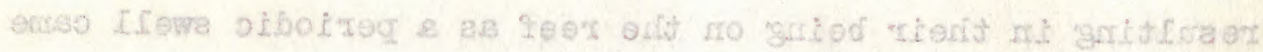

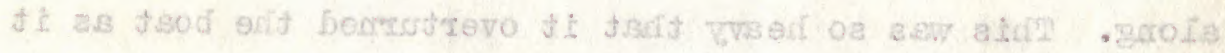

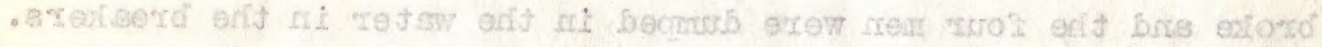

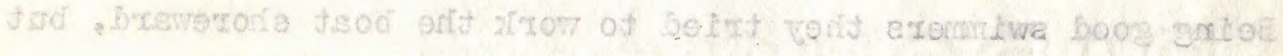

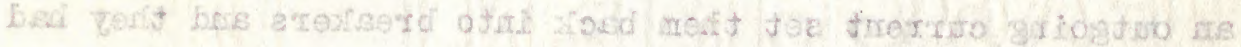

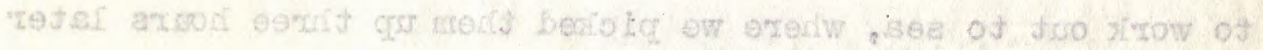

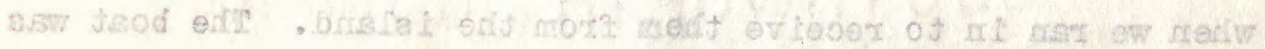

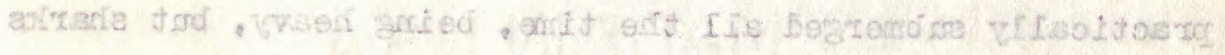

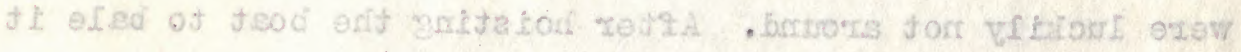

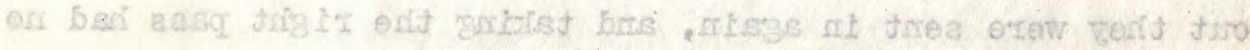

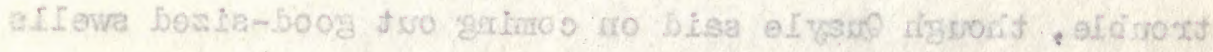

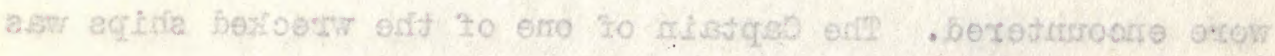

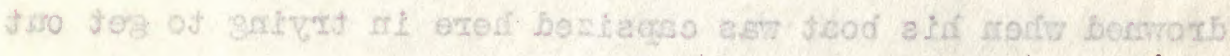

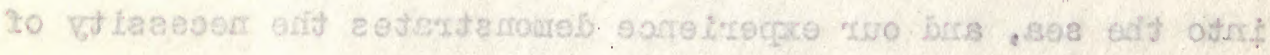

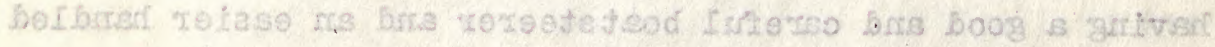

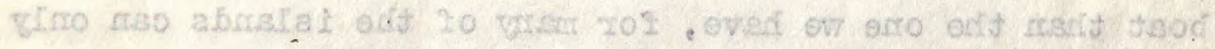

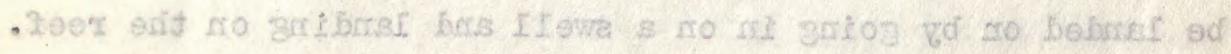

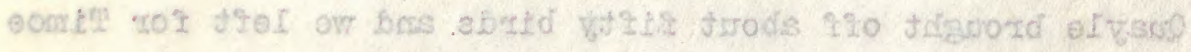

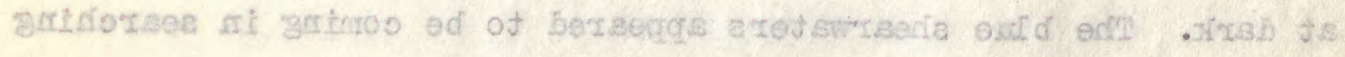


for nesting sites, as he found more the last day than before, but he found no rail and heard nono, though he spent two nights listening and watching for them. He saw bat did not get the white heron seen and this one was the only heron noted here.

\section{$\Delta$ pri1 20, 21, 22.}

Sailing for Pimoe and one hindred miles away at 23 when wind started. Couple of neslecta shearwaters around at dark on the 2 and and one or two others seen during trip.

\section{Apri1 24}

Timoe sighted about nine A. M. and after lunch Quayle and Curtis go ashore. Within two miles of island three or four obscuras shearwaters are seen and an occasional neglecta farther off. White and noddy terns seem to be the principal birds viewed from sea, though a single young red-foot booby flies past. Three or four of the Nangareva Islands as we lay off Timoe can be seen twenty miles to leeward, the highest looming up lize in the Mrarquesas.

\section{Apri1 25}

No land birds on $T 1 m o e$ and few sea birds, red-tail tropics a couple, couple of blue and a Ducle shearwater were taken and 


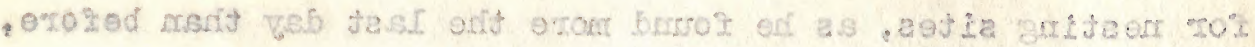

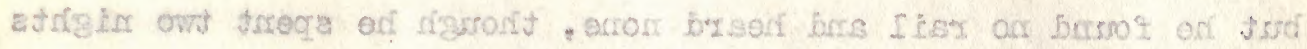

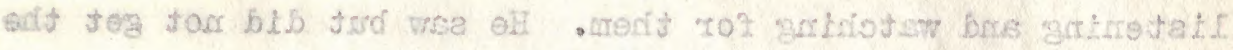

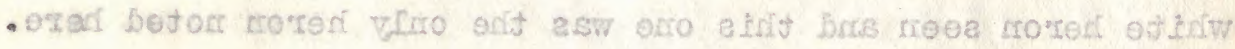

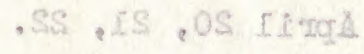

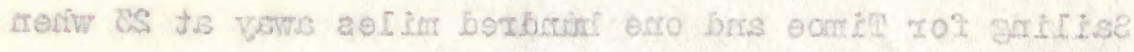

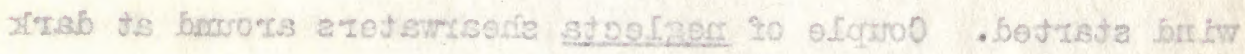

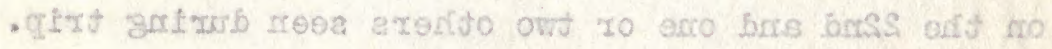

\section{AS IITeA}

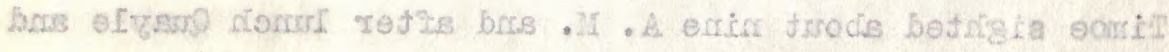

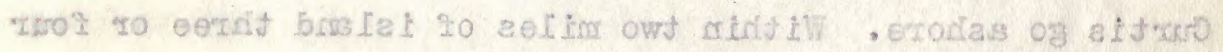

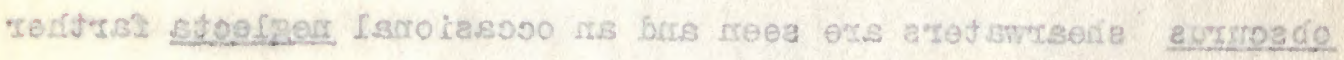

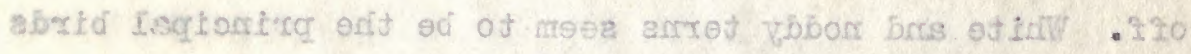

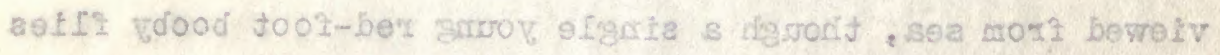

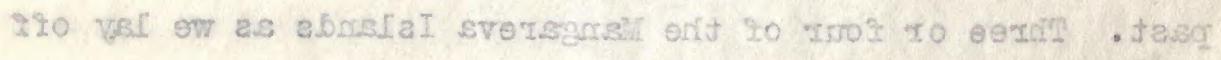

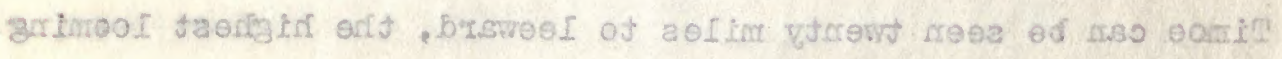

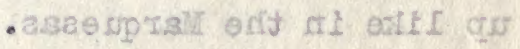

\section{as $18 \operatorname{sg} \mathrm{A}$}

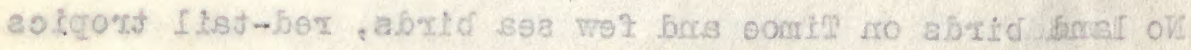

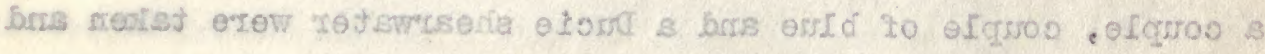


a couple of white reef herons as well as fairy noddy and lesser noddy terns. A yellow-bill tern or two was seen over the lagoon.

\section{April 27}

Arrived at Mangareva, seeing yellow-bill terns about anchorage. Ashore and find fairy and noddy terns nesting along cliffs, the fairy in trees and the noddies on the cliffs.

$$
\text { April } 28 \text { to May } 7
$$

I work Nangareva for birds, seeing a cuckoo two or three times in the distance and hearing one from the ship, but not getting a shot. Pick up a few yellow-bill troples at base of cllfis where they are seeking nesting sites and where some have nests. Sometimes eight or ten fly high in air together and often pairs or three or four may sail about, sometimes so high they can only be heard and not seen. Pairs sail and dart down to nesting sites in the cliffs timo after time in the strong breezes, and sail across island from one high cliff to another. Reef herons are infrequent, but euayle found a nest with two incubated eggs on a motu on the reef. Quavlo has been working the other islands of the group, finding sandpipers on two, Kamake and Makaroa,where no cats or people occur. He got the puffinus shearwaters also with young birds and eggs, and found 


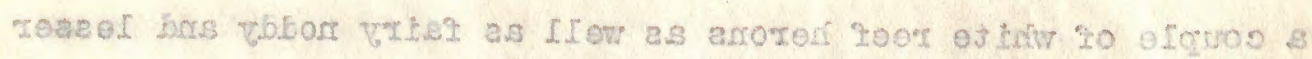

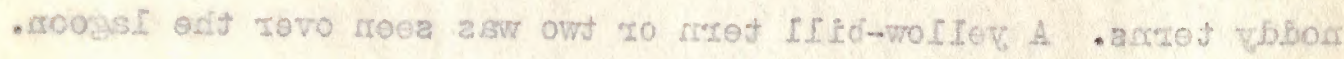

\section{TS IfIgA}

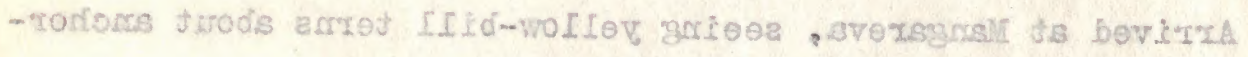

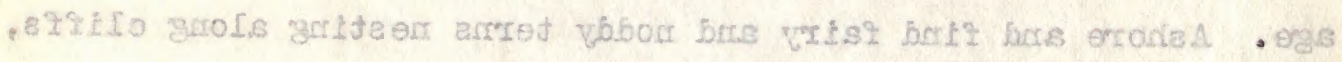

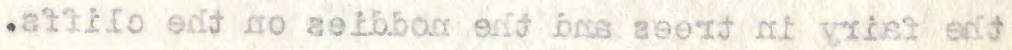

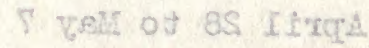

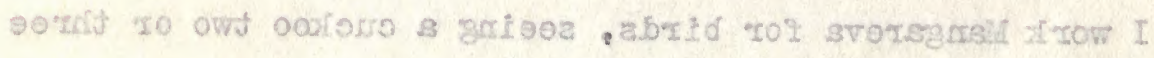

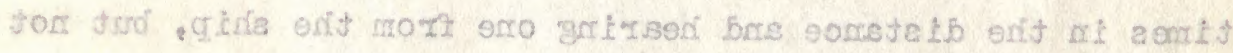

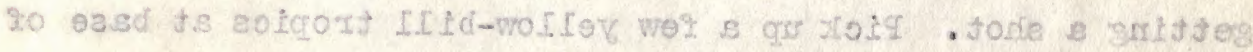

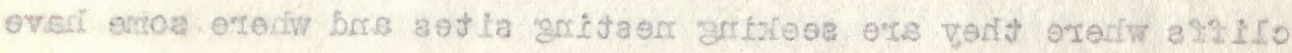

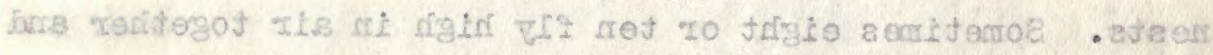

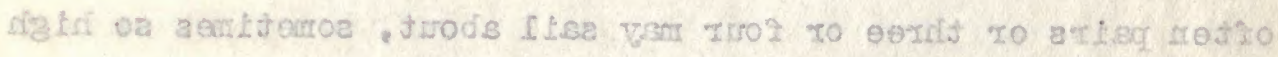

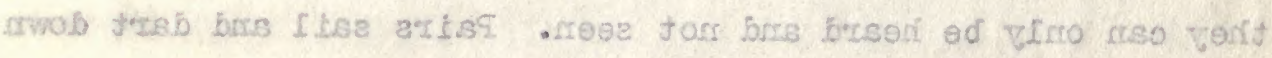

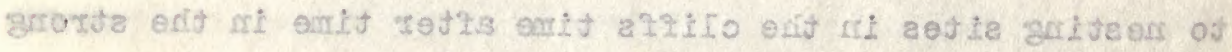

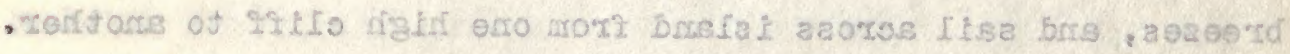

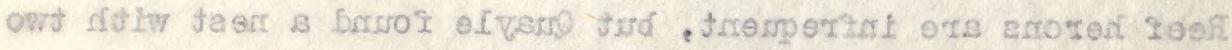

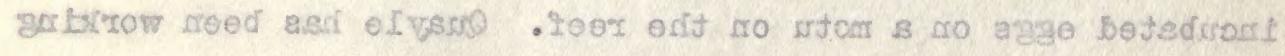

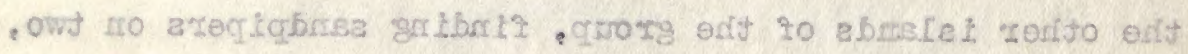

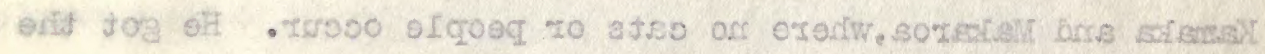

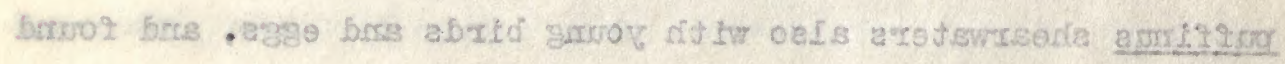


a dead nativitatus shearwater and a white-chinned petrel also dead. Though quite wooded, one of the islands was without warblers or other land birds. The ternlet here is bluebreasted instead of white as to the eastward and Rapa, and the fairy becomes blue-toed as to the westward.

\section{Nay 8}

Quavle went to Manoui Island Monday, the 8th, and found a few puffinus shearwaters as well as four nearly fledged wedgetailed shearwaters. CaIm and had to row most of way. I went to north end of island and got ono cuckoo and shot a tatler in winter plumage, seeing two or three others. Quayle got also three sandpipers and a blue ternlet.

\section{May 9}

Quayle, Charley the mate, and Curtis leave for Manoul again, as Quavle got a rail yesterday and Quayle will stay all night if weather looks farorable, while the mate and curtis will bring back the birds secured and will return for Quayle tomorrow. I skin the birds, about two hundred, brought by Quayle yesterday. Boat fails to return though light breeze in P. II.

\section{May 10}

Rain and strong wind started at midnight last night from 


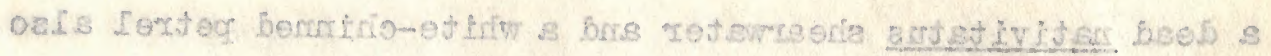

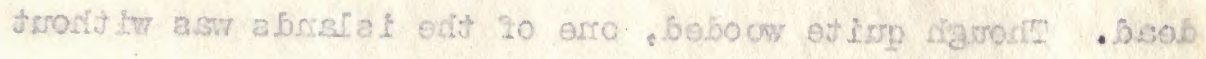

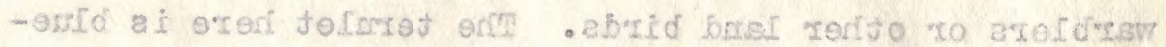

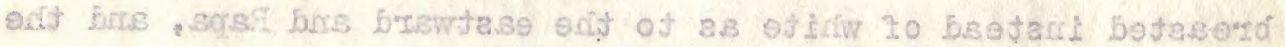

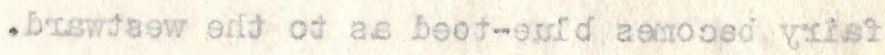

\section{$8 \mathrm{vat}$}

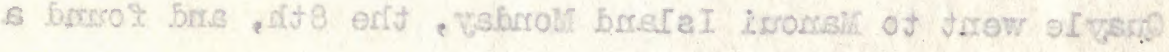

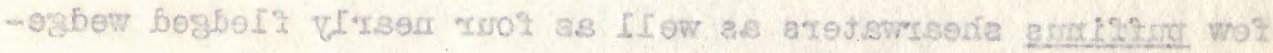

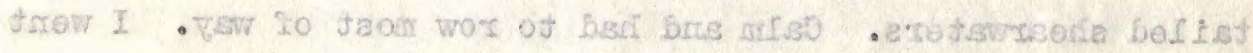

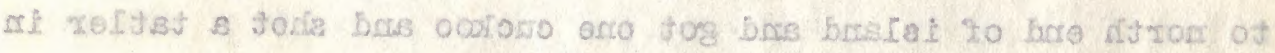

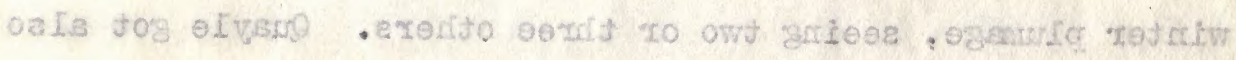

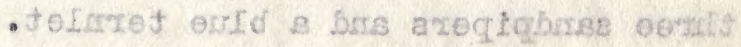

\section{8 vist}

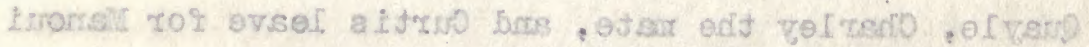

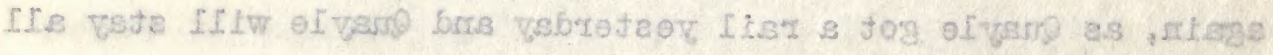

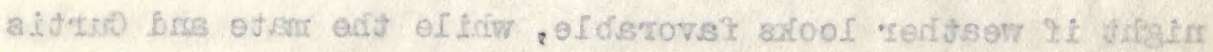

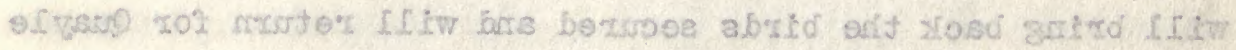

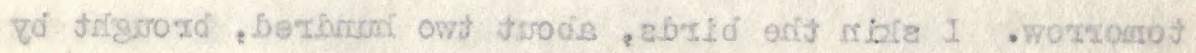

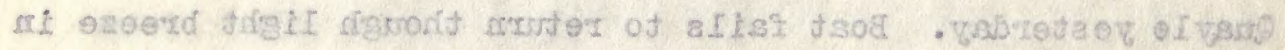


eastward and this moming I hire a native cutter with two mon and send two sallors with them to go to Manoui and the other near-by islands to look up the missing boat. Mrs. Routledge of England, studying the natives here, came on board with her interpreter to get the native names and common names of resident birds. He seoms little acquainted with thom.

At 8 P. M. the sailors return with report that the missing boat and sailors are at Taravai Island, which they will work tomorrow as rainy today. This will finish this group, as Manoui is a bad place to land in any but favorable weather and this wind will likely hold for several days. Decomber might yield other tubinares, though the man today did not know the blue shearwater of several islands and I saw a pair of Ducie shearweters over the peak here in a strong wind seeking a nesting site.

List of native names of birds at liangareva.

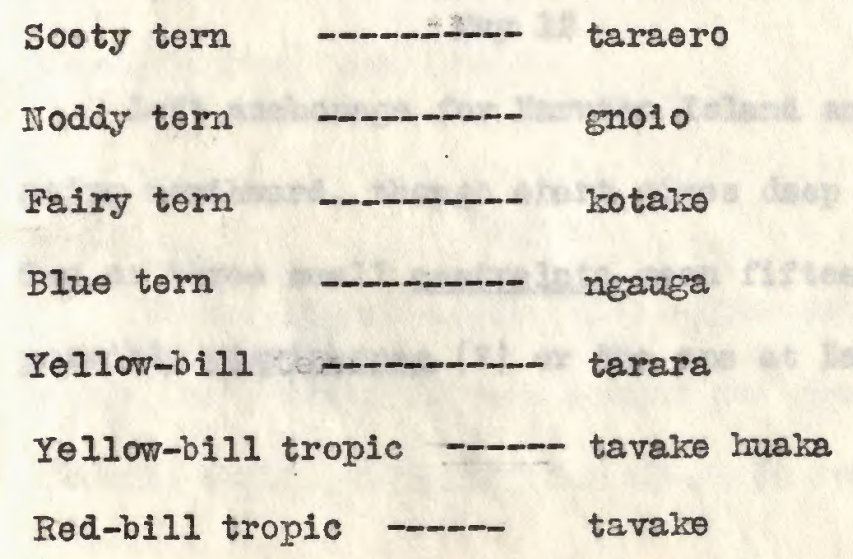




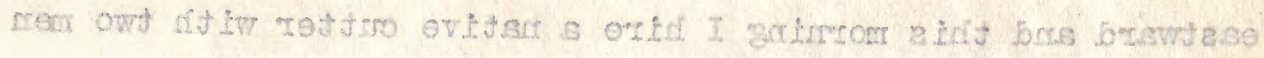

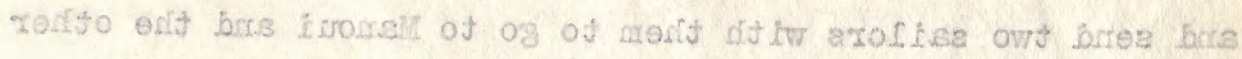

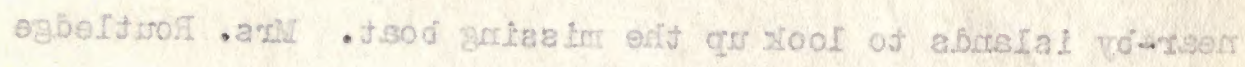

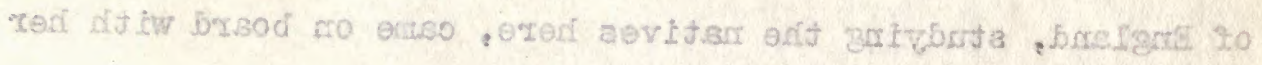

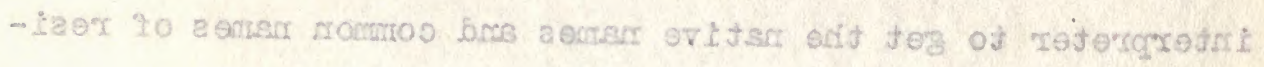

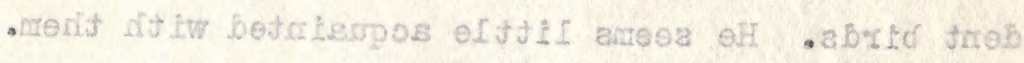

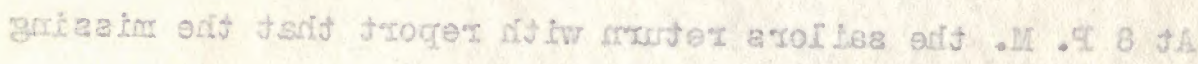

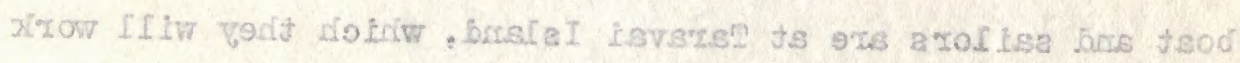

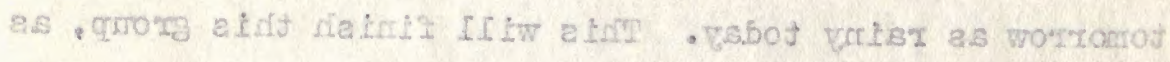

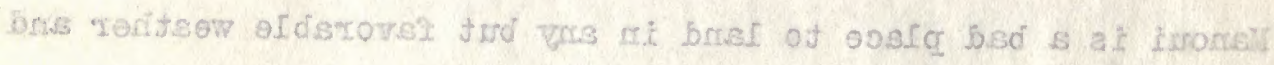

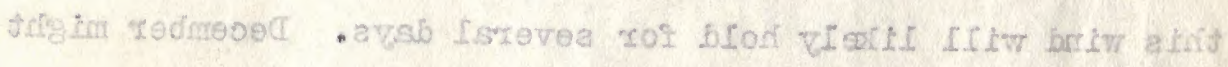

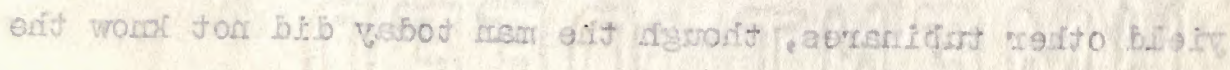

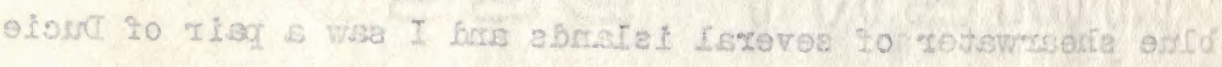

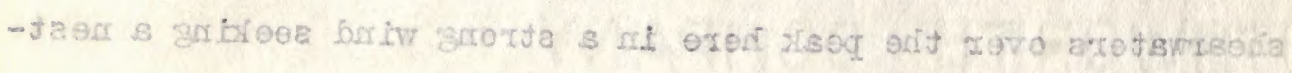
- ejle ginl

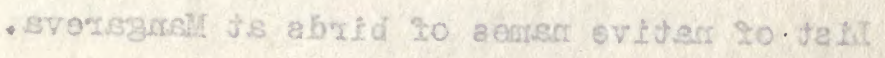

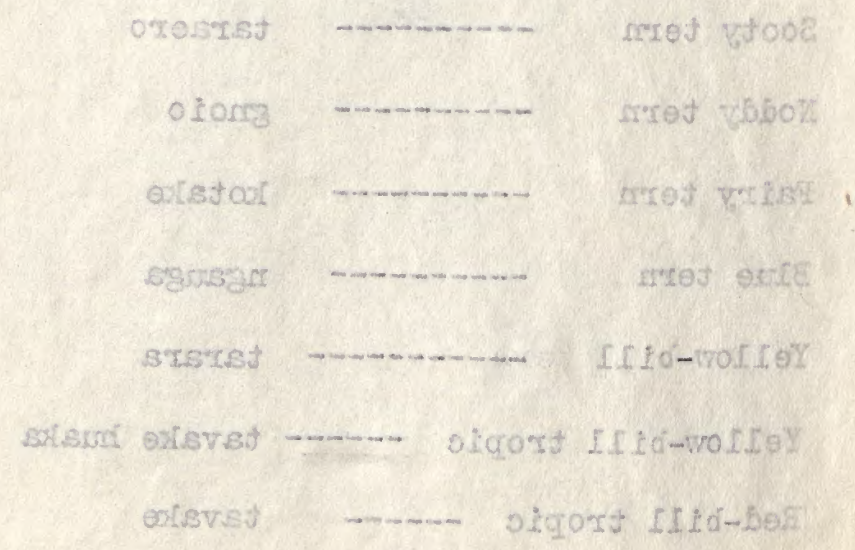




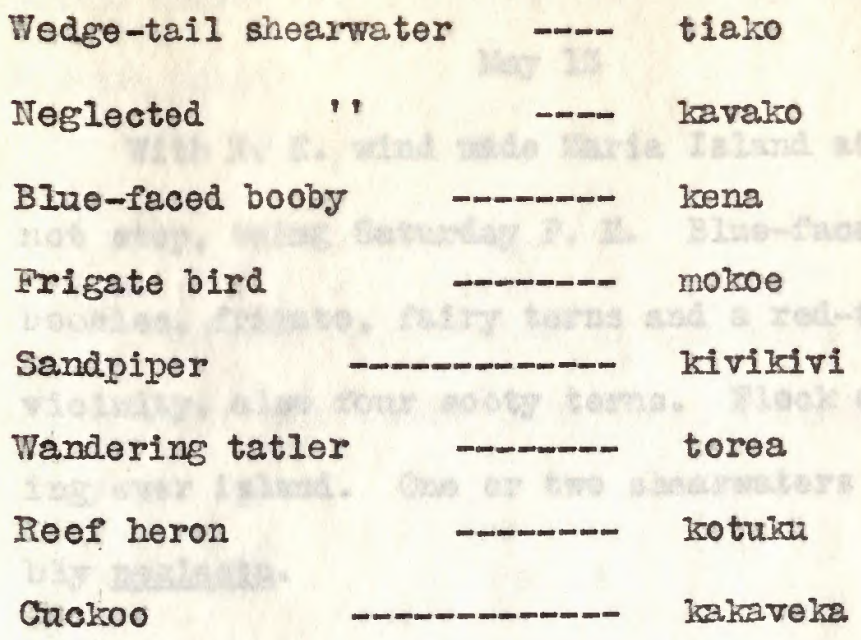

May 11

Quayle and curtis back from Taravai Island with report of petrel and shearwater nests on near-by islets but no birds, as the season is pest. I went to top of Nangareva Island and found a body of Ducie shearwater eaten by cat (?) on hillside, near top. Rainy and foggy with but one or two tropics about.

\section{Nay 12}

Left anchorase for Marutea Island and touched on the reef going northward, though chart gives deep water in vicinity. Two or three small aestrelata seen fifteen miles off Nangareva, possibly nigripennes (?) or the ono at Bass Rocks. 


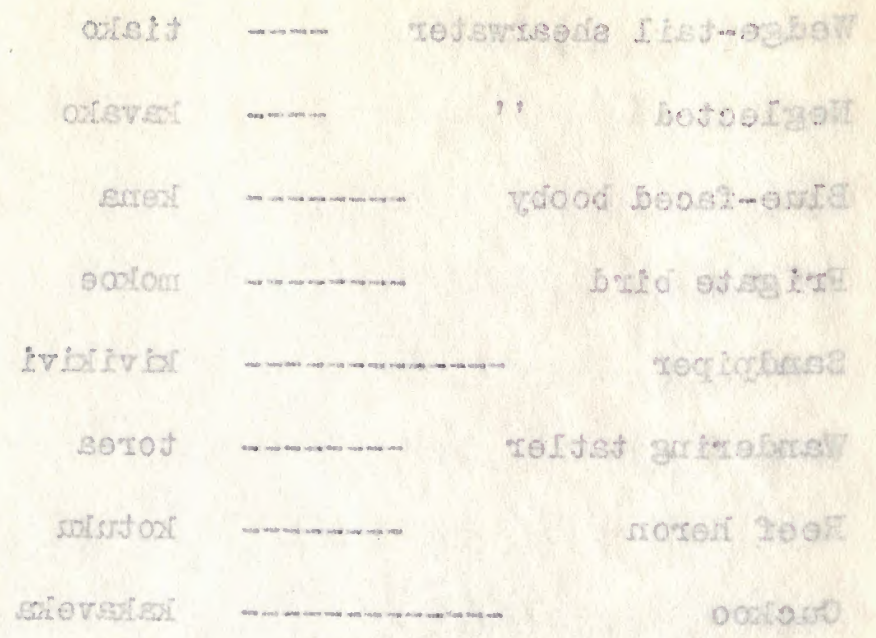

II vall

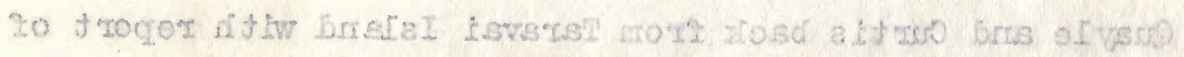

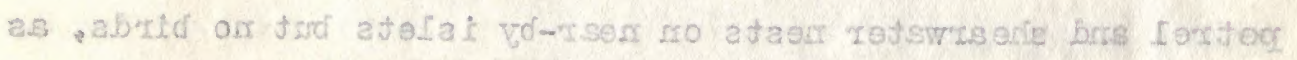

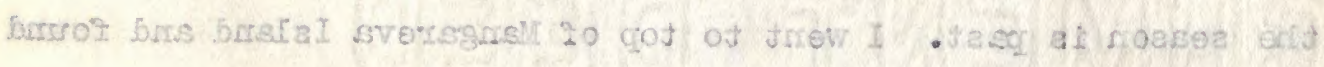

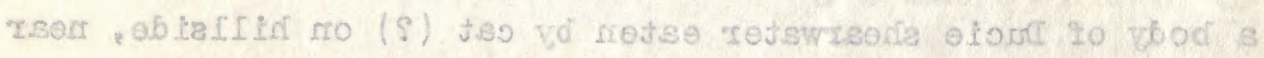

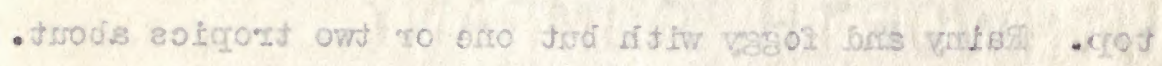

\section{SI rati}

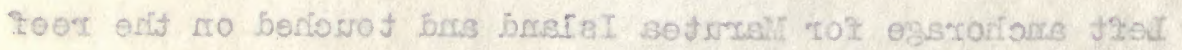

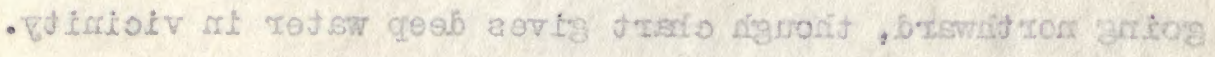

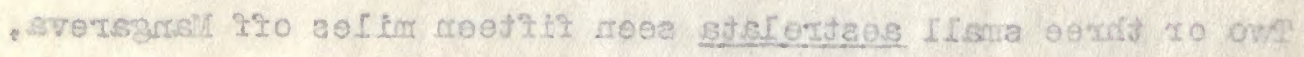

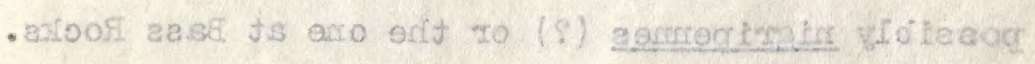


May 13

With $\mathrm{N}$. E. wind made Maria Island at three P. M. but did not stop, being Saturday P. II. Blue-faced and red-footed boobies, frigate, fairy terns and a red-tail tropic seen in the vicinity, also four sooty terns. Flock of frigate birds sailing over island. One or two shearwaters seen off shore, possibly neglecta.

\section{May 14}

Few fairy terns seen twenty and thirty miles off Maria and Marutea; also a yellow-bill tropic as well as two sooty terms. At noon fifteen milos from larutea, headed for it.

\section{May 15}

euayle went ashore and got a couple of sandpipers and a white heron which had a lot of lizards in its stomach. An Anorican is in charge of the settlement with three or four laborers from Reao Island.

\section{May 16}

Quayle stajed ashore last night and today went to a motu where the sandpipers were cormon and secured 25, as we 11 as several doves, bringing back 50 birds for the day's work. He 


\section{$-810$}

E. $\mathrm{VBCH}$

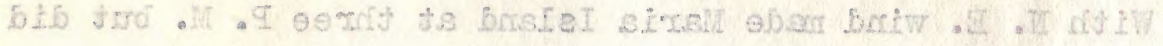

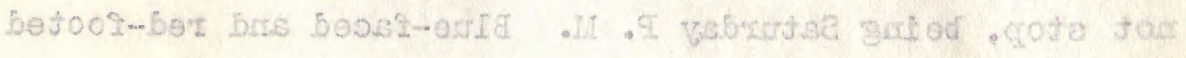

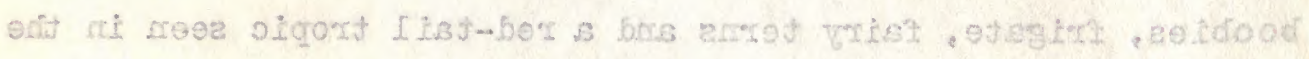

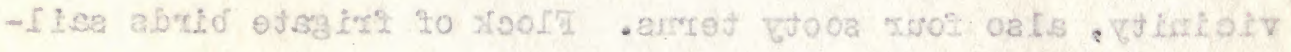

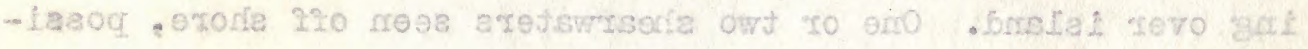
- stostson Víl

\section{AI VBM}

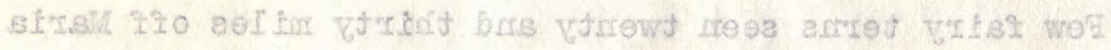

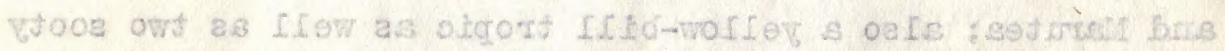

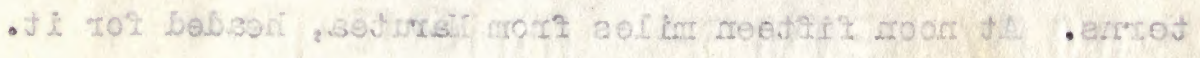

\section{B. V, vilf}

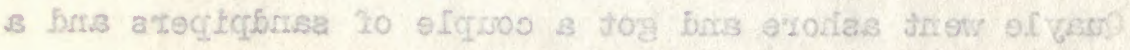

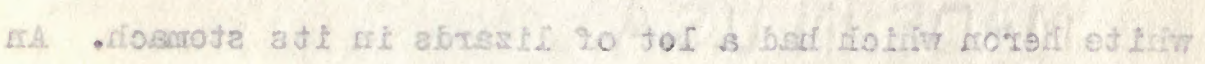

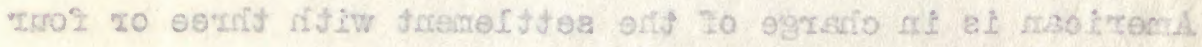
- birstai oner mort atrotodef

\section{af rith}

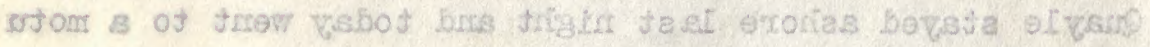

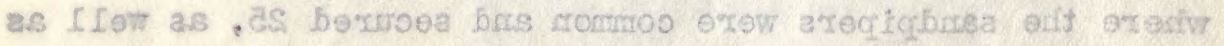

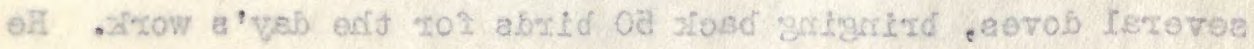


stayed ashore and I skinned ten of the doves before quitting for the night.

May 17

I finished up the rest of the birds and Quayle sent in a dozen and a half more, including a frigate.

\section{Nay 18}

Quayle and Curtis tried to visit other motus with native canoe, but too mach wind, so returned and came aboard and we sent over the Fan fan, our smell sailing boat, and carried this across the island and put in the lagoon where they started out in the aftermoon to go to farther motus nine miles away. Yesterday a couple of the natives helped the sailors get our boat off the reef, as swell was heavy and ono of the natives was washed off the reef into the breakers, where he was knocked unconscious against the sharp coral and his clothing caught on a projection under water. He was drownding when his companion dove after him and hauled him to the boat, which brought both on board for the night. The landing place is merely a narrow opening in the edge of the reef, into which the boat is steered in the intervals between the heavier swells. As soon as they are in the sailors jump out onto the reef and hold boat from returning in outrush of water. It is then guided across the 


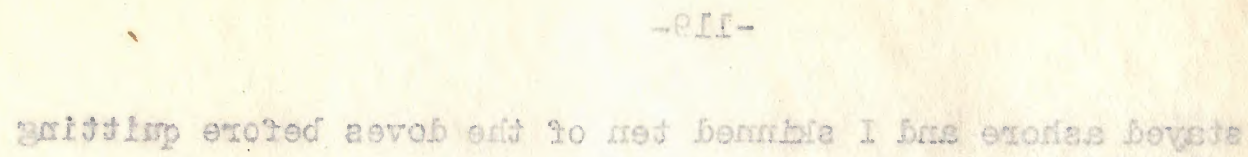
- trigiar anif ro?

\section{5: reall}

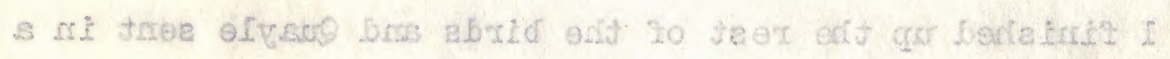

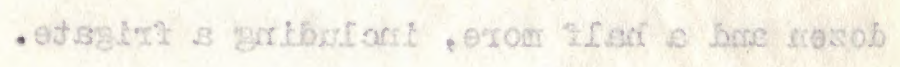

\section{5 vilf}

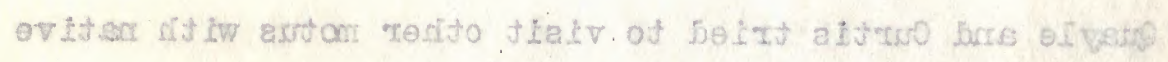

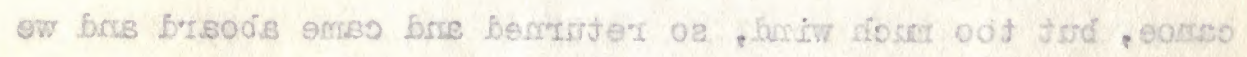

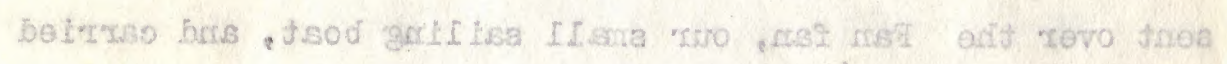

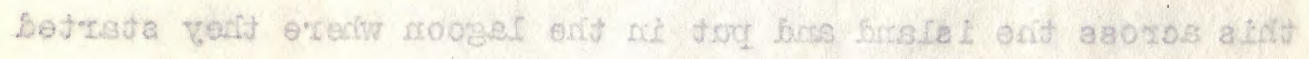

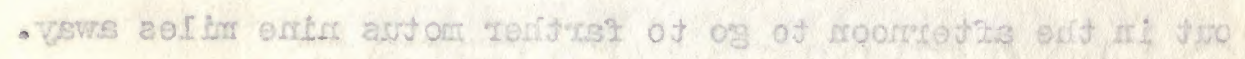

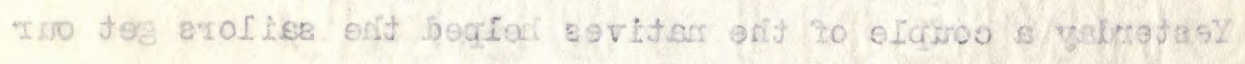

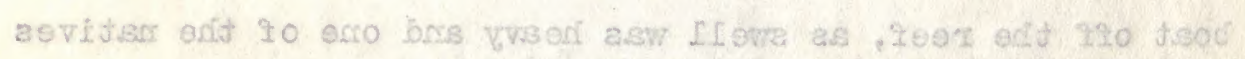

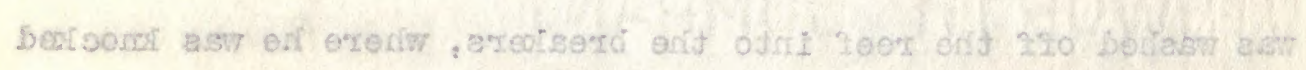

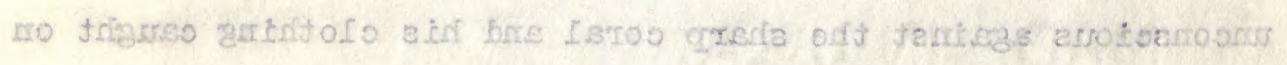

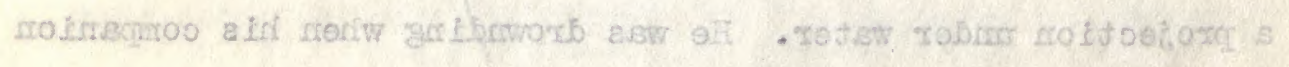

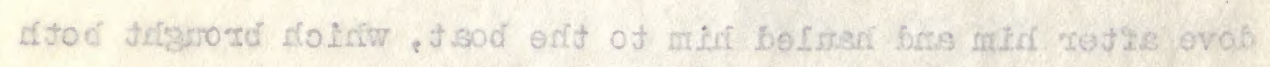

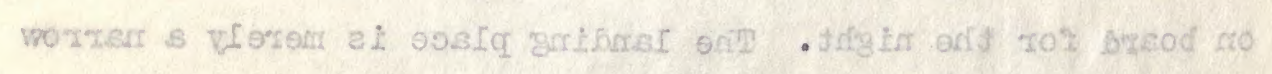

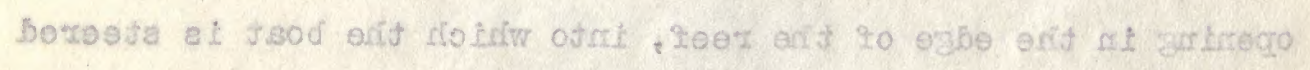

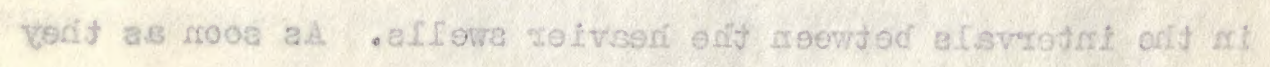

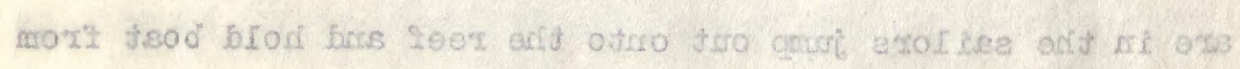

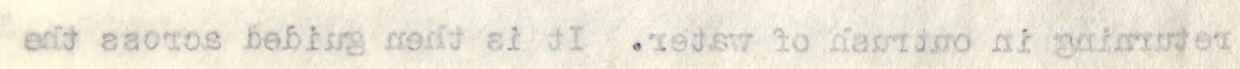


reef to shore, or as far as water on reef will permit.

\section{Nay 19}

Strong wind all night and laying to we drift ten miles or so away from island. Few birds, a fairy tern and several sooty terns were heard in the night passing to or from the rookery. A nigripennis shearwater came up to ship at daylight, but none seen after. A single obscurus, probably young, was seen a couple of times near shore fishing with a small flock of terns. Heavy wind all day and quayle unable to set back from across lagoon, as we saw his lanterm after dark across the lagoon.

\section{Hay 20}

Pair of obscurus shearwaters seen at dajlight, and a half dozen with a flock of terns fishing at ten o'clock two miles off shore. At ten A. M. I noticed a sail in the distance, and as it noars us the Captain says 'Moana', which will be told in a half hour more. The boat has gone ashore for Quavle, as the wind is light this morning. 'Moana' comes up and we go aboard for an hour, after which she heads for Reao Island, 160 miles to the north. She had 60,000 oranges on board to sell to natives, having paid thirty francs a thousand in Mangareva yesterday. 


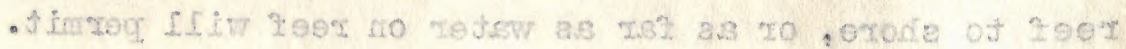

\section{e. raill}

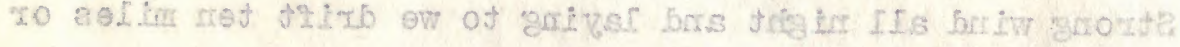

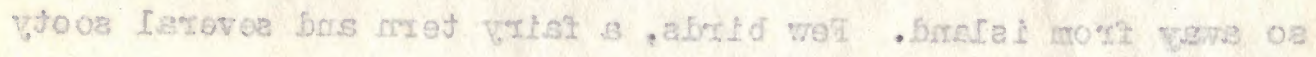

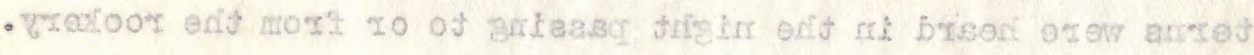

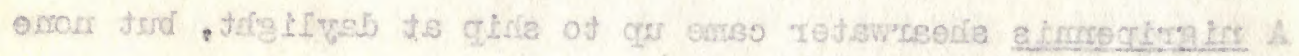

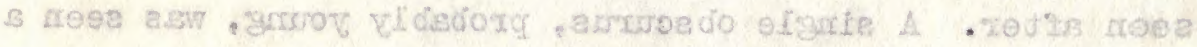

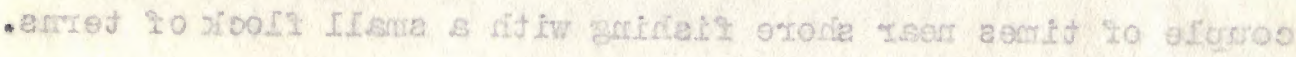

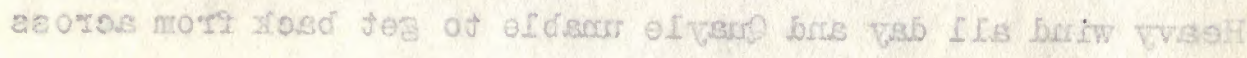

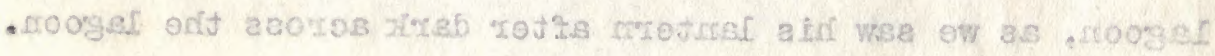

\section{OS rall}

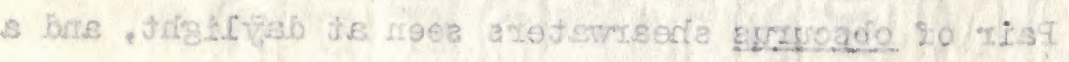

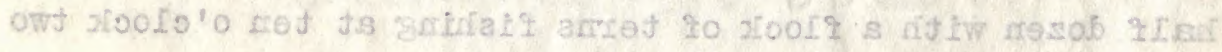

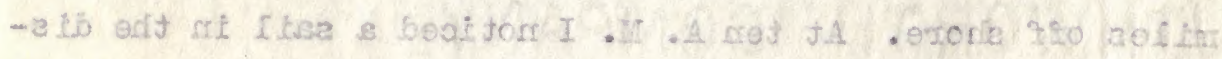

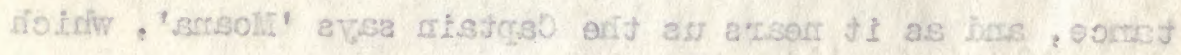

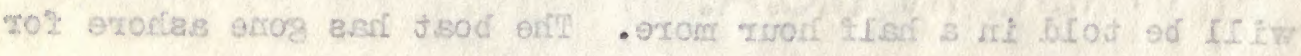

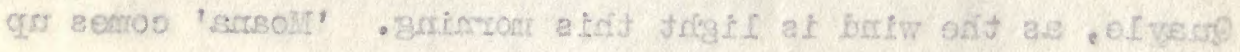

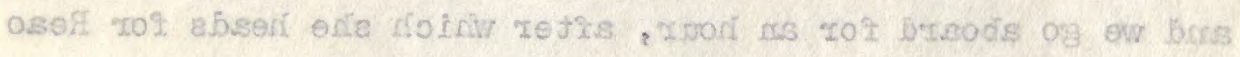

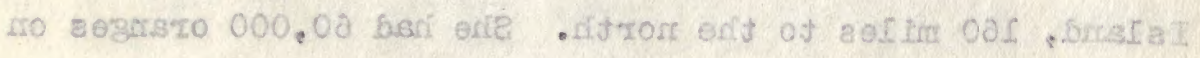

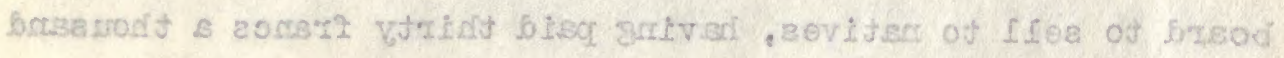
- tebrejagr svomacriat as 
Way 21

Nice warm day, the first for a week. Calm in P. M. Paroquet caught at Henderson lives principally on sugared water, while a dove caught here eats the large winite berries the size of cherries and white in color that grow wild on islands.

\section{Way 22}

Ashore and to scutinwaxd along shore. Got two sandpipers that flew 150 yards to meet me, and two or three terns. Quayle and Curtis took Fanfan and two sallors in a canoe to eastward and sent sailors back at three P. H. with 35 birds, eighteen doves and a dozen sandpipers. Quagle went to eastward end of island to work that while I go aboard and skin birds.

\section{Hey 24}

Skinned birds yesterday while sailors went ashore in P. II. and got a load of water, the water in a well four feet deep being very satisfactory to the taste. Quayle didn't show up.

\section{May 25}

Ashore and got few lesser noddies, several of which sit and fly along the reef at low tide picking small fish out of shallow pools. Also got a couple of reef herons, one white 
$1 S$ vart

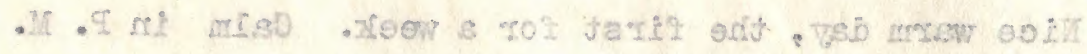

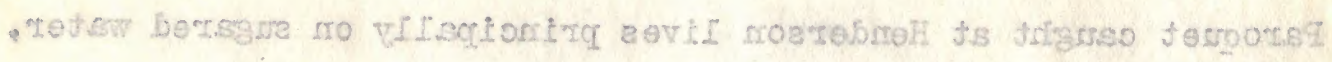

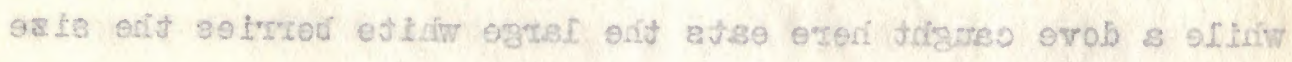

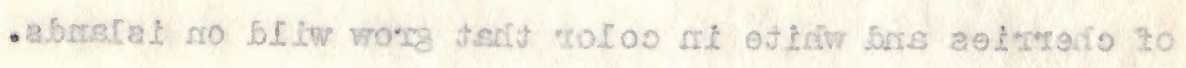

\section{SS RBII}

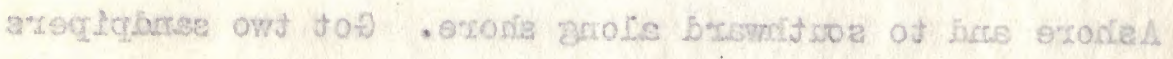

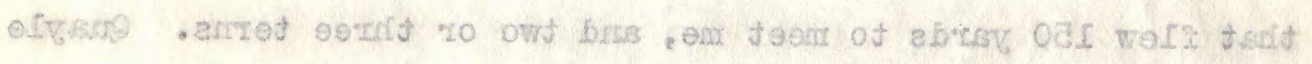

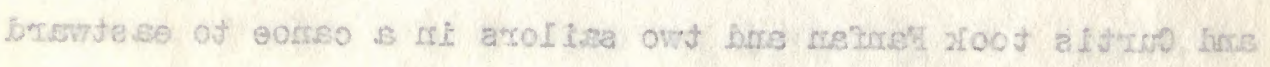

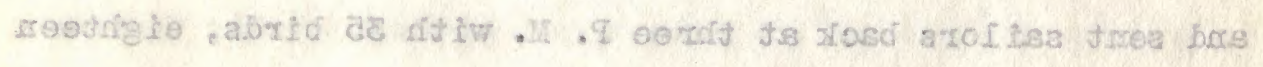

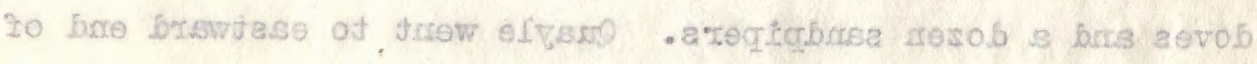

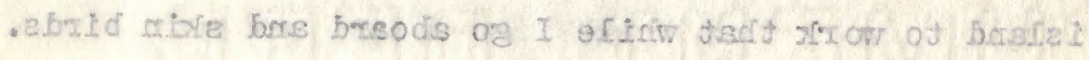

\section{AS YRIT}

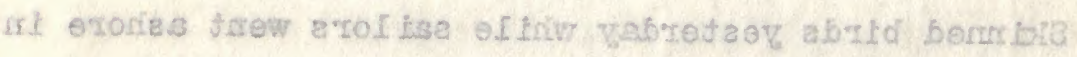

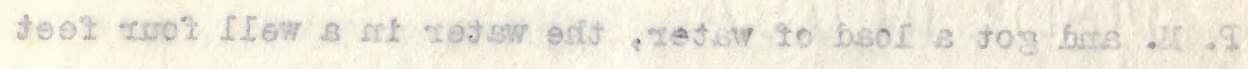

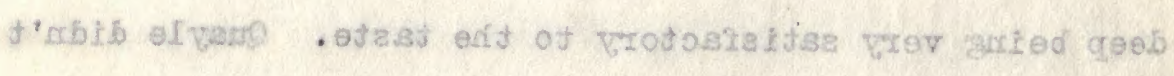

- que woría

\section{as vals}

Loldir to furrovea , aelbban reagel wel tog brre orocia A

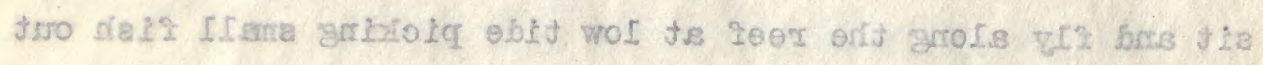

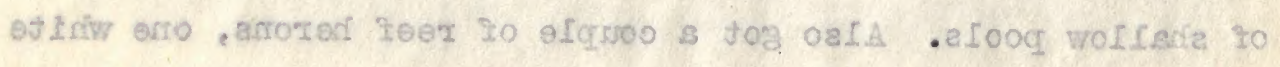


and other dark. Dozen yellow-bill terns were fishing in water just at edge of reef. Saw four wandering tatlers in a flock,-a.1 appeared in winter plumage.

\section{May 26}

Quayle and Curtis left again last night to visit several motus that they left last trip. Quayle heard several rail and got one at other end of island, but did not find the sooty terms nesting nor any boobles, though he shot a single plotus. Most of the sandpipers and doves appear to be on the islet weok

where he got a series last, though I got three or five on another islet near the settlement.

\section{May 27}

Quayle got back this evening with a fow terms and a tatler in sumner plumage, though its organs show little signs of enlargement. No other rail were heard or seen, and as the one taken seems to resemble the Rapa one closely we will leave tonight for Maria Island forty miles to the southwest. Heavy winds and mich rain delayed us here, but today promises better weather.

\section{May 28}

Sunday and approaching the island of Maria at one P. M. 


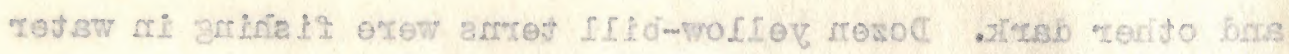

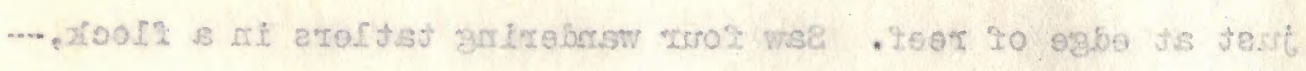
- egenvia zojatw at sorscegote lifs

\section{dS V YSH}

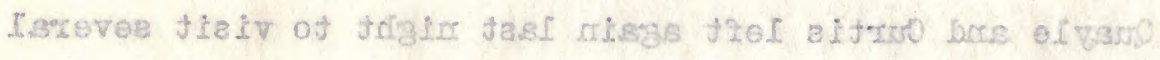

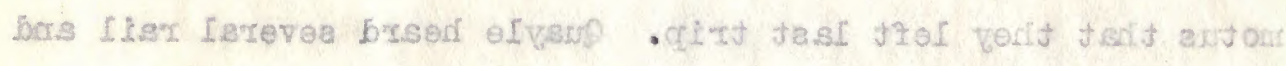

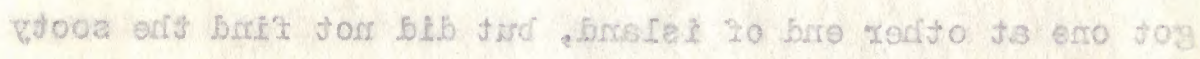

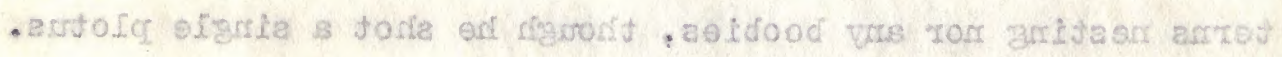

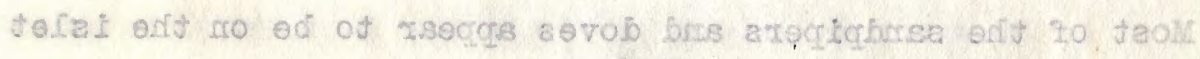
Xoow

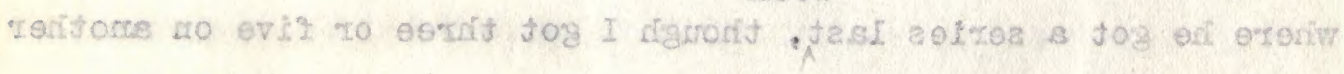

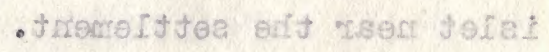

\section{rS vill}

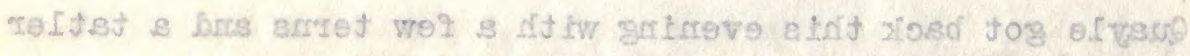

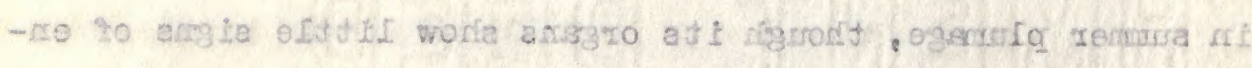

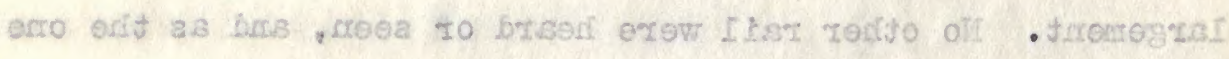

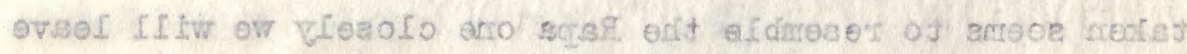

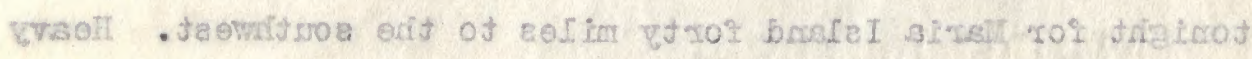

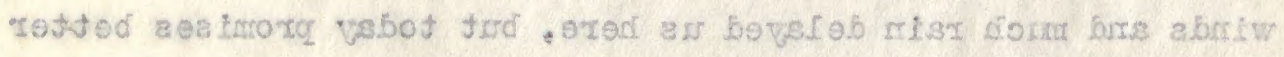
- Zoritserr

8S Y.Sil

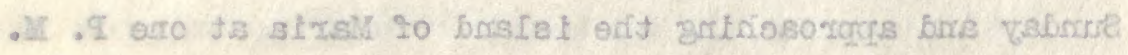


A couple of fairy terns seen this morning and a single distant shearwater, probably obscurus.

\section{May 29}

\section{MARIA}

Quavle ashore and finds the ground dove, the first we have seen. He took camping outfit and will stay ashore while I skin birds aboard.

Nay 30

Doves are scarce, three yesterday and five today. Frigates and blue-faced boobies are nesting. No warblers or fruit pigeons.

\section{May 31}

I go ashore and take picture of frigate nests which are close to the ground in some bushes, while none exceed ten feet from the ground. Most eggs are hatching, a couple of dozen nests being seen. Shot a Ducie and neglected shearwater, the only ones seen, and Quayle shot a blue one, though all are scarce hore now seemingly. I shot a couple of doves, the only ones seen. Three curlew and a tatler shot and a white heron seen; fairy terns common, but few others; noddy, lesser noddy, and yellow-bill, and I saw two blue at sea, though none ashore. 


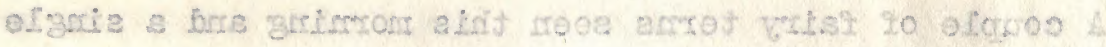

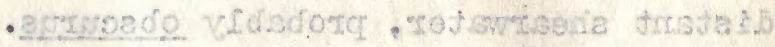

CS vil:

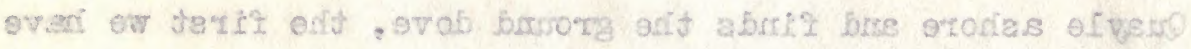

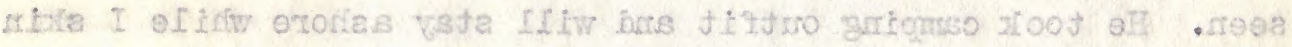

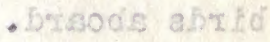

$08 \mathrm{~V} B \mathrm{ll}$

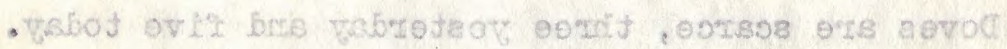

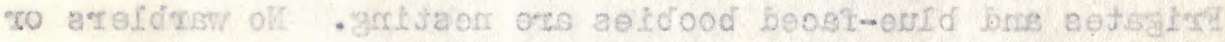
- arroeglog jistit

\section{$[\vec{E} \nabla \mathrm{B}$}

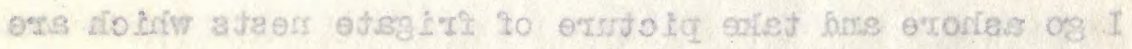

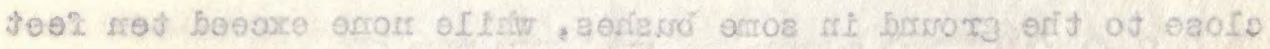

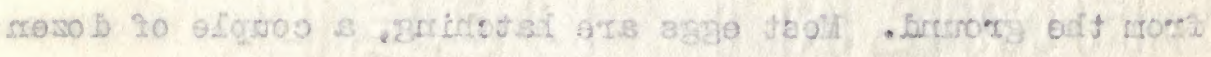

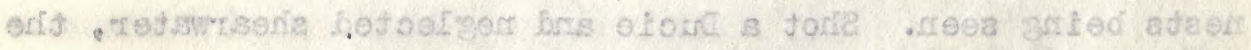

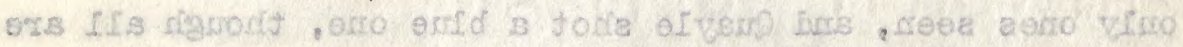

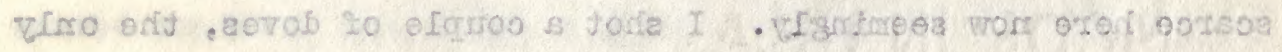

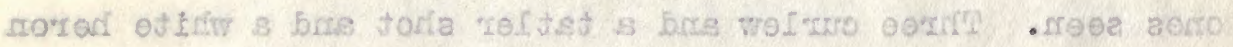

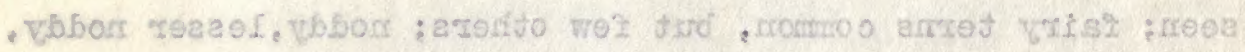

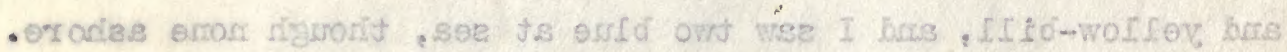




\section{June 1}

Ashore with camera and took photo of blue-faced boobies, several of them nosting along lagoon shore. Sandpipers are common and perch in bushes and trees close to me while using camera.

\section{June 2}

Shinning birds and send boat ashore. Saw cuckoo yesterday, and Quayle got one. Sailors caught eleven lobsters under one rocis on reef and a half dozen cocomat crabs in pandamus groves, the crabs being as good eating as lobsters or crawfish.

\section{June 3}

Quayle aboard in P. M. with few tropics, neglected shearwaters, etc. Got about 25 ground dores from here and leeve tonight for Actaoon group forty miles to N. W. of us. Wind has been to north of $\pi$. $\Xi$. for a week or two in $N$. N. W. part of time when we expected East wind. I skinned a tropic in seventeen and another in sixteen mimates by woricing lively. Quayle turned out a couple of shearwaters in a minute or two more, but to skin and complete to writing and tying labels on in that time is rather faster than one cares to work for more than an hove 


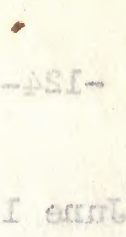

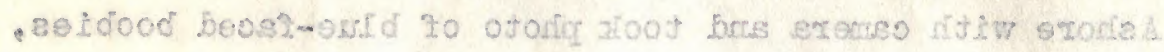

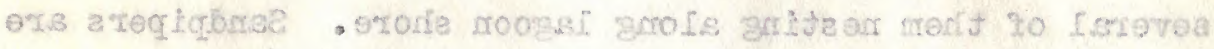

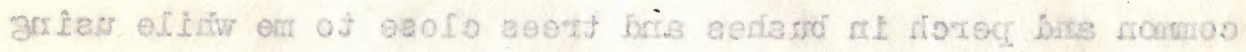

- stertos

S emoto

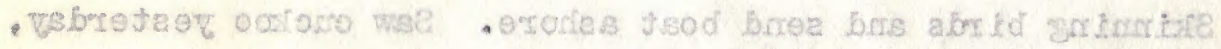

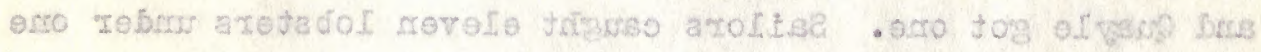

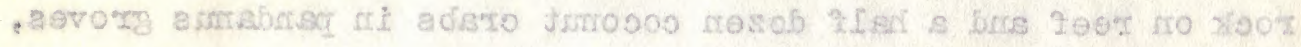

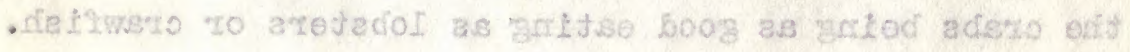

¿ onst?

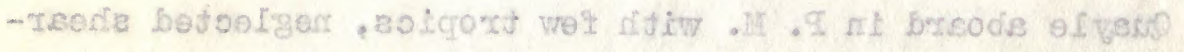

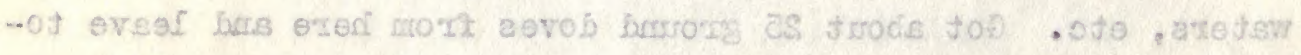

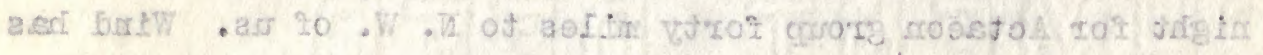

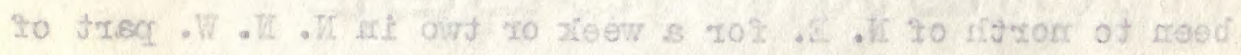

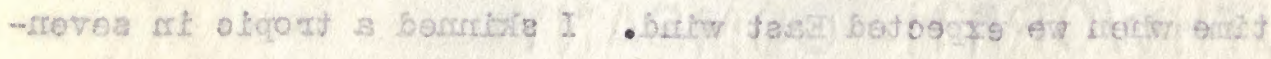

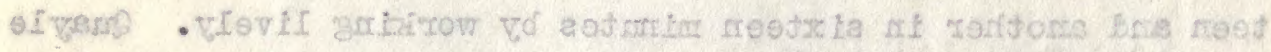

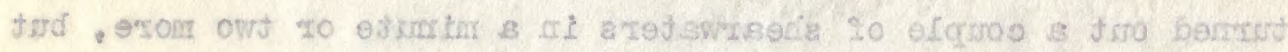

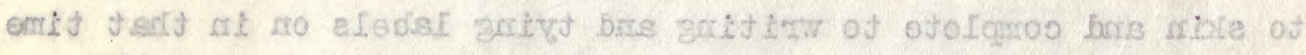

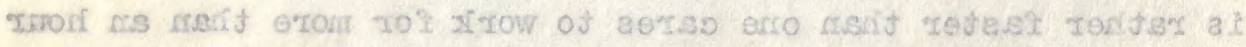


or so at a time. Two live ground doves from Naria are in the cage with a paroquet from Henderson and a green dove from Marutea. The green dove has a much larger gape than the ground doves and can swallow much larger berrios than the latter birds. The green dove is beginning to like the sweotened water that the paroquet lives on. The paroquet has been living on water with sugar in exclusively for the last month and is lively as ever. The ground doves seem to prefer the dropping of the green dove to even their natural food, though several of them had caterpillars in their gullets.

\section{Juno 4}

Sunday and laid off Maturel vavao Island till the fifth.

\section{June 5}

Quayle and self ashore for day, Quayle taking outfit to stay. I found red-foot boobies building nosts of finer sticks than I remomber seeing elsewhere. Pairs were sitting by nests, though by eleven A. M. most had gone to sea. Two noddy nests were seen in low bushes neer lagoon shore and had young birds nearly ready to 1 Iy. The nest was better built than most I've seen elsewhere. Sandpipers thick. Counted fourteen around mo while packing dove away and twelve in one tree near me again. 


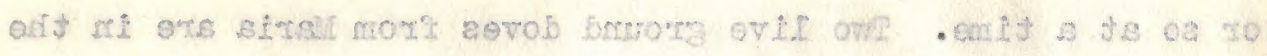

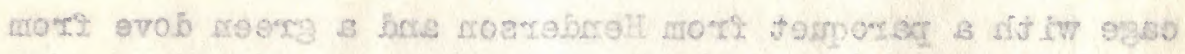

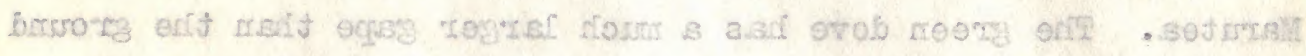

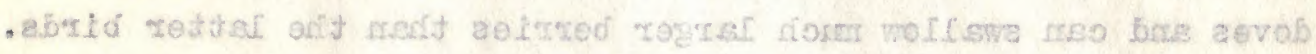

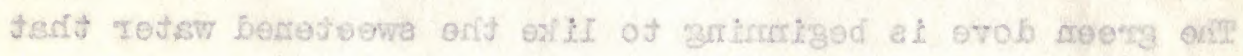

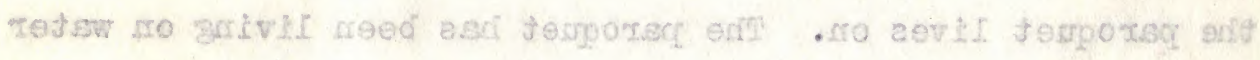

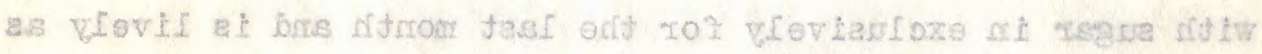

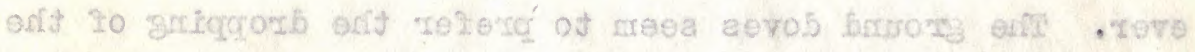

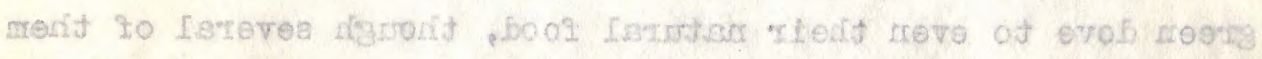

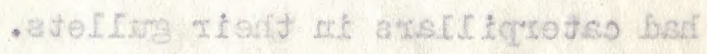

A actert

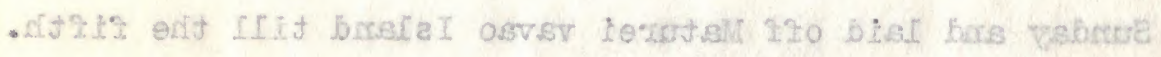

C. $\operatorname{ercut}$

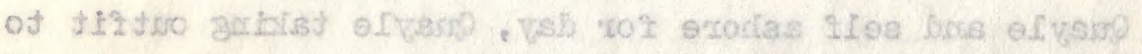

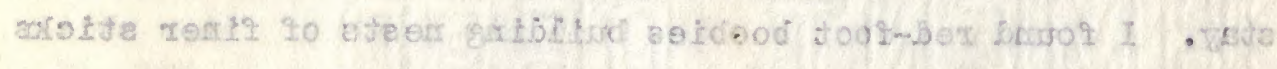

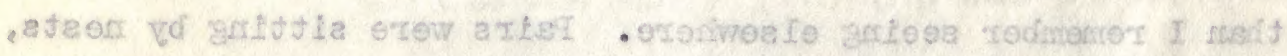

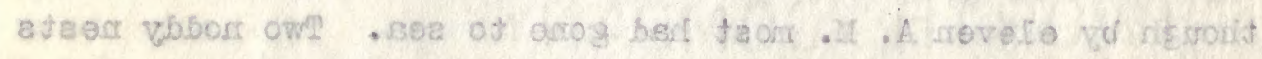

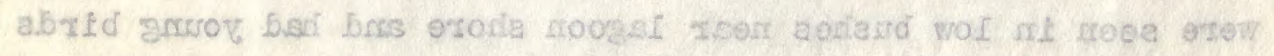

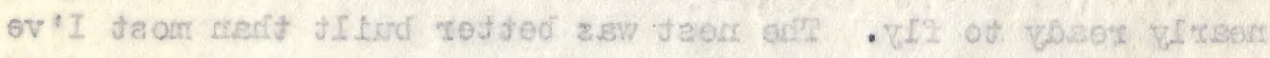

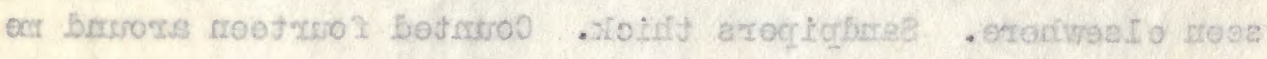

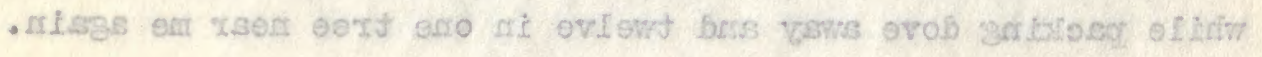


They $11 y$ to meet one from one hundred yards or more. Fun around in trees as well as a warbler. Three peirs of blue-foot boobies seen by nesting spots. Doves are tame, four sitting near me while eeting,--one at four feet. Few yellow-bill terns on sandbar in lagoon.

Coconut crabs common, four being seen under one pandams tree. Aboard at two P. H.

\section{June 6}

Sent boat in for Quayle and birds at two P. M., but he aid not get to boat till dark. As the sea was bad, the sailors thought it best to stay ashore all night. Squalls and strong wind from North and as boat lands on north side it is difficult to get it launched. The lee side of the island is mach worse, as heavy swell from the 5 . W. is nearly always breaking there.

\section{June 7}

We got back to landing place at eleven A: $M_{\text {. and the four }}$ mon ashore tried an hour to get off, finally maiking it, though thrown back several times before they could get outside of the breakers.

Leave at noon for next island six or eight miles to westward. Last night a large flock of fairy terns and a few of 


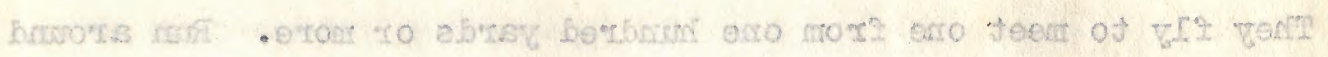

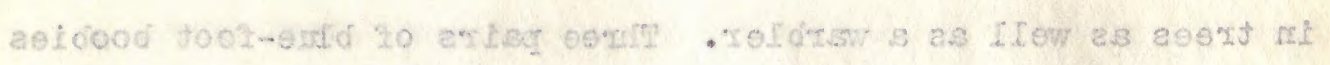

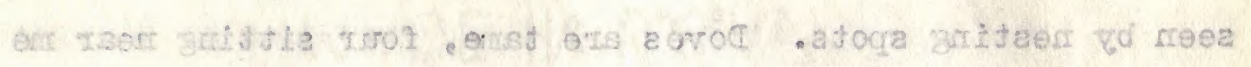

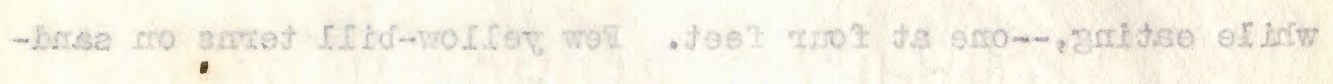
- acoogsi mi zad

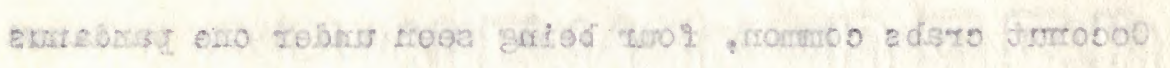

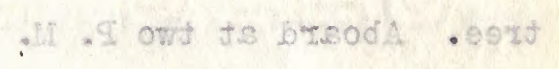

a secsto

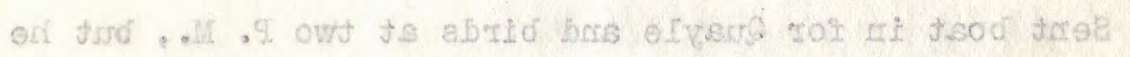

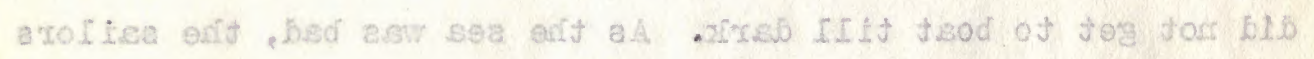

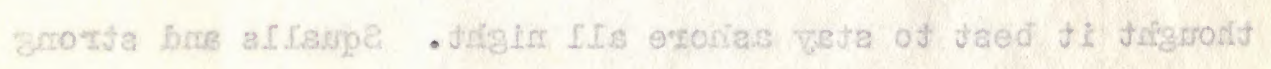

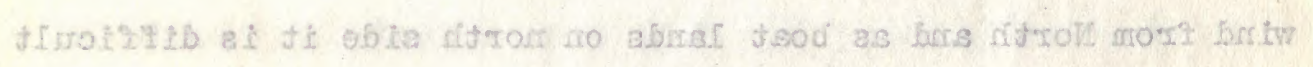

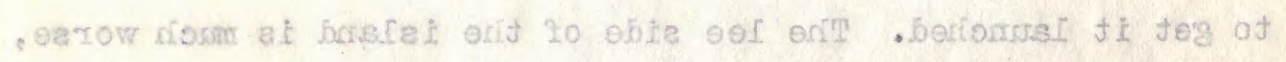

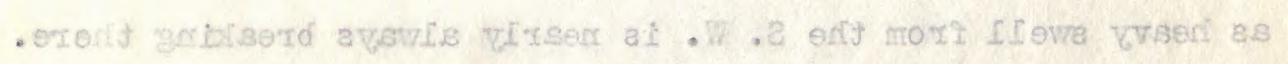

\section{5 ertst}

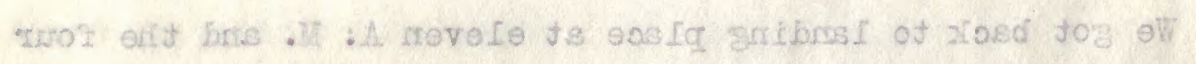

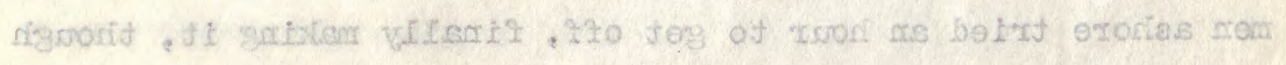

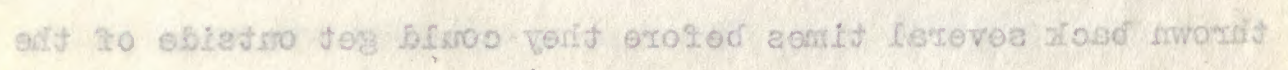

. arseyise"d

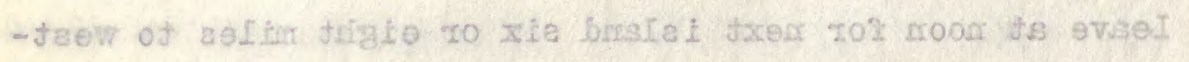

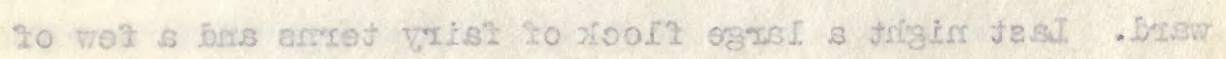


noddy and lesser noddies with several redfoot and blue-faced boobies and half dozen obscurus shearweters fishing a couple of miles off shore between squalls and rains.

\section{June 8}

Sailed along two islands, but strong north wind maizes chop too hoavy on north side, and a heavy swell from the south makes heavy breakers there. Over to reneraro, last island of group, and find a cut in reef which allows boat to run in away, so we go ashore in P. I. and get a bag of dores, or Quayle gets them while I work aboard.

\section{June 9}

I go ashore and get a couple of ground doves and guayle gets one. We find boobies (red-footed only) beginning to nest. Sandpipers are not as common as last island and fer females found in those skinned. Got eight lesser noddies from a flock resting on beach close to water, which seems to be a favorite place for them when not nesting. Five curlew shot were all males, and in the moming four were seen two miles off island headed north, probably migrating. They swung around when called, but headed out again and flew rapidly close to the water out of sight, though mistaken for ducks when first sighted. Sailor caught five doves and a couple of sandpipers with string: 


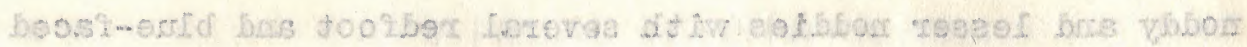

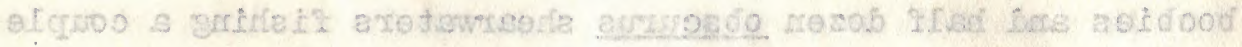

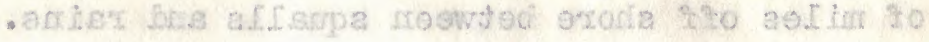

8 exrets

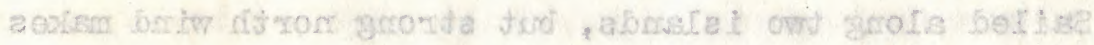

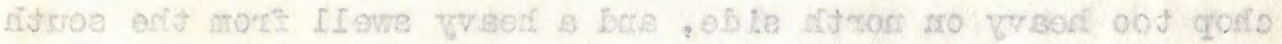

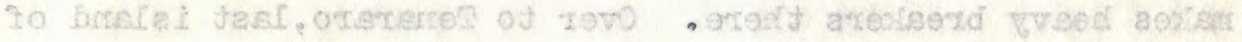

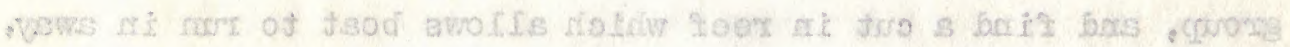

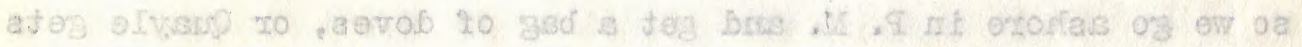

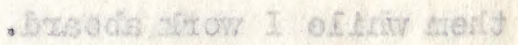

e encets

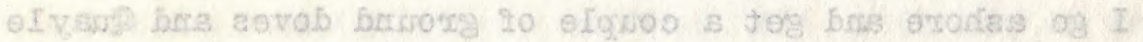

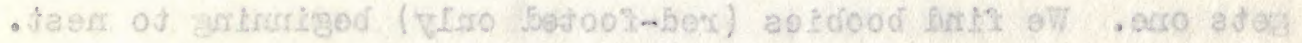

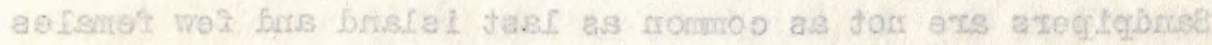

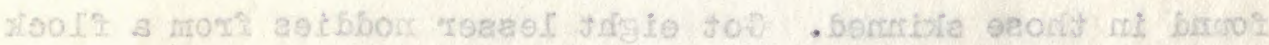

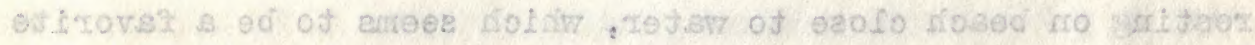

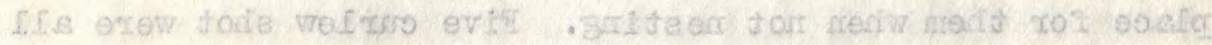

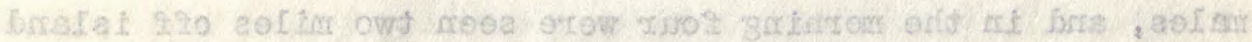

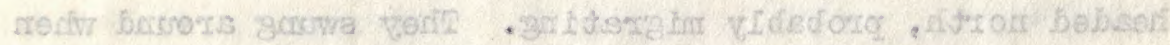

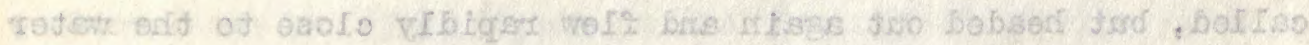

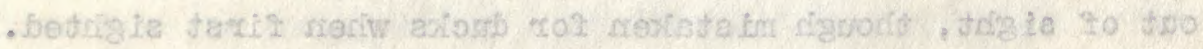

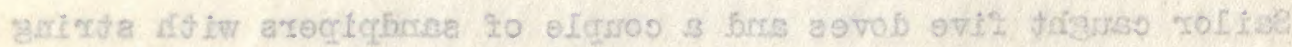


or pole this P. M. in a couple of hours. Doves are tame already and others take berries out of hand less than a week from catching. A sendpiper is running around in hold at my feet as I type this, catching cockroaches and ants. Very tame here, though one put in cage with doves fluttered and was wild. Went to cabin and found piper on table and muning over typewriter on return. He is now ranning over table within two feet of me. (Above written on 11th.)

\section{June 10}

Quayle ashore last night and this morning gets five more ground doves and three or four white boobies, the latter being few in number and the standard color beine gray with white tails, though gray runs from dark up to the white birds. Got a fair series from here and I put up ten today by four P. M.

\section{June 11}

Foggy clouds in A. M. and a drizzle or two with long expected east wind. We work toward eastward island, seeing middle one six miles away.

In P. M. a flock of birds ahead called a sailor and he hooked five bonitafbefore the school passed. Several obscurus shearwaters were in the flock, but we have not found then on the islands north of Garnibier group yet, though they may nest 


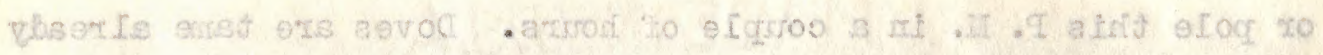

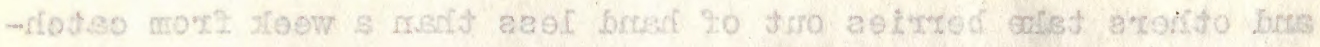

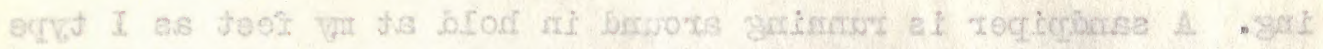

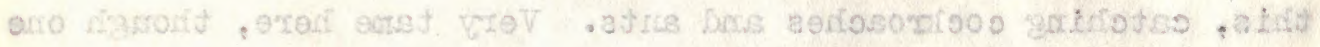

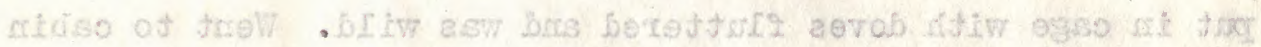

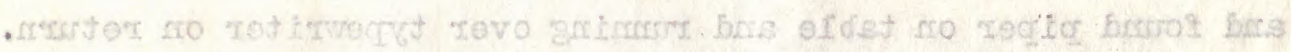

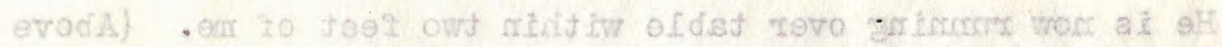

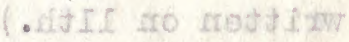

\section{OI 9rustis}

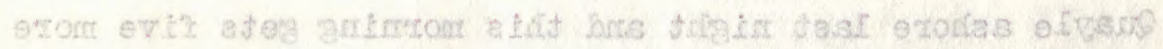

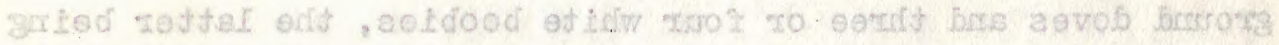

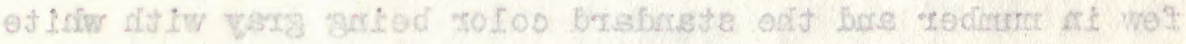

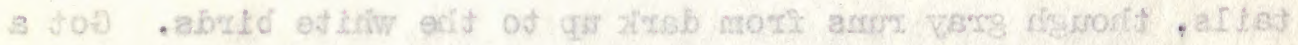

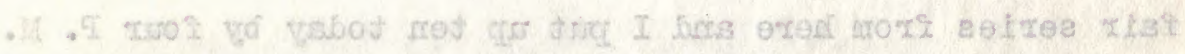

\section{If. orsot,}

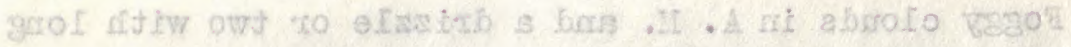

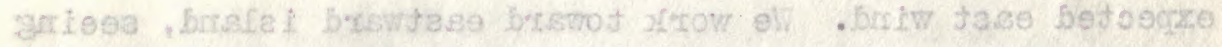

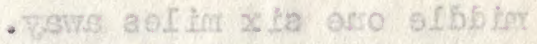

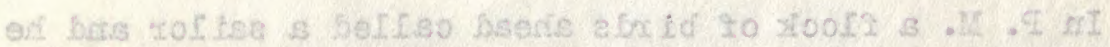

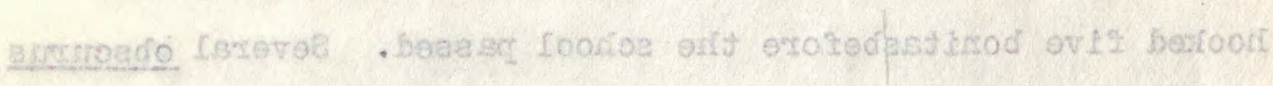

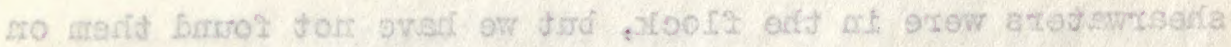

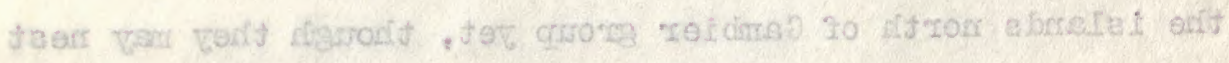


under pandanus trees. It is not likely, however, on account of the big coconut crabs which are common.

\section{June 12}

Stop at Vahanga, the middle island, for a day, but only a fow sandpipers and terns seen and no doves, so we go on to Tenarunga Island and find green doves but only one ground dove.

\section{June 13, 14, and 15.}

Spend a couple of days here and go back to Tenararo, where Quavle stays ashore all night and finds a half dozen ground doves. A sailor with a short line on pole caught twenty green dores in a couple of hours in the tohunu "trees along the shore. They become tame in a day or two and perch on the Captain's hand when he feeds them berries, which they gobble down two or three times a day. A couple of sandpipers were also caught and liberated in the hold, and these in a couple of days run around under our feet chasing cockroaches and ants without fear. One muns around on the table where I skin birds.

\section{June 16}

Leave for Island 120 miles to westward with very light S. W. wind. 


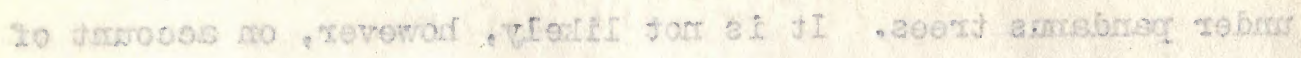

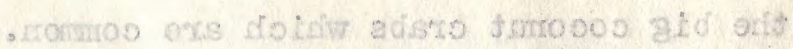

\section{SI erisoto}

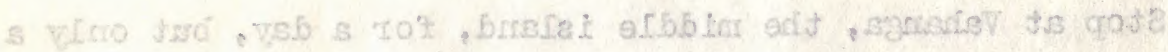

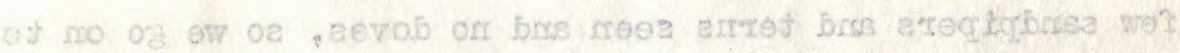

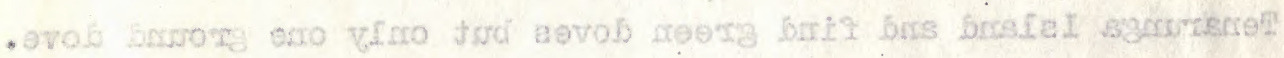

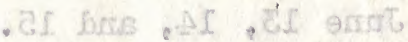

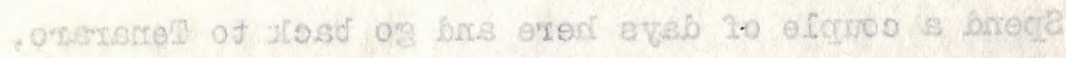

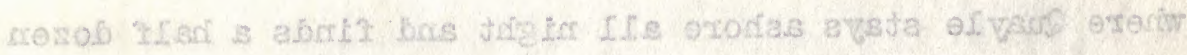

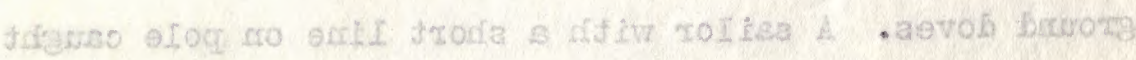

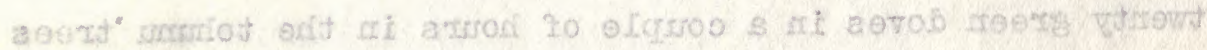

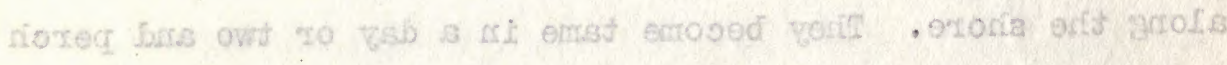

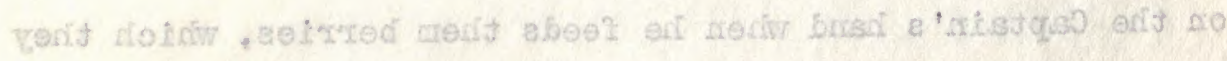

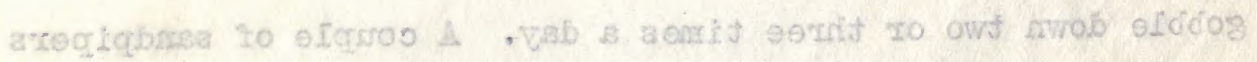

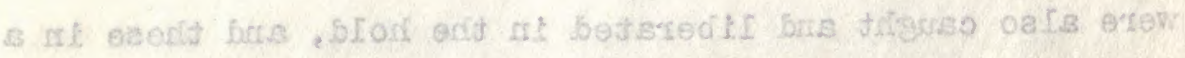

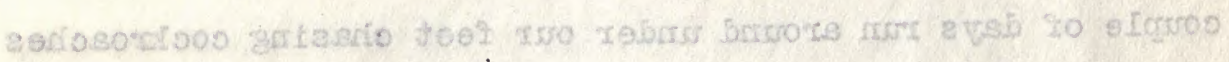

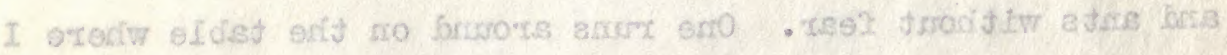
- aberis nitia

\section{af onst}

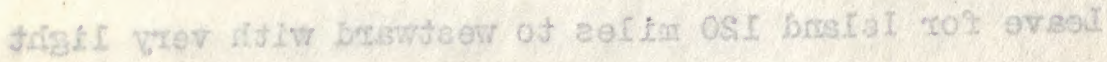


June 17 and 18

light wind and calm and twenty miles to go sundey eve, the 18th.

\section{June 19}

Ashore at Mureia Island and I got a warbler and a couple of white terns, while Quayle got four yellow-bill terns. About sixty people live here and cats have cleaned out doves if any ever were here.

June 20

I got seven warblers and a couple of fairy terns, while Quayle went around island and camped part way, getting eight warblers and seeing a cuckoo.

\section{June 21}

Quayle beck and I skin his birds while he gets another one and a white heron, only thirty birds for two of us in the three days. Leave for Vanavana at eight P. M. We hear sooty terns nearly every night after dark or middle of night.

\section{June 22}

Both ashore at $\theta$ leven A. W. and find quite a plantation 


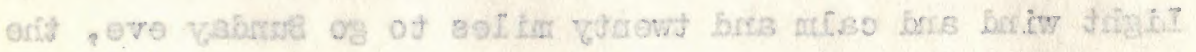

, sttef.

\section{8. ersat,}

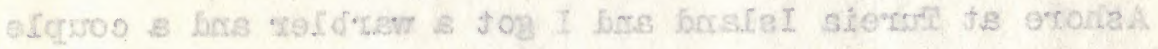

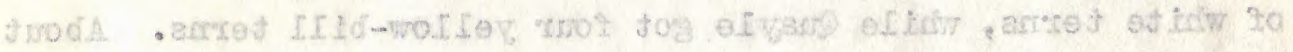

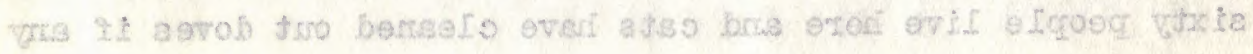
- omeri exom semo

\section{OS anert?}

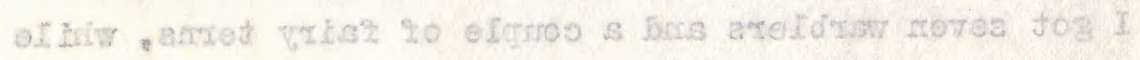

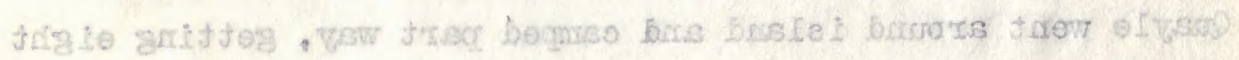

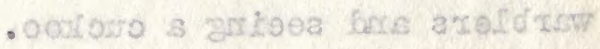

\section{Is eatert?}

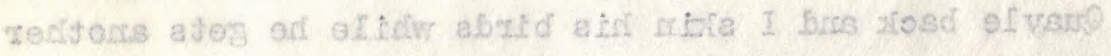

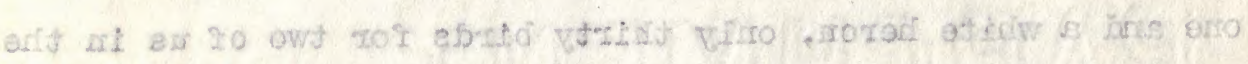

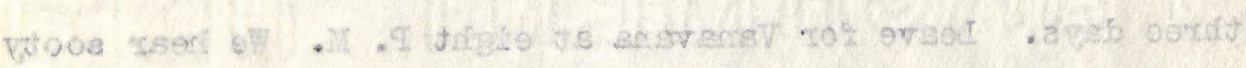

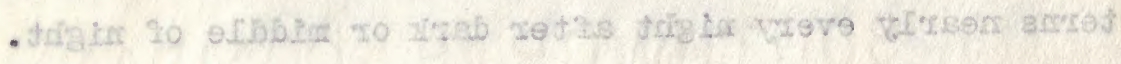

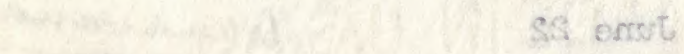

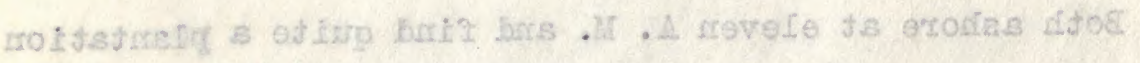


of coconats two and throe years old and a half dozen natives taking care of the grove and clearing more land. No vessel has been here for eight months and I noted where pandanas had been gathered and a couple of sharks' heads were hanging up by one hat, these being principal food, though they said they caught the ground doves for food. We found the ground doves plentiful in a portion of cleared ground where a creeping plant which furnished food for the green doves on Tenararo Island was growing thickly, covering the ground to a height of two foet in many places. I shot fifteen doves in an hour or so about three P. M. when they came out from the thick cover. Though Quayle was not more than a mile from me he saw none during his trip through the forest. Several of mine were sitting on dead limbs of the fallen trees and some were on grass tops where feeding. The males were seen throe or four times sitting on fallen limbs, reminding mo of Califormia quail by their actions. When flushed thoy flew low and quite rapidly a hondred or so yards and lit in the bushes or in the low limbs of thick trees.

Though there were a half dozen dogs on the island there are as jet no cats, and so these birds and the sandpipers have survived, but it will be but a short time till some laborers are brought with and accompanied by cats and that will end these two species. Why no green doves occur is surprising to 


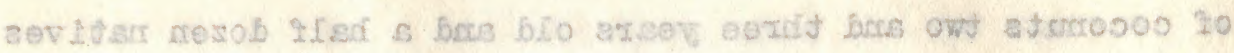

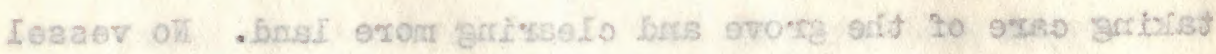

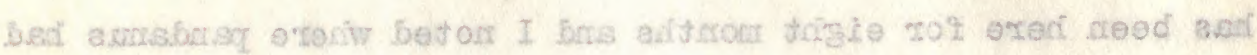

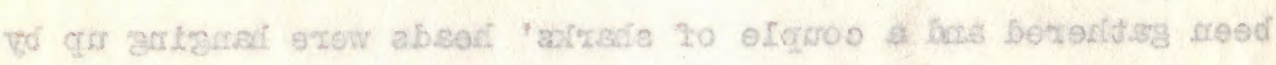

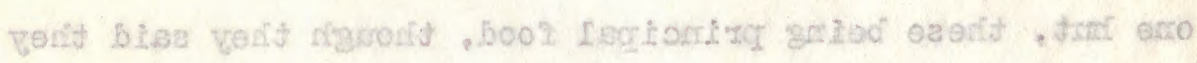

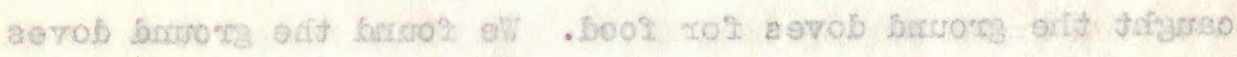

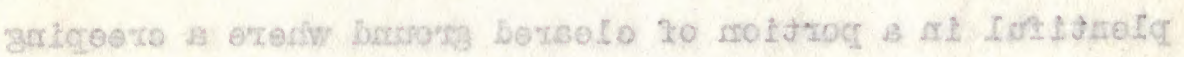

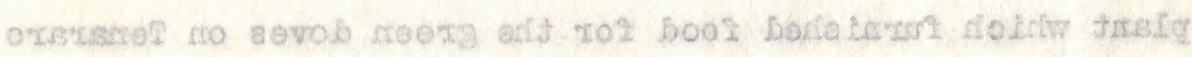

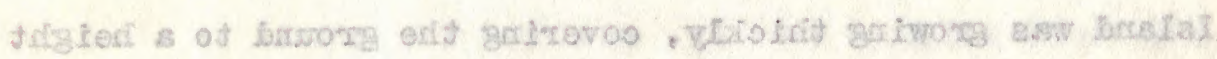

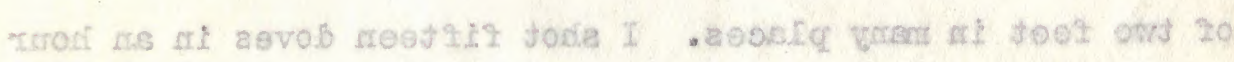

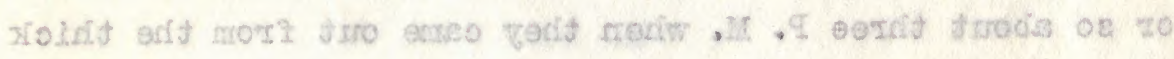

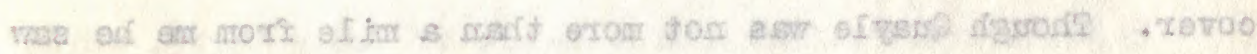

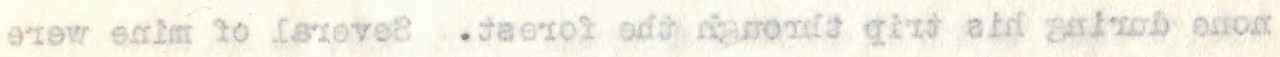

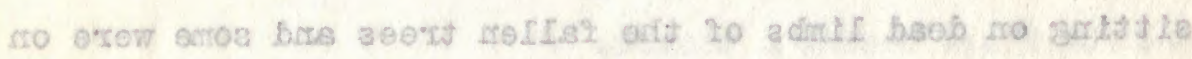

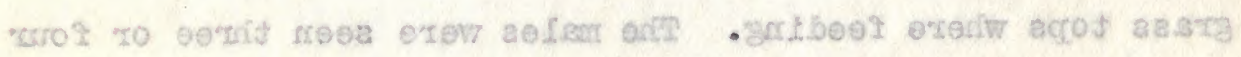

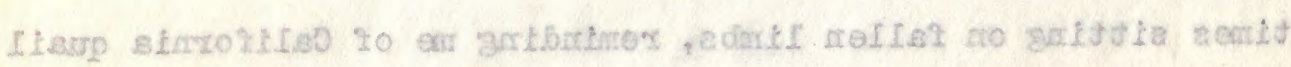

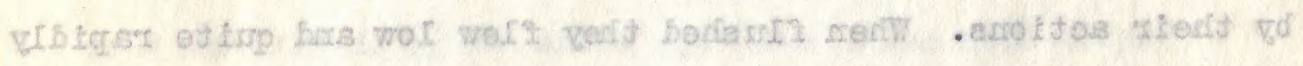

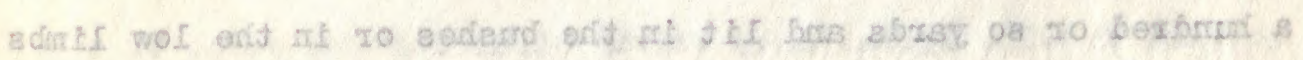

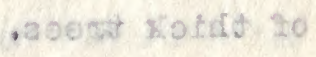

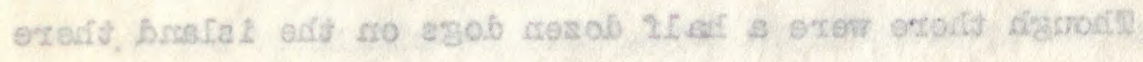

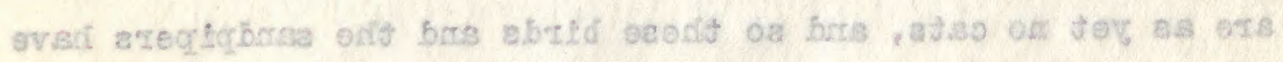

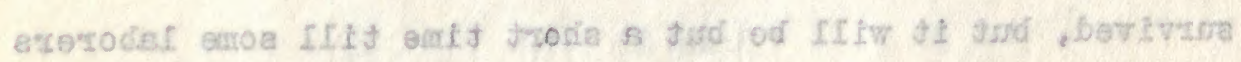

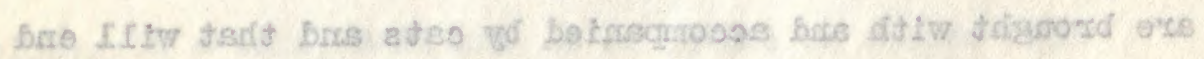

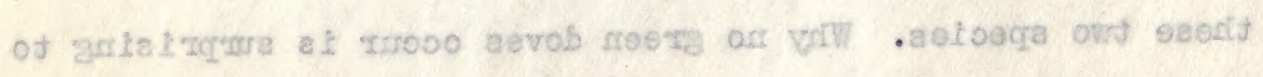


us. Warblers are common and Quayle saw a cuckoo. Noddy terns' nests were seen in the tops of several pandamis trees and a few red-foot boobies were sailing around. Three or four blue reef herons were seen, and I got a couple; also sew a couple of curlew and tatlers.

\section{June 23}

Quayle went ashore and got seventeen doves during the day and a half dozen warblers while I put up yesterday's birds,-about fifty being taken. A heavy S. W. swell made boat work dangerous in P. M.

\section{Jrune 24}

Heavy easterly wind and the S. W. swell made reef too unsafe to try to get ashore, so we laid to till four $P$. $M$. and thon salled for the noxt island one hundred to westward.

\section{Juno 25}

Reached Ahani Island at twelve $0^{\prime} \mathrm{clock}$ and lay to till morning. A couple of red-foot boobies, a couple of fairy and lesser noddy terns and a frigate seen as wo near island.

\section{June 26}

Ashore in morning and find but three warblers in a day's 


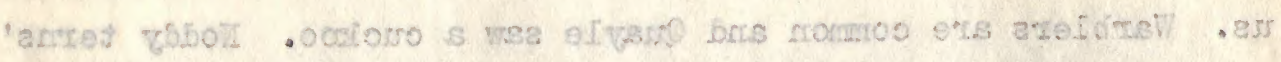

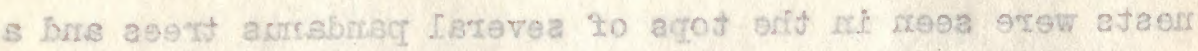

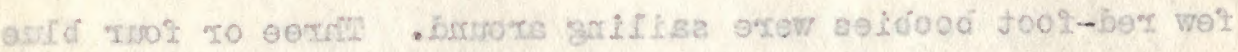

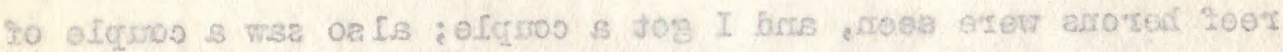

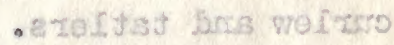

CS encet

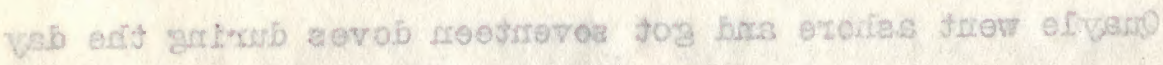

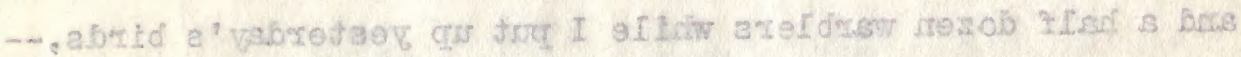

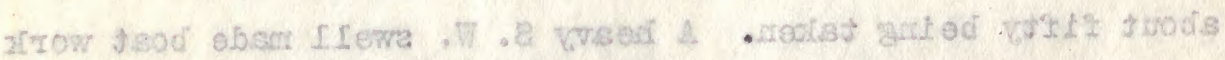
$.7 \%$. at atrotognah

AS eiturt

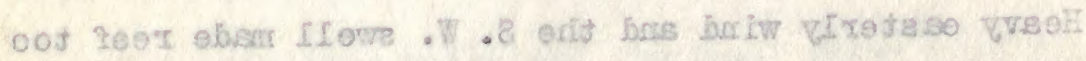

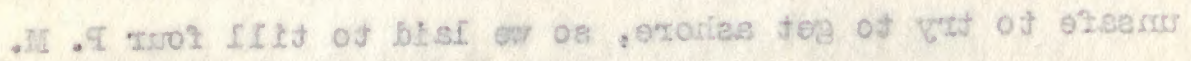

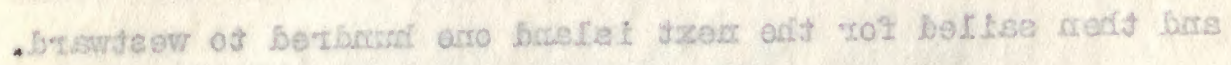

\section{ES orest}

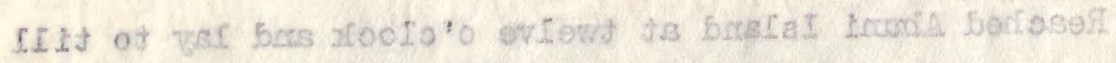

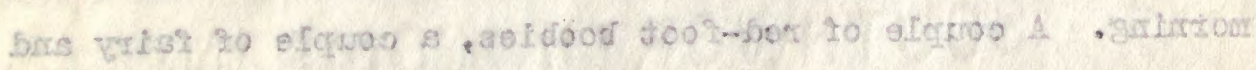

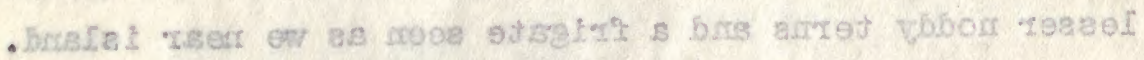
as ensts

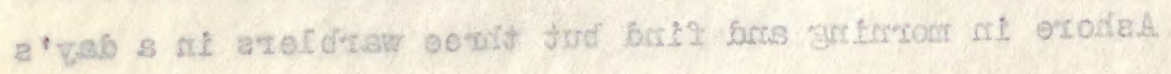


hunt by Quayle and self. No sandpipers or doves encountered, but red-footed boobies were nesting along the sea side of the island and birds in various stages were found and eggs seen. A couple of curlew and four reef herons taken. Some of the weed the ground dove eats was seen, but no berries that the green dove likes. Fairy terns cormon and I shot a female frigate sitting along the lagoon shore. Some hundreds of coconuts planted but seem to lack water though three old trees look pretty good near landing place. Leave after daris for Paraoa Island thirty miles away.

\section{June 27}

Ashore at eleven $0^{\prime}$ clock, as wind died during night and had to use motor four hours. A hundred or so bearing cocomats and some hundreds of young belonging to Hao Island people, but birds scarce and find red-foot boobies nesting along lagoon shore instead on see shore as at our last stop, Ahumui Island. Got a dozen warblers between us and took four or five boobies. INo berries seen for doves and doves not found. Few fairy terns about and several yellow-bill terns on point of land by lagoon. Couple of tropics seen near shore and four frigates over lagoon.

\section{June 28}

Quayle went around to other side of island and got ten 


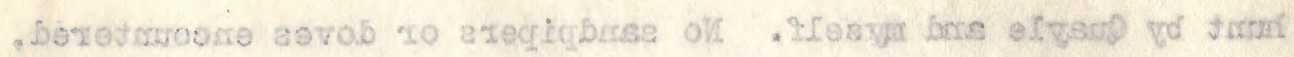

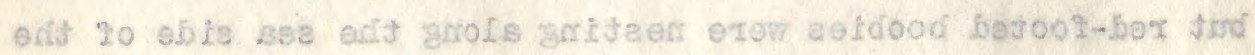

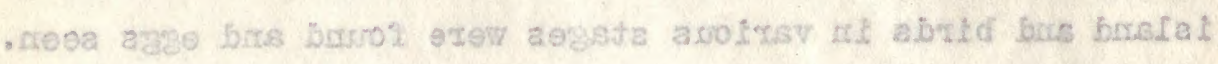

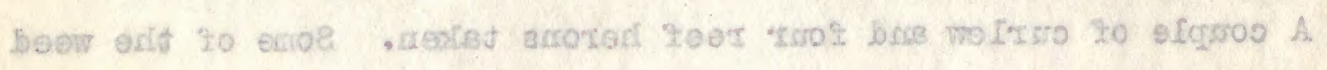

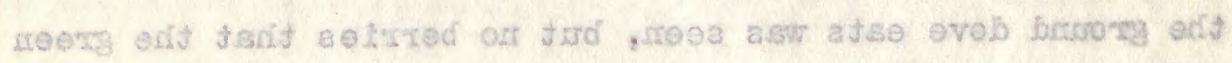

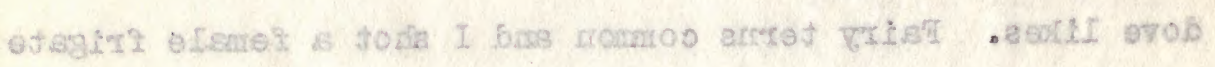

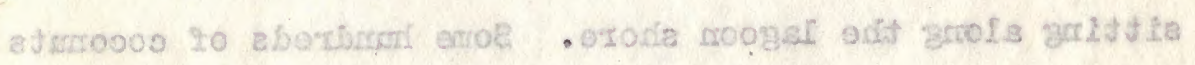

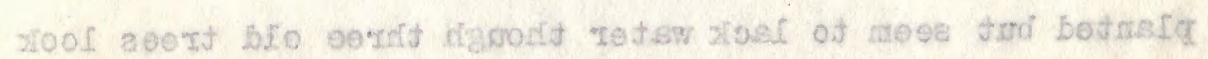

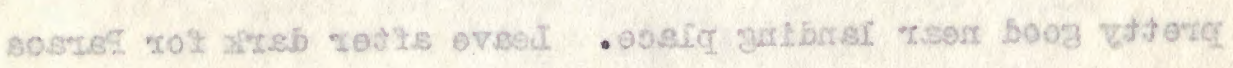

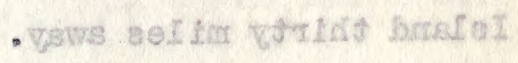

is ensst

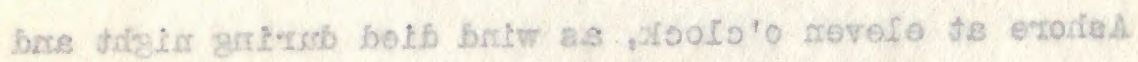

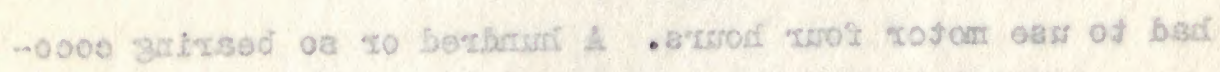

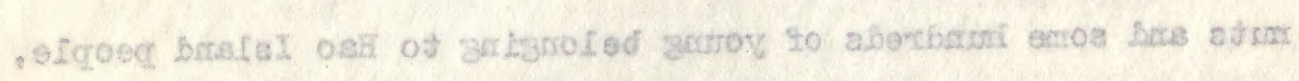

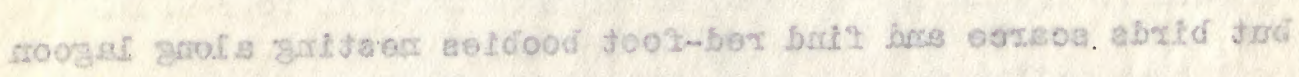

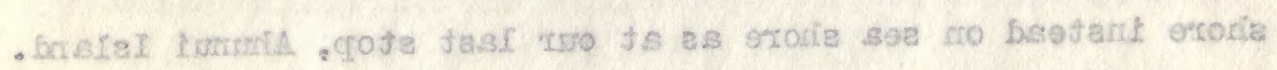

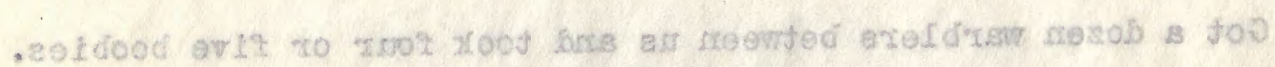

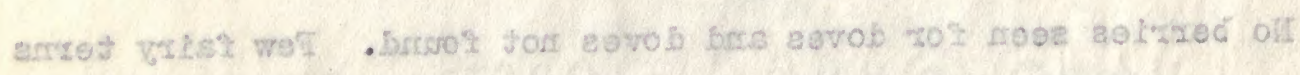

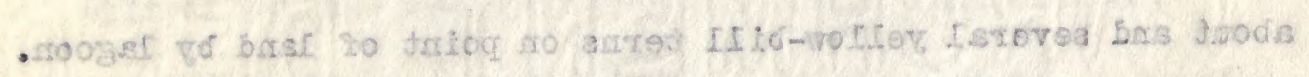

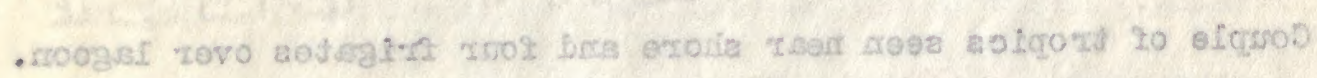

8s. ersuth

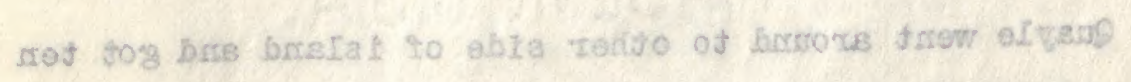


warblers durlng day and at eight P. M. started for Nengonengo Island, as rising swell made it unlikely landing on small island to soutinward of INengonengo.

\section{June 29}

Quayle sick with stomach trouble, so at ten o'clock I go ashore with Curtis collecting. Strike a colony of perhaps two hundred pairs of small frigates, the first time I have ever seen thern to recognize them. They were nesting in low bushes a foot or two above the ground and were more wild than the common frigate, rising from the nests while I was some ways off in most cases, though I shot a dozen, taking two birds usually as four or five were nesting in the same bush often. The males in the air are recognizable at once by the white on the abdomen and I saw but one young bird in the entire lot,-a young male which I shot. Birds hung overinead while I stayed in colony, but returned to nests when I left, as there was a high wind and it was squally.

Shot four neglected shearwaters as they came in from sea, but had not timo to search for nests. Only young poor noddies were sitting on ground in most cases or in low bushes where their old nests were located. Fairy terms were common and several downy ready to fly; redfoot boobies were in nests or 


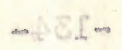

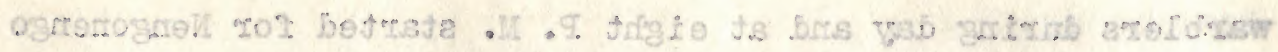

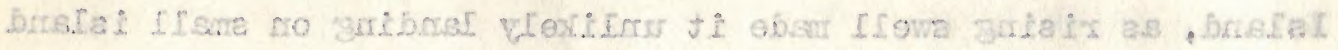
- ogresrogmetr \%o bromiduos ot

eS onsst

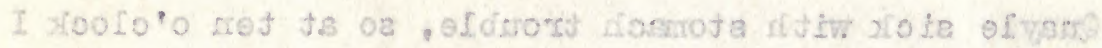

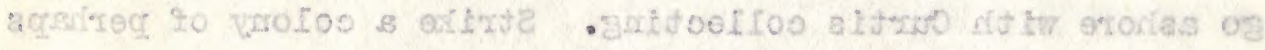

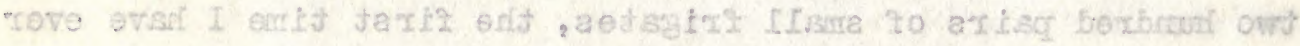

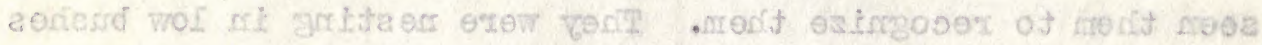

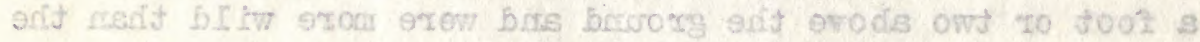

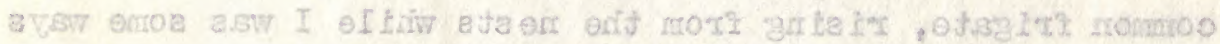

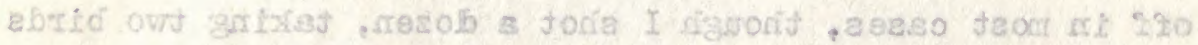

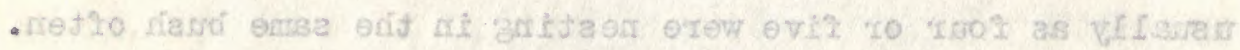

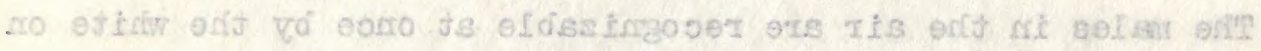

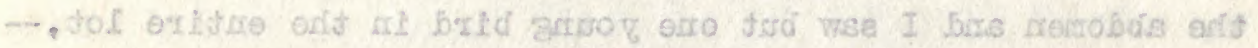

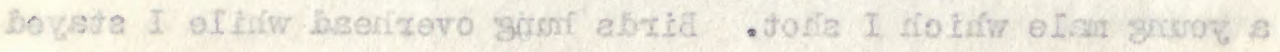

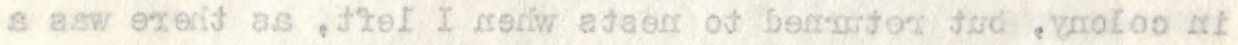

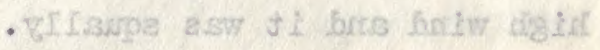

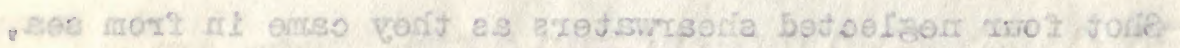

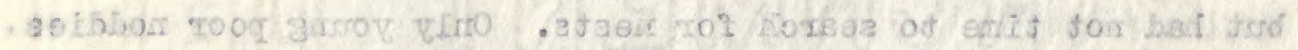

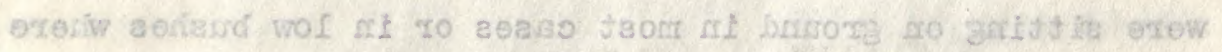

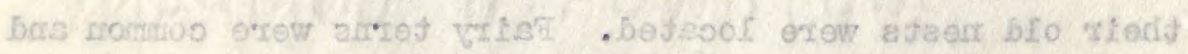

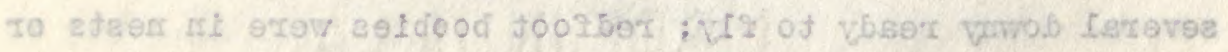


perched alongside of them. Two reef herons, two curlew, two tatlers and several yellow-bill terns seen. The island here has been swept by hurricane and plants are just getting foothold again. No land birds or sandpipers seen, though possibly in other patches of bushes they might occur. As material aboard will be used up when these birds are done and high fair wind for Tahiti is blowing we leave at four P. II. for there. Couple of lesser noddies seen and a single peir of adult blue-faced boobies at nesting site flew at approach.

\section{June 30}

Cup of coffee and biscuit, the regular morning mesl, at six A. M. I then tackled the frigates, getting nine done by eleven A. M. when breakfast is ready. In P. M. finished two more frigates and five red-footed boobies and a fairy tern by four P. I1., three of the boobies being large, downy ones in different stages. Louis, the engineer, skinned four neglected shearwaters and a half dozen noddy terns. Cleaned up all the grass excelsior and straw that came around alcohol bottles for stuffing, using last one half pound of cotton, the last spool of thread, and last magnesia for drying feathers. Have used the last bit of arsenic and have been using labels improvised for last few hundred birds, as well as using beach sand for 


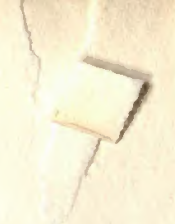

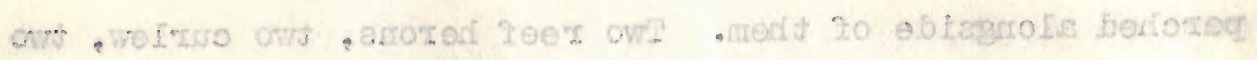

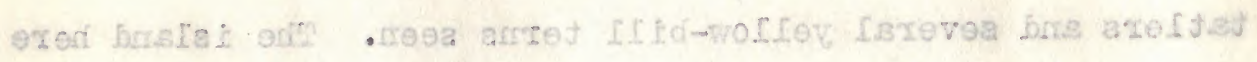

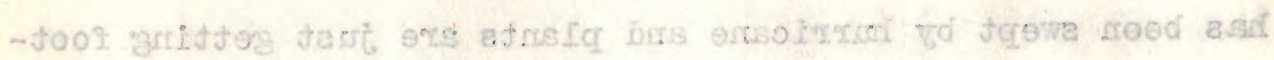

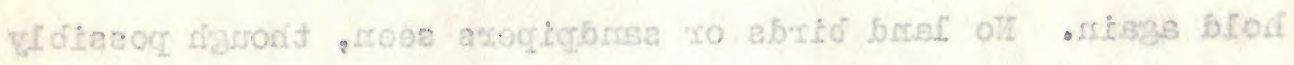

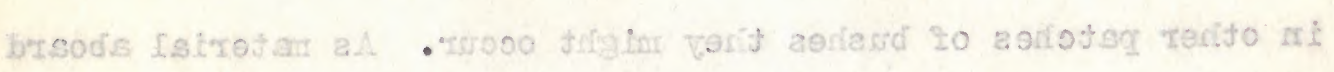

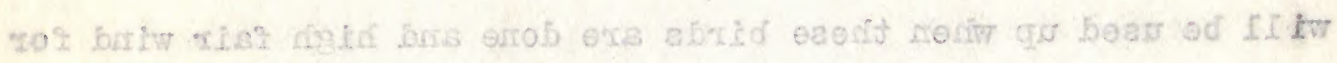

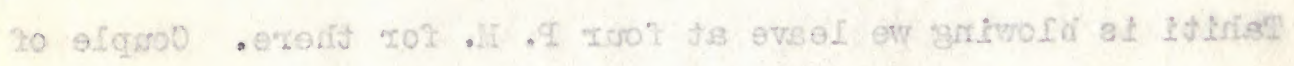

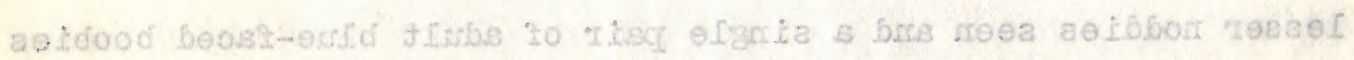

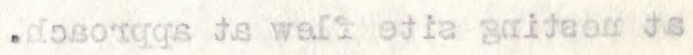

08 enst.

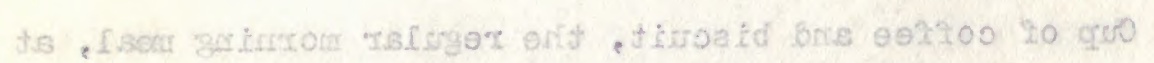

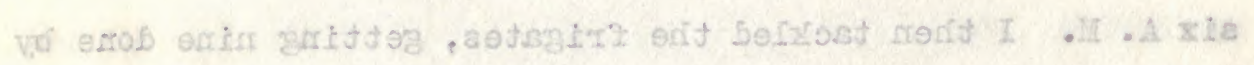

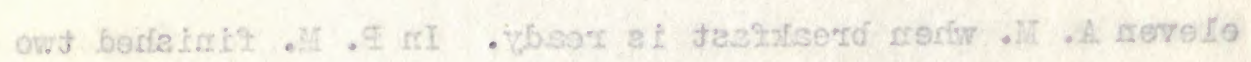

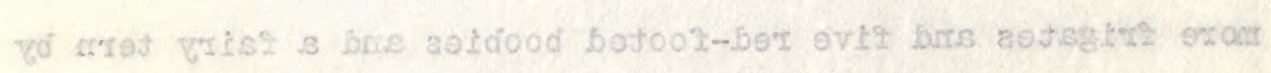

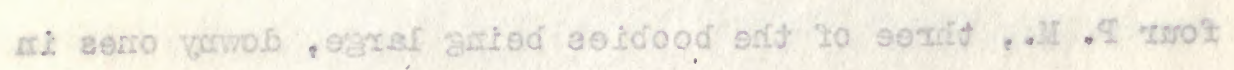

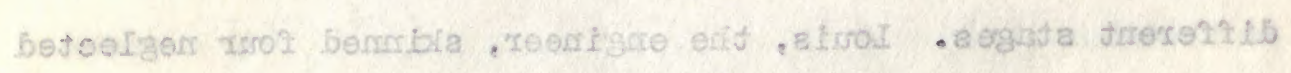

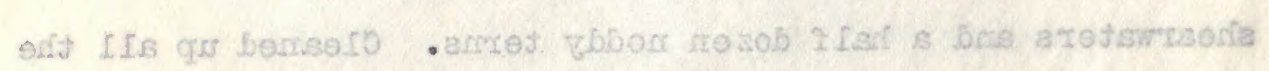

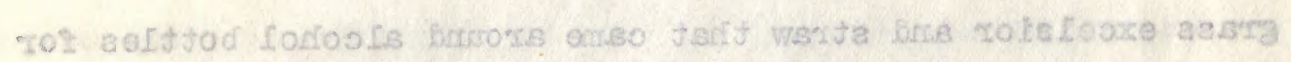

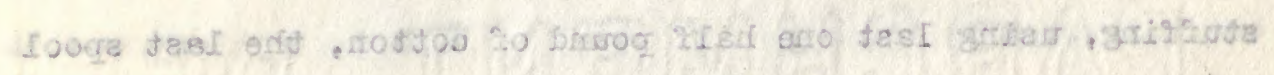

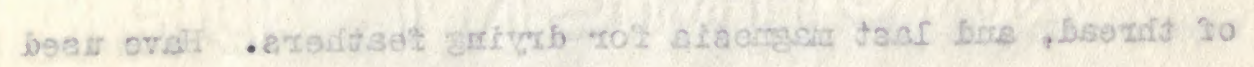

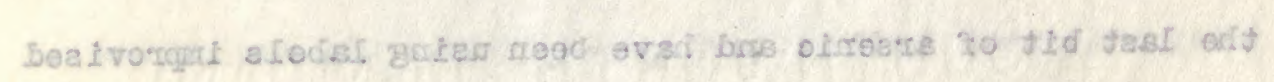
rof brse dosed gatem as If 
skinning since Ducie, though have a sack of ten pounds of cornmeal still. Had a mandred pounds of cornmeal at Ducie when we started to use sand for large birds, and black small ones. Saw two redfoot boobles at noon and hear the sooty terns nearly every night. Wade 180 miles from four P. M. to six P. M. today.

\section{August 14}

Start at noon for the Marquesas, having spent six weeks in port, the first three of them waiting to get on the slip for cleaning and painting the bottom of the ship. We found one worm eaten spot that required the removal of parts of four planks before all bad parts were repaired. Had the mainsail renewed and added fifteen fathoms of good chain to the equipment.

\section{Augrast 15}

Fine breeze from S. B. gradually worked eastward and we made Hiau Island after 36 hours salling.

\section{August 16}

Quayle and Jones ashore for plants and birds on lee side. Jones joined us at Papeete to collect plants if satisfactory. Mrs. Beck doesn't recover readily from seasickness, so we head 


\section{$-3 E^{-1}-$}

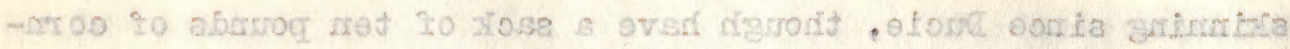

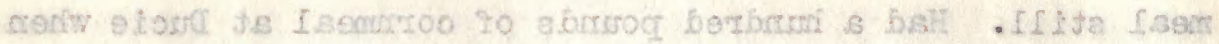

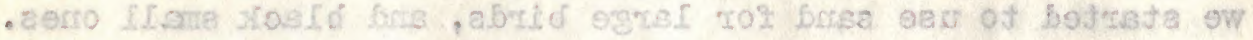

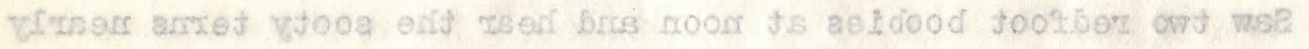

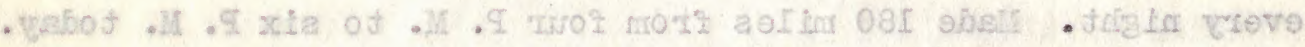

\section{Af jasposit.}

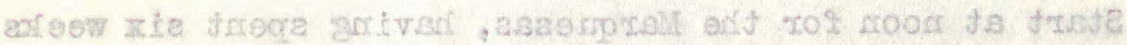

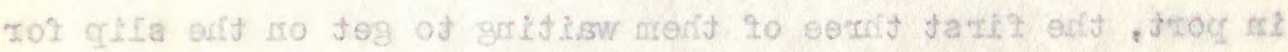

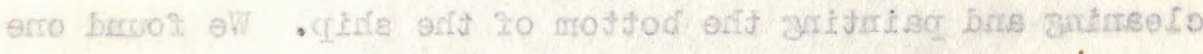

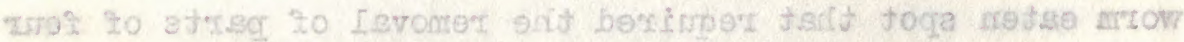

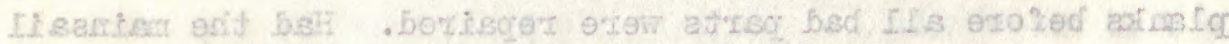

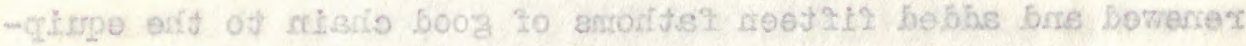

- jusear

\section{af Jespge}

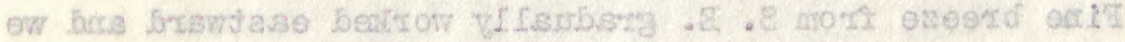

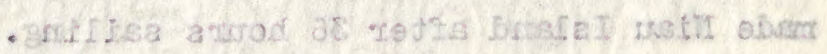

$$
\text { af tamas: }
$$

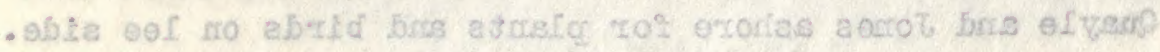

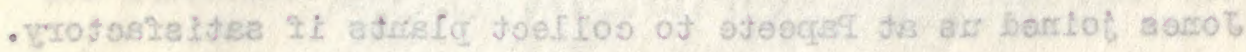

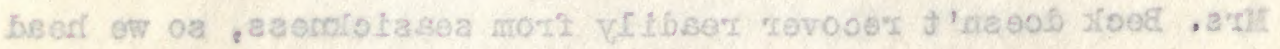


in eve for Makatea for her to take 'Cholita' to Papeete.

\section{August 17}

Few noddy terns and fairy seen twenty miles off Makatea, where we anchor at six $P$. M., tying to buoy after getting permission.

\section{August 18}

Quayle and Louis ashore and get a few doves and warblers and a couple of pigeons. I finish bills to catch 'Cholita' going to Papeete tomorrow.

\section{August 19}

Quayle and Louis get a few more birds of the three land species.

Augrast 20

Sunday. Light winds from MNE last two days.

\section{August 21}

Quayle and Louls ashore at five A. M. to go for pigrons and stay all day, Quayle getting three and Louis none. I went along the coast a mile to west of mill and found noddy terms nesting on cliffs and plotus boobies resting on ledges and on 


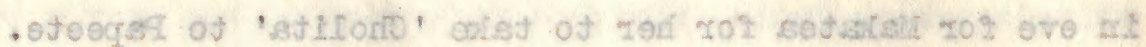

FI. tesough

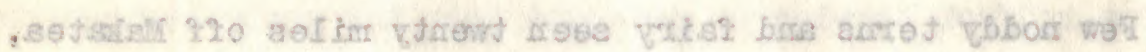

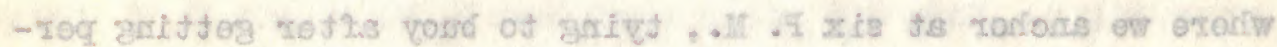
.rrolaster

\section{ef jemonid}

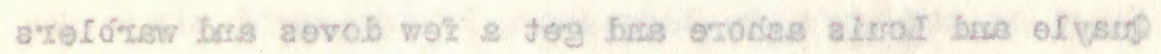

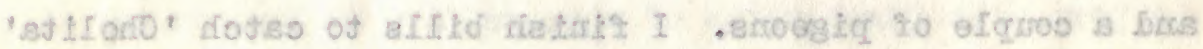
- vortomot ejeseger of gertog

\section{RI te wrasta}

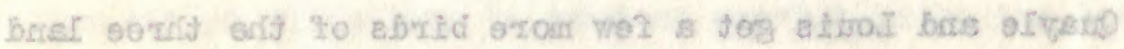
- aetoogge

\section{OS jamsta}

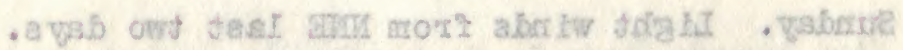

\section{IS fastogsA}

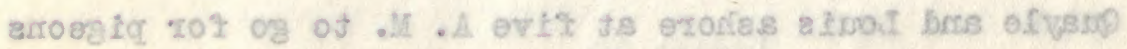

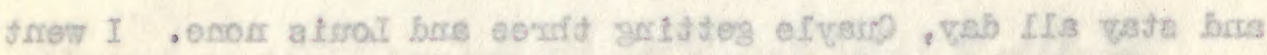

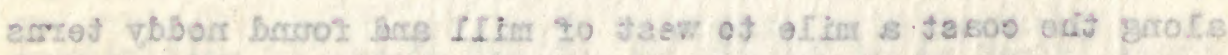

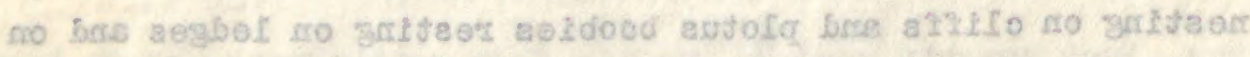


top, a couple of dozen birds being seen. Mree or four fairy terns were seen on top and a couple of yellow-bill tropics were seen to onter holes in the cliff, but shooting at holes failed to bring them out. Iesser noddies were fishing along the edge of reef and a flock of a half dozen wandering tatlers were noted along shore as if just from the north. In P. M. I went ashore and got a cuckoo close by village. Doves and warblers were not uncommon, but the extremely rough coral ground maikes collecting off trails almost impossible. The Chinamen and Tahitians sometimes go down twenty feet or more into a hole after the phosphate which is being dug on the island. In evening leave for North.

\section{August 22}

After Iunch the boys go ashore on S E end of Rangola Island where a large colony of sooty terns are nesting and get a series of old and downy birds as well as a couple of doves and few warblers. $A$ curlew also shot.

\section{August 23}

Ashore for four hours at eastern pass on north side of Rangiroa. Get a half dozen blue termlets and Quayle gets.a couple of graybacks. Few warblers and couple of doves. 


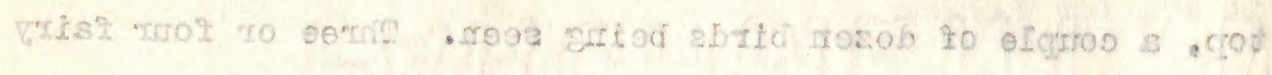

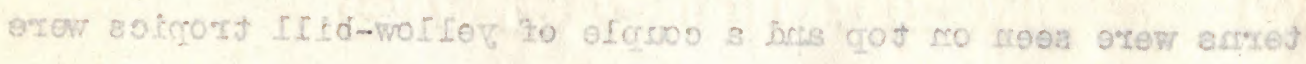

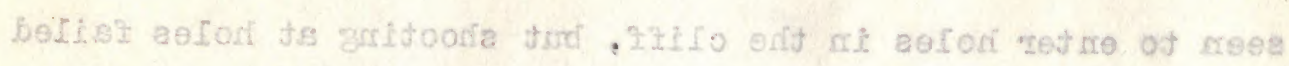

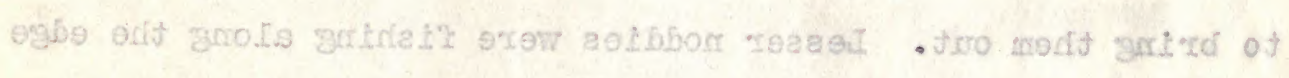

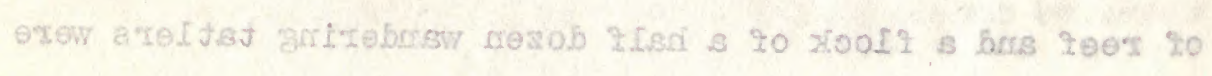

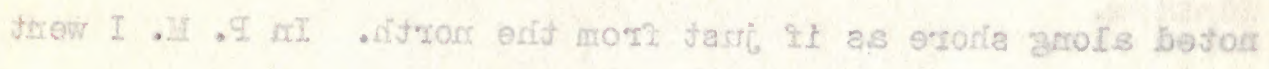

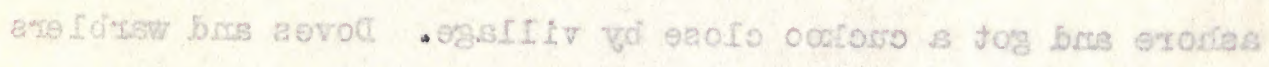

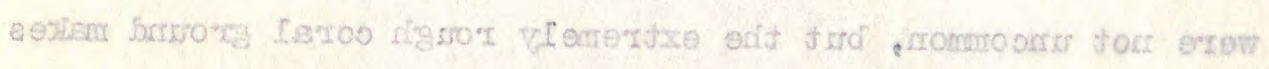

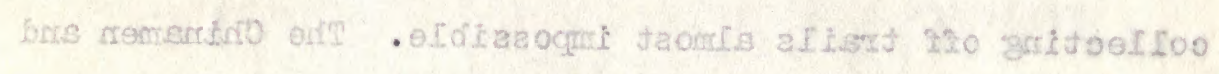

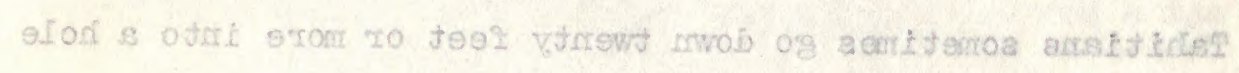

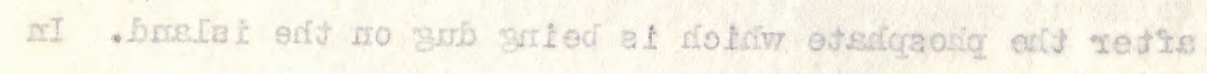

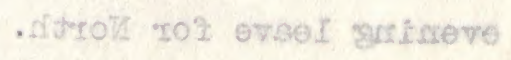

SS ta ugreA.

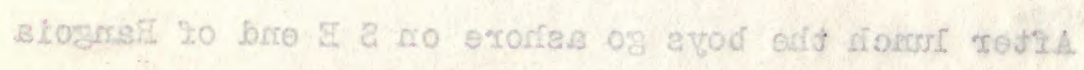

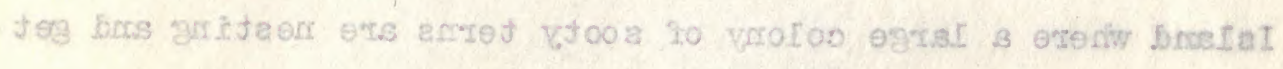

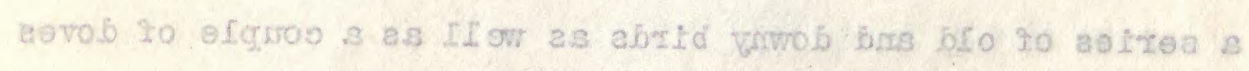

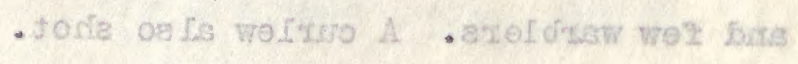

ES Jewgers

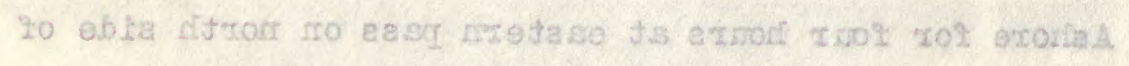

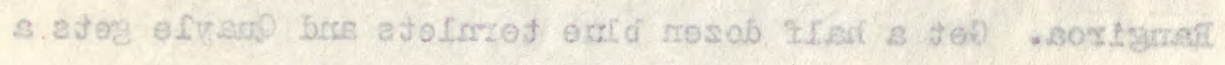

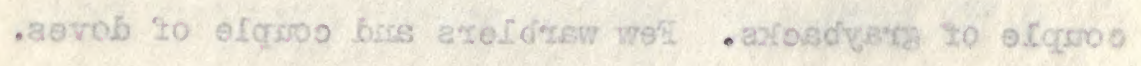




\section{August 24}

Stopped four hours at village by eastern pass yesterday on Rangiroa Island and today at noon went ashore near the $S \mathrm{E}$ end and got a half dozen yellowbill terns and three curlew as well as few warblers and four doves. Leave at five and head out $\mathrm{H}$. E. with light wind.

\section{August 25}

Iight wind and head toward Ahil Island which we reach at tweIve P. $\mathbb{I}$.

\section{Augrast 26}

Ashore at 6:30 A. M. and find a few warblers and doves. A curlew and plover as well as tatlers seen. White terms scaroe, only a half dozen being seen, but a flock of noddies (several dozen) were resting on rocks on windward side of island. and were fishing a short way outside of reef, returning to rocks to rest. Several lesser noddies were fishine in shallow water on reef and quite a few were doing the same on Rangiroa. Island, catching very small minnows.

Came aboard at eleven A. M. with fifty birds between us, and I skinned by $6: 30$ P. M. 32 of the lot, Quayle being under the weather and Louis skinning eight sooty terns and making thom up. 
AS JägenA

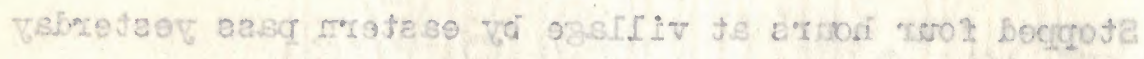

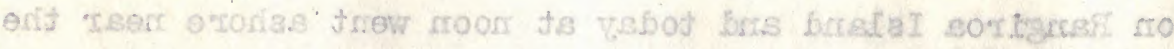

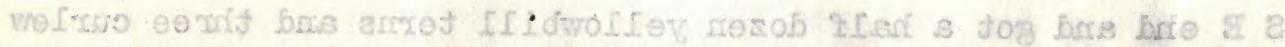

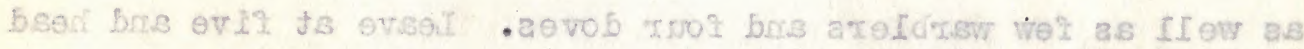

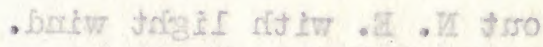

is tergers

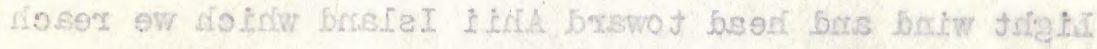

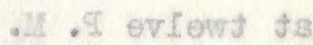

as tastgut

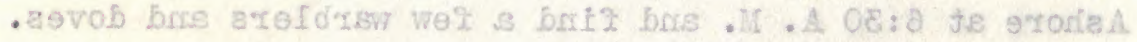

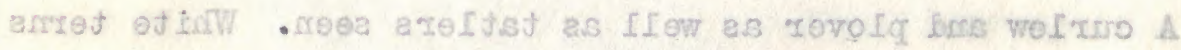

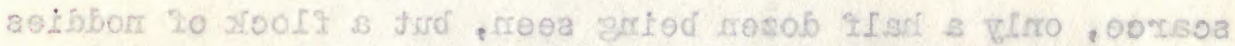

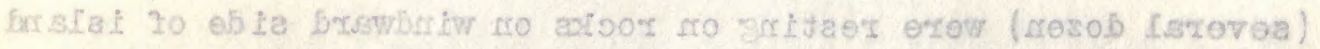

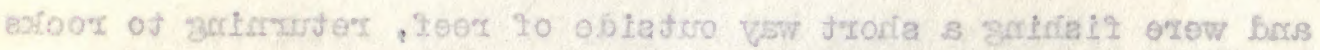

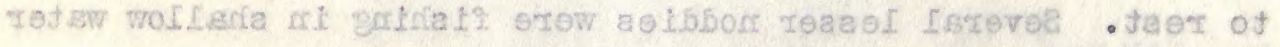

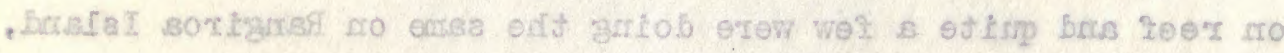

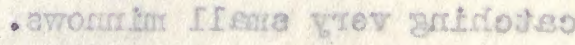

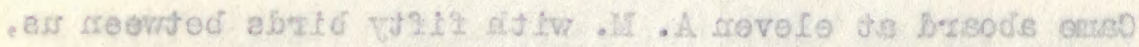

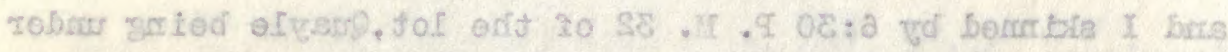

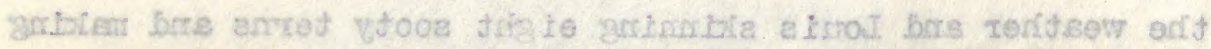


August 27

Heading toward Takapoto with twelve miles to go at noon. Sooty terns noted at daylight working west and for last three days at sunset noted flying toward the west to Arutu perhaps, as a colony occurs there as well as Apataki.

\section{August 28}

Ashore on Makaroa for the day. Quayle and Louls work the east side and I do the south and none of us see or hear a land bird. Got a couple of herons and a couple of tatlers. Saw a half dozen yellowbill terns but no noddies or fairy terns.

\section{August 29}

Ashore on Taleapoto for seven hours and get 25 warblers but no doves, though the natives say they occur. I saw a rail, but gun didn't work. It was small and black with slightly different call from Rapa bird. Louis heard a couple and the Captain also. Two or three yellowbill terns seen and a couple of fairy but not low.

\section{August 30}

Squalls and wind last night and heary sea today. Beating toward Tikei. Redtail tropic and couple sooty tems seen. 
Is trancurl

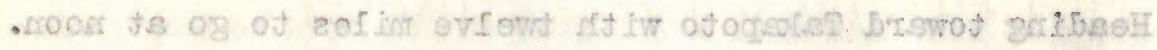

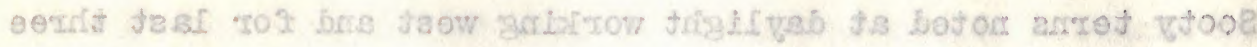

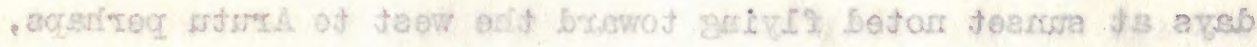

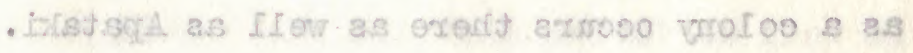

BS jastom

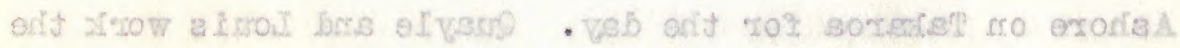

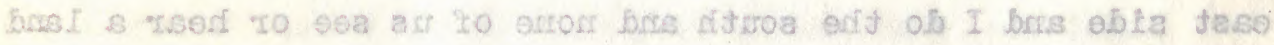

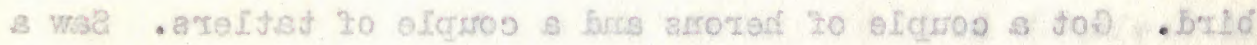

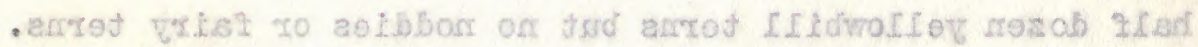

\section{es tament}

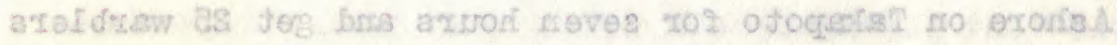

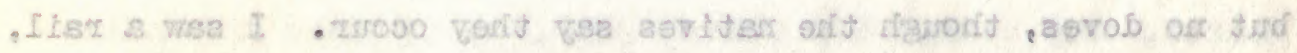

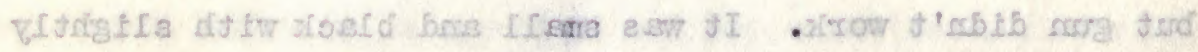

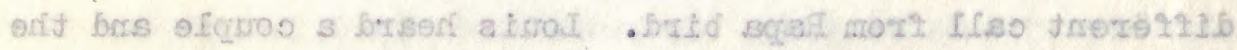

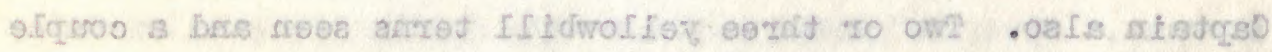
- wor ton and gataz zo

\section{OE. JamsuA.}

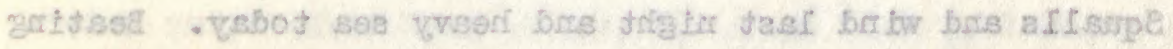

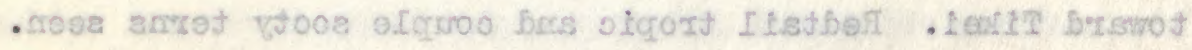


August 31

Ashore on Tike 1 at $6: 30$ and stay till three P. K. finding warblers not uncommon and seeing a single rail, but getting none. Noddy and lesser noddy and fairy terns were all common and breeding. Some lesser noddies were just hatched, while many nests were still being built. Several nests were usually in the same tree of lesser noddies, while the noddies used coconut and pandanus trees, and in one case a noddy was seen on its nest on the rotting top of a dead coconut tree broiken off thirty feet up. A dozen frigates vere over island as we landed, but left. Sooty terns flew across 1 sland all day, but whether looking for nesting sites I could not be sure. They may have been fishing from islands to south.

\section{September 10}

Sunday and aboard.

September 11

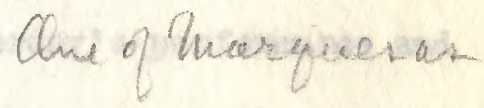

Quayle and Jones go up for couple of days and Quayle gets to 3,500 feet, finding Dacie shearwaters flying about and nesting likely on inaccessible pinnacle rock. Several yellowbill tropics seen and noddy terms, as well as fairy nest high.

\section{September 13}

Collecting and skinning warblers, doves and paroquets. I 
CE tomat.

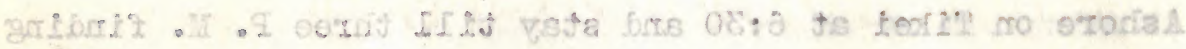

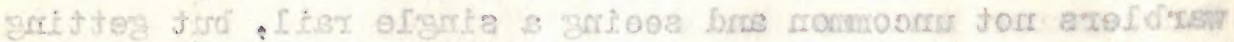

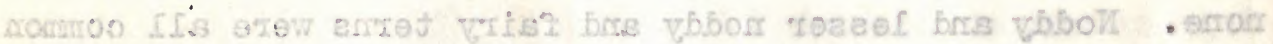

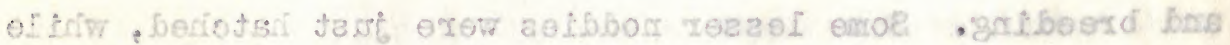

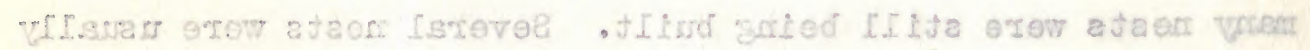

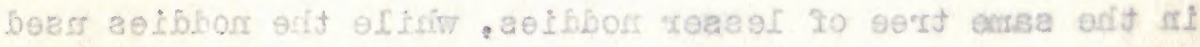

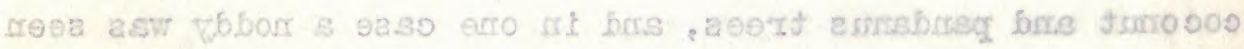

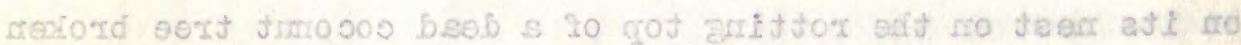

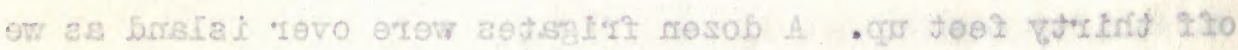

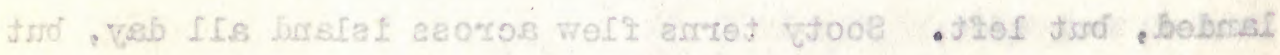

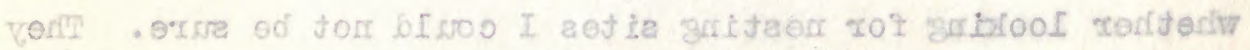

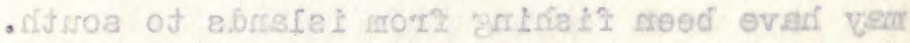
OL redimejcę

- Dezsodis dices rabreuta

If rodimetge\&

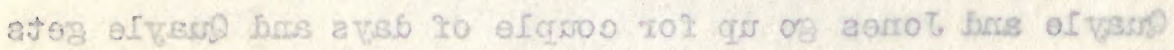

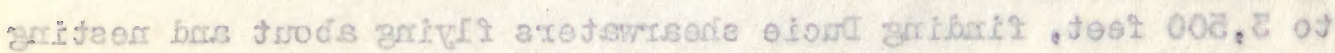

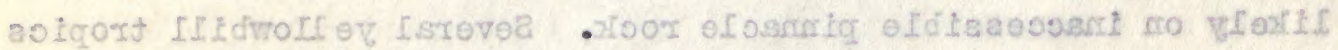

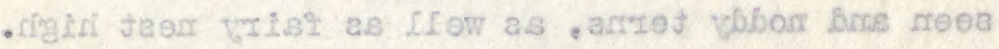

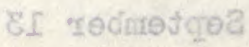

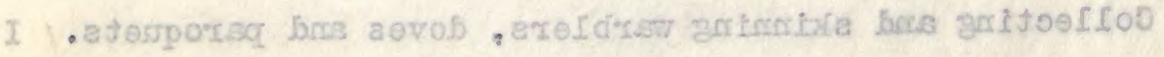


found a warbler's nest in a willow-like tree and the engineer found a couple in trees a few feet high. Could not get Iy nest without spilling eggs, as nest is firmly tied to small twigs with strips of bark of which it is composed. The nost is as deep as entrance is broad, about an inch and a half deep. Saw a nest of flycatcher forty feet up in a big tree, but could. not shoot the branch down on which nest was placed.

\section{September 14}

Started for Nukahiva, but ran into Bulwers petrels south of Huapu, so I spent a few hours in boat and shot several, as well as three wite-chinned petrels. Iried to land on pimnacle rock where many sooty terms nesting and probably petrels, but sea was too rough. Ran back and anchored for night.

\section{September 15}

Started out again and repeated yesterday's performance and bettered it, as we found a streak where Bulwers petrels were plentiful and I shot about 25, as well as nine white-chinned and one Peales, though the primaries do not correspond to description. This petrel came up to bait, as several of the white-chinned seemed to do, though the Bulwers did not appear always to pay attention to it, although many came up. Petrels have quite definite feeding grounds, as we sailed for some 


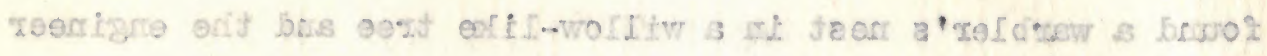

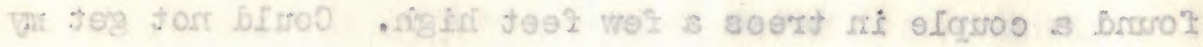

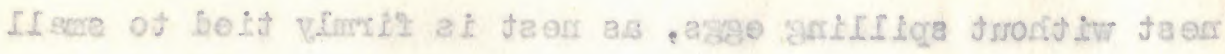

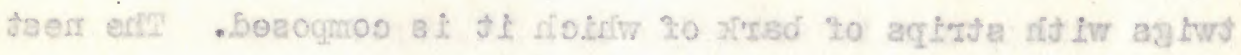

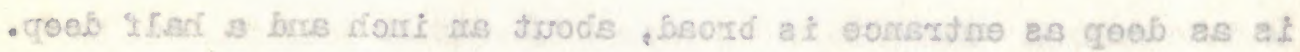

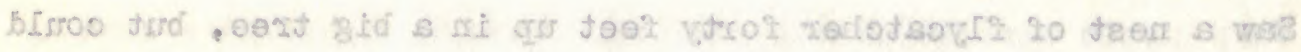

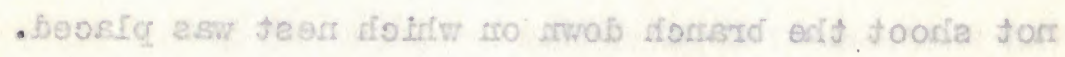

\section{A. r. rodmetgoe}

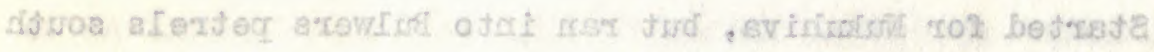

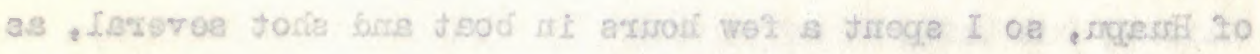

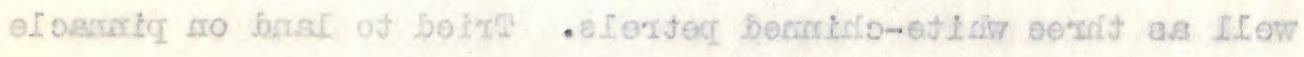

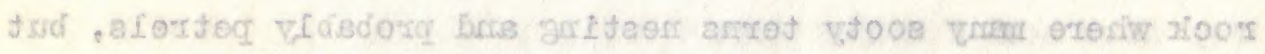

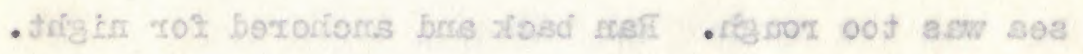

\section{at redinetcoe}

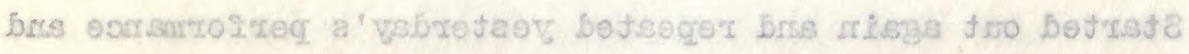

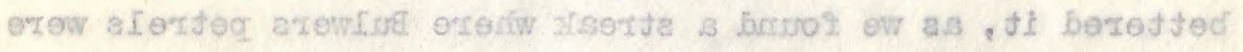

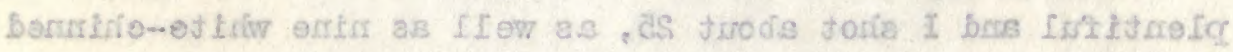

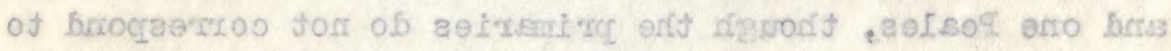

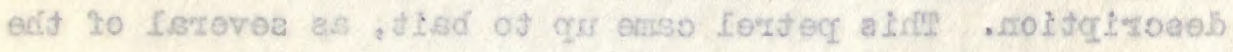

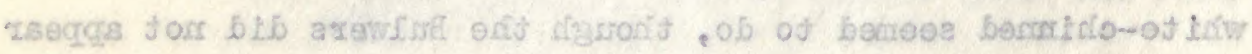

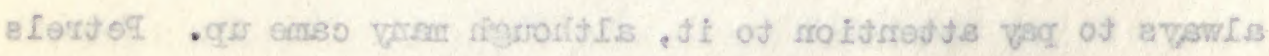

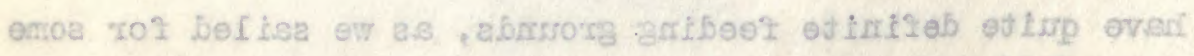


hours and saw occasional birds but found dozens on water sitting as I did last year, though there was some wind today and last year when I passed them it was celm. Bulwers are nesting and the white-chinned are getting ready. Peales may be nesting from organs.

\section{September 16}

Reached Nrakhiva and found the Browns, Bishop Nuseum people, packed up ready to leave on steaner overdue here for Papeete. Shot twenty Ducie shearwaters day before yesterday with the petrels, and probably they nest high on the mountains. Saw but few yesterday but got an obscuras yesterday and saw a couple of others.

\section{September 17}

Sunday and aboard all day.

\section{September 18}

Moved around to west five miles and left Quayle to work the upper part of Nukahive with a native guide who helped the Browns here. Swifts common about village.

\section{September 19}

Got out of bay this morning, it being too rough in narrow 


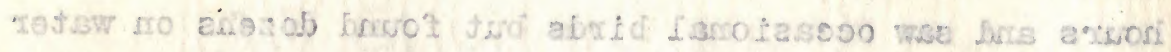

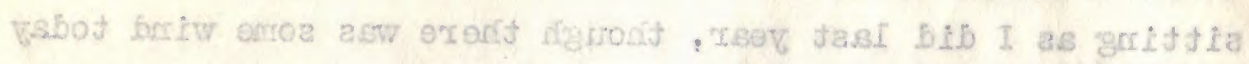

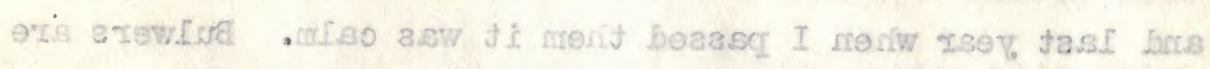

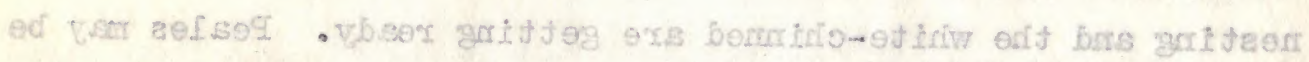
- ausgio mori anitaor

\section{d. Teontejegę}

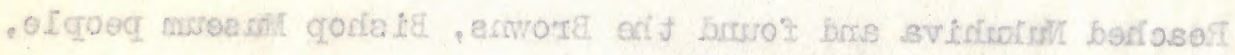

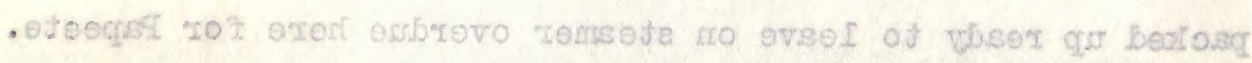

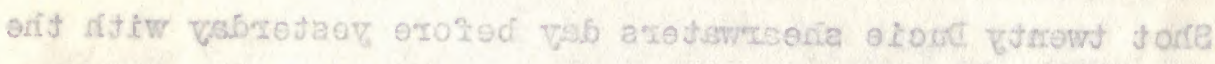

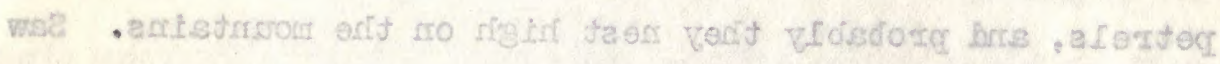

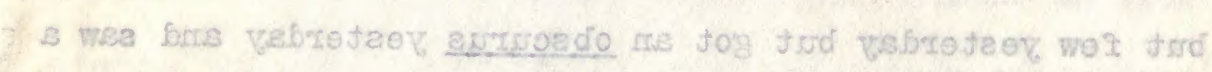
- a terito to elgeros

SI. Teclicitojer

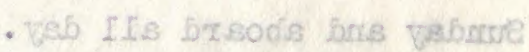

\section{1. redmojegea}

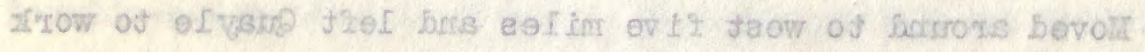

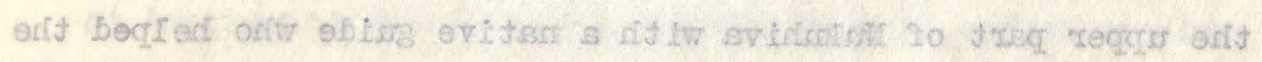

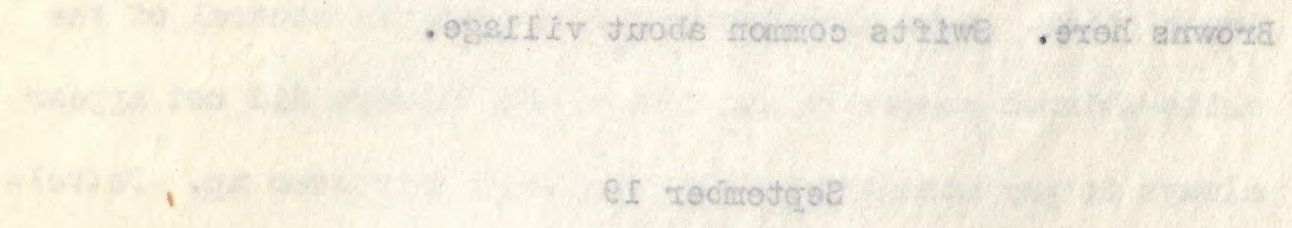

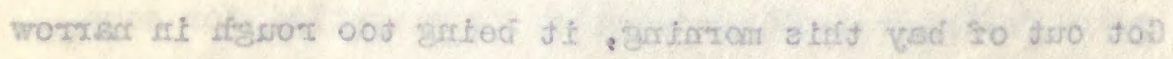


entrance last night to attempt it, and this morning the engine stopped as we were in narrow part, but luclily the engineer got it going in a mimute or two and reported a short circuit the cause.

Heading across for Motu Itu. Redfoot and plotus boobies, noddy and lesser noddy, sooty and fairy terns are fishing in flocks less than ten miles from islet which looks rough. One obscurus but no other tubinares seen yet.

Ashore at Motu Itu in P. M. and I find three pairs of wedge-tail shearwaters in burrows under tussock grass and in a cave. Several other burrows under grass roots were examined, but birds vere not in. $\triangle$ lesser noddy young was photoed in nest that was built on cliff and gray ternlets were also evidently nesting there but out of reach on cliffs. Several of the lesser noddy nests were close together, guano covered, and are evidently used repeatedly. A pair of Ducie (?) shearwaters or two flew over the island while I was ashore, but I did not go to the top, being too busy and the patiway dangerous if possible. I shot one shearwater as we left the island and a noddy tern also. Three redtail tropics were taken from nosts in small caves on the ledges and a dozen or more birds were sailing around on the lee side of island as we neared it. Plotus boobies were also flying about and sooty terns flew in a swarming cloud 


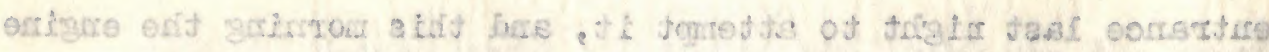

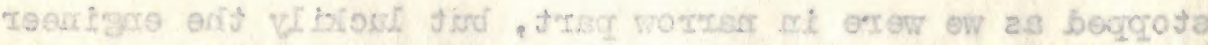

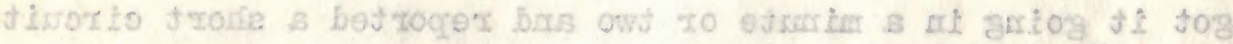
- onsese arit

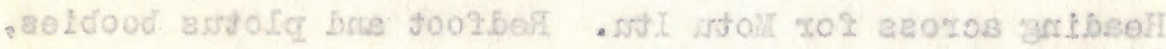

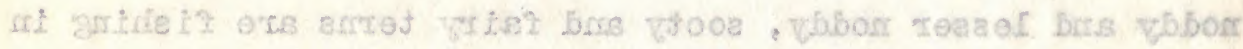

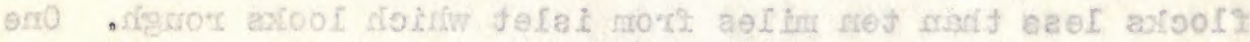

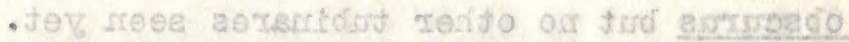

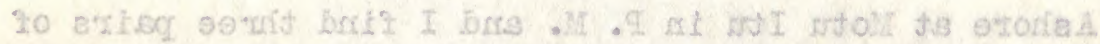

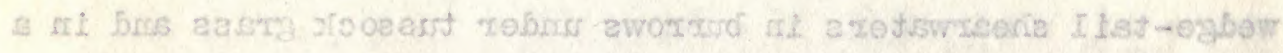

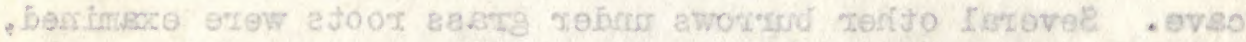

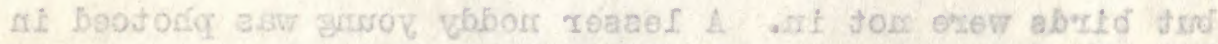

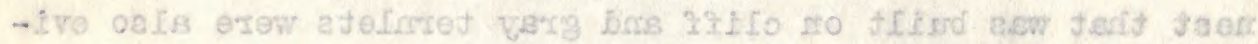

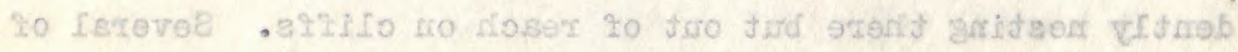

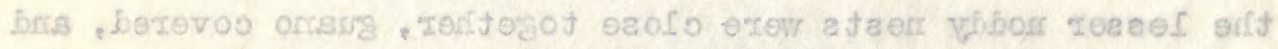

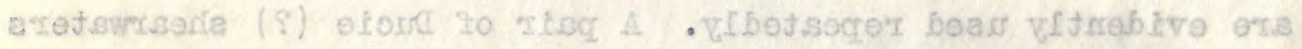

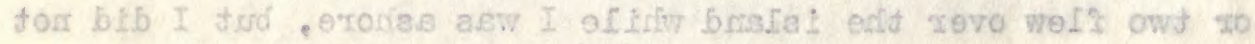

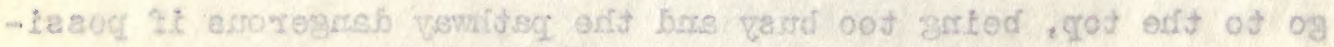

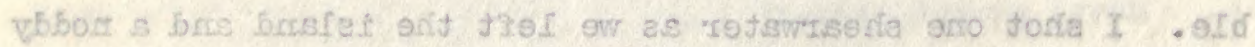

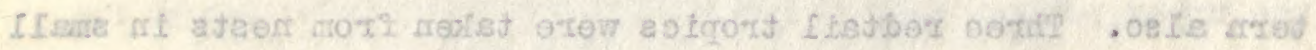

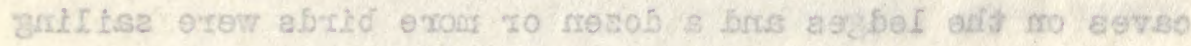

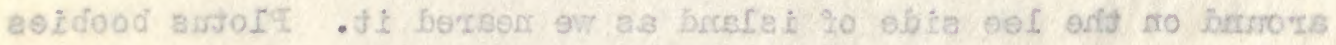

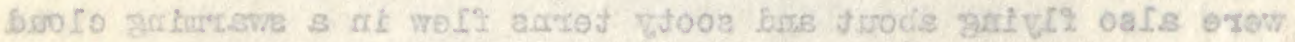


from the small islend half a mile to eastward of big rock when we rowed to it, but we could not land on it as sea was too rough. The island was covered with tussock grass and a few long brittle-stemed ferms grew in little caves where water seeped and made moist earth. This was a big island. The small one was guano covered. One tropic-bird egg saved of two taken. Sailors caught some fish near shore. Left for Eiau at dark.

\section{September 20}

Ashore at Eiau and find warblers and flycatchers comon. Sheep and pigs common,--sheep fat and pigs poor. Sooty terns nest around island on cliffs and a fow plotus and redfoot boobies fly along and also frigates. Few gray or blue ternlets and lesser noddies noted and four reef herons lit early in morning of the 2lst on cliffs near ship.

White terns are comon around trees and a few swifts are seen along top of island. Many old peepees seen near top and many piles of chippings from stone instruments that natives wore maling here. Few discarded incomplete picks or axes (?) noted. Buro forests on top and ono grove of six or seven cocomat trees in a little flat near top, and a single tree near top seen. Pigs husk nuts as they fall at grove and no now trees are starting, the tops being eaten as they grow. Six or oight cattle 


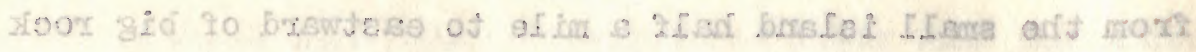

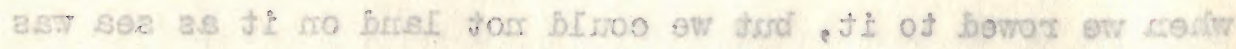

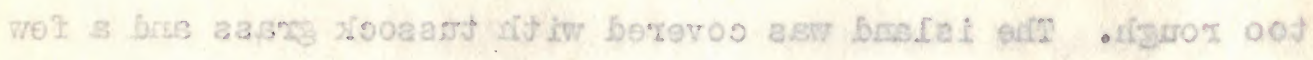

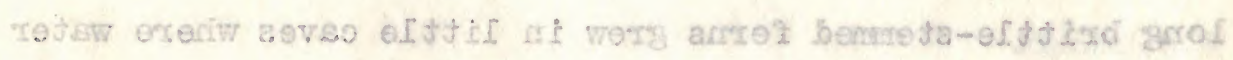

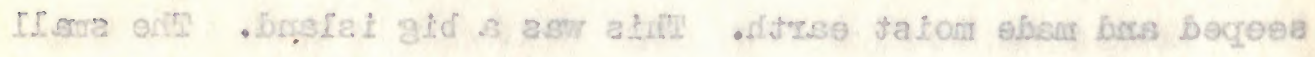

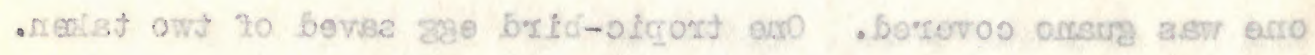

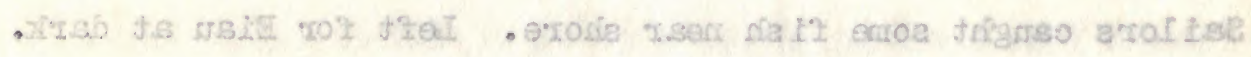

\section{OS rodimatqoe?}

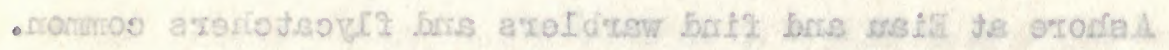

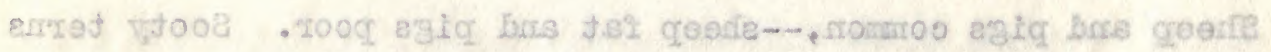

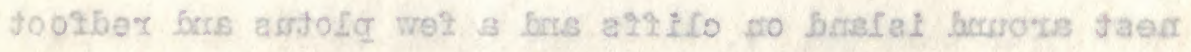

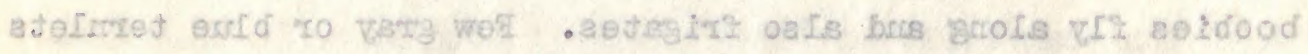

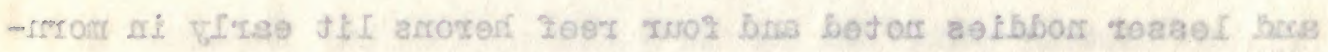
- cicia coor axilio mo tals edit to gnt

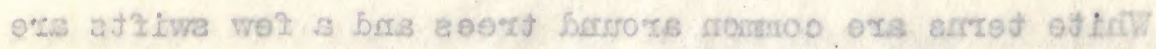

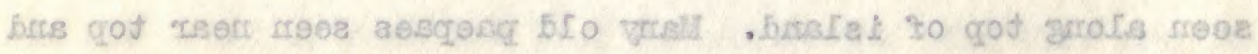

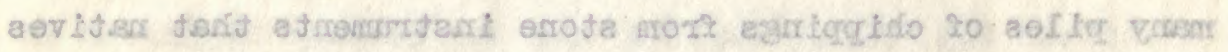

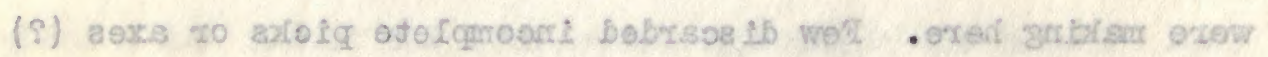
-0000 novea zo xia lo evorg eno Bna qoj no ajagro? ornd . Doton

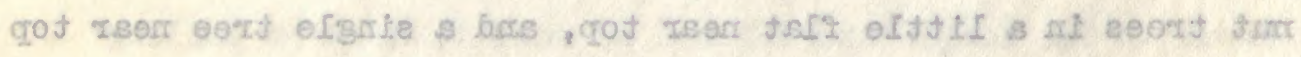

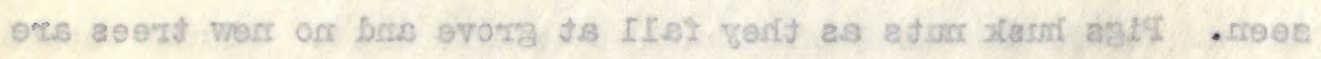

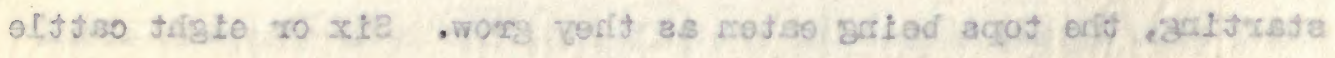


seen, but sheep in flocks over island, five hundred perhaps being seen altogether. The pigs are poor looking and find living poor. Pandanus trees grow largo on top of island and are covered with Spanish (?) moss where fog or rain often strike along $r$ idge.

\section{September 24}

Last three days working on birds in harbor. Sunday today.

\section{September 25}

Got a dozen frigates flying over a point of land and on the 27 th went to Hatutu where we found ground doves waiting for us at the landing place. In low bushes over the island Irigates and redfoot boobies were nesting, and on top the plotus boobies had young birds and a few eggs. Redfoot boobies also had nests in trees where the lesser noddies were nesting and meny fairy terns were roosting. Several Ducie shearwaters were shot es they flew over island after two P. M., none being seen before that time. One bird wanted to ligint at one place, and on going there I found an adult on a nest but no egg. On the cliffs on east side many redtail tropics were nesting and a flock of noddy terns were sitting on an open spot on the cliff. A few warblers were scattered about through the bushes and the 


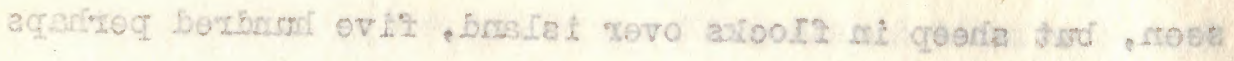

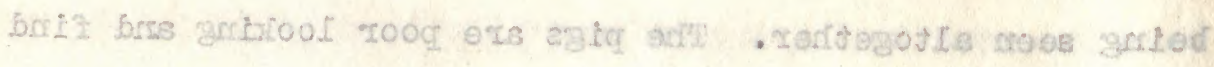

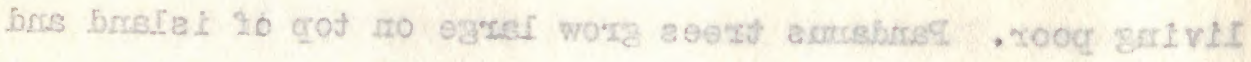

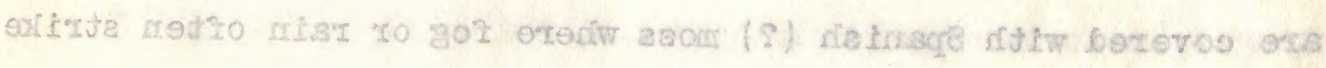
- exphos grotis

\section{AS rodmetcrez}

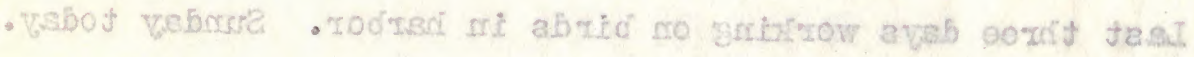

\section{GS todmstrel}

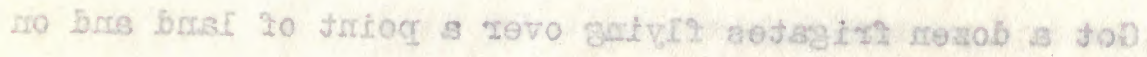

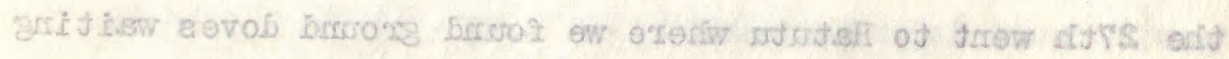

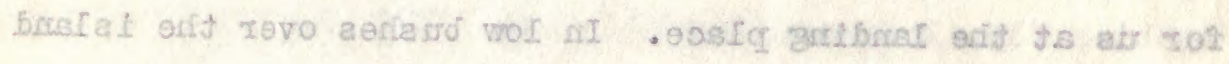

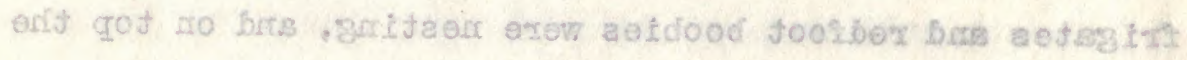

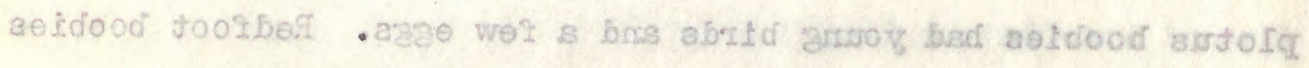

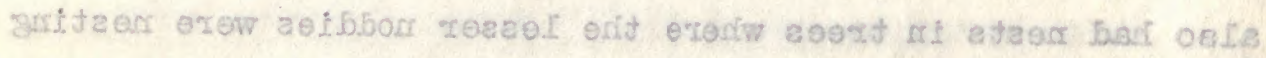

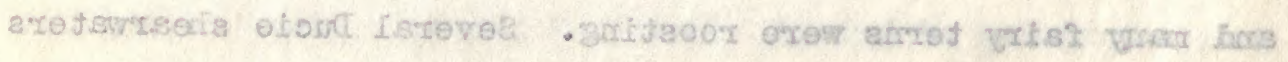

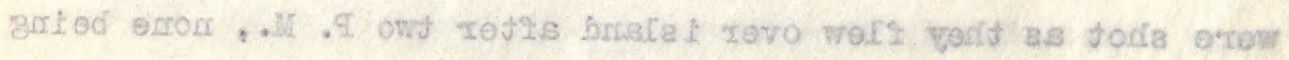

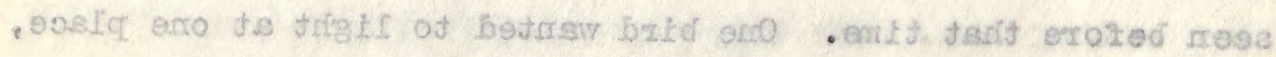

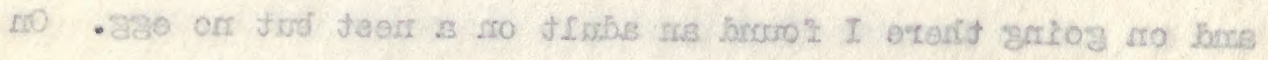

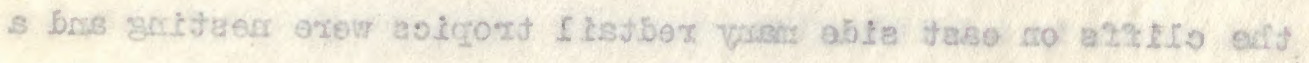

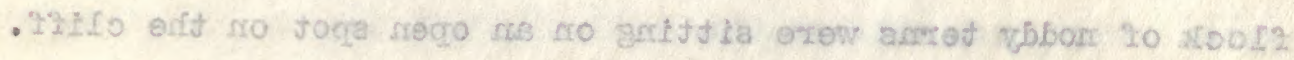

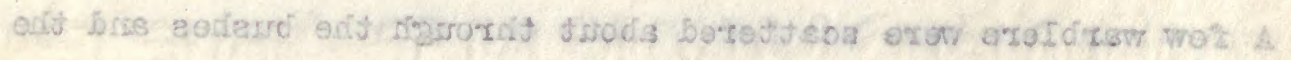


ground doves were common over the top of the island. Few were seen on the west side where we landed.

\section{September 26}

Skinned birds and ran close to the corr. islands ten miles to eastward, but a barren sand bank, and did not land as it looked dangerous for a boat. Shoal water extends for two miles or so on either side.

\section{Septomber 27}

Put out boat in eve and picked up a few Bulwer and witechin potrels, an obscurus and nativitatus shearwater, many of both working toward the island at sunset.

\section{September 29}

Ashore at south end and find thousands of sooty terms resting in flocks in tussock grass selecting (?) nesting sites. Three or four fresh eggs seen. In holes in cliffs found several nativitatus shearwaters, one adult on young, and tropics nesting. Found a large Ducie young under a tussock grass on top and shot some more adults in P. M. Miles of impossible cliffs give breeding places for petrels and shearwaters. 


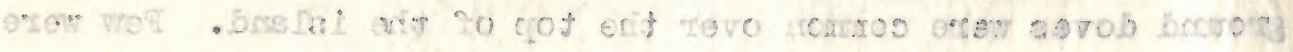

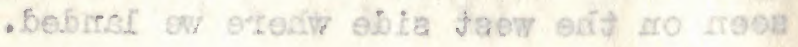
as recimetcioe

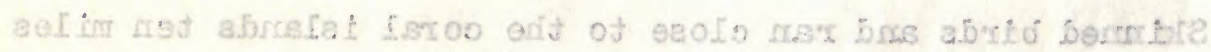

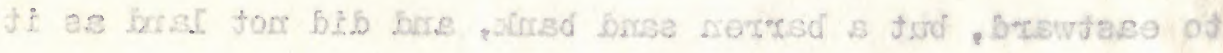

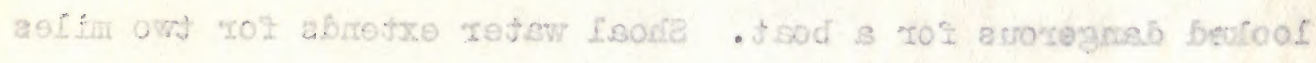
- obla xedisto no da to

IS redinetgoè

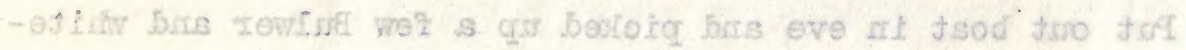

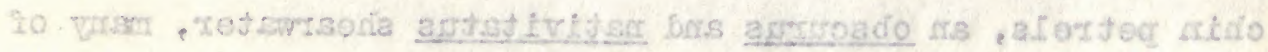

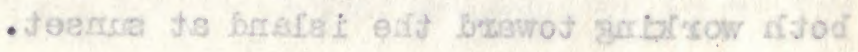

\section{es vedimeterge}

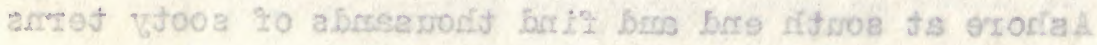

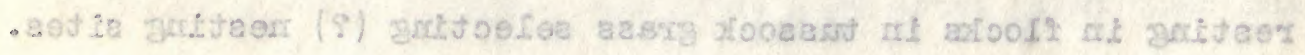

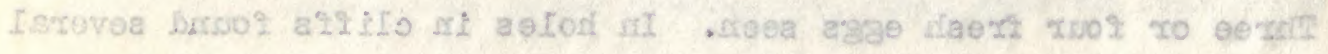

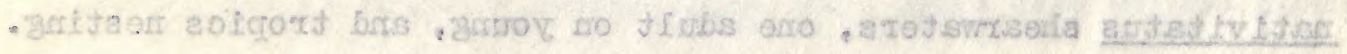

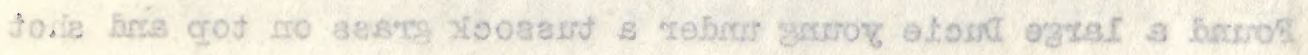

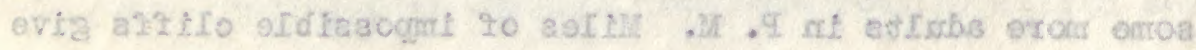

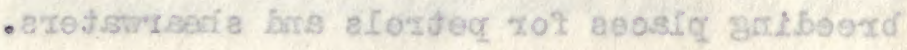




\section{September 30}

Found the fresh water stream in Liau Island wrongly located on chart and anchored over Sunday.

\section{October 2}

Ashore on Hatutu again and get more birds.

\section{October 4}

Stand out to north about twenty miles to find where the obscurus shearwaters go every morning as they pass the vessel at dayligint with the lesser noddies and boobies all headed that way. Twenty miles off find a large flock of lesser noddies and a lot of obscurras, and I put the boat out in a choppy sea and worked down on the flock winich was resting on the water every few minutes and then taking wing again to fish. Before getting in gun shot the birds were off the water and I failed to get a shot, though picked up a single Christmas shearwater as returning to vessel.

\section{October 6}

On Hatutu again and I get two rail and Louis got one yesterday. They seem to keep to the brush patches and are very wary, running along through the brush very rapidly. One missed at ten feet with the auxiliary ran awey and cut across 
$\cdot S-$

\section{os. $\cos \operatorname{sic} \theta$}

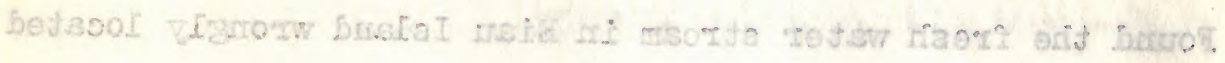

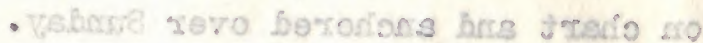

\section{S roojotoo}

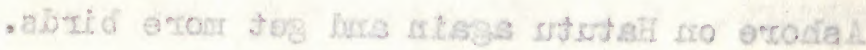

$\$$ xecioso

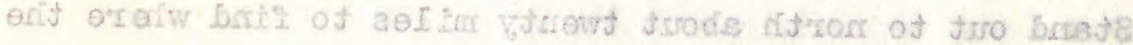

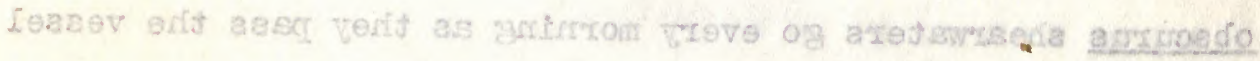

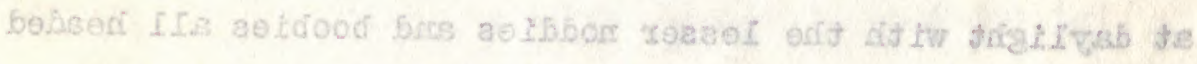

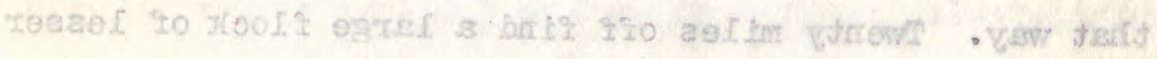

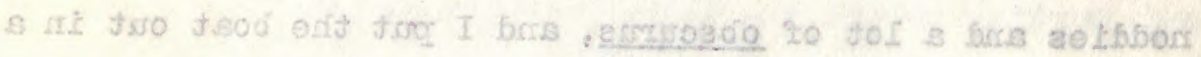

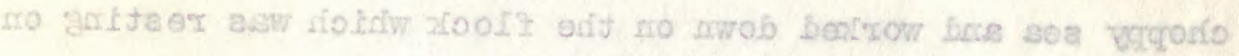

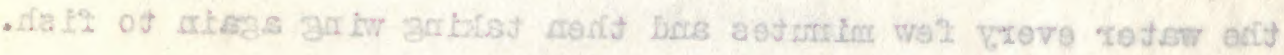

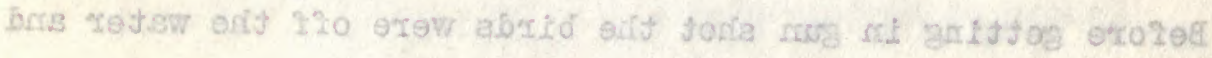

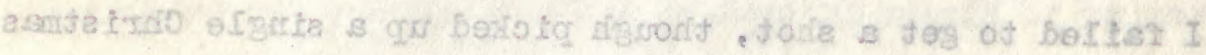

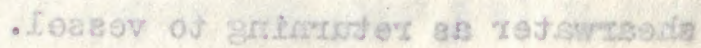

\section{(2) Todotod}

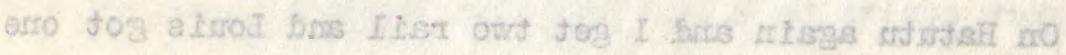

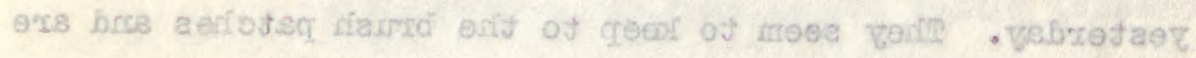

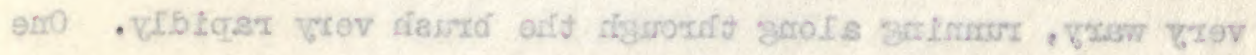

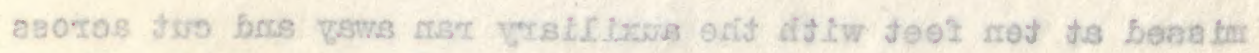


an open spot, raising a foot or two off the ground a couple of times, but seemed feeble on the wing and preferred his feet to wings for escaping. The lesser frigates seem to nost princlpally along the top of the island on the leeward side just below the top where the wind is not strong, but the frigates nest in bushes from near sea level to near the top. The lesser nest on the ground principally or a few inches above. Lesser noddies nest with the redfoot boobies in trees, and the fairy terms are seen often sitting on lesser noddy nests and probably use them for nesting purposes, though fow of elther species are nesting now. Many of the lesser noddies sit and rest on their nests though not asing them otherwise, while in the trees nearby sit many others. By one clump of trees this morning a dozen or more lesser noddies were resting in bushes out of the strong wind and a single bristle-thighed curlew was standing near them with a couple of frigates within a few feet in the bushes and dozens of redfoot boobies and terms in the trees.

On the cliffs at the north end of the island I found two pair of Christmes shearwaters sitting on a ledge outside of the ceve that they expected to use for nesting purposes later. Jany spots were seen where the shearwaters went into the volcanic cliffs to lay, but in all cases the nests were in out of sight and impossible to reach. 


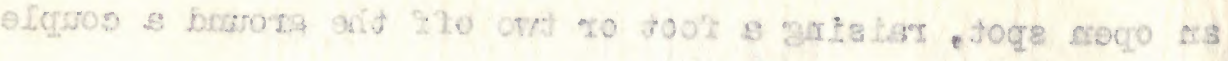

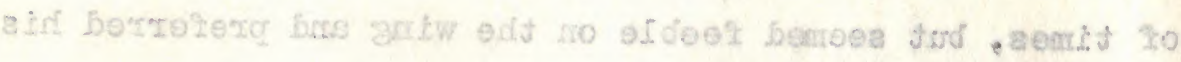

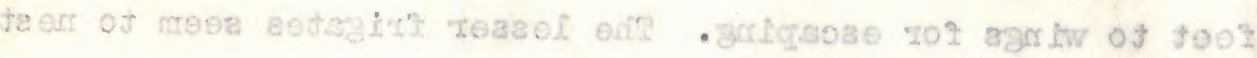

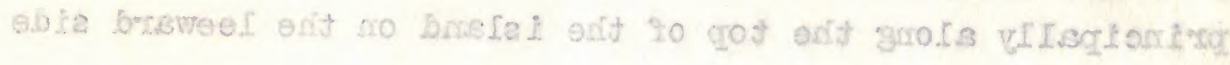

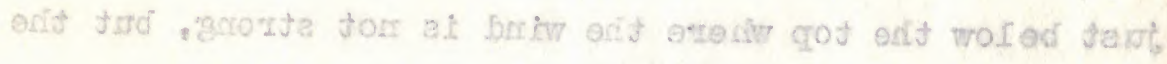

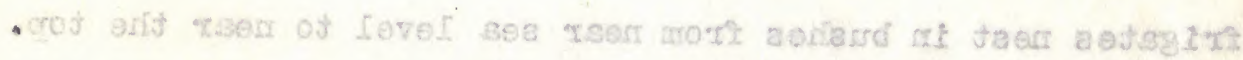

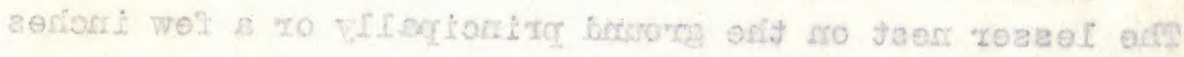

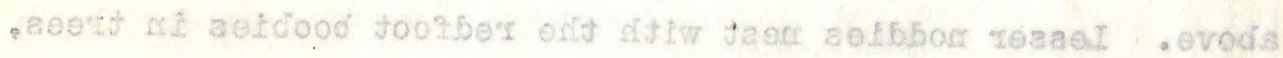

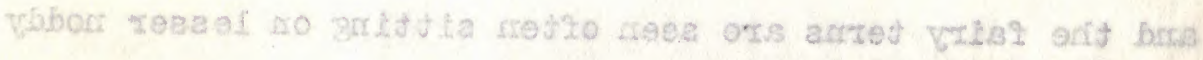

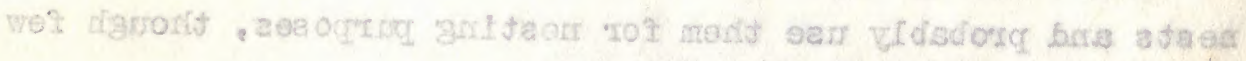

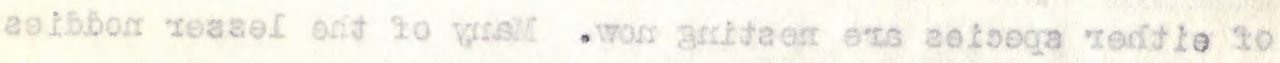

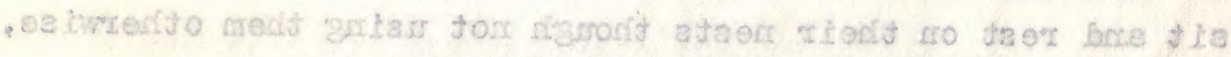

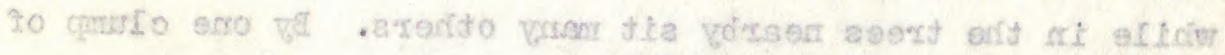

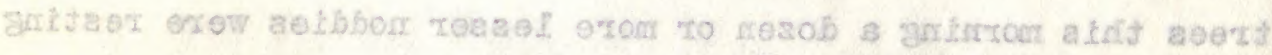

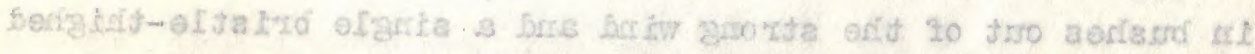

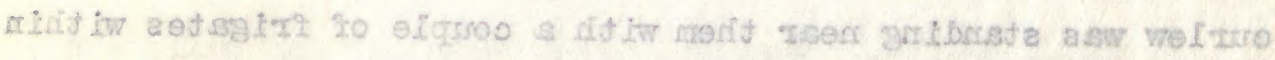

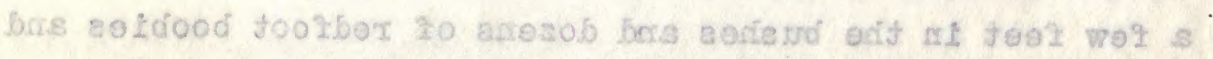
- acety enfs mi anved

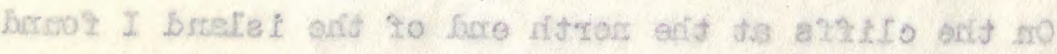

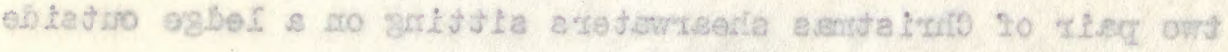

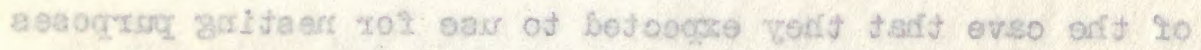

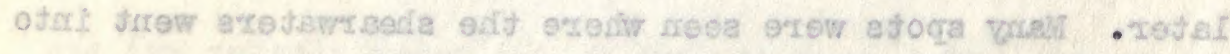

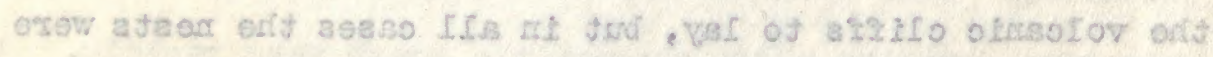
- fisses of eflieaocmi bins trigta to two enz 
Sailing about wi th the numerous redtail tropies I saw a yellowbill tropic go into the cliffs and light and sail again. A couple of yellowbills taken have yellowish tail feathers instead of white. Found a fairy term egg on a cliff resting on the rough lava rock wi thout a twig to show for a nest, and see several noddy terns sitting on rocks over the top of the island,--in all cases a few grass stems for lining of the nests which they are getting ready to use. Redfoot boobies sail over the top and light in the bushes to tear off twigs to build their nest of. One failed to tear off a tough branch, so shifted a little lower and plucked an easy ferm stem which he carried off. Golden plover as well as a few curlew hane around the top of the island, while on Eian wandering tatlers are often with the plover and curlew in the open sheep range on berren top.

On the 2nd went to south end of kiau and saw many sheep and twenty or more cattle and several burros. Pigs are cormon and not wild. I could have shot many had it been desirable. A few chickens are seen, all the roosters being of the same reddish color and size, the hens keeping more under cover and I saw but one.

October 7

Anchor at Iiau again by water for Sunday. 


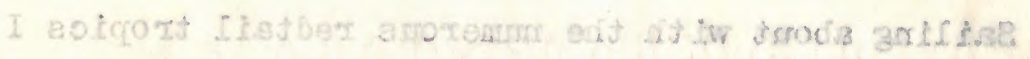

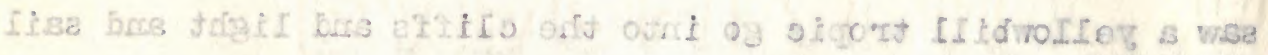

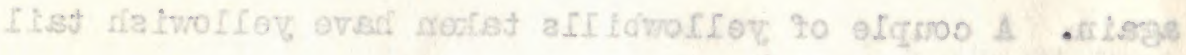

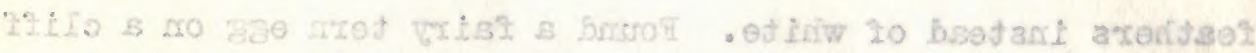

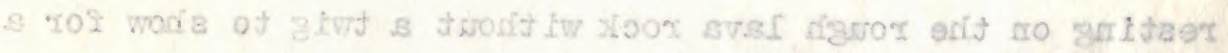

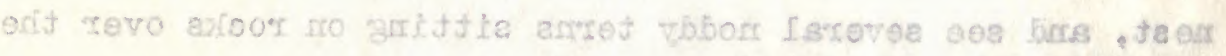

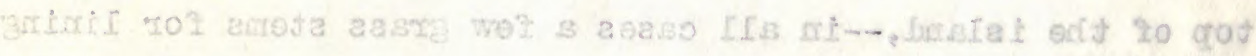

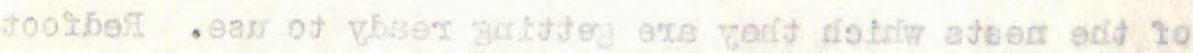

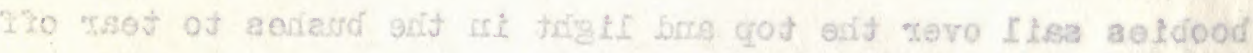

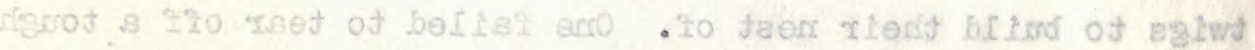

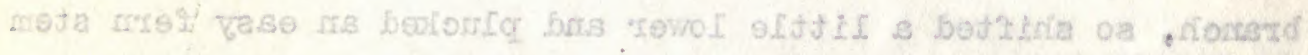

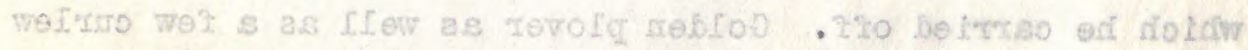

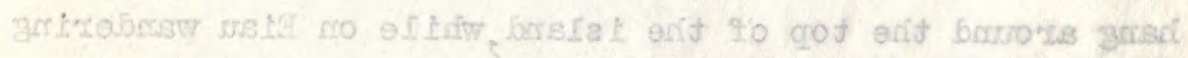

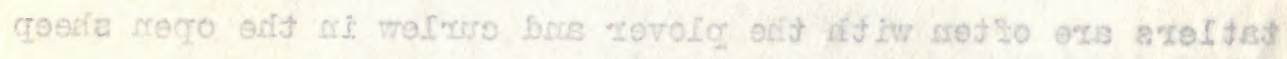
- goú mexrad ro egriar

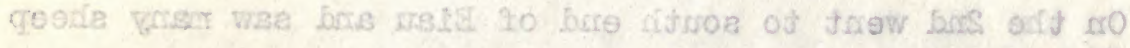

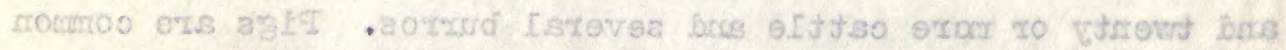

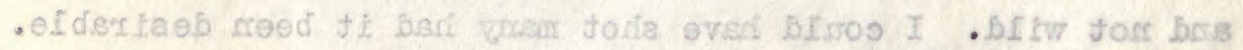

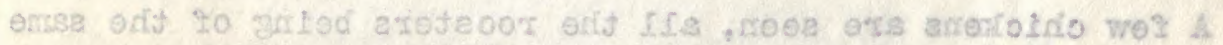

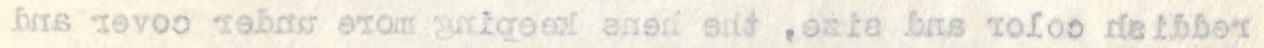
. erro jarci wea 1 
October 8

Sunday in Biau at anchor.

October 9

Collect a few blue ternlets along the shore and get over to Hatutu in eve. Find a wedgetail shearwater in hole on top under a rock and get a rail in dry bushes, as well as doves.

October 10

Run out twenty miles to northwest and find big flock of fishing lesser noddies and some shearwaters, but birds flew about and I get but three obscuras and few blue ternlets.

\section{Oetober 11}

Ashore again and find the wedgetail shearwaters' burrows near east end at top of cliff. Two birds in several holes and others go too deep to get. A dozen Ducle shearwaters fly at one time over island. Saw but a couple of white-chin petrels off shore other day and fow Bulwers.

\section{October 14}

Pick up Quayle and go into Taiohae for water. Quayle has twonty pigeons and sixty-five other small birds. Paroquets, fow flycatchers and a rail. 


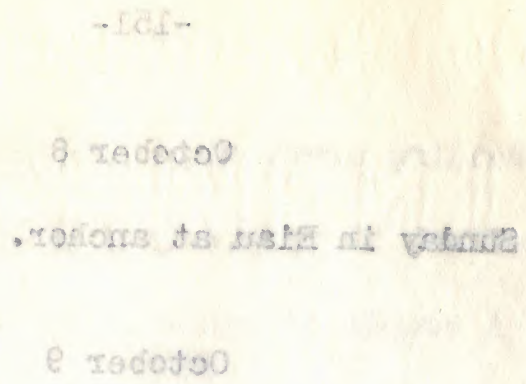

\section{II. rocodoo}

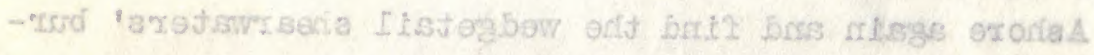

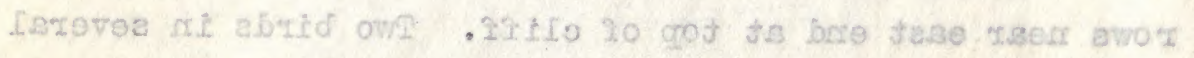

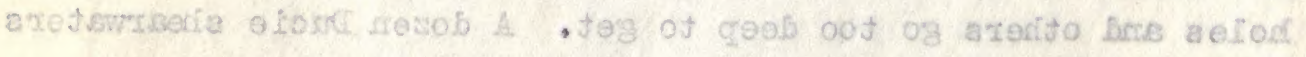

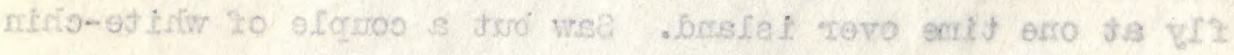

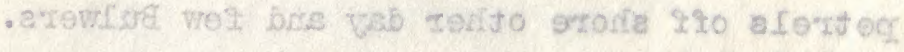

\section{A sodostoo}

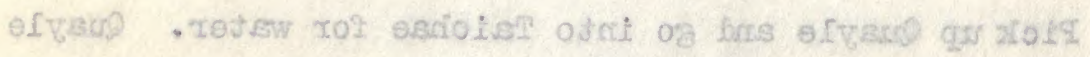

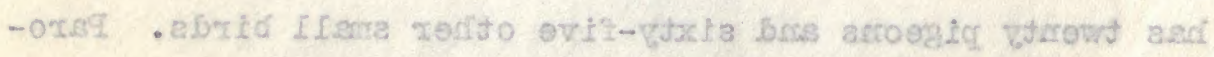

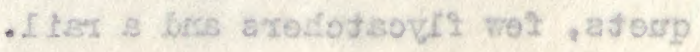


October 15

Sunday at anchor at Taiohae.

\section{October 16}

Leave Taiohae and go around and pick up Quayle's guide, who takes us to cañon on west side of island where pigeons are common. In P. M. Quayle takes guide and goes up canon for night, while I go up on ridge and get seren pigeons, most of them from trees near head of a canon where they were feeding. Hoarse call "Craaal" reminds mo somewhat of crow, and flight is similar, though wingbeats slower. They sail a lot with set wings, and one was noticed to drop down a thousand feet like a hawk or eagle on set pinions.

\section{October 17}

Quav lo back with thirty pigeons and fow flycatchers and paroquets.

\section{October 18}

Skin birds.

\section{October 19}

I go up canon which ends in a high cliff and find fow flycatchers and see a few pigeons and two or three nests which are built of small twigs and put in crotches of small limbs 


\section{AI rodosso}

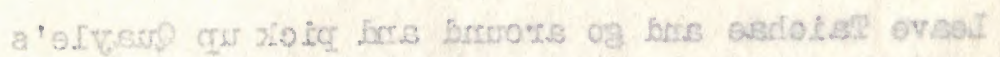

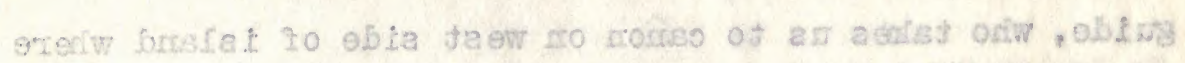

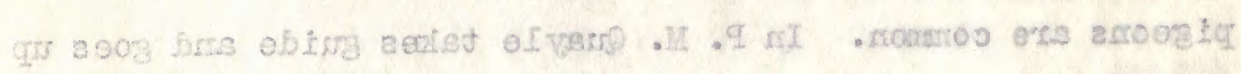

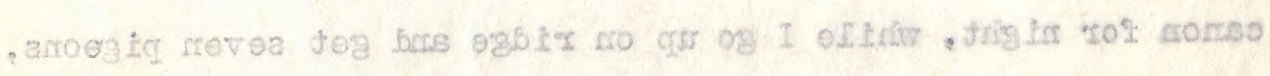

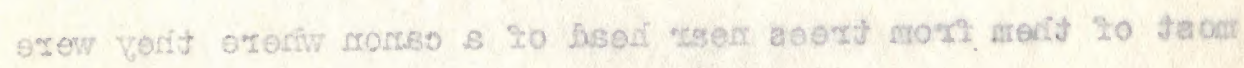

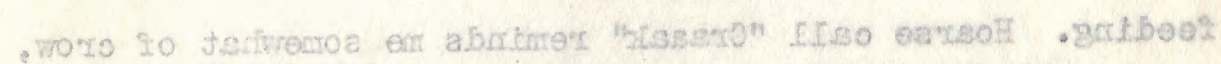

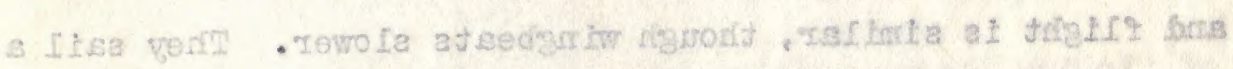

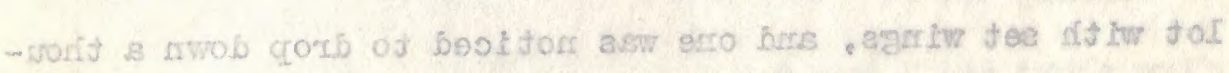

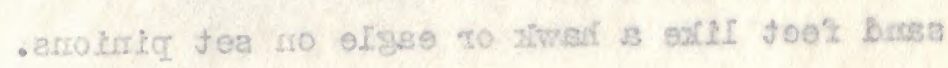

\section{PI Iedojoo}

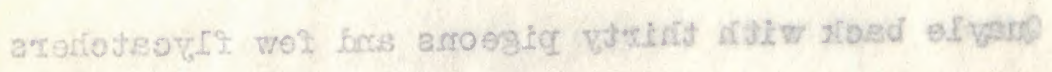

- asesporeg bina

8I. rodotoo

$.3 b 516$ abie

\section{eI zadotso}

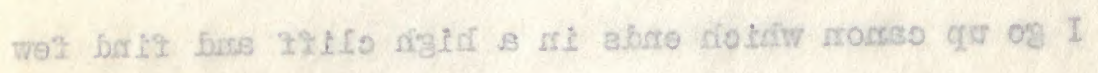

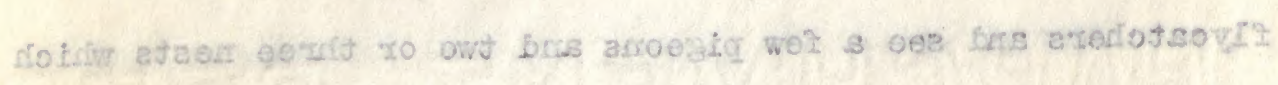

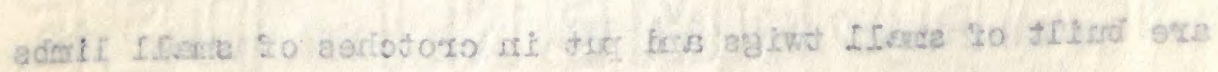


on little branches high up in tall trees. Climbed up cliff above one and looked into it and saw it was flat but contained nothing. Quite a collection of sticks, mch more material than a dove uses. Saw one nest in similar location that belonged to a dove probably. Pigeons fly over canon high up and light in trees on sides of cliffs. Call occasionally the hoarse call and a sort of gurgling, deop cooing also. Groves of tall trees in bottom of camon most frequented, but fly out around in other canons after food. We got about forty and reduced the number in canon noticeably. The guide told of getting forty in a day one time in this canon.

\section{October 20}

Up canon and get a few flycatchers and but ono pigoon. Quayle gets a dozen, haring stayed all night. Fairy and lesser noddies and a few noddy terns are nesting in the canon on the two first in tall trees along the bottom of canon. Fow yollowbill tropics fly along about cliffs also, and a wandering tatler is seen high up along the water which flows but a short di stance and goes in ground again, though a small fish and shrimps are in pools that evidently retain water all the time.

\section{October 21}

I go up the canon in Marquisene Bay and find plenty of 


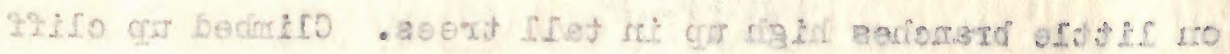

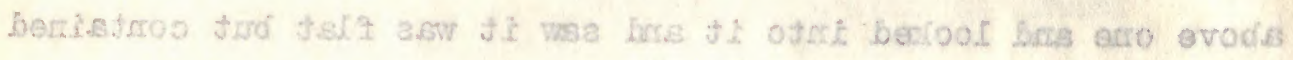

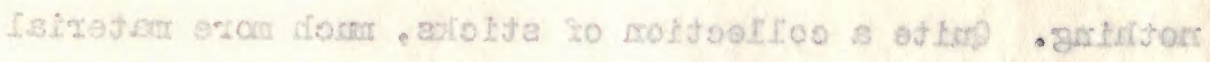

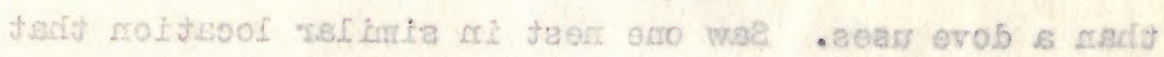

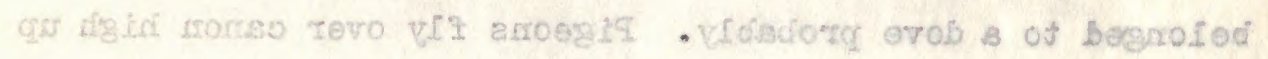

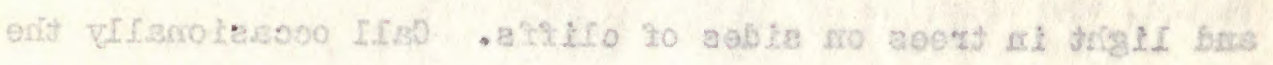

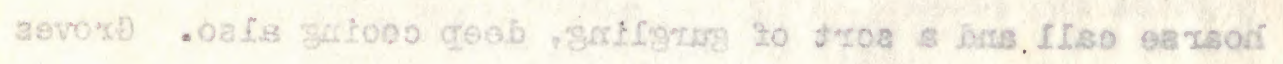

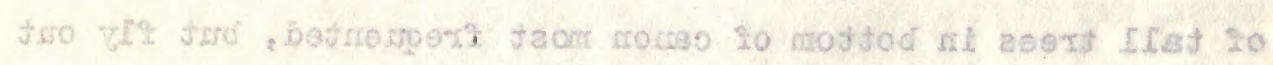

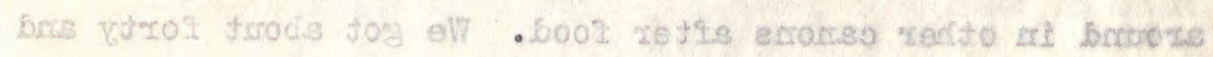

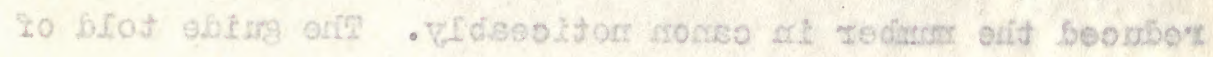

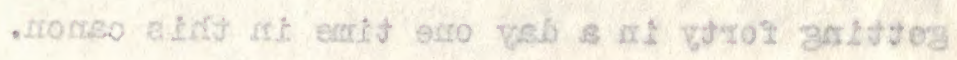

\section{OS xอฮั0\$00}

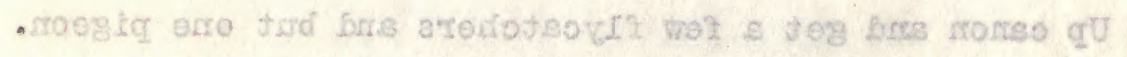

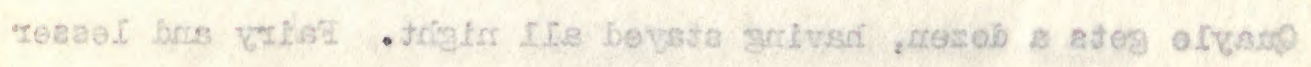

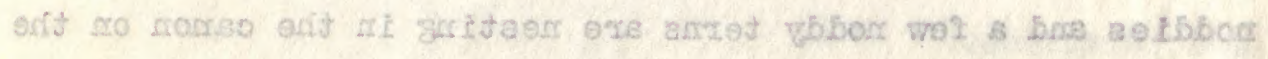

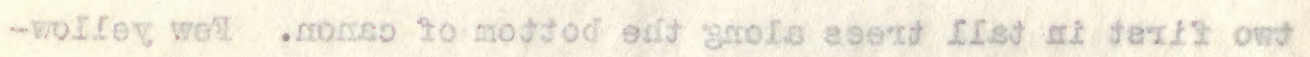

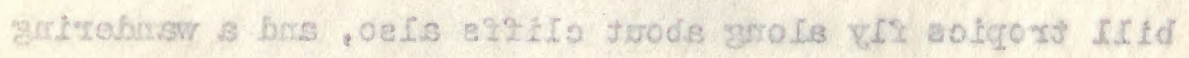

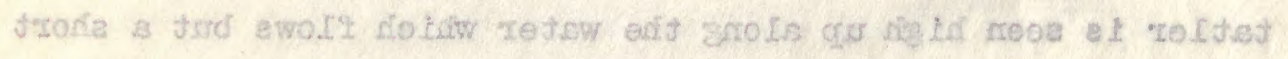

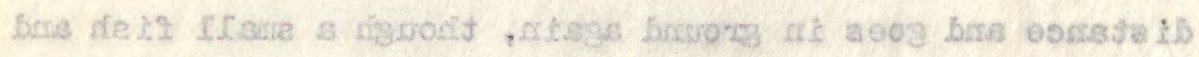

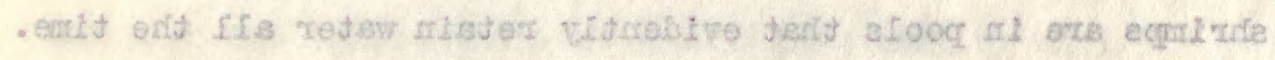

\section{IS redojoo}

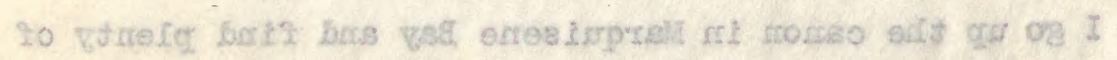


water but no pigeons or flycatchers or paroquets, which we found in the canon with the pigeons first visited. Go up on top of ridge and get into tree ferns, but find no pigeons or flycatchers and few warblers or doves, though water in several streams. One curlew and a half dozen golden plover seen. Saw eighteen cattle in one herd and a few others scattered along. They were fat and good-looling, while lots of goats and some pigs. Sail at dark for Typee Bay.

\section{October 20}

Off Typee at seven A. M.

\section{October 22}

\section{Sunday.}

\section{October 23}

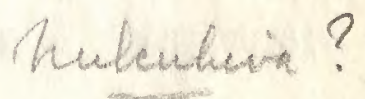

Ashore for birds, but rain during day makes traveling difficult. Warblers singing and couple of doves heard and few swifts. No flycatchers, though I went far up canon.

\section{October 24}

Get seven herons rowing along shore to south end of island. In $P$. M. tako bif boat and sailors and get a dozen blue termlets and few young lesser noddies fishing. Then up 


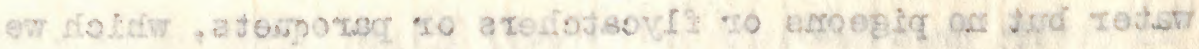

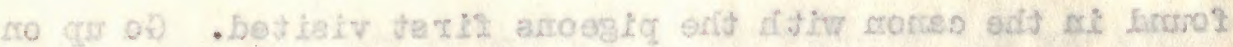

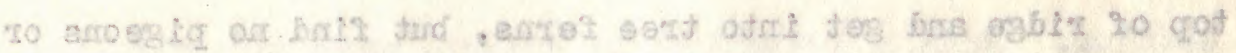

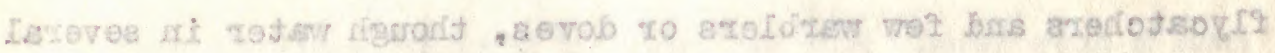

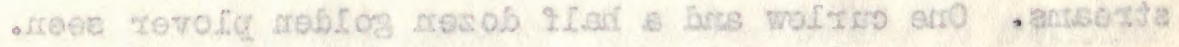

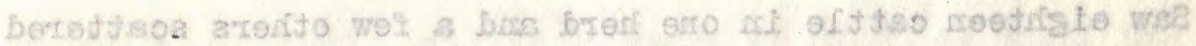

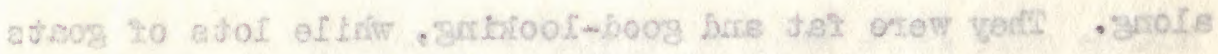

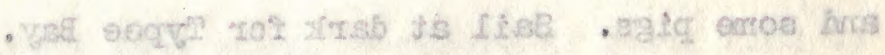

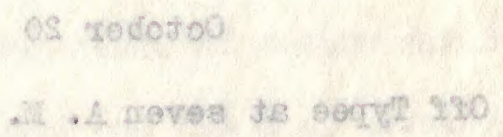

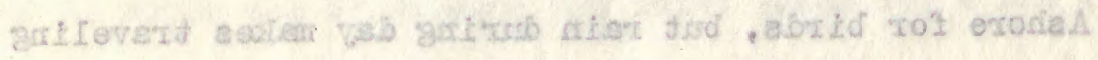

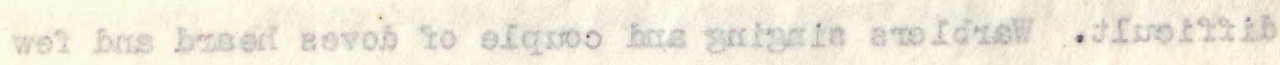
. AS zodoto

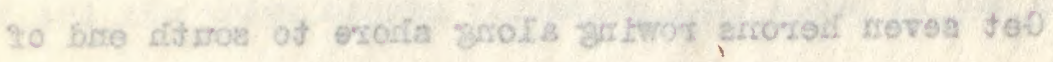

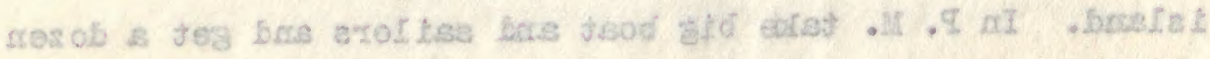

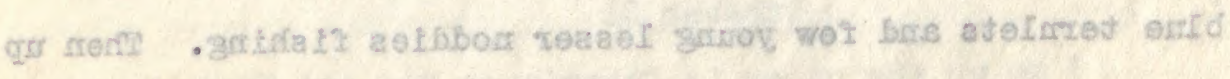


on south point of island where boobies nestinf and frigates roosting and get fow white boobies from colony after looking over a hundred or so. Several chickens about colony and a rooster shot had a squid in gallet dropped by some booby. Around to Taiohae, as schooner reported to have mail for us.

October 25

False report, so sail in eve for Fivaoa to land euayle and Jones for a couple of weeks while I go for petrels off Huapu.

October 26

Between Hrapu and Hivaoa and see some birds, but not worth putting boat out, as flock moves a mile or more in five minutes.

October 27

Start engine at five A. M. for Hana Mema Bay. Wind light and reach it at eleven A. M. Ashore in P. M. and find a few flycatchers, doves and warblers, but natives say no redcapped doves here, so go along coast to Hana Iapa Bay.

\section{October 28}

Ashore and find doves and few warblers and get one of 


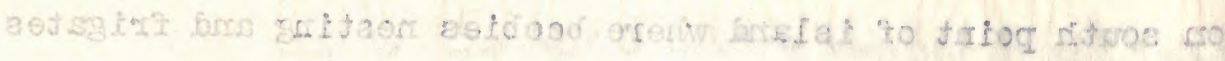

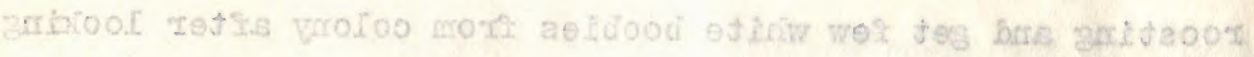

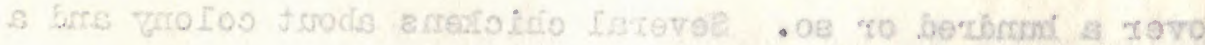

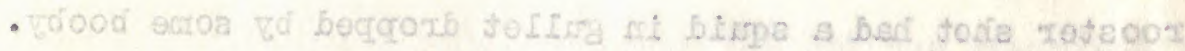

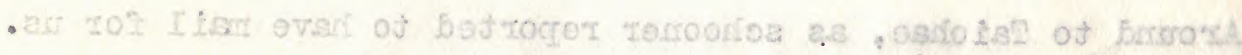
as tedojoo

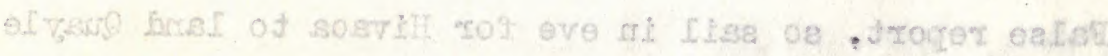

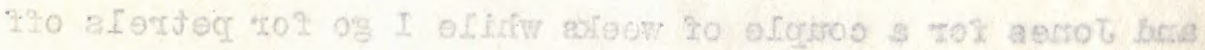
- Mrgersech

as rodotos

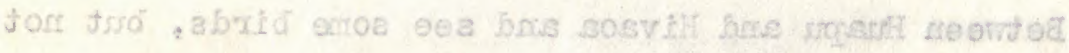

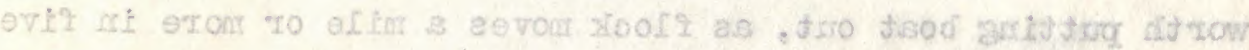

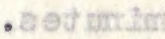

\section{RS reviotod}

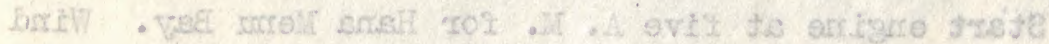

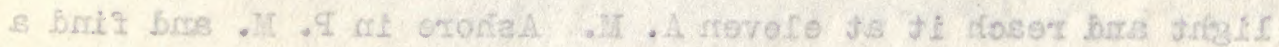

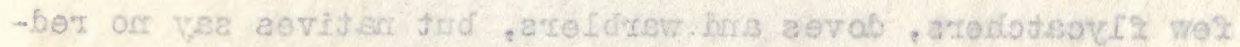

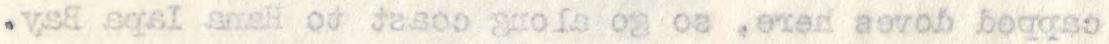

8S $2000+00$

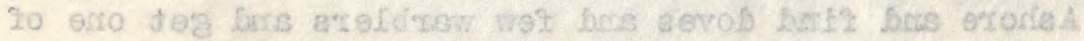


three kingfishers seen. Ieave Guayle and Jones to collect birds and plants while I go to Huapu for petrels.

\section{Octoper 29}

Sunday and heavy rain last night starts weter pouring over cliffs in every little canon. Leave in eve for Fatuhala, fifteen miles from here, before goins to Huapu.

\section{October 30}

Go ashore on Fatuhuka and find ground doves scarce on Iow parts of island and too risiy trying to get on top. Get three doves and see lot of young frigates ready to fly and fow young redfoot boobies in trees. Few plotus and couple of red-tail boobies flying about. Got an egg of blue ternlet on cliff and others fly along by their nosts. Hang in air and drop slowly with spread wings along face of cliff. A curlew heard and couple of reer herons seen.

\section{October 31}

Iay off Huapu and shoot a few Bulwer petrels and see only a couple of white-chinned, which I get. In eve man across to Nularhiva, where anchor at Maiohae.

\section{November 1}

In P. I. ashore and get eight doves from a couple of 


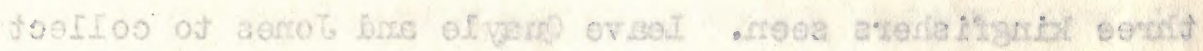

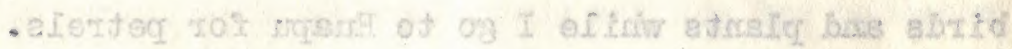

PS medotoo

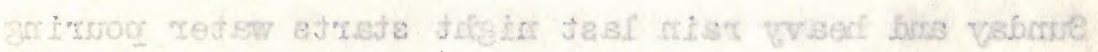

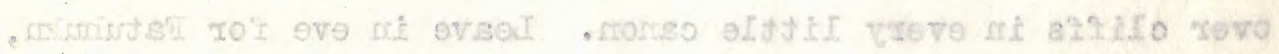

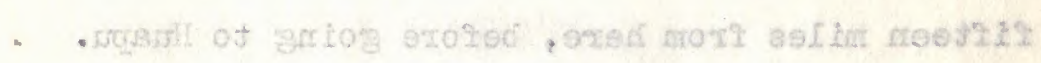
os $200+0120$

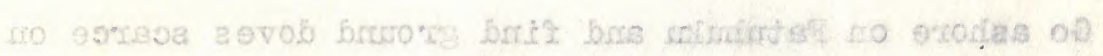

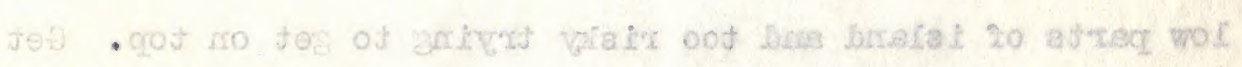

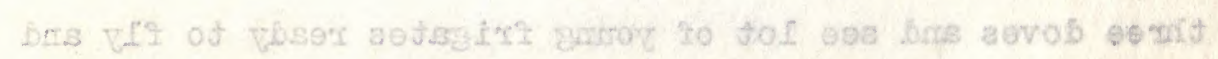

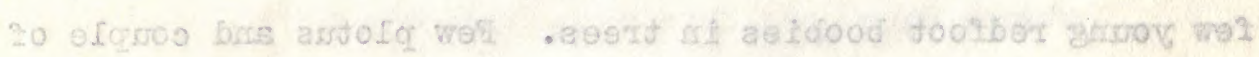

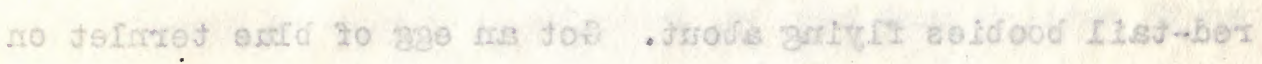

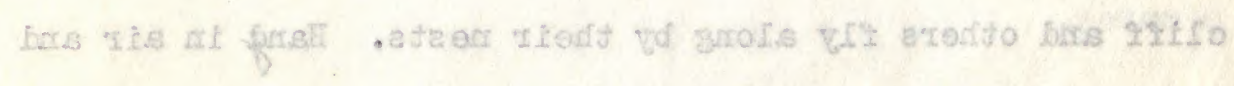

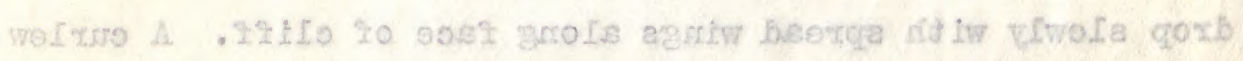

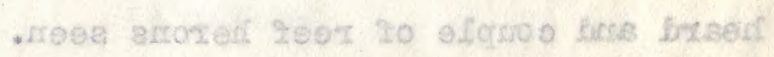

\section{IE tedotso}

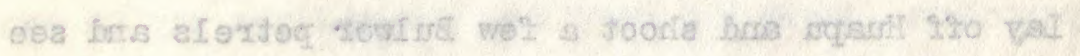

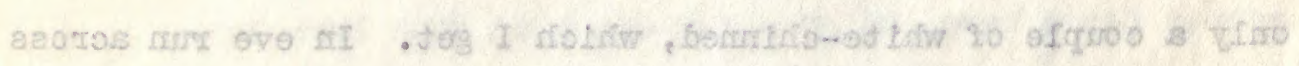

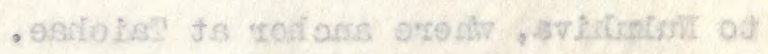
I. Iseingvols

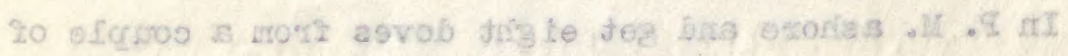


banyan trees in hills where they come at wy calling.

\section{November 2}

Bacr at Huapa and calm sea allows going ashore on sma.ll islet near pinnacle rock which is too rough to land on. Find Bulwers petrels wherever place offers under scattering grass roots for nests. Couple of eggs leid in open, as likely all available spots were occupied by other birds. Only one young just hatched found; many eggs incubated, though some fresh and some sites not yet laid in. Absence of rats makes this islet desirable for nesting. Three downy white-chinned petrels were found, and probably season is earlier for this species, as fewer birds are seen a.t sea than a month ago. A few sooty terns were nesting. Fow fresh and incubated egfs and young birds. Took about 75 Bulwers and three whitechins with photos of nests. Pan around coast and anchored.

\section{November 3}

Skinned birds in A. M. and ashore in P. M. and got few . birds.

\section{November 4}

Ashore and got few doves, warblers and flycatchers. Leave for Hivaoa. Two colonies of twenty or so swifts seen nesting on cliffs along shore. High cliffs nests inaccessible. 


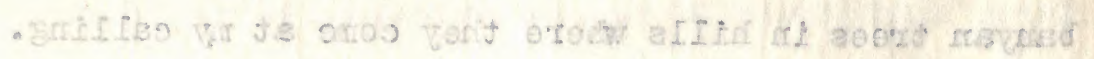

S xodmevoth

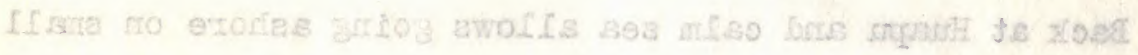

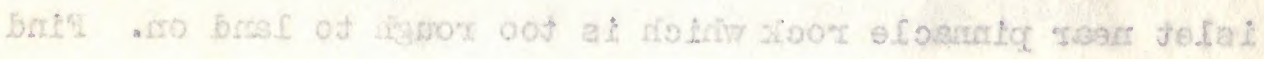

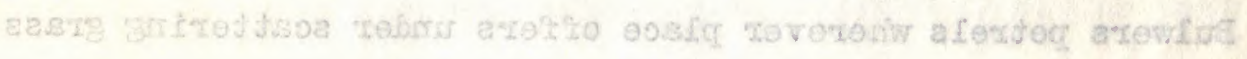

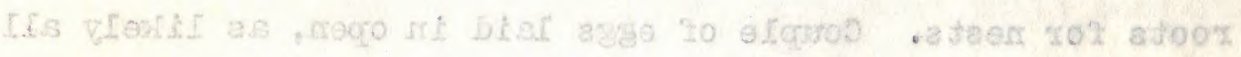

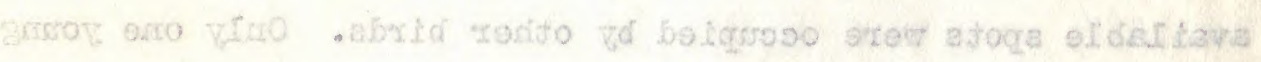

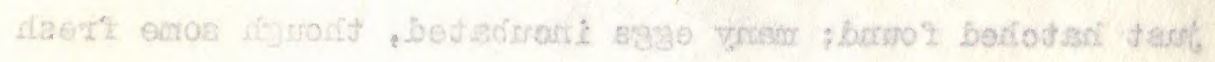

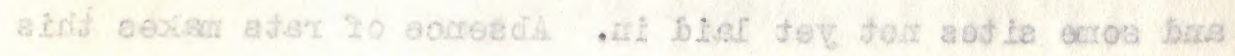

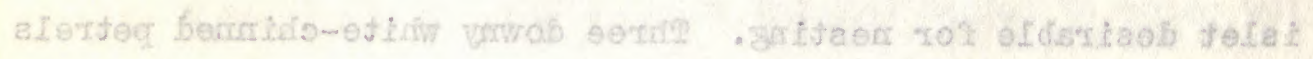

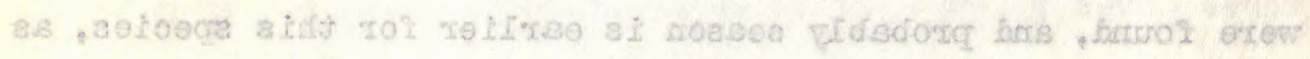

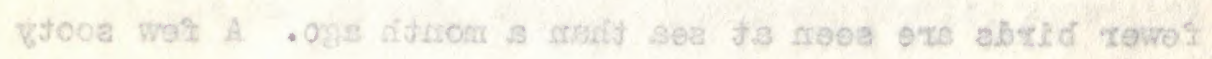

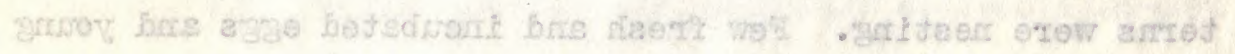

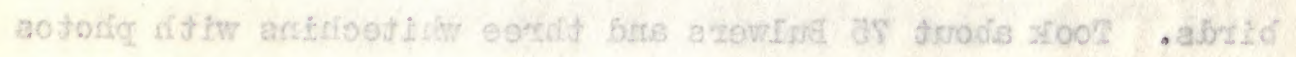

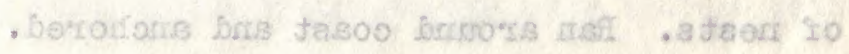

(4) zedmerom

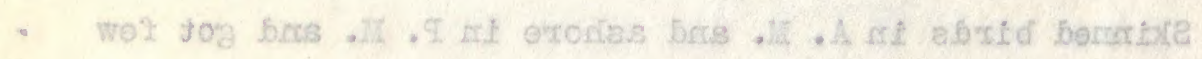

$.85 \times 26$

A rodituevall

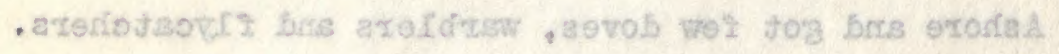

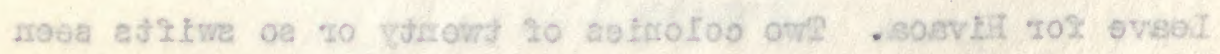

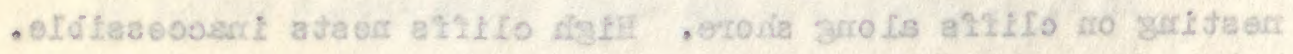


November 6

Ashore for few hours at Hana Memu and get few flycatchers and comple doves and warblers. Few fairy terns in canon also and a couple of yellowbill tropics seen.

\section{November 7}

A shore at Hana Iapa and up hill to Quayle's camp and find he has a dozen redheaded doves taken last woek. I got a couple along trail and get a couple of kingfi shers also. White-headed doves the commonest by far and few red-headed ones. Not as many as I saw at this point in January, 1921, when here on 'Hoana'. Take a native to show us trail to top of Fatuhuik and leave at night, four A. M., for there.

\section{November 8}

Quayle ashore with native and sailor and gets about fifty ground doves, finding no warblers. Doves in poor shape, possibly not enough feed for all, as there is little grass. Frigates common on top and some boobies of both kinds. Back to Hana Iapa at dark and get our mail from boy sent to Atuona for it. Leave for Uahum at dark.

\section{November 9}

Ashore and find a few flycatchers and warblers, but doves scarce and scattering. Quite a lot of swifts feeding 


\section{$-925-$}

2. reciriovoli.

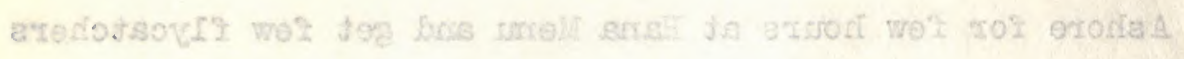

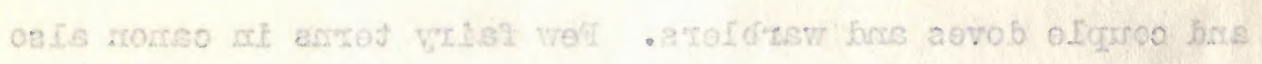

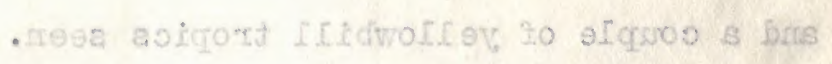

Y reditrevoll

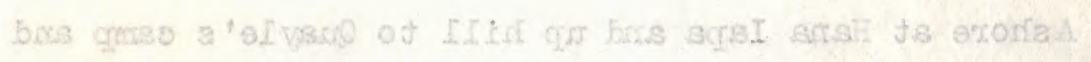

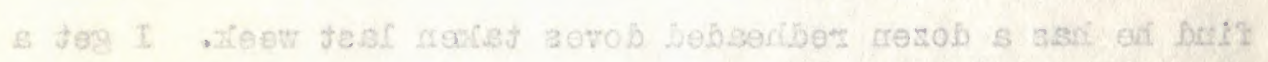

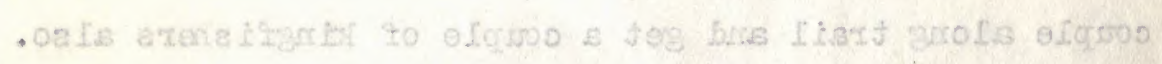

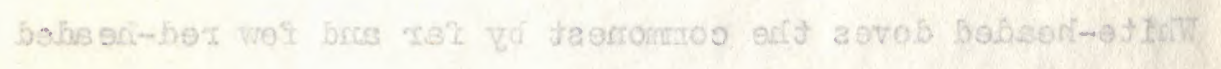

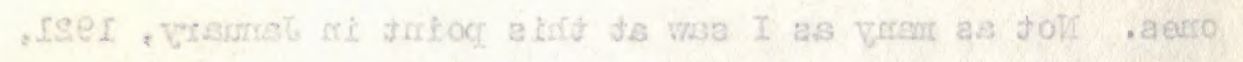

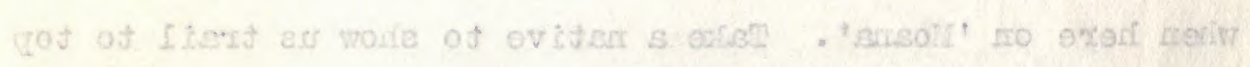

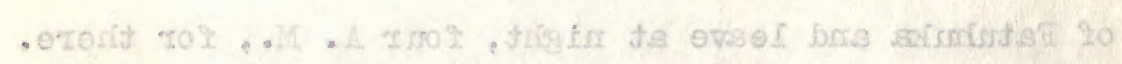

\section{8 rediuevolk}

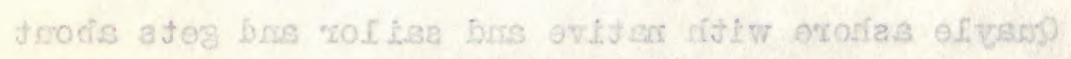

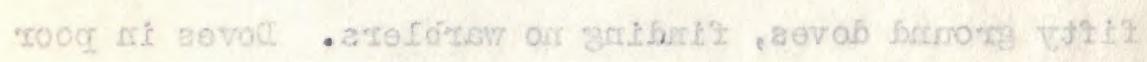

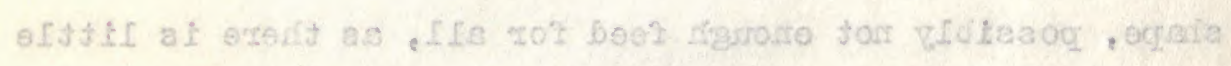

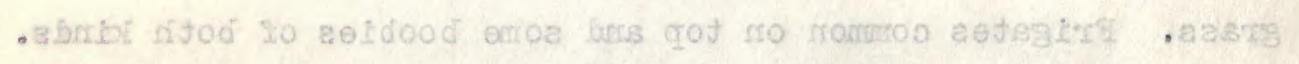

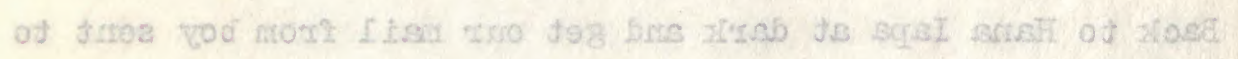

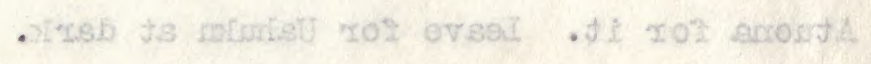

\section{e recingatis}

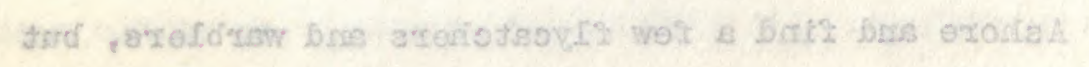

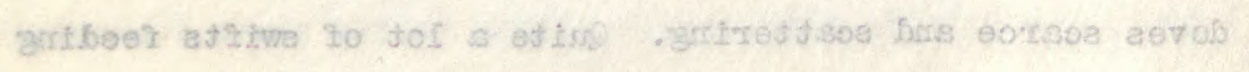


over dry, brushy canon and on top of one ridge others feeding. November 10

To top of ridge and find doves scarce, though one once in a while seems to rise over ridgo to feed in wooded canons. Flycatchers and warblers not rare, the warblers boing partial to pandans trees. Got a half dozen chickens along trail as they were feeding on the ripe guavas winich on top fruit close to the ground, permitting the birds to pick at the fruit from the ground.

\section{Hovember 11}

Go to islot close to anchorage and see dozens of swift nests glued to rocks on leeward side of island. Two or three or more up to dozens of nests are in one place, and many rociss from near shore to near top of island were used for nostine sites. Nests were of a reddish moss, probably taken from rocks or trees well toward top of island. This probably led natives to think the birds had red breasts, as we were told that on Iy on this island were the red-breasted opeias to be found. Quite a mamber of downy sooty terns were found. A singrle obscurus shearwater and a single Bulwer petrel also was takon, both from nests with incubated eggs. Several young 


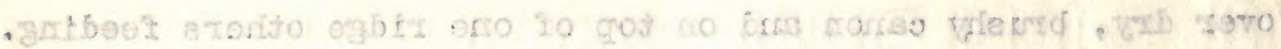
QI. Tedimevoh

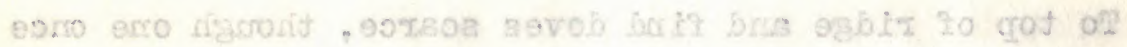

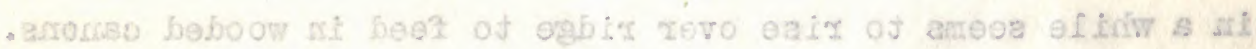

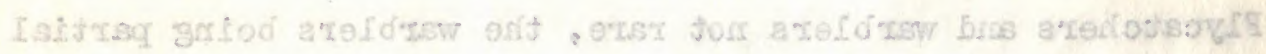

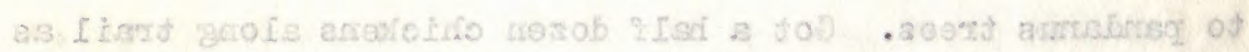

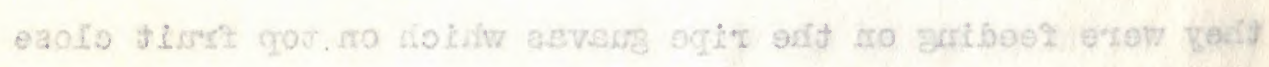

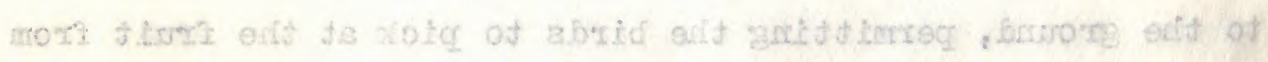
- orssoung encit

\section{If tounevoit}

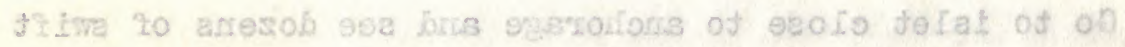

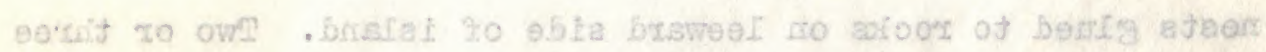

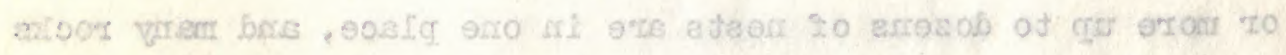

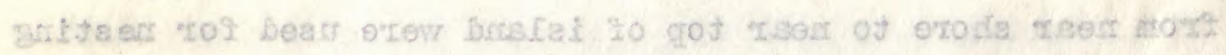

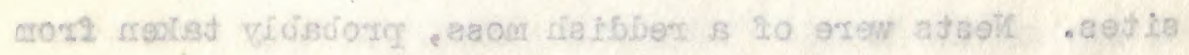

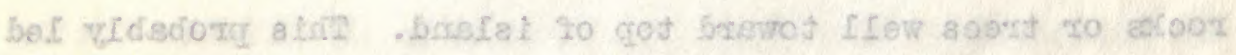

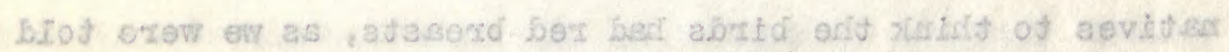

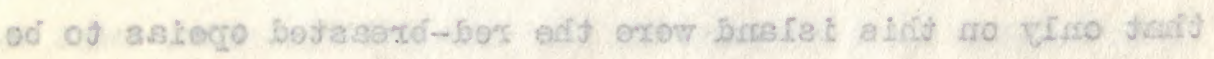

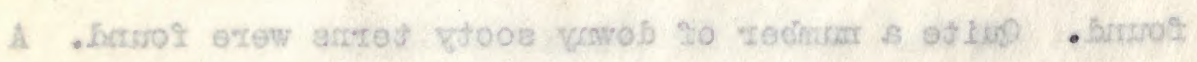

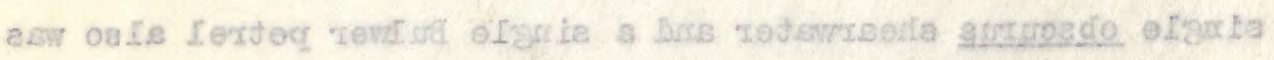

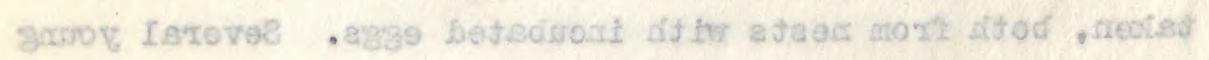


reef herons nearly ready to fly were seen and some old ones taken. One well built heron nest was seen, but was empty, built under a rock overhanging on a cliff. A few blue termlets, as well as noddy terns seen and both likely nesting. Leave at noon for Taiohae, as steamer with maị is expected tomorrow. 1.90 by 1.35 inches, egg of P. obscurus pipped.

\section{November 12}

Sunday two P. M. and no steamer in sight yet.

November 13

Sunday at Taiohae.

November 14

Quayle gets a few sooty terns on islet at harbor's mouth. Sail for Uahula at four P. M.

\section{Hovember 15}

Quavle goes inland and gets a few doves and warblers and I go to islets close by. On ono a quarter of a mile long I find sooty terms covering top with most nests containing incubated eggs and many young birds of all ages. Many young dead about colony. I ascend to top by rope twenty feot as up and down all around. Sailor goes up holding by toenails to 


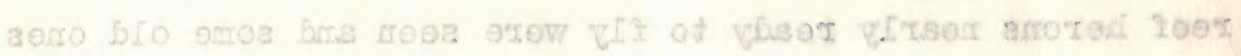

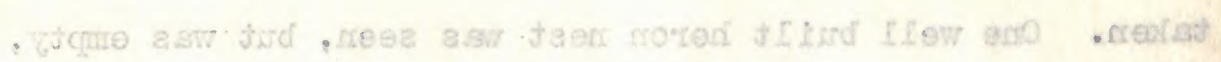

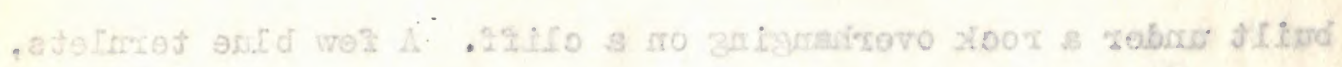

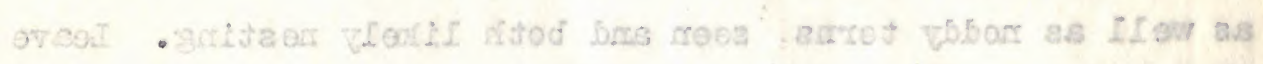

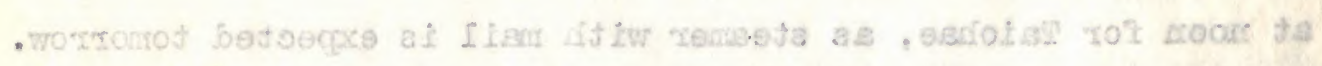

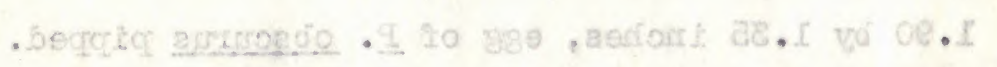

\section{Sf seontevoll}

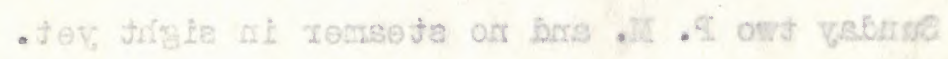

EL veciere wots

- arsiotor te veberue

N. Ioderovols

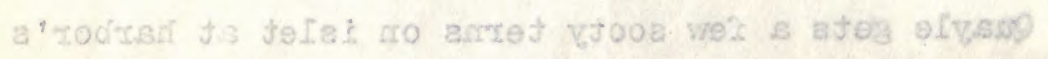

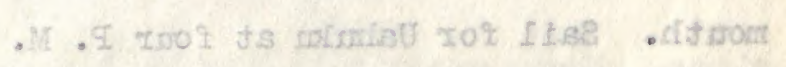

\section{aI recinovoll}

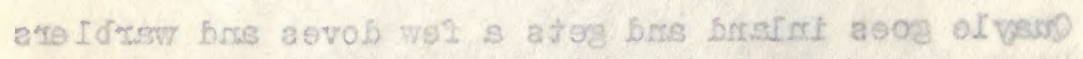

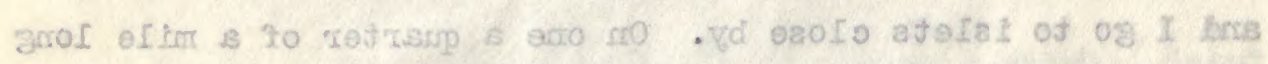

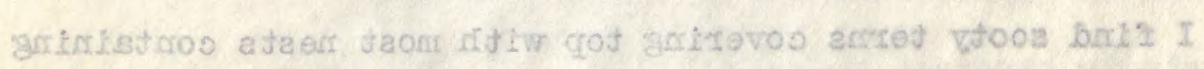

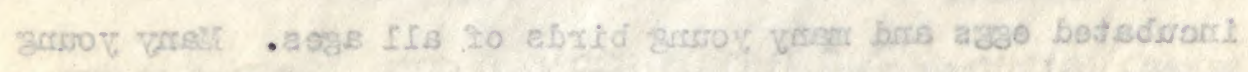

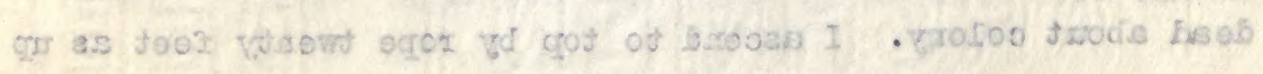

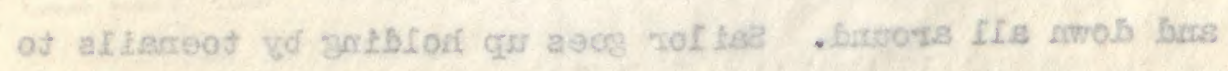


place rope.

After a couple of hours and getting few fresh eggs we go to another islet a few hundred yards off and find many sooty terns, --young birds flying and ready to $f l y$, with few jounger. Many eggs brolien and rotten lying everywhere. Alons the cliffs were a few Iunatus terns, nests with eggs, three young nearly ready to fly. Nests on bare ground or few pebbles. Under grass roots were found several Bulwer petrels' nests; incubated eggs in most, and in a couple of nests were found young whitechinned petrels and an adult on an incrbeted egg. No boobies here, as a couple of miles from village perhaps and natives come fishing here.

\section{November 16}

Around coast five miles to an islet half a mile off island where Bulwers petrels are abundant, many birds being forced to lay their oggs on the open ground, as suitable sites are all occupied. In crevices in rocks as well as under grass; sometimes three nests under one bunch of grass. Young birds found in several nests and a single dead young white-chinned. found under one grass bunch and the nest occupled by a pair of Bulwers petrels settled down. A couple of skeletons of winitechinned seen, but this species has to nest earlier perhaps to 


$$
\sim \mathcal{L} \partial-
$$

- acgor posife

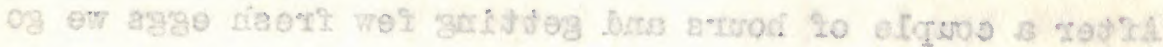

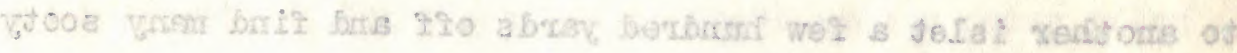

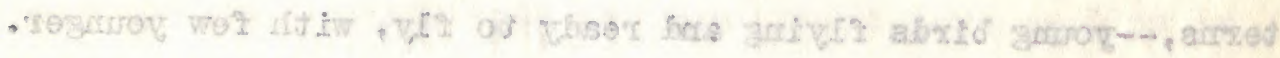

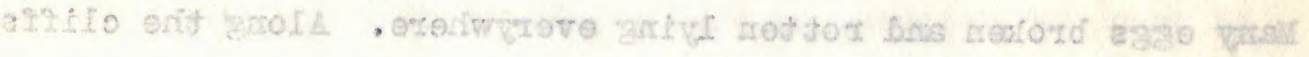

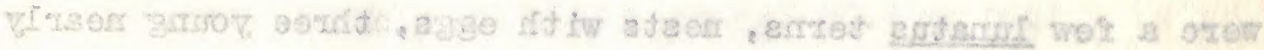

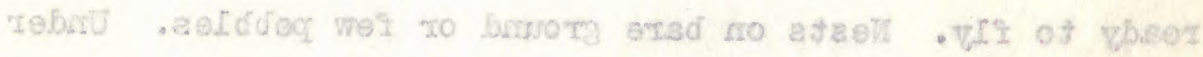

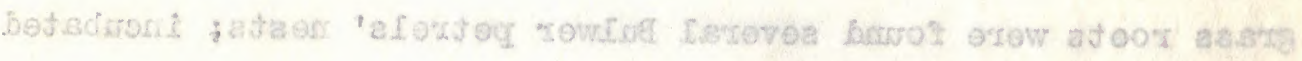

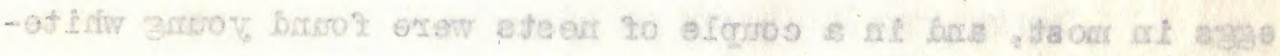

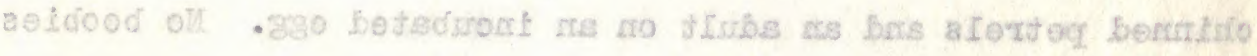

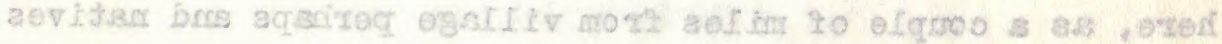
- vrent artialt enoo

\section{af. "xodisovoln}

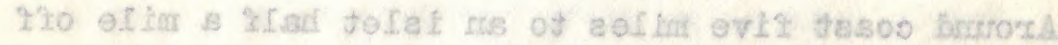

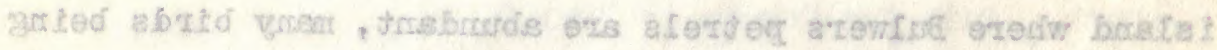

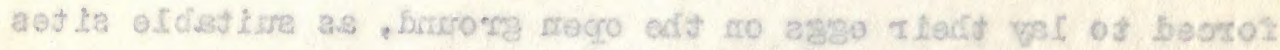
tavisy reburo as. II

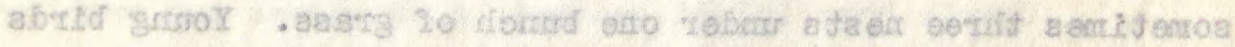

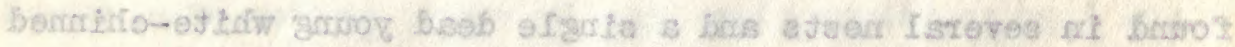

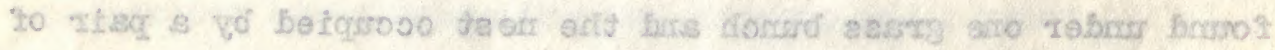

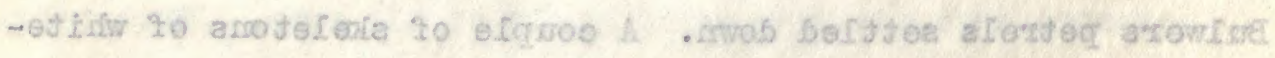

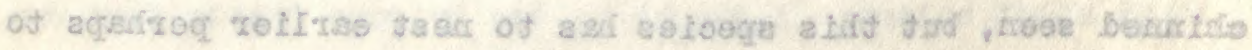


obtain a site. I examined dozens of birds to find those that showed unusual wear on their bellies, fetting several from a hundred or so birds looked at. Sailors gathered a couple of dozen birds and we got some fresh eggs as well as seeing meny pairs of birds in holes where no eggs occurred. A fow blue termlets nest on the island and a nest with a couple of eggs of plotus booby found and a nest of reef heron seen well built under rock, -18 inches wide and 6 inches deop. It was empty, though birds hung around and I photoed, putting a rotten sooty tern, a booby and petrel egg in nest as accessories. Quite a few sooty terns nest here also.

\section{November 17}

Anchored again in Shavey Bey yesterdey, and today went up to ridge and along it to near the mountain top. Warblers feed in grass along top and swifts al so feed along ridge, while doves flew over and sailed out of sight on set wings. Found a banyen tree loaded with fruit and got several doves in morning and again in eve at 1t. Few fairy terns in trees.

\section{November 18}

Got to Taioha yesterday and took Administrator aboard for Atuona and arrived this P. M. and find two letters from land 


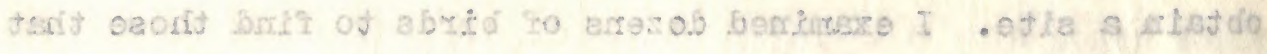

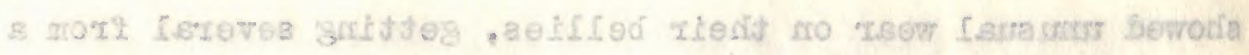

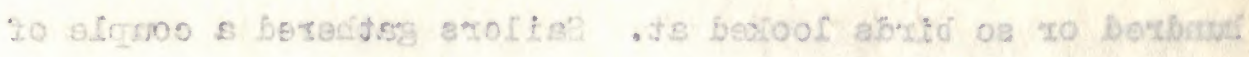

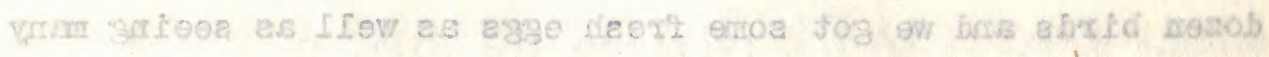

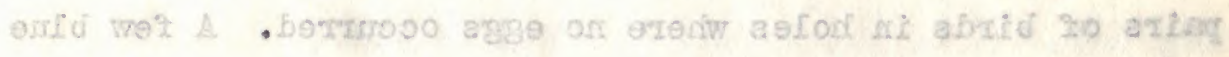

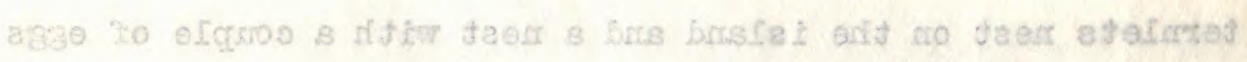

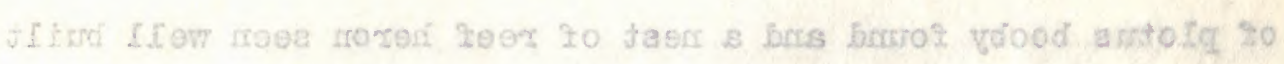

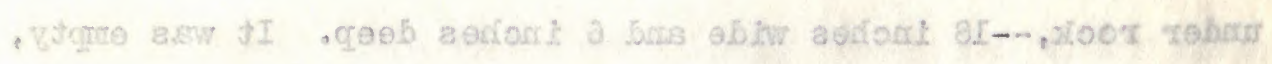
एक

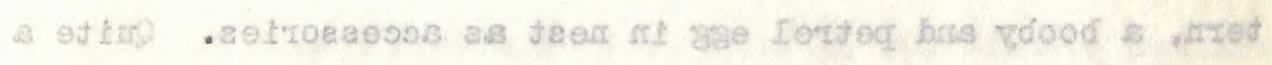

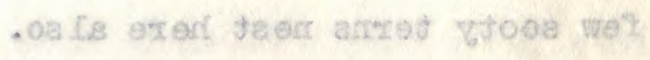

\section{If. Tedinewold}

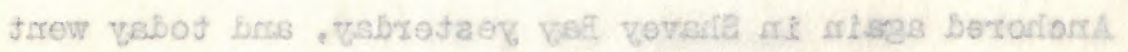

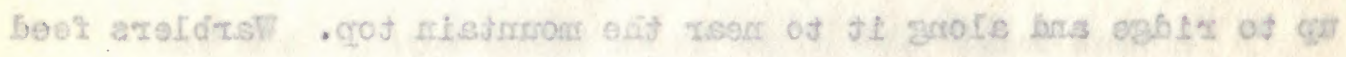

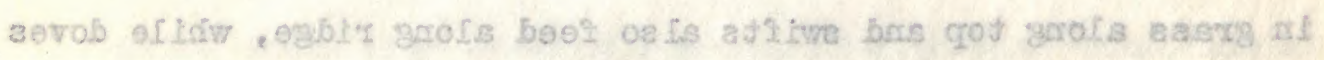

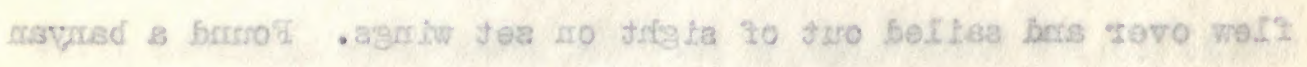

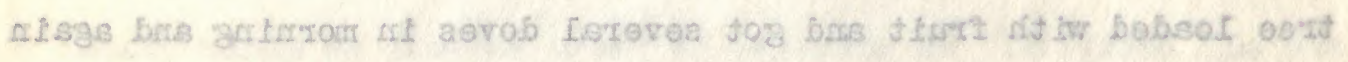

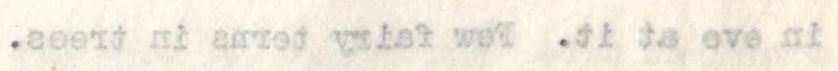

81. sedmeroil

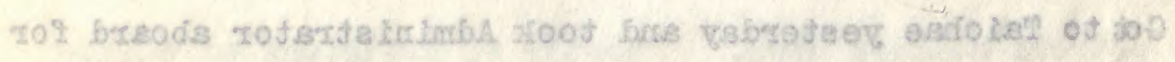

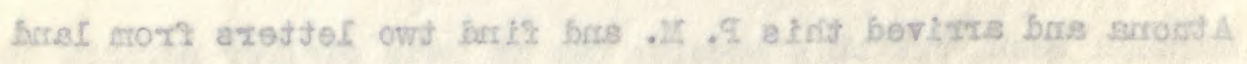


owners here prohibiting me from hunting on their property. Get permission to visit Notane, our next island.

\section{Novomber 19}

Sunday and aboard.

\section{November 20}

Leave Quayle to go up to top of island and we talce one of owners and dogs to Motane for three days. Iand in P. M. and find doves, warblers and flycatchers. Flycatchers the most common and larger than other places. Doves were in bright plumage, mostly males taken and were found largely at a fow bushes with green berries on which they were feeding. \#1733 is number In plant catalogue of bush. Ola nests of warblers and flycatchers were noticed in trees well out on limbs. One young fairy term was taken and several noddy terns with grass in bills were noticed. One noddy was seen flying over dead grass on hillside trying to pick up nesting material while flying, but finally lit for a moment to get a long streamer of grass, with which it 1 low away to pandemus tree. Noddies were using pandems for nesting, as on many other islands, while the lesser noddies were nesting high up in the cormonly used tree. Host lesser noddies were sitting in trees, but few nests being seen. A 


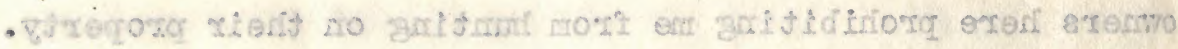

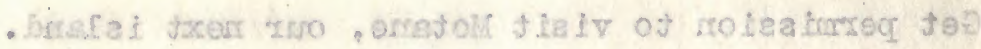

es redmovoti

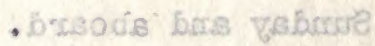

OS nedmoror

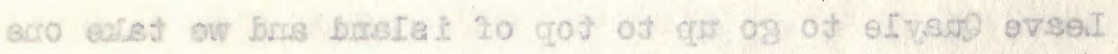

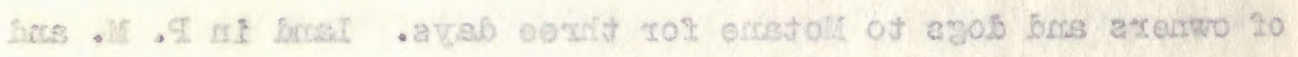

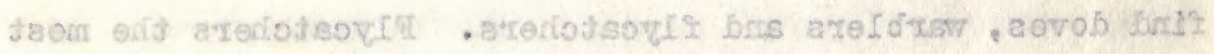

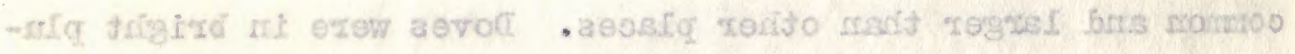

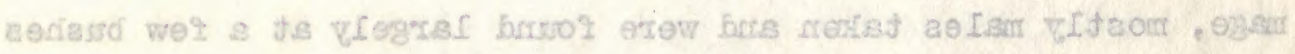

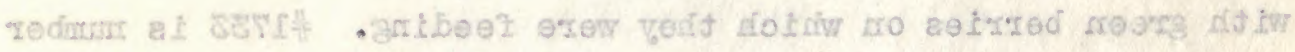

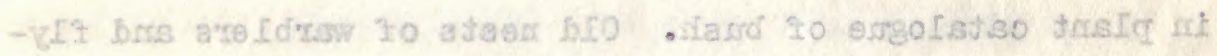

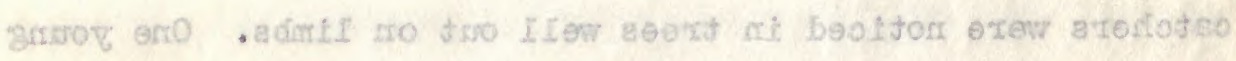

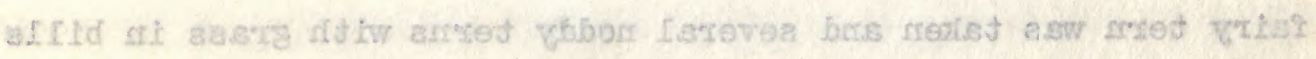

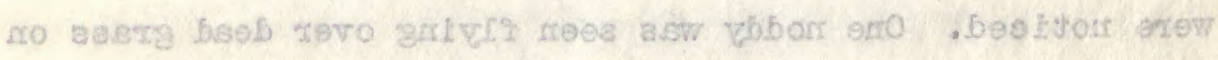

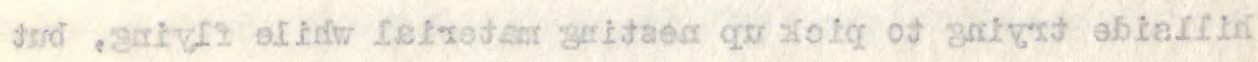

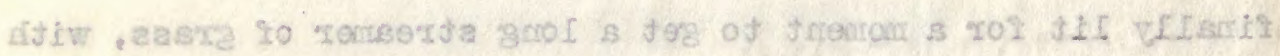

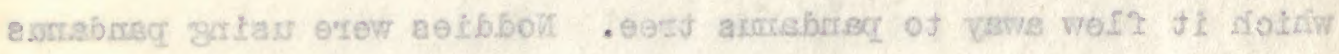

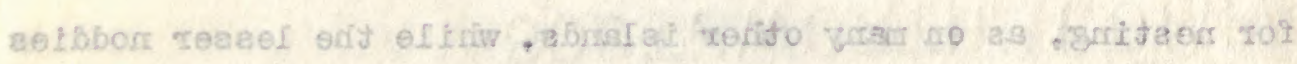

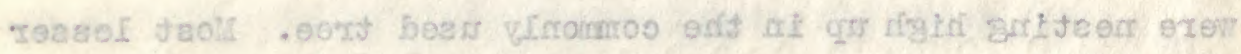

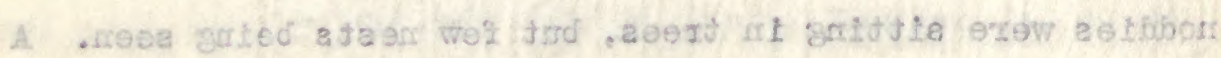


noddy was taken on the ground entangled in the seeds of the treo in which the lesser noddies and boobies nest. A fairy term was flushod from its nest along the trail on top of the island. The nest was a small limb of breadfruit tree two and a.half inches in diameter. The top was rotted out into a hollow, the hollow being one and a half by four inches and twelve foet up from ground. A few boobies were sitting in the high trees on top of island. One handred to two hundred feet are the trees. Chickens are common in the forest and we shot several to eat. Two hundred or so sheep range on the island and we took two live and two dead to eat, the ormer catching them with his dogs. A few swifts fly about the top of islend and one shot. Saw several wedgetail shearwaters off island in early morn. They likely nest on a rock at south end, which is too steep to land on. Ieft Wednesday for Atuona fifteen miles away.

\section{November 23}

Paid the owner ten francs each for the sheep taken and went to Pahuata Island where we anchored at noon and went ashore in P. M. Warblers were singing in trees, but not common in forest. Got a lingrisher and saw another. Several doves heard and seen, but none taken as hard to see in forest. 


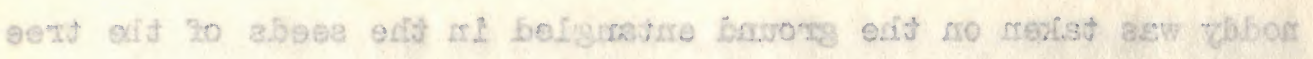

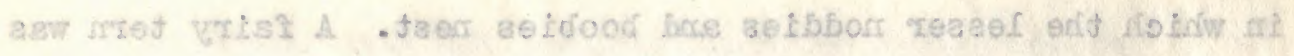

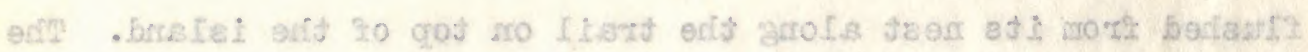

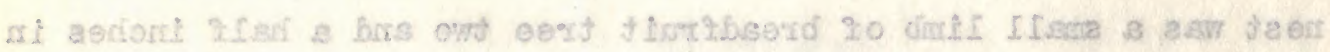

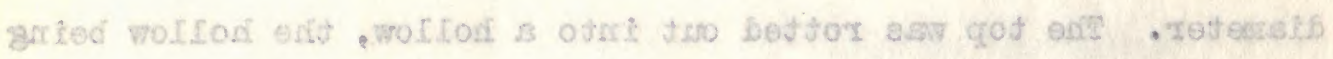

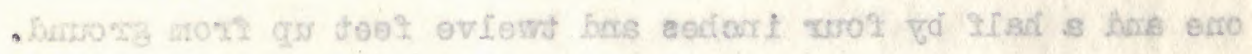

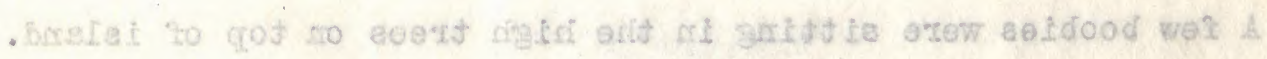

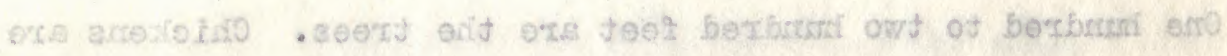

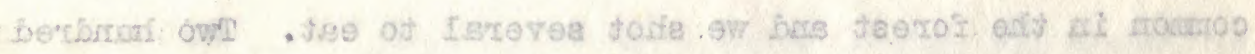

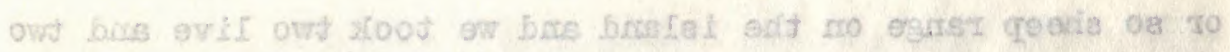

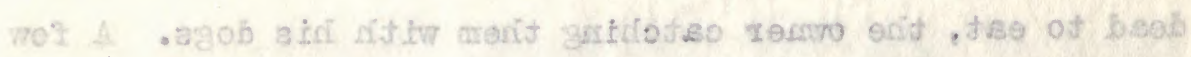

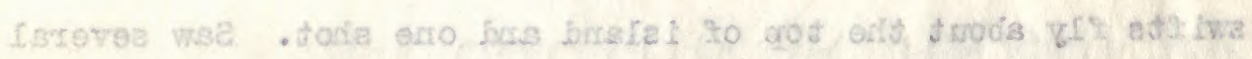

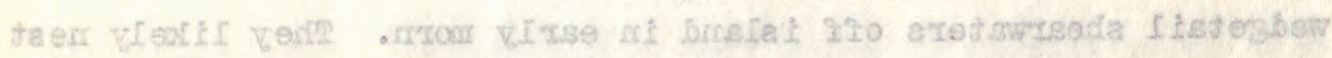

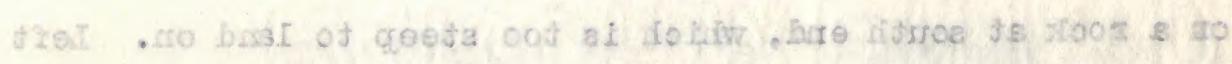

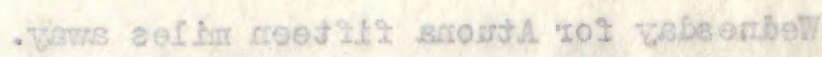

\section{ES redmero\%.}

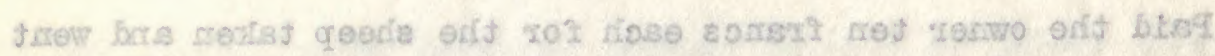

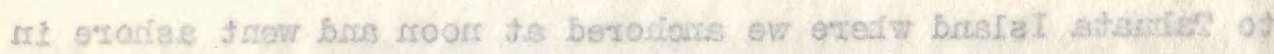

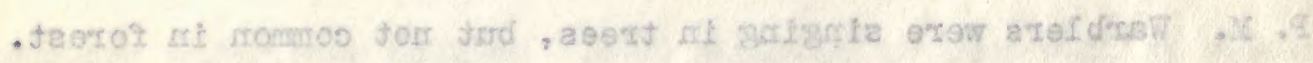

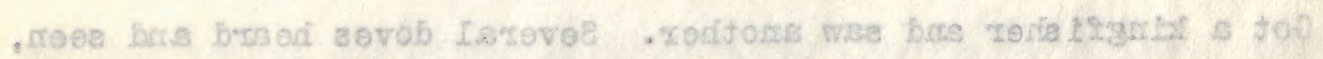

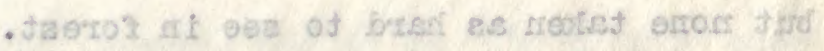




\section{November 24}

I go to top of island and see elever yellowbill tropics flying about one cliff, but none near me. Doves heard near top, but see no redcaps. Fow swifts fly about ridge and likely shearwaters nest somewhere, but top is sharp ridgo and heavy vegotation covers it. Get few doves and kingfishers lower.

\section{November 25}

I skin birds all dey while Quayle and Lorie go ashore and got a fow birds.

\section{November 26}

Sundey.

\section{Iovember 27}

Up along treil to southorm part of island and find flycatchers in hibiscus forests near top of ridge on steop slopes. Find none low down.

\section{November 28}

Up in thick forests in cenons near base of cliffs, but find no flycatchers, though Quayle finds a couple in big canon.

\section{November 29}

Went ashore noar north end of island and get few doves and 
AS zodmevoll

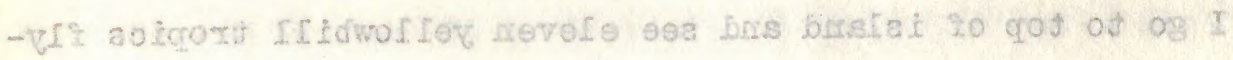

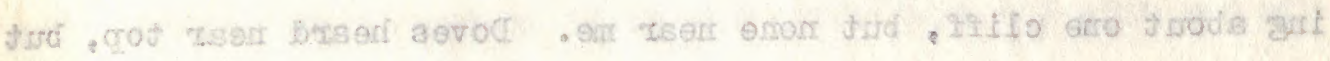

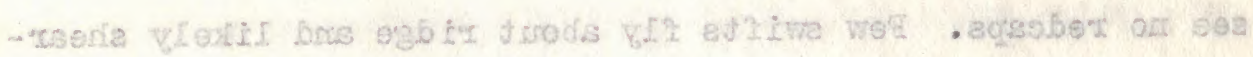

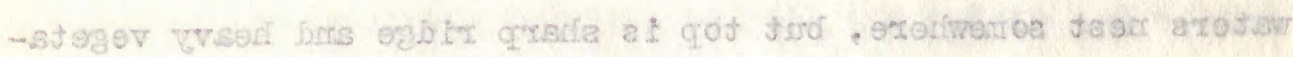

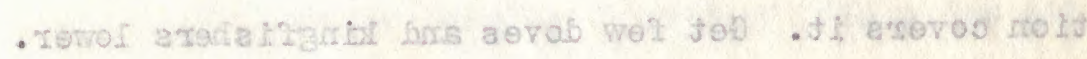

as redintroth

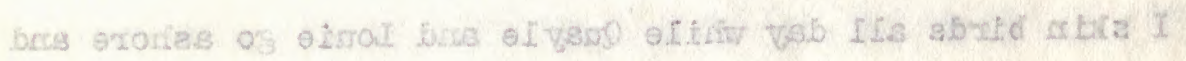

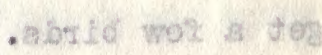

DS mecinovold

- verseret

Fis secimetroli

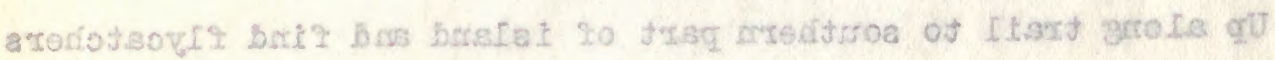

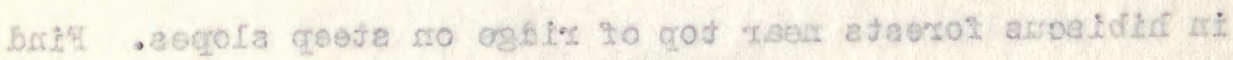
- rrwab nos essors

BS zodmsvok

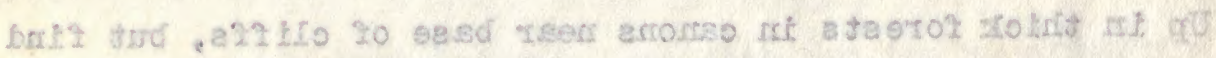

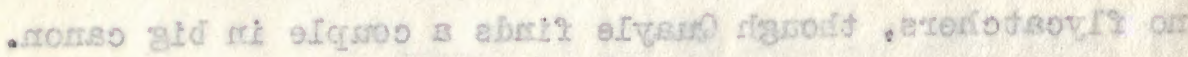

\section{eS rodinevort}

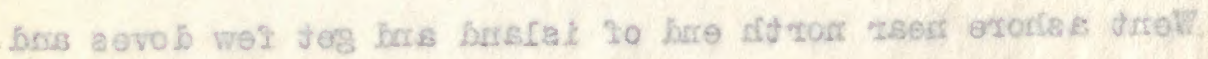


Quavle gets 23 warblers near beach. Go to Hivaoa and finish birds in $P . M$.

Novamber 30

I go to top of island looling for redcap doves and get four. On way up stop at camp of laborers and talk few mimutes, then walk few yards on trail and flush a pintail draice duck from a small pond left from yesterday's heary rain. Probably bird came in with jesterday's heavy northerly wind. Was a couple of miles from shore at one thousand feet elevation and in only waterhole known to me in the hills, though ruming streams in many canons. Bird was fat and in good condition.

Thanksgiving day and guayle stayed to improve acquaintance with an American artist in Atuona, but I was surprised at six o'clock on returning to find his things packed and ready to go ashore. He has decided to accept a proposal of the artist and spend a few months in the llarquesas hunting birds' eggs for the artist, hoping the change from ship life will benefit his stomach which is now bothering him too mach for satisfactory work. Sail for Fauniva at eight P. M.

\section{December 1}

FATUMIVA.

Reach island at ten A. M. and ashore for permission to hunt 


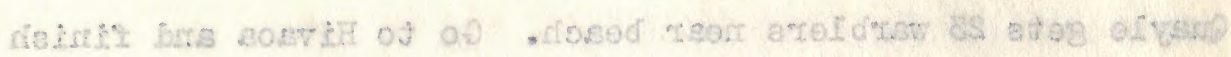
- I a a aboita

\section{of racimevok}

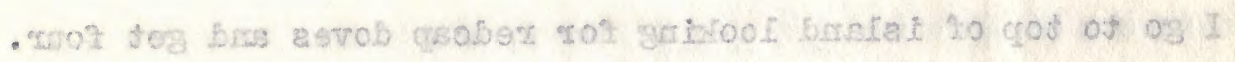

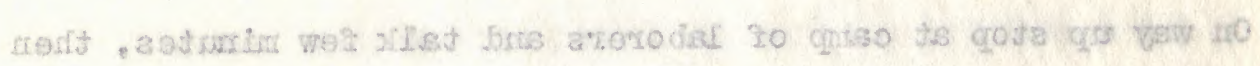

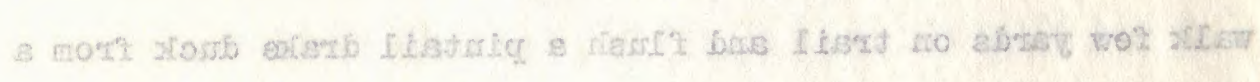

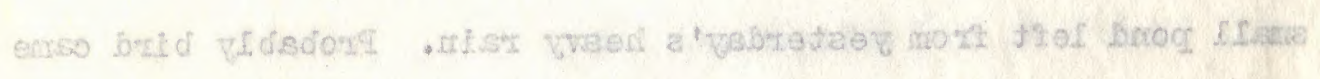

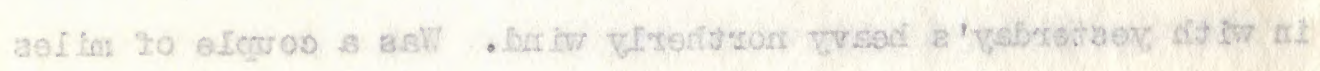

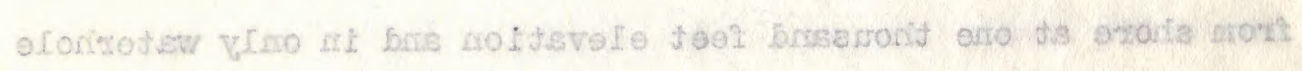

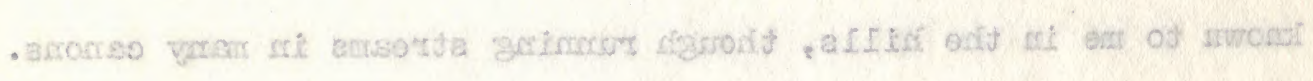

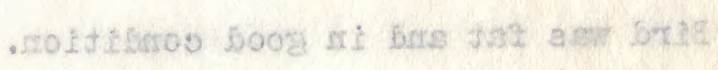

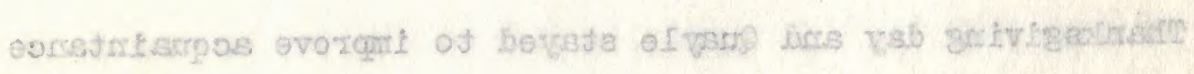

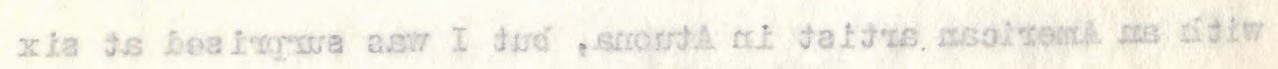

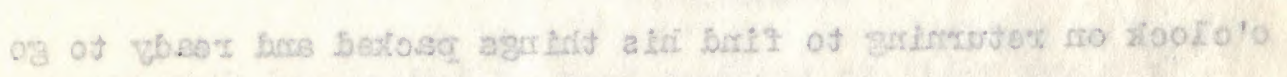

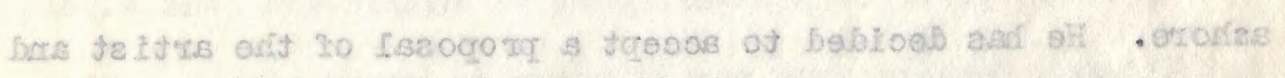

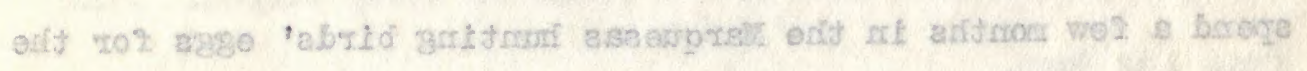

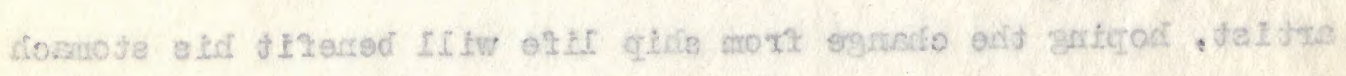

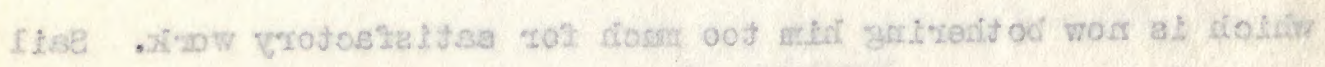

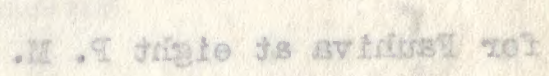

\section{I. zedireosd}

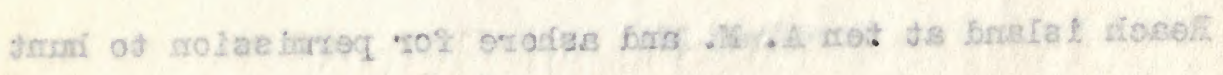


which was granted. Ashore in P. H. but rain for last four days and heavy rains today make worix difficult. Shot flycatchers and find them mach larger than on other islands and warblers seem larger, while two doves taken show little if any difference. Surprised on skinning to find female flycatcher black.

\section{Decomber 2}

Ashore with Louie to hunt and he strikes a tree where doves are feeding and gets a dozen, while I get but three that called from forests into bushes on ridges where I can get them. But a couple of flycatchers found in a place and well scattered. in canons. The young have similar call to the birds of other islands, but the rare call of the old birds is different. Think I heard cuciroo call a couple of times, but possibly it may have been this flycatcher. Warblers are scarce here, but the valley is small and runs in a mile from shore to end in little canons that run up on to the base of cliffs that form backbone of island. Yellowbill tropics are common. Birds sailing about many cliffs high above valley.

\section{December 3}

Sunday and take few pictures.

December 4

I take trail to top of island and go along ridge for a 


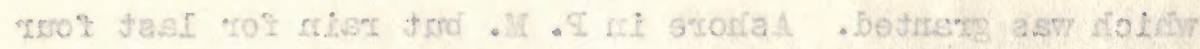

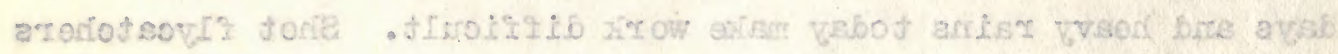

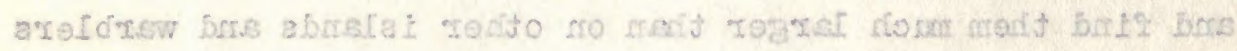

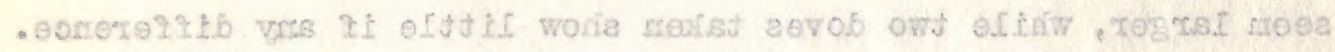

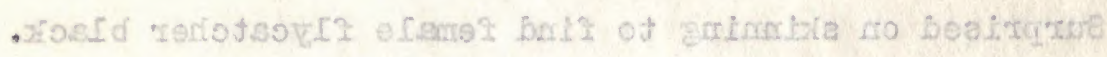

\section{S roumesol}

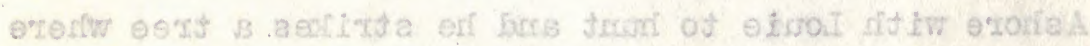

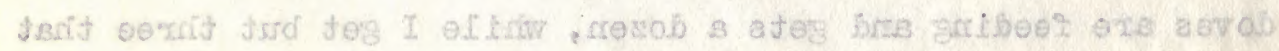

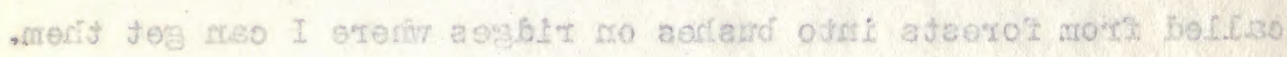

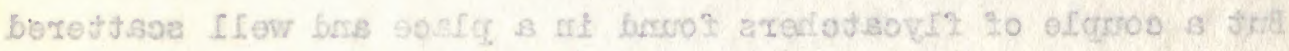

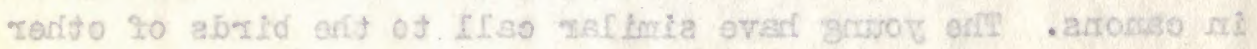

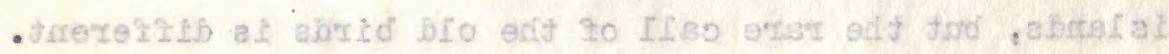

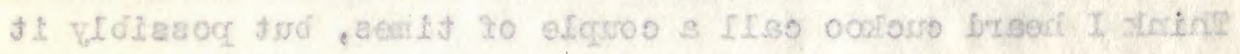

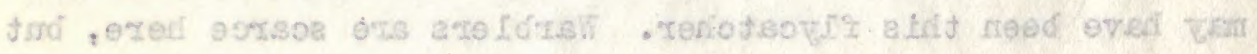

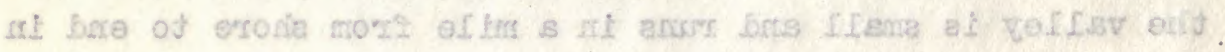

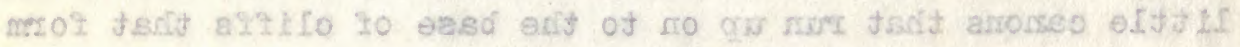

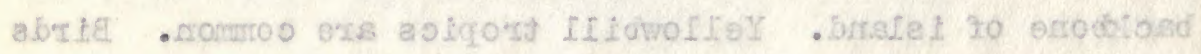

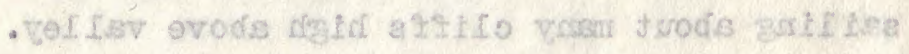

\section{8 rodineoed}

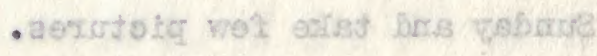

4 rodmeoect

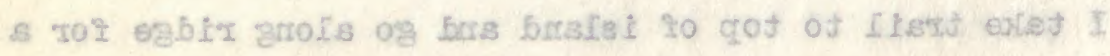


mile on trail that leads to windward side of island. Scattering warblers, flycatchers and doves are seen, and about cliffs on top yellowbill tropies $\mathrm{fly}$, as well as a pair of noddy terns. Rain most of day. But few birds seen. One call of flycatcher starts like the wail of a cat when tail is stepped on, ending with a whew. The call of the Joung bird is "Chi chi" repeated, while one call of male is "Creu re a reek". But little singing is heard as young are flying or ready to leave nests probably. "Kik kik kik" rapidly called is note of old birds when disturbed. Warblers as in other islands seem to fancy pandanus trees to sing in, but do not know if they nest in these. Doves feed in several kinds of fraiting bushes as well as trees, some birds eating the ripe guavas also. A wild pigeon is reported as formerly living on this island, but is now rare if not extinct. As forested ridges comprise the highlands of the island one would need weeis to properly hunt for them and the mountain guide of the island is busy with copra now, so I do not try to get up highest peaik where a few shearwaters may nest.

\section{December 5}

Move to other bay couple of miles to southward.

$$
\text { December } 6,7,8 \text {, }
$$

Collect same birds as on first days. Find warblers keep 


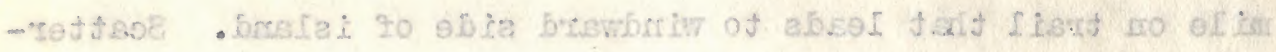

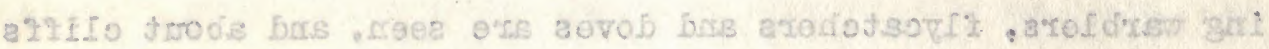

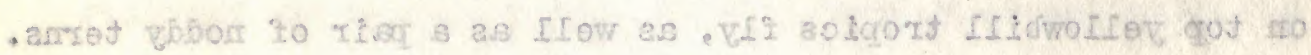

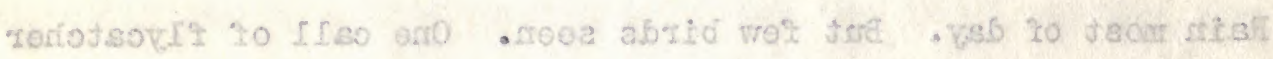

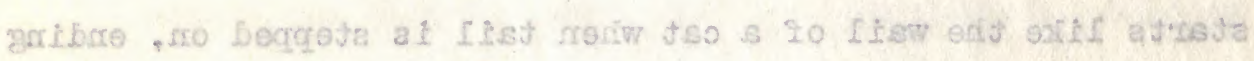

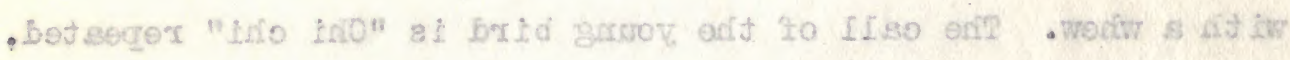

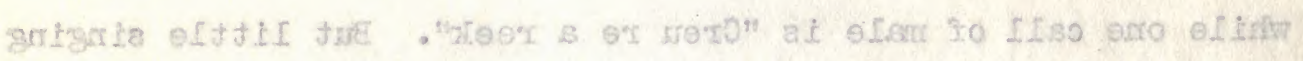

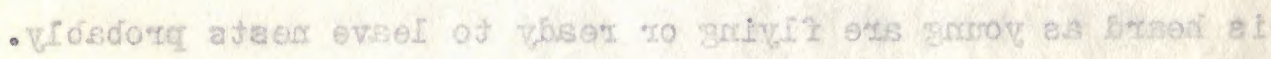

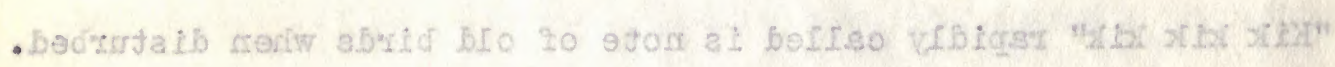

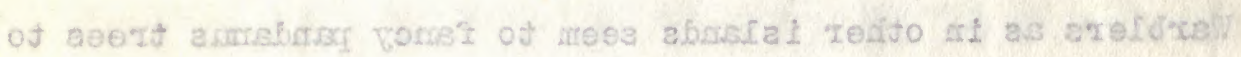

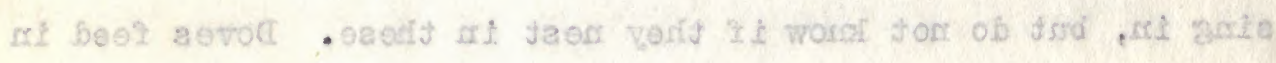

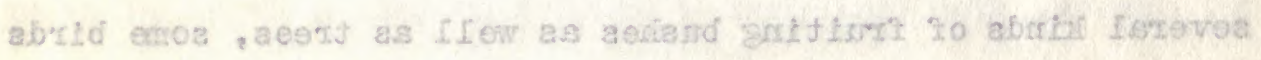

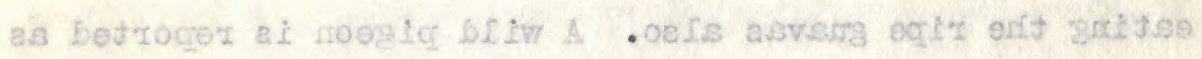

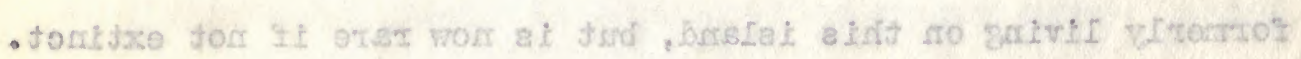

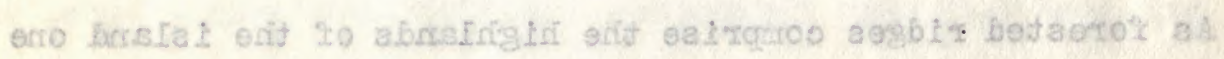

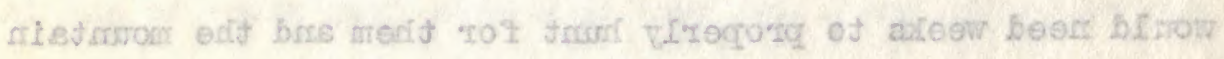

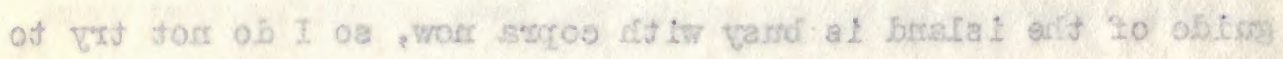

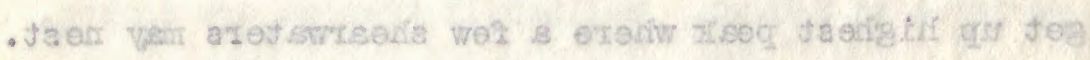

\section{d redireood}

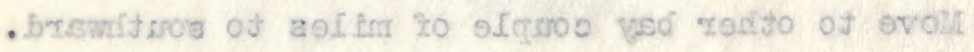
.8 .8 .3 zodimoose

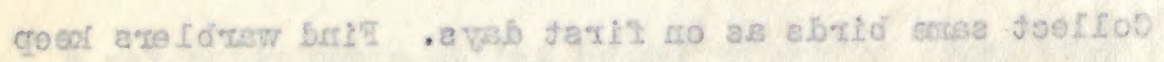


to the more open hillsides and seldom in the mope forests, while the flycatchers are in the mope and hibiscus forests. Tako the small boat and go along coast, finding lesser noddies and blue termlets fishing with a fow noddies and scattering fairy terns. A few sooty terns are flying about the thousand foot cliffs.forming the shore and redfoot boobies nest in trees high up in hills, while a few plotus boobies fly about and frigates are seen also. A couple of the latter were taken. Leave in evening for Papeete, having put up about 2,300 birds in the three months in the Marquesas.

\section{December 9}

Sooty and fairy terns during day as well as yellowill tropic and a Bulwer petrel. Also saw a shearwater with grayish back and wings browner. Ten sooty terns in one flock 120 miles from land.

December 10

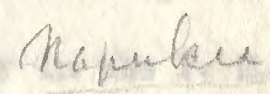

Nearing island at ten A. M. and ashore at three P. M., but chief says very few birds. See a couple of yellowbill tems off landing, but hear no warblers ashore. Take a few pictures and aboard till tomorrow. The people are more copper colored than other islands, but are no worse looking. Quite a bunch of children in comparison with Marquesas. Night before last a 


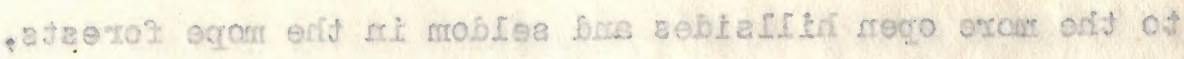

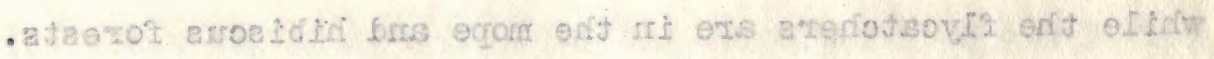

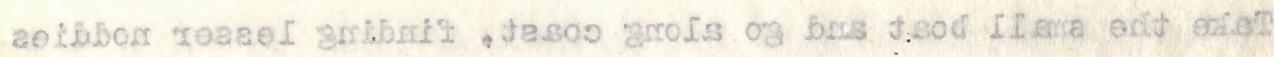

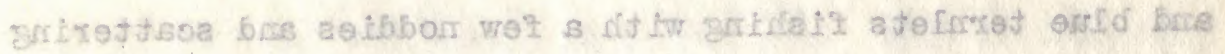

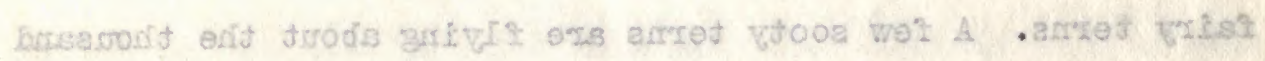

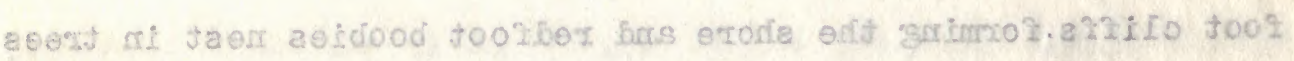

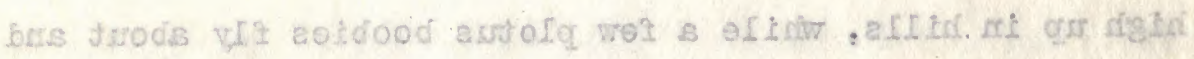

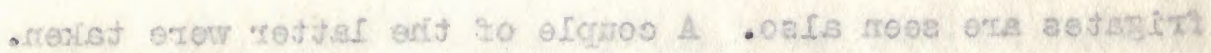

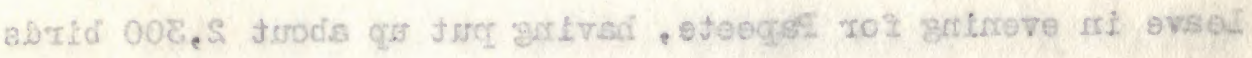

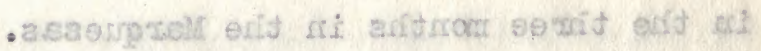

\section{8 recinteose}

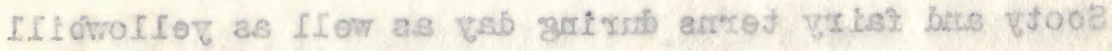

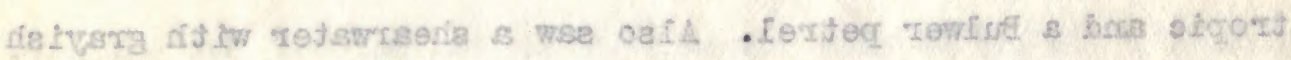

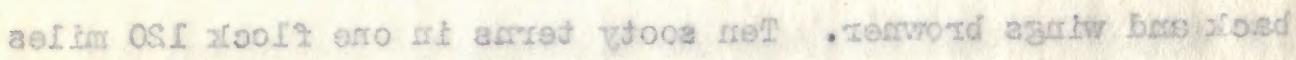
- borsir mova

\section{of reokrteopd}

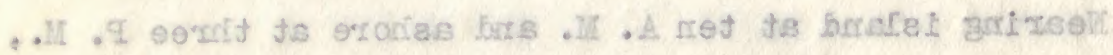

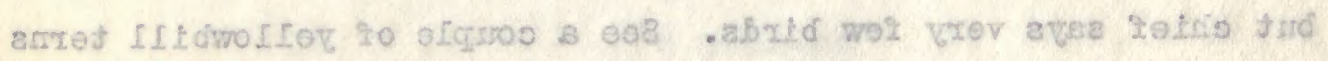

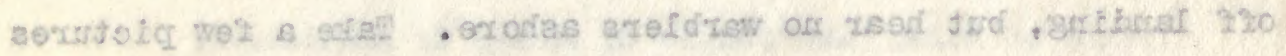

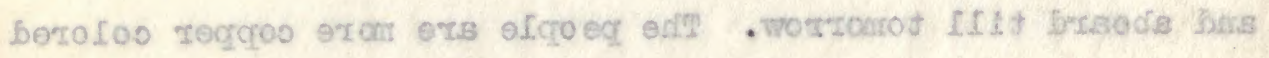

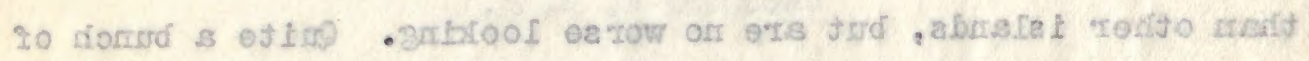

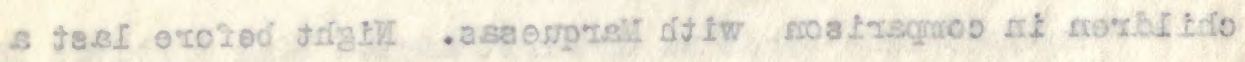


sailor fell overboard about ten P. H. losing balance with roll of ressel, but boat was put out and he was picked up in a few minutes, wi th his overcoat and the bird net which he grabbed in going over.

\section{Decomber 11}

Ashore at Napula and find very fow birds, the warblers only being found at the east end of the island were there are still thick groves of pandanus. I went along the south side, while Loule took the north side. He found no warblers, though he went nearly to the east end. I passed many clumps of trees and brush, though had to wade to the knees over much of the reef which is barren. Coconuts are planted in many of the motus. Fairy and noddy terns were found at one or two spots and a couple of nests of the latter were seen in pandarns trees and fresh eggs taken from them. A cuckoo flew from near me when I shot the first warbler but was not seen again. A couple of lesser irigates were noted high in air in the P. M., and a few yellowbill terns were flying over the lagoon and resting on the bars on the edge of it. The natives say rails formerly occurred but the cats have exterminated them. The noddies and fairy terns were together, the pandanus trees being but a few trees

yards from the high that the fairy terns were roosting or nesting in. The houses of the natives are covered with pandanus leaves, 


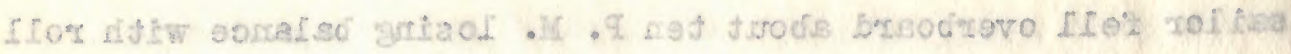

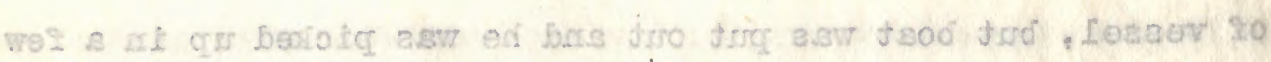

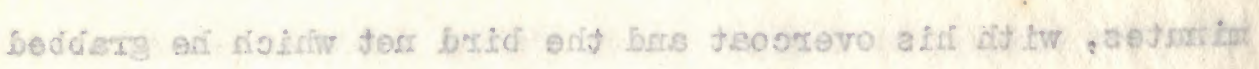
- 2ovo zestog at

\section{If. Iedíc ooth}

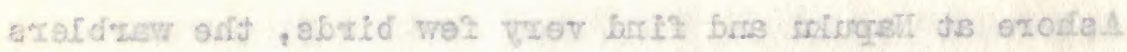

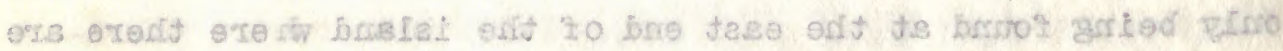

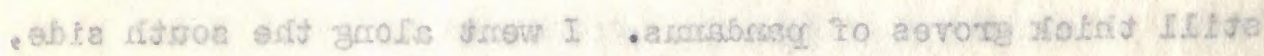

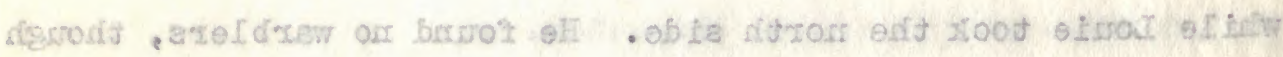

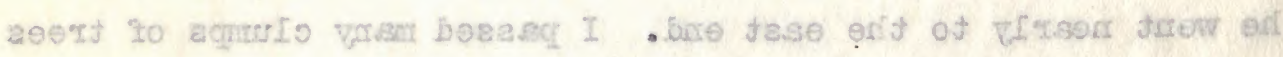

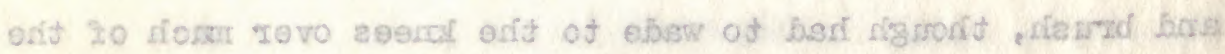

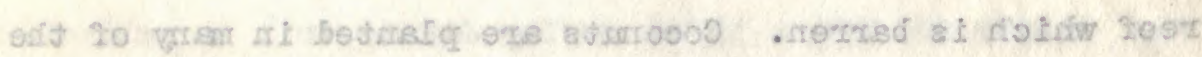

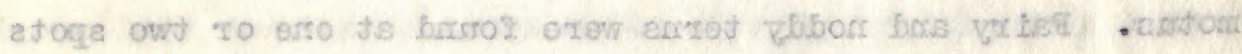

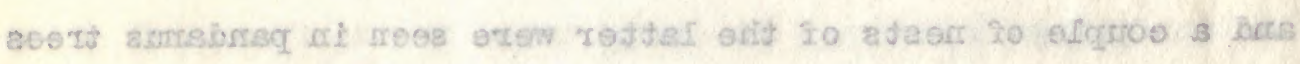

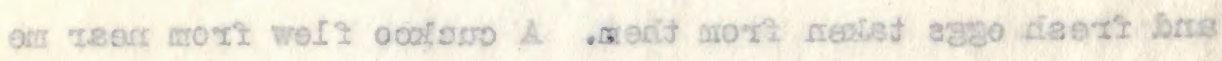

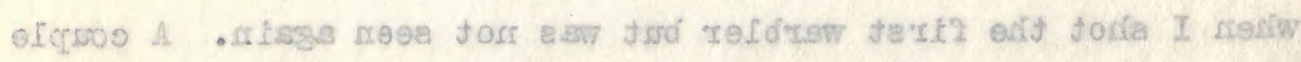

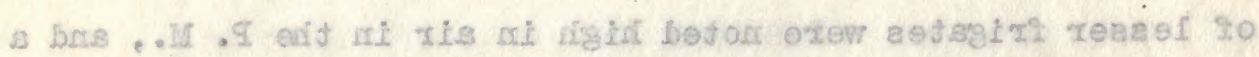

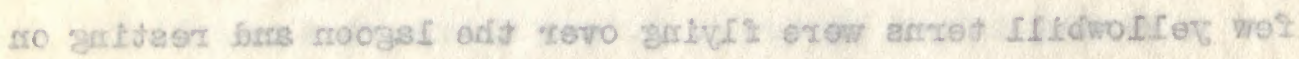

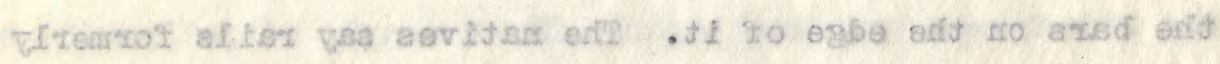

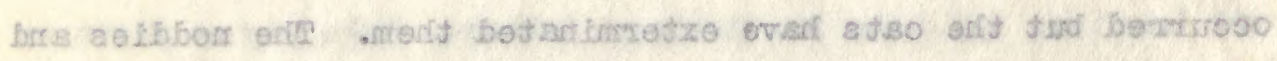

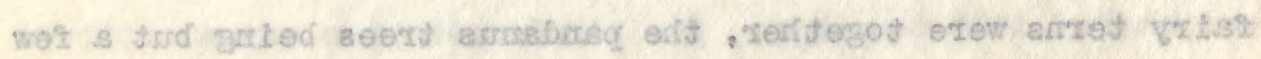
eserty

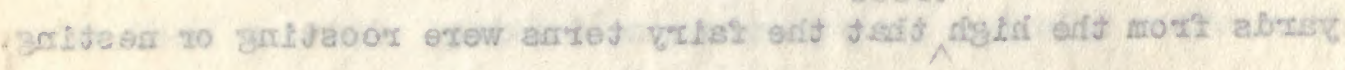

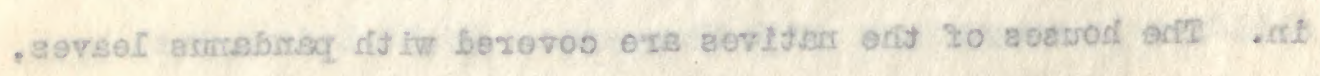


and the doors are of coconut slabs in most cases.

We leave in the evening for mirei on the way to Papeete. Only got five warblers, all males, and a half do zen noddy terns.

\section{December 13}

Reach Tikei at two P. M. and ashore for afternoon. Find natives making copra. They say a few days ago that a lot of ducks were here coming in with heavy rains. I saw four in a flock and think they were spoonilis as they flew over mo out of gunshot. All were females, or at least no males were noticeable. Quite a few golden plover were present with the wandering tatlers which were about the ponds in the center of the island. Young noddy terns were common, and I got a young lesser noddy from a tree which contained a couple of nests, and also an egs from a nest in the tree. Fairy and lesser noddy terms seemed scarce, but it might be that I did not go where they were. A couple of herons were on the reef, one white and the other blue. A warbler's nest was found in a tall bush containing a single bird just hatched. The parent stajed close by but made no sound. Several young birds were heard calling for food, and a couple were taken. Some adults have molted and some are in old plumage. Two taken with short tail feathers. Louie saw a rail but could not shoot it. Ieft in eve for Papeete with ligint NG wind. 


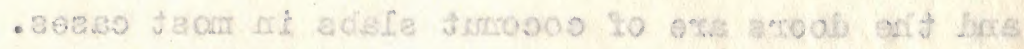

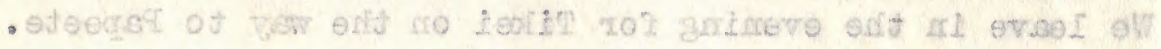

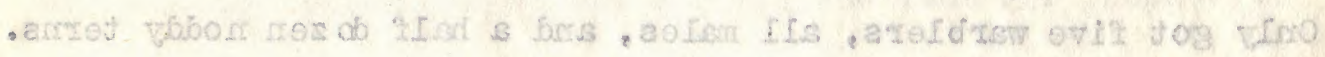

\section{Q1. Toukeoed}

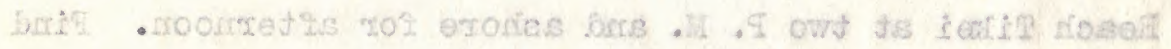

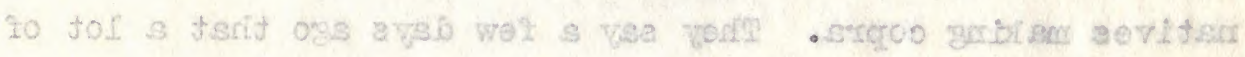

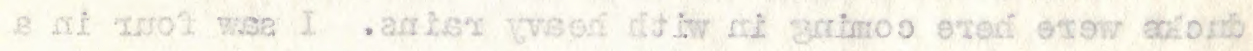

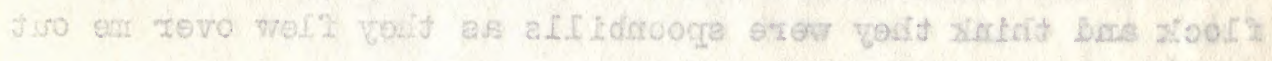

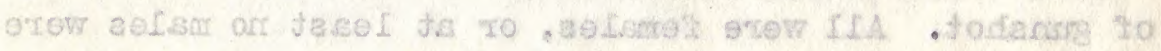

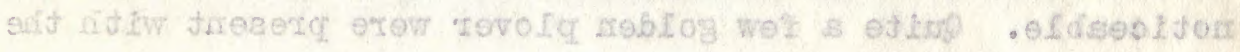

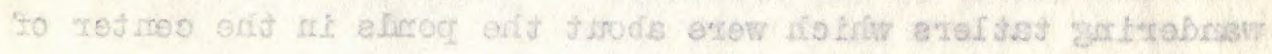

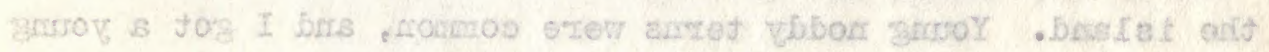

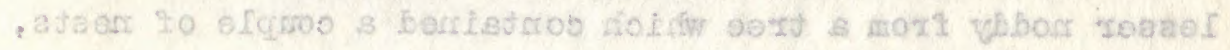

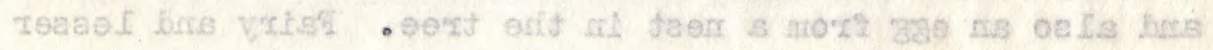

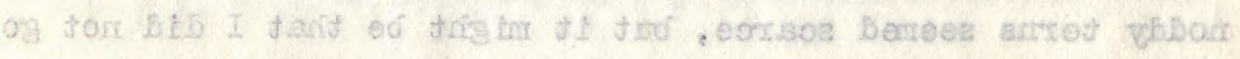

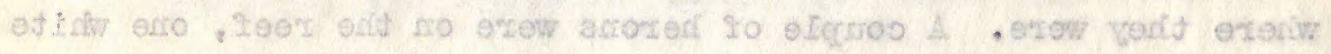

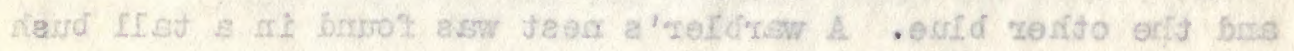

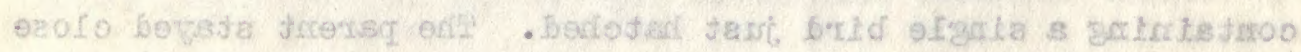

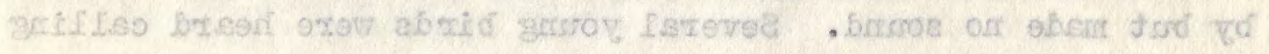

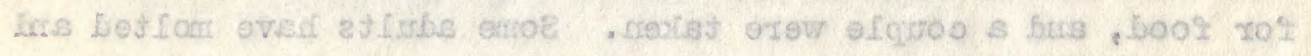

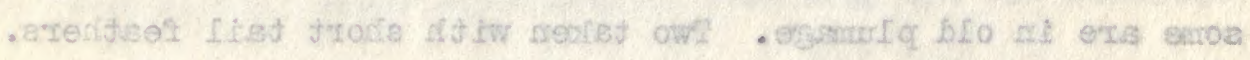

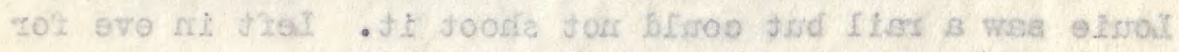

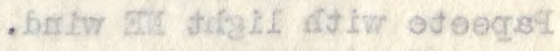




\section{December 14}

Ianded at the west pass of Aratika Island in P. M. and found only three warblers. Iouie got a dove, the only one seen. "Lesser noddies were nesting, and many nosts contained young birds. I took several eggs fresh and saw birds fly to the ground and pick up dead leaves just after it rained. They likely do this so the dead leaves of which the nest is made will hold together. Nests varied in height from eight to sixty feet, and I noticed three placed in a dead leafless tree forty feet from the ground. Noddies nest in palms. Arrive at Papeete December 16. 
AL 20 cineoed

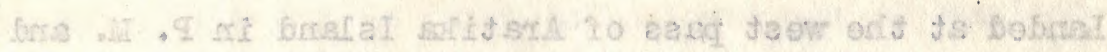

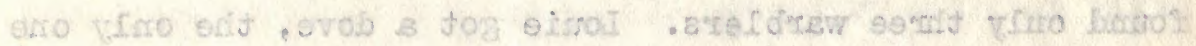

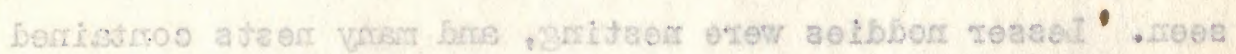

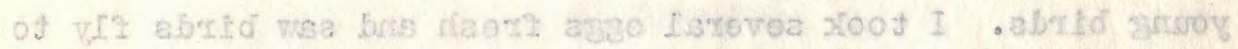

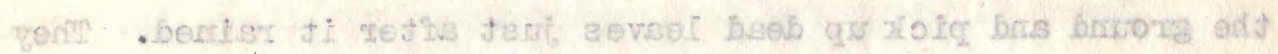

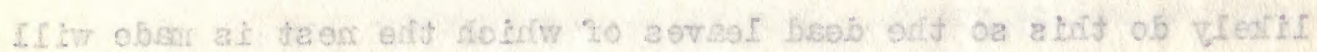

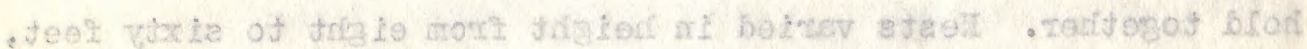

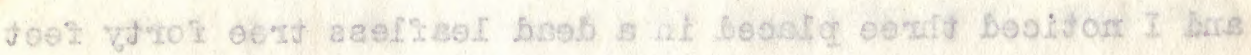

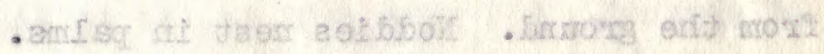

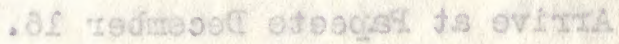


Jamary 27, 1923.

Left this afternoon for the Buamotus, expecting to work in the western islands till April and the danger from hurricanes is past for the year. Most of the western 1slands have passes into the lagoons and we stand a better show for our lives than if we were at sea in the Archipelago.

For the last forty days we have been in Papeete waiting most of the time to get into drydock to paint the bottom of tho 'France'. A couple of trips outside the pass yielded no birds and a half dozen redfoot boobies and a few lesser noddy and fairy terms were the only birds seen. The engineer and cook spent eight days hanting pigeons, but saw none in country where the birds were formerly common.

Several redfoot boobies, lesser noddies and fairy terns are seen fishing off Point Vemas and a small flock about ten miles off. Toward sunset severa. small flocks, elght or fewer birds in each, of redfoot boobies 1 y toward Tetiaroa Island to the west, and perhaps a dozen scattering rostrata shearwaters are seen within twenty miles of Pt. Vems. Westher is getting settled, though a heavy shower passes over Papeete and for the last week mach rain has fallen. Iight wind today and calm eve.

\section{Jamary 28}

Sailing slowly ESE and in P. M. have Mehitia to windward, where we may stop to collect. $\triangle$ couple of yellowbill tropics have 
- ese a tis trasuret

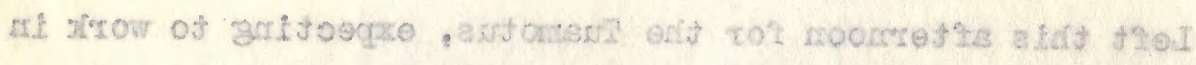

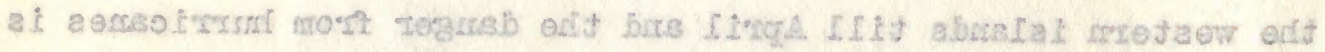

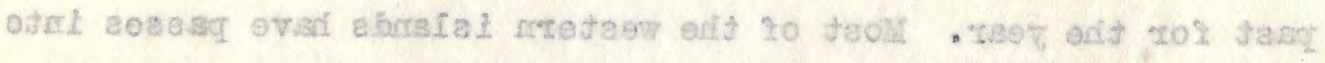

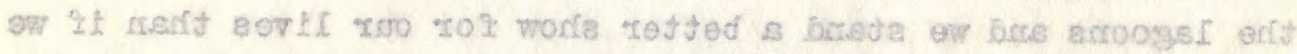

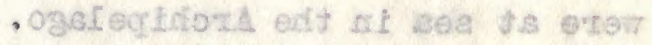

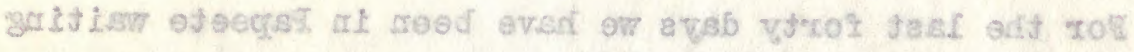

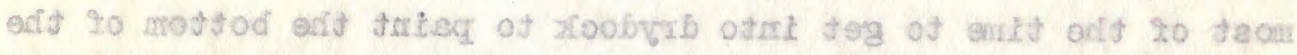

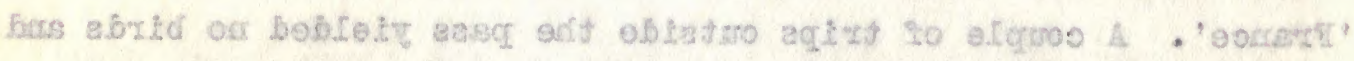

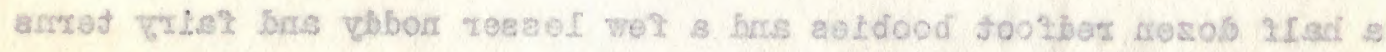

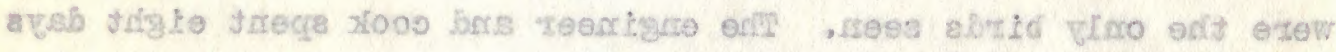

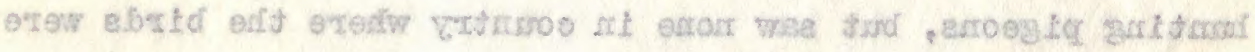

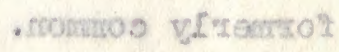

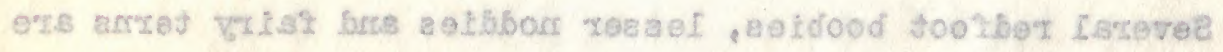

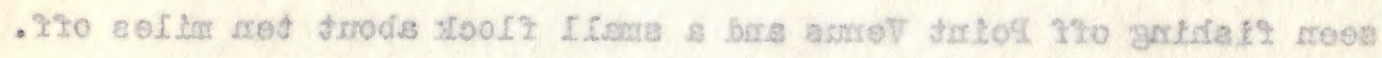

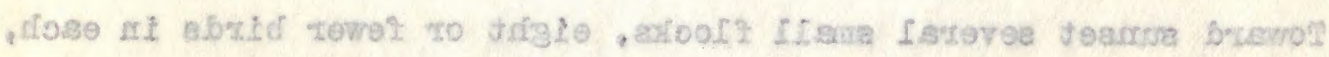

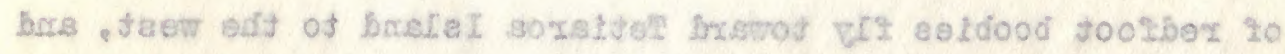

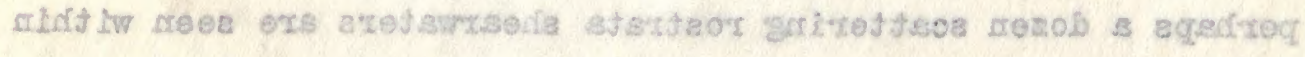

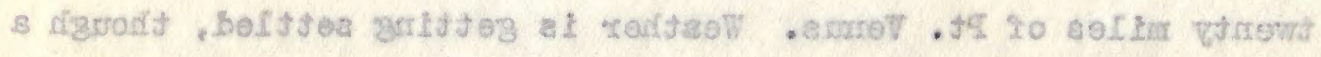

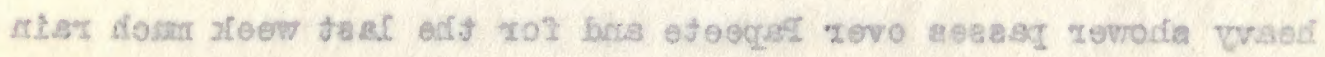

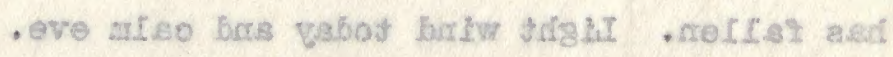

8S vxisporsst

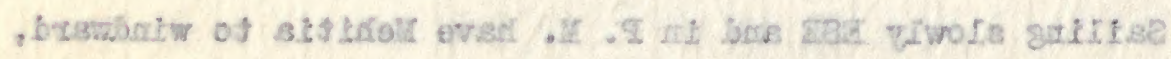

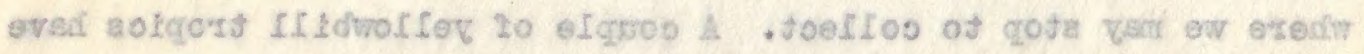


been seen, one rising from the water ahead. Fifteen miles from the island a plotus and a redfoot booby fly past and a corple of fairy terns are seen fishing. Weather clear.

\section{Jamary 29}

A shore at Mehitia and I go first to the top. Teri forest of large trees (hotu) covers the lower slopes and reaches well toward the top on the west side where we landed. The island being rolcanic is covered with broken lava stones and on top is a crater over 300 feet in depth and possibly 300 yards across the top. Hibiscus trees and a large banyan (?) tree with ferns grow plentifully in the crater, and in tho bottom are a dozen or so feils. One might possibly go to bottom but small cliffs nearly encircle 1t. Three or four falry terns were flying about the trees near the bottom, and over the top three or four yellowb111 tropies sailed around. Two nests were found, one only three feet below the top and the other five feet. One nest had a fresh egg and bird, while the other on a little ledge behind some grass and vines had a bird. Three or four frigates sailed over the top and in the lower levels fairy and noddy terms were flying about the trees. On the west side a lot of redfoot boobies sat in ironwood trees above the shore, not a pare white one being seen; most of the adults had white tails. Ioule found a wedge-tail 


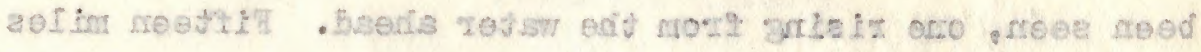

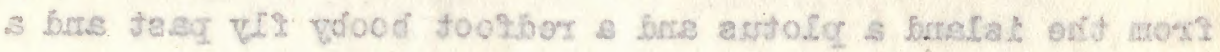

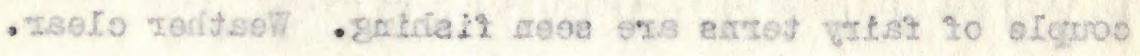

\section{QS verecorsts}

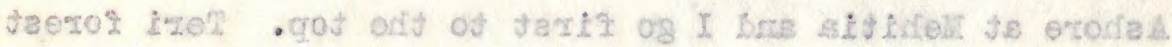

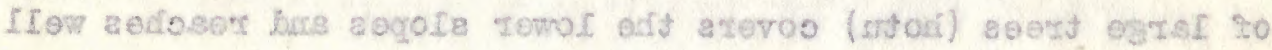

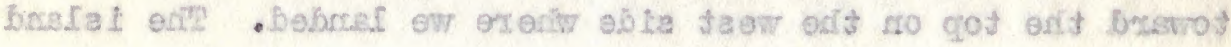

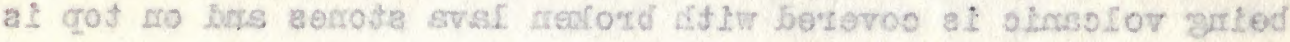

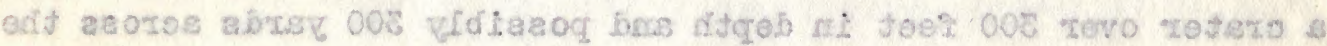

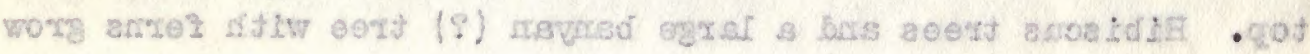

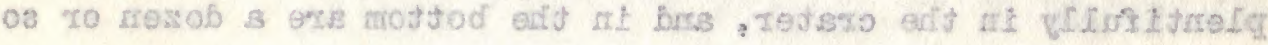

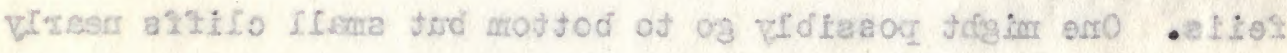

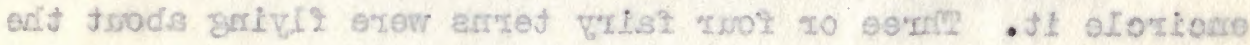

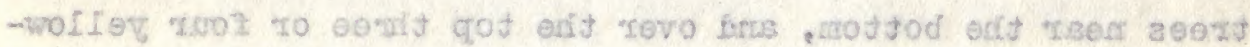

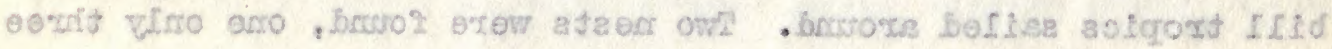

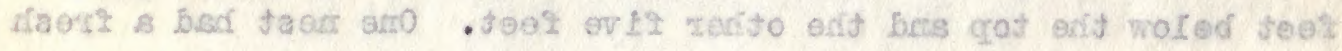

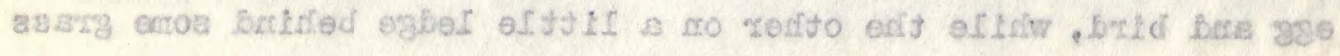

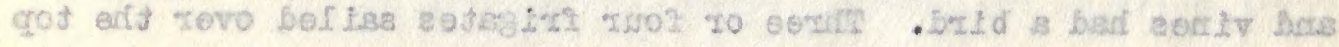

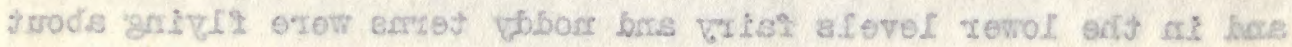

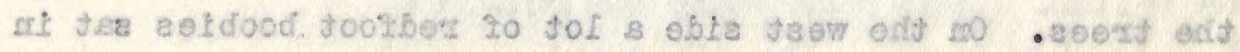

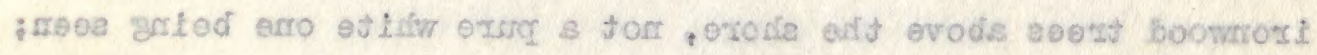

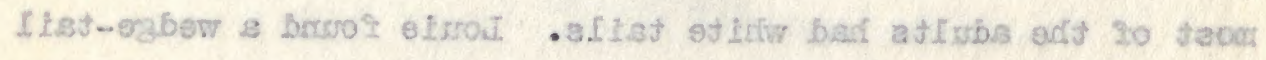


shearwater that the dog pointed out to him in a hole in the rocks on the east side of the island, and I saw several of them in the early morn as we neared the island. No land birds were encountered except a cuckoo which we managed to call up to us in the forest. Little or no underbrush occurs for the gosts, a few being seen,--are now beginning to eat bark from the tree roots which run over the ground. A dozen people were on the island, having come from Tahiti to make copra. They had about ten tons ready for the boat they were expecting.

Left in the evening for the Muamotus with squally weather.

\section{Jamuary 30}

Rain and squalls during night and first on one tack and then on other. A wedgetail shearwater and feiry tern seen during day. Half dozen fairy terns seen fishing in eve.

\section{January 31}

Good weather and reach south side Rangiroa Island in afternoon, but stand off and work to eastward during night as landing not good.

A few redfoot boobies and fairy noddy and lesser noddy terms along shore. 


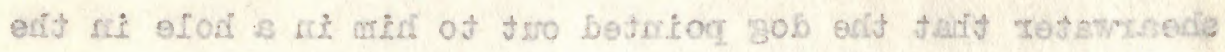

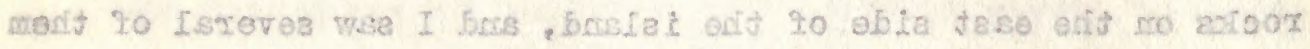

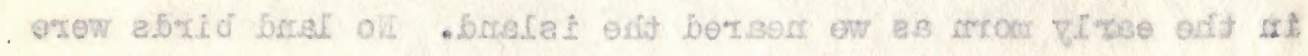

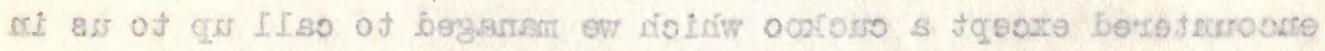

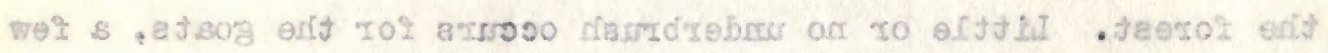

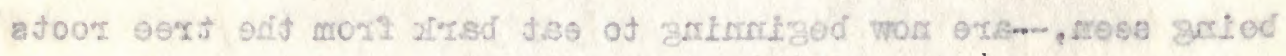

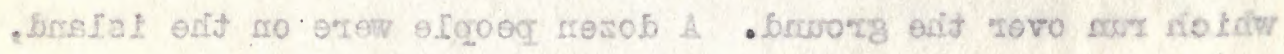

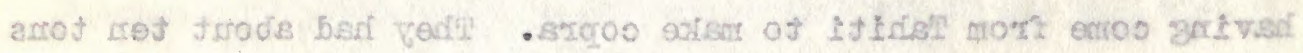
- art toegze ezew verit jood erit sol vbeer.

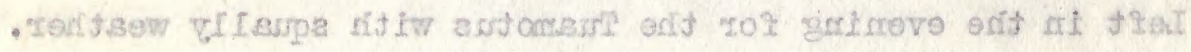

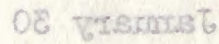

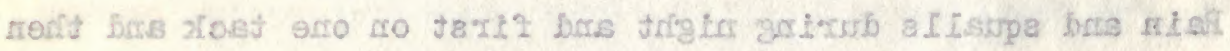

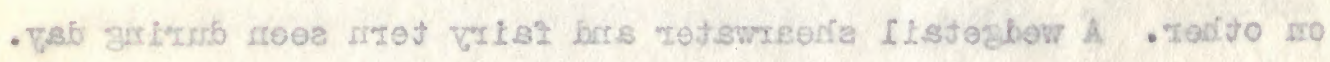

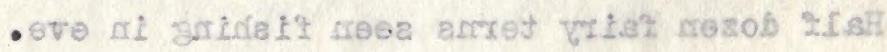

\section{IE एాarrate}

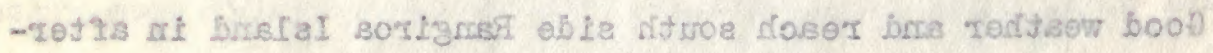

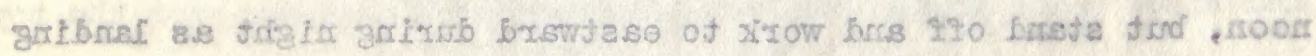
- boog toor

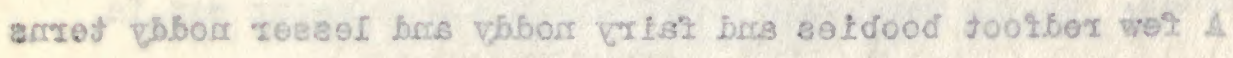




\section{February 1}

Light wind during night and twenty miles to west of Karkara Island in morn. Tack back towerd the north at daylight. Light wind a.1 day and beating north to get to Arutualsland. Occasional fairy or noddy tern and three plotus boobies flew past in afternoon. Sew Rangiroa and Arutue Islands at four P. M. and hope to get ashore on Arutue Island tomorrow morn.

\section{February 2}

Iended on Arutua at eight A. M. on the west end and collected for about three miles to the eastwark on the northside. Cocomats were bearing on most of the islets, though many young trees had. been planted within last ten years. Here the land is broken by frequent channels into the lagoon where the water is about lonee deep. In crossing one of these chamels I stumbled and partly fell, catching nuself on one hand. Iike a flash when I fell three sharks were darting around me, one two feet long and the others four feet. When I stood up they swam off. Another time I heard a splash behind me and turned to see a six foot shark making off.. One four foot one came straight at me till I waved my gun in the water toward him, and he then oircled about. A six foot swordfish was also startled from one pool waist deep and swam rapidly toward the lagoon. 


\section{I. vasurciog}

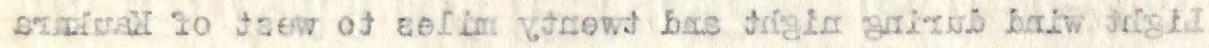

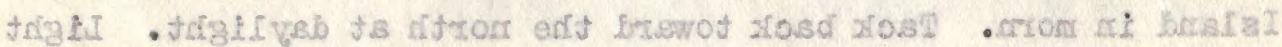

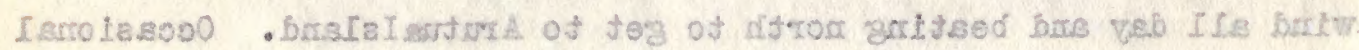

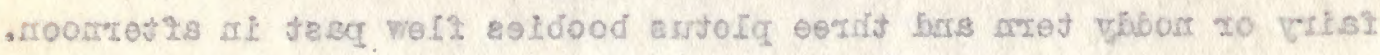

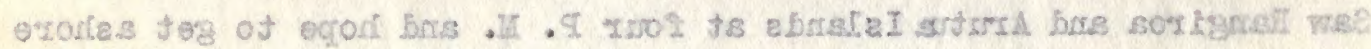

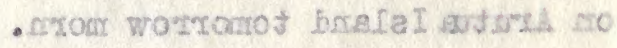

\section{S Trsurdert}

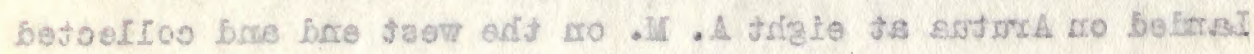

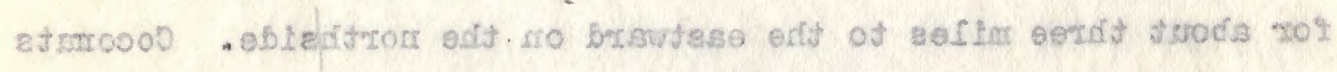

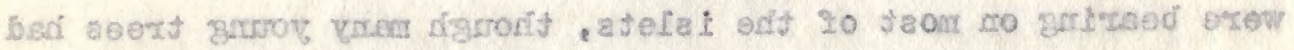

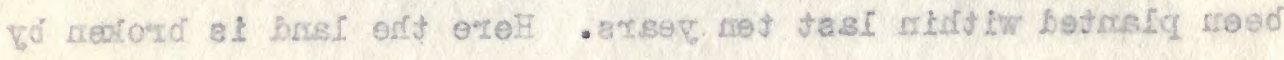

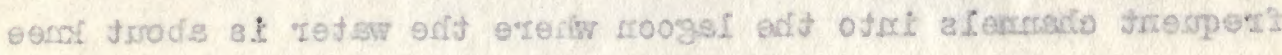

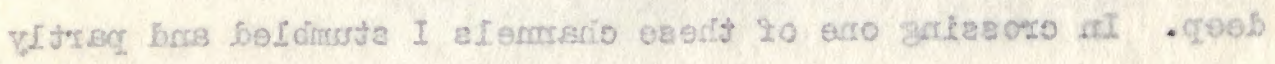

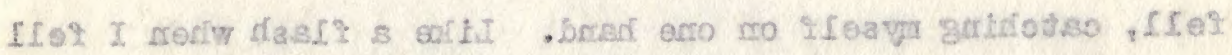

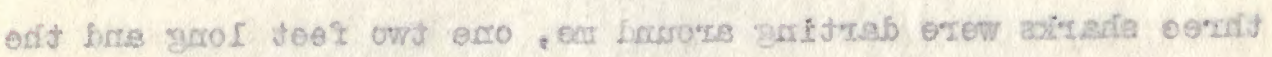

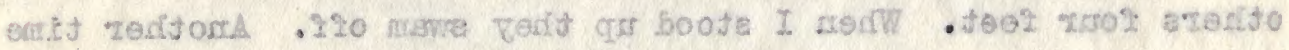

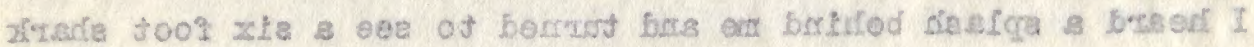

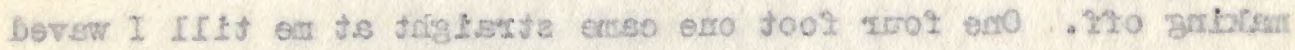

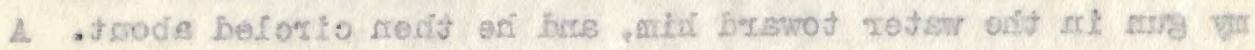

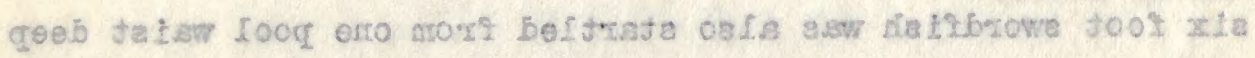

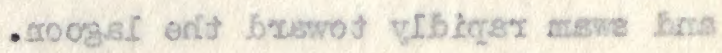

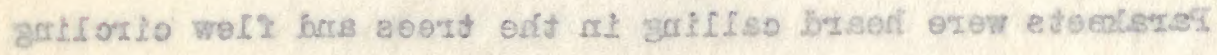


about to light near the tree from which they started. Two or three usua.ly flow together, not many being seen. The pairs usually sat in the trees close by one another. Warblers were mostly silent, only a couple being heard singing speringly. They were scarce and came to ealling in the thicker parts of the woods. The common atoll plants were here, but few plants bearing the berries eaten by the doves were seen, and no doves were found. A flock of five or so yellowbill terns were fishing in the shallow water on the reef near the edge and they were joinod by three lesser frigates, one of which I shot. The frigates fishod. part of the time for themselves and sometimes chased terns that had perhaps caught fish. Iesser noddy terms had young birds in scattered colonies in different places in the highest trees, but on one islet where noddy terms were nesting I found a couple of dozen nests of lesser noddies in tohum trees, closer to the ground than they usually are, except when built on cliffs. A single egg was seen, but this wes ready to hatch, judging by the sound emanating from it when touched. The young were of all ages and stood upright in their nests when I approached, thereby differing from the young noddies in nearby nests, which squatted or tried to escape by getting out of their nests and running off on the ground under the bushes.

The nodajy terms' nests were in low mickymicly bushes usually, 


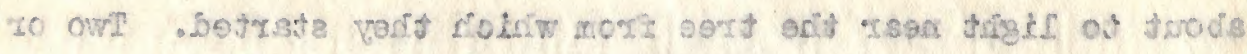

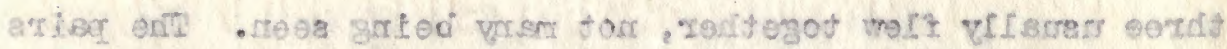

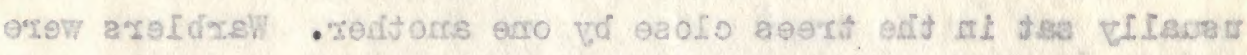

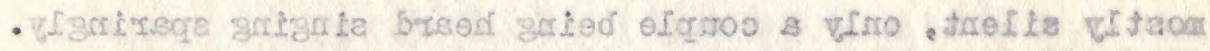

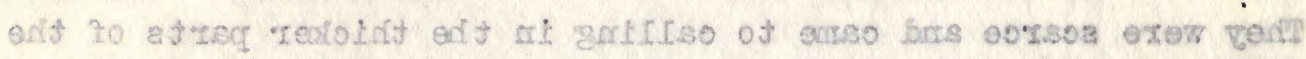

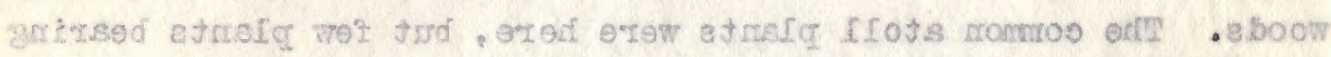

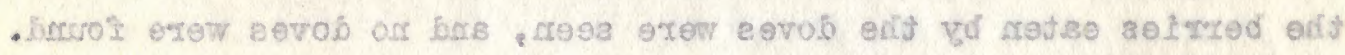

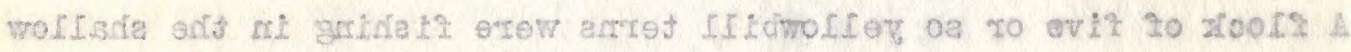

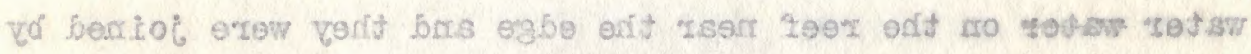

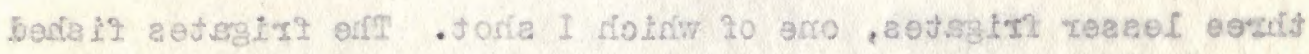

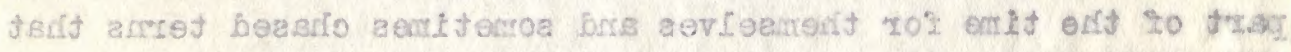

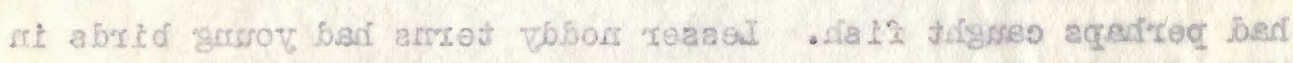

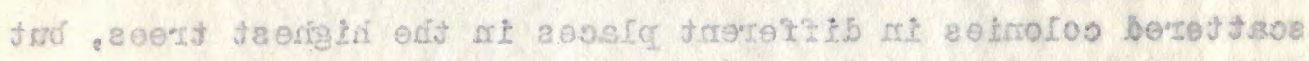

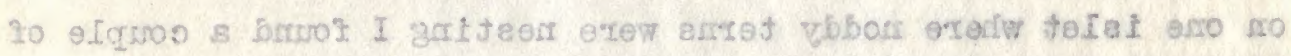

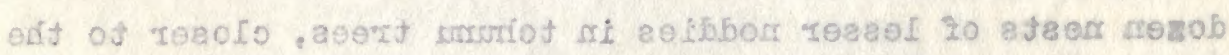

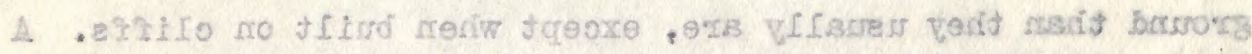

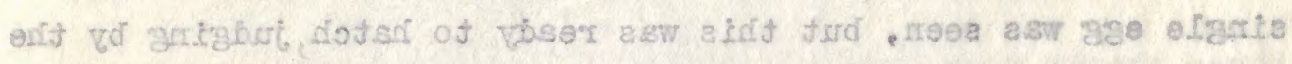

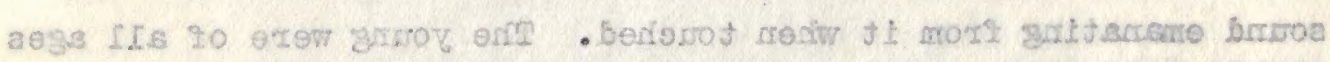

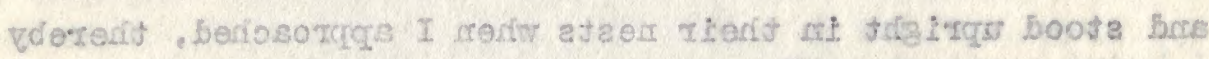

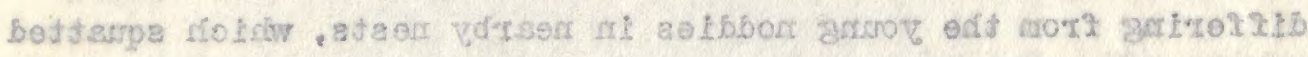

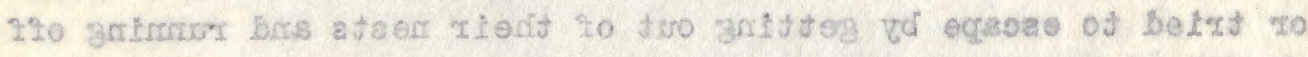

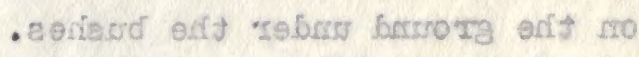

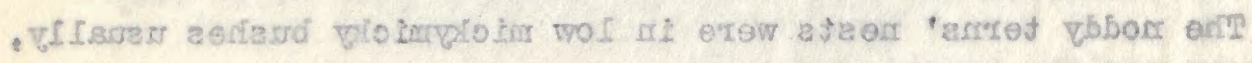


some but a couple of feet off the ground. Of several very young ones noted, there were more of the white phase noted than the dark. A couple of young birds coughed up two or three small blue fish when I neared them. As I passed one thick bush in which several nests showed I heard a squawing on the other side, and looking through saw a young night heron grabbing another by the neck. A crying young noddy ran toward me and stopped in the open alongside, and the two young herons, followed by a white one, came to my feet, then seeing me scuttled and flew away through the bushes. Possibly the young herons rob the noddies, which should be easy as the noddy nests are exposed to the open sun on top of the bushes. One noddy nest had two or three pounds of small coral pieces hanging to it, evidently for decorative effect, and one nest had in it a large white smooth dried shell much larger than the egg which was under the nest, caught in the twigs. Noddy terns sat in flocks near the nests, and in one of the clumps of tall trees in one islet lesser noddies were sitting in flocks and in pairs in the trees. I shot seven at a shot from one place and later saw a couple sitting in a group with one wing extended as one often does when lazy or the weather is calm and hot.

$\triangle$ few fairy terms were about the trees and a couple of carlew, golden plover and wandering tatlers were seen. A white and blue reef heron kept together near where the three young birds were 


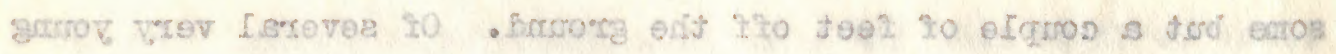

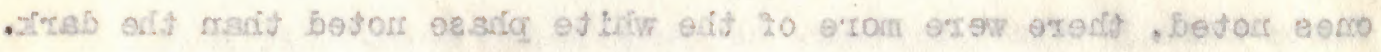

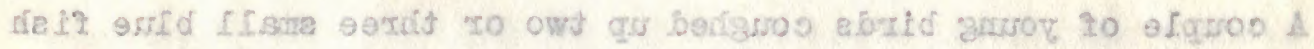

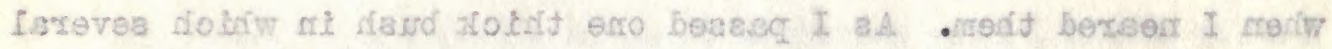

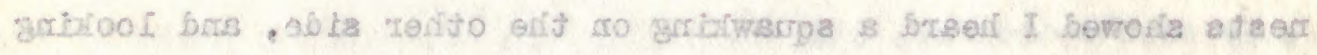

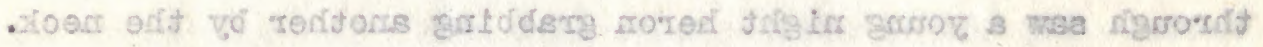

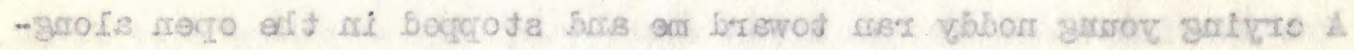

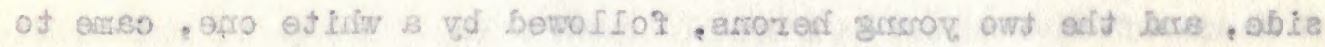

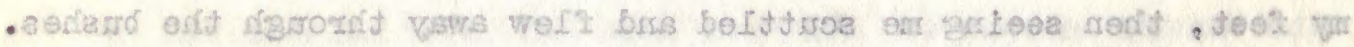

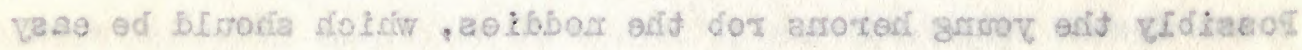

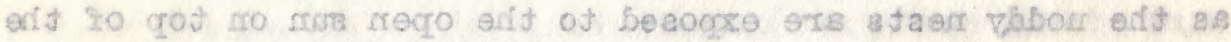

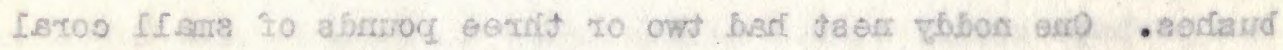

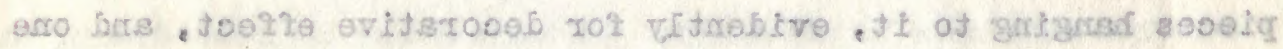

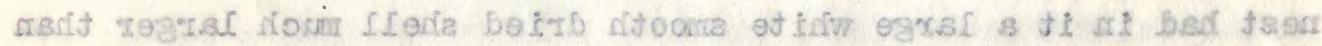

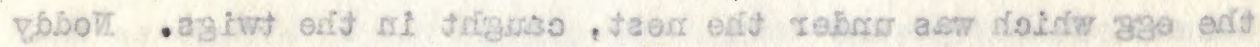

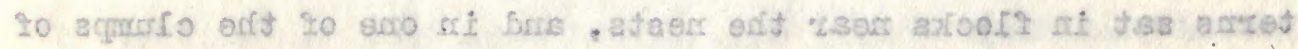

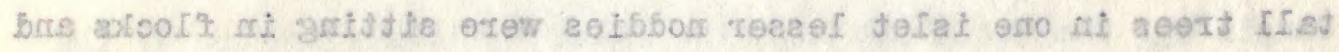

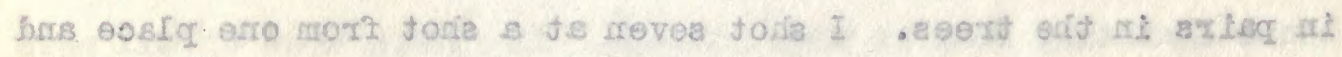

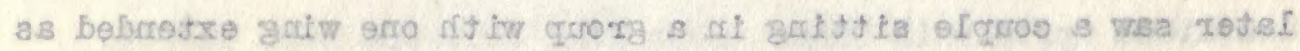

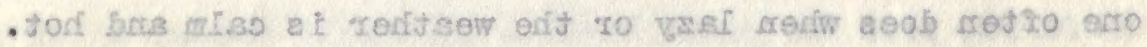

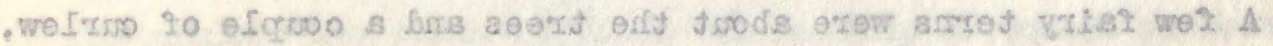

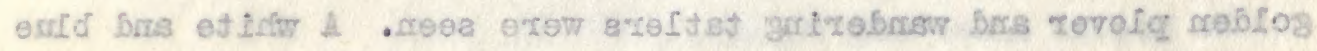

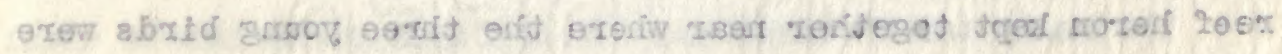


seen. A warbler nest was seen in top of a tohuma tree twenty feet up, but no bird nearby.

No boobles seem to nest here, but several native huts may account for their absence. No natives were seen.

\section{February 3}

Loule went ashore and got one dove and a few warblers and parakeets about five miles to east of our jesterday's landing place. I skinned birds all day. Sooty terms fly along the island and may come from the large colony on Rangiroa Island, though they might nest on this island also.

\section{February 4}

Reing and calm in the morn and at ten start engine to reach Ahif Island twenty miles away at four P. M. to enter the pass at slack tide.

At three P. M. go into lagoon and across to anchorage which is tying up to a rock a few inches below the surface of the lagoon, a sailor going overboard and making the line fast under water. Young and old yellowbill terns are sitting on stakes and flying about fishing. The young have a shrill cleek as a call, quite different from the cry of the adults. Going ashore for an hour find the dozen or so frame houses deserted, as the people 


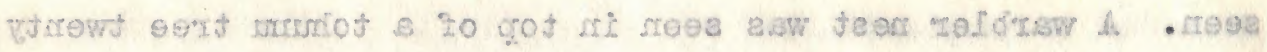
- ziduser buid ort fud, gha sook

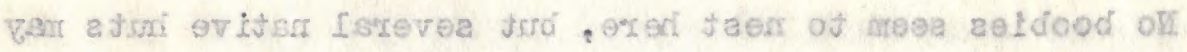

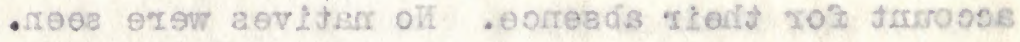

E. Wautereq

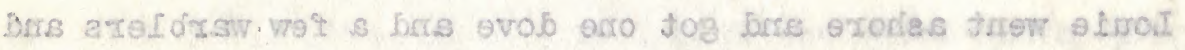

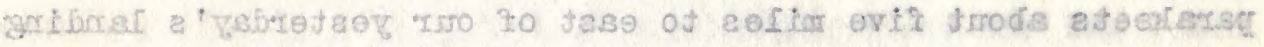

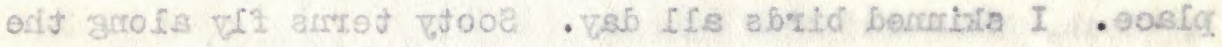

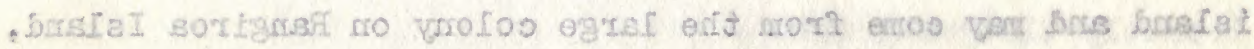

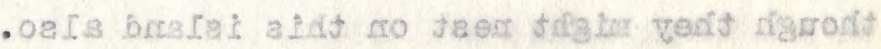

\section{A visurgoto}

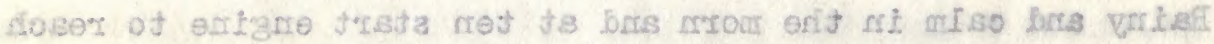

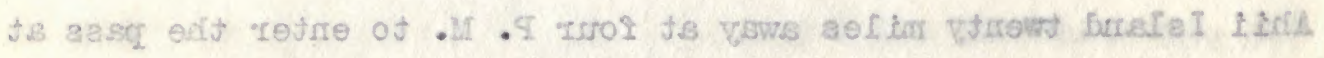
$.0,6 \pm 3$ sosia

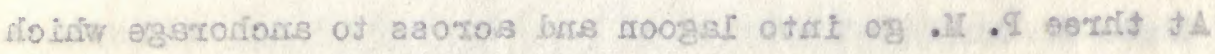

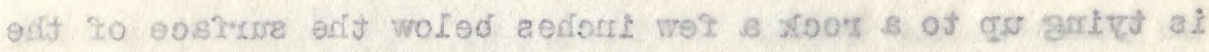

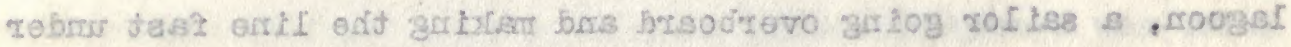

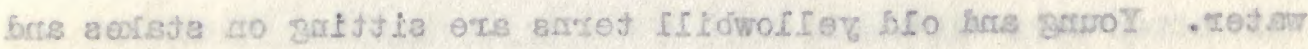

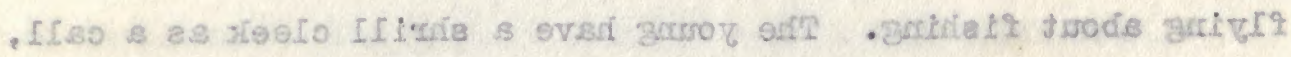

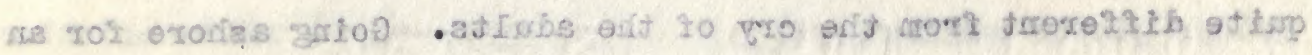

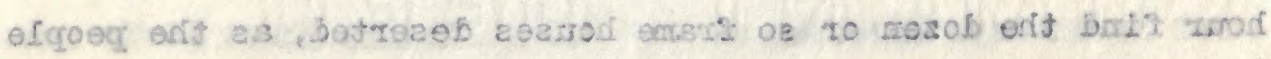


are at Nanihi Island ten miles from here. They live here awhile to make copra and then go back to Nanihi, having houses on both islands. Several warblers and a dove were heard oh shore and $a$ reef heron and a golden plover seen.

A few lesser noddies and several fairy terns were observed as we came through the pass. This island, as my others, is broken up into sma11 patches of vegetation seperated by barren reef. Cocomats seem to be pretty well scattered along the whole strip. Weather is hot with occasional heavy showers. Calm all day.

\section{February 5}

Louie took motorboat and went to a dozen motus and found very few warblers or doves. I went ashore and walked a couple of miles finding six or eight warblers and a half dozen doves. A single dove sat in a cocomat tree near a pair sitting in a tohum tree and a young bird flew a few yards along shore looking for berries. \& comple were seen flying across a wide barren pert of the reef from one mota to another. The warblers sang but little, usually two or three times and then quit. They were usually in or near the thick uncleared jungle, though occasionally one was in a cocomat tree. Noddy terns were sitting about in many coconut trees and some were flying around over pandanus trees. Heard a young one in a coconut tree and saw one in a 


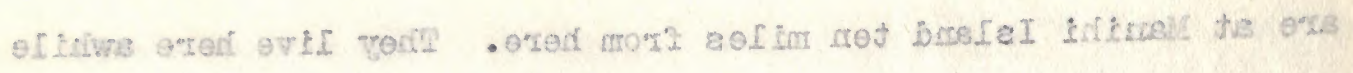

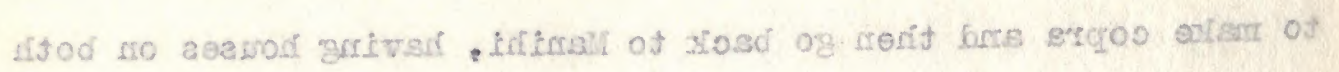

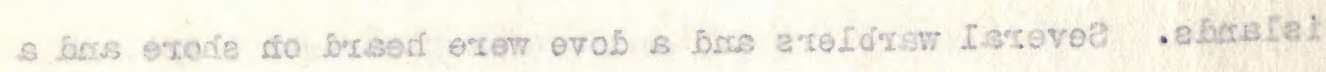
- roez tevolq sabjog s brus sored toer

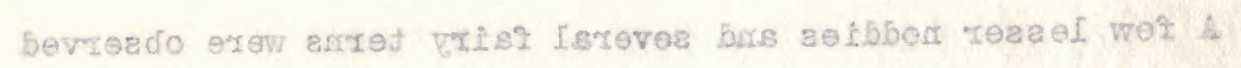

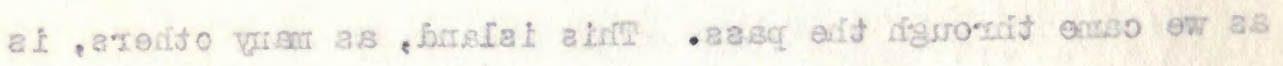

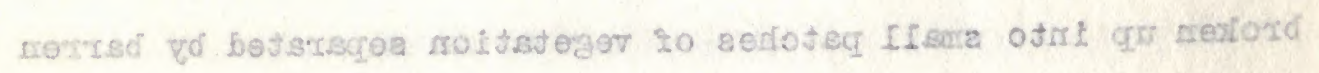

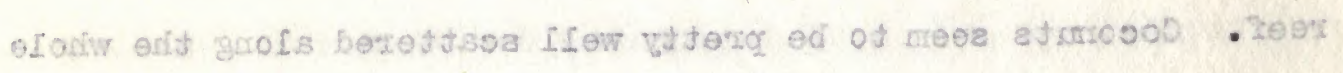

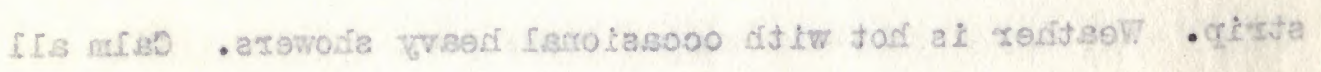
- $\forall$ sb

\section{¿ vtsurosos}

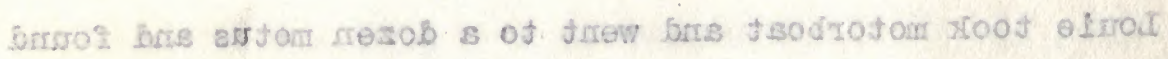

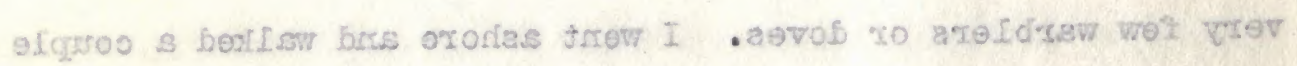

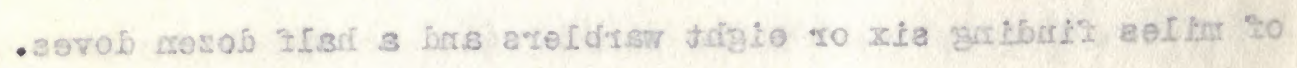

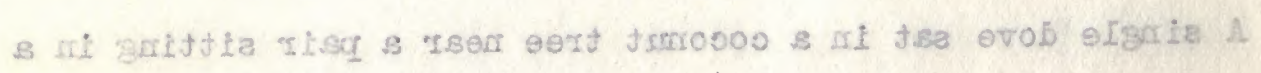

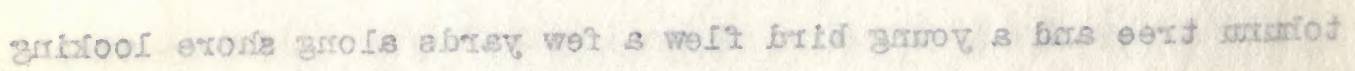

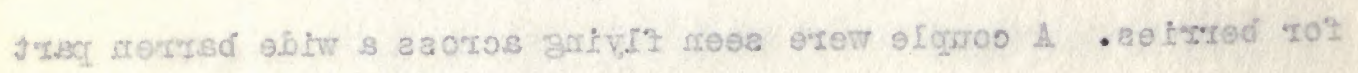

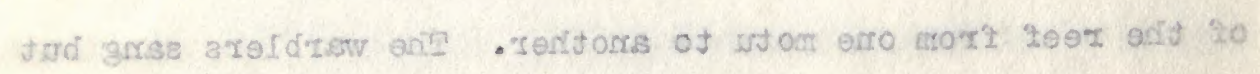

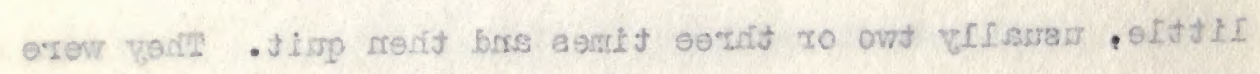

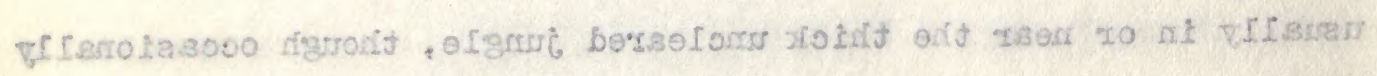

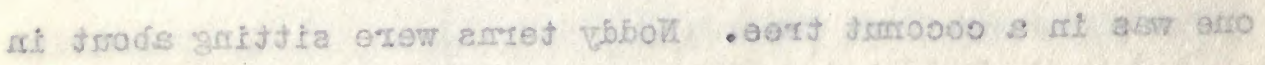

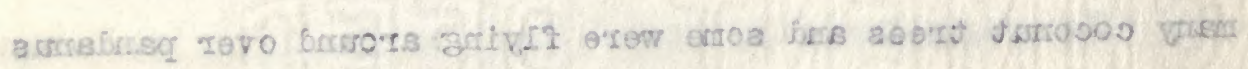

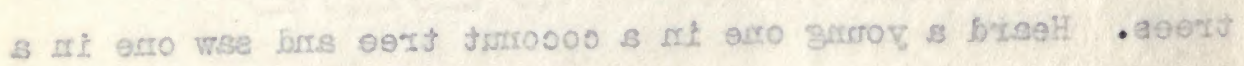


pandanus. They were undoubtedly nesting in both. A dozen or two fairy terns were seen and a fow lesser noddies were fishing along the reef in shallow water. A dozen or so jellowbill terns sat on the lagoon shore or flew over it fishing. The call of the young is weak for a bird its size. Three or four golden plover, two curlew and several tatlers were along lagoon. Reef herons, blue and white, were fishing on outside shore on reef close to edge as well as on lagoon side. Weather calm and hot. Showers at night and a couple during day.

\section{February 6}

Louie went in motorboat to motas not visited yesterday and got a dozen warblers and four doves, while I skinned birds in A. M. and at two P. M. went ashore and looked for warblers, finding seven or eight in thick jungle and coconut trees not yet bearing. Saw three or four nests and took one to describe, being built recently, the others old worn ones. Finally saw one twelve feet up in a tohuma tree with a bird on it. Bird first sat low, but when I approached it looked over at me while I stood under and snapped the Small Ica at it. Then climbed the tree with camera but corld not stand six feet off so climbed down again. Then went up and took out eggs, three being in nest. The bird hopped off and stayed within three or four feet, uttering not a sound but moving around watching me. The nest was in the forks 


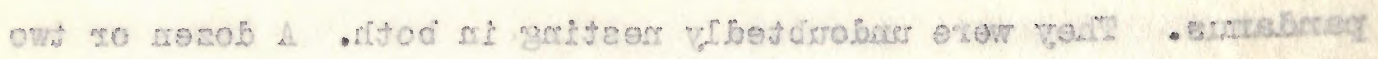

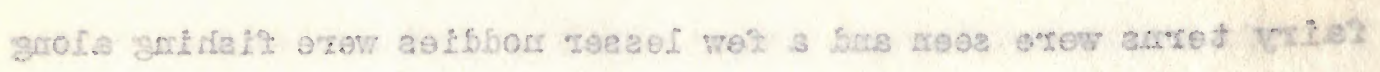

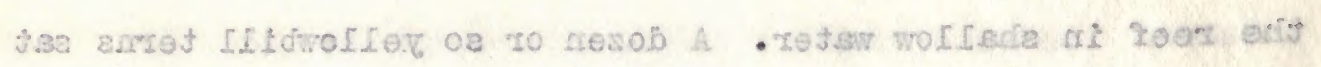

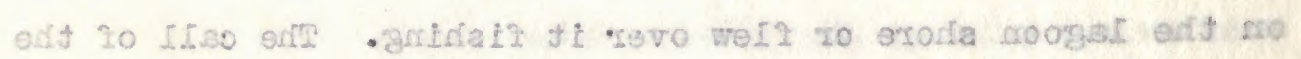

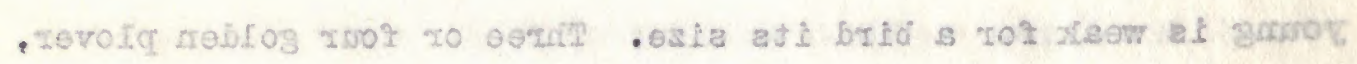

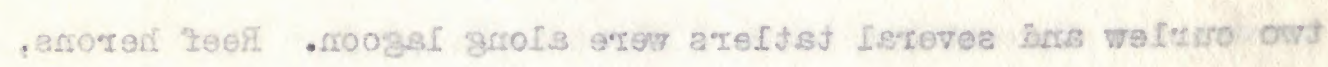

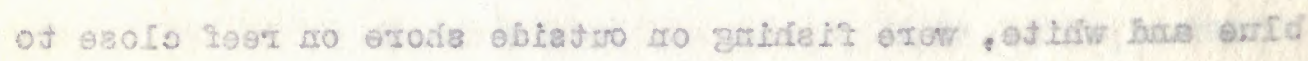

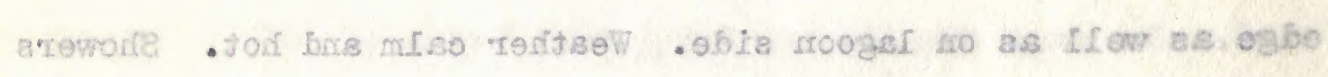

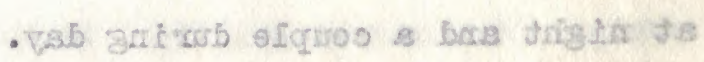

\section{a visirö}

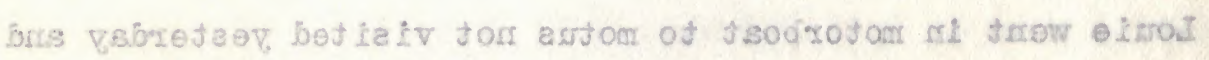

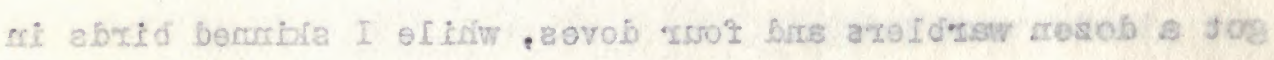

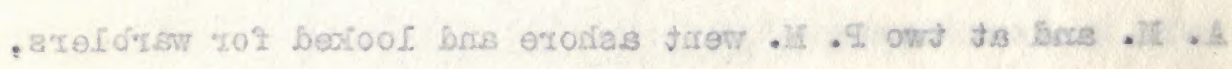

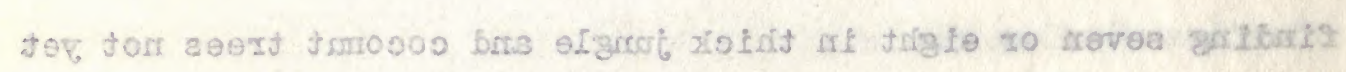

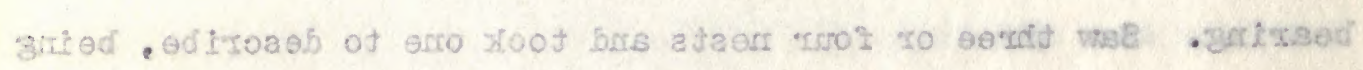

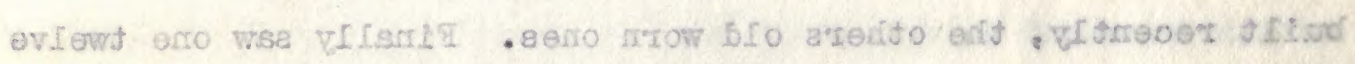

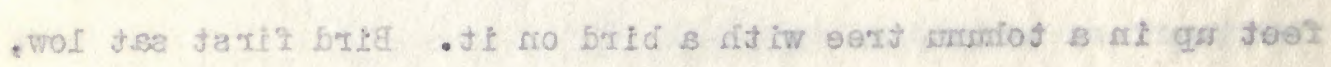

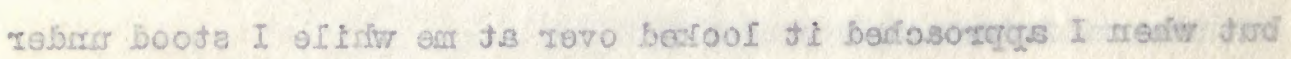

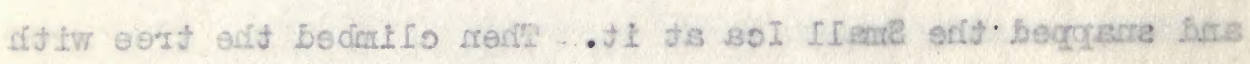

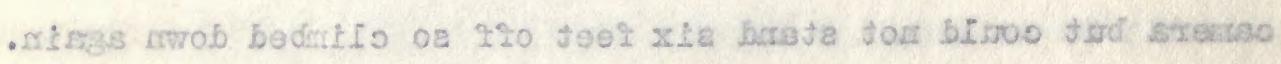

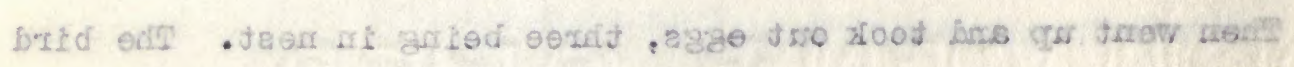

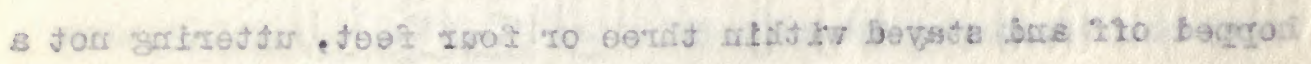

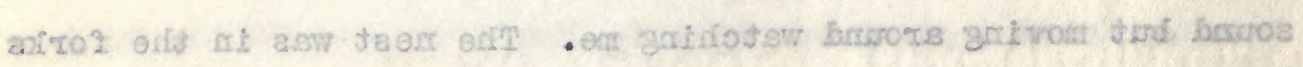


of a small shoot running up alongside a dead limb. Before I went up to the nest the male came and lit in the tree and I shot him, the female remaining on the nest. When I cut off the limb with the nest in it the female stayed in the tree and I collected her also. The nest was fairly well hidden by the thick leaves that hang down below 1t. I broke off three or four before photoing the nest later, sticking the branch in the sand by the lagoon shore and using water for background.

One bird sang quite awhile this P. M. sitting out of sight in a tall coconut tree, and one or two were heard practicing as though they were joung birds. Noddy terns swing along over the trees to nests farther along the 1sland, and the yellowbill terms fly about fishing and resting on stakes in the water, as well as using isolated sand beaches or protruding rocks.

\section{February 7}

Louie ashore in A. M. and got a few warblers and after lunch we moved down near the pess and he went ashore again and lilled a big pig as well as four doves. The warbler eggs were slightly incubated, showing the bird sat from time of laying first egg. Sallors caught a few fish, while we were tied to a rock which showed above the surface of the lagoon. A few lesser noddies and several fairy terns were fishing in the lagoon near us in a strong 


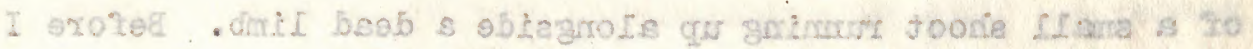

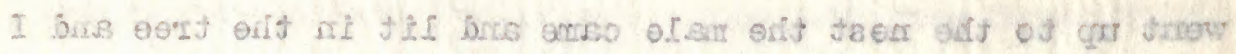

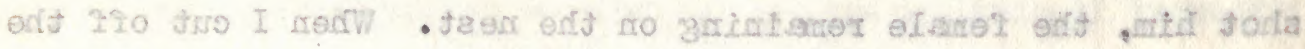

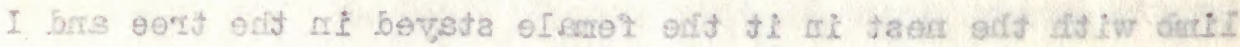

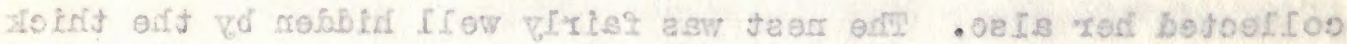

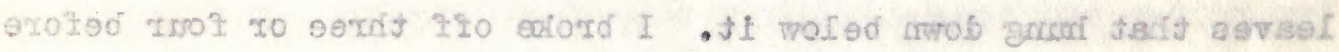

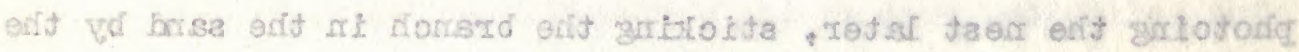

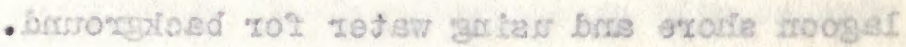

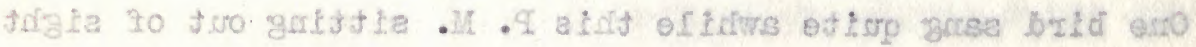

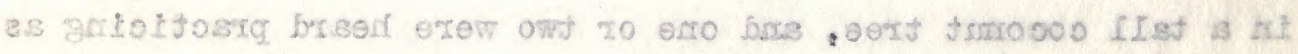

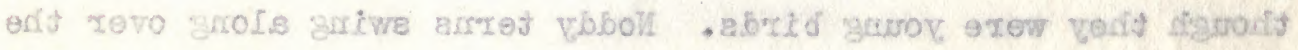

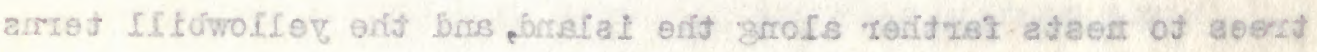

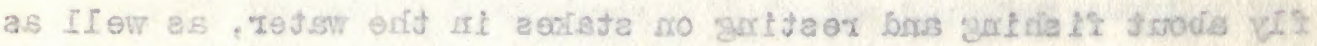

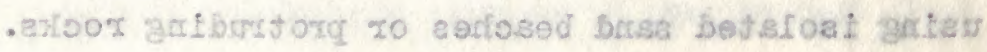

\section{Esisardol}

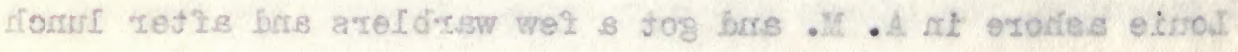

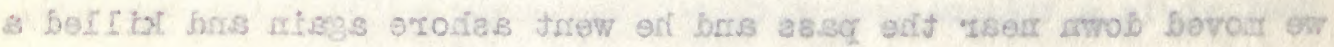

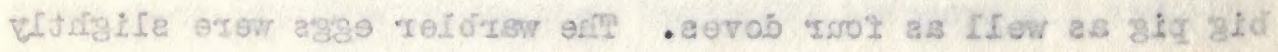

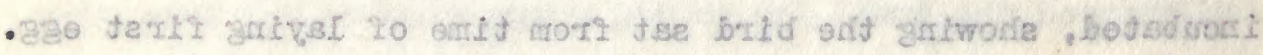

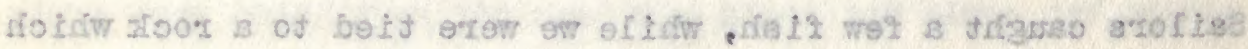

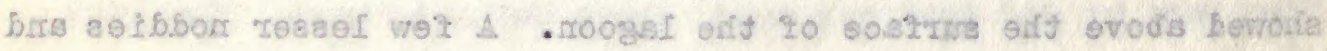

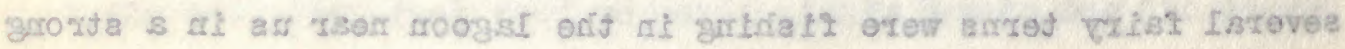


breeze. Louie shot a lesser frigate yesterday, but in falling from a great height it burst open the entire breast when it hit the water.

Flies are thick here and at Arutua, while mosquitoes are swarming in the calm thichots due to rain lately. One has to keep moving in the jungle, for mosquitoes are ravenous. Warblers are molting now and several had no tails. A couple of young ones are quite white-breasted, while the freshly plumaged adults are more buffy in color. Two warbler nests examined were made of pandams and coconat bark shredded and lined mostly with hairlike threads of coconut fibre.

\section{Fobruary 8}

Leave at five-thirty for llanihi twenty miles away to the eastward. Going out the pass we see lesser noddies and a few white terms flying about the trees and a circling flook of thirty-elght frigate birds sall around, climbing into the air to head out to sea. These may be lesser frigates, but it was too dark and against black rain clouds to distinguish white on the underparts. Outside the pass lesser noddies were flying about just over the water, but not finding many fish as far as I could see. One flock of sixty was counted and a larger flock was seen farther out. \& few were seen fishing till five miles of more off the island. Fairy terns also were frequent between Ahii and Hanihi. 


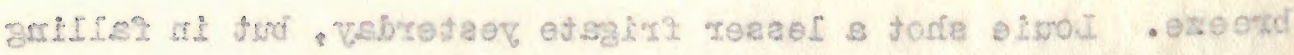

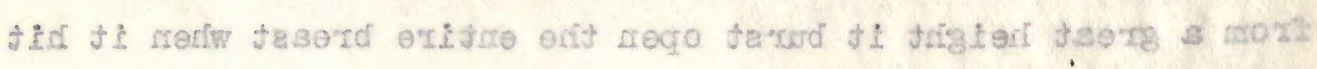
- retsm exty

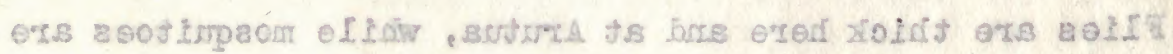

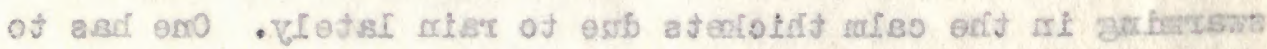

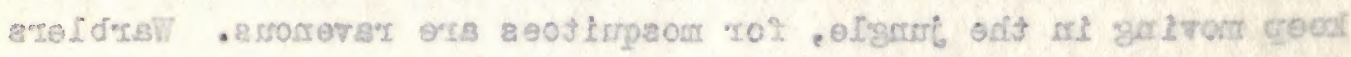

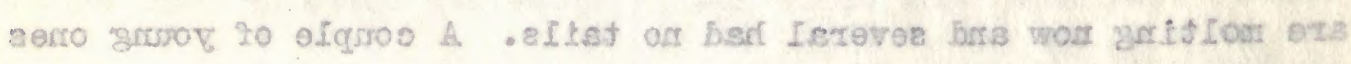

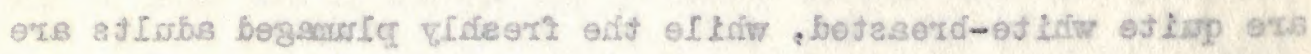

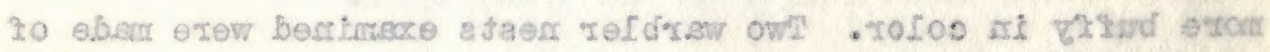

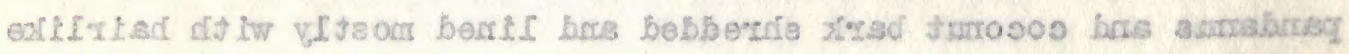
- erdit suropos to abseralo

8 पुนsurcte?

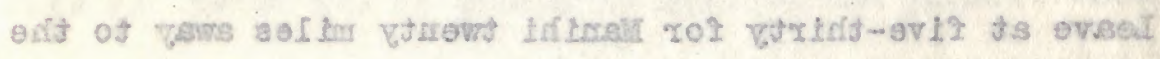

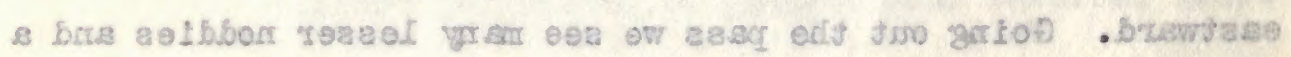

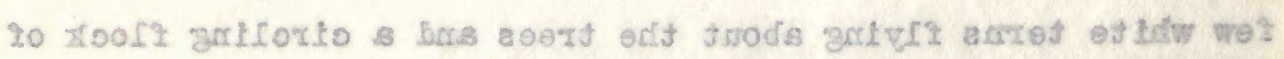

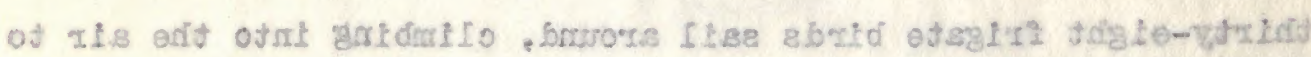

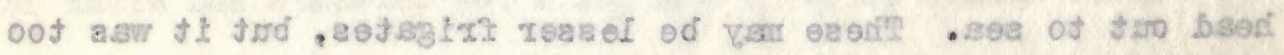

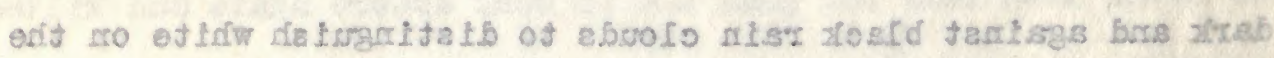

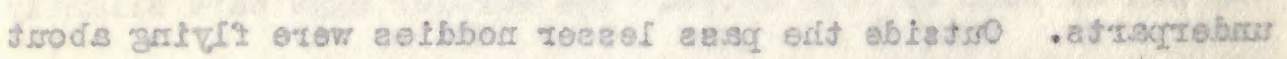

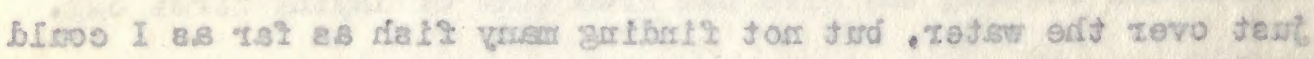

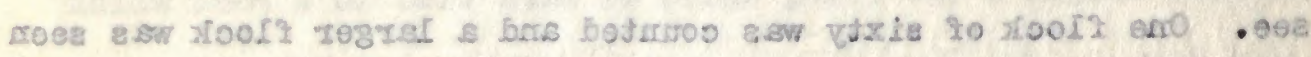

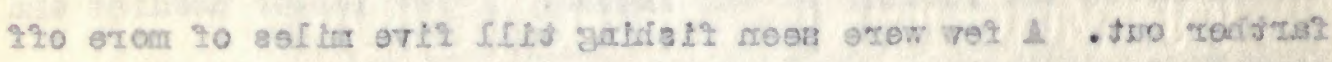

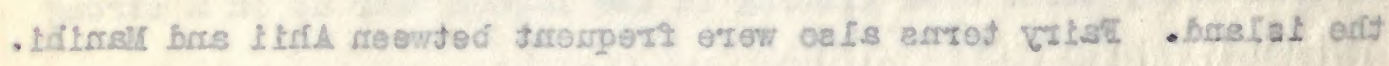


Reach Manihi at eleven $0^{\prime}$ clock and see several small houses with galvanized roofs noar the beach. A stone wherf affords a plece for the ressel to tie to. Few lesser noddies and a couple of fairy terns are birds seen entering the pass. The village is on east side of pass and wharf is on edge of pass.

Tied up at ono P. M. and on Inquiry found that the chief was up at other end of island and the old men here did not want to give permission to hunt without the chief's say-so, so I went with Loule in motorboat to the motu where he was supposed to be but he was still farther, and being nearly four then we collected two or three birds and started back. Inree miles from town the motor brolve a spring and I rowed the outfit back to the ship. Lesser noddies were nesting abundantly where we landed and I got a couple of young fairy terns. A single grayback tern was seen flying across the lagoon and a goodly number of sooty terns were flying along shore, but possibly they were birds from Rangiroa.

\section{February 9}

I went ashore early, leaving Loule to work on the motor. Daring the day he got a spring from an old clock ashore and made "a make and break" as he crlled it. I struck several pieces of coral a mile from village which had been sawed and chipped for house posts, there being no suitable blocks nearer. On the second motu I struck a rail and heard another, both being near pandarras 


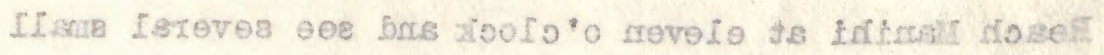

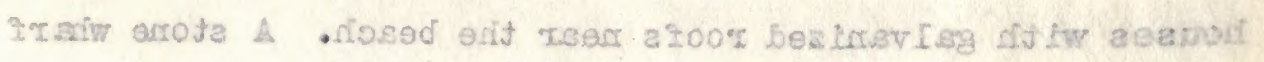

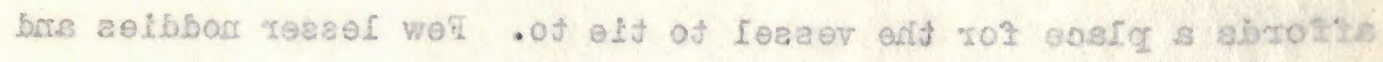

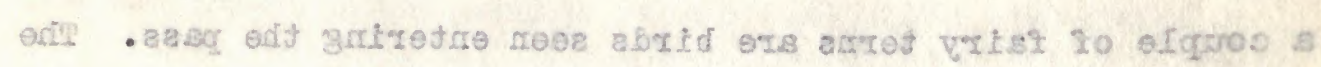
- earer to ezbo to el merrim bus azsq to ebja jaso fro al egaffiv

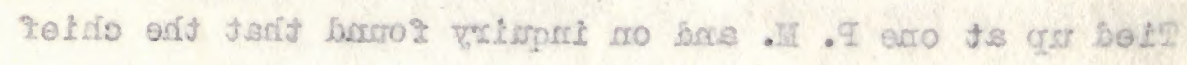

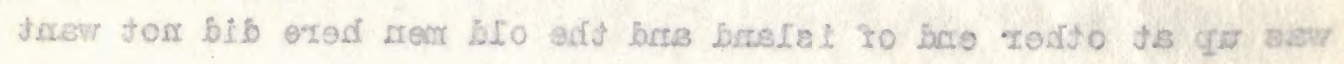

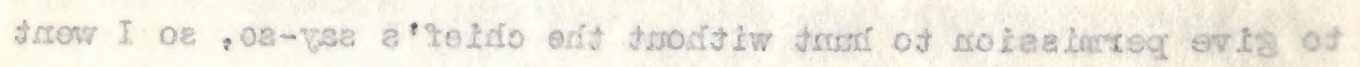

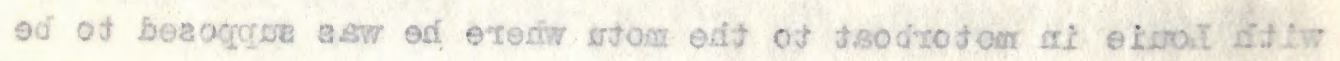

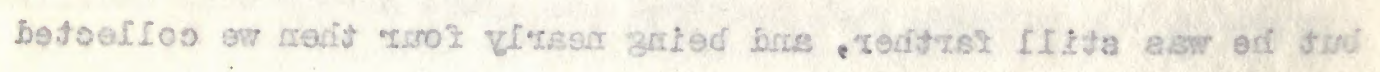

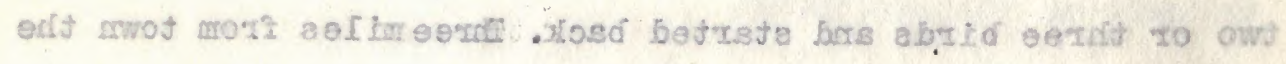

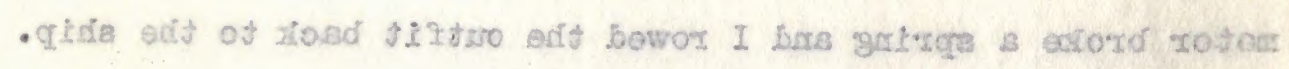

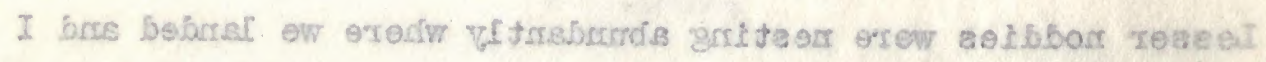

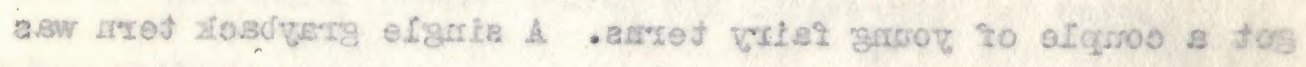

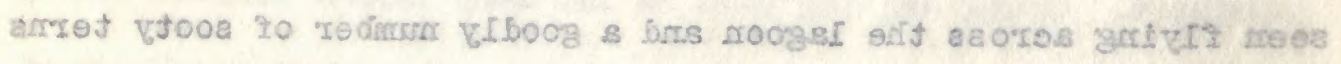

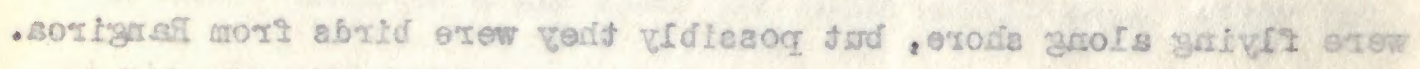

\section{e vestedea}

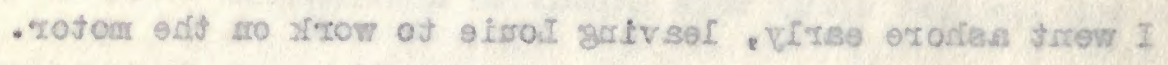

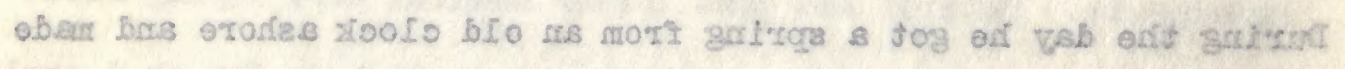

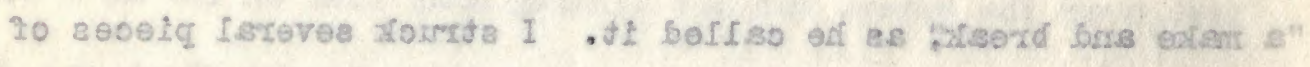

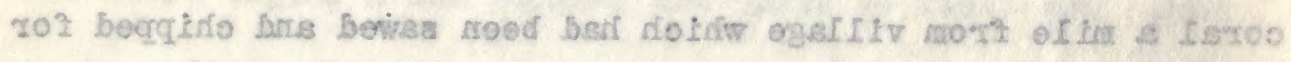

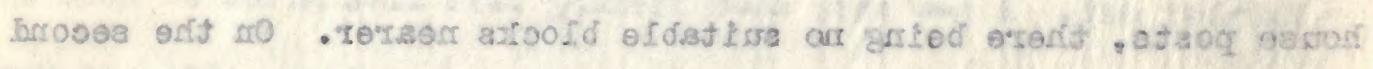

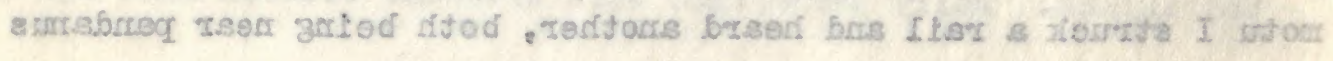


trees. I climbed a few feet in a tree to see the one I shot as it kept a pandanus tree between us while it called. In the P. M. returning I shot a couple more, both being in open ground with only mickymicky bushes for cover. A female (?) called repeatedly as she walked along ahead of mo, and I shot a crab through the bushes in

thinking it wes the rail, but a minute the rail passed the same spot and I got her. A little later I saw another by a pool of water and got it as it started off. Louie went there a half hour later and saw a half dozen, but they ran too fast for him or were too far away.

Saw a dove fly with a twig to a tohunu tree, and going to it saw two doves on the nest which was only started,--a few fine dry twigs on the branch of a tree (2 inches) and ten feet from ground. Both birds stayedawhile, then the mate went and later the female. Nest in young coconut grove. Several lesser noddy nests in tohum and hotu trees. Few young but most old. Old and young yellowbill tern fishing near ship in return, and at sunset thick flock of several hundred lesser noddies fishing outside the pass where current strong. Several golden plover and one curlev and scattering tatlers seen.

February 10

I skin birds while Louie goes up lagoon and gets few warblers 


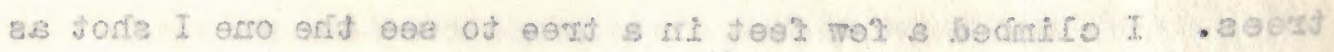

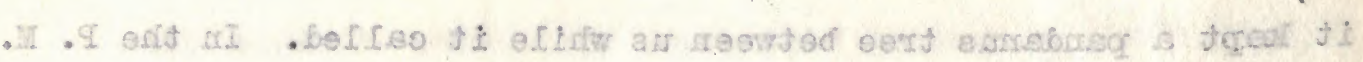

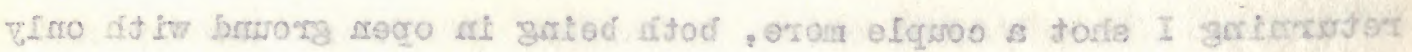

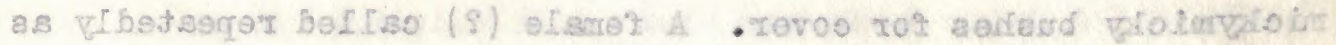

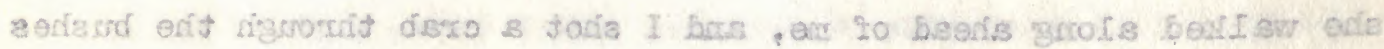
m!

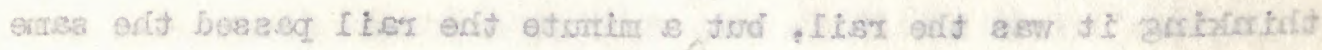

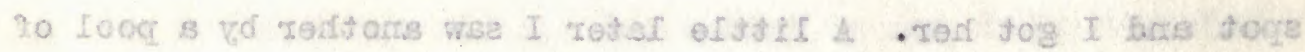

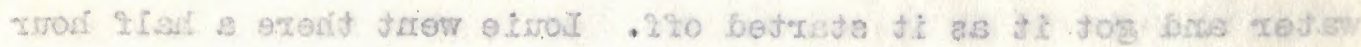

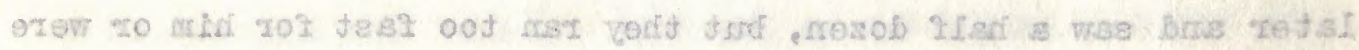
- Vesure rast oof

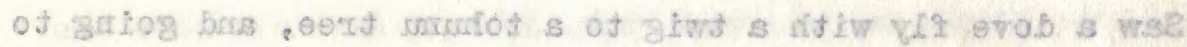

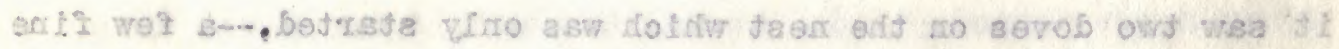

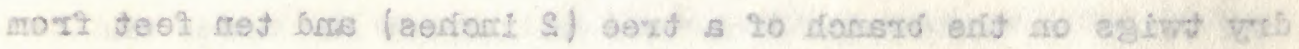

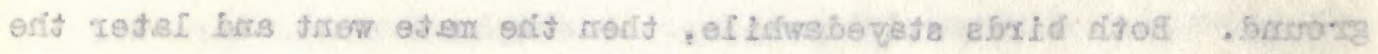

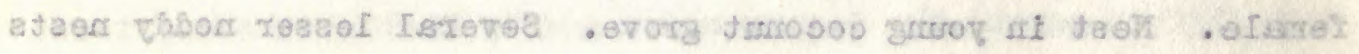

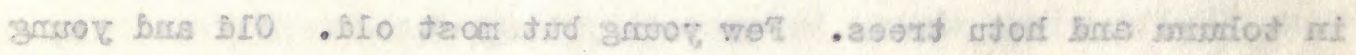

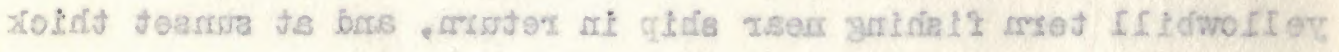

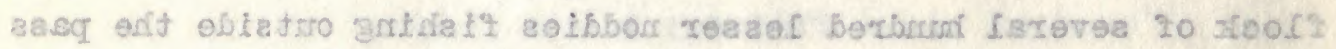

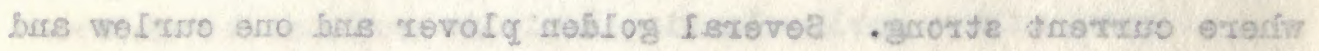

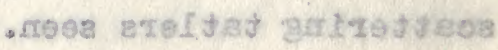

\section{OI versurder}

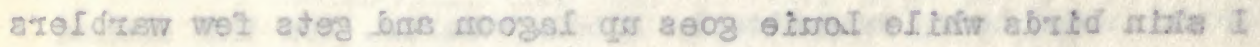


and doves. In P. M. I go out for a couple of hours and see a rail as it flies from edge of clearing in grove to thicket. It flew well but a short distance. Louie back with twenty birds at four and we ran those out by quitting time. In the morning a fer natives were on board and saw a school of fish on the reef across the chamel from us. They took our net and several spears and went across, and with much excitement managed to get a dozen. A couple of dogs swam after them and added to excitement by chasing fish, the water being less than a foot in depth. Six inches perhaps, for one dog caught a sizable fish, shook and killed it and watched It till one of the men came and picked it up. \& tame young frigate bird flew across and tried to help in the work, but the fish were too big for it to handle. The frigate roosts on a shed and flies around the village at will. A native brought in a live warbler and nest containing a young bird just hatched and an infertile egg. Early in morming saw a school of fish (bonita?) outside a mile with flock of terns with them. A native went out in canoe but did not see his return.

In P. M. a half dozen cutters came in from up the lagoon a few miles loaded with cocomats, and all afternoon people were carrying the strings of mats to their house B, women with wheelbarrows, and poles on their shoulders carrying nuts, as well as the men. Chinese merchant was offering 3.75 per 20 muts, while 


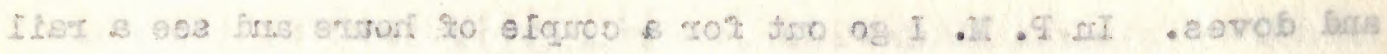

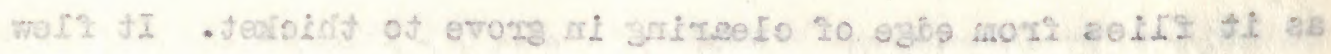

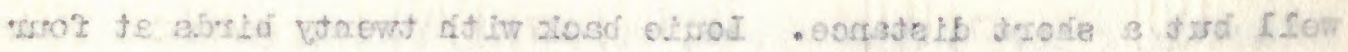

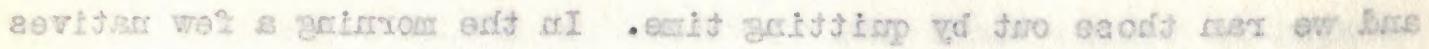

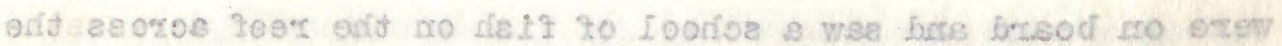

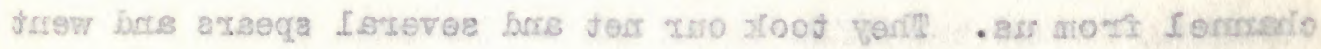

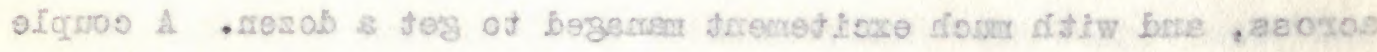

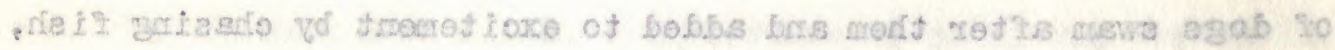

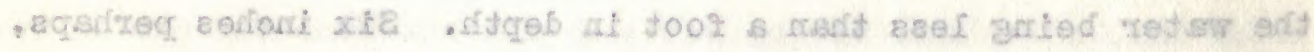

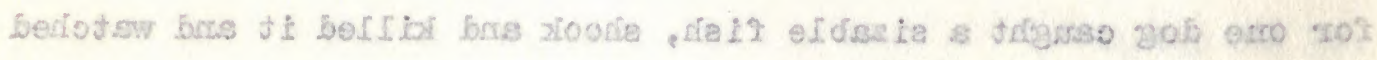

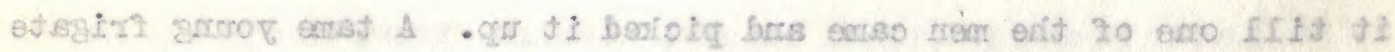

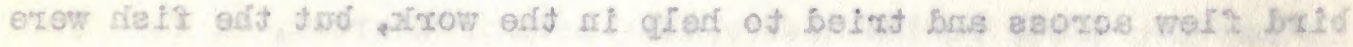

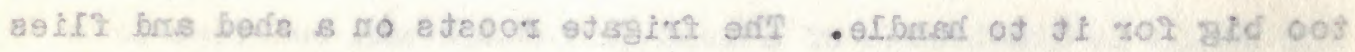

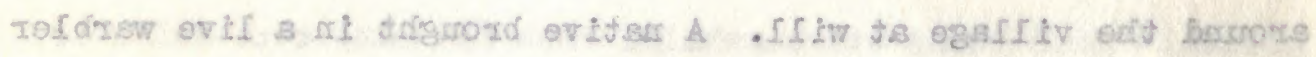

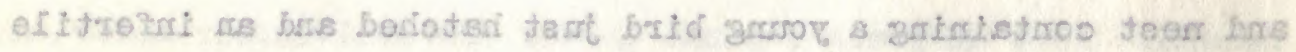

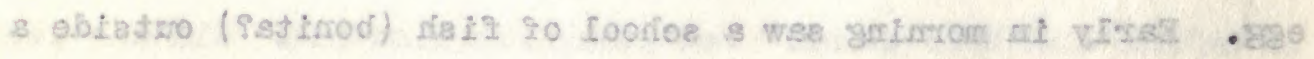

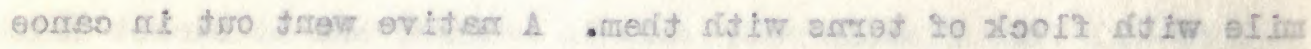

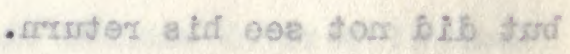

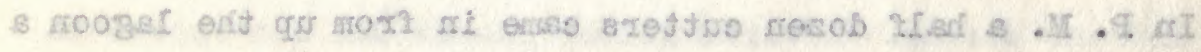

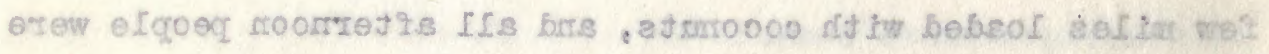

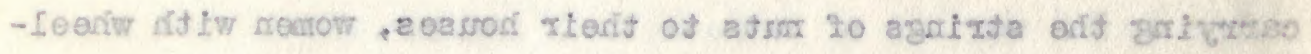

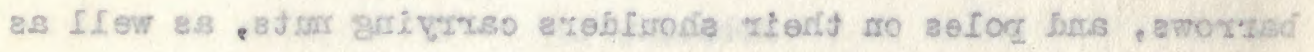

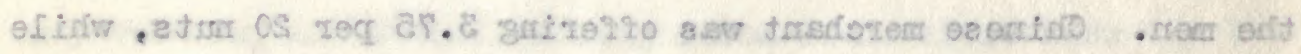


the 0 il Co. representative offered four franes per 20 nuts. Heary squall at night and stormy looking all day.

'France Austral' stopped outside for an hour but no copra ready so she went on to other islands.

\section{February 11}

Squally in morning. Sunday.

\section{February 12}

Out in early mom for rail but saw none. Back at eleven and sicinned birds till three, then out again for rail. Saw one but too far to shoot. Iouie went up lagoon a few miles and the dog caught a young one for him. He reported they were numerous, so will have him go tomorrow.

\section{February 13}

The spring Louie made from an old clock spring was too weak for the purpose, so this morning he takes a spring from an old graphophone and malses another. He left at eleven for jesterday's ground, while I finish birds and at nine go to look at dove's nest found last woek. It has an egg today and the bird was absent when I arrived, but while I was in the tree trying for a photo one dove came and lit in the tree for a few moments. It then flew 


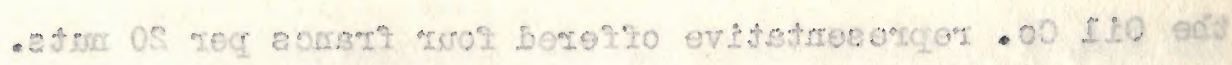

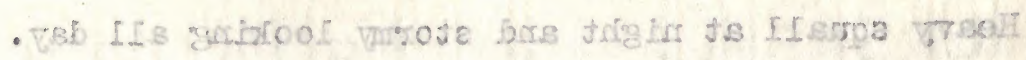

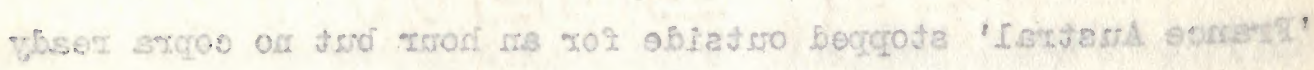

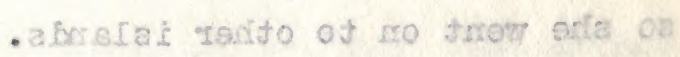

\section{If visstor}

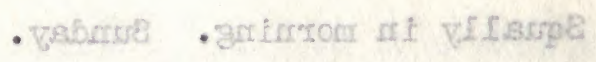

SI trosutor

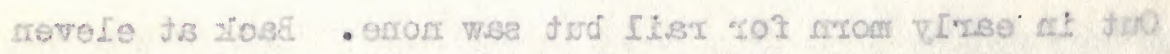

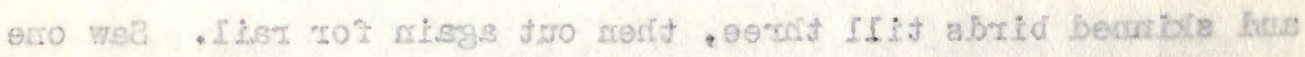

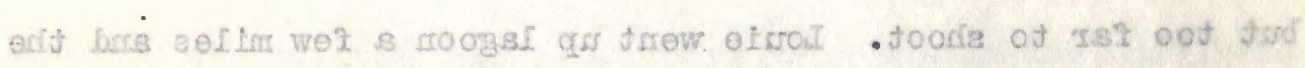

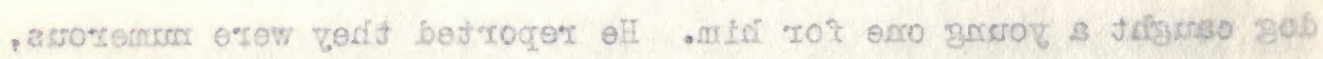
- worzonios og mild evedí Ifiv oa

\section{EI reseroter}

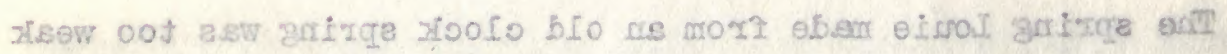

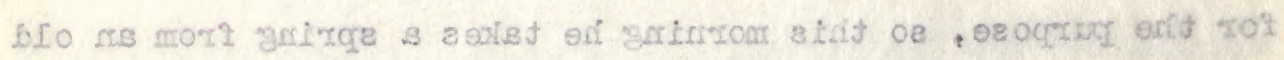

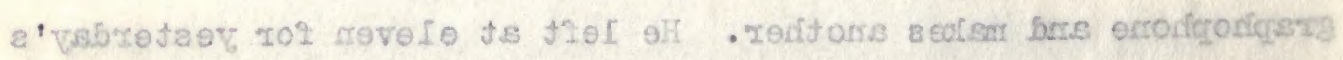

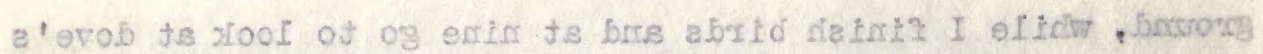

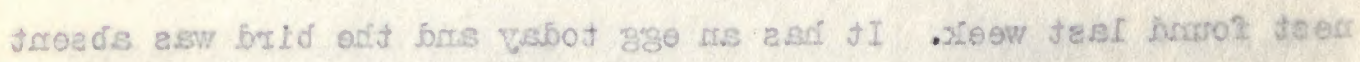

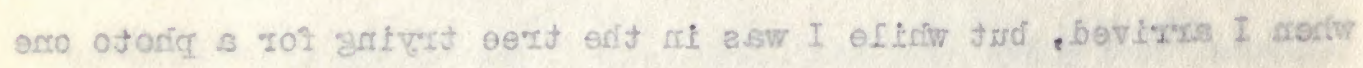

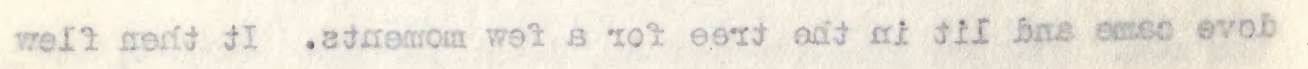


away and was not seen again, though I stayed over half an hour at the spot. A couple of dozen fine twigs formed the nest and the egg was plainly visible through it from below. Piled up a few coral blocks under the nest, and with forked stick pulled limb down, took the egg, sawed off $1 \mathrm{imb}$, and took portion of limb with nest. The male (?) called several times from hundred yards away. I went over after finishing and got him presumably. Spent three hours walking about after rail and saw one under same bushes, and before he saw me I shot and secured him. The rail that see the hunter before he sights them run so fast that he never sees them, while the occasional ones that he sees see him usually at the moment of his discovery and usually two seconds places the bird out of sight behind brush or trees. A single curlew was seen at the same spot that one was seen last week,--only one seen here. Yesterday got a young varicolored heron and have seen white and blue ones here. Saw several nests of warblers in tohunu trees, all of same composition,--shredded bark and from ten to thirty feet in height. Saw one yesterday in pandanus in middle of tree and possibly many nest there for the nests would not show often from below. Nests examined seem unused though deserted. Irregular flight of noddy and fairy terns all day flying along land to nests farther to windward and many young noddies heard in coconut trees. Flocks of noddies rest on sand beaches near water composed of young and old birds. 


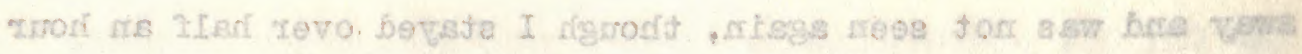

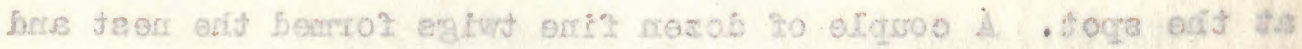

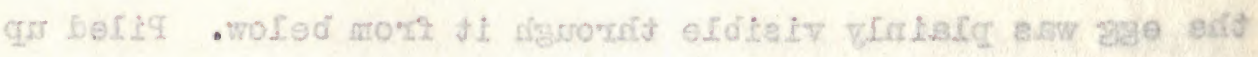

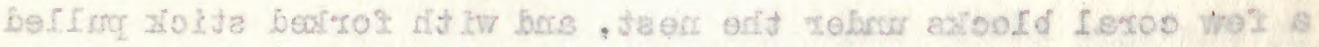

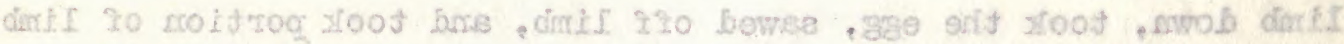

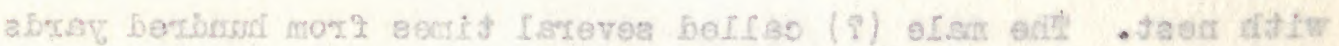

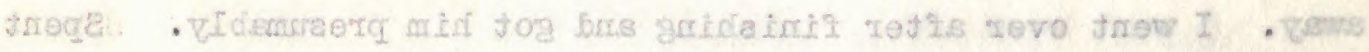

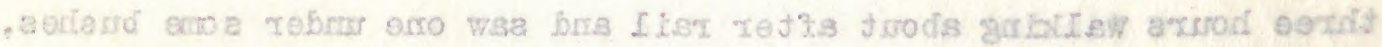

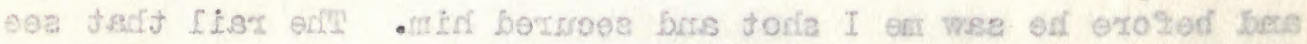

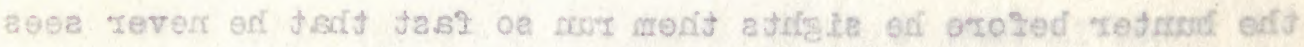

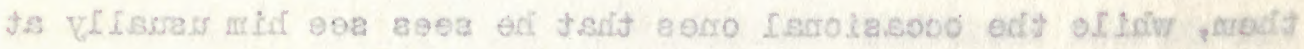

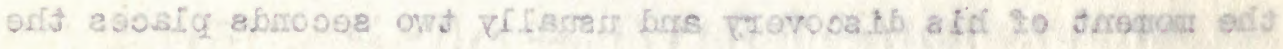

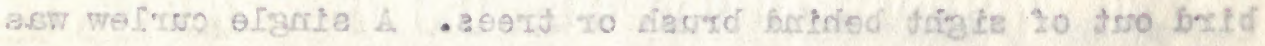

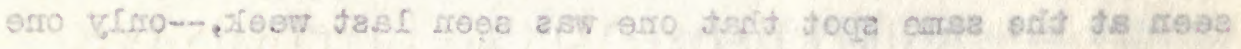

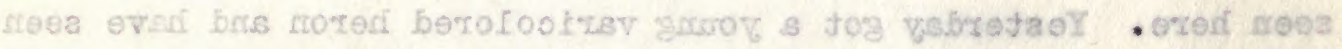

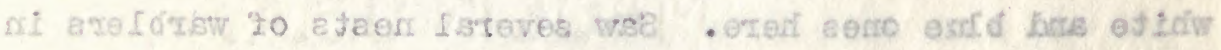

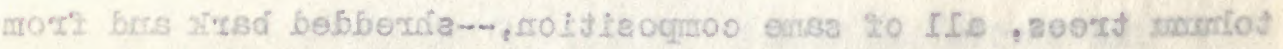

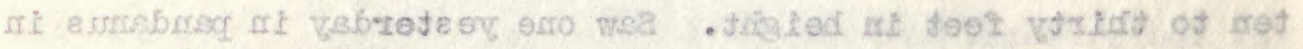

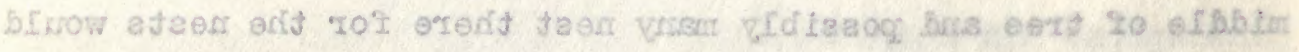

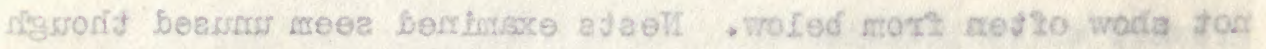

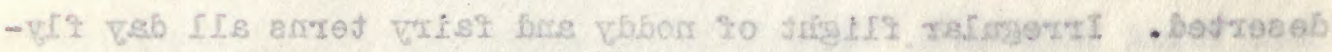

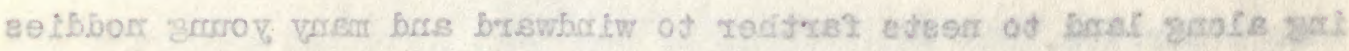

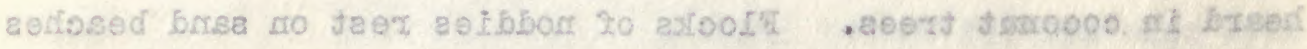

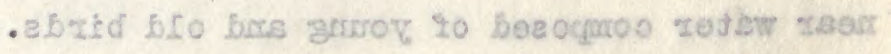


February 14

Iouie sent in a couple of rail this morning by a cutter coming in with load of coconuts and this ove returned with a few doves, saying a crowd of people invaded the motu where he was hunting and spoiled the shooting for rail. I sleinned birds till three and then went after rail but saw none. Three or four grayback terms fished along the pass when the tide turned today and I shot one. A couple of kids fought all the way out to it in the current trying to be first to eatch it. Then they fought back again with the bird, which went into pickle. A young dove yesterday called so low that I barely heard him at forty feet. His call was "Coo cucu! Coo cucu! Coo cucu!" the second call being lowest. Nearly a.ll the cooing doves here seem to be weaker in calls than in other islands. Yellowbill terns fish along in the lagoon daily but do not allow close approach. Golden plover 80 well back in pandamas and coconut, hunting where the ground is moist. Tatlers keep more in the open, though both are well back from beach 200 or 300 yards.

Fobruary 15, 16, 17

Managed to get a rail and see three others, all being wary. Louie went up to motu agzin where birds are plentiful. The people being gone he got three more. We will try again before leaving. He called at the lunatus tern colony, finding a handred birds 


\section{$-98 \Gamma_{-\infty}^{-\infty}$

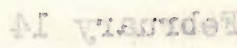

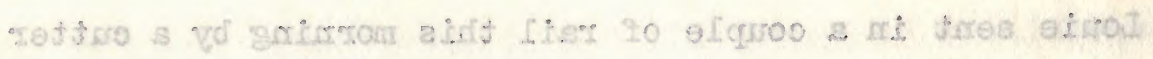

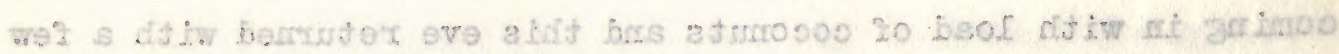

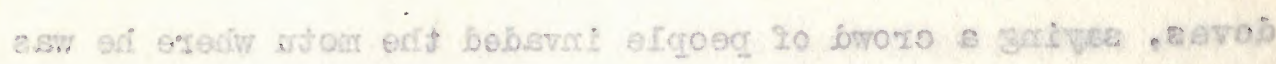

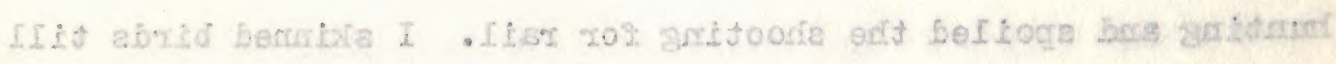

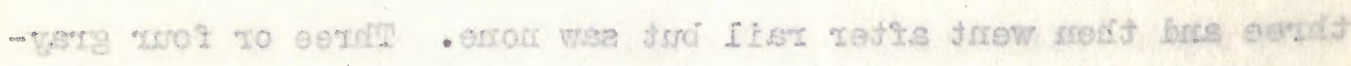

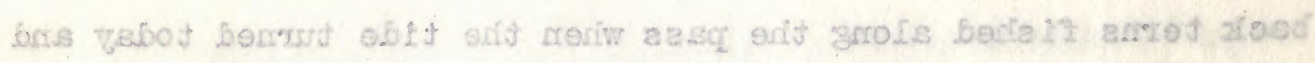

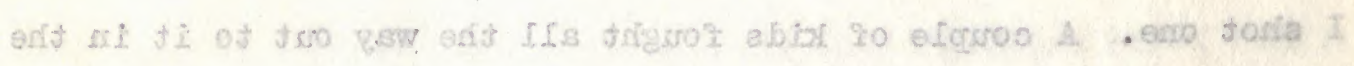

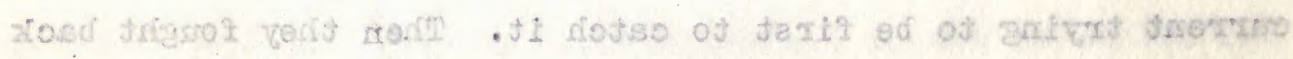

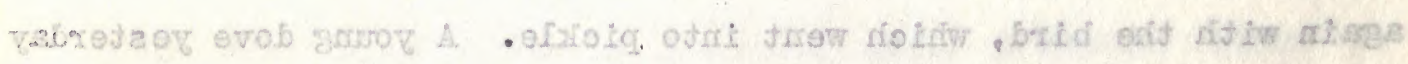

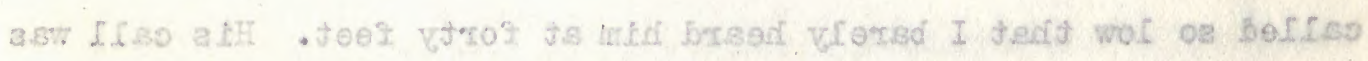

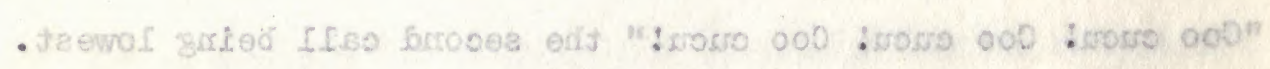

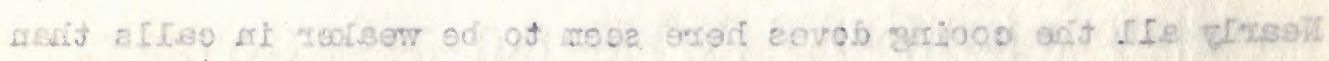

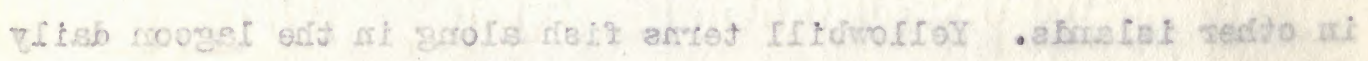

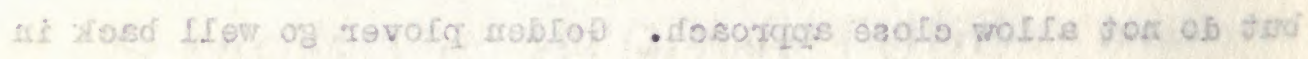

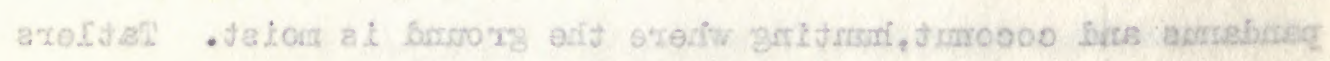

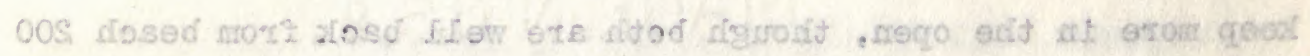
- .5xisy 008 re

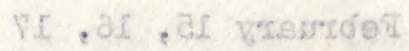

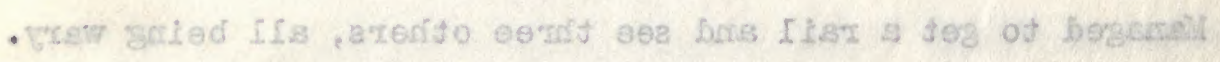

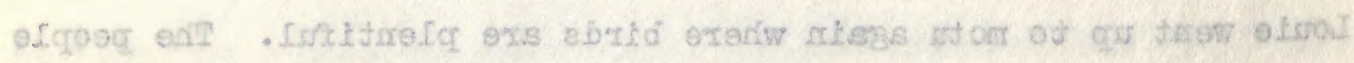

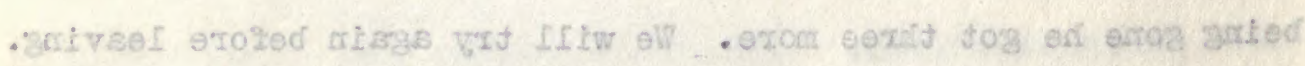

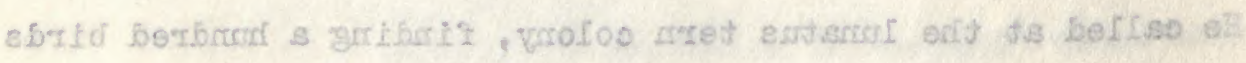


nesting amongst the rocks on open reef where vegetation has been washed off. Got downy Joung and few eggs. Natives bring in young noddy and fairy terns, as well as lesser noddy birds; children pley with them awhide till they die I presume, though the young frigate is fed regularly and goes and comes at will. Children play for hours in water alongside vessel,--five years old and up to ten, swimning and diving in the strong current thet runs either in or out most of the timo. Women work at copre. drying as well as mon. Saturday several canoes are seen fishing inside pass for half day. After dark with small hooks and couple of white feathers tied on the Captain and engineer catch 30 or so eight inch fat $f i$ si for our sunday dinner. The water is clear alongside and fish of many kinds are seen lat one time sharirs five leet long) but they do not bother kids who swim across channel one hundred yards or more wide. Hgangahu is name of old stone axe given me by native of Manihi Island, who found it in old house or where old house used to be.

\section{February 18}

Sunday. Aboard most of day.

Eebruary 19

Expected to go in motorboat up lagoon, but it wouldn't work so I went usual trall for rail. Saw none though hanted all day. 


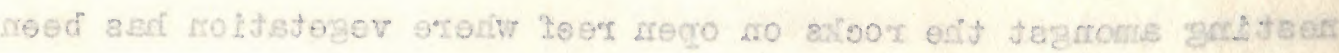

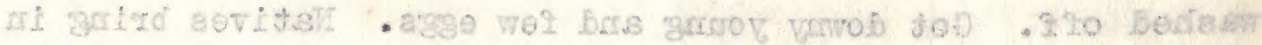

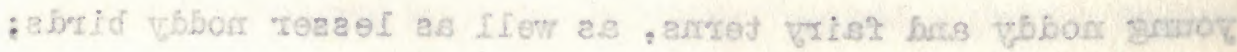

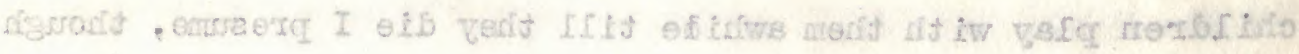

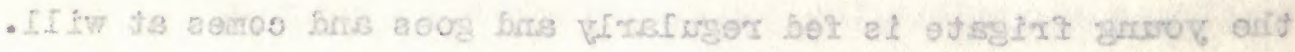

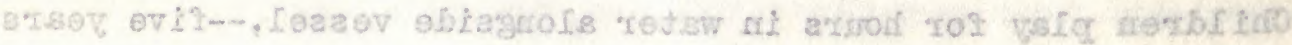

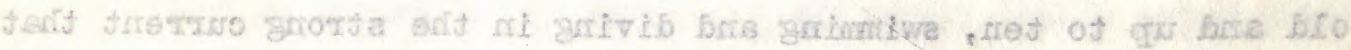

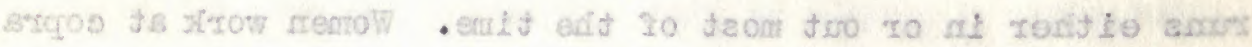

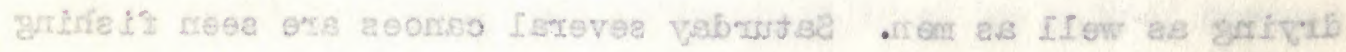

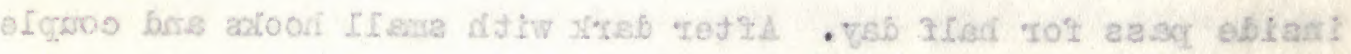

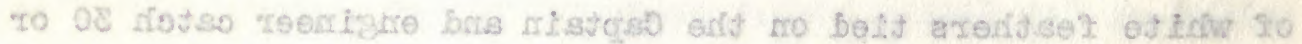

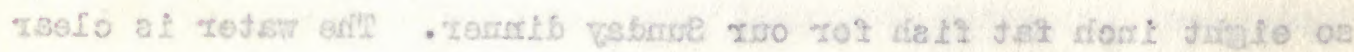

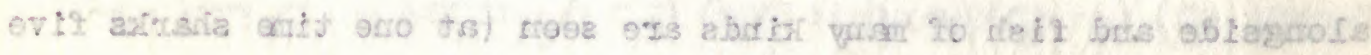

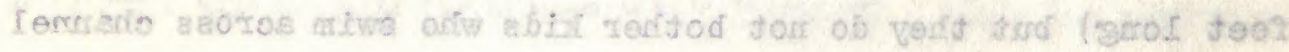
orrota bis 20 ecrest a

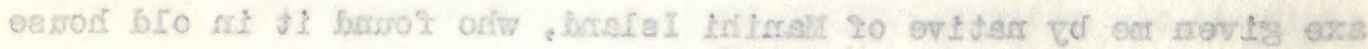

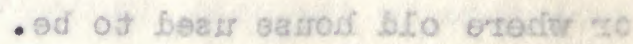

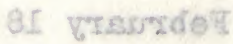

- tab io jeom brooda. vaburua

\section{e. सrsingdot}

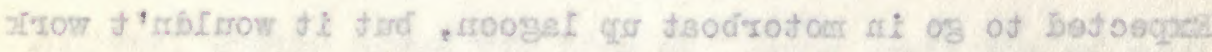

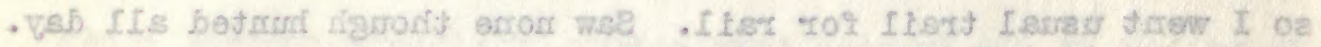


Saw a dove flying with a twig and followed and found nest with male (?) on in a long-limbed shrub that grew under a tohunu tree. Nest ten feet up and a foot under a dead coconut limb that has not fallen yet. I stood twelve feet away from bird and he cooed once while I watched him. Arranged and picked at twigs and finally I climbed the tohunu tree and stood ten or twelve feet from him; so he sidled out of nest, perched on limb and flow off. Couple of hours later I called again and saw the female (?) fly to nest, arrange a twig, climb around male and fly away, while the male stayed till I neared nest. Female flew to tree a few yards away and picked a crop full of berries, malberry type, and flew away after watching me awhile. Nest is placed on top of insecure limb with few little cross twigs to hold it.

\section{February 20}

Motor won't start, so I tako boat's crew and go four miles up lagoon to motu where rail occur and get eight in a. fow hours' hunting. Motu is not more than half a mile long where birds were seen, and it is probable that no cats occur here as there are several channels of water between here and settlement. First bird shot was a young one under the brush. Hearing another clucking in farther, I climbed a tree and watched awhile till I caught a glimpse of second bird, which was an old one. While birds were 


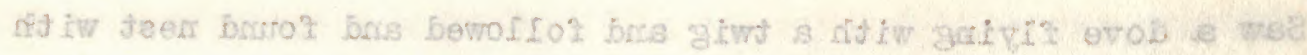

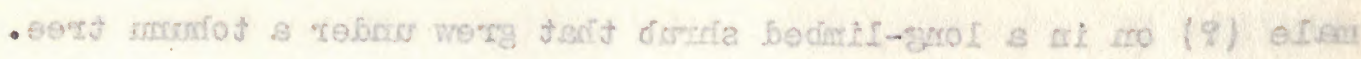

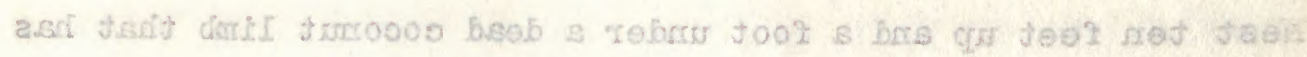

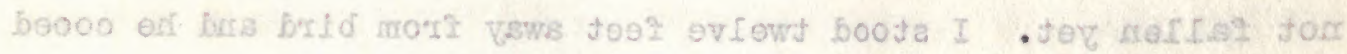

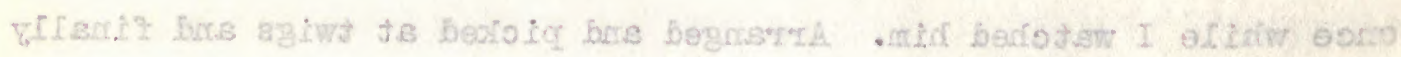

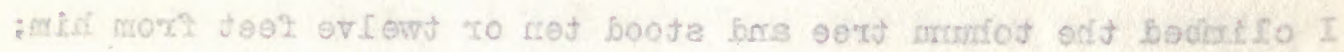

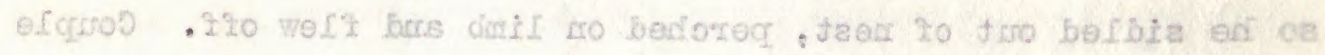

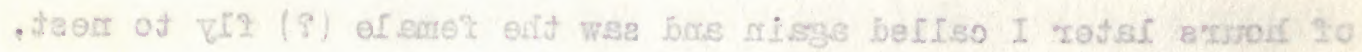

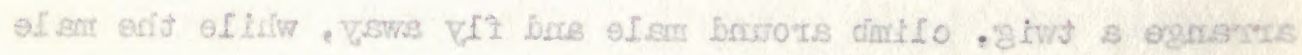

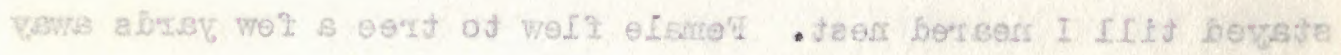

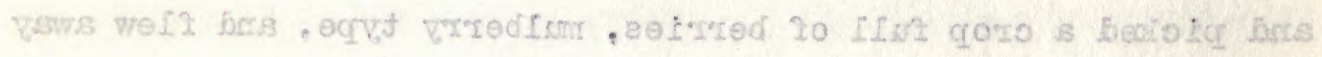

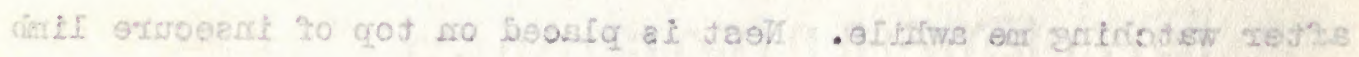

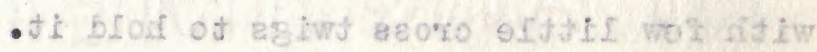

\section{OS Fasurder.}

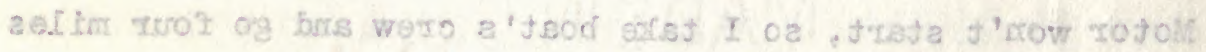

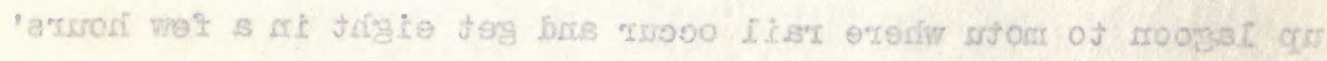

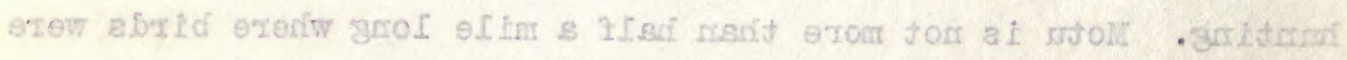

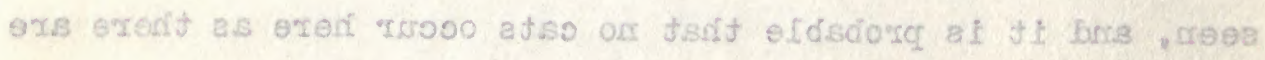

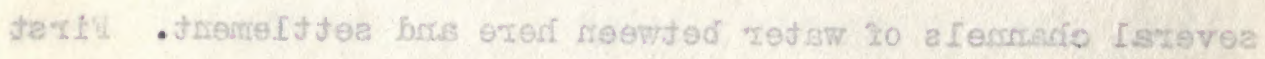

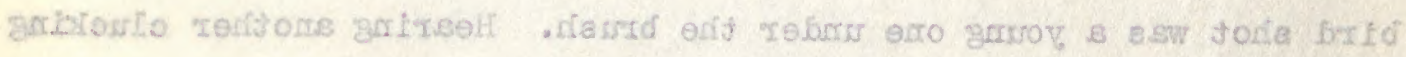

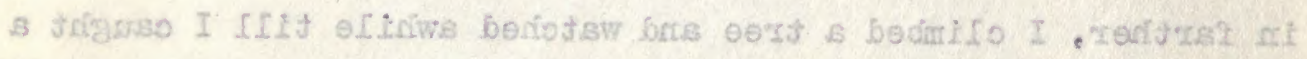

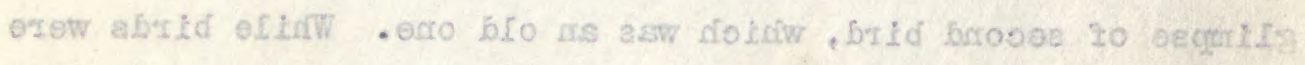


mostly under thick brush one walked across an open place under the trees near while I was taking a drink from a coconut. It must have seen me before I saw it, for I had been busy with the nat for some time. Another walked along under brush clucking till it got into a clear place and I stopped further progress. Saw but nine birds and got eight of them. Fairy, noddy and lesser noddy terns were common here and a few young lesser noddies and a fairy tern seen. The fairy was sitting on limb of hotr tree and did not move while I watched it. Sooty terns are frequently seen and heard, some flying high, and I think likely all are bound to or from Rangiroa Island. Lesser noddy nests were in a few pandanus trees as well as hotu and tohumu, scattered about, a few in two or three trees and farther on a few more. Intended to run back to Ahii Island to look for rails as natives say they oceur, but the people here asi me to wait till next week when they expect to go over for six months. As I don't care to put in five more days here will head for Takaroa.

\section{February 21}

Get away at six 0'clock and light wind all day. Few miles off north end of Wanihi in eve.

\section{February 22}

Wind light during night and not much progress. Flock of sooty and few fairy terns fishing at six A. M. See south end of Takapoto Island at four P. M. and will lay to for night. 


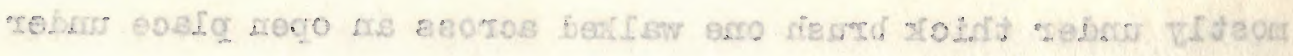

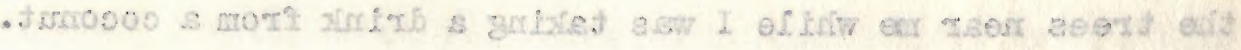

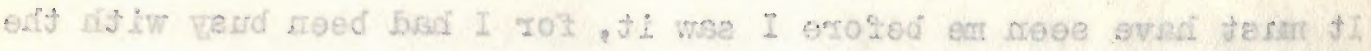

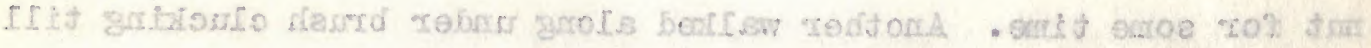

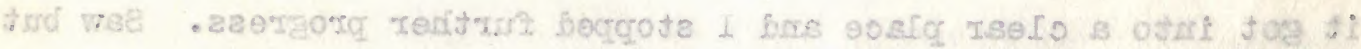

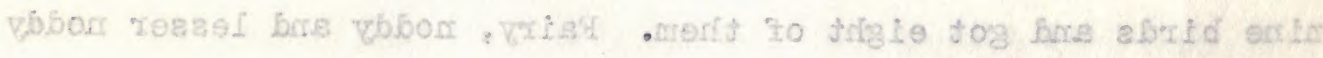

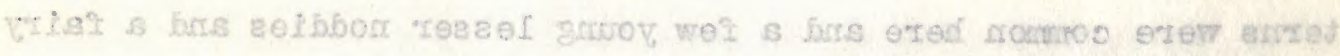

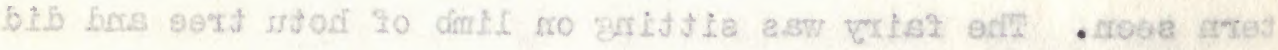

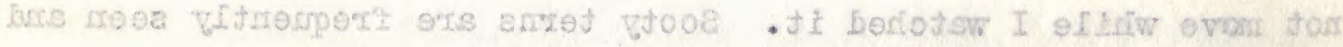

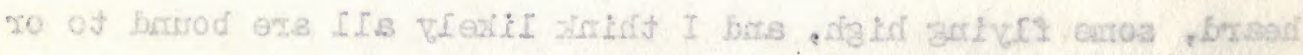

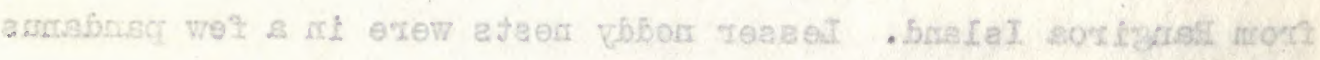

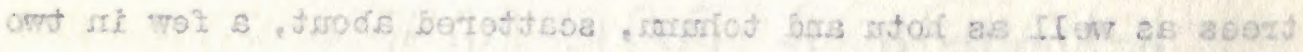

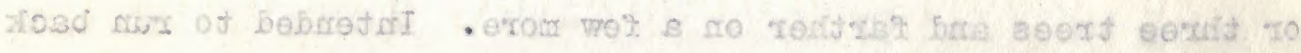

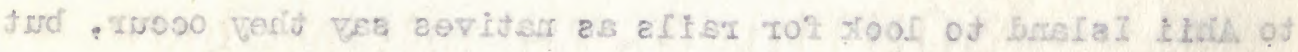

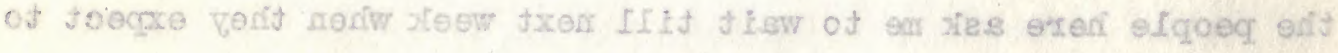

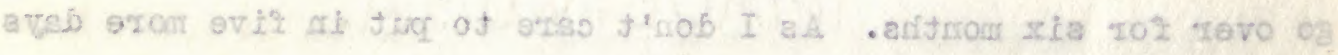

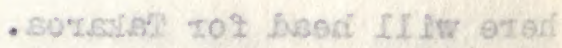

\section{IS V2 Sirto'}

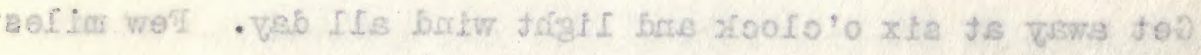

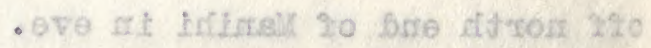

\section{SS Rzenrdet}

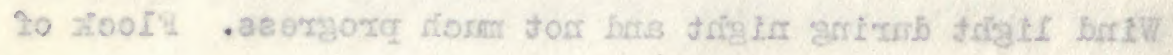

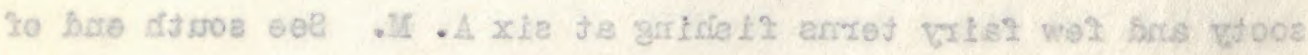

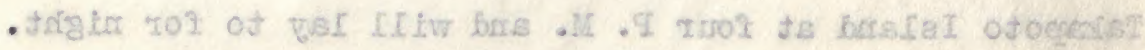


February 23

A shore and tramp several miles for rail and doves but find not a one of either. Pick up four warblers and note perhaps a dozen nests of warblers, one of which may have had an egg in it, but the egg was broken while fresh. Most of the nests were never used. Nearly all were in tohunu trees, and four or five were only four or five feet from the ground in young trees in clearings where the tohum is starting to grow again. One had been placed in a young coconut tree a few feet up, but the tree in growing had dislocated the nest and it was hanging by a thread. A few noddy nests and several young noddies observed, while at one place on the lagoon shore on a sand beach there were thirty or more yellowbill terns resting. Three or four yellowbills were shot as they flew along the shore. Half a dozen herons were noted along outside shore.

\section{February 24}

Out again on other direction and saw a lot of berries that are eiten by doves on other islands, but here bushes seem to be undisturbed. Natives say fev rail occur but the cover is so thick that small chance of getting them. Get a sailing canoe and Louie spends day on other side of lagoon, but only secures a few warblers. We leave in eve for Makaroa to try for the third time for land 


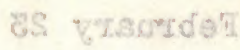

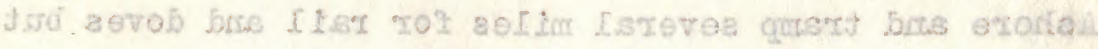

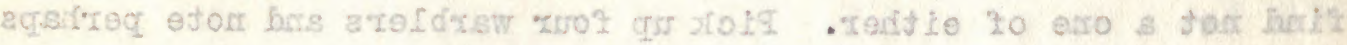

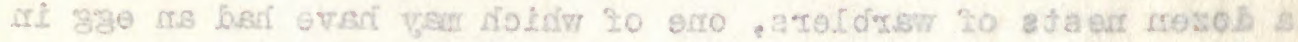

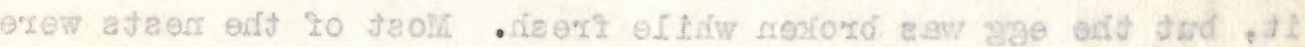

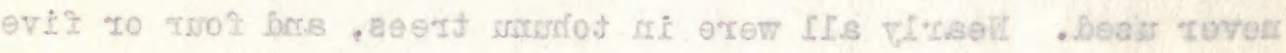

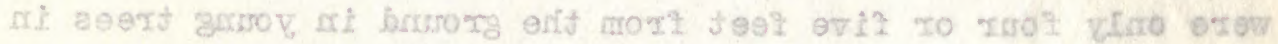

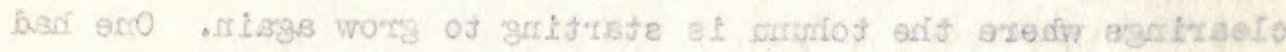

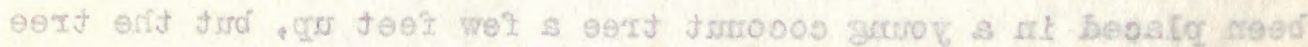

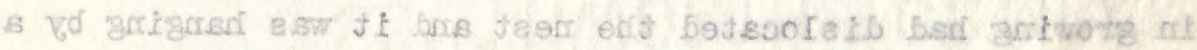

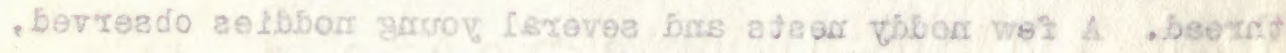

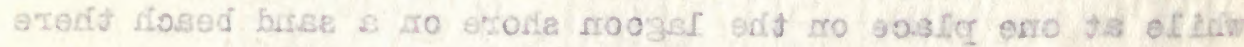

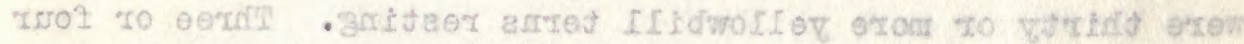

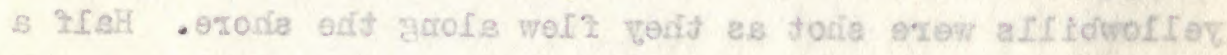

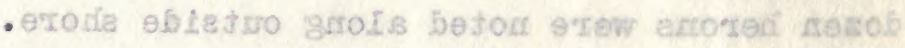

\section{As rastrde\%}

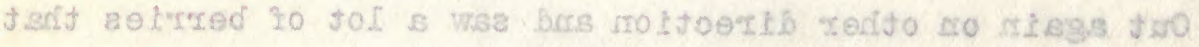

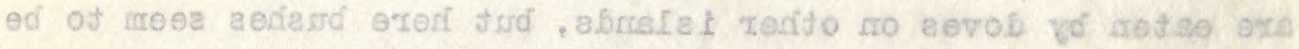

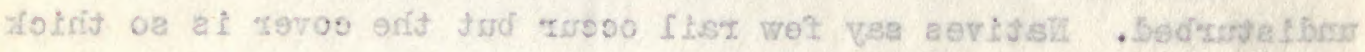

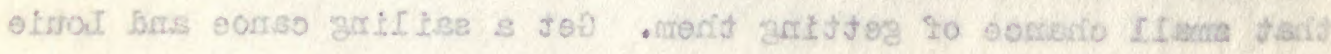

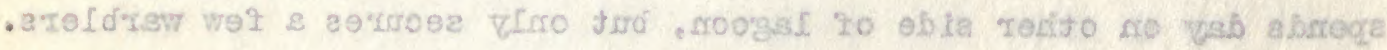

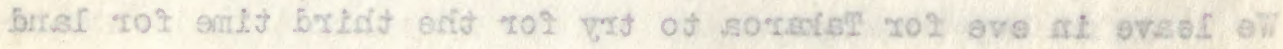


birds. Some fairy terns were seen here and a few lesser noddies noted flying to the north along shore. Coconuts do well on new ground, some having mats on only four leet from the ground.

\section{February 25}

Sunday. Arrive early in morn and tie to wharf.

\section{February 27}

Hire launch and go six miles up lagoon, where we leave Louie for few deys as we find scattering warblers. I get a couple of doves and see one other. The part of island visited is being cleared gradually for cocomats, and the warblers and doves seem to inhabit the uncleared parts. One dove was heard calling in the jungle and the other was one of a pair that flew by me in the forest. Warblers were heard singing in most cases and would have been unnoticed otherwise. Few noddies had young in coconuts and a few fairy terms were seen. Scattering lesser nodaies flew to the eastward and sooty terns flew at times along the shore.

Finished birds and went fow miles along shore but did not see a land bird. Tatlers and a couple of plover seen.

\section{February 28}

Walk along the shore for miles and get one warbler, hearing 


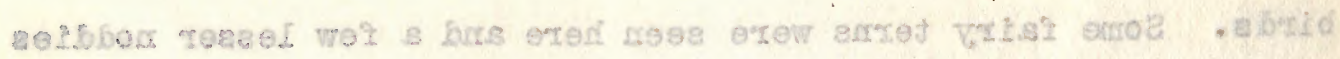

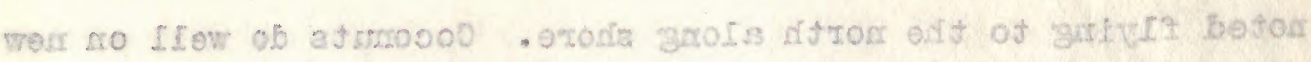

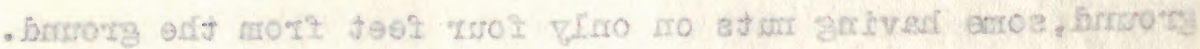

\section{as vxeurdots}

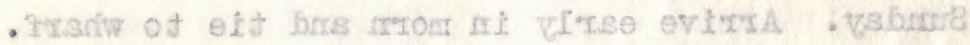

TS pourded

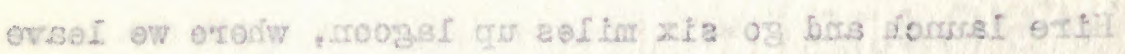

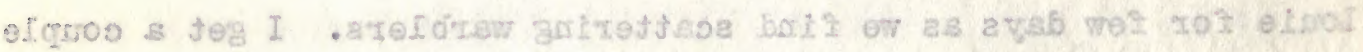

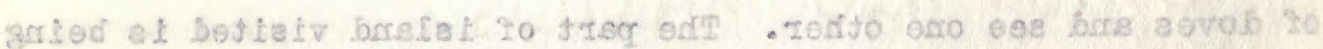

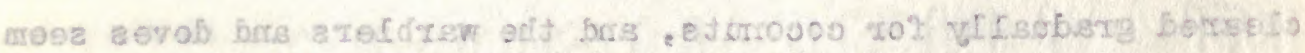

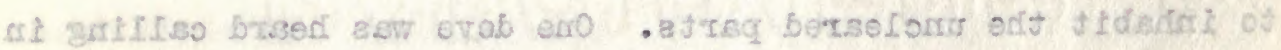

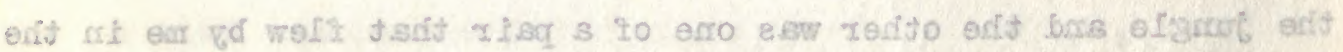

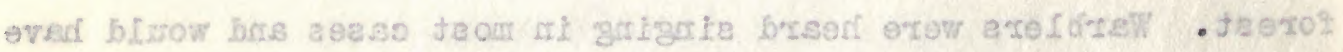

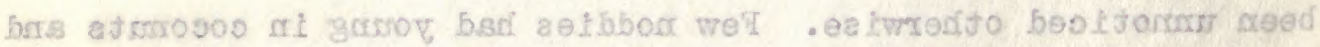

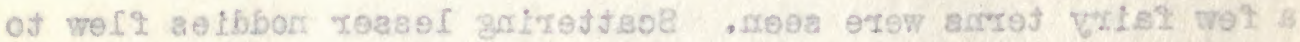

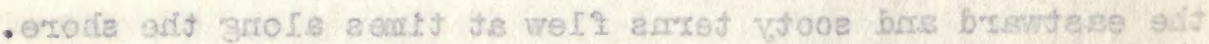

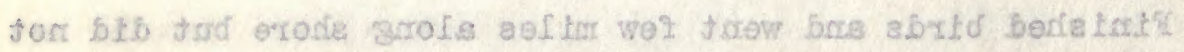

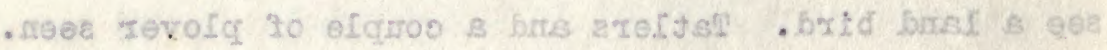

\section{DS visurdort}

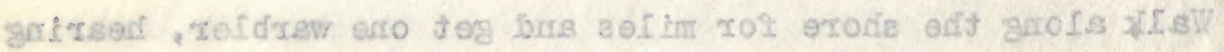


him singing in thick jungle where it was difficult to get. I went near and called when he came up to me.

\section{March 1}

Went on reef into lagoon and got six yellowbill terns, but all were bloody and pat up only two.

\section{March 2}

Louie gets back with three warblers and doves for three days" collecting. We leave to collect tomorrow on Takapoto again.

\section{Narch 3}

Ashore at village and find a now lighthouse about twenty feet high erected on the beach, and word that the Administrator of the Tuamotus will be here with the people of Takaroa on the 15 th of Harch to celebrate the erection of the building, which is of concrete. Nicely kept streets and a covered building in center of street at min corner of village. Loule goes one wey and I go other, each getting about ten warblers. A mile from village saw a couple of hundred lesser noddies in trees with few nests and young birds in some. Several golden plover along lagoon shore and one male killed in nearly full plumage, the organs not at a.l 


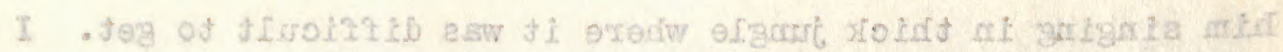

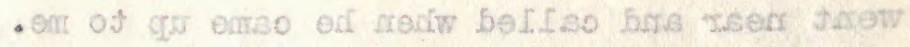

I. Nots:

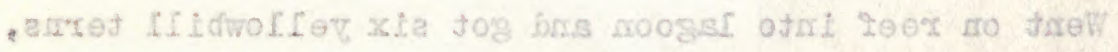

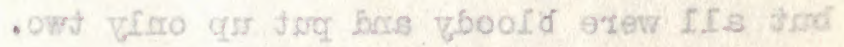

\section{S foren}

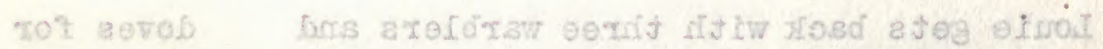

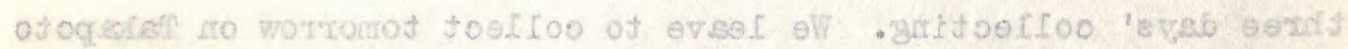
- riegas

\section{E. fiomel.}

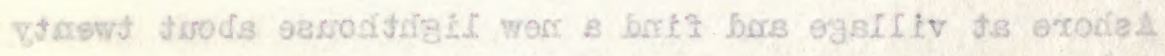

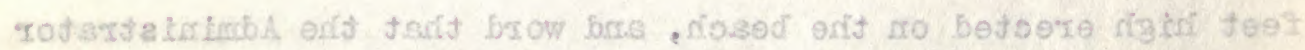

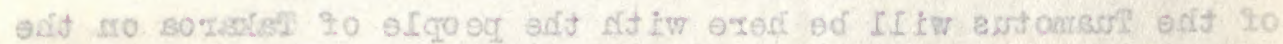

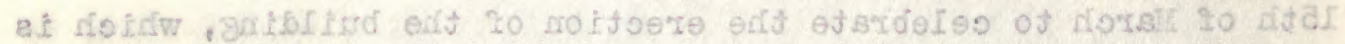

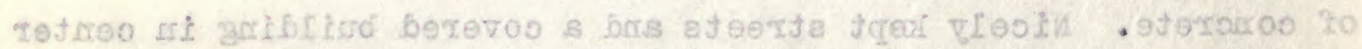

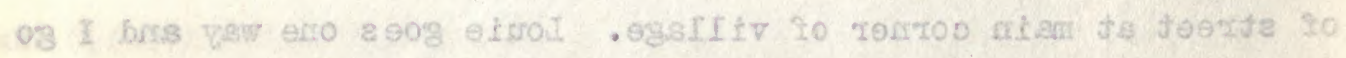
vrise agsilv roxt of tar

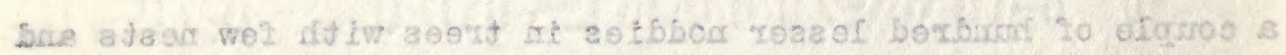

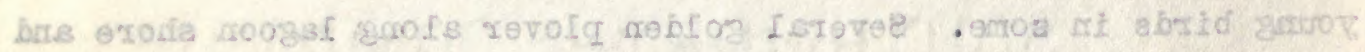

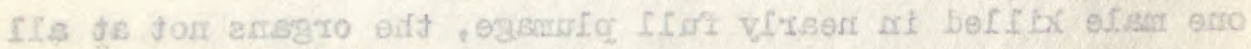


swelling. Few fairy and noddy terns about, and leave at four for the south with light wind.

\section{$\operatorname{March} 4$}

light wind and fifty miles to island. Several sooty terns flying south and a fairy and noddy tern flying to north. At two sailing along Kauehi Island on the west side. Small patches of vegetation and a long strip of it with a few coconuts in places. Two or three patches of rocks above water of only an acre and on both sides the reef is covered with water. A pair of doves seen flying along and a plotus booby flew in and lit on a rock in patch of few yards diameter. Hoddy and jellowbill terns fishing outside reef and a few lesser noddies and fairy terns seen. Couple of white herons on motu near where we anchor or tie to rock a half mile inside pass. Much of the atoll is barren of vegetation, and some with low shrubbery.

\section{March 5}

Ashore early and I walk along several miles on the west side where noddy and fairy terns are common and a few lesser noddies have nests, one being seen in a tohunu tree about six feet from ground. A couple of nests noted with egss, but most of the couple dozen looked at had young of various ages. The noddy terns 


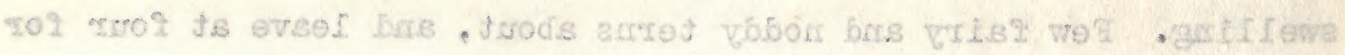

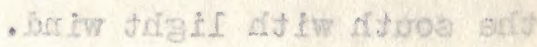

\section{4 fiosald}

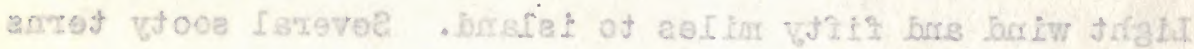

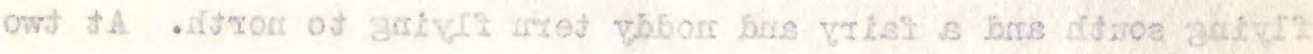

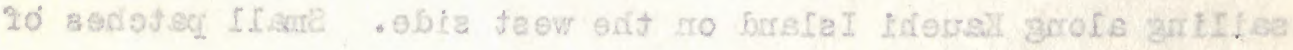

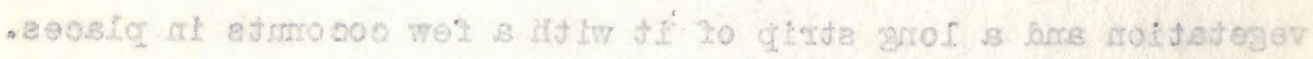

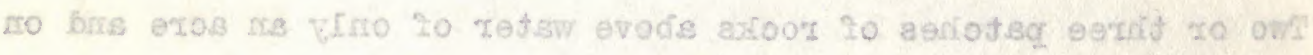

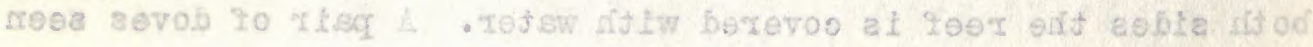

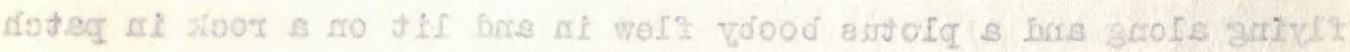

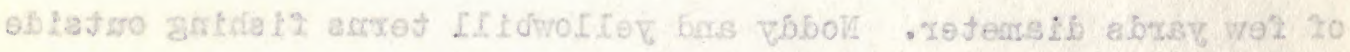

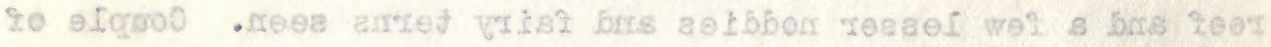

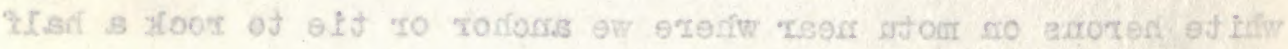

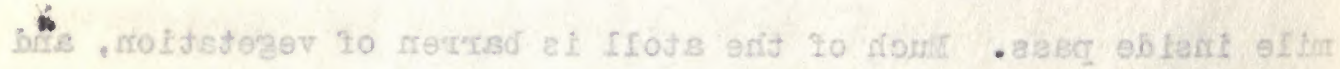
- vrodicistaia woj citiw emoa

\section{c dorcall}

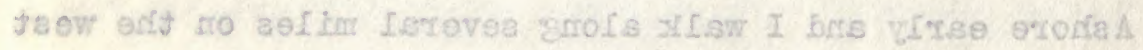

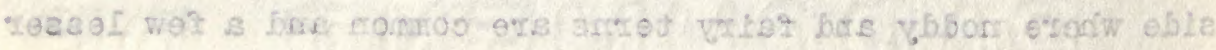

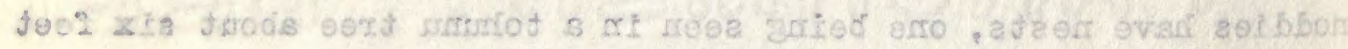

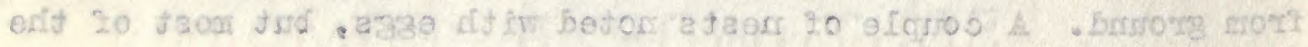

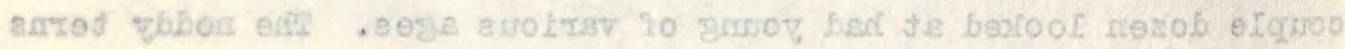


were nesting in the miclymicky bushes close to the lagoon shore. A few young nearly ready to fly, though two nests with eggs noted. Nany young were flying. A single nest of fairy tern seen in a mickymicky bush only four feet above ground, and a little higher in the same bush was a nest of noddy tern with an incubated egg. Noddies frequently use an old nest, for one or two we noted had partly fallen and the birds had replaced the nest on the old site. One nest had a string of old material strung below for two feet that a heavy wind had probably dislodged. Half a dozen curlew shot. Some were fat and freshly molted. A flock of five others were seen later. Wandering tatlers are in fine plumage in most birds observed. Curlew were frequenting a bare alkali spot, though one was flushed from a grove of cocomats, possibly one hit by stray shot before. A couple of blue ternlets were flushed along the beach at noon separately, and Loule shot a couple fishing in the lagoon at fire P. M. A few yellowbill terns noted, and sooties fly along shore in scattering bunches and pairs. Warblers were not uncommon and at three P. M. I struck several doves along lagoon shore in muberry-like trees where they were feeding. Were tame as I got very close to some. Inree or four white reef as well as a couple of blue ones seen (herons). Loule found not a dove on the three motus he visited on the south side. A boat comes alongside from the village and the occupants 


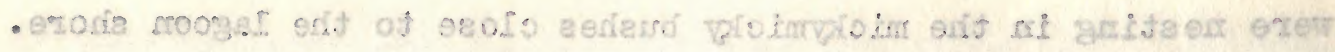

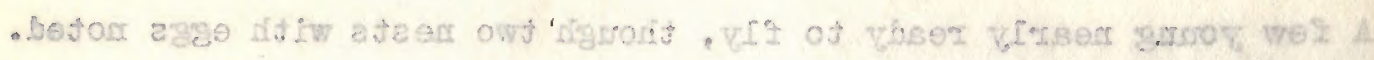

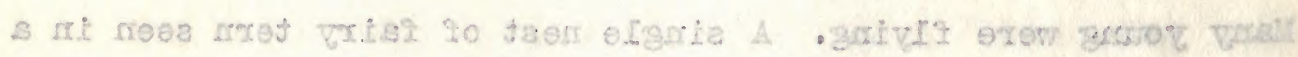

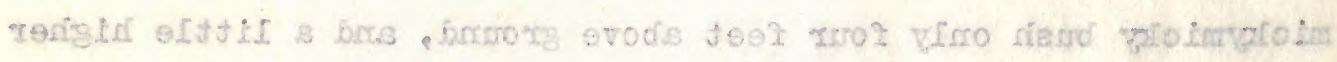

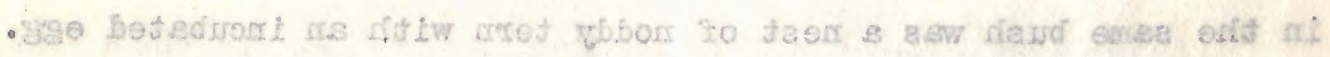

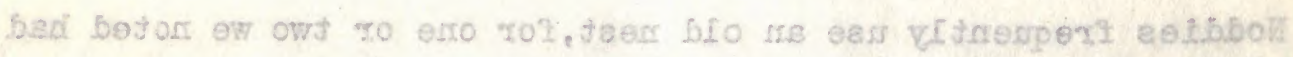

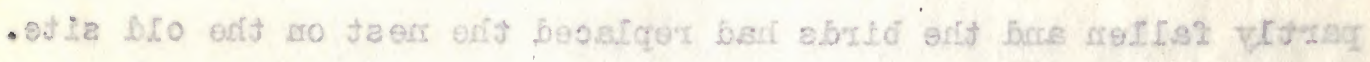

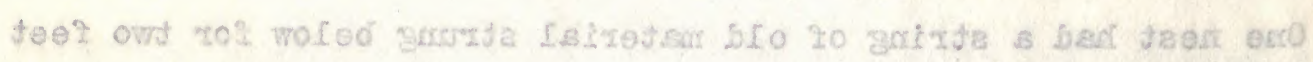

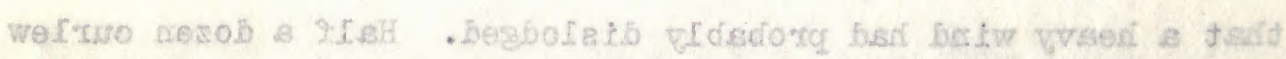

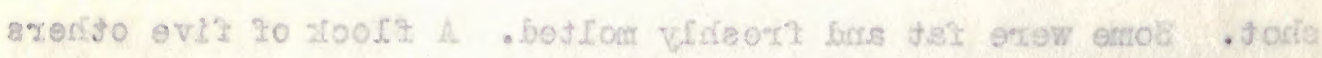

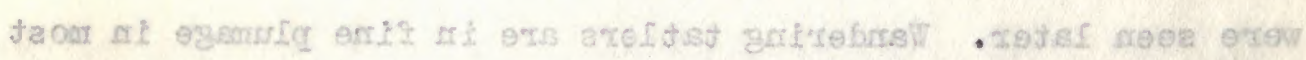

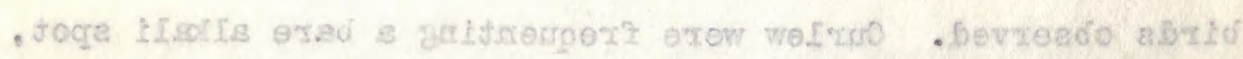

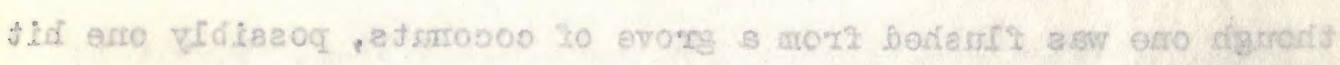

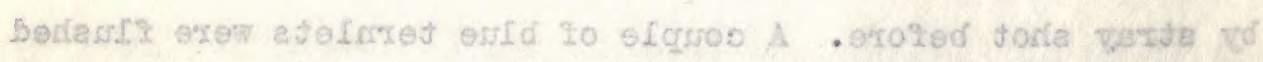

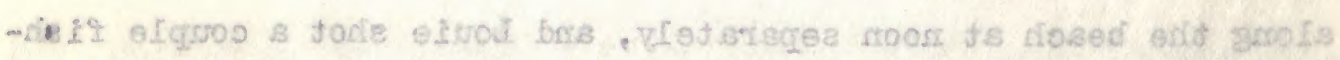

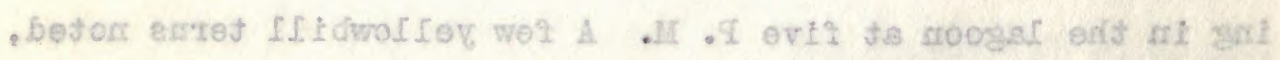

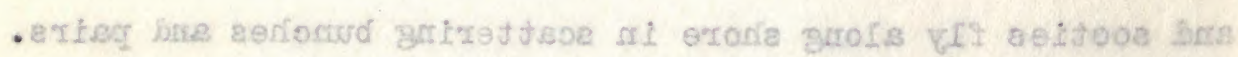

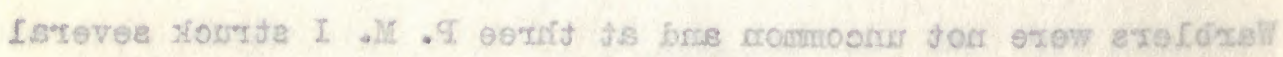

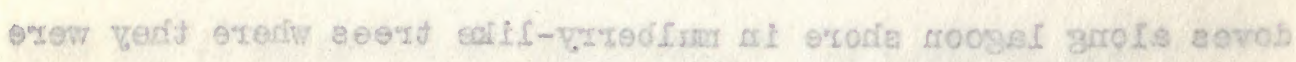

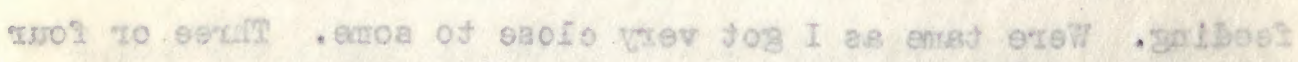

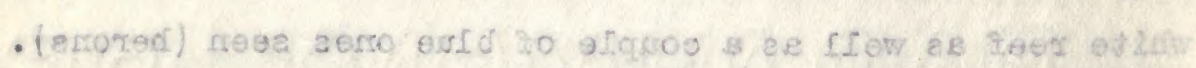

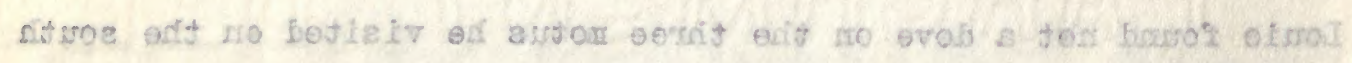

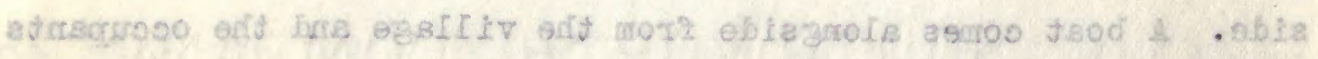


say rail occur near the villege, so we will go there tomorrow,-a distance of ten miles from the pass where we are anchored.

\section{March 6}

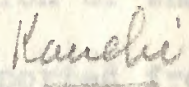

Skin birds till eleven when we start for village. Irun

up into a sort of cove and put kedges out on small rock that comes to surface of water. Two or so yellowbill terms sitting on rocks and fishing, while a couple of lesser frigates hover over the fishing birds. One frigate sot a long fish and couldn't swallow it, so a term started after the frigate and chased it for a couple of minutes, circling with the frigate till the latter, high in air, downed the fish.

A shore and get permission to hunt. Walk out behind village and flush a spoonbill duck from a low marshy place fed by high water from lagoon. She flew wild and went out into open lagoon and lit off shore a hundred yards. I went a mile or two down beach and worked through woods, finding only warblers. One native reported ground doves as well as rail, but I saw neither.

\section{March 7}

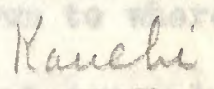

Ashore and flushed the spoonbill at another low spot. She flushod wild, but I saw her later at another open marsh, and, making a long detour, crawled up behind some bushes toward her, and though she saw me she thought she was safe as I was over 45 yards away. 


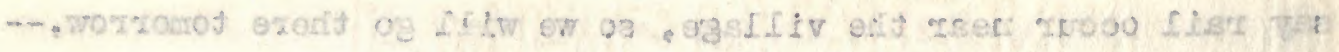

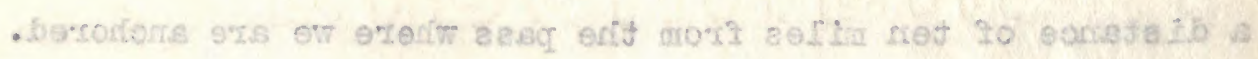

\section{2 nox.sh}

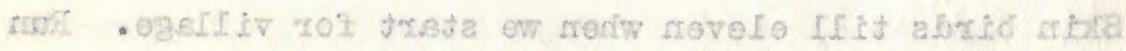

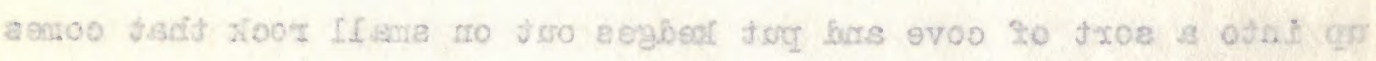

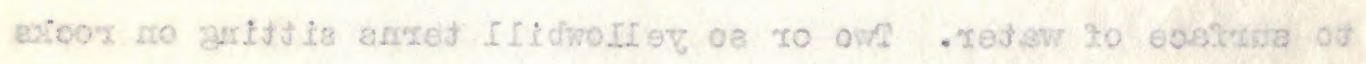

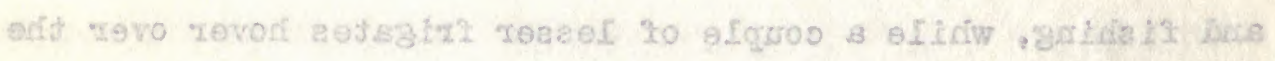

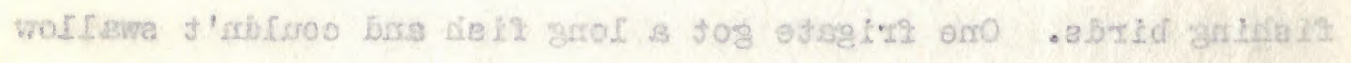

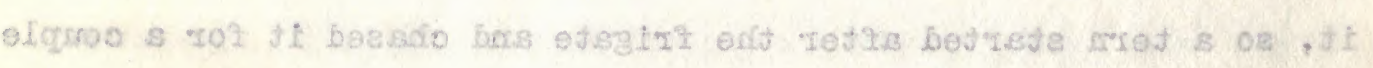

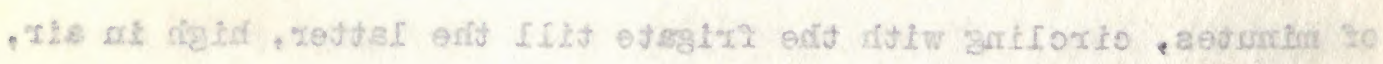

- riais ecis berrtiob

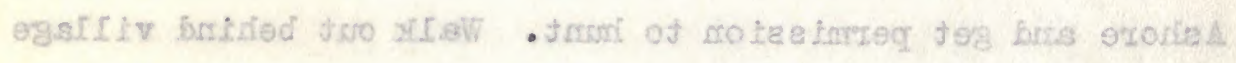

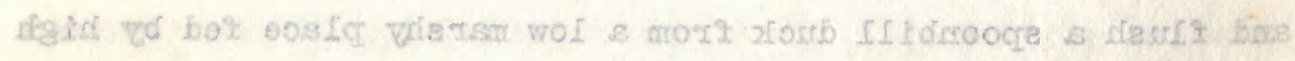

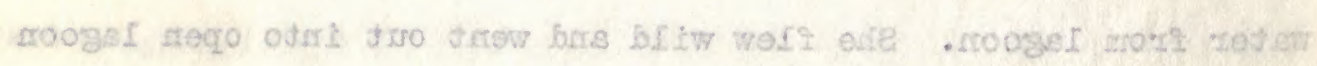

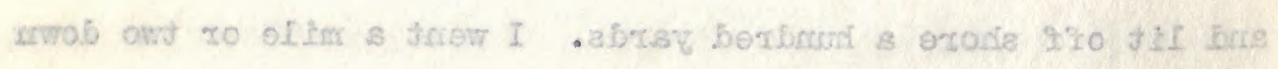

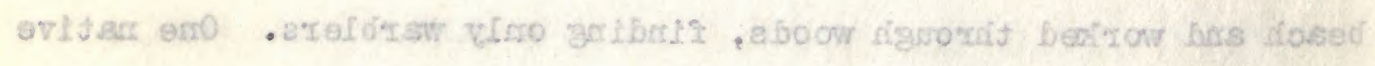

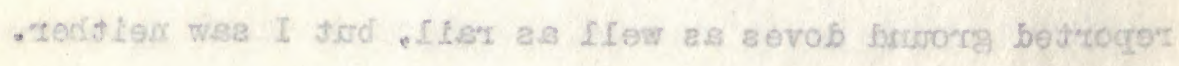

\section{5 clorsilh}

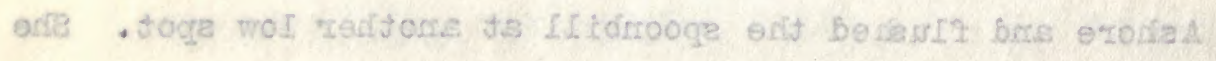

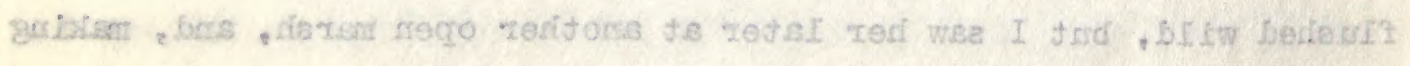

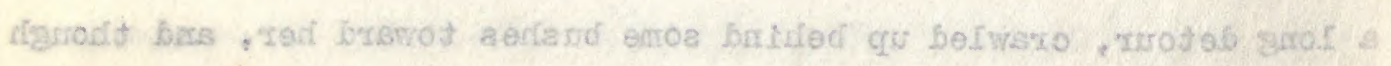

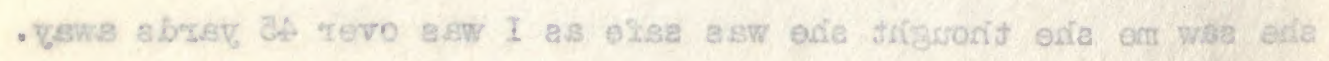


Consequently she lost her life, as the 20 gauge shoots close jet with the left barrel, though I used it much on the South American trip. Getting this bird confirms my identification of the Mikei ducks which I saw but did not get. Ducks are reported from many islands in rainy weather and they are probably northerm birds, as we heve not found the Society bird in the Tuamotas yet.

Went to north and saw several places good for rail, but saw none though saw several green doves. Iand being gradually cleared, but not enough people here (about 50) to take care of a.1 the land. Saw a lot of coconuts growing that should have been picked up. Nice small Catholic church and village in sheltered grove with plenty of old holes aug long for planting taro etc., so the natives say. I see these holes in many islands, but none being used now. Three lesser frigates fising with yellowbill terns today in the lagoon. Saw a noddy sitting with several yellowbills in the limbs of dead tree in lagoon.

\section{Varch 8}

Skinned birds till eleven, then moved down to where Louie got a dozen blue terns yesterday. I go ashore but see only one where he got his birds. Noddies, lesser noddies and fairy terns as well as sooty tems fly along the land to windward, probably going fishing at two P. M. Ashore an hour, and, finding no blue terns, move along again to where I stopped first day here. 


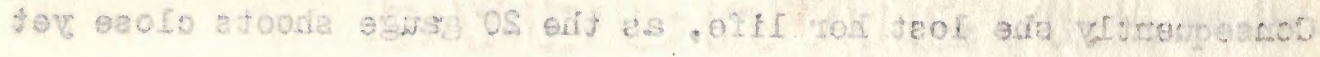

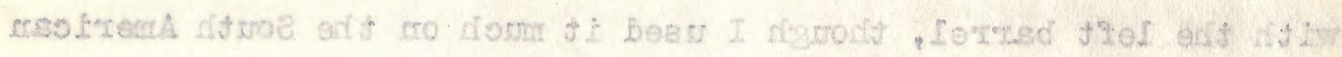

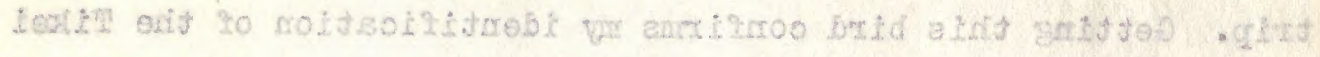

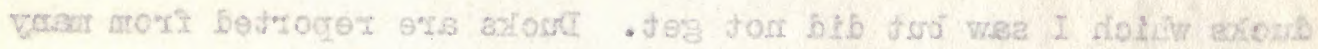

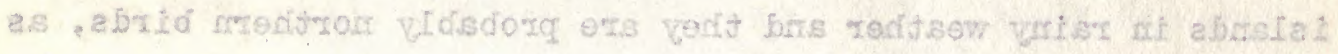

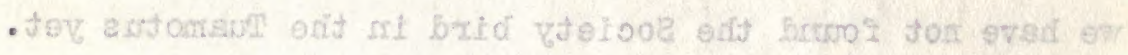

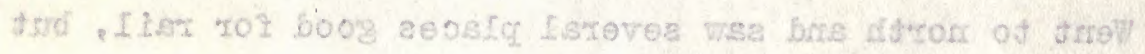

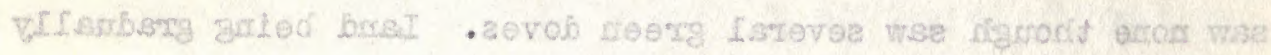

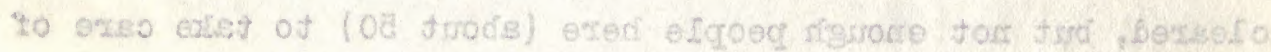

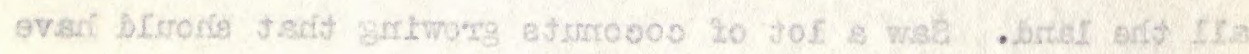

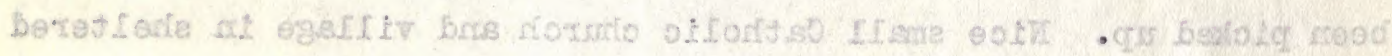

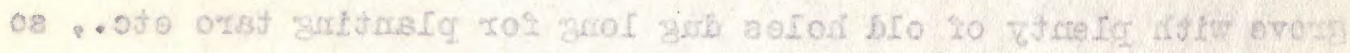

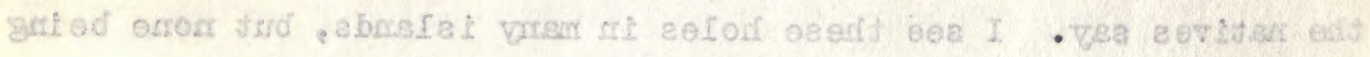

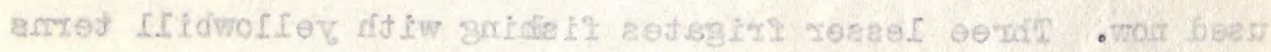

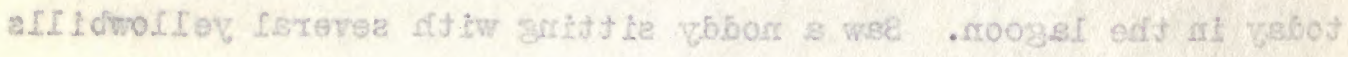

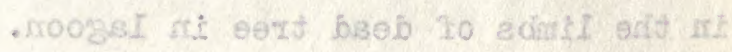

\section{8. dorsh}

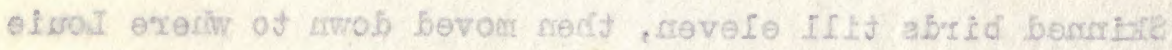

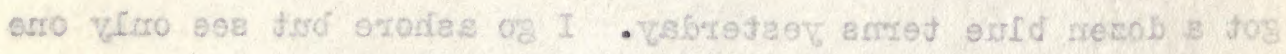

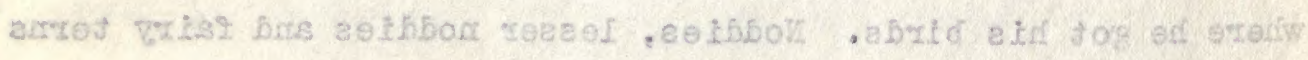

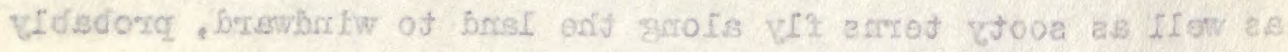

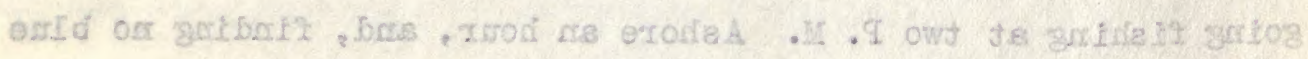

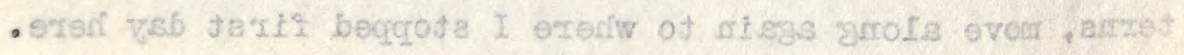




\section{March 9}

Ashore and work to westward as far as motu extends. Fairy terns more common here than at any Iuamotu visited. Lots of lesser noddies, and I flushed a half dozen blue ternlets along the beach in a two mile walk. Also flushed a sandpiper along the edge of the forest and it flew up into a tohunu tree away from me and remained without calling till I shot it. On a couple of motus beyond range probably a few lunatus terns nest as we saw about 20 fishing in the lagoon last night, but the wind is too strong yesterday and today to reach the motus, the small motor being worthless in a choppy sea where it gets wet. Six curlew in a flock flew past me, and one was shot in the shade of a forest tree where it was resting for the sun is hot on lee side of forest.

Harch 10

Start at six A. M. for Raraka and reach the re at ten, using motor as well as sails. Ashore after lunch and get 20 warblers and natives say ground doves occur on the other side of island ten miles away. We will shift there Monday. Ground doves occurred near the village awhile back, but cats were introduced to keep down rats and they wiped out the doves. Sandpipers are reported also to be across the lagoon. But 30 or so people live here and most are living in hats made of coconut leaves. Curlew, tatler and plover seen this P. M. and lesser noddies fly along over the 


\section{$.005-$ \\ P sorall}

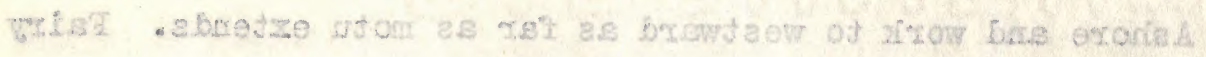

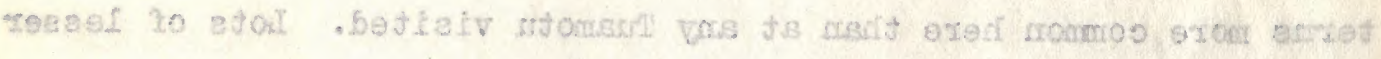

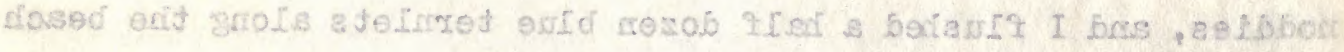

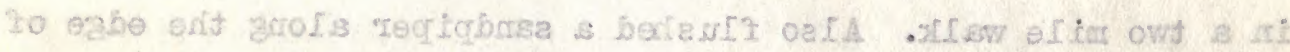

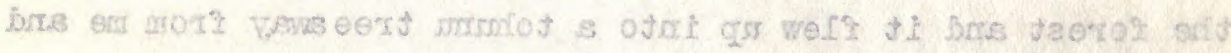

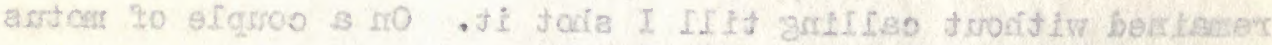

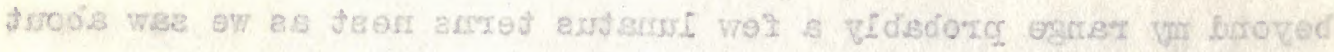

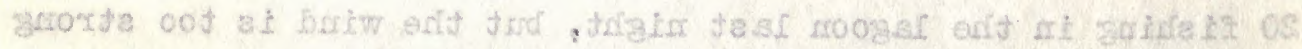

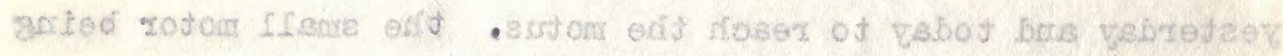

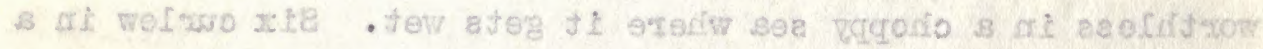

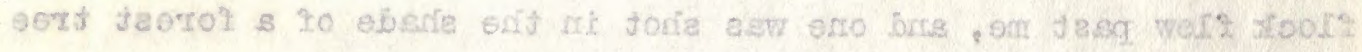

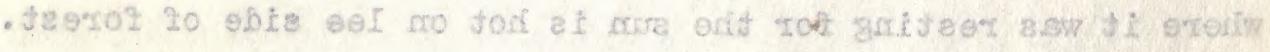

\section{of siossts}

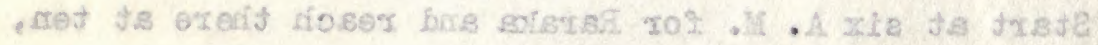

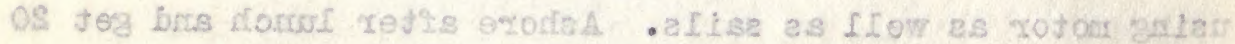

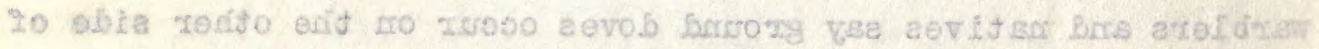

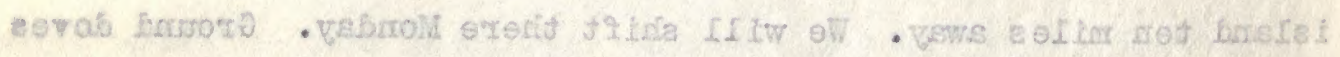

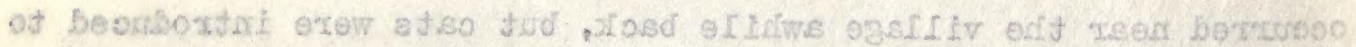

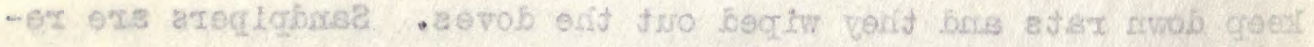

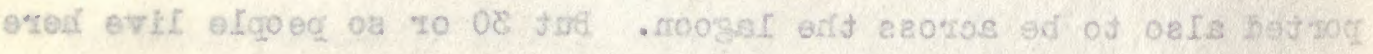

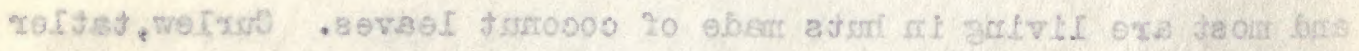

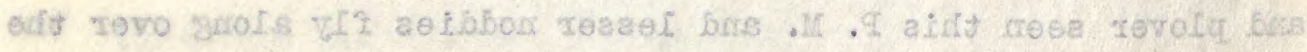


island to windward to colony beyond. Yellowbill terns are present here.

\section{Narch 11}

Sunday and strong wind a.1 day.

Narch 12

Start at 8:30 for east end of islend. We couldn't start earlier because coral heads below surface couldn't be seen. Lightning and thunder at daylight, but clears at nine o'clock. Going up lagoon see low bushes and petches of coconuts on north side, while on the south little motas are seen but a few hundred yards long. Rocigy patches seem nearer the shore, as we are off a coaple of miles from north side. Bushes and trees are low except the coconuts and the southern motus show up at seven or eight (?) miles as being two or three miles apart. Island is more than ten miles long and fairly circular from appearance. Notice no birds in pessage and terns were much fewer Satarday than on Kauehi fifteen miles away, though a goodly mubor of lesser noddies were noted as we approachod tho pass.

\section{March 13}

Ashore yesterday and today and find doves rare and warblers fairly comnon. One of the sailors found a rail a couple of days 


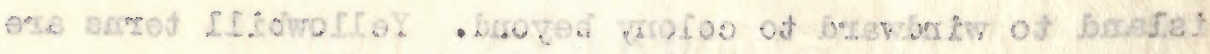

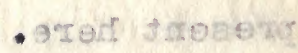

\section{Corell}

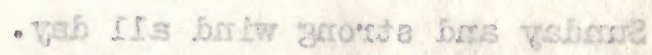

SI norsin

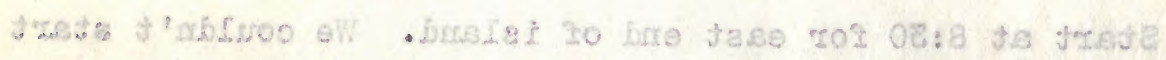

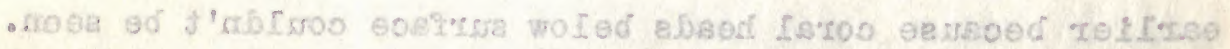

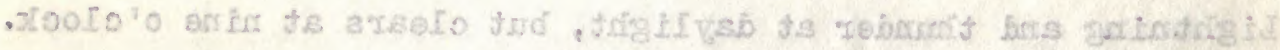

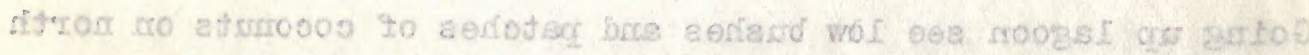

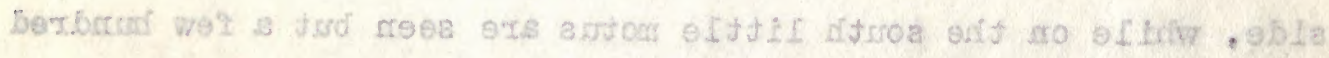

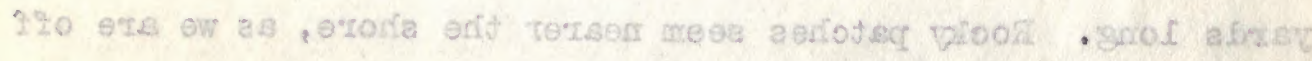

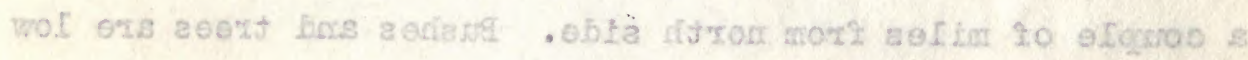

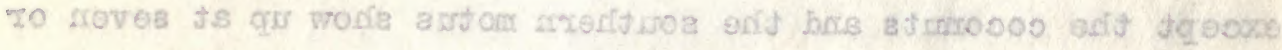

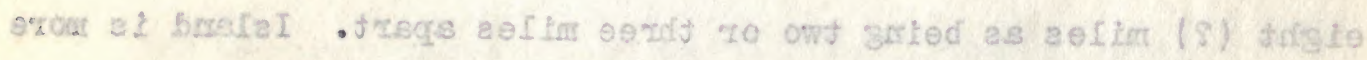

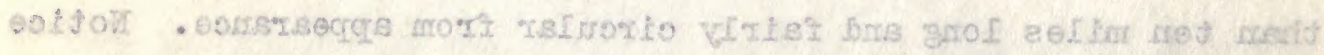

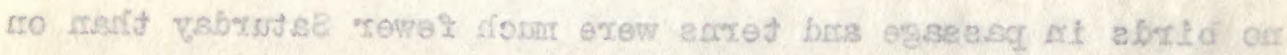

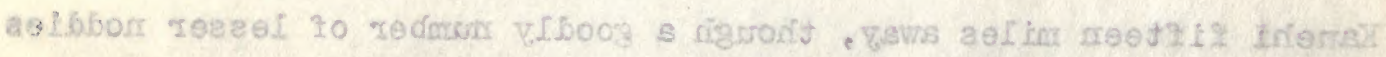
- aasq erit berlosorqgas ew as betor exew

\section{EI cioneld}

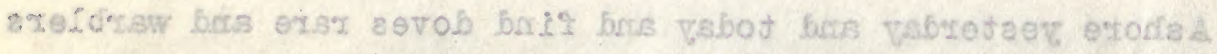

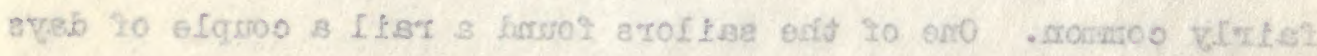


old where we landed. The Captain spent a couple of days hunting in the small patch of woods where the young was found, and he got four more, while Louie and myself manting in other motus were able to secure but one apiece. Lesser noddies have young in many trees scattered along and the noddies also, though most of the young are flying. The noddies rest in various places, along beach and lagoon shores in low bushes, as well as high trees, and the coconuts harbor many. Many noddies nest in the coconuts, while some select low bushes. One nest in a pendanus near lagoon shore was only four feet high.

Squid seems to be a favorite food for the young birds, though many fish of different kinds are thrown up by birds when taken. The fairy terns very often bring fish crosswise in their bills to land, and often two small fish may be carried by one bird this way. The yellowbill tems frequently fish close to the lagoon shore in eighteen inches or so of water. A couple of blue ternlets were seen and one taken. A few lmatus terns are seen fishing in the lagoon; one shot was nearly ready to deposit egg. Most are in young plumage. One dove seen carrying twig in bill and followed by mate flew into thicket. Several taken are young birds, and some adults seem lighter yellow than from other islands.

\section{March 15}

Move across to west side of lagoon, stopping at several 


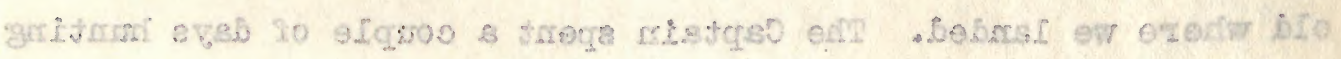

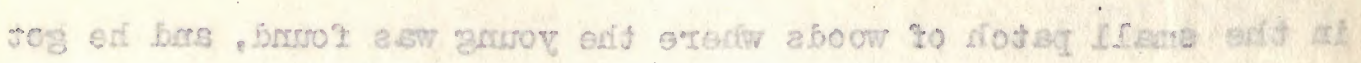

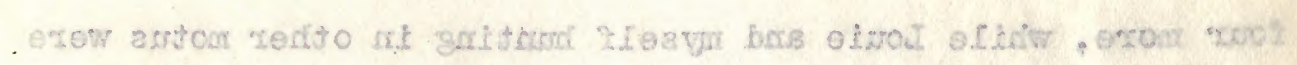

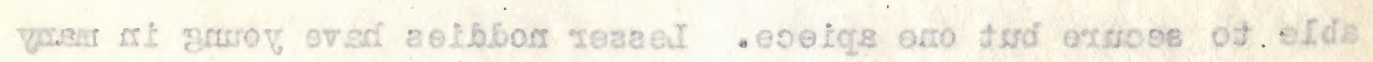

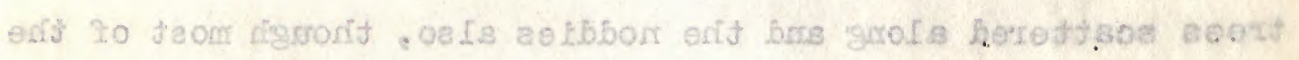

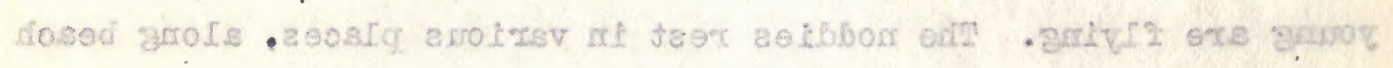

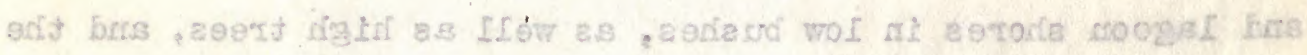

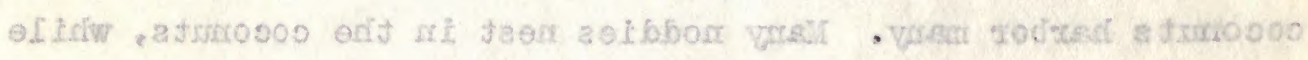

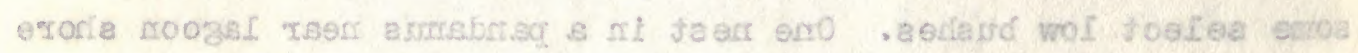

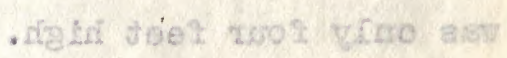

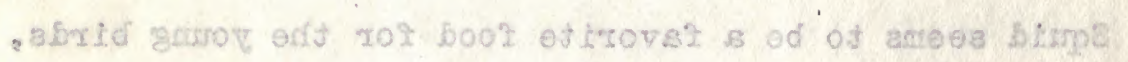

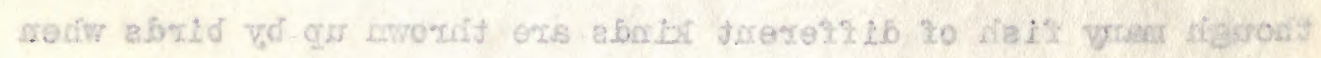

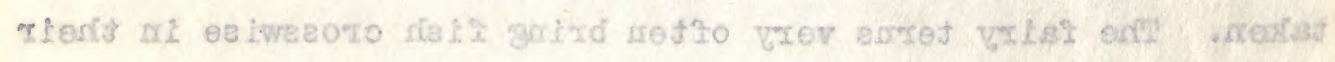

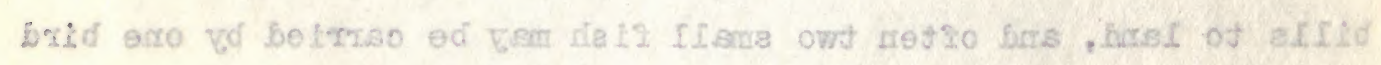

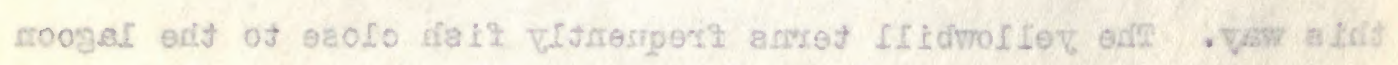

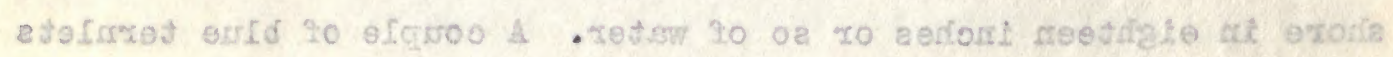

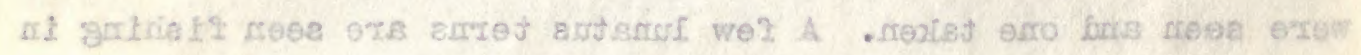

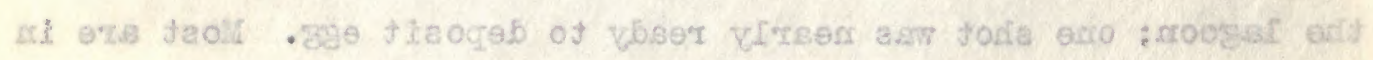

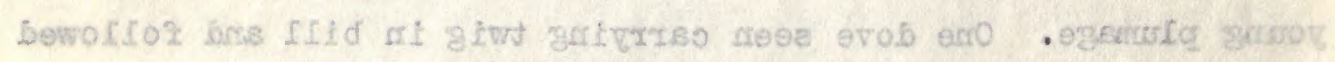

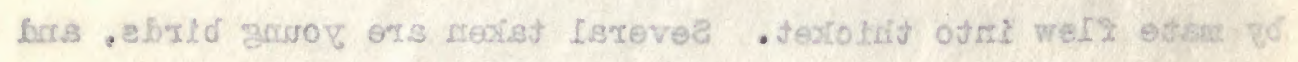

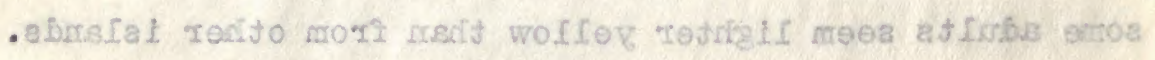

\section{¿I dioxs?}

Lerevea is gniqgosa, troogsi to obla taom ot aboros evoli 
motus on south side to look for ground doves in the motus of couple of acres size, but find none. Get a couple of sandpipers and a couple of herons. The noddies on these small motus nest in low bushes, often a couple of feet above ground, though there are plenty of pandanus trees within a mile on other motus. Most nests are ermpty, though an occasional young bird is seen in the nest. Doves seem not to. eat here the berries that form the staple food for doves on the islands farther east. Possibly at other seasons of the year they may. I do not remember the fruit eaten here as common or present on islands east near liarutea, but the food of the eastern birds is seemingly not eaten here now. Not many doves occur here and the cats will likely gradually clean them out.

\section{March 17}

I went down shore a couple of miles and ran across the native who told us of seeing ground doves here. Took him aboard and we go back to a motu we missed, as he said the birds were there. Both go ashore and find no doves, and I had looked on the others where he reported birds. It is possible a few may be hidden in the undergrowth, but the motus are but a couple of acres or so in extent, and if the birds were common at all I would have seen one. The native says that formerly they would catch a mundred in a day with a string on a pole, but the introduction of cats wiped them out in short order a few jears ago on the large motus. 


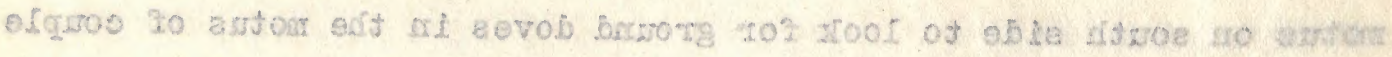

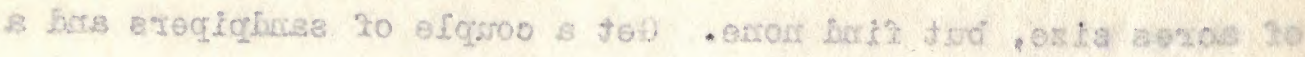
wol If fash astom If

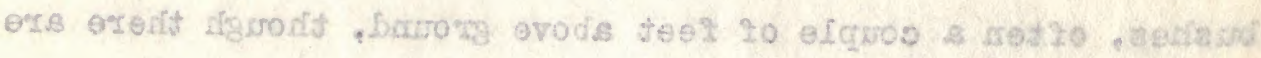

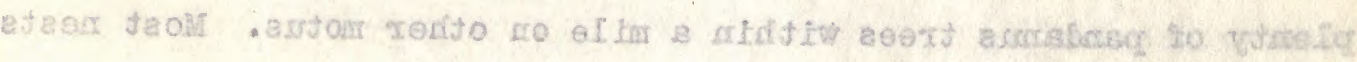

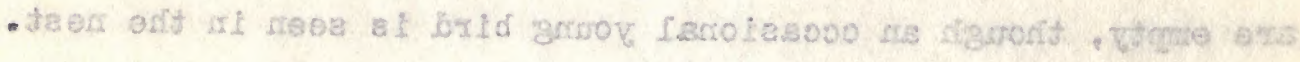

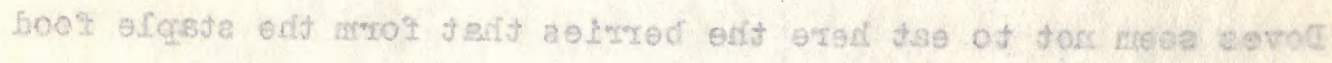

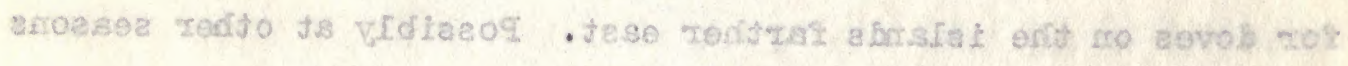

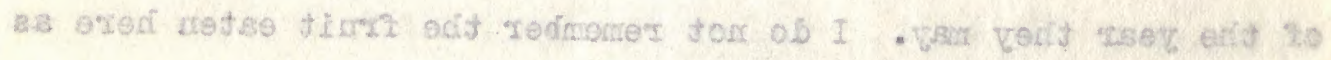

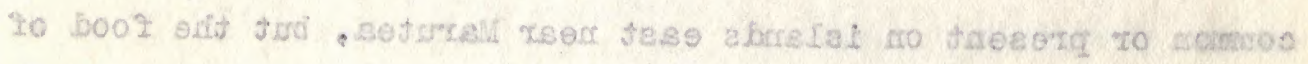

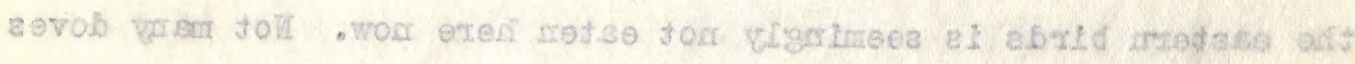

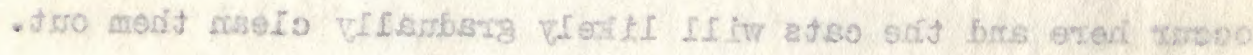

\section{FI sionsil}

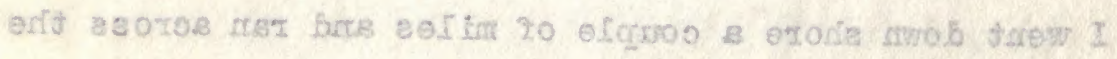

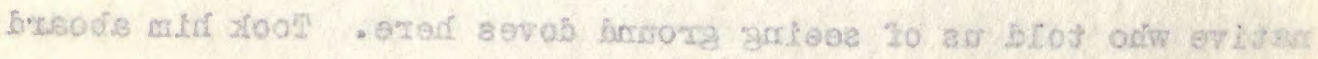

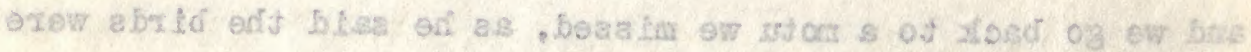

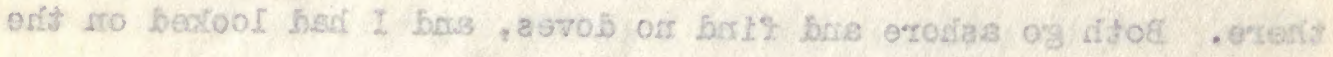

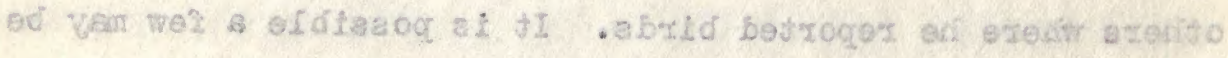

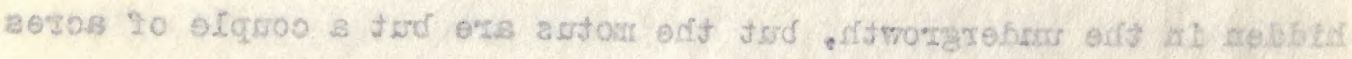

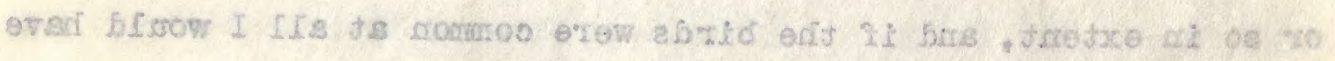

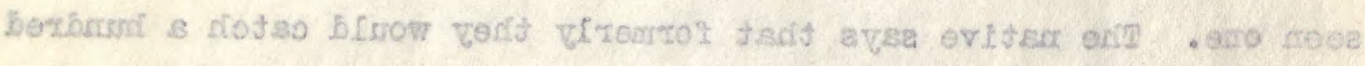

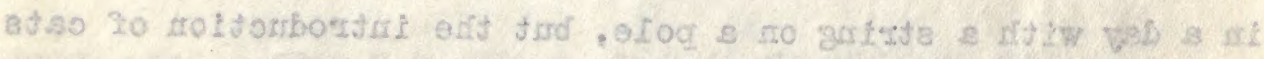

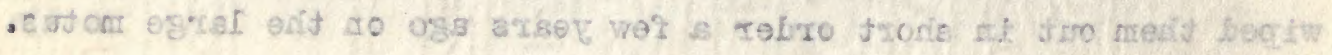


The small motus harbored a few birds for a while, but they may have flow a mile along the sand beach to the next mota and gone to the big brush patches where the cats keep watch.

One small motu has three or four pairs of plotus boobies on it, and one nest being repaired is seen. Cocomut husks and vines, as well as coarse grass, is used for lining. A couple of sandpipers also are found here, and a few noddies unable to $f l y$ yet. One nest with a bird in it is only a foot or less above rocks. Golden plover in summer plumage seem to be gone last three days, though a pair of curlew and plover were seen at Kauehi, and I got a couple of black-bellied males here first of week. Found a nest of reef heron on one motu in a tree surrounded by pandams trees. Nest was of usual heron construction, fifteen feet up on outer limb of tree; two eggs; incubation started a couple or three days. The herons were the vildest seen anywhere on the east side of this island, but the native says he hunts them there, as on his land, with coconuts. I saw one heron on one small motu crawling carefully through the brush, stalking a lizard in all likelihood, as lizards were frequent there and herons like them. The jellowbill, lunatus as well as noddy terns sit on the low beaches of the shellstrewn strand waiting for fish to digest before flying out a few yards to capture others. The boobies flew around over the motu where the nests were to be located several times. I got an adult and a 


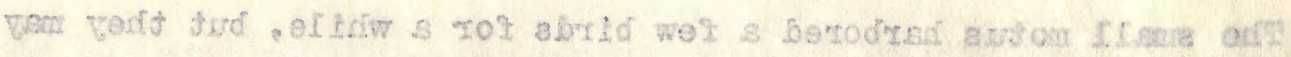

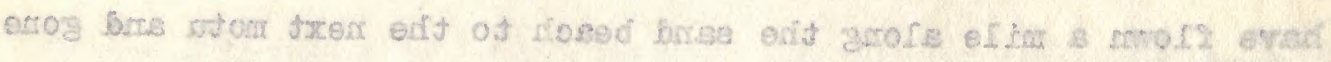

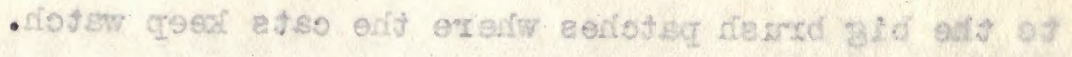

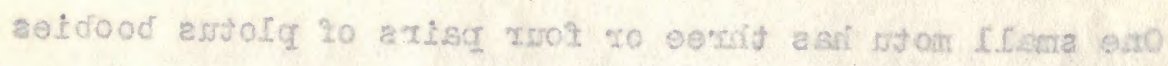

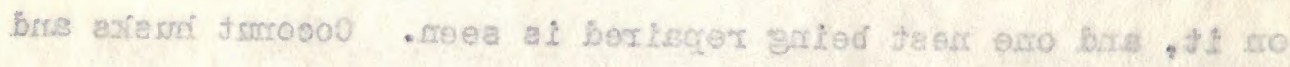

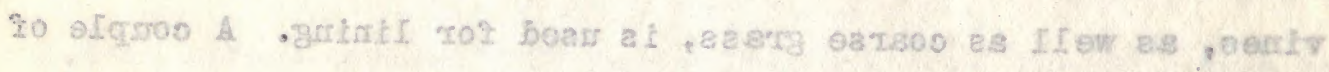

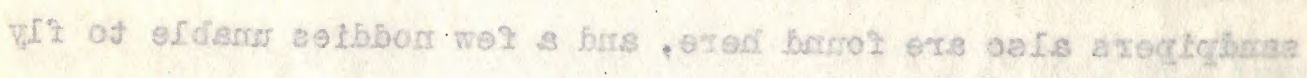

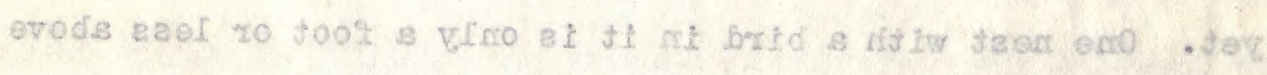

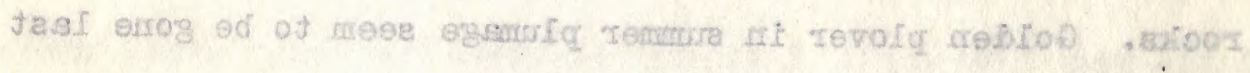

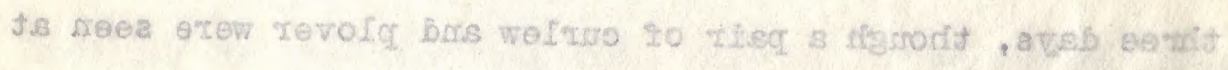

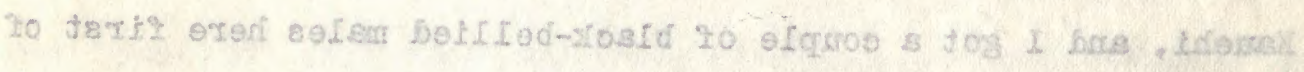

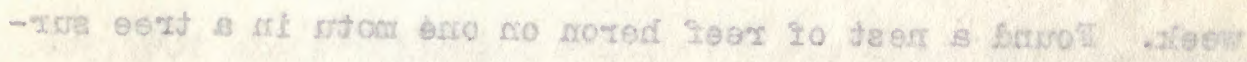

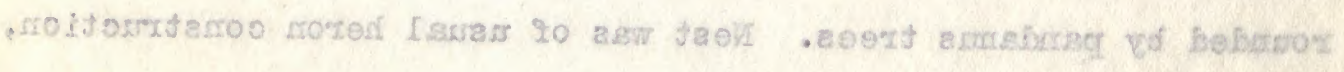

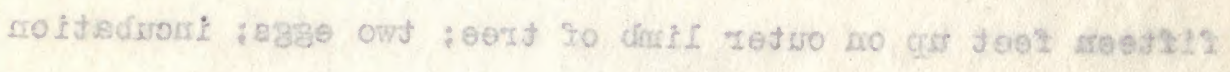

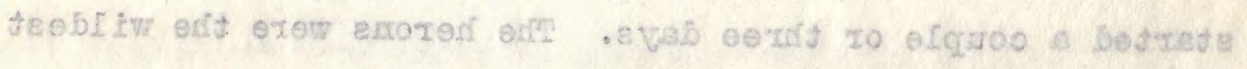

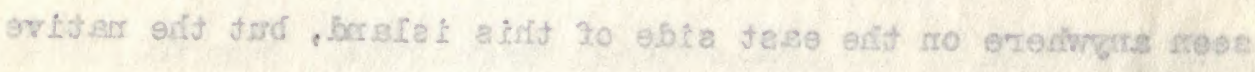

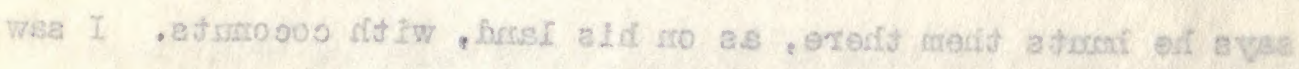

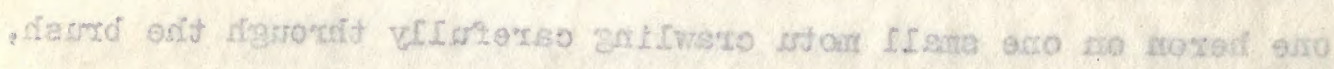

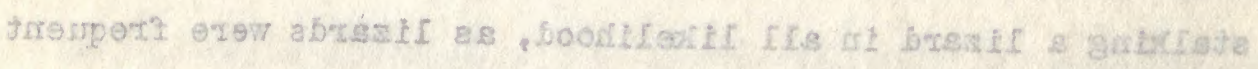

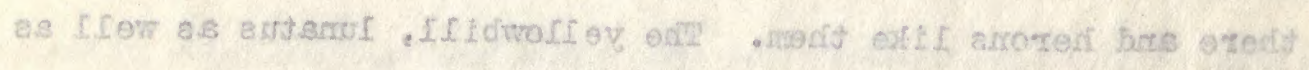

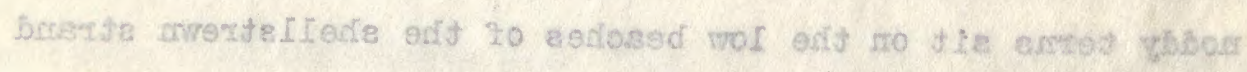

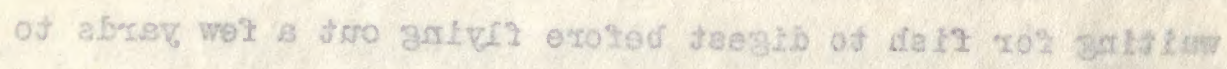

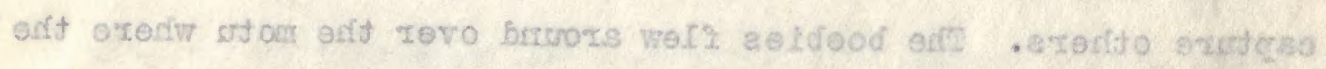

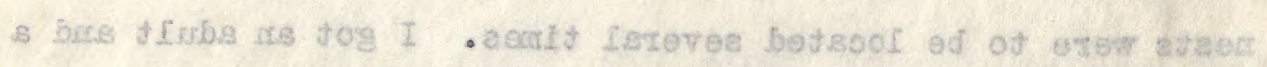


single young bird of last hatch. A couple of frigates sailed about high in air but did not come near.

\section{March 18}

Discovered yesterday that lunatus term is described from Kauehi Island, so will wan in there again to see if we can get a few. They occur on one of three or four motus that we did not visit, and to get the sea birds of these islands it may be necessary to trevel clear around an island and go ashore on twenty or thirty or so little motus to be sare one misses no nesting site of blue termlet of some other scarce bird. The boobles here were only on one of thirty or forty perhaps islets in the forty mile ring of this atoll. Very few, six or so, sooty terns were seon here, though they probably nest at Kaueh1. While at Takaroa and Takapoto we saw many that nested. on island fifty or more miles away. Doves are quite scarce here, perhaps due to cats, and warblers are not very common. Louie found a warbler nest being built. Wo looked at it a second and found one bird in the nest and the other in the bush below. It was in a clump of bushes only four feet up.

Leave this morning for Kawehi, the wind boing light in comparison with the last fow days which have been squally at times. Many rocky patches are along the shores of the lagoon 


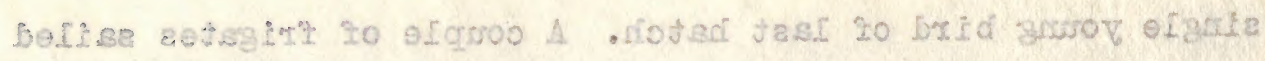

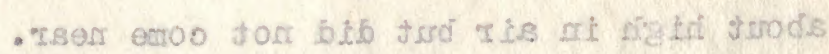

\section{of nowsil}

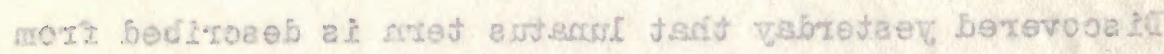

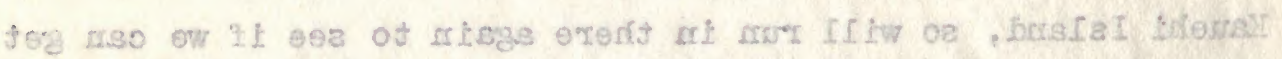

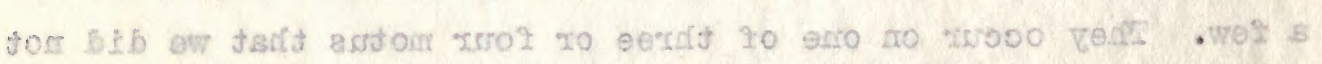

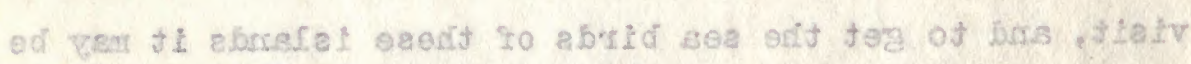

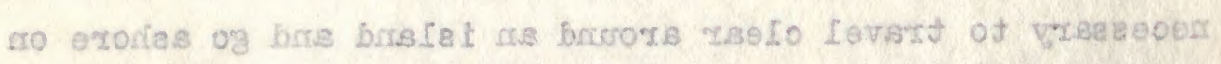

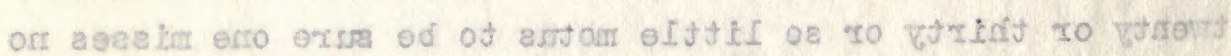

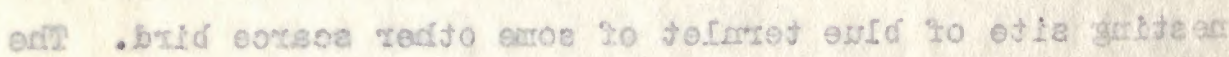

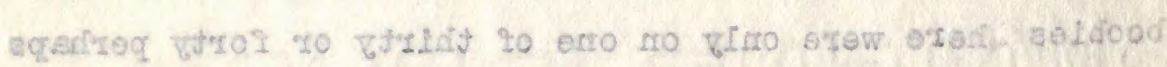

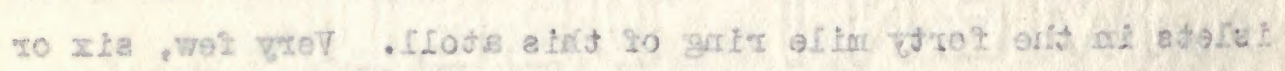

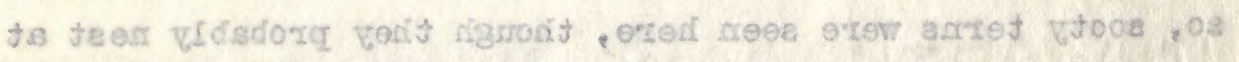

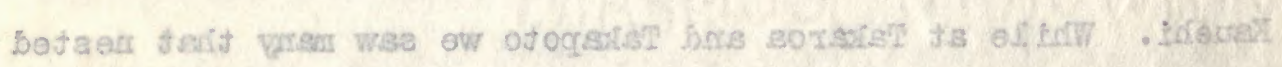

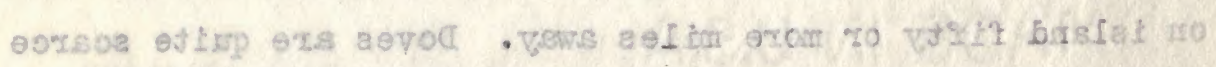

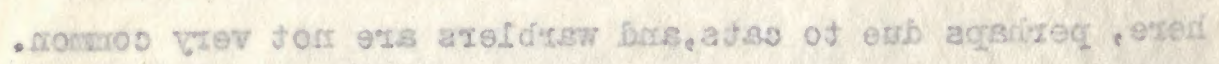

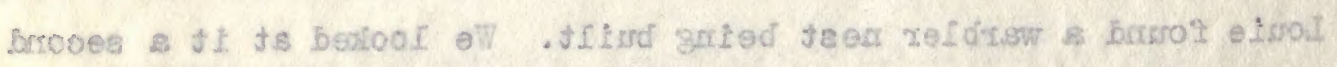

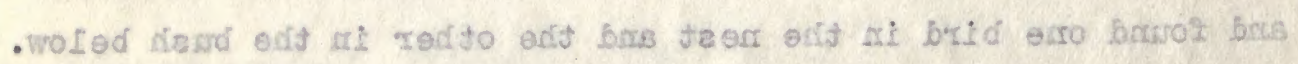

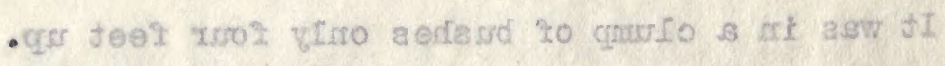

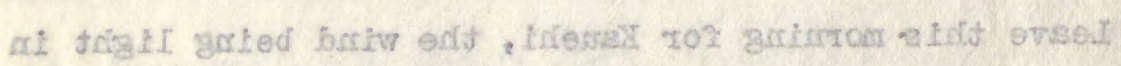

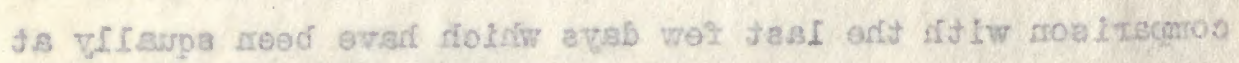

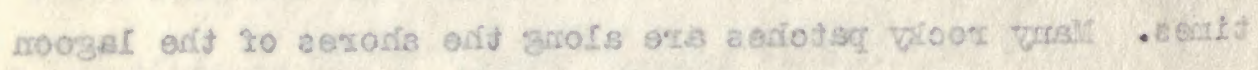


and the mate stays at the masthead while we move.

Warch 19

Cabin boy while hunting lizards on Raraka Saturday said he saw four cuckoos, and I saw one fiying southward along over the trees but could not find it.

\section{Varch 20}

Came across from Raraka yesterday, as I discovered this

island was the type locality of the lunatus term. We secured none while here. Louie took motorboat and went to point we finished up on last time, and I took ship boat and went to other end having a half dozen motus strung along for four miles. I found man noddy nests in low miclymicky bushes and a couple on bird the ground. Most were old, but an occasional one held a young, but I found only a rotten egg. In one thick bush I found a heron nest a foot off the ground with an addled egg in it. A few of the noddy nests had bits of shell or coral in them, but most were of the small twigs picked up close by the nest probably. A lesser noddy had a nest in one tree eight feet above the ground, and a few terns were roosting in low trees. Aboard the schooner which had anchored near us, and after lunch went again to the next motu and found sooty and lunatus terns sitting about as though they had nests, but we were unable to find one though flushed several young lunatus just able to fly. On the beach 


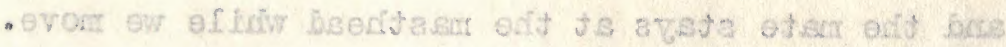

\section{e[ notsil]}

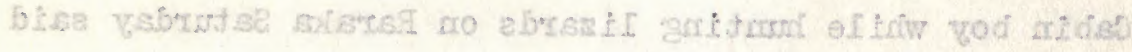

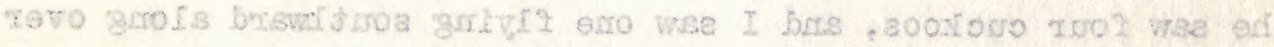

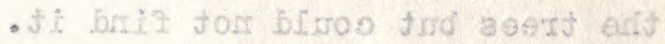

\section{OS nions:}

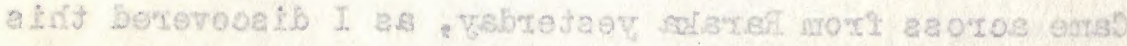

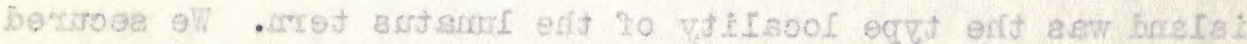

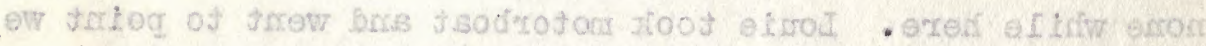

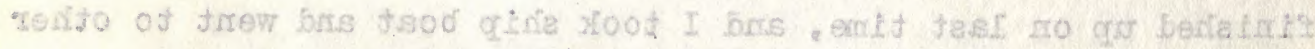

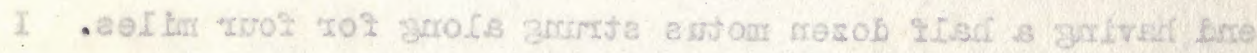

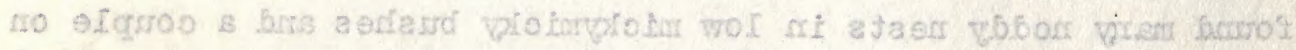
bes?

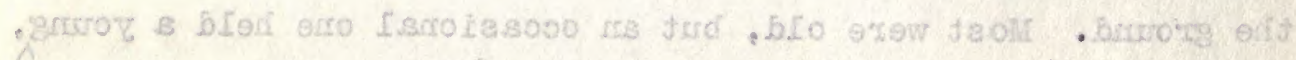

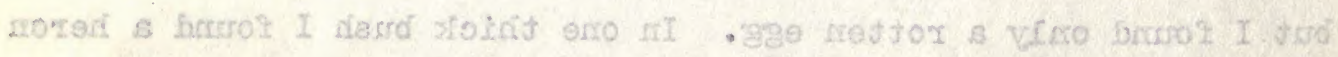

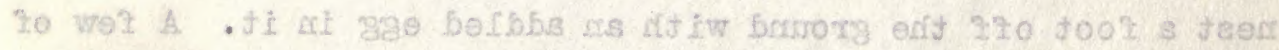

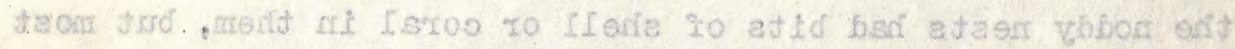

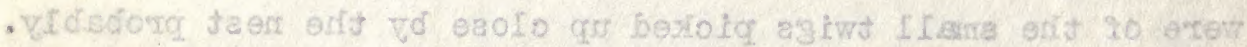

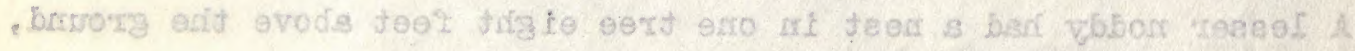

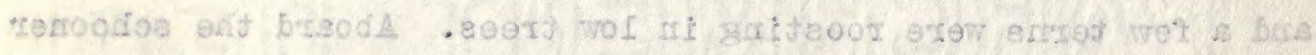

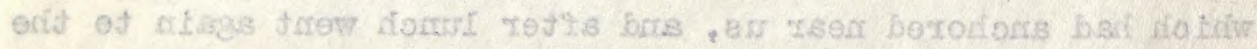

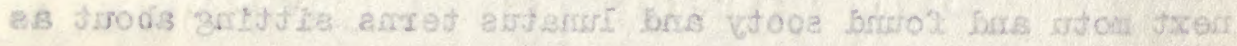

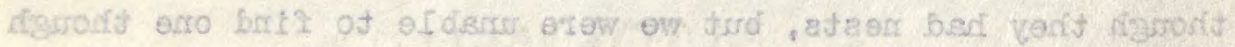

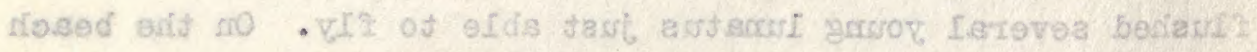


near our landing place were several rectirostris terms, and going to the spot I found five nests with fresh eggs, the first eggs of this species we have taken. Two nests were within a couple of feet of each other in two cases, one pair being but a couple of feet or so from high water mark in a little patch of sand; while two other eggs were in the coconut drift a little higher, and one nest was back thirty feet from the water in the solid coral with a few small pieces of coral pebbles about the egg. The old birds flew about and along the beach every few minutes for an hour. I finally shot four, all being males. A hundred yards, more or less back, the sooty and lunatus terns vere claiming the territory, and I collected with the auxiliary as many as I cared for. Near the outside of the dry land several blue ternlets were sitting on the rocks and I shot four or five of these. I was surprised to see a young fairy tern sitting on a large coral boulder that was surrounded by water near the edge of the reef. This was an unusual nesting place, as the fairy term as a rule nest in the trees. Though the sooty terns fly along the land both ways from their nesting site, the lunatus were only seen a short distance out in the lagoon in front of the colony. A flock of 75 so or lesser frigates was scared by the schooner from its roosting place a mile from the terns' colony, but I could only get one as they rose high in air and went out to sea. Louie cane along with 


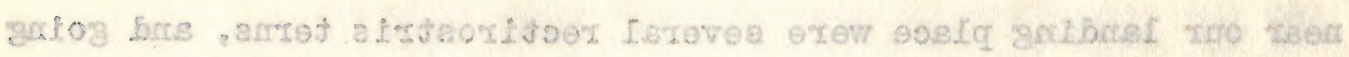

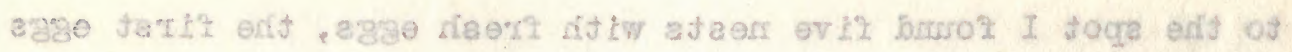

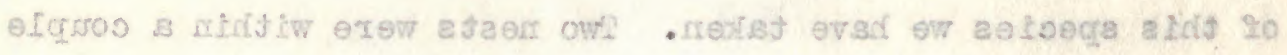

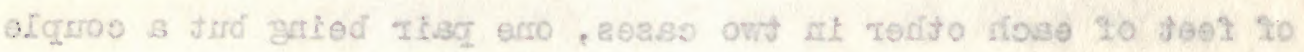

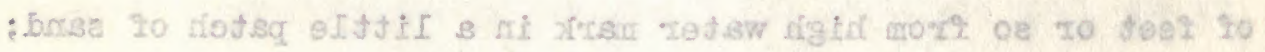

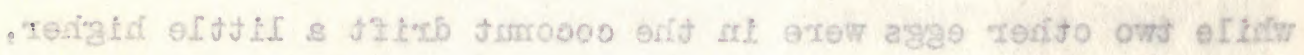

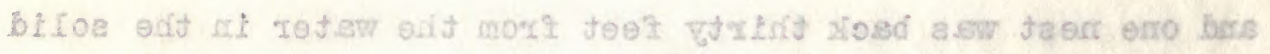

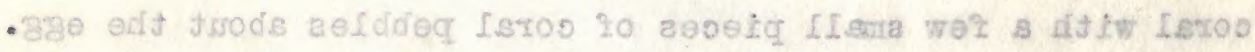

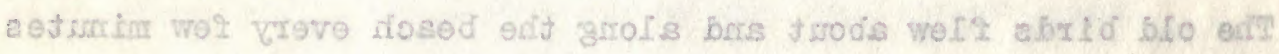

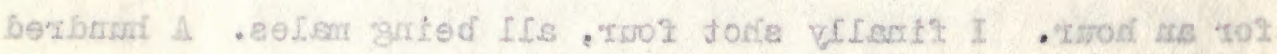

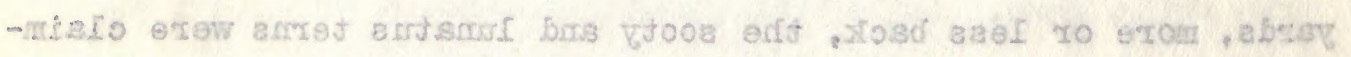

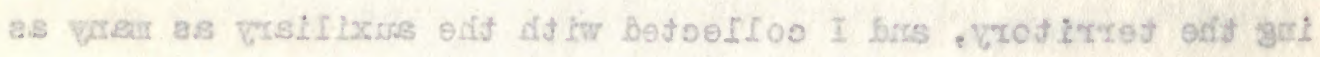

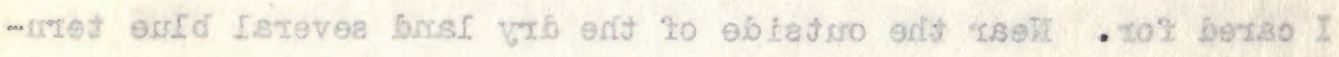

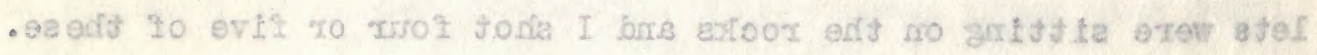

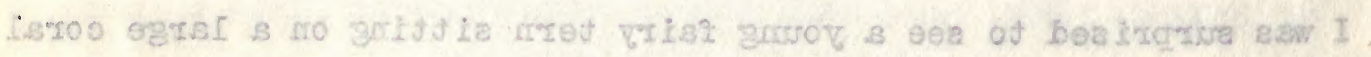

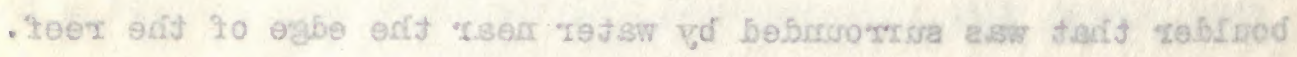

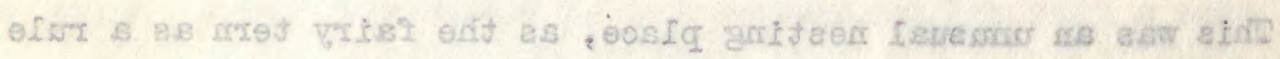

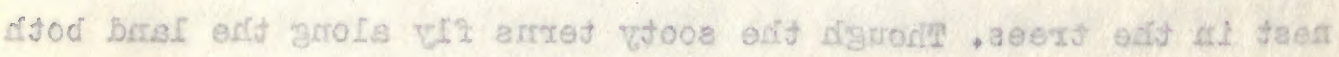

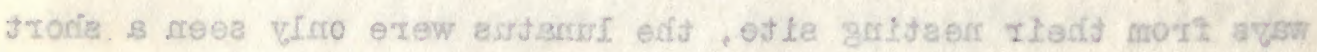

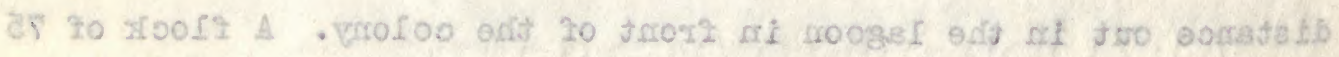

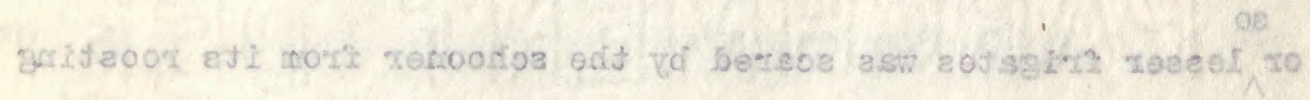

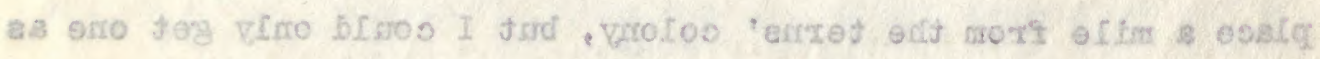

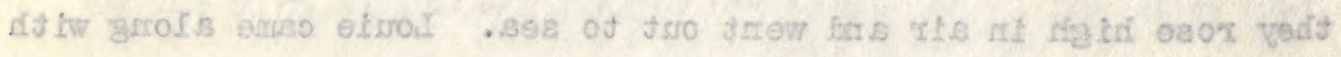


a dozen or so blue termlets and reported no lunatus seen till he reached us on the colony ground. At four P. M. I went aboard and wo sailed for Tahanea Island, sixty miles to the south.

March 21

Reached Tahanea at noon and found a small mota near tho pass with a couple of families making copra and waiting for the 'Vaite' to pick up their two tons of copra, after which they will go back to Katiu Island. I managed to get a foolish young heron that was resting in the shade of a small bush on the beach, but did not hear a warbler on the motu and was disgusted to learn from the native that it had been several years since he had seen a ground dove here. It begins to look as though this species, if it has a white head sometimes as he said, is now exterminated. On some of the motus of most islands where coconuts are planted there are some cats left to combat the rats, and they, of course, make short work of the doves. It is probable also that the natives have caught many of the birds for food. Fook the boat and went along to the west for a couple of miles and found a number of noddy nests on a small mota in low mikymiky and other bushes,-a few with young birds in them. Yellowbill terns were fishing along the reef on the outside and sometimes in the lagoon. A sincle frigete was seen and a booby in the distance. The native 


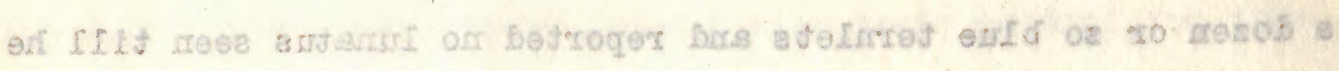

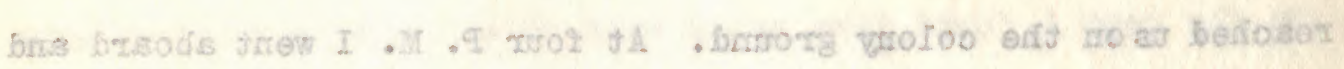

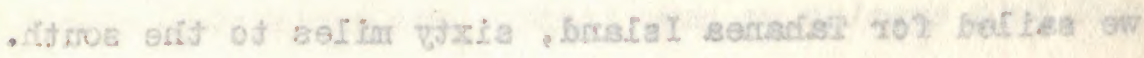

IS cotsil

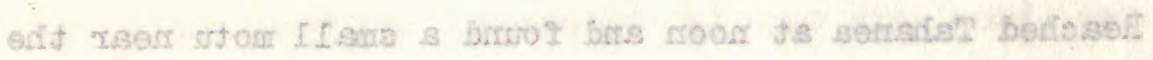

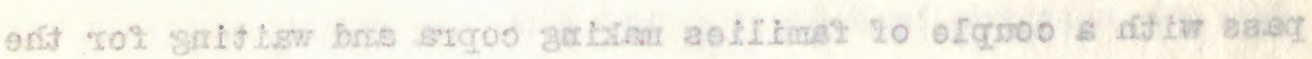

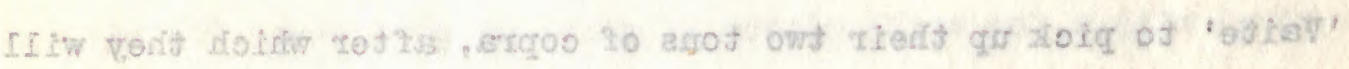

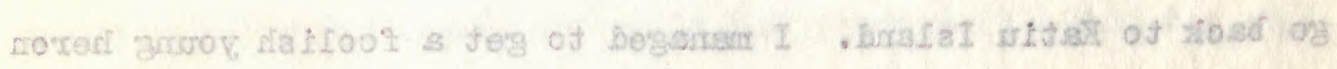

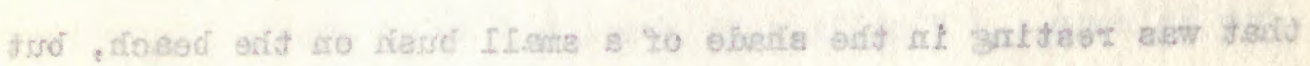

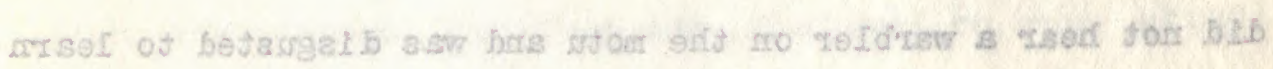

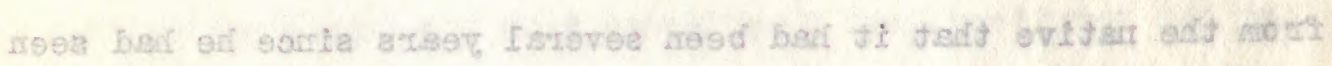

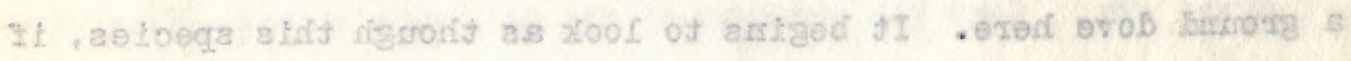

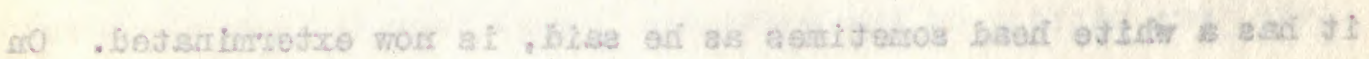

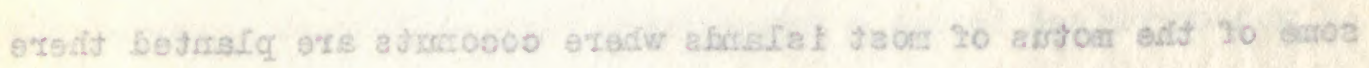

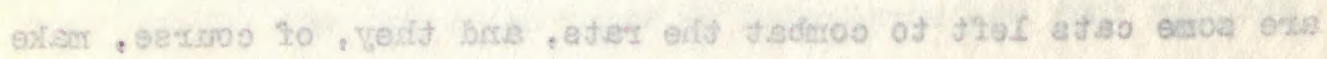

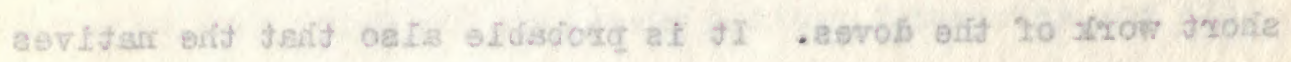

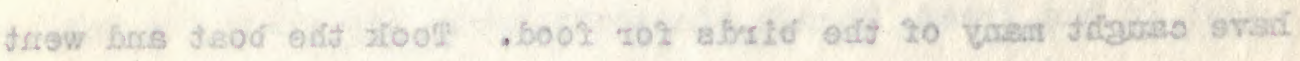

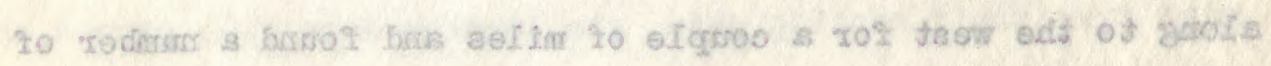

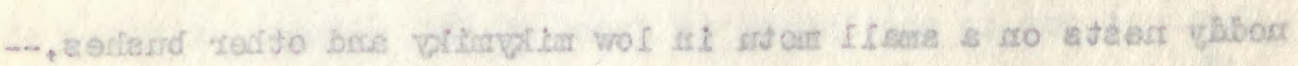

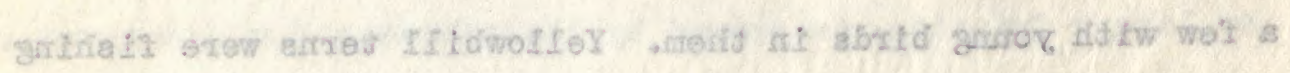

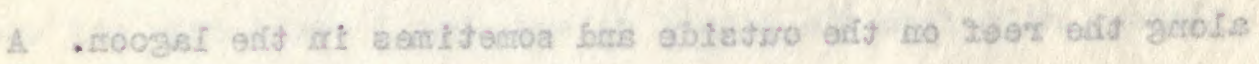

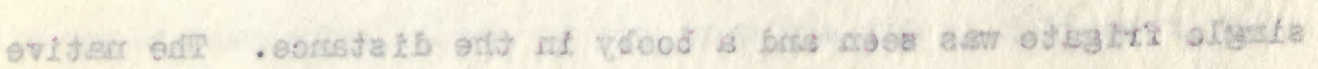


said the boobies roost at night on a small island four miles or so away from the pass.

\section{March 22}

I took boat and went along shore to east and the ship followed at ninec o'clock when the sun had gotten high enough to reveal the coral heads which dot the lagoon. I got a few warblers and we went to the southeast end to a motu that the native said held rail. We worked three or four motus and saw no rail and only a couple of doves and warblers, though picked up a couple of sandpipers that appeared along the beach. I also shot two separate golden plover in sumer plumage, the first seen for a week. There appears to be a small flight on today as weather is windy and promising more for tomorrow.

\section{March 23}

Went farther to another motu and got a couple more sandpipers and found a half dozen doves and several warblers, the doves finding plenty of food on this motu at present. They are not eating here the food of the eastern Tuamotu doves, as I mentioned in Raraka notes, but are feeding on the white maliberry-like fruit that is common on this motu and less common on others.

Louie went nearly ten miles to west with the motorboat and found not a dove on a large motu, though he got about twenty 


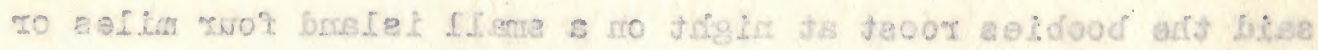
- ared odf motat verre de

\section{SS siseitif}

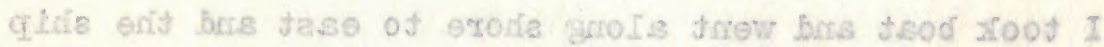

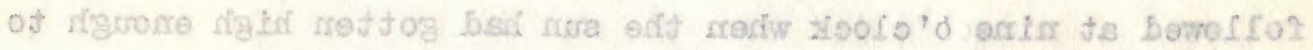

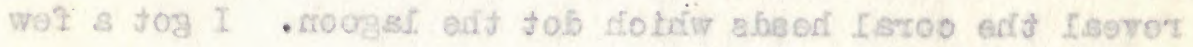

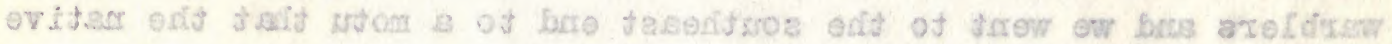

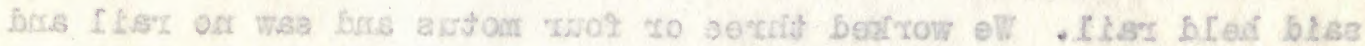

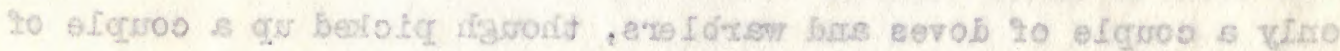

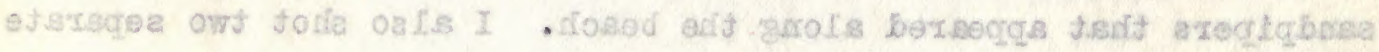

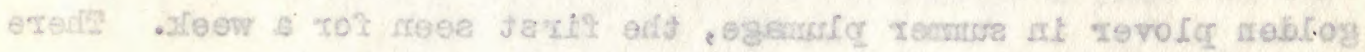

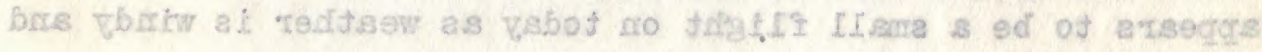

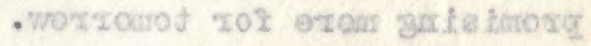

\section{ES Iotsit.}

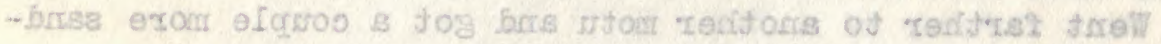

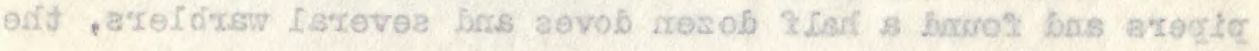

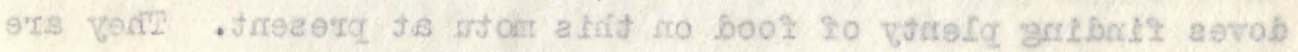

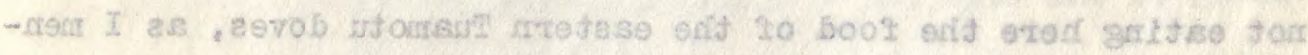

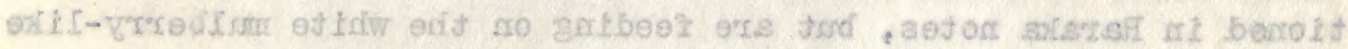

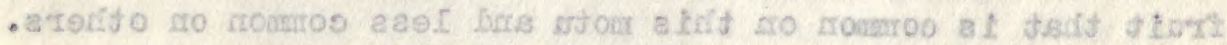

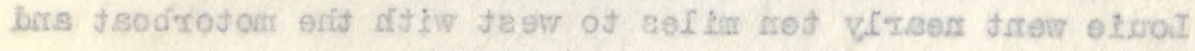

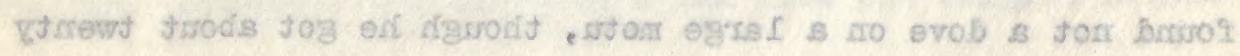


warblers. I flushed a small dove anead of me from a pandaras tree, and after securing the bird went back and found the nest hanging in the pandanus where the bird had perhaps fallen with it on my approach. The dove, as most of the other island birds, seems to have no hard and fast rale for a nesting site but selects one very easily. The noddies here are using the pandanus trees and the lesser noddies three species of trees that they use largely on other islands.

\section{March 24}

Louie and Captain went ashore early to look for rail but found none. I went to the next motu after breakfast at eleven to get a few birds to work on as our supply was running short, but the Captain wanted to start at twelve for the island where the boobies roost, so I got back and we were unable to head direct as sun on the water prevented the mate at the masthead from seeing the coral rocks that come to the surface at many spots. By heading off a few points we reached the island and saw no boobies till nearly dark, when perhaps thirty birds were seen coming in, and one came along with a frigate bird for companion. I shot a couple from the vessel and the Captain went ashore with a light and shot five in the trees. Fairy and lesser noddy terns were coming up the wind to the island in a scattering stream till after dark, and a couple of the lesser noddies were seen flying around in their mating flight as do the noddies and various shearwaters. 


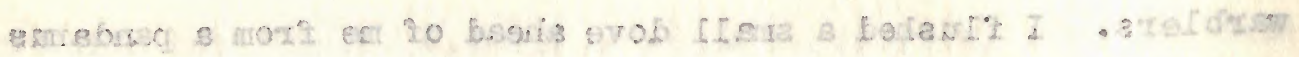

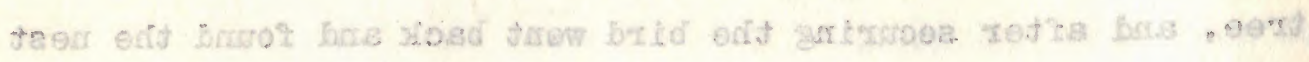

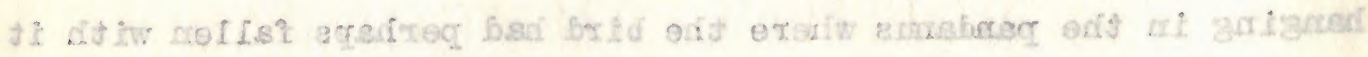

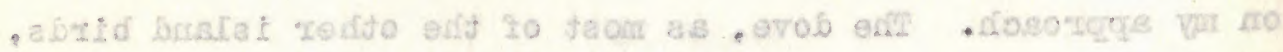

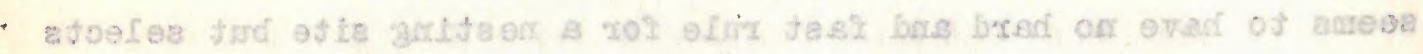

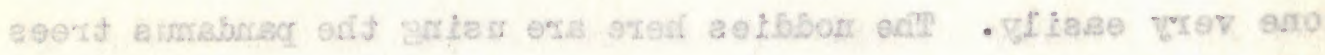

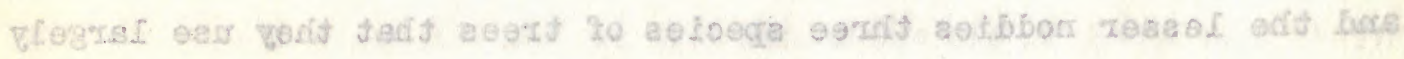
- abcos le? reajto fro

\section{HS IDTald}

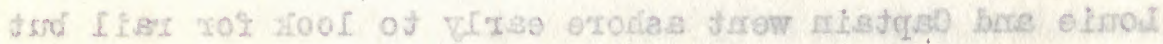

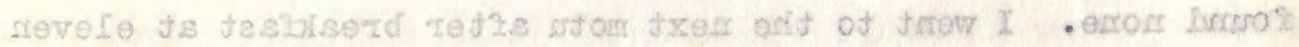

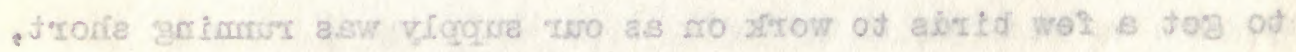

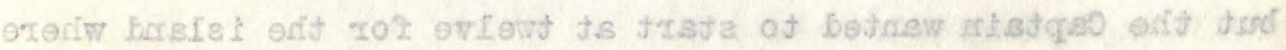

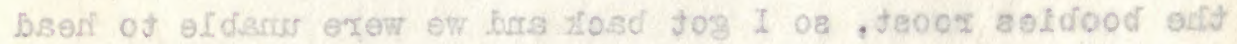

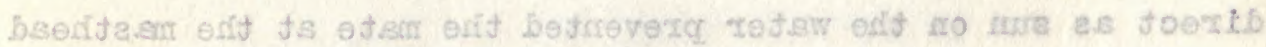

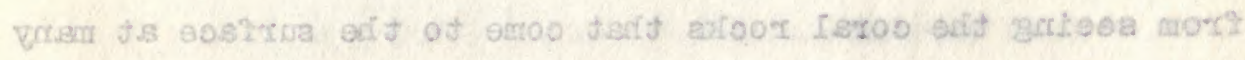

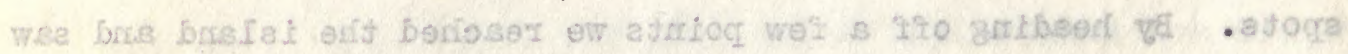

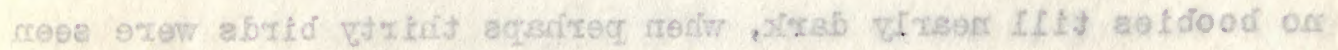

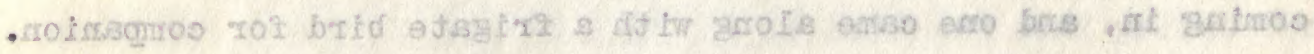

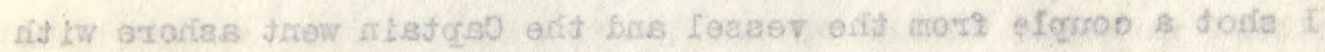

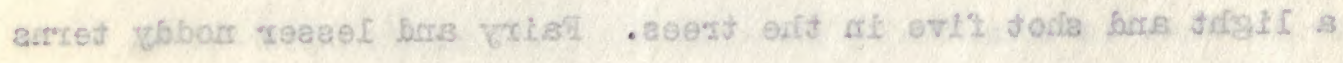

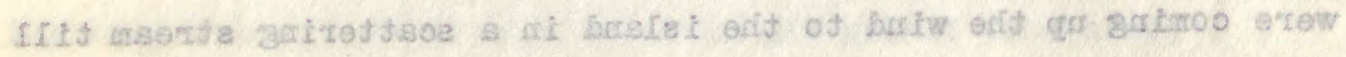

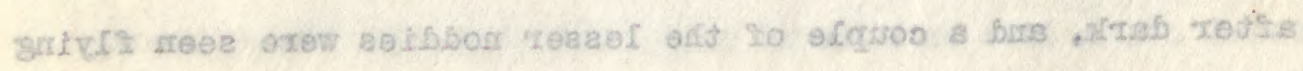

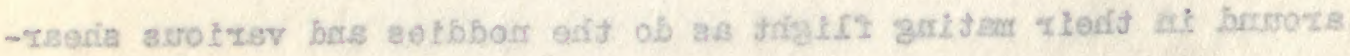




\section{March 25}

Rainy and heavy wind this morning, but I go ashore and. find no boobies so collect a few fairy and noddy terns to work on today. The lesser noddies are practically all gone from the island, but a goodly number of fairy terms hover over the island while the drizzle lasts, but by ten $0^{\prime}$ clock most of them have gone fishing and the most of the noddy terms left are young birds. A lot of noddy nests are scattered about in the mikgmily bushes and a few downy young are seen in some. Many of the nests are large ones and are used repeatedly, as are the lesser noddy nests which are common in several trees in the center of the island. One fresh egg of lesser noddy was taken from a nest twenty foet up in a tree containing several old nests. The nest had been repaired by ading a few leaves to the top of the old excrementcovered ono. A couple of joung lesser noddies were seen in nests, but a hundred or so old nests were unused. One young fairy tern was noted, and one female skinned was just about to lay or had laid. Four wandering tatlers were about the island; a couple of plover while a heron flushed a couple of times finally left, chased by a couple of noddies; and I have usually seen herons followed closely by noddies when they leave the shore. The island covers a couple of acres probably. Ten frigates hung in the air over the island at deylight but left before I got ashore. A couple of warblers were taken and an old warbler's nest seen. 
aS wionell

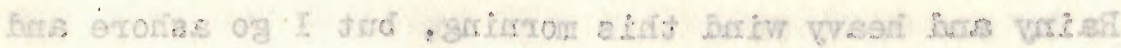

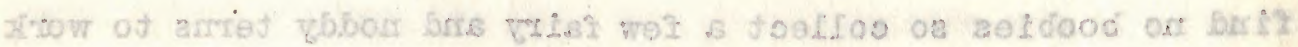

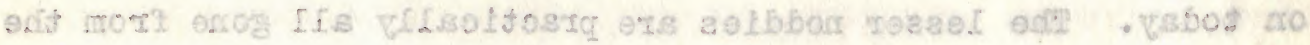

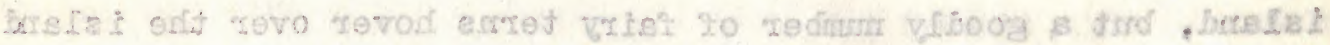

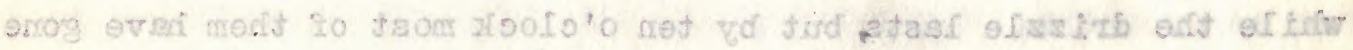

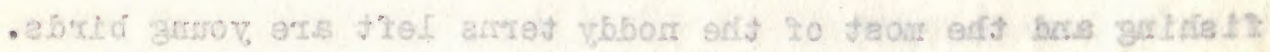

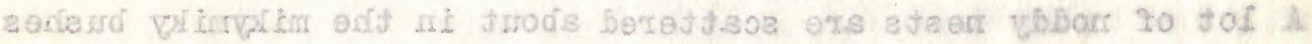

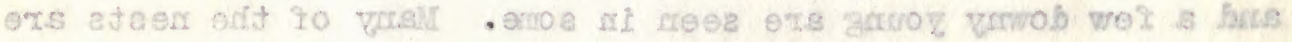

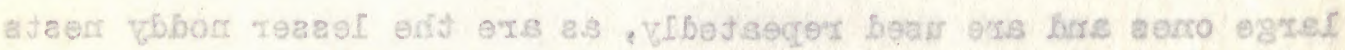

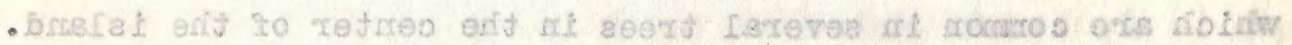

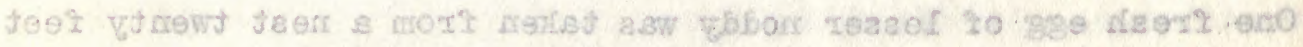

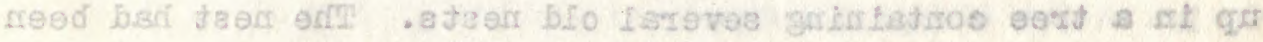

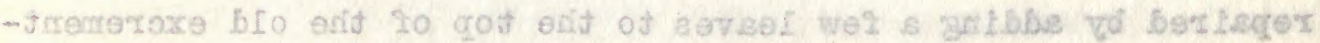

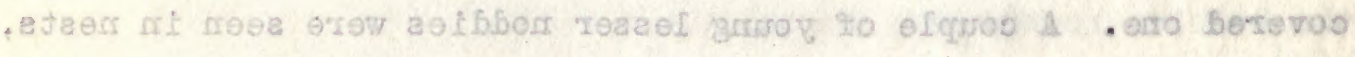

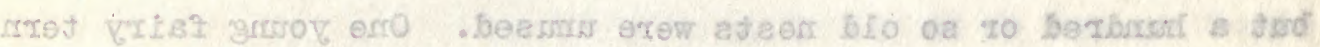

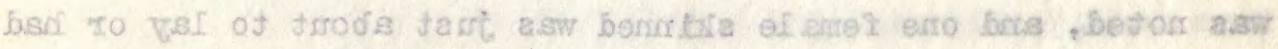

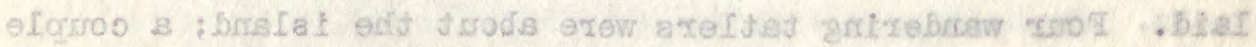

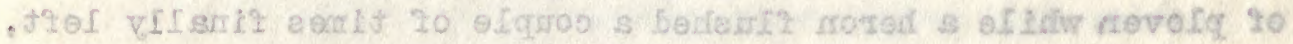

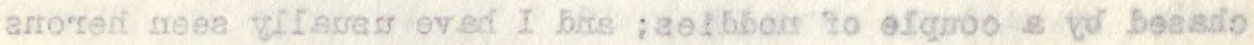

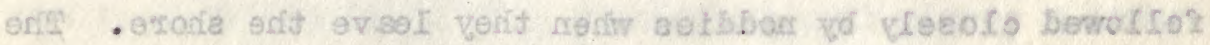

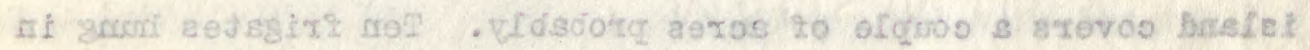

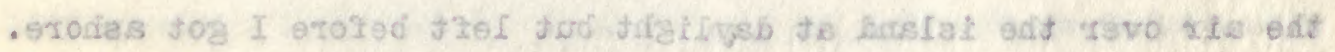

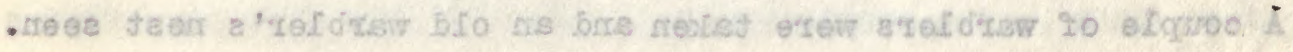


A couple of plotus boobies swung up astern the ship at dark but drifted off without approaching the island, while a young bird came up to the vessel and was shot at ten o'clock. Captain went ashore again at dark but only got two boobies and I got one from the vessel at dark.

\section{March 26}

Louie went ashore till eight and came back with a dozen lesser noddies and we went across to the north side to some small motus which we worked till three, getting a dozen warblers and no doves. Rall were not found, though the ground looked favorable. Several noddy nests were found in mikymiky bushes from one to four feet up, and a few young birds and a couple of pipped eggs noticed. I took a nest and an egg that the bird was setting on, but she had neglected to take care of it properly and it was rotten though incubation had begun. We moved down to the pass at three and the Captain went ashore and got some yellowbill terns and a heron.

\section{Mareh 27}

Got under way at eight o'clock and headed for Papeete with a few over a thousand birds for the two months' trip. Days spent looking for rail and landbirds on Takaroa necessitated collecting more noddy and other terns than would have been the case had the 


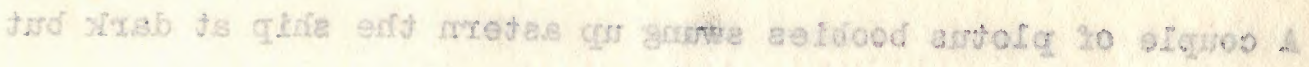

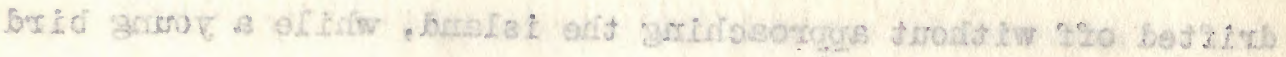

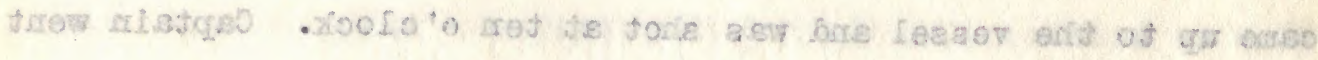

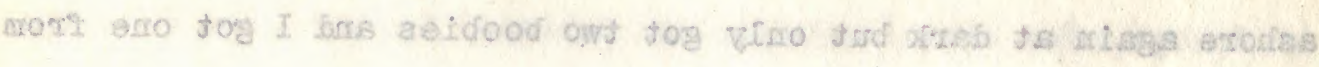

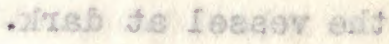

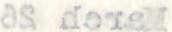

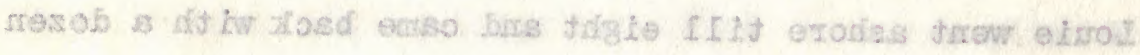

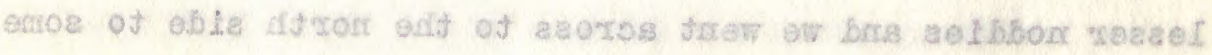

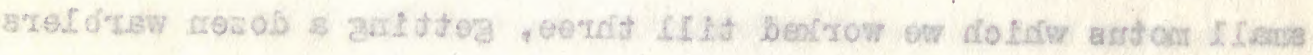

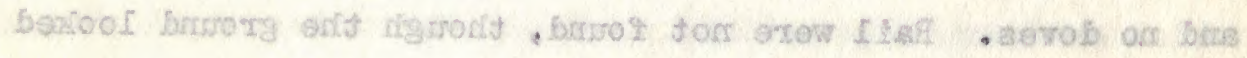

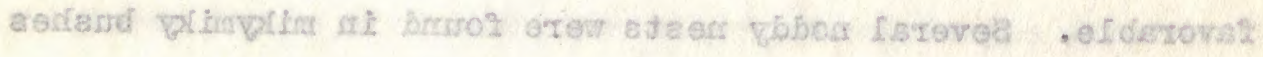

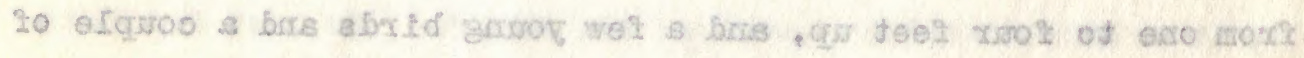

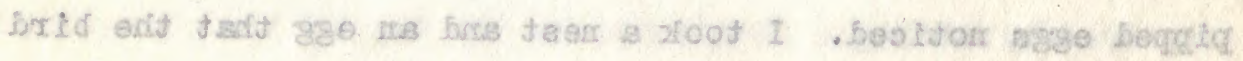

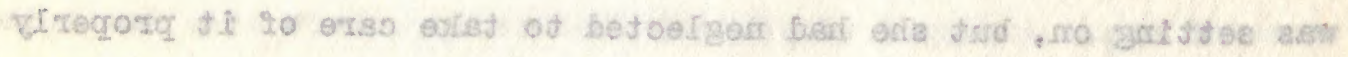

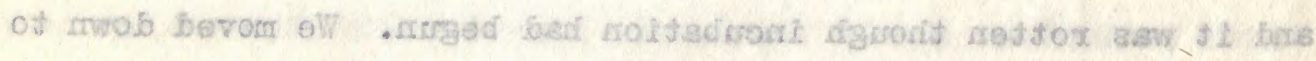

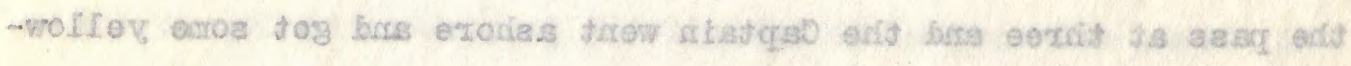

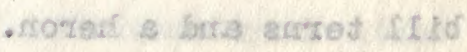

re dioxall

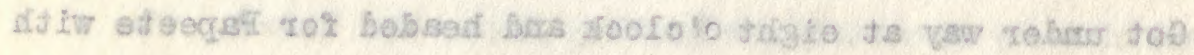

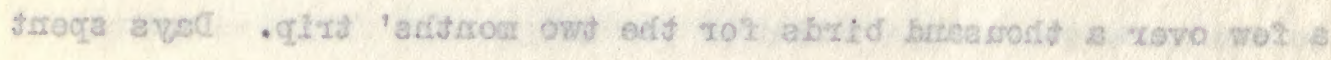

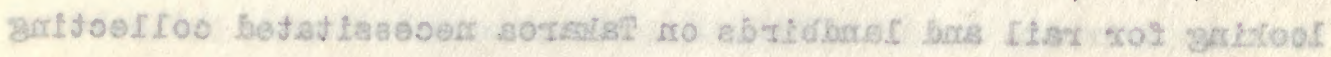

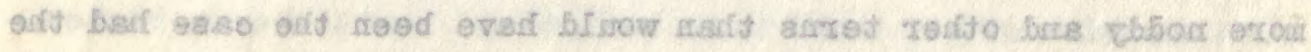


rail been more in evidence. After hunting all day for a rail it was orten necessary to collect the commonest birds at hand to have something to do in the evening, working hours extending: to eight $P$. II.

A few miles out of Tahanea pass a blue shearwater was seen flying to the westward, this being the first of this species seen since leaving Oeno (?). The west end of Tahanea Island is planted to coconuts, but no noddies are seen flying about as on most of the motus to the eastwerd. With a light fair wind we are passing the west end of the island at twelve $0^{\prime c l o c k .}$

In five miles or so of the west end of Tahanea Island I count nine motus with coconut trees, some with less than a dozen. Twenty miles scuth of Tahanea I noticed about twenty (?) sooty shearwaters flying NW by $W$ and WW and two tomorrow morm.

March 28

A sooty tern and a fairy tern as well as a young noddy which came aboard and left in the morning were seen. A yellowbill tropic came about in the evening. A couple of sooty shearwaters also passed, westward bound.

Harch 29

$\triangle$ few redfoot boobies and fairy terms fishing fifty miles off Mahiti, and at fire P. M. twenty miles to NW of Pt. Venus 


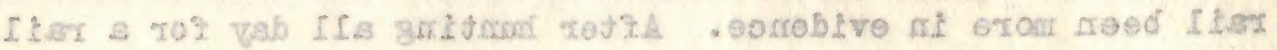

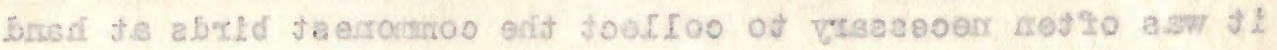

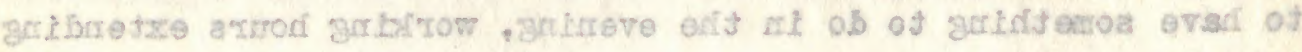
.25 . I trigle os

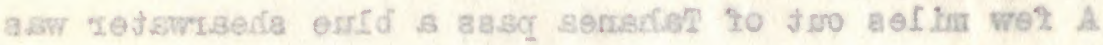

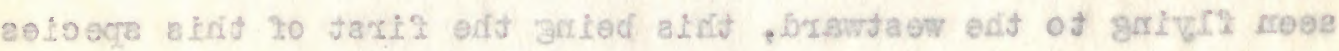

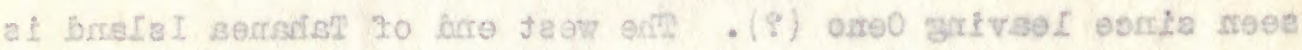

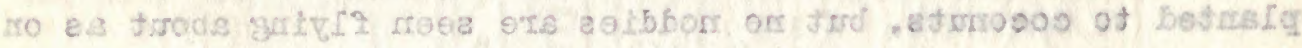

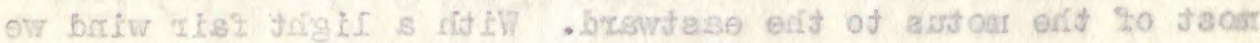

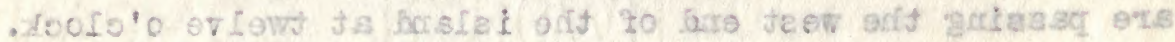

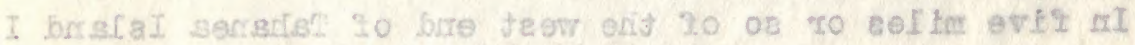

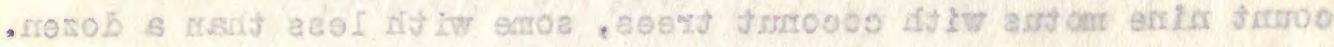

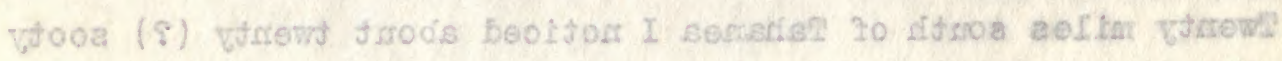

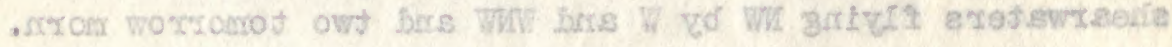

\section{gS ciotisilf}

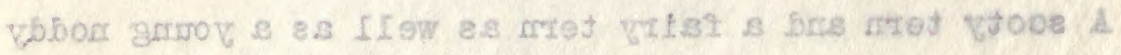

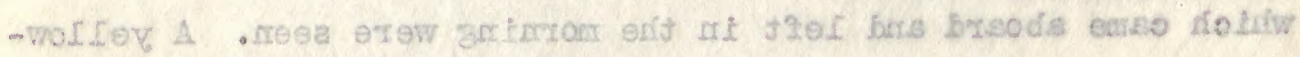

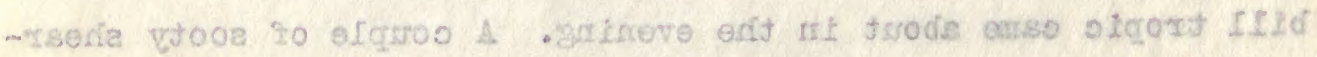

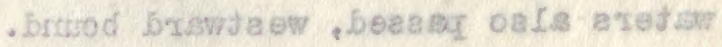

\section{PS florter}

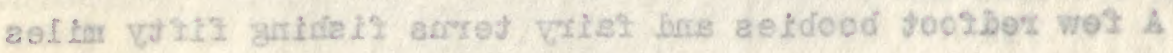

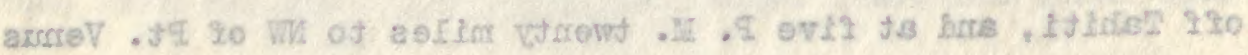


several sooty shearwaters passed, going to the west north west. I have not seen this bird north of Tahiti before, though saw several on the trip to Rapa, which was made in March; also in 1921. From the number seen here it is a migration north. Fine weather and light wind and expect to reach Papeete late tonight. Two or three puffimus shearwaters seen fifty or more miles off Taniti. 


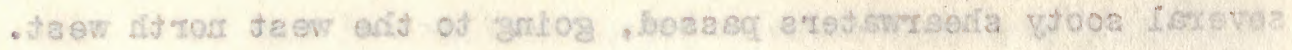

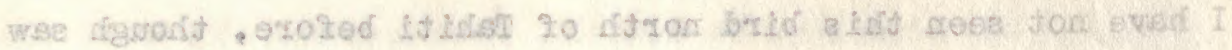

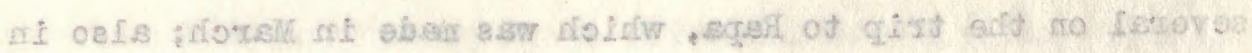

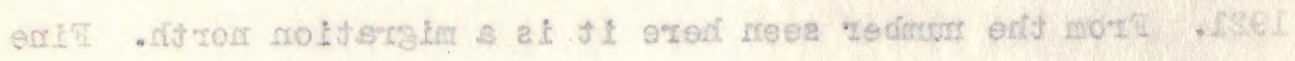

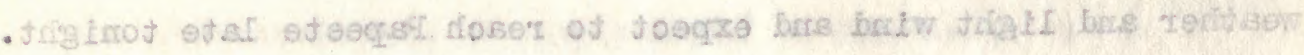

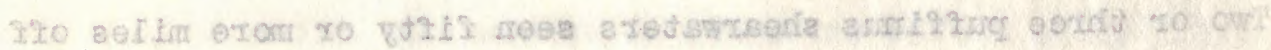


April 11

Left Papeete for the Thamotus again, expecting to return early in July. In P. M., as we motored a few miles to the north of Tahiti, flocks of redfoot and a single plotus booby were seen fishing with a lot of lesser noddies and a few fairy terns and a few noddies. A half dozen or so obscurus shearwaters were seen with the fishing birds, but no rostrata though two or three of the latter were winging their way over the ocean twenty miles off land. One bonita taken was full of small fish two to three inches long, and the birds were taking these also from their actions. At dark a few of the birds were heading toward Metiaroa Island to the west. Iight wind and calm.

\section{April 12}

A light $\mathbb{N W}$ wind forced us to the east and Mehitia showed up clearer as the day passed. But one jellowbill tropic came about during day and two or three boobies seen. At dark three and four boobies were seen heading to island and several flocks of larger size were noted also bound islandward.

\section{April 13}

Island well astern of us twenty-five miles or so and we headed north with light wind. 


\section{- dis- \\ L. İerch}

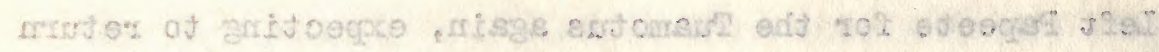

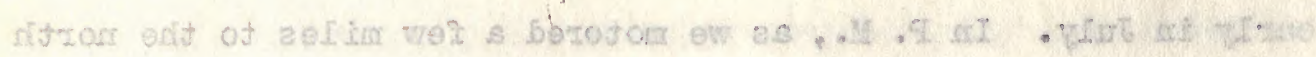

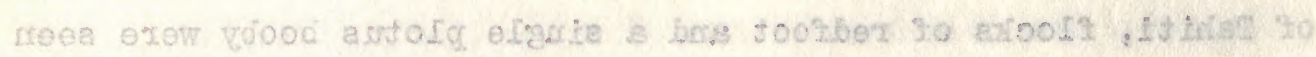

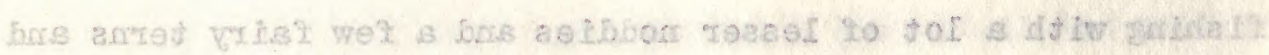

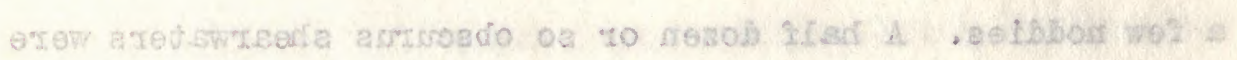

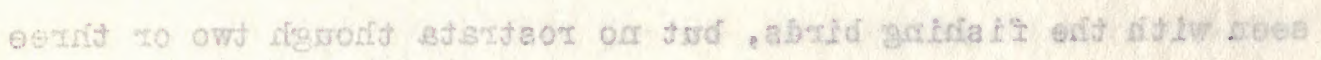

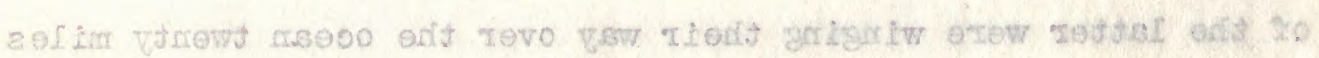

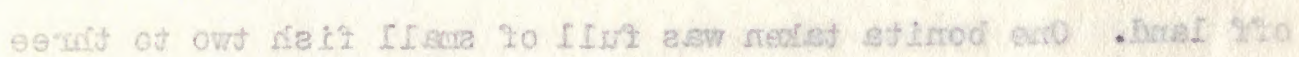

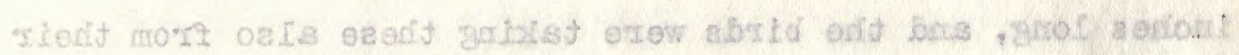

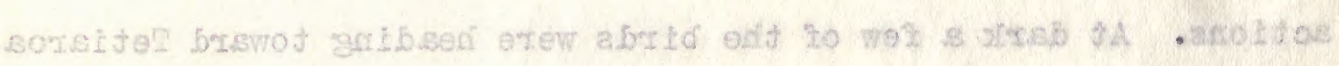

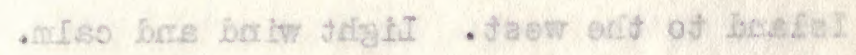

\section{S.L IITOA}

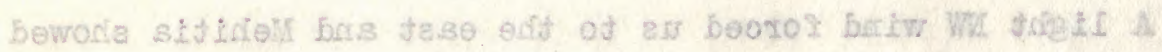

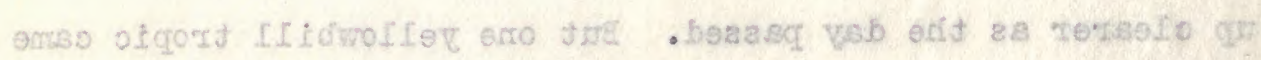

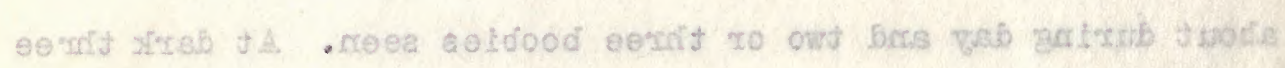

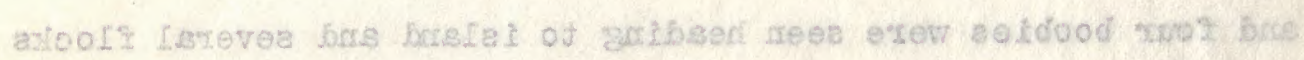

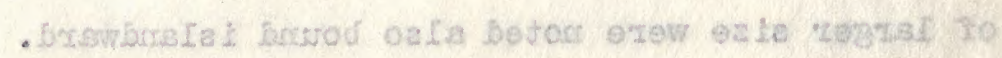

\section{EI IIsqA.}

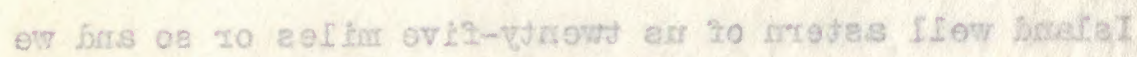


April 14

$\Delta$ wedgetail and three obscurus shearwaters seen in morn.

\section{April 15}

Sunday and we passed Niar at eight in the morn, seeing several flocks of lesser noddy and noddy terns with a few fairy and a half dozen lesser frigates fishing off the east end. Reached the west end of Toau Island at two and went ashore awhile, seeing a dove, warbler and four curlew. Louie saw a rail and a cuckoo, while I heard a cuckoo. A few terms of the three common kinds flew along shore. Anchorage is in a former (?) pass with coral in inside part too shallow for vessel to cross. The reef to the south of the part where plants can grow is wider than most reefs, being perhaps a half mile wide in places with a small motu a couple of miles west of the southeast end and no further regetation as far as the eye can see.

\section{April 16}

Ashore and find birds scarce. I got three warblers and three doves, while Correia got three doves and a few terns. I went down the reef a couple of miles to the eastward to a small mota and got a warbler for mains. A large flock of noddy teras were resting on the reef and I noted old nests in the bushes and on the ground, so likely no cats are on this side of the 


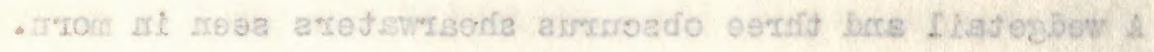

\section{aI I I LQ⿻}

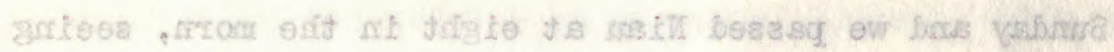

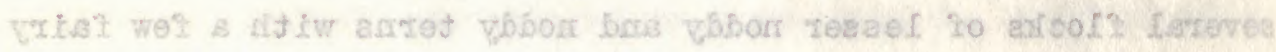

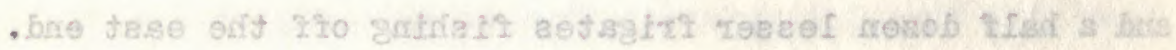

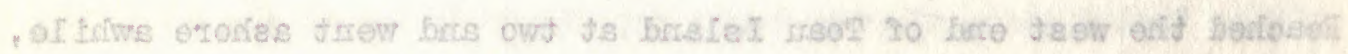

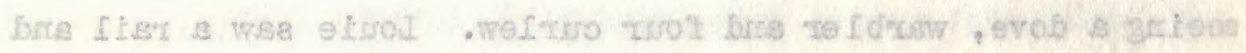

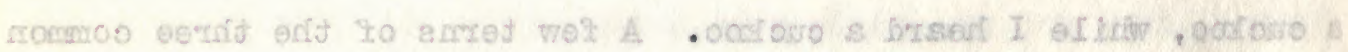

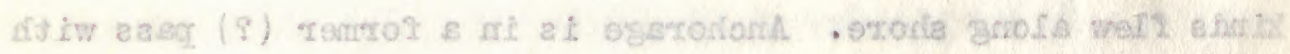

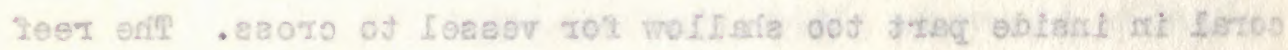

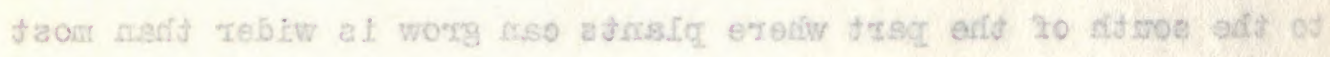

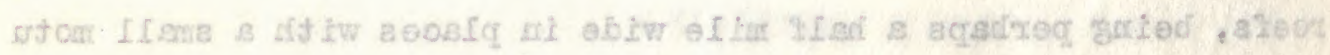

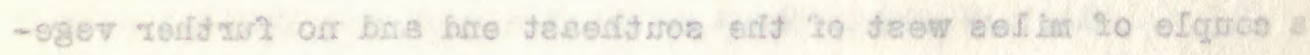

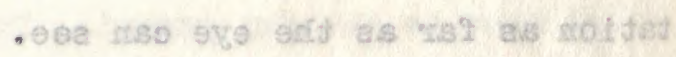

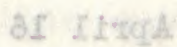

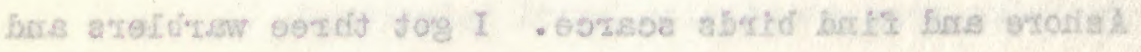

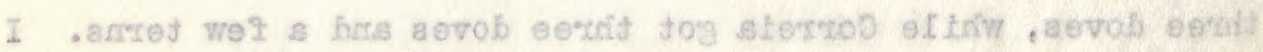

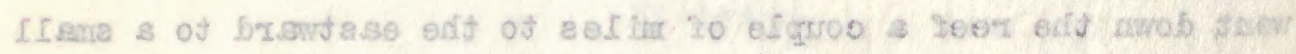

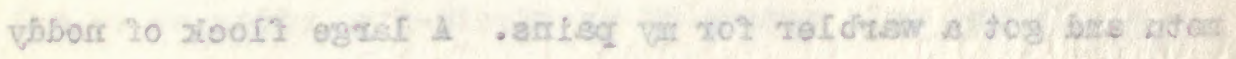

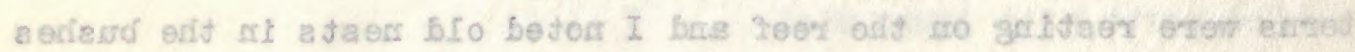

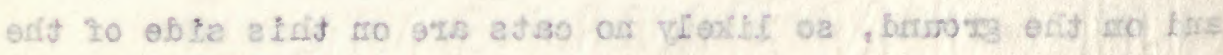


anchorage. Captain saw a rail but missed it. I went ashore again and looked for them but saw none.

\section{April 17}

I went to the southwest end of island about four miles from anchorage and shot a cat and one warbler of two seen, the other escaping. In one motu were a lot of lesser noddies resting in the trees by old nests. A couple of wandering tatlers were shot of several seen, the two being in summer plumage, while the several golden plover seen were all in winter plumage. A couple of curlew were noted also. Shot and organs small, while one of the tatlers showed evidence of enlargement. Most tatlers are in winter plumage. As many white as blue herons seen. Can't account for scarcity of warblers, as quite a bit of likely looking territory seemingly suitable on a couple of notus and saw no doves at south motu, though several at anchorage. Loule got five warblers, while Correia got a few terns etc. as well as a couple of herons.

\section{April 18}

Started at daylight for Fakarava, which we will reach at noon with light wind and motor going. South side of Toau is water covered reef and a dangerous place for vessels at night. On northeast end is a motu which shows well. 


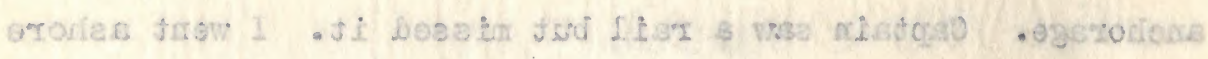

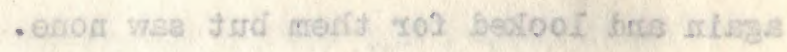

\section{re $\operatorname{Linc} A$}

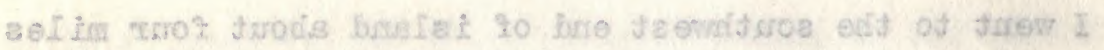

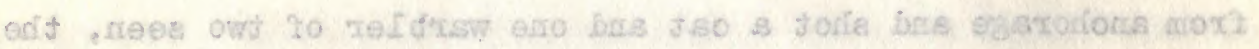

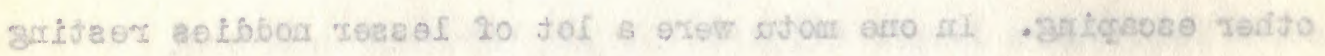

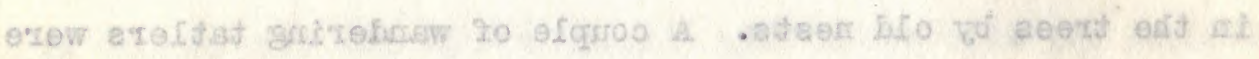

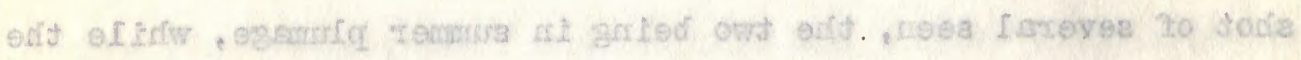

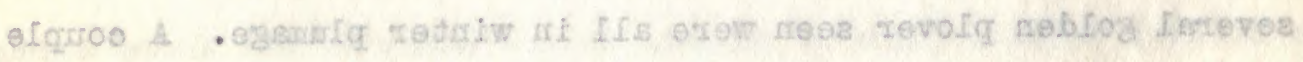

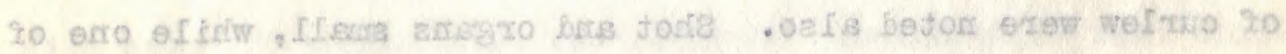

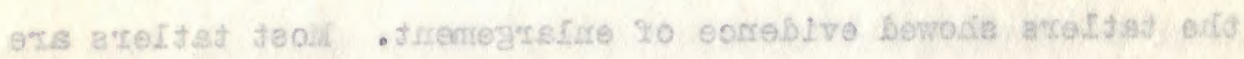

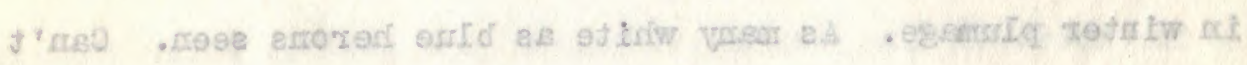

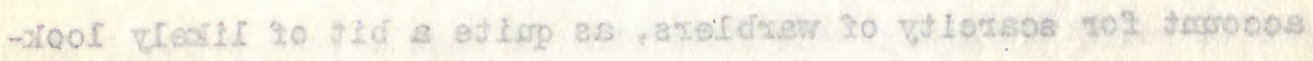

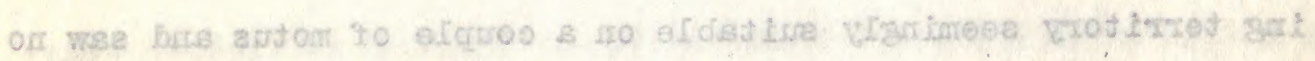

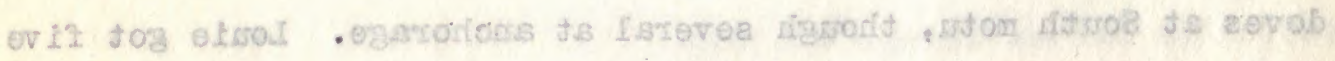

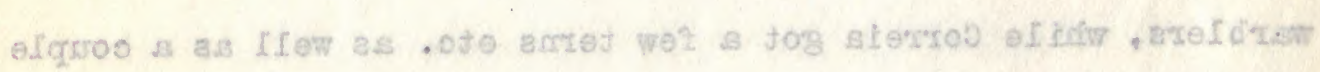
- exroged 20

\section{BI. I.teg.}

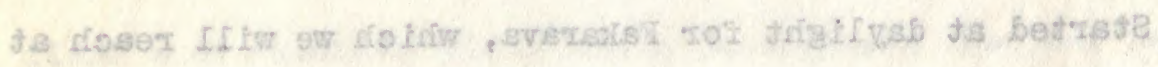

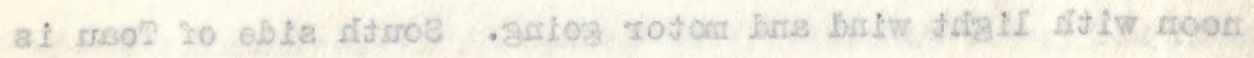

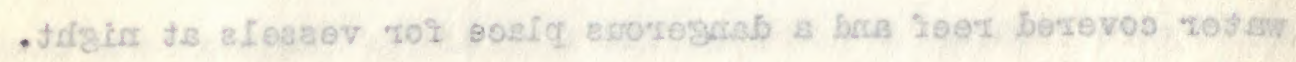

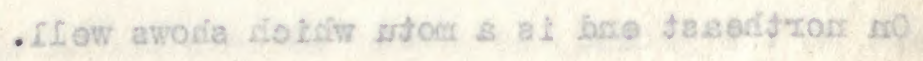


Ashore at Fakarava at $12: 30$ and spend three hours covering two miles of likely looking ground and seeing no warblers or doves, so go aboard at four and go to village five miles on. Correia got a warbler and we both shot a wandering tatler, both showing few sumer feathers. Few rectirostris terns seen fishing inside and a few noddies fly along over trees.

\section{April 19}

Three of us ashore and work three or four miles both sides of village, getting thirty warblers but no doves. Correia got a couple of herons also.

\section{April 20}

Leave early for islets in lagoon and motus on south side where natives say boobies nest. Scare a few frigates from small islet but no nests. Going ashore in P. M. on motus on reef find a few plotus boobies nesting on ground and three or four redfooted in mikgmiky bushes about 16 feet up. Redfoot nests are small and new, so collect a couple. Flocks of young noddy terns are sitting on the sand beaches and in bushes on the small motus. water from sea drops a foot or more in waterfalls when tide runs into lagoon. Nany sand beaches on lagoon shore where motus exist. The motus are farther from the outside reef here than on any island yet visited, being 300 yards or more in places, but on 


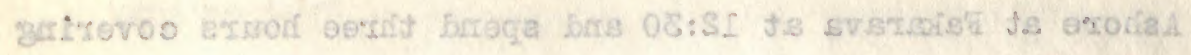

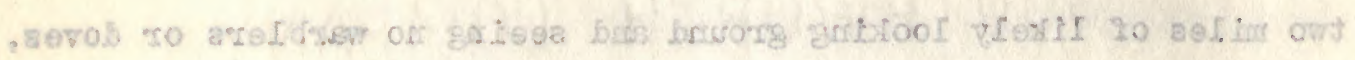

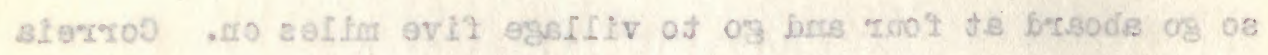

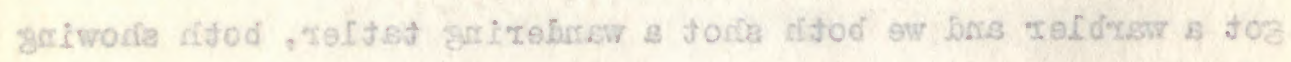

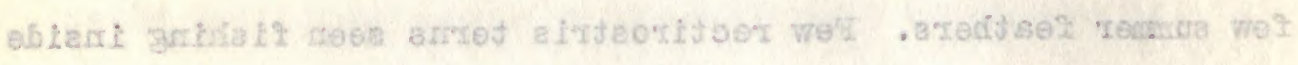

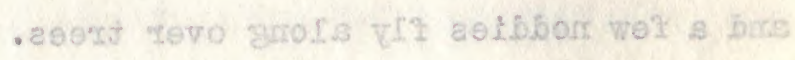

\section{QS. I. Imo \&}

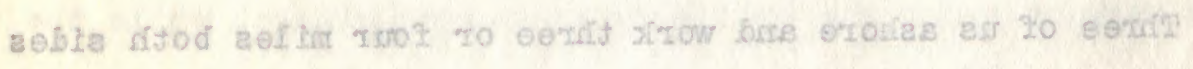

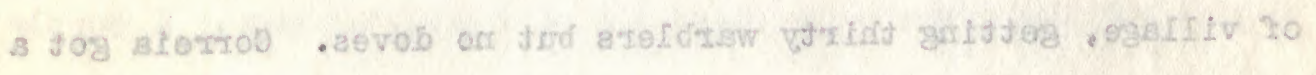
. oefa arroterf to elckioo

\section{$\operatorname{OS} \operatorname{Iig} \mathbf{A}$}

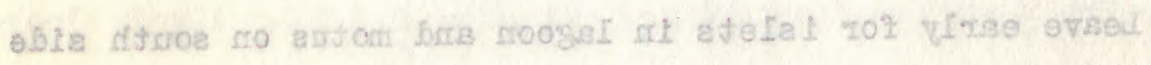

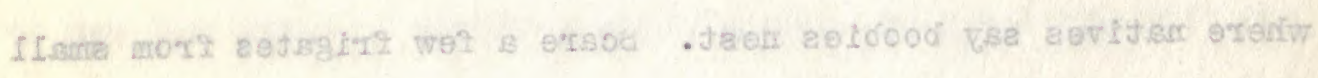

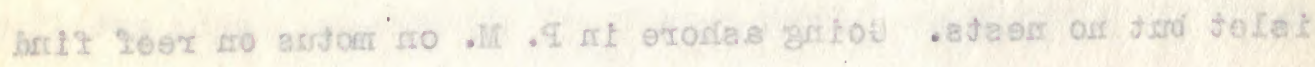

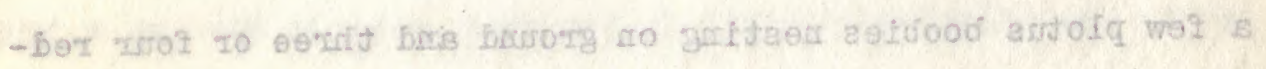

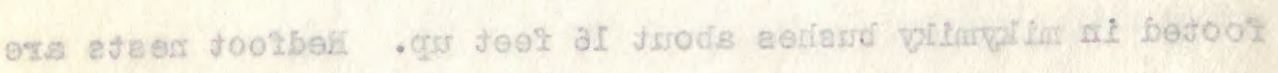

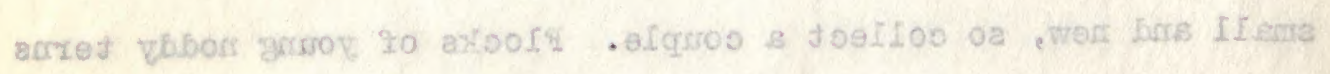

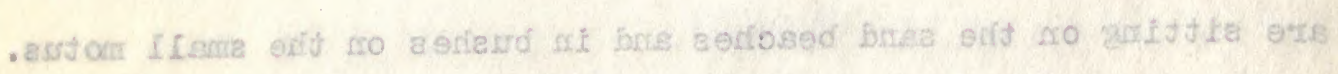

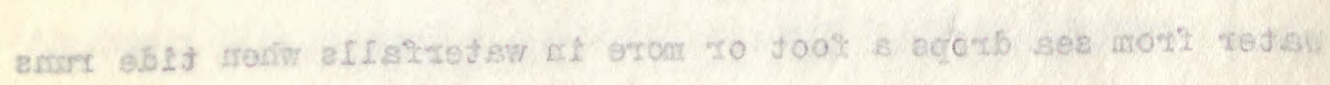

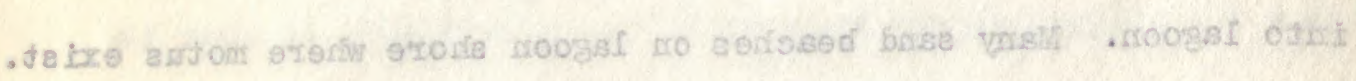

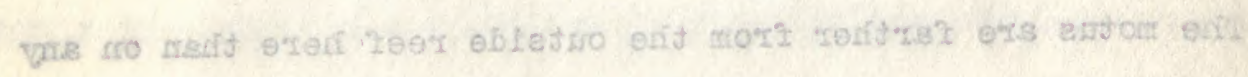

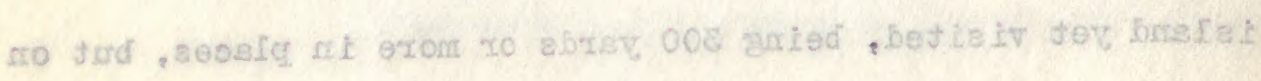


Toan a motu is farther in than that perhaps. Fairy terns had eggs and one nest was seen and photoed where the egg was laid on a rough coral rock a foot and a half off the ground. A couple of curlew and golden plover and tatlers seen.

Apri1 21

I went ashore for an hour in morn as a lot of boobies were seen lighting in mikymiky bushes and trees, but mejority rose and flew before we got to the beach. I got a couple of white ones out of the flock of fifty or so. A few feet below a booby nest was a fairy tern nest with egg visible from below when bird was on it. A very small dry dead branch twisted with hole in bottom, but after three of us had tried in vain to break limb below nest I shot the branch below the dead one on which egg was placed and the jar broke the large limb and shattered the nest limb into pieces.

Started about eight for islets scattered in lagoon and landed on severel, but found nothing till after lunch when we reached a small islet of 30 by 50 yards in extent and on this about 20 fresh nests of plotus booby were located. One had two eggs and three others one each. The nests were mostly of the grass growing over the top of island and a few small sticks sometimes. The birds left as we neared islet and sailed around out of gunshot, one occasionally flying over islet. Three small 


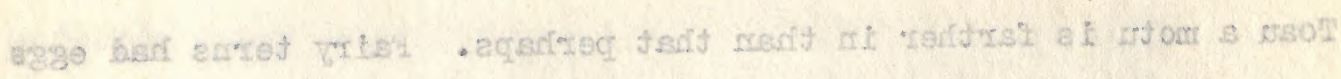

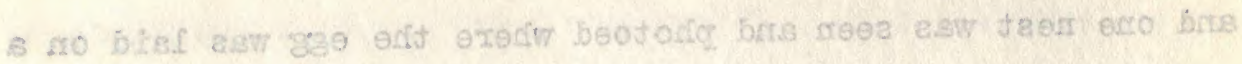

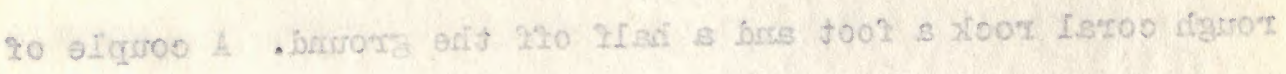

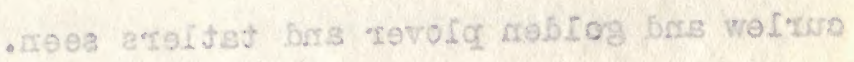

\section{$1 S \operatorname{Sirct} A$}

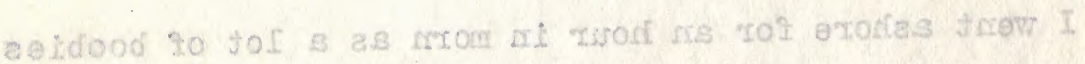

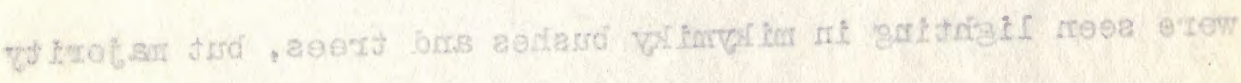

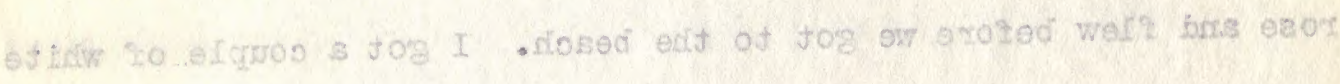

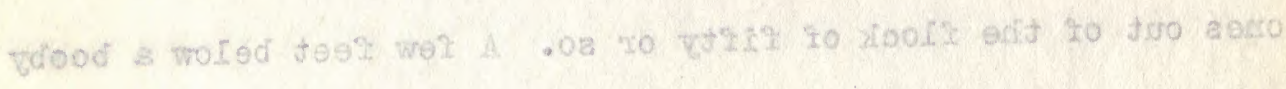

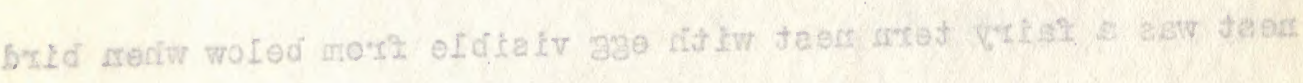

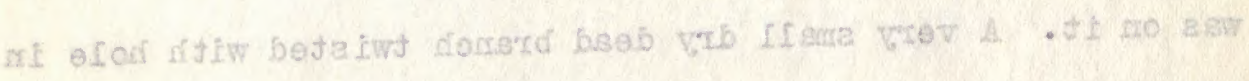

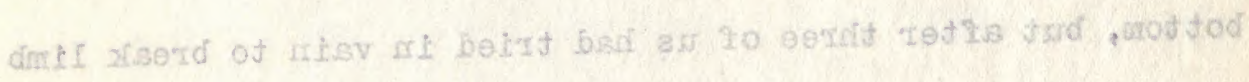

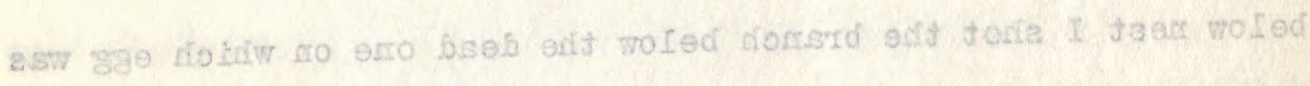

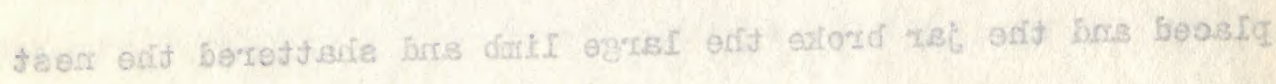
- neosla otrk dintl

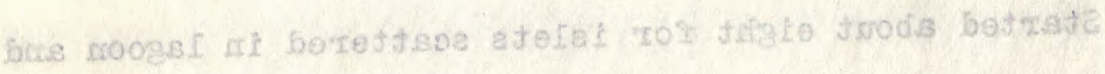

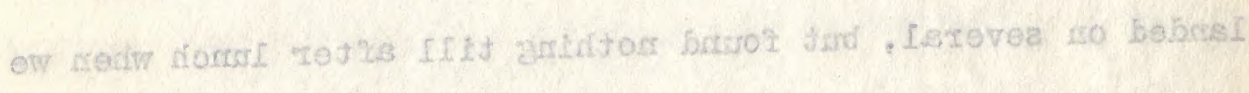

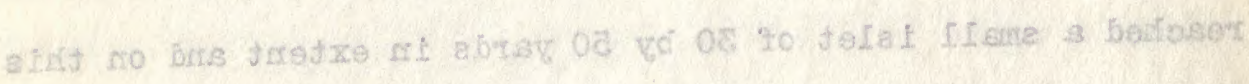

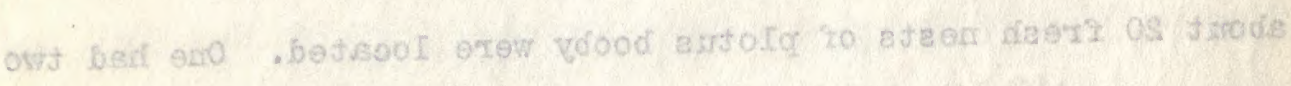

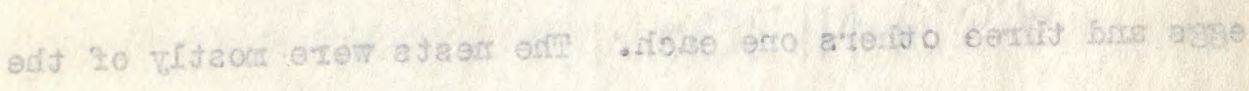

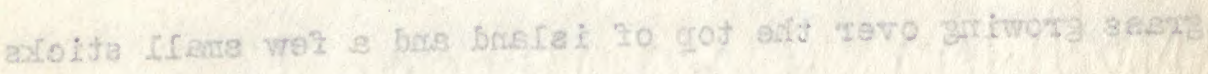

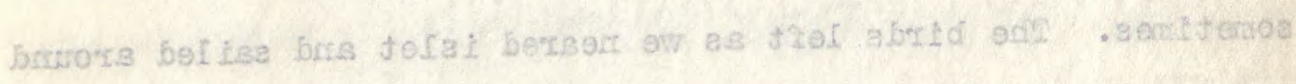

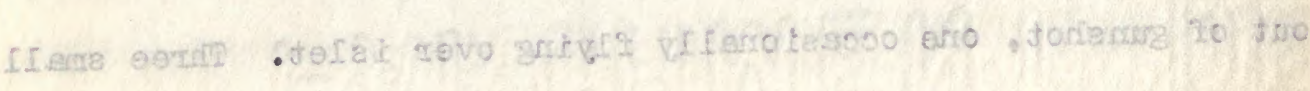


mikymiky bushes were growing on one side and a sandpiper was resting here. Collected and male with small organs. Passed close by other islets and saw nothing of interest except on one little beach of one four rectirostris terns sat with a few noddies and a half dozen lunatus terns. Motored across to north side again and anchored for over Sunday. I went ashore for couple of hours and got a dove and three warblers. Some very rough territory here, ragged coral boulders grown over with dense tangled bushes ten feet high in places. Coconuts are planted on lagoon shore in many places but very seldom do they reach across to the outside shore, though once in a while a row will run across, possibly bounding different tracts of land. A fine cement lighthouse has just been completed at the northern village on the outside of the vegetation and should be seen for ten miles. It is about thirty feet high and should be useful to the trading schooners that may be passing in the night from east to west along the coast.

\section{April 23}

Correia and Louie ashore for birds while I blow the booby and tern eggs taken last week. Rain for an hour this morn and collectors ashore get wet. Get but few birds, warblers mostly, tatler and couple of lesser noddies. 


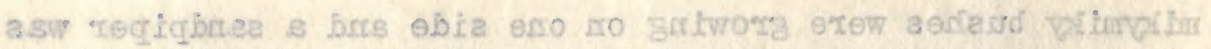

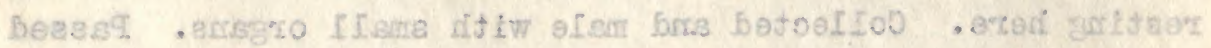
erro no tqeoxe jaeretal Lo goritor wase frre ajefal zonito vd eado

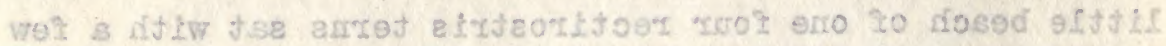

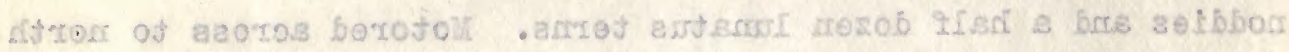

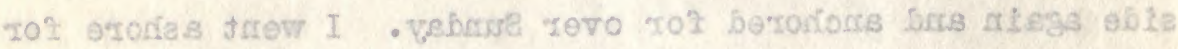

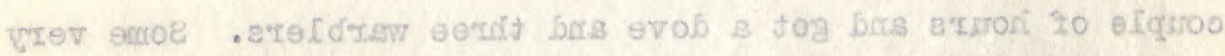

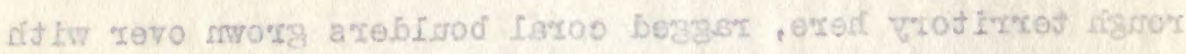

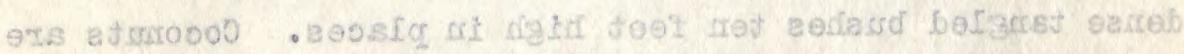

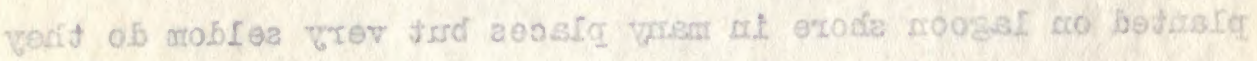

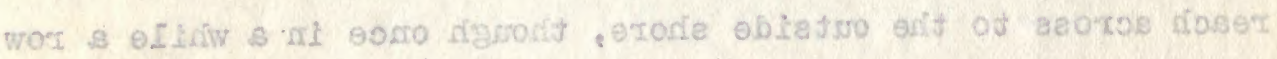

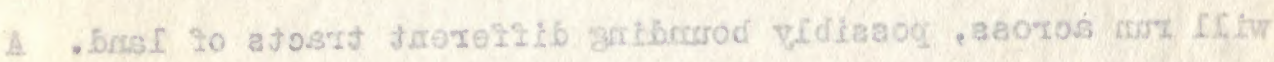

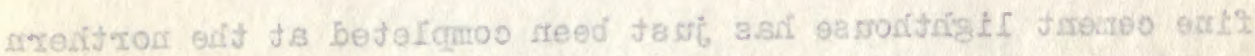

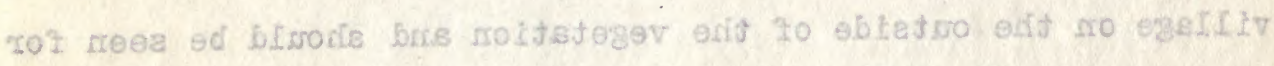

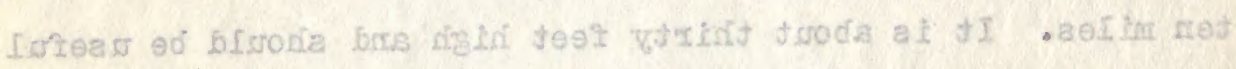

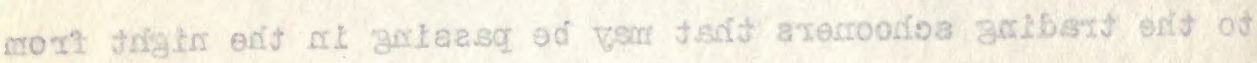
- tasoo ext' grols jeet of tase

\section{ES I Imo A}

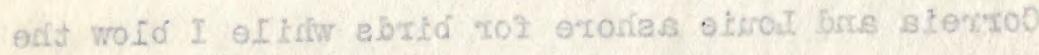

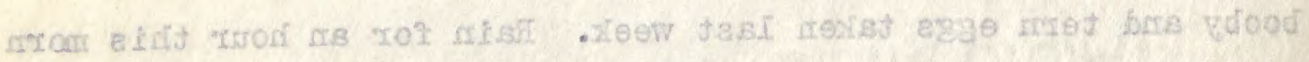

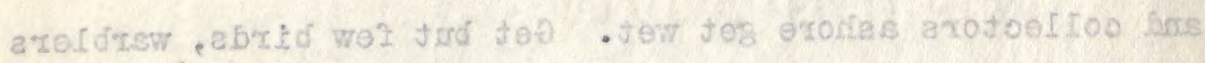

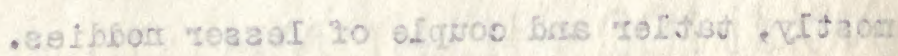




\section{April 24}

Moved along coast a ways yesterday P. M. and ashore this morn gave us a couple of doves and a couple of herons. In P. 1 . left for Faaite and arrived after couple of hours' sailing. Ashore and get permission to collect.

April 25

Moved up into the lagoon a few miles and ashore after ten o'clock. A flock of 20 or 30 rectirostris terns were resting on the rocky lagoon shore and others were fiying along and of ten fishing in the lagoon and in the stream of water that flowed a foot or more deep across the reef from ocean to lagoon. Several herons were seen and I, 3 at one place secured. Warblers were frequent but I found only a single dove that had just eaten one of the large berries that the eastern Tuamotu doves live on. This bird had also eaten a lot of the same food that the western Tuamotu doves live on. The dore was shot close by bushes of both sorts, which were growing close together. Qulte a fev nests of lesser noddies were seen in trees with young recently hatched.

At sunset a stream of losser noddies were seen flying along the trees to their nests from the west, it probably being easier flying over the land than the water as the wind was from the east. A few old noddy nests were seen in bushes and a couple 
AS IIIOA

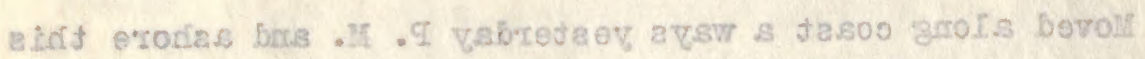

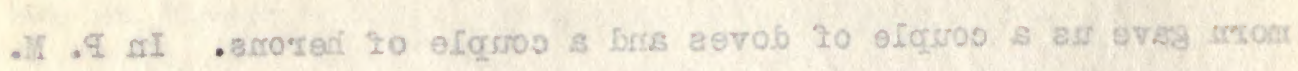

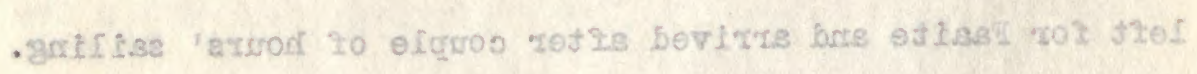
- tooflos of crotazimrog jog foris gradia

\section{as flrod}

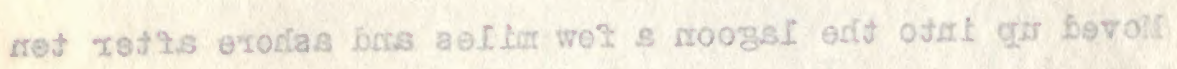

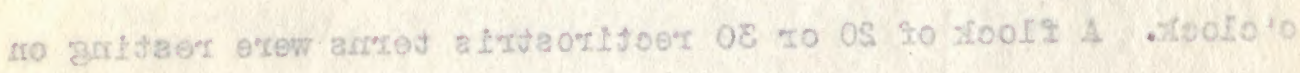

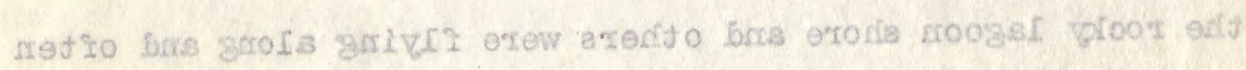

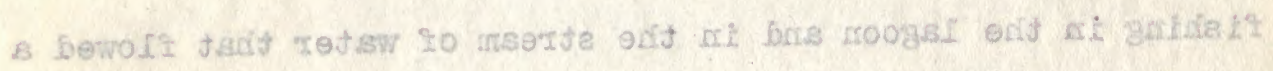

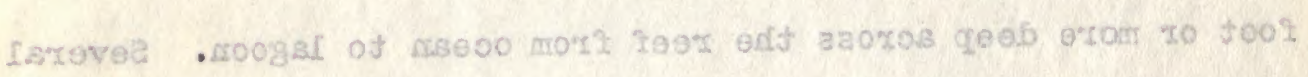

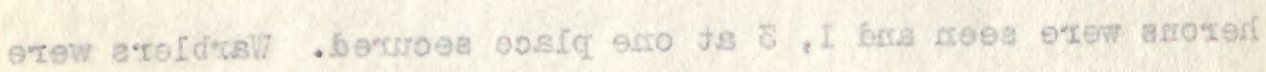

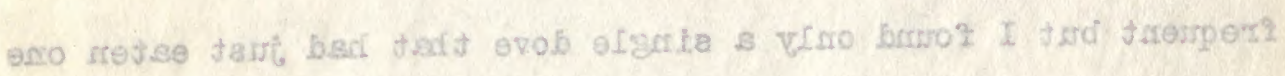

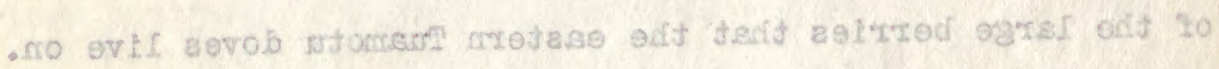

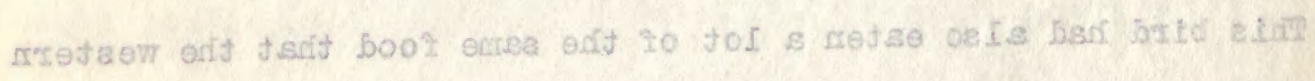

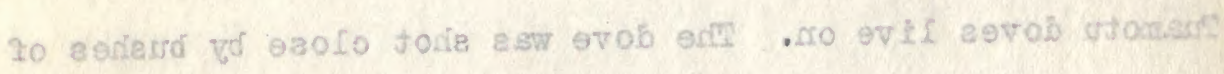

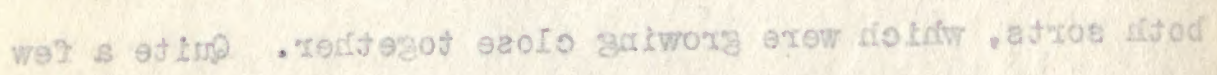

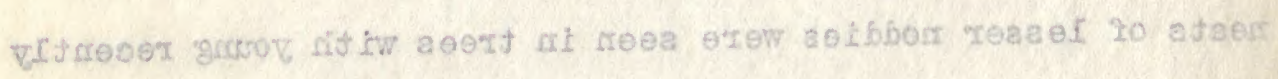
. Sorioted

gntrlt nosa exew a

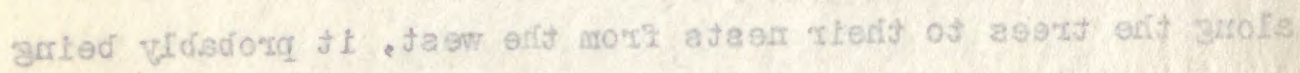

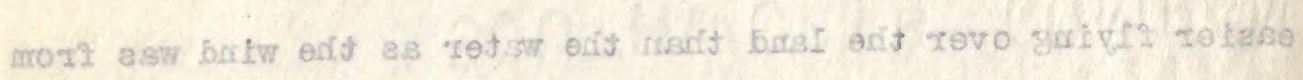

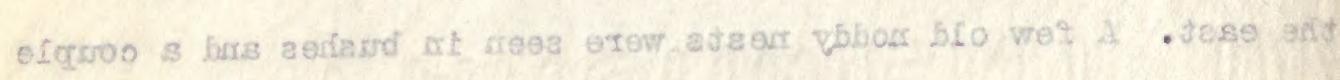


of warbler nests also were located in a pandanus joined by an old shred, one nest having fallen and the other having been built in its place. Reef in places here is only a foot above sea, for at slack water there is little flow and lagoon level is nearly that of ocean.

\section{April 26}

Moved a few miles to east, as natives said rail were there, and one sailor said he saw a couple; but the three of us with guns encountered none. I went along outer shore and found flocks of lesser noddies sitting in trees, some in leafy tohunu and a flock near them in a dead leafless tree, those in the dead tree all facing the brisk wind from the east that was blowing. Noddies were in a flock on the beach not far from the smaller birds. Correia found a young warbler unable to fly in a nest.

\section{April 27}

Ashore early for rail but none seen. Few warblers taken.

Apri1 28

Moved toward pass four miles and went ashore where natives said doves were common, but I found but one and Correia and Lorie saw none. We got a few warblers and Louie shot a cuckoo to pieces by mistake. 


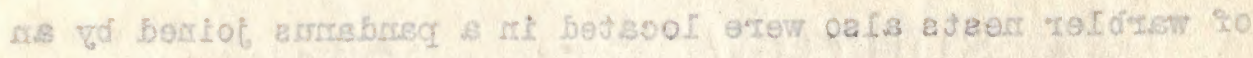

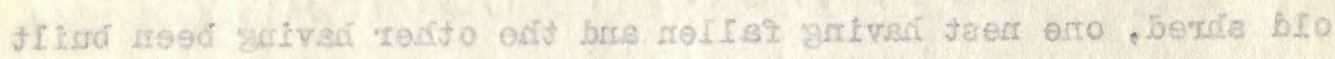

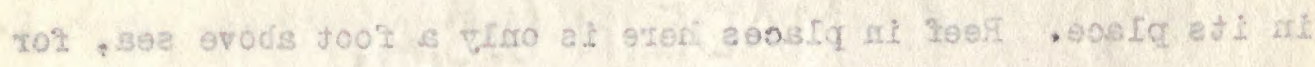

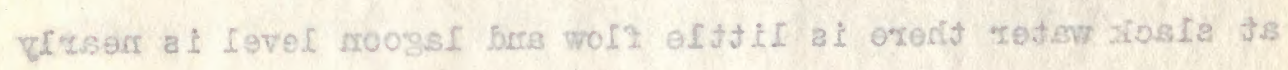
- mso00 to jecid

\section{as $\operatorname{cisc}^{3}$}

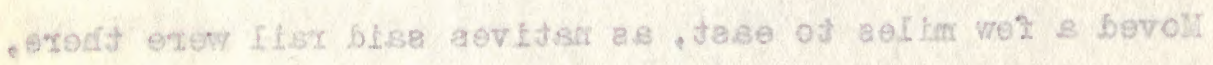

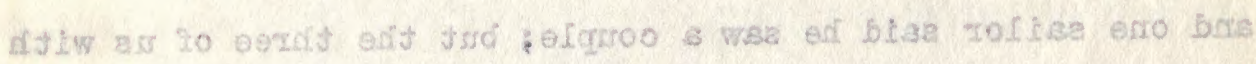

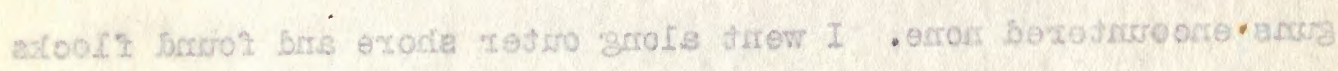

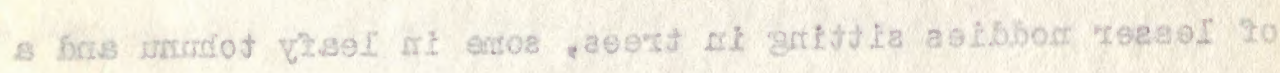

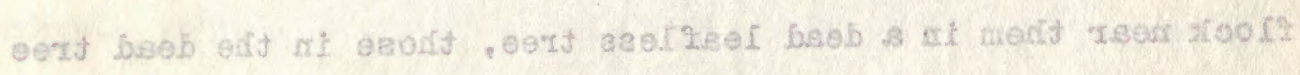

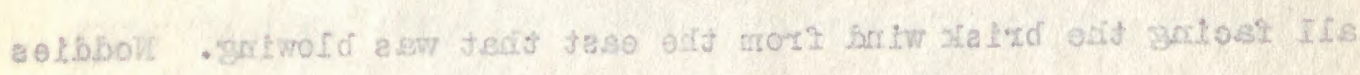

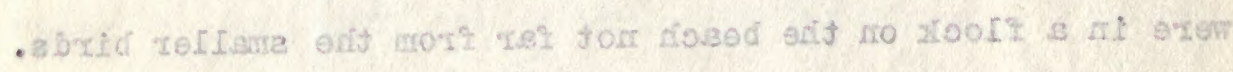

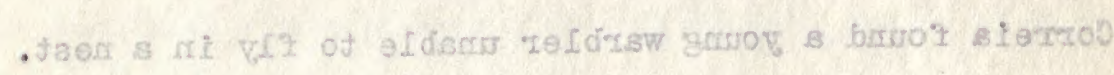

\section{TS IITSA}

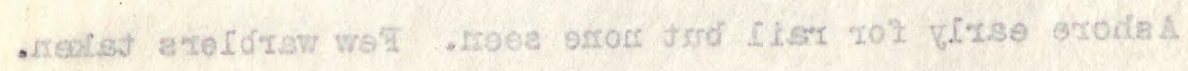

\section{$8 S \operatorname{Irg} A$}

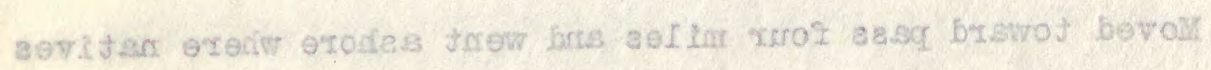

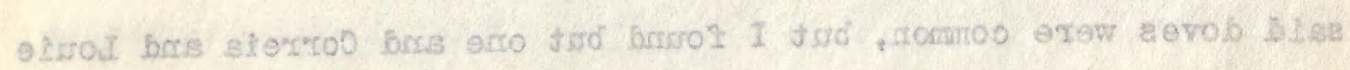

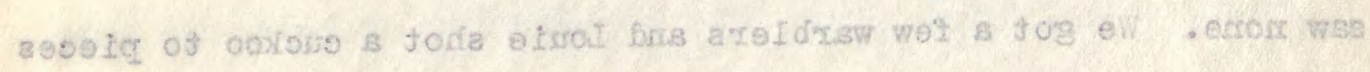
- exieje tro xd 
Apri1 29

Sunday. At eleven we went to sea around the south side of Faaite to stop at west end of Iahaena, as natives say the ground. doves occur there yet. Before the hurricane they said the birds were common on Faaite and I saw no old soll on the island, all of the land having been washed over. At the settlement close to the pass were washed out places over six feet de日p.

In eve a few lesser noddies were fishing three or four miles south of Faaite and these are likely tho birds we saw coming across the lagoon dally when anchored on the north side of the island close to where the birds roosted in flocks in the trees.

\section{April 30}

Tahanea ahead at $7: 30$ and a couple of plotus and a joung redfoot booby fly about us in fresh breeze.

\section{May 1}

Ashore at Tepoto and get several sandpipers and warblers. Redfoot boobies had young birds and eggs. Some nests were but four or five feot high. Half a dozen frigates flow away as I worked along. Few falry terns and noddies of both kinds were scarce. A cuckoo seen and doves were few, some young birds being taken lately from nests. The east side of island looks as though the top had been washed off into the lagoon, as it is shallow all along for a mile or so. 


\section{es inga}

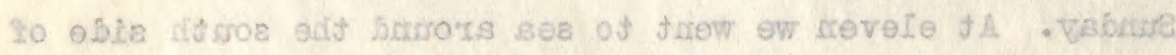

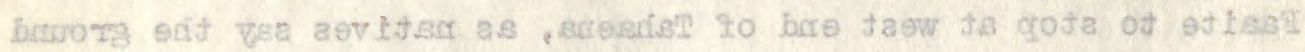

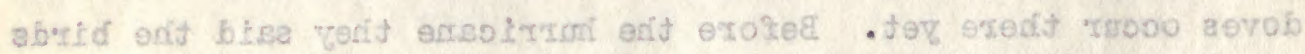

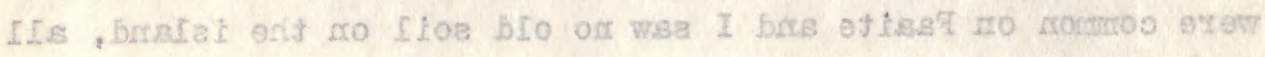

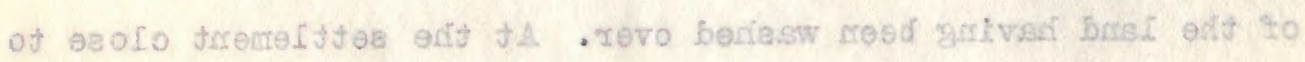

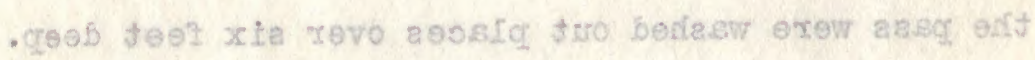

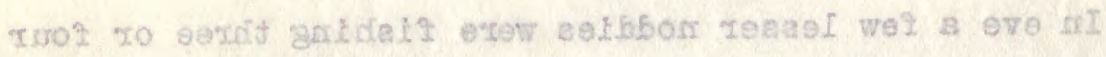

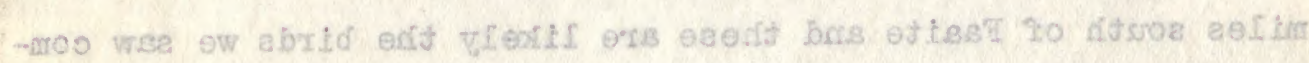

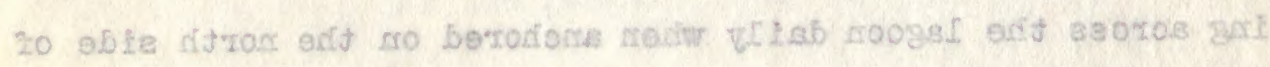

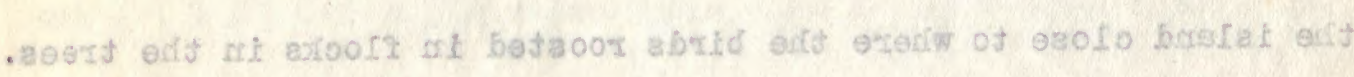

OE $\operatorname{Ltg} A$

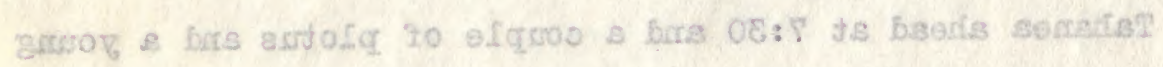

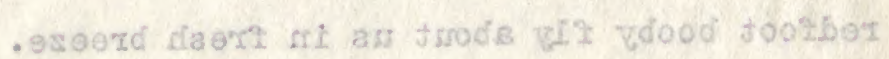

\section{I. $\mathrm{g}$ \&ill}

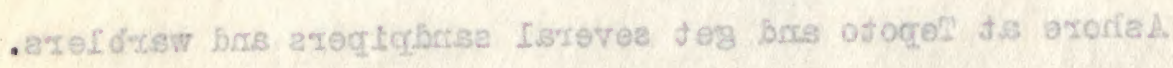

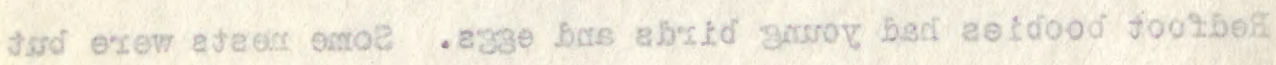

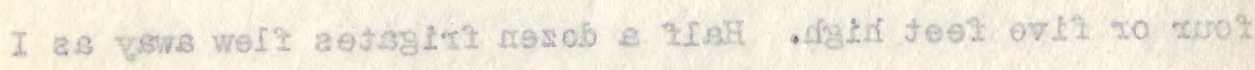

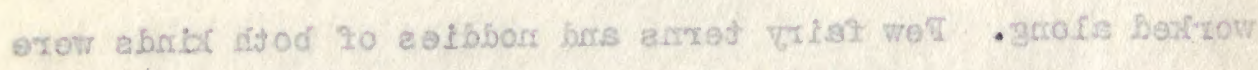

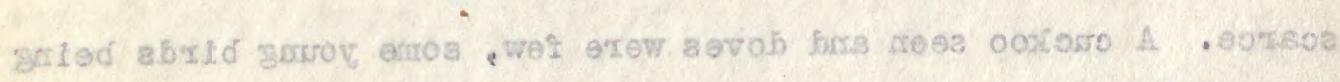

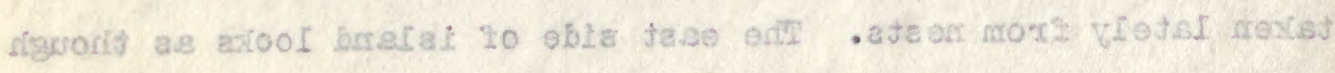

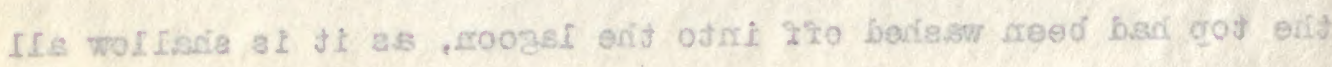


$\operatorname{Mag} 2$

Ashore at Tuanaike and Correia got a ground dove, and I saw a rail so will let Correia and wife spend a few days here looking for rail and doves while we work a couple of other islands near by. Hiti is only about five miles to east. In a mikymiky bush about 5 feet up I found a dove's nest and touched the wing of bird a couple of times. I then went on and returned later and put hand under her, took out egg shell and looked at joung bird just hatched. The old bird struck ny hand several times with wing as I lifted her (?) up. It was rainy and that perhaps kept her from leaving. The nest was on outside of mota with several bushes with feed close by.

\section{May 3}

Put Correia ashore and motored across to Hiti, as calm for last two days. Ashore in P. M. and I get a ground dove. Was striding rapidiy along lagoon shore, headed for landing place and saw bird run into bushes. I stopped and bird turned back and ran back toward me. I took out shell, put in auxiliary and shot bird as it was nearing to get better look. Fat when skinned. Found a colony of lesser frigates nesting on lagoon shore, some nests only a foot from ground. About ten in one mixymizy bush, all being in same kind. The birds are wilder than other species and I shoot a couple of immature plumaged 
S vailf

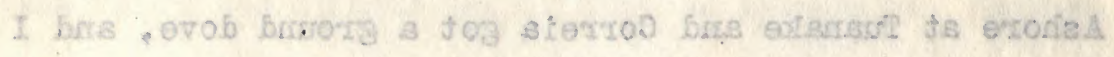

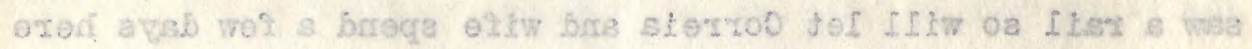

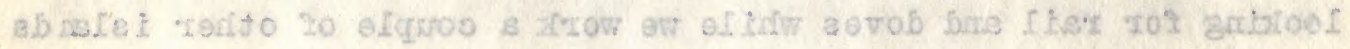

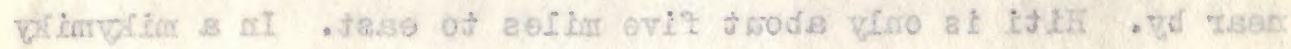

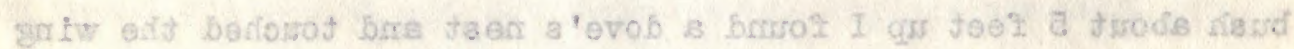

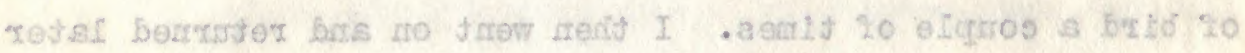

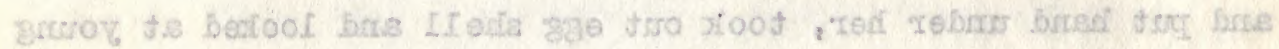

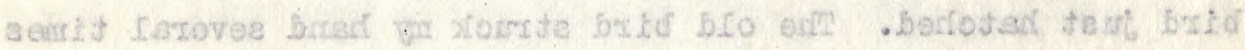

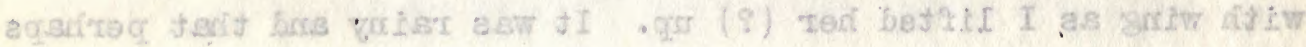

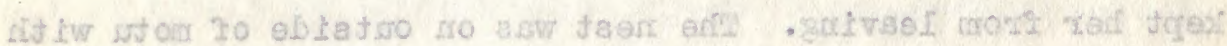

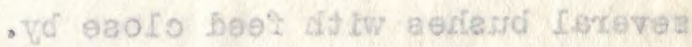

\section{B $\times, 3:$}

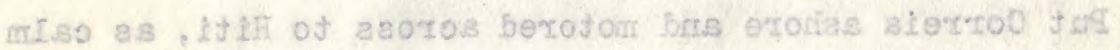

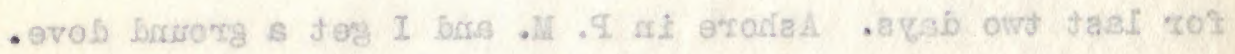

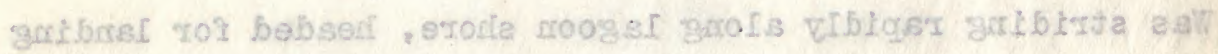

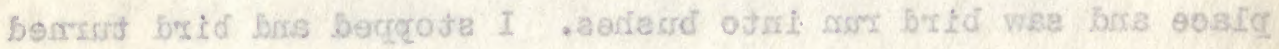

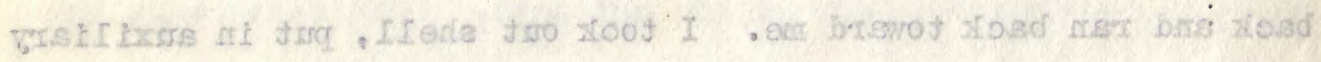

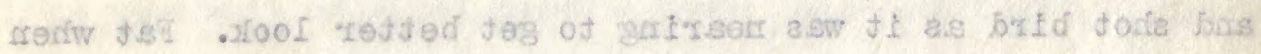

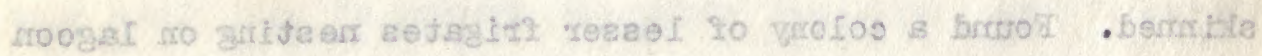

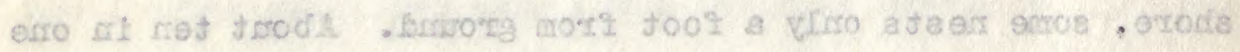

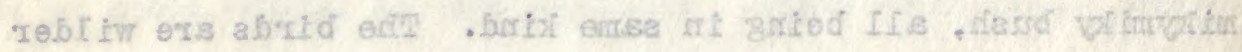

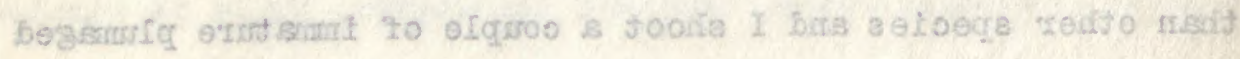


ones, seeing only a holf dozen in flock of a hundred that are not adult. It was so at Nengo Nengo and Hatutu Islands where I saw other colonies of this species. The frigate bird of large species has plenty of immature plumage about the colonv and it is so here. A colony of the large kind nesting in same trees with boobies half a mile along shore from the lesser frigates. Downy young frigate birds are seen in the green tree, while the lesser birds are sitting on fresh eggs and some nests are not laid in yet. Took a dozen redfoot boobies' eggs from a few tohunu trees. Three or four nests in some trees and many nests not finished yet in other trees. Toung birds of last season frequently roosting in trees which contain setting birds. Ten or so roosting birds in one tree sometimes, and once in a while a frigate bird is in same tree resting that boobies are using for roosting purposes. Walkingliong sandy beach of lagoon I flushed a dove from a fresh egg: in mikgmizy bush only three feet high. Whis nest was away from brush, and later I found another similar nost and wondered if possibly they nested so to escape rats which climb about in the bushes where vegetation is thick. These birds flushed before I reached them and both were fresh eggs they covered. Nests about twenty or so small twigs from the bush which they built in or the same kind, for I saw doves flying some distance with twigs in bills in other places. Roa bush is the Tahitian name for the plant that 


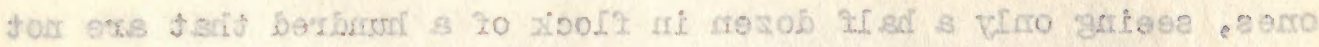

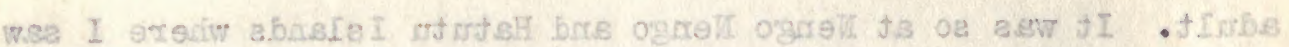

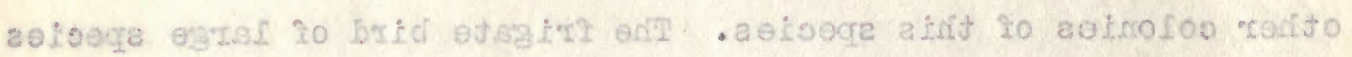

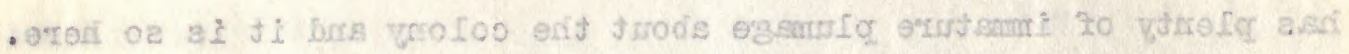

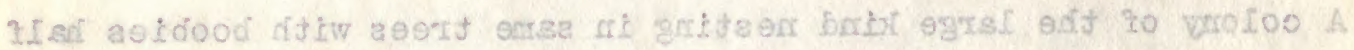

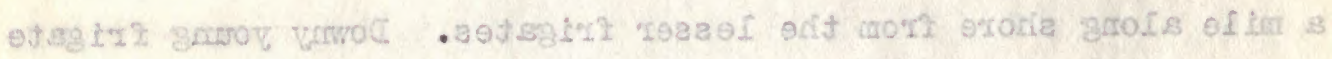

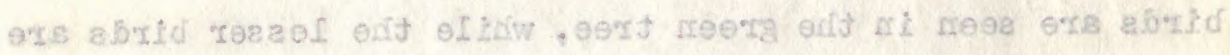

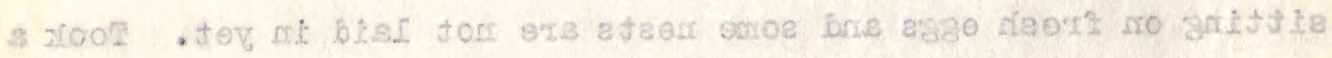

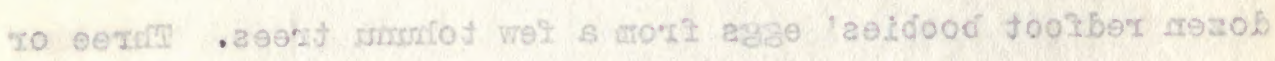

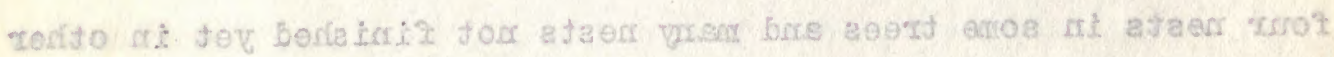

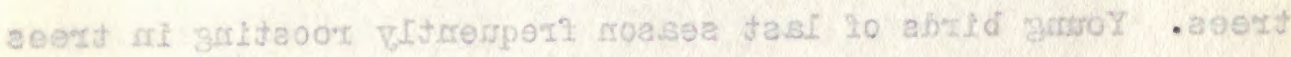

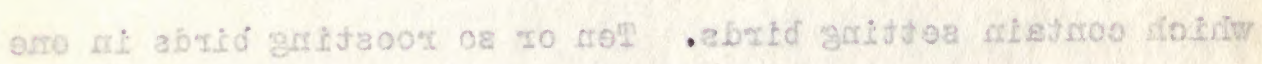

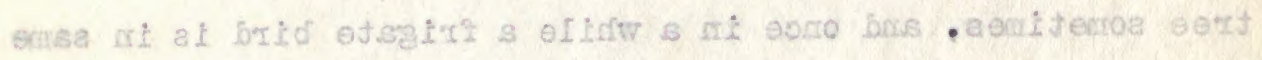

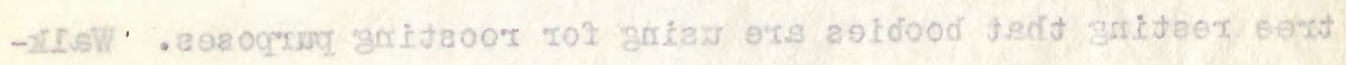

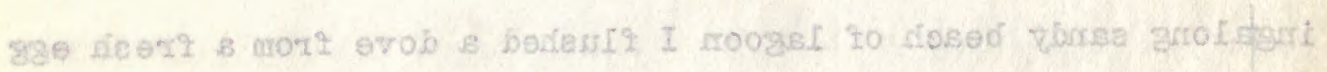

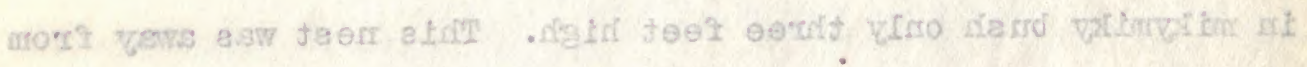

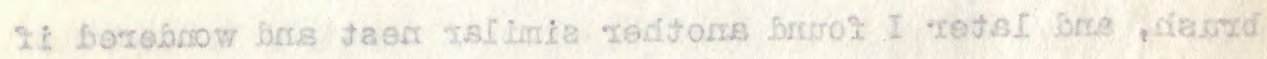

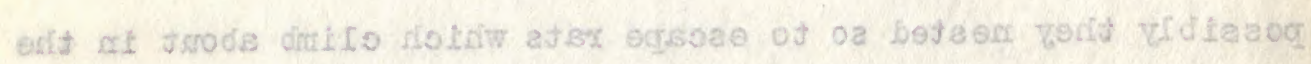

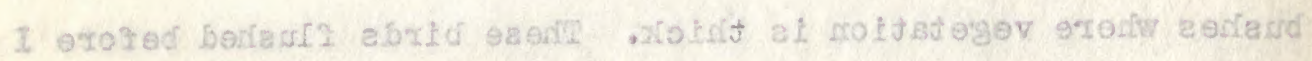

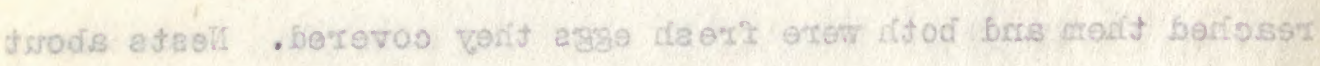

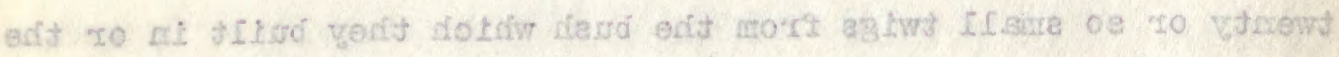

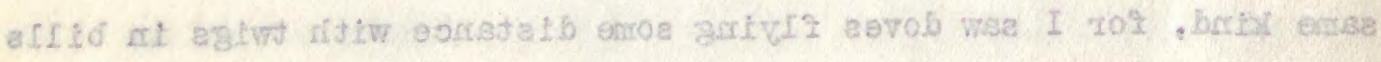

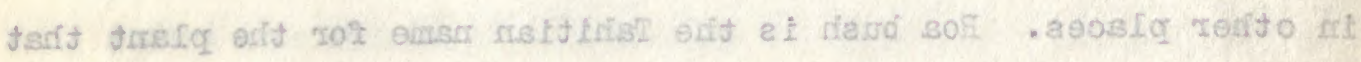


furmishes food for doves in west Tuamotus. Potea tree is one occupied by nesting frigates and boobies, and is used largely by lesser noddies in some islands for nesting. Lesser noddies and noddies are very scarce here and at last two islands.

\section{Niay 4}

Ashore with camera and Teri, leaving Louie with few birds to skin. While Teri sat under a tree waiting for me to photo lesser frigate a ground dove ran around him and he shot it, and later shot another near the lagoon shore. I took pictures of lesser frigates' and doves' nests and we returned with few birds at four P. M. Saw eight land crabs near where we ate lunch under birds" nests.

May 6

Sunday, and ran up fifteen miles to lay in lee of Nakemo Island and will run back at deylight tomorrow to Hiti.

\section{Nay $?$}

Wind light and make Tuanake, so pick up Correia who has gotten no more ground doves and has seen no rail, and take him to Hiti. Mrs. Correia found a sandpiper nest with two eggs in it on lagoon shore by side of a rock. I noted birds getting ready to nest, but none that seemed to have nests. Fut Correia off in 


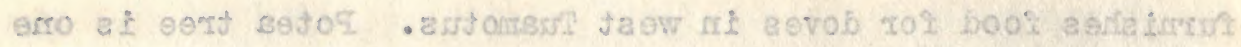

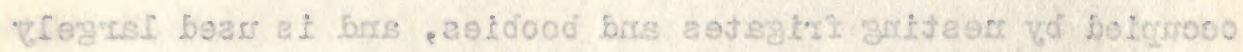

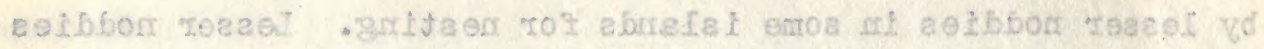

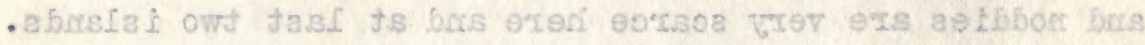

\section{A vell}

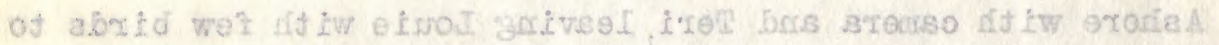

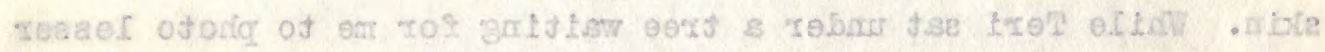

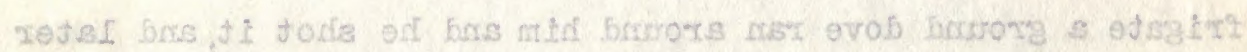

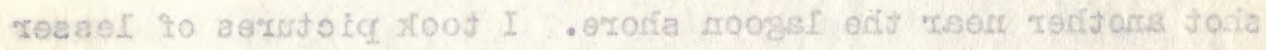

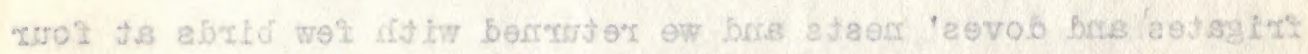

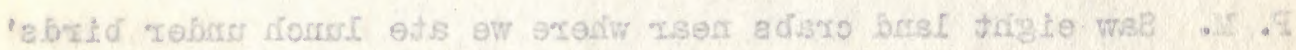

\section{a $\pi a^{2}$}

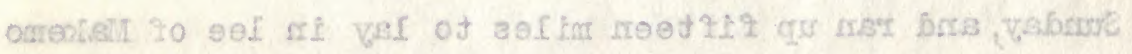

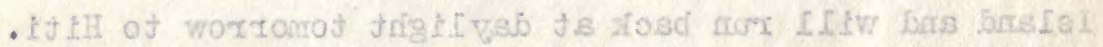

\section{Y. Visth}

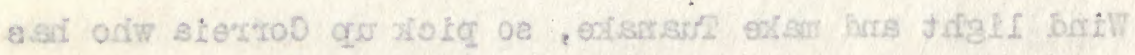

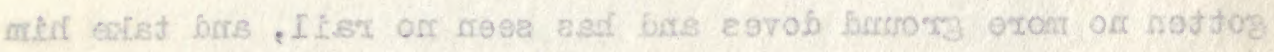

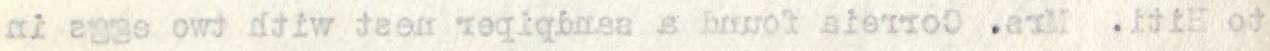

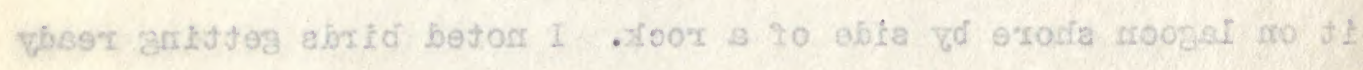

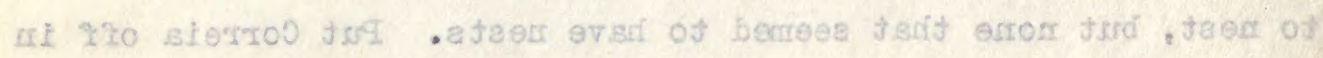


eve and expected to run down to Motutunga, but calm prevented, and we lay to off Hiti.

May 8

Louie ashore to get $a$ bunch of frigates and returned with ten and a couple of ground doves Mrs. Correia spotted, and one Louie got as well as a rail he captured. Ground doves are very fat and the male taken had several of the mulberry type of fruits that the green doves are partial to, as well as a lot of very small seeds in crop.

\section{May 9}

Ashore and find the lesser frigates have left the island after I took thirty or so eggs from them. Correis found three fresh eggs laid probably on sanday, and he also took a frigate egg; and I saw one in a tree where there were several young downy frigates, and redfooted boobies were nesting within a few feet of the young frigates. Whe frigate nests looked the same as the boobies' nests within a radius of ten feet. There are a lot of booby nests being built, as well as a few with eggs and some with very young birds. Many booby nests are built on old sites with a lot of old sticks and grano under the nest, but whether the booby destroys the old nest I could not determine, though every stick was new in many nests, but these were possibly new pairs 


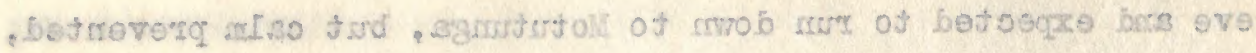
- ItiE 120 of UEI ow DEB

\section{VSII}

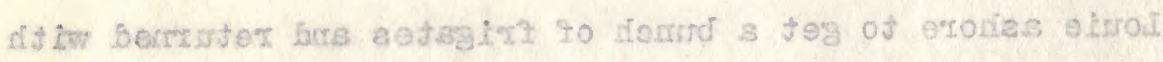

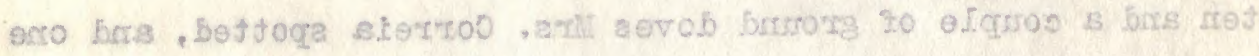

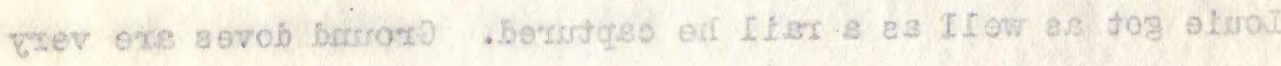

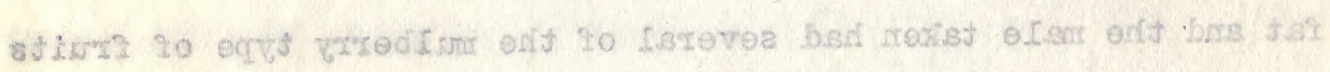

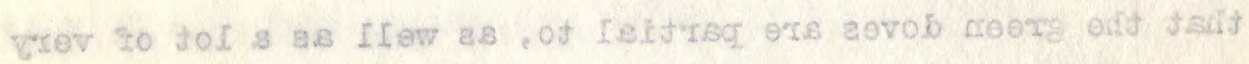
- qoto mi abova Lrenta

\section{e vell}

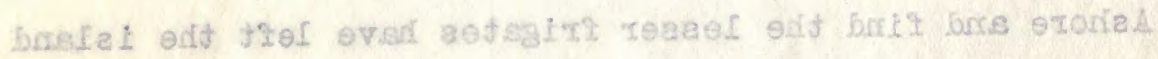

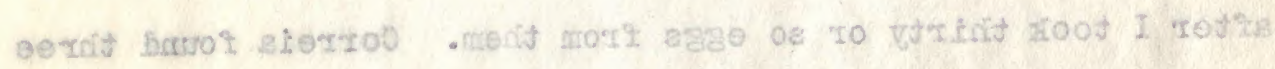

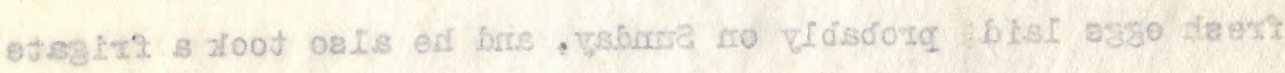

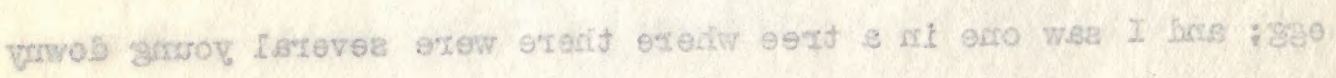

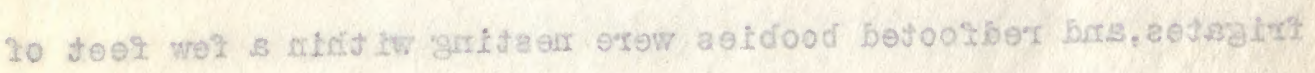

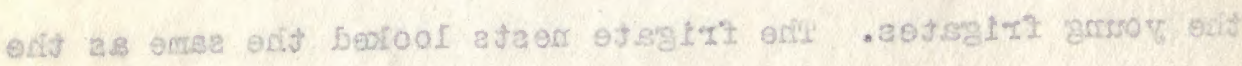

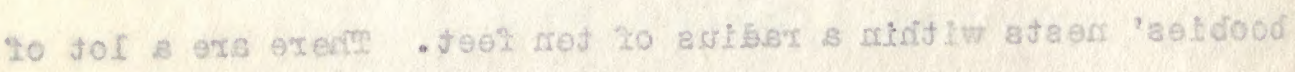

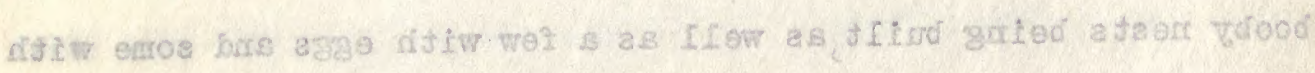

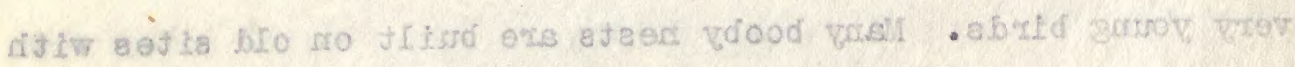

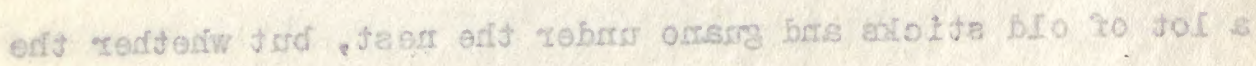

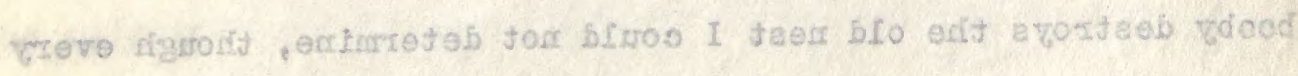

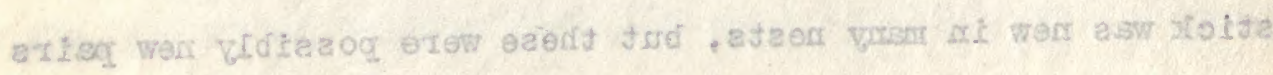


of birds. The lesser frigates' nests were newly made also from their appearance. Saw one booby standing in a now nest and presently the mate came with a stick and with a lot of talk placed it and then went off while the standing bird stayed. All make a fair warning" when ready to light. "Kick, kick, kick, kick" is one usual call, as "Kuk, kuk, kak" is of the frigate.

Loule found a dove's nost along the beach in mikgmiky bush two feet off the ground very similar in position to the two I found. It is possible they nest in the open to escape the rats which run over the bushes, as do the large mice, a couple of which we got here. Coconut crabs are common, and I saw eight where I ate dinner one day. One walked off with a salmon tin that had been emptied. The south side of this island, as many others, is barren reef, mach of it covered with water at all stages of the tide. Iight south wind induces us to leave Motutunge Island and hoad for Takume Island to the north.

May 10

To the north of Taenga Island at daylight, but wind is failing and tack to make hoadway to destination if chance of arriving tomorrow. Got a series of different plumaged redfoot boobies and string of frigates from Hitl, as well as three or four lesser frigates in plumage not quite adult. Have seen in two hundred or more lesser frigates not more than a dozen that were elying in 


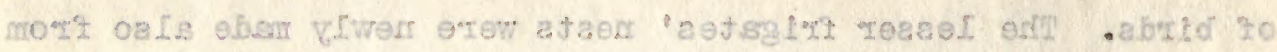

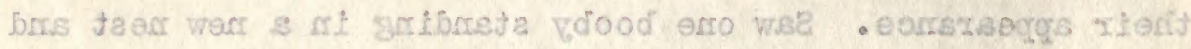

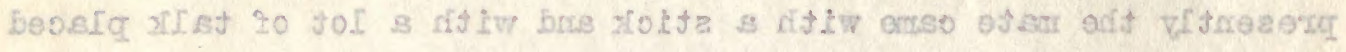

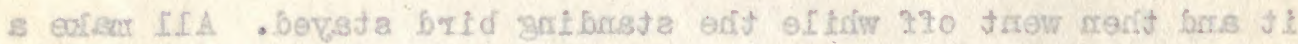

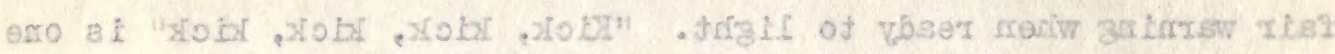

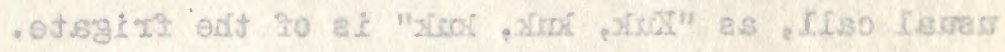

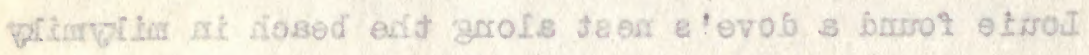

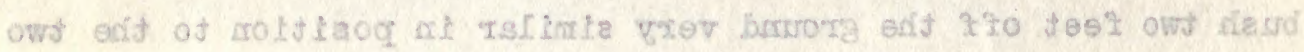

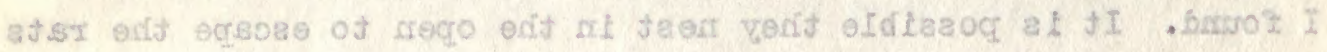

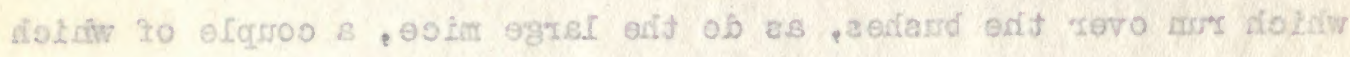

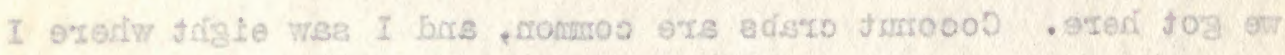

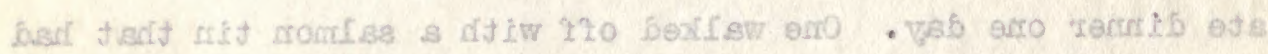

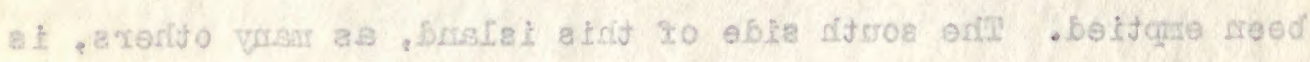

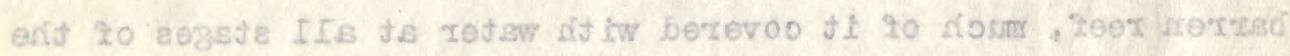

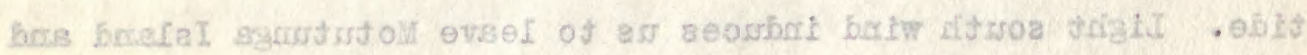

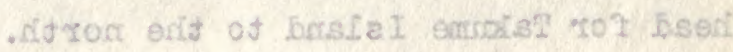

\section{of veli}

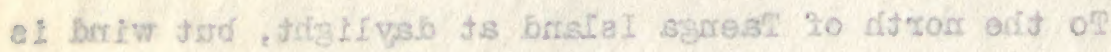

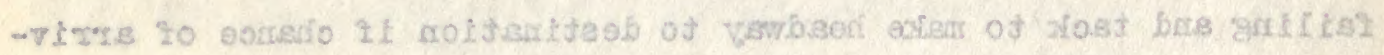

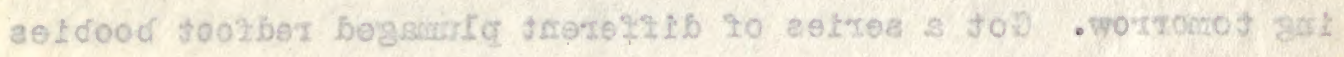

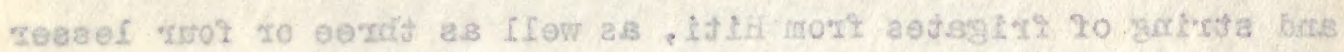

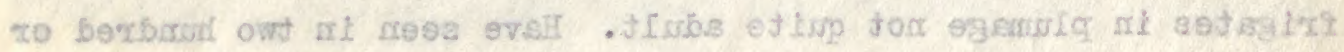

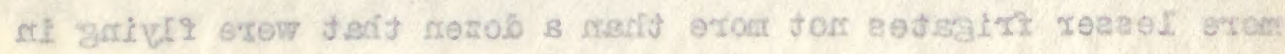


immature plumage. Of erigates there are plenty of immature plumage about the nesting colonies. Saw last night at sumset several sooty shearwaters flying to the westward within three or four miles of Makemo and one that I thought was an aestrelata with grayish underparts, smaller than sooties. It was in this region that we saw a few sooties going in the same direction when going into Papeete last March. They do not come near the ship, and appeared to pay no attention to a flock of fishing boobies that were far asterm of us. Though boobies were headed toward the fishing birds, possibly the boobies were homeward bound to Hiti twelve miles away. Squally weather and progress slow, though only fifty miles to go.

\section{May 11}

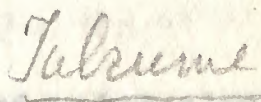

Wind NE today and use motor to reach island by eleven when we go ashore. Find deserted village at north end, where a motu about a mile long harbored a few warblers. Calling for warblers I got a cuckoo that flew near me to investigate. Also found a dozen lesser noddies nesting in tall treos, the nosts over forty feet up. Got three herons of severel seen, and sew several yellowbill terns fishing along lagoon shore. Three of us got six herons and skinned out the twenty birds in eve.

\section{Nay 12}

Ashore at village and motu atmile long at south end 


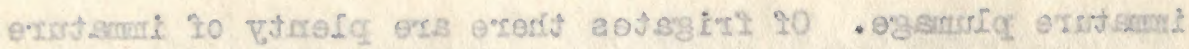

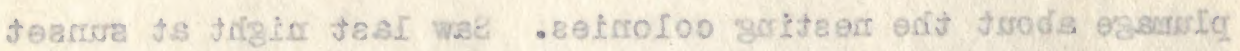

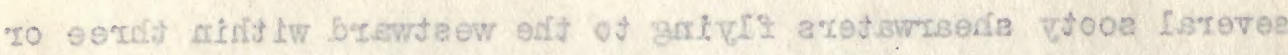

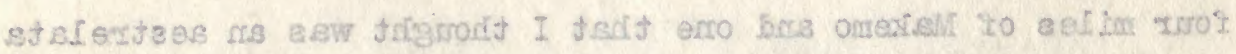

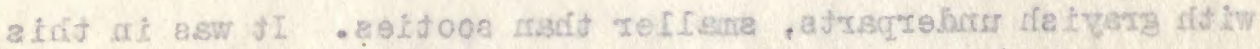

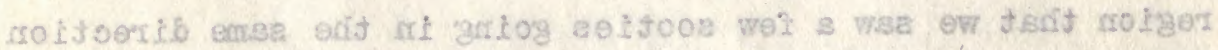

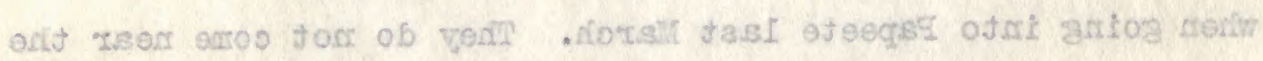

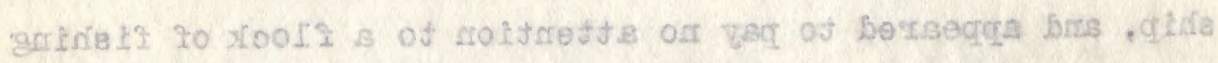

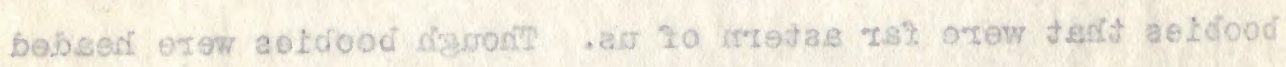

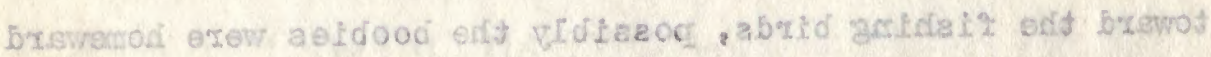

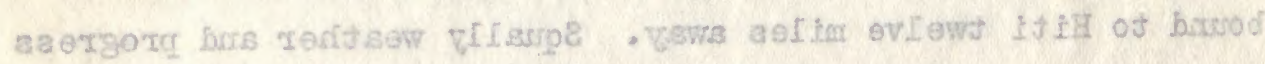

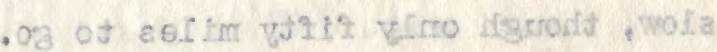

\section{Rath}

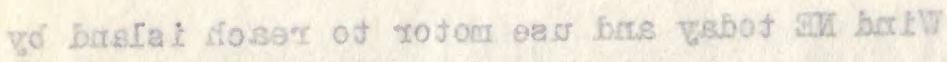

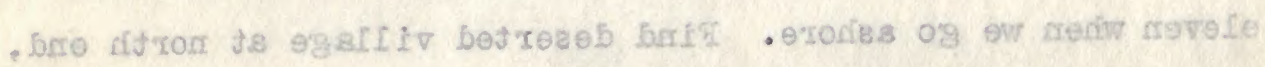

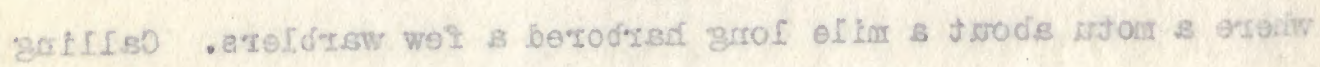

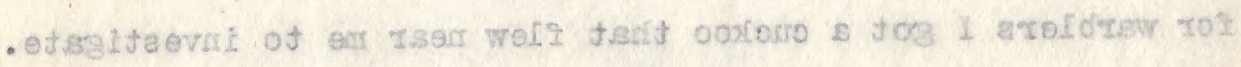

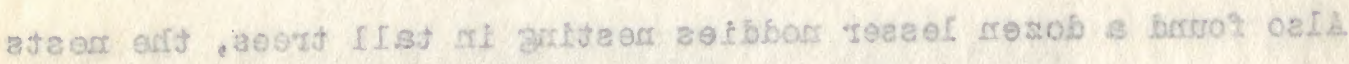

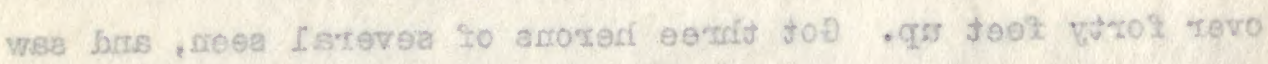

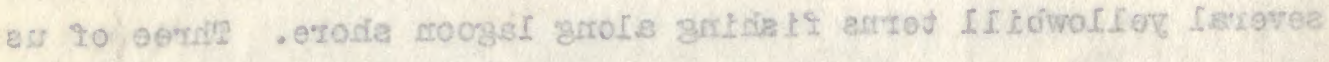

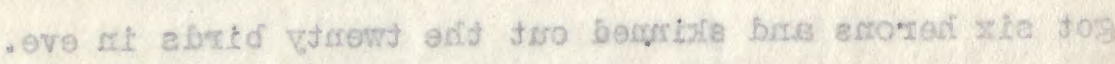

\section{SI. vall}

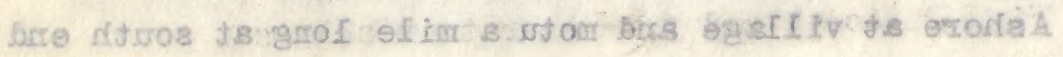


island and find not a warbler,--one bird for the three of us. Aboard at eleven and motor across to Rairoa, ten miles to south. Why no warblers at south end palaume pazzling, as it is good country for them. Spiders were thicier at north end of island than anywhere else noted. Webs everywhere but only two or three species seemingly.

Talame has a cinema house with nobody living within five miles, used for diving season only. The west side of Rairoa is made up of little motus of few acres with few coconuts and from those down to motus with bushes and single cocomut trees. Boulders are seen on reef as on some other islands.

\section{May 13}

Ashore in P. M. and walk a couple of miles along through the brush and find no warblers or doves. Get three young noddy terns sitting on a dead tree on outer edge of grove and shoot a fat carlew standing on top of a dead coconut stump forty feet high. See also a couple of herons, getting one.

$$
\text { Nay } 14
$$

Sunday and get a few pictures.

\section{May 16}

Go across to east side. This island swept by 1906 


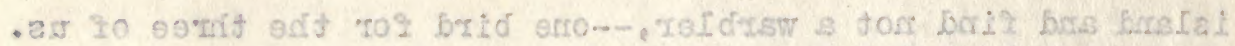

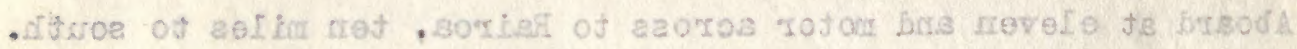

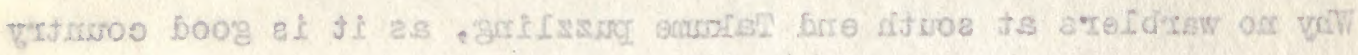

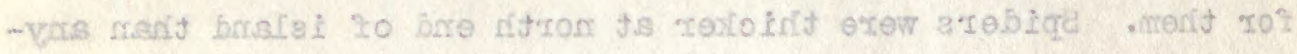

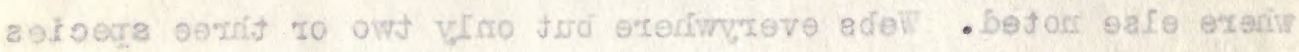
- vfgaimpee

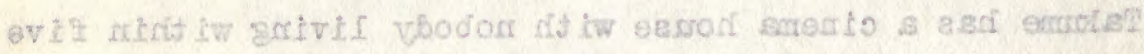

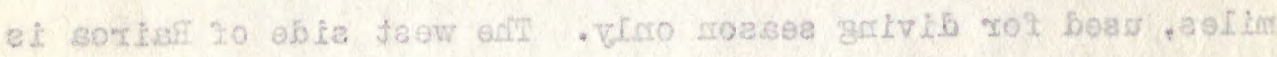

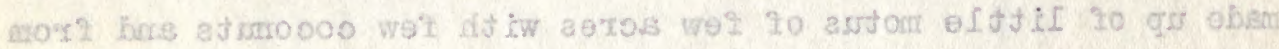

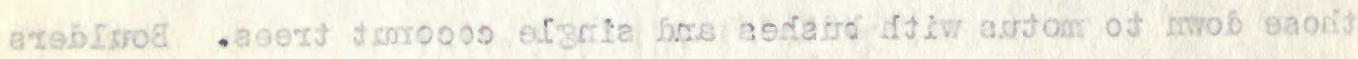

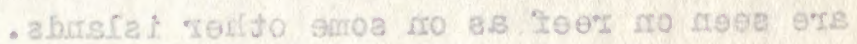

\section{EI Fell}

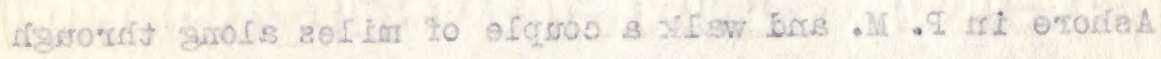

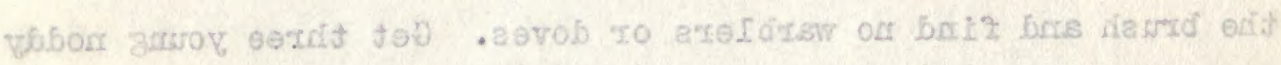

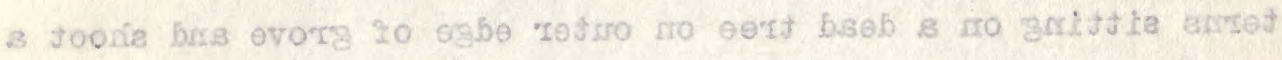

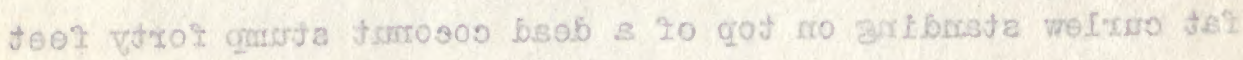

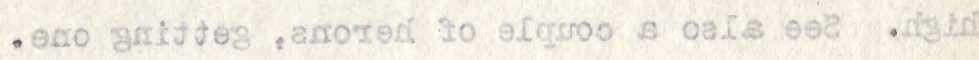

\section{A. vill}

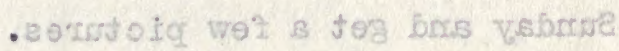

$$
\text { af KSill }
$$

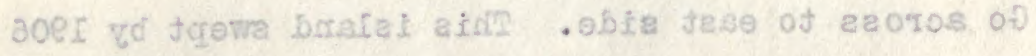


hurricane accounts for no land birds here, but expect to find them on north end, if not on motus on east side. Get a few herons but see no landbirds. Golden plover and tatlers are migrating today with a strong northeast wind. A couple of curlew also seen. Wreck of old steamer on east side of the motu we visit. Move down to north end of lagoon in afternoon and a singile plotus booby came around the vessel and is shot.

\section{Nay 17}

Ashore at motu on north end which extends a mile or so, but no warblers are found. Few herons and a big flock of noddy terns are noted, the terns in a close flock resting by a pond near the outer shore. Fairy terns are common, and nests of lesser noddy terms are seen in some low trees. Iouie takes motorboet and visits small motus but gets nothing but a lunatus term of three seen and notes young noddy terns in a few nests. We go out of lagoon and lay off the southwest end for the night. I go ashore for a couple of hours and shoot a tatler, the other bird being seen being a yellowbill tern. Two birds seen in two hours ashore.

\section{May 16}

Ashore at southwest end and I go for three miles or more along wooded part and find no warblers or doves. This entire island seems to have been swept clean by the 1906 hurrioane and land birds perished from lack of food perhaps, if some lived through 


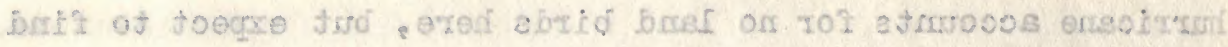

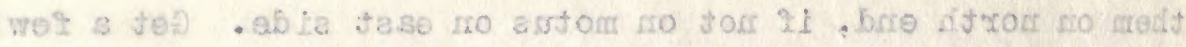

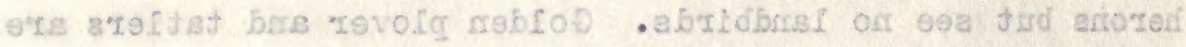

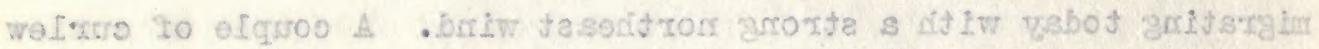

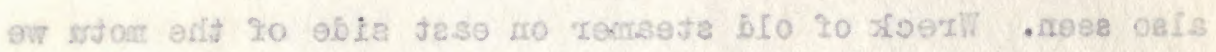

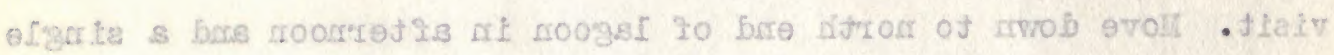
- jorie al brrs fealav orit burwors emso zóood entofor

\section{SI ViBll}

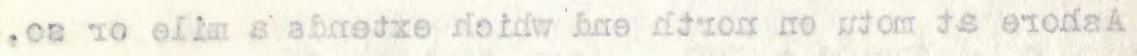

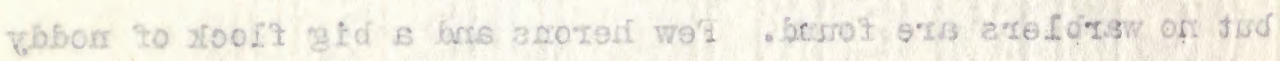

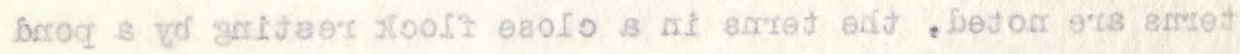

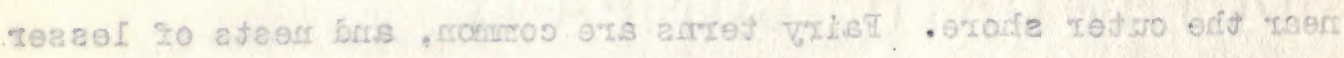

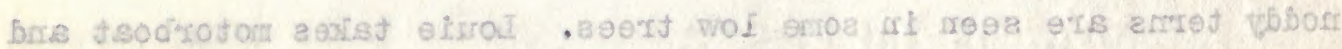

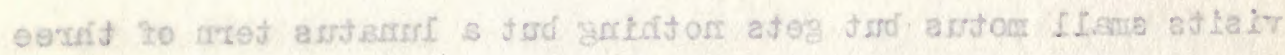

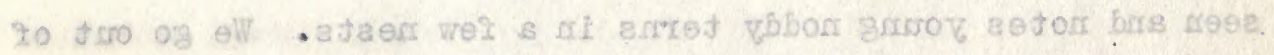

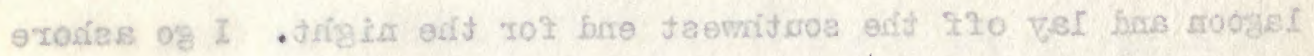

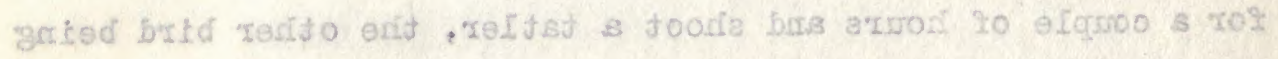

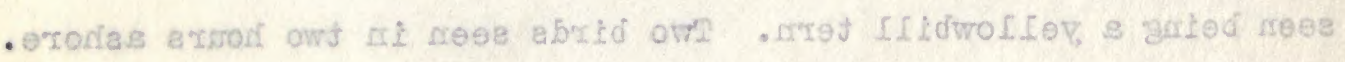

\section{OI Vell}

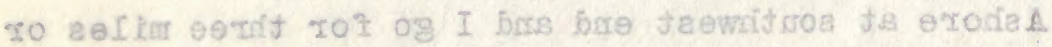

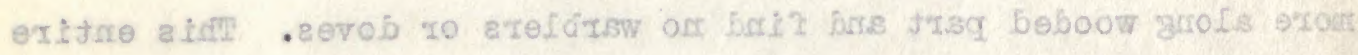

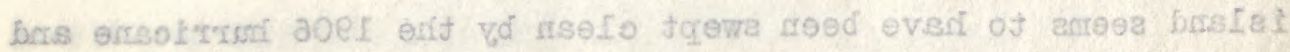

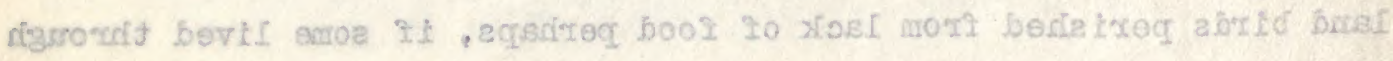


it. The berries eaten by the doves are thick on the scattering bushes noted and many new bushes just starting to grow. Half a dozen young noddies seen roosting in dead trees and scattering fairy and yellowbill torns as well as five herons along the reef. Most of them were fishing on the outer edge of the reef, which is nearly out of the water at low tide. I followed one for over a mile and finally it joined another, when they both flew along the shore and lit far ahead of me. A half hour later I managed to get near them and shot both. llale and female, and they were under a tree in which an old nest was seen. Both were white. Leave at nidnight for paenga.

\section{May 17}

Ashore at west end of Taenga on largest motu of the island, and between us got about twenty warblers and four doves. Cover about five miles of best ground on island and natives say that this is best place for birds. Correia found a warbler's nest, but though we waited half hour at nest no bird showed up. Birds did little singing and most were secured by calling. Correia's nest had one egg. Scattering noddy and fairy terms noted and a heron taken.

\section{May 18}

Went to mota on which village if located, bat no birds seen there as it is small. There are fifty or less people, though 


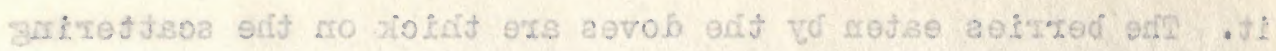

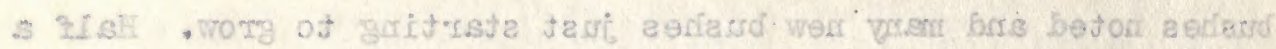

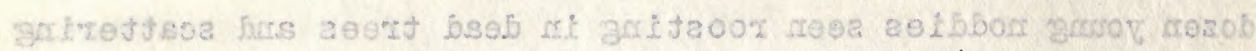

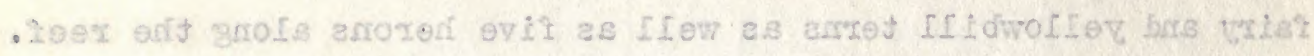

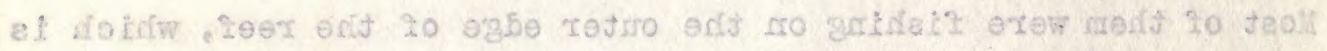

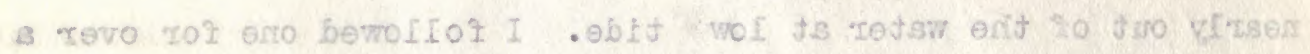

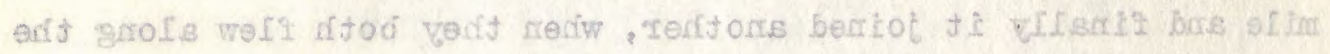

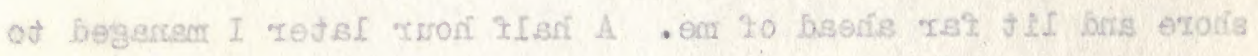

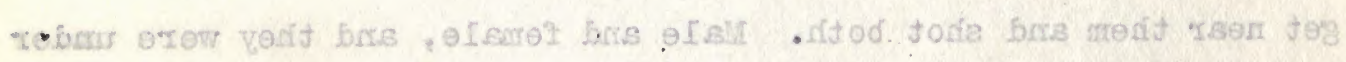

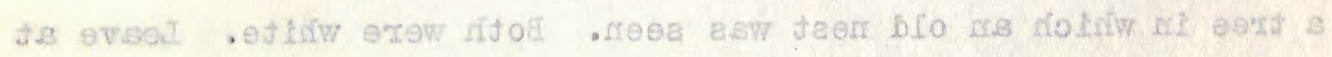
- agcroate rot jelglabirs

\section{II toith}

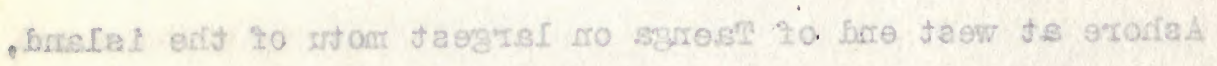

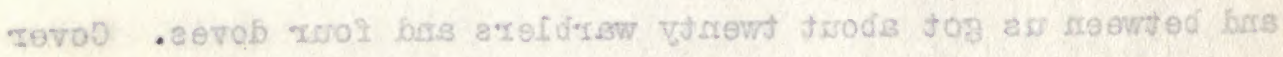

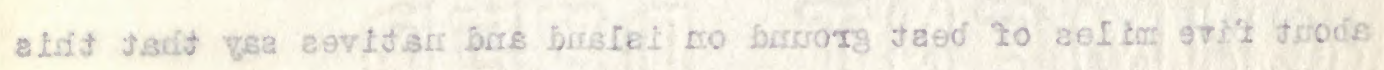

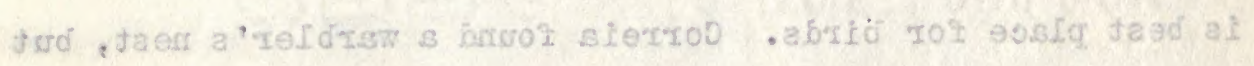

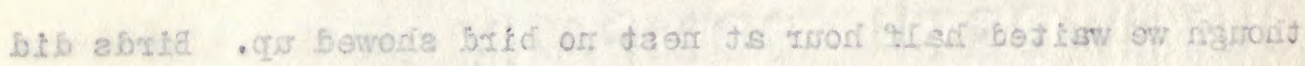

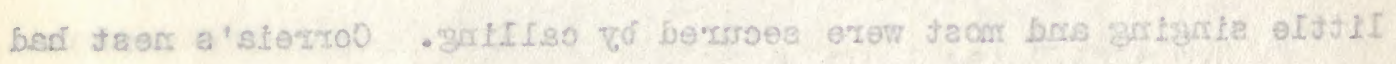

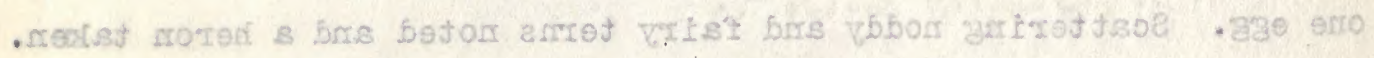

\section{I. TSBIf}

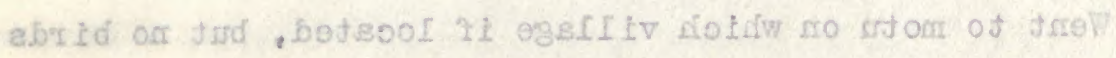

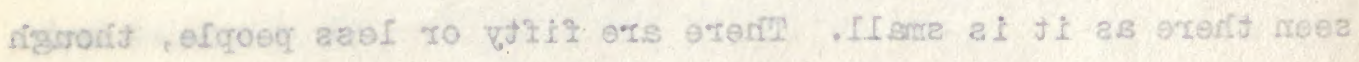


village has nice streets lined with blocks of coral shells, or rather blocks of coral in which many small shells are imbedded, the sholls being the principal part of some blocks. In $P$. $M$. sail across to Makemo, but light wind keeps us from reaching pass till after dark and lay off.

\section{May 19}

I go three miles or more to west. of village and see no warblers. Hear a cuckoo and get a heron for my day's walk, while Correia and Louie go to east of pass a couple of miles and find twenty warblers. Rail are reported to be in the section they visited and we will try again Monday to find one or more.

\section{May 21}

I go to east side of pass whore others found warblers, getting twenty by eleven. Correia takes motorboat and goes to rail section but sees none. Return at noon and we move down to west ten miles inside lagoon.

\section{May 22}

Ashore and find two or three doves and a few warblers. Plenty of food for doves but very few present. I get a cuckoo that flew past me and lit in sight for long shot. Couple of boobies flew over me from south, probably coming from Hiti, as 


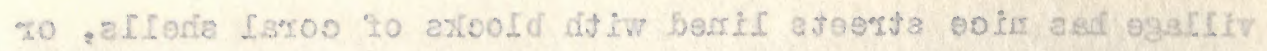

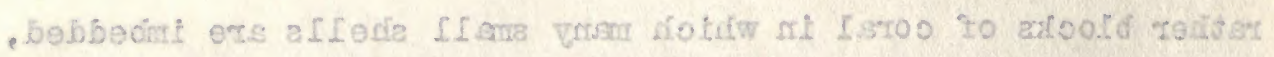

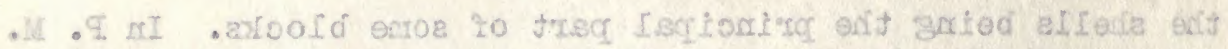

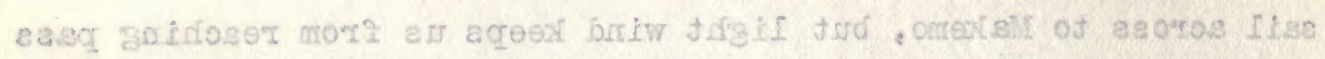

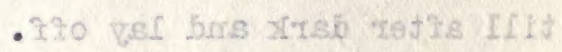

\section{ef vell}

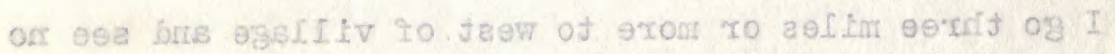

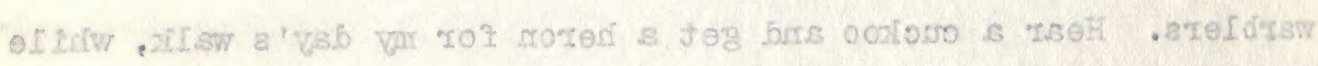

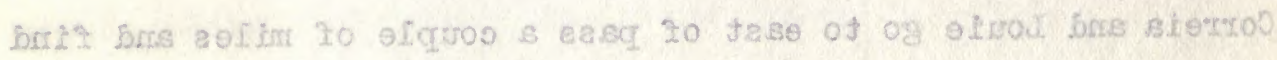

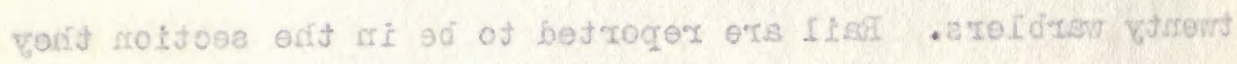

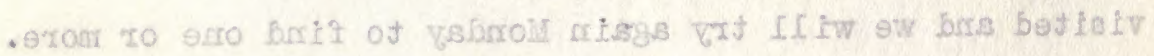

\section{IS reali}

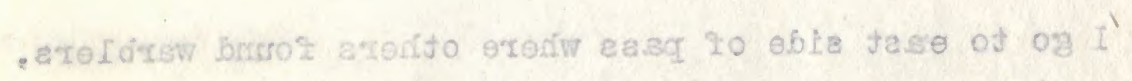

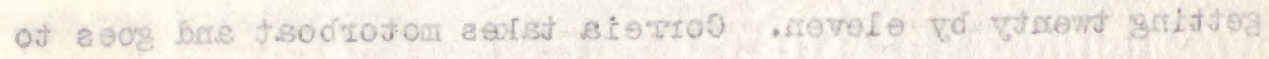

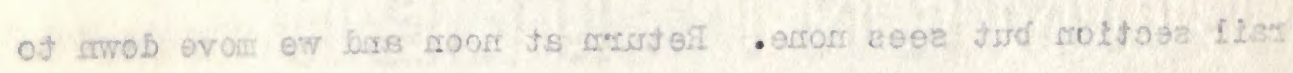
- noogsi objant aolim rou jagm

SS veV

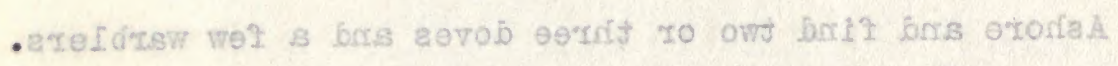

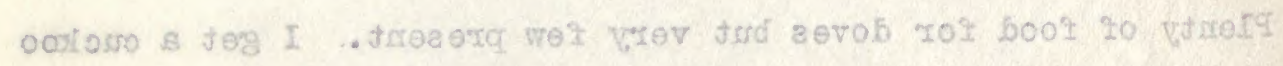

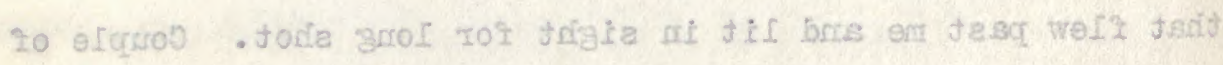

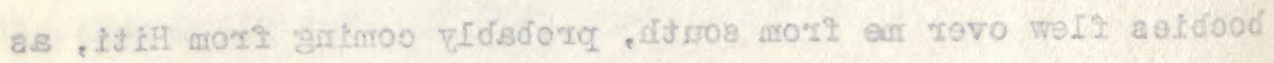


south side of this island is under, not a motu being visible

except small sand spits. Couple of lunatus terns fishing with few noddies in eve.

\section{Hiay 23}

Find half a dozen doves in morn and at noon move outside north pass and go ashore on westernmost motu south of the pass. Parakeets were reported here on Ilakemo, but natives say they see none. Rail probably occur, but it takes a lot of time to get them usually, and there are few other birds to work on when the rail are not found. Pen years or more ago ground doves were here, but cats or hurricanes have exterminated them.

\section{May 24}

Reached Katiu at noon and ashore to find birds very scarce. Correia went to east of pass and found no land birds, and Louie and I went to west and found a couple of doves and four warblers. Half a dozen herons were taken and a cuckoo heard. Few yellowbill terns were fishing in lagoon and a tame frigate flew about the settlement and $f$ ished with terms.

\section{Nay 25}

Ashore on west side of pass and Correia and self got one 


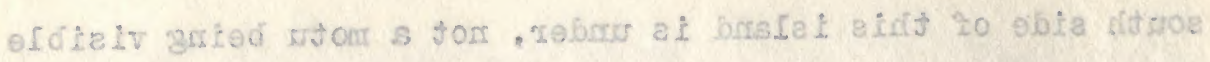

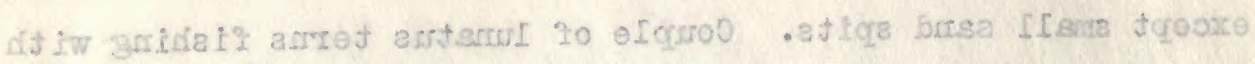

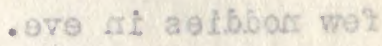

CS VSil

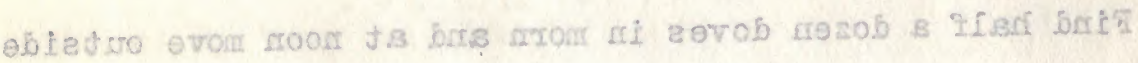

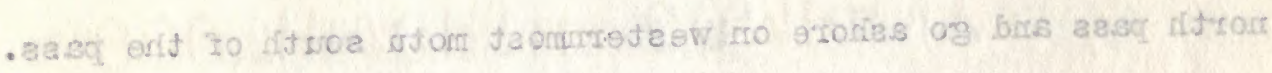

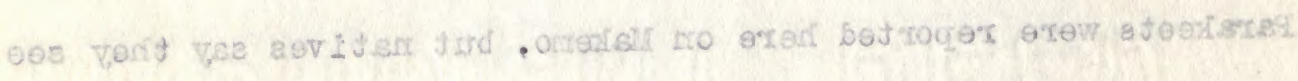

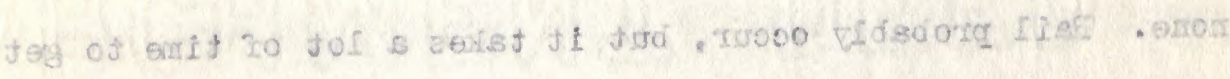

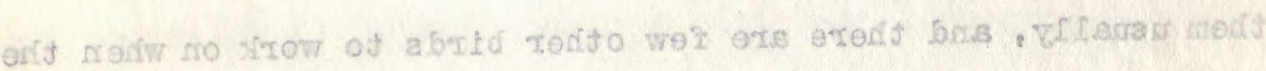

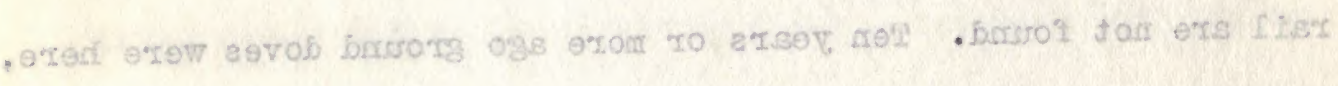

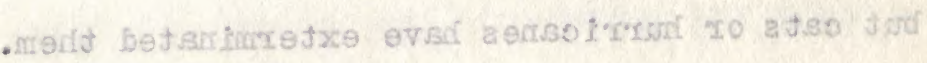

\section{AS vall}

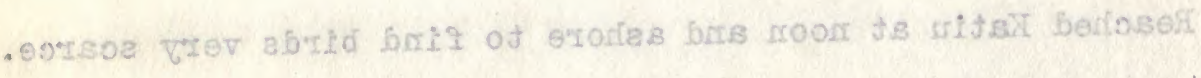

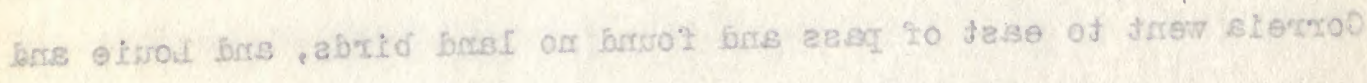

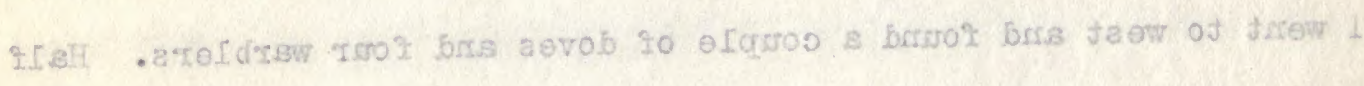

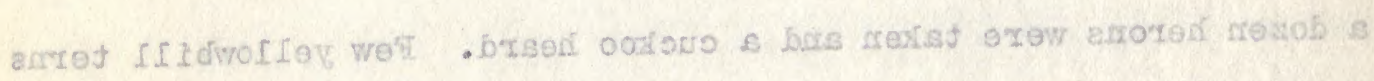

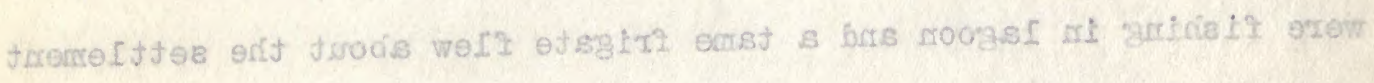
, atret ditu borielt . Sera

\section{CS v}

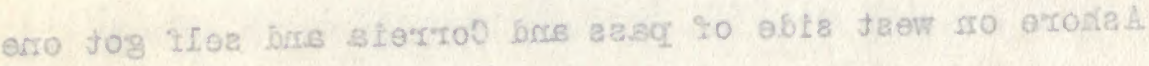


warbler and two doves for the day's bag. I got a couple of sandpipers at end of motu, and they may exist on little barren motus on which are no cats, or they may come across from Tuanake, which is in sight from Katiu. Several blue termlets were flying to windward with lesser noddies orer and along the land in the early morn. In eve boobles were flying low over the water north of the island toward Tuanake and Hiti Islends a few miles to the eastward.

\section{May 26}

Nove around to west side to try there. A Frenchman gave me a deep water crab, dried, for the linseum. They are said to be rare. Ashore at the soutiwest end and I find a couple of warblers and call up a cuckoo that called aherd of me. Several lunatus terms were fishing along the reef on the west side of the island, bat I could not determine if they belonged ashore or came across from Rarake or Kauehi. A couple of blue termlets were also seen,. and rectirostris terns were common, fishing in the lagoon. The west side has two or tirree little motus on 1t, and the south side is barren reef most of its distance, though two or three little motus show. The motu at the southwest end is about a mile long and a pass runs through it on the east side. Quite a lot of coeomats are planted, nearly all of the suitable land being occupied. A noddy or two and a few fairy terns nest here, but nothing in comparison to Kauehi Island where the noddies nest by hundreds. 


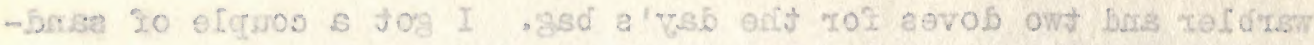

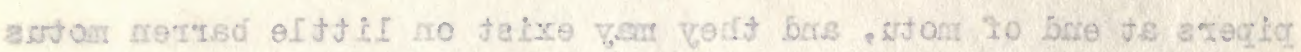

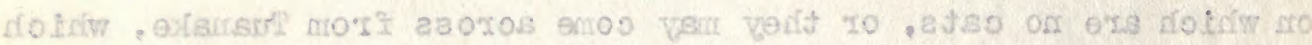

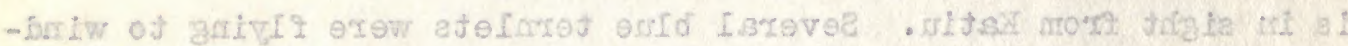

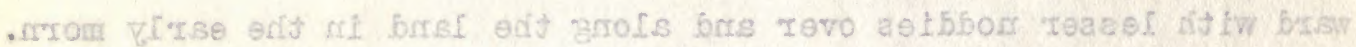

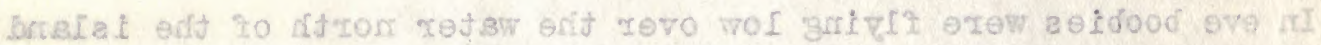

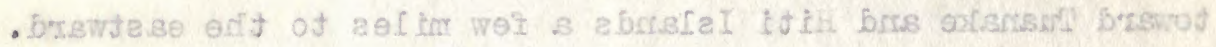

\section{dS YoSM}

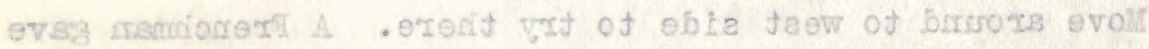

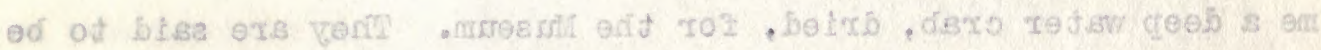

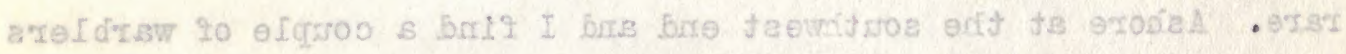

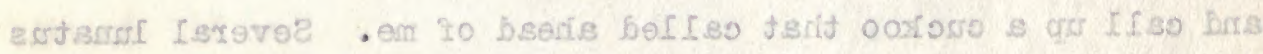

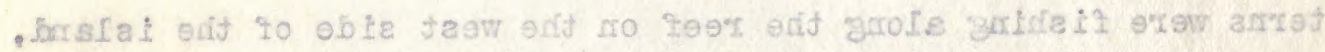

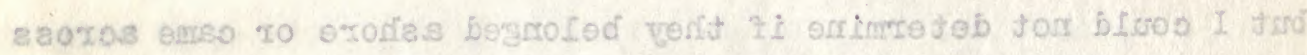

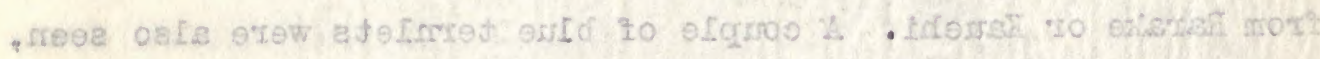

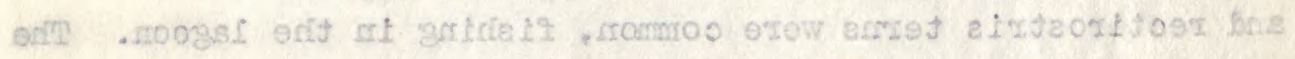

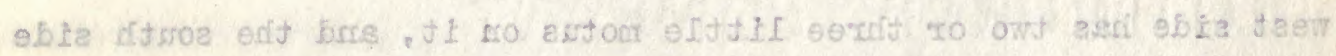

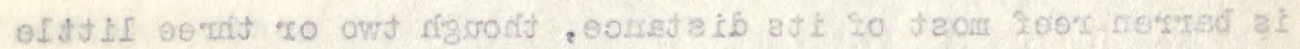

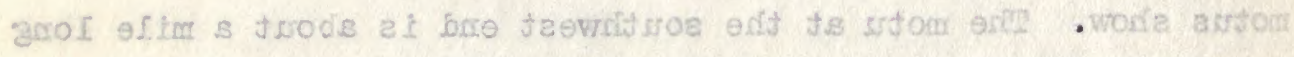

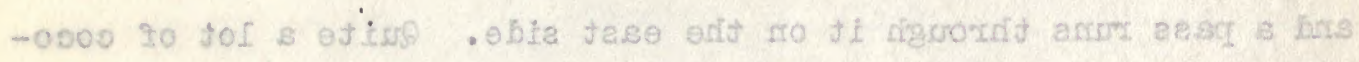

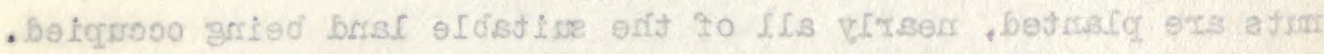

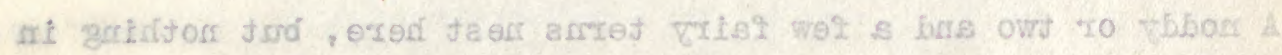

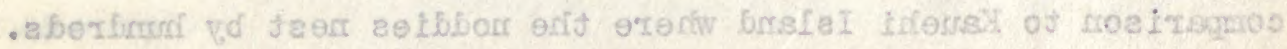


Reached Taiaro Island after noon, as wind light and calm during night. Laid to five miles south till tomorrow.

\section{Way 28}

Ashore and find an American young man in possession with a girl and a little boy as helpers. Island contains a lot of cocomut trees, though room for plenty more. I walked around it in about eight hours, collecting meantime. A few yellowbill terns are seen on the reef and in lagoon on rocks resting. Only a half dozen noddies and the same of fairy terns, though both nest. Warblers are not rare, and the three of us get about fifty during day. Correla got a dove and Louie a cuckoo, while I picked up a couple of herons. Sooty terms fly by the island as we lay off shore, but they probably come from Karahi. As we left Katiu a flock of redfooted boobies were fishing and at dusk several were seen flying close to the water, bound for Hiti or Tuanake. The south side of this island is some feet higher than many others, though quite similar in material. A flock of eight tatlers with a single golden plover are seen on the shore of the lagoon. All the tatlers were in winter or young plumage.

\section{May 29}

I skin birds till noon while the others go a shore to 
TS Retis

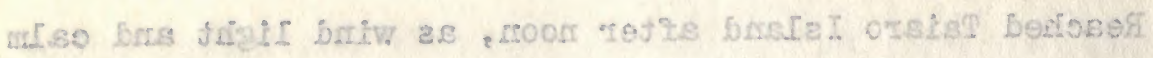

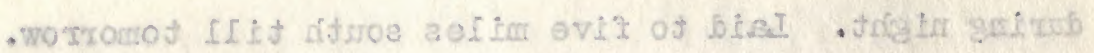

8S vali

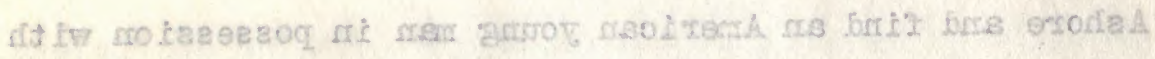

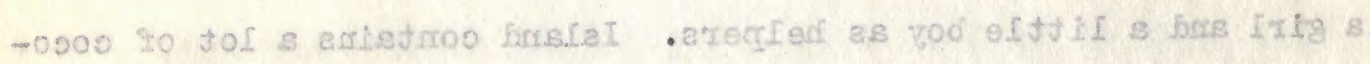

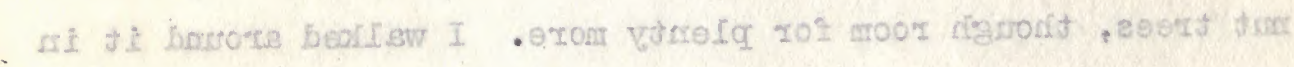

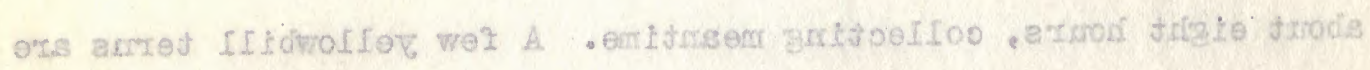

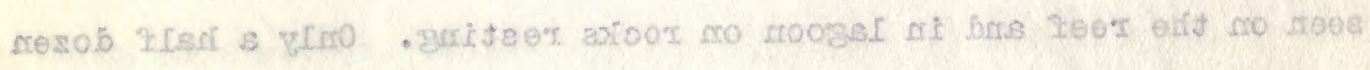

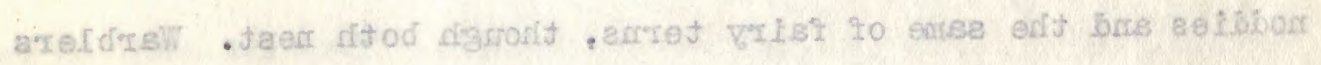

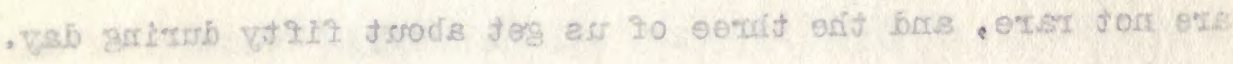

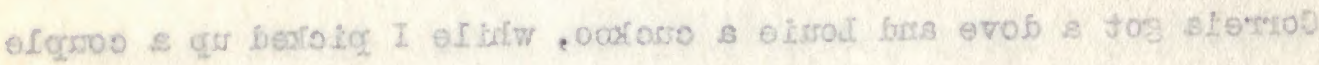

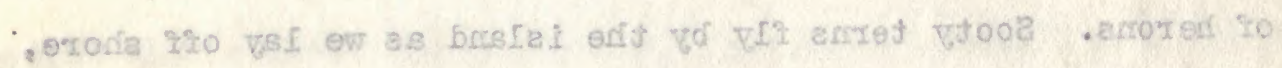

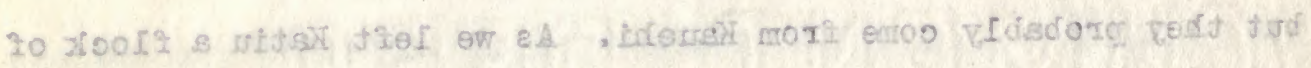

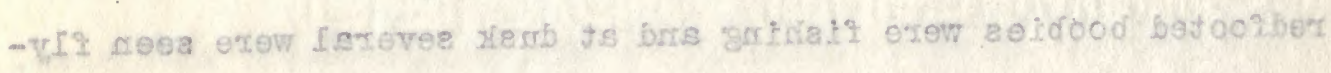

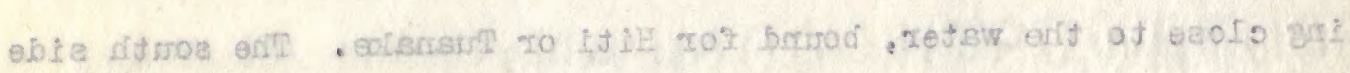

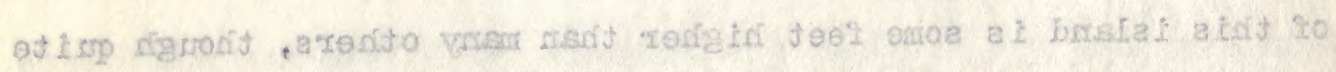

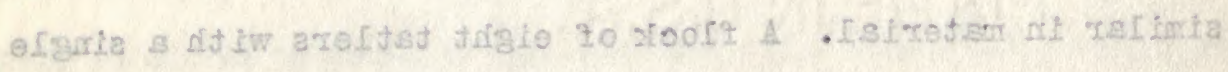

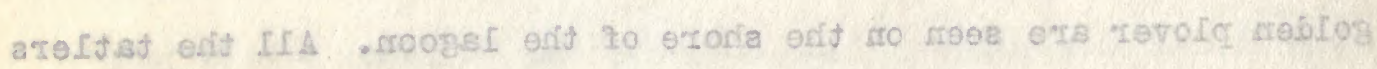

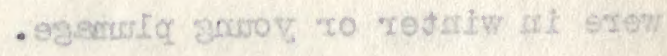

es valf

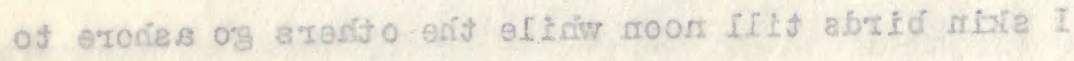


collect awhile. Weather fine and not mach wind lately. Iouie and Correia get twelve warblers apiece and Correia gets a plover with a few black feathers in the breast. Ioule saw the flock of ten tatlers near where I saw them yesterday. Leave for Aratika this eve with light wind. Buy six chickens at seven and a half francs each, about fifty cents.

\section{Nay 30}

Sailing slowly along the east shore of Kauhi Island at eight in the morn a mile from the sooty tern rookery to look at the terms and to see whether lesser frigates are nesting. All seven species of terns were here on our visit in March within a few handred yards of one another, and to note what difference in colonies we are stopping as it is ten miles or so out of our way to Aratike. Sooty terns are flying in couples and small companies from colony as we approach. Small motus with tohomu trees principally and six or eight cocomut trees; we pass land but four or five feet above sea and between motus water is on reef in some places. "Crk, crik, crk! Creak, crik, crik:"call the sooties over my head as I type this on deck sailing. Couple of fairy terns noted, as well as same of yellowills over notus. "Crkik, crkik!" is common call also. Tohuma trees are but six or eight feet high on some of the smell motus, and a pandams tree stands four feet or so above them on one motu, the only pandanus in sight. Iwenty or so bushes 


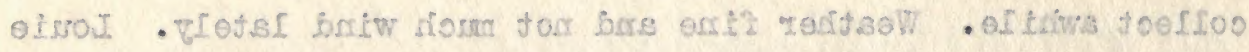

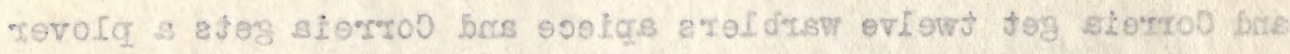

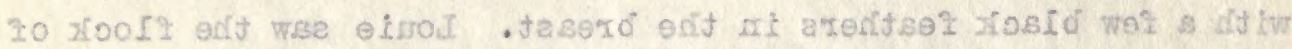

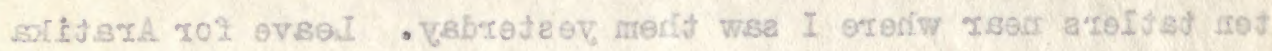

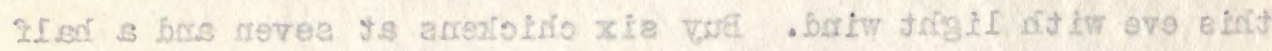

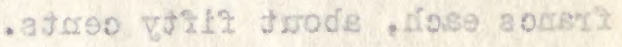

\section{OE NBDH}

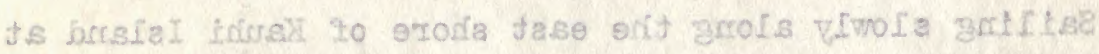

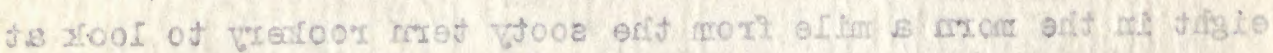

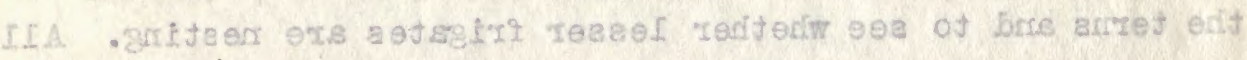

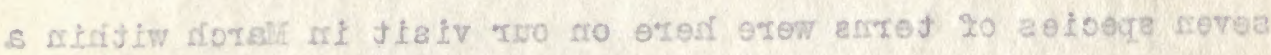

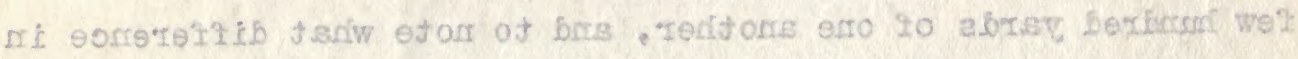

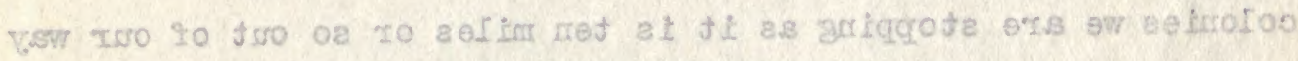

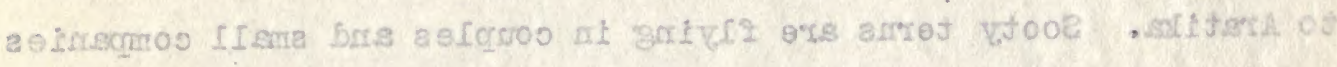

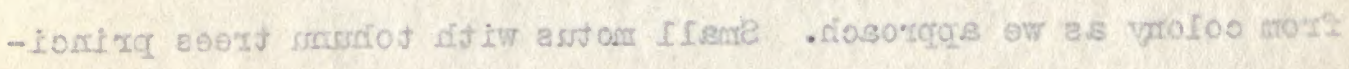

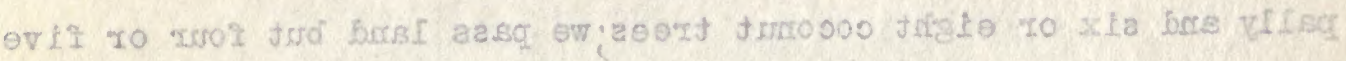

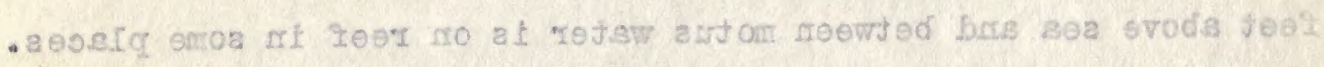

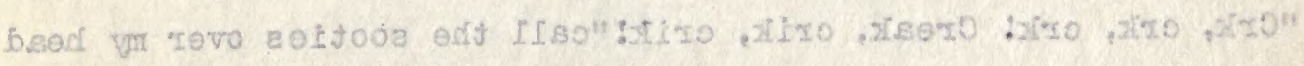

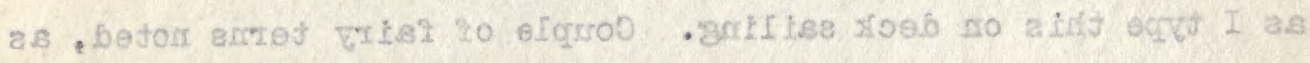

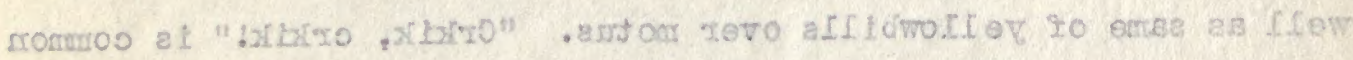

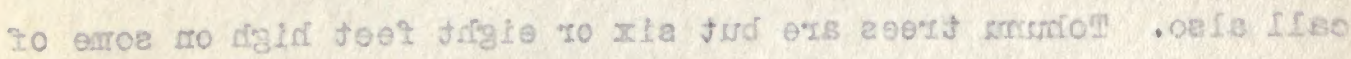

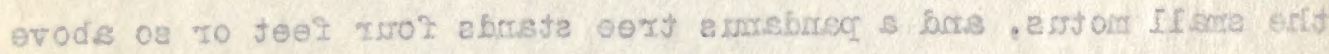

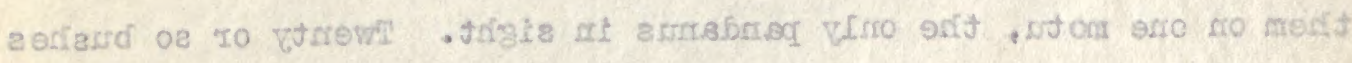


comprise the vegetation on some places and from that up to miles long on the north and south sides. Three feet above the sea are motus here on east side and water between them in some places. Terms other than sooties are not seen, though hundreds of noddy nests are within a couple of miles.

Ashore on reef, where we found the lunatus terms with young in Warch (?). Kauehi Island and see not a lunatus but 10,000 or so sooty which are beginning to nest, and the sailors picked a thousand or so fresh eggs to eat. While they were gathering them the terns hang overhead and many lit in other parts of the colony, which covered an acre or so. $\Delta$ few hundred lit on the ground a couple of hundred yards away. After taking a few photos I left and they built a fire to cook some eggs, and the disturbance drove the greater part of the colong to leave for a motu a mile or two to windward where the birds were swaming in the erening as we passed for Aratika Island. The lesser frigates were not seen, and the rectirostris terns were nesting within a hundred yards of the place that eggs were secured in Narch. Jiggs were fresh to incubated and a couple of young ready to fly were taken. The nests were close to the lagoon shore among the drifted coconuts hulls, and four nests were within the length of the gan laid alongside of them. The old birds stayed about some time and I shot several. One darting at me was shot with the auxiliary, 


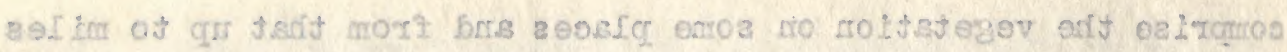

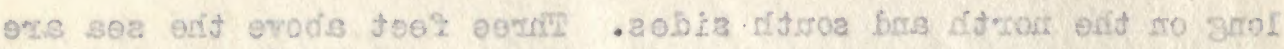

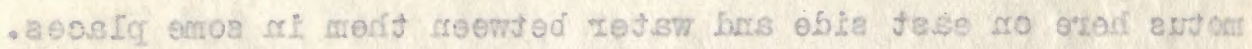

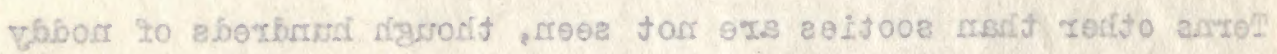

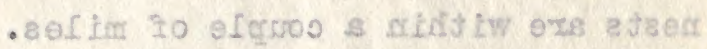

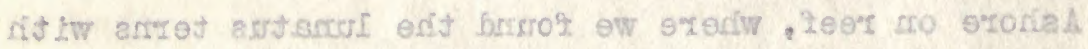

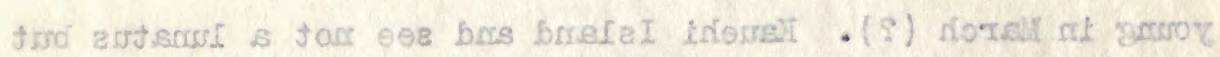

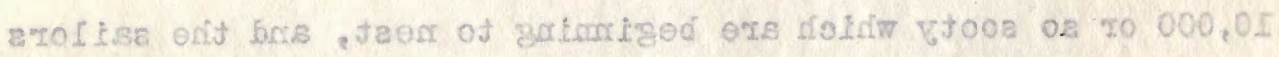

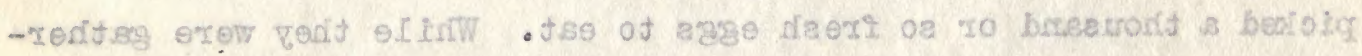

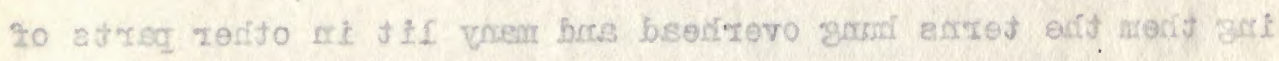

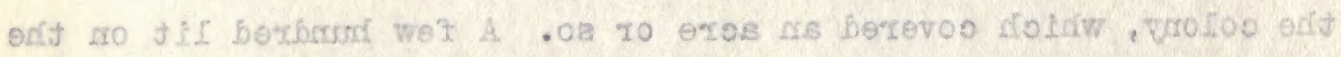

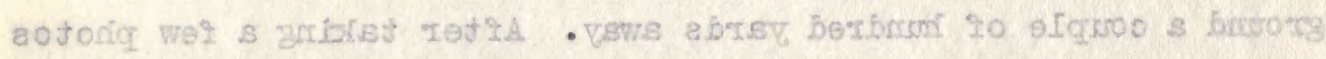

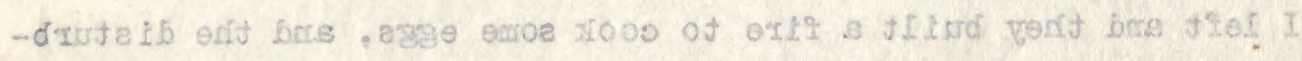

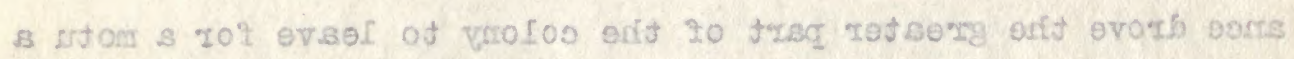

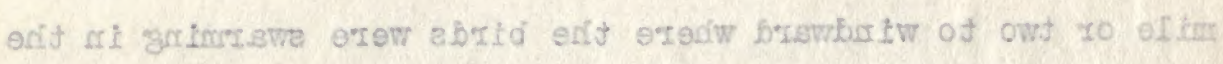

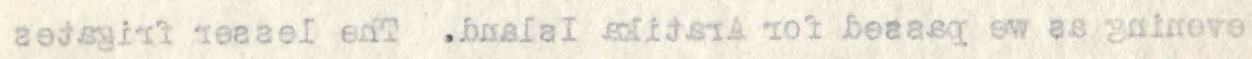

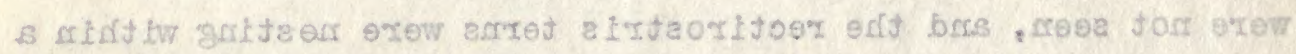

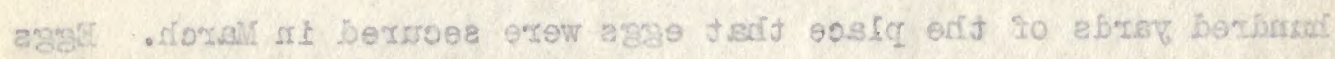

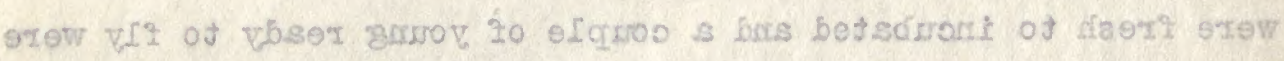

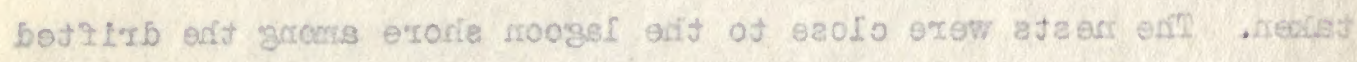

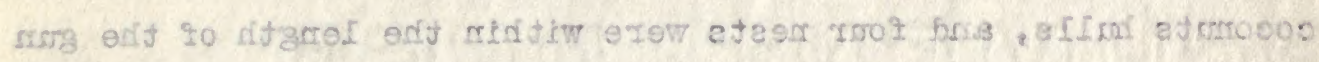

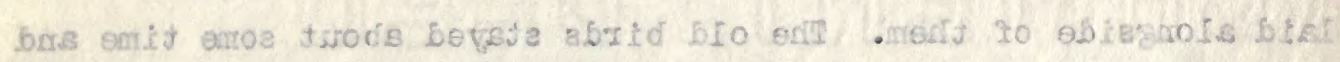

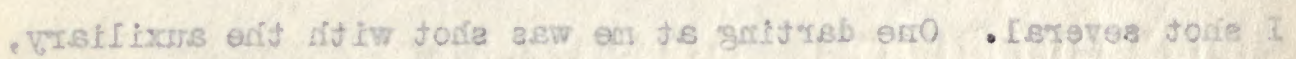


and I had to dodge as he swang to the ground. Several darted down straight at me and swerved when close. Some vent down the lagoon shore a quarter of a mile and lit for a while till I left. On one of the big rocks near the edge of the reef I found a nest of the blue ternlet incubated egs. Another pair perhaps had a nest on another rock, as the birds hung around. The nest with egg was lined with small bits of coral and shell fire feet off ground. Several of the birds were about here on last trip. A nest of fairy tern was seen in tohuma bush two feet off ground, egg fresh and bird flushed. Noddies were not nesting on motus visited. A peir of nesting sandpipers were taken. We left in eve for Aratika.

\section{May 31}

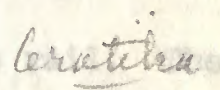

Sailed up to pass at seven in A. M. but current too strong to go in, so went to west a mile or two and went ashore. Got doves and warblers.

\section{June 1}

Moved a fow miles and ashore and met a native who said rail were common on motu to south of village, so we went in west pass at slack tide at three P. M. Supper early and ashore hearing two or tinree rail but saw none. At dark many lesser noddies were flying to south and will tell tomorrow if going to 


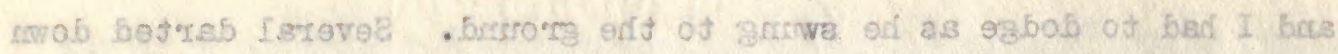

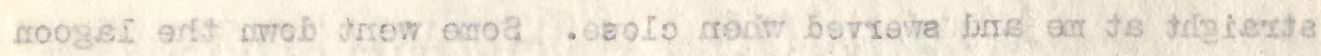

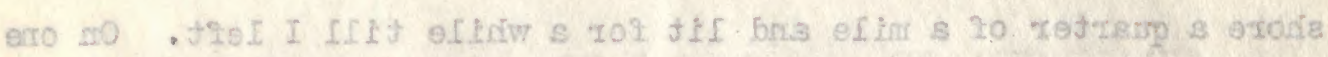

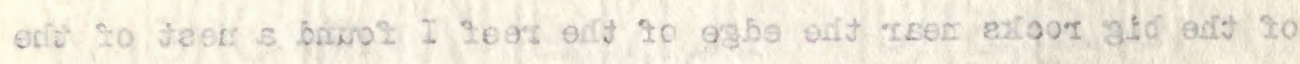

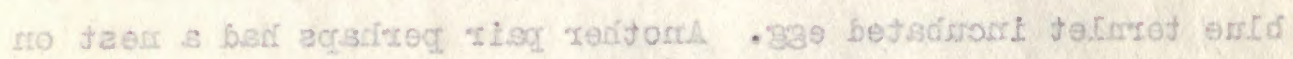

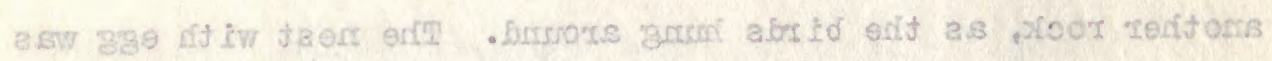

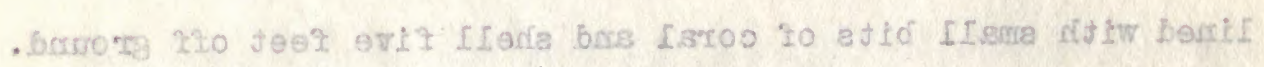

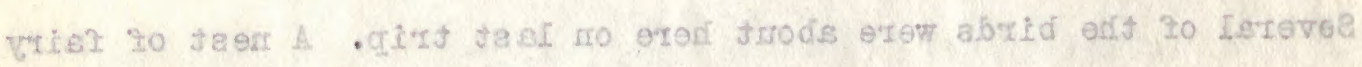

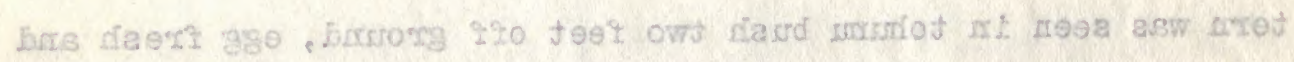

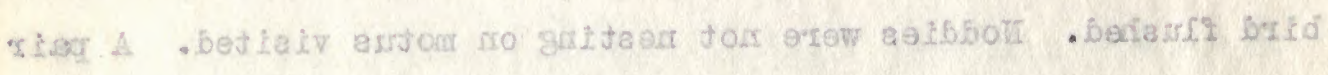

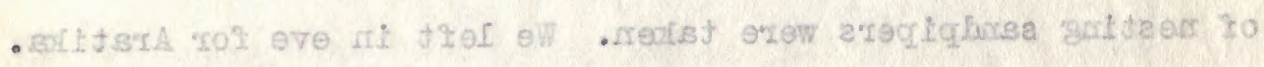

\section{I.8 vals}

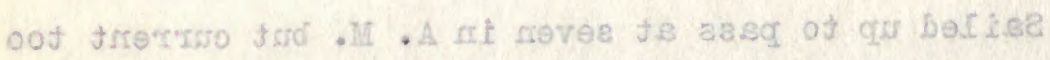

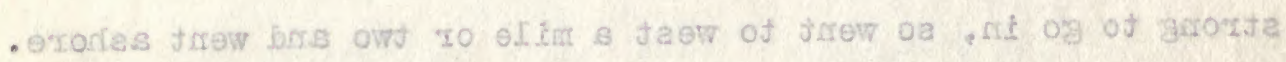
- araíloram bris aevoli jof

\section{I encuts}

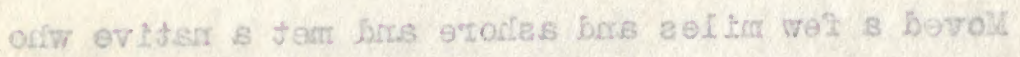

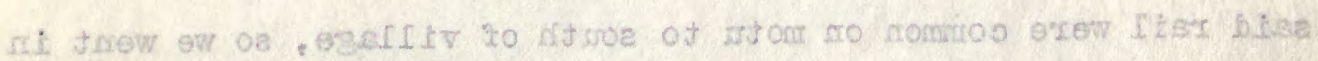

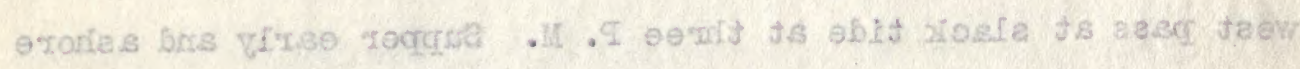

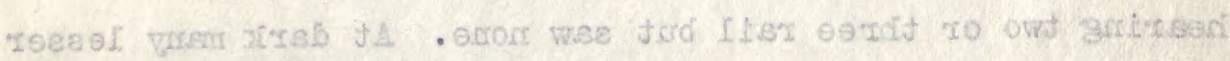

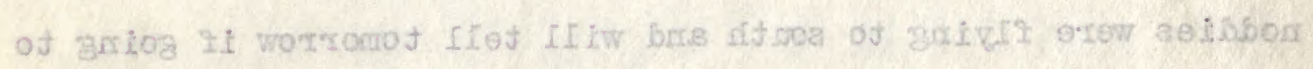


or from nests. Saw small flocks on beach yesterday and a flock of noddies today on rocks on reef.

\section{June 2}

Ashore eaxly and I get a rail standing in the open between two patches of brash where small pools of water stand. Young bird. At eleven get into an open spot under large trees and get three more. I called few times, scared and ran into cover but later secured. I called a while and one walked near me and another headed my way after persistent calling on my part.

Came to same place at three P. H. and got another by watching under the bushes. They maire no sound frequently and the lizards and hermit crabs are easier noticed than the rail. The lesser noddies roost in the leafless trees near where tho old nests remain in trees. No occupied nests are seen. Young doves are common and Correia gets one just from nest. He got one rail and Louie got two.

Two or three plotus boobies seen fishing in lagoon and sooty terns fly across often, bound to or from Kauehi Island.

\section{June 3}

Sunday and aboard.

$$
\text { June } 4
$$

Try again for rail and I get four more, the other two 


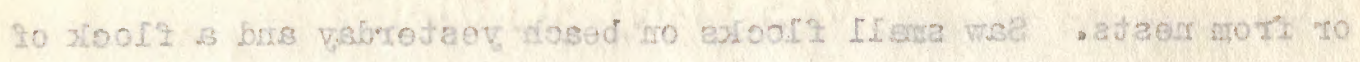
- 2eer no etroos no rebot asibsotr

S orsst.

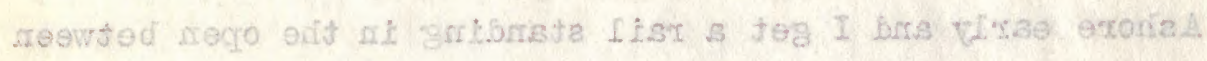

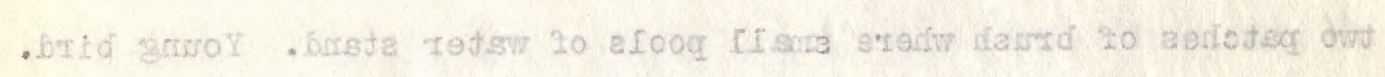
estrit łeg boce a

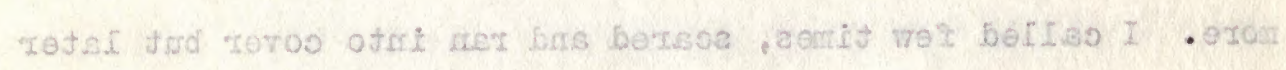

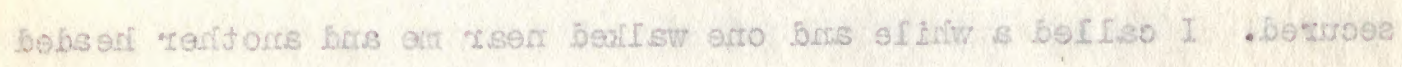

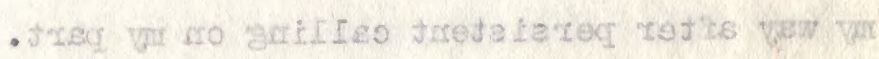

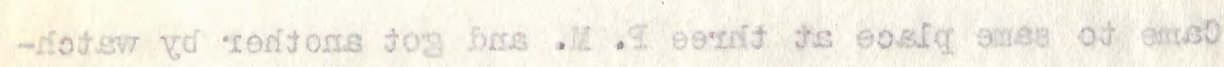

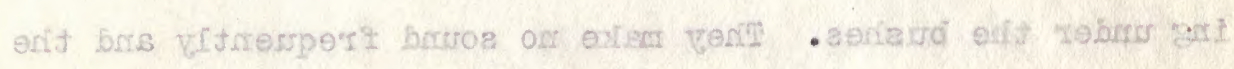

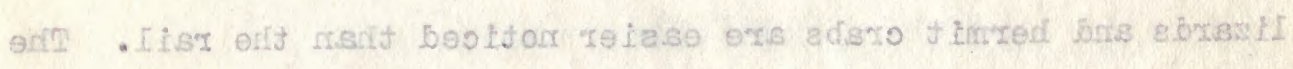

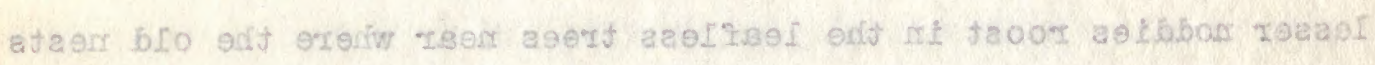

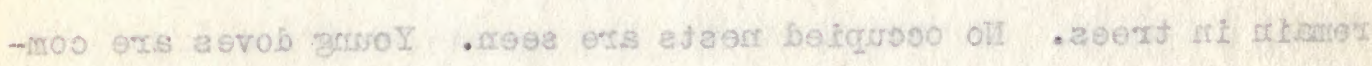

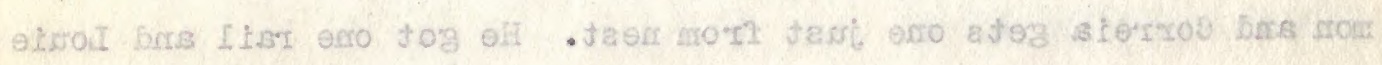
.0 ove $\$ 08$

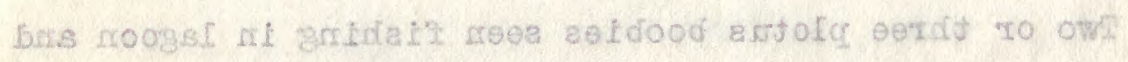

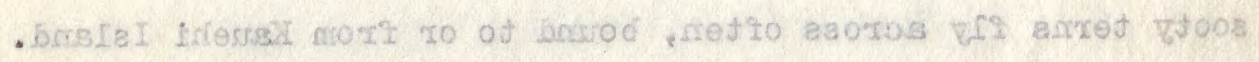

Es errosts

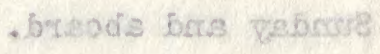

\$ ensst?

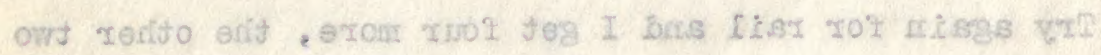


finding none. One came within ten feet of me, looked, and started off, then turned back a couple of feet, and then went off again.

Most keep under thickest brush and are perfectly quiet most of time, though occasionally one will call when some distance away and going farther.

\section{June 5}

Leave at nine for Toar but stop outside on lee side of Aratika where small motu supports one coconut tree to look for booby nests. The nests are there eresh, but the birds very wild, the most keping high out of gunshot. Some nests are elaborate with a pile of coconut husks as pert of material used. About a dozen nests, though only half a dozen birds seen. One bird taken.

\section{June 6}

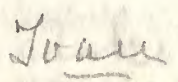

Ashore and I find but two doves and no warblers in a couple of miles' search. Louie and Correia in the motorboat go to farther motu and get six warblers and a rail as well as six doves. Lesser noddies are roosting in flocis in dead trees as they were on last island. Noddies were on reef in flocks. Pair of blue ternlets and few lunatus terms noted outside pass.

\section{June 7}

Leave at $\operatorname{six}$ A. M. for Apataki and find coast line wrongly 


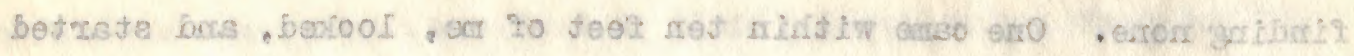

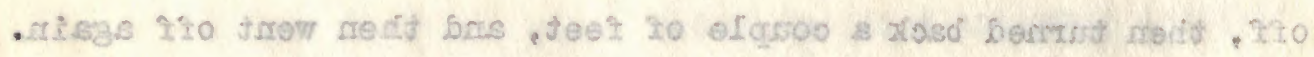

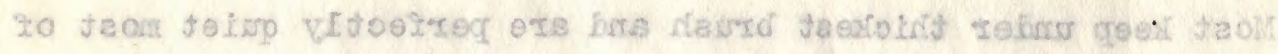

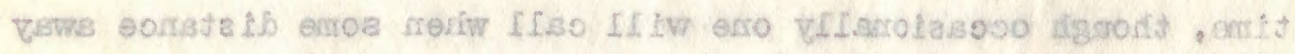
-tedituse oujog bro

\section{a ensuto}

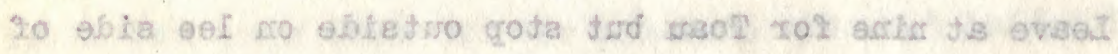

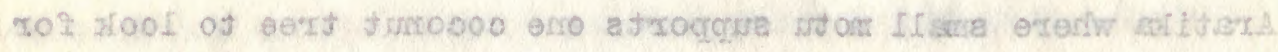

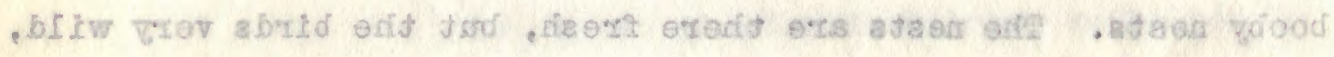

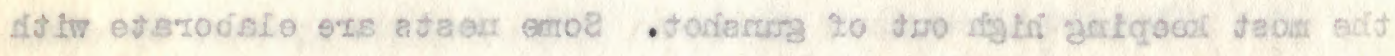

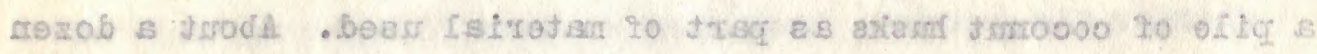

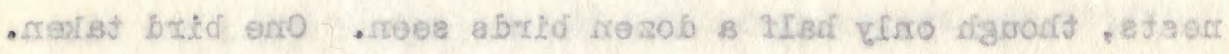

\section{Derosts}

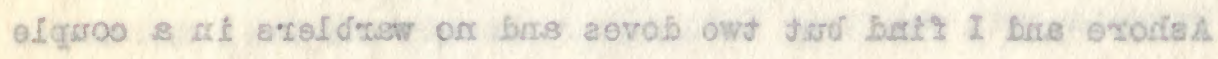

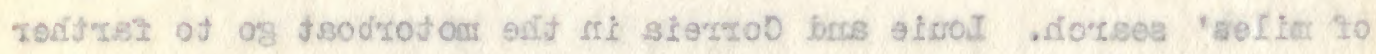

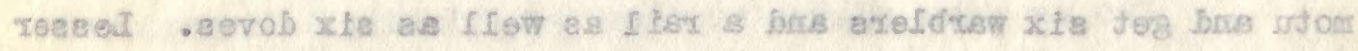

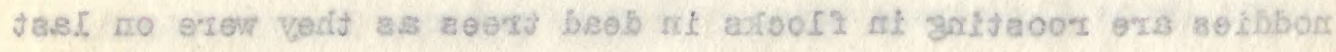

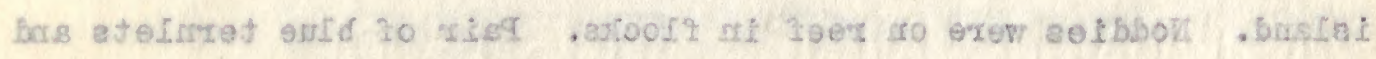

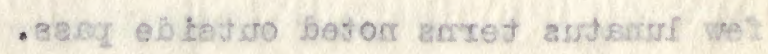

\section{7 encer}

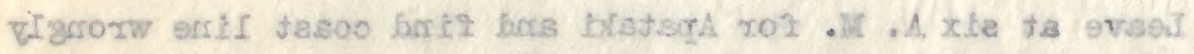


charted as we sail $\mathrm{NW}$ by $\mathbb{N}$ along it instead of $W$ by $\mathbb{N}$ as course calls for.

Tied up at Apetaki at two-thirty and ashore for couple of hours, finding half a dozen warblers and a dove. Few pooplo (dozen) as most inside making copra. Fish are in schools alongside of many colors and shapes and sizes. Yellowbill terns fish along in the pass and outside was a big flock of lesser noddies sitting on the water until fish were driven to top, when they gathered over the fish. A dolphin followed flying fish for a quarter of a mile, making great long leaps repeatedly in pursuit of flying fish which were in the air much of the time. He finally caught one not far from the ship. The wharf here is best place in Tuamotus for any kind of wind that might blow, being protected by curved channel from swells from lagoon or sea.

\section{June 8}

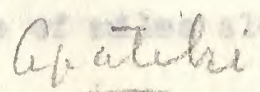

At $8: 30$ current slacks and we steam inside and will leare by pass in north. Stop at village and find people inside maiking copra. Get a rail and find parakeets common on east side, so Correia and Louie go there, while I so in opposite direction where little vegetation and in open sandy spot on barren part of land find a dozen or less rectirostris terns nesting. Eggs have no particular nest but laid on sand usually and close together. One and a half leet apart are two, though plenty of similar places within forty feet. Birds fly around for few mimates, then go away, 


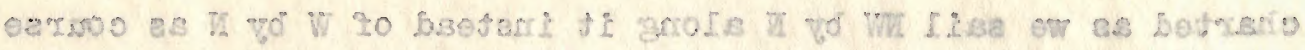
$.10 \%$ a.15:S

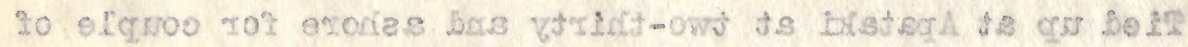

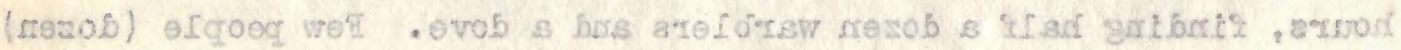

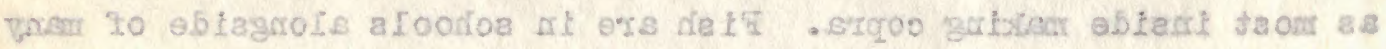

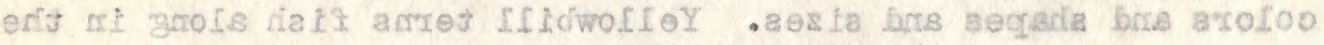

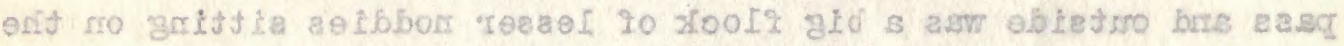

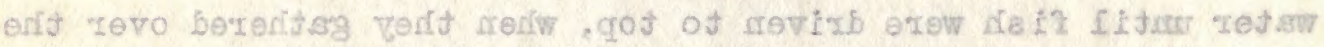

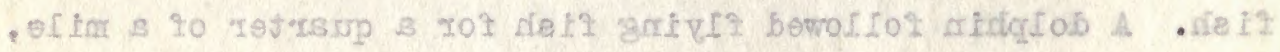

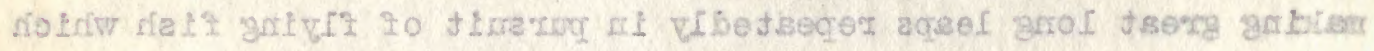

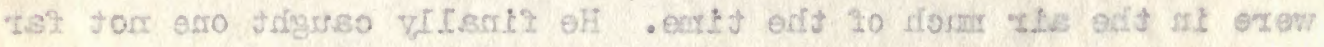

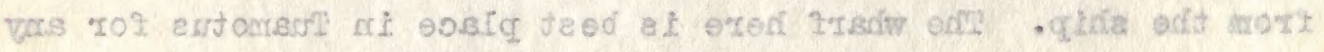

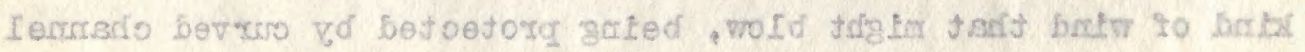
.003 to moogsi movet af ave moti

\section{8 grsut}

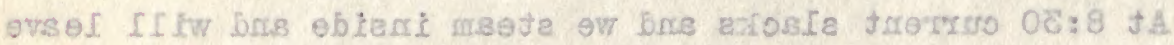

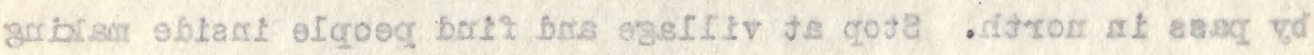

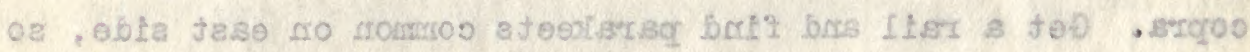

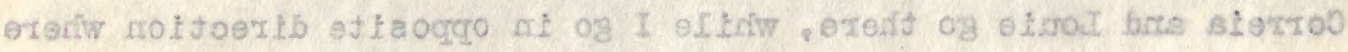

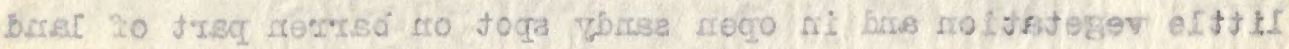

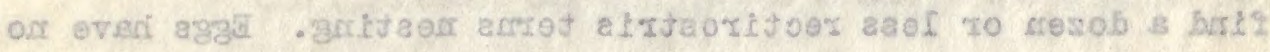

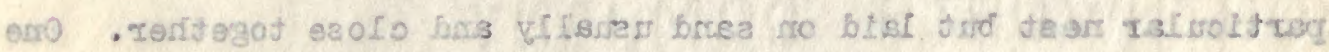

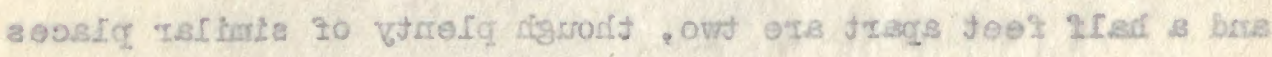

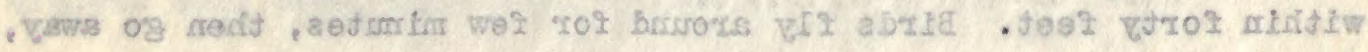


one or two occasionally flying over. QJW mile farther find couple of other nests, where from tracks in sand they have been disturbed. by native and dog. Several nests were here from appearances. At first place three or four lunatus terns acted as though they had nests, but young bird seen and probably nesting over. Coming back about four o'clock there were a couple of dozen or more Iunatus old and young flying about and lighting, and others noted fishing in lagoon. Three or four blue ternlets also noticed and one shot which was young. They perhaps nest on some of the larger rocks which stick up three or four foet in places.

\section{June 9}

Mored down or up to northward ten miles or so where people are at work. Find good rail country, but people and cats and dogs make finding birds unlikely. I go couple of miles along coast and native takes me to sooty tern colony where young birds are beginning to fly. All young seem to be of same age within a week or two, though I found a dozen fresh eggs in one spot. The young are mostly sitting on rocks at edge of reef, and as we approached they flew a hundred or two hundred yards farther along and lit again. Old birds were coming in from along the coast usually, and some seen leaving by same route. Some young throw up squid when hard pressed. Five thousand or so young birds perhaps in the colony. Two other 


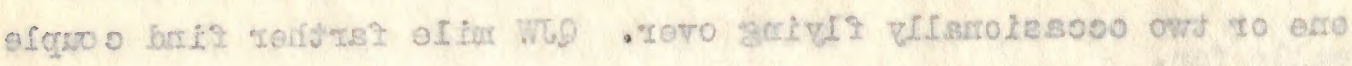

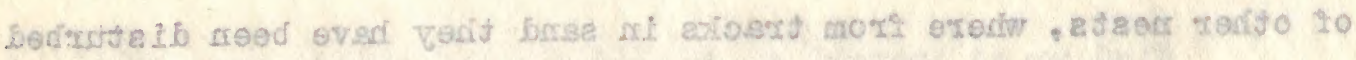

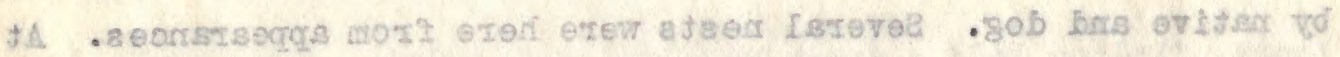

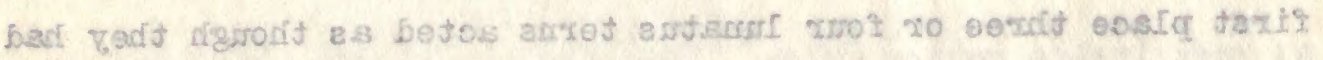

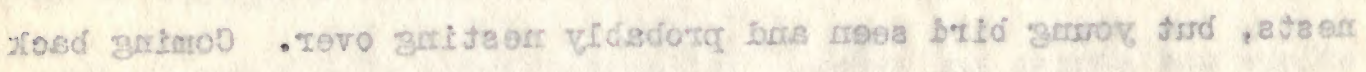

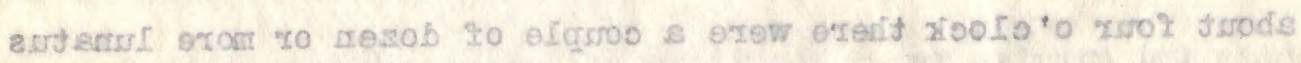

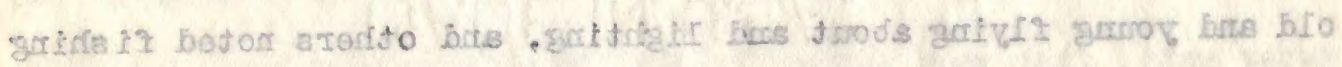

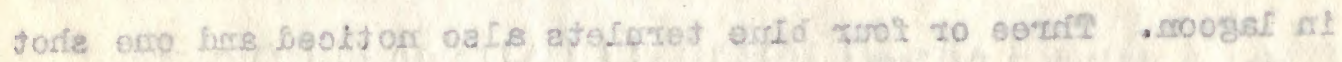

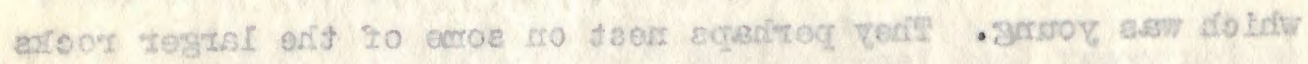

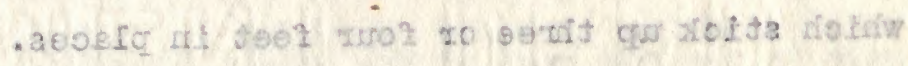

\section{e exsit.}

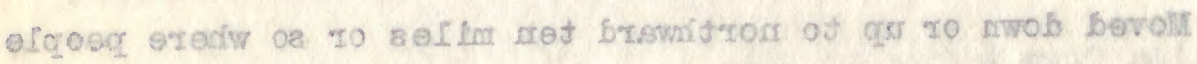

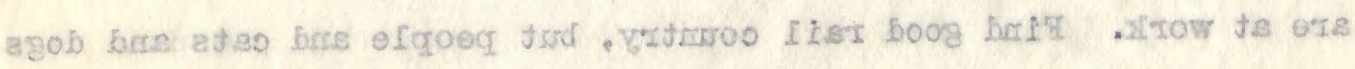

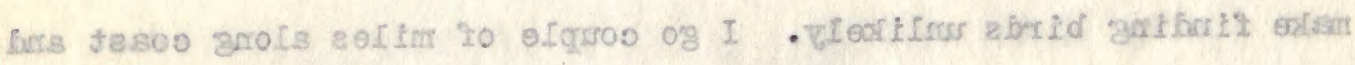

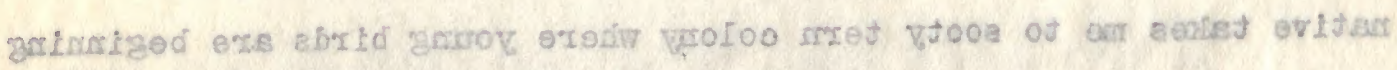

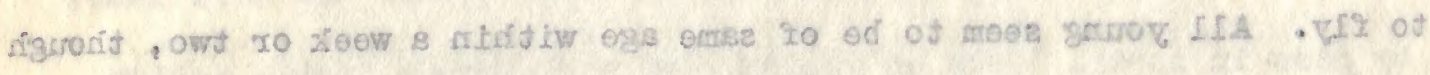

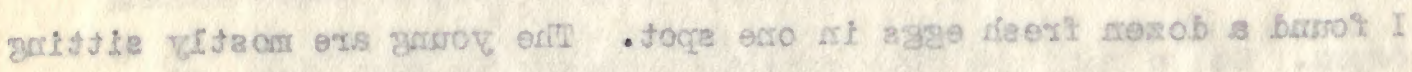

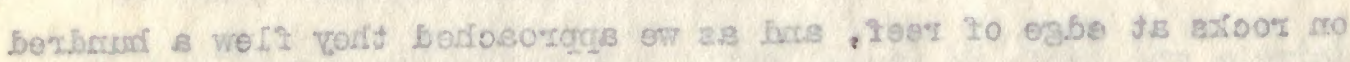

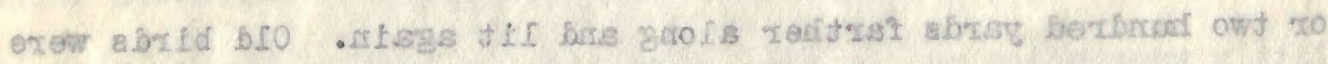

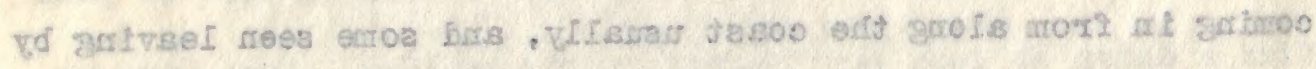

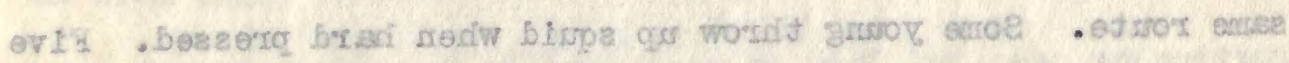

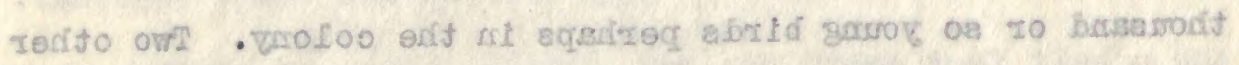


colonies are reported on the island by the natives. A wandering tatler and a plover seen in summer plumage and expect to take next ones to see if returning birds from north, though seems early for a week or two yet. Couple of young blue herons noted playing along a pond and I shot a couple of white ones that were recently from the nest.

June 10

Sunday.

June 11

Moved down to west few miles and ashore for day, but found only a few warblers and parakeets. Saw a few young and probably old rectirostris terns fishing, all in winter plumage, while the birds nesting are in high feather. Sooty terns were working back and forth, mostly forth in the P. M. along the lagoon shore to the west with a north wind. They followed the shore much as some gulls do in California in migrating, but the sooties are probably going to good fishing grounds, for they fish a hundred and more miles from home frequently.

\section{June 12}

Leave at seven in the morn for Kamkara, but reach pass and 


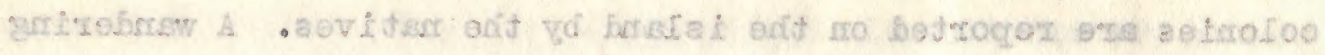

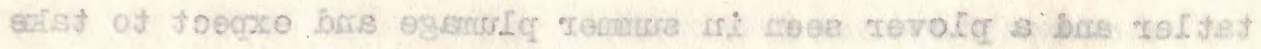

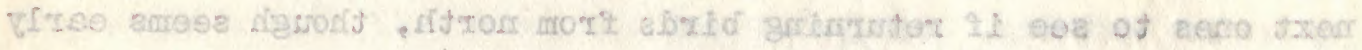

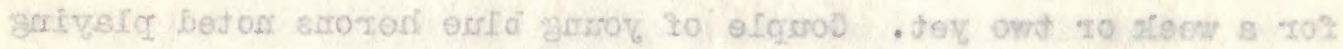

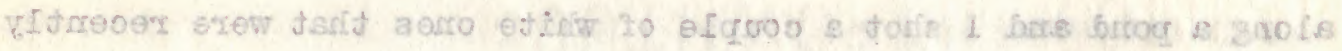
- teor encid aroos

Of ersit:

- vebosure

\section{J. อाrs]}

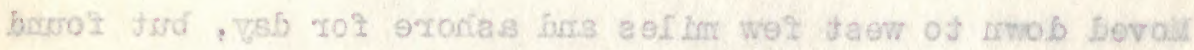

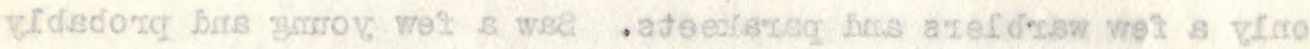

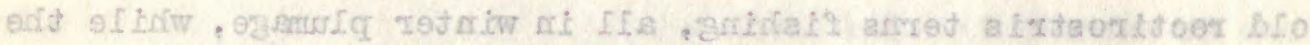

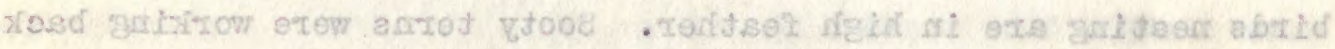

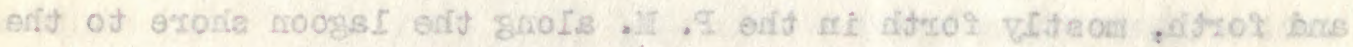

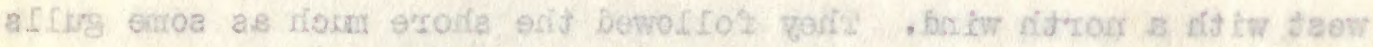

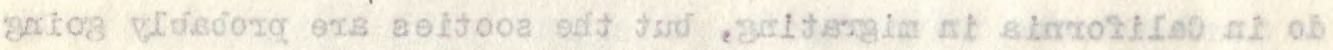

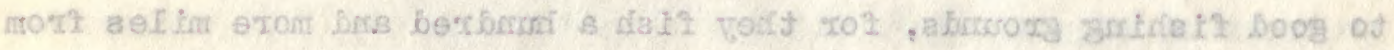

\section{SI grapto}

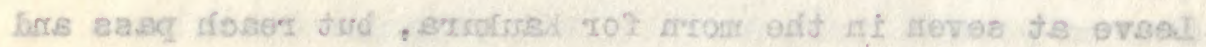


find it too rough to go out, and north wind makes landing at Kaukara unlikely, so tie up near pass.

\section{June 13}

Wind still wrong, so stop another day and hunt warblers and parakeets, finding a few of each. No rail, though good looking ground. Got a fresh water eel and saw small shrimplike swimmers common in fresh water pools. Shrimps are an inch long (the large ones), while the small, which are plentiful, range to a quarter of an inch. Three curlew and few tatlers and plover seen. Scattering lesser noddies and no noddies or fairy terns at this motr now.

\section{June 14}

Leave at seven in the morn for Kaukura, as wind around to SSE.

\section{June 15}

Ashore and get Chief's permission to hunt, so wark the motu where village is, as that is the largest and has most birds, say the natives. Find parakeets common and warblers not rare. No doves are seen, though natives say a few occur. Quite a lot of plover and tatlers are feeding on large flat covered with few inches of water driven up by high easterly wind, fifty or so plover being scattered over half a mile of ground probably. I got six 


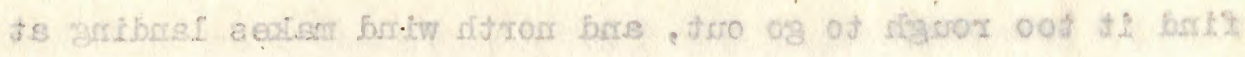

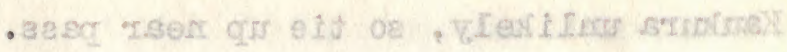

\section{EI oxut}

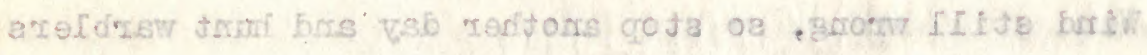

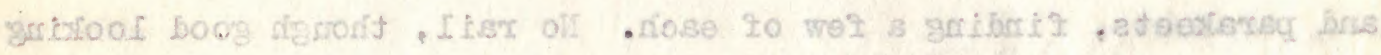

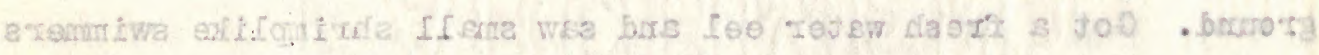

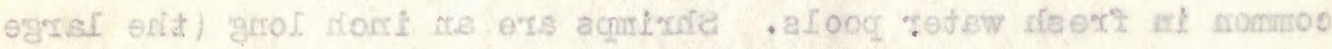

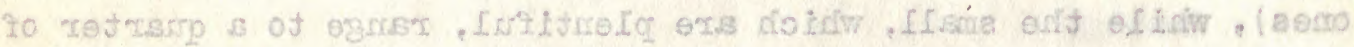

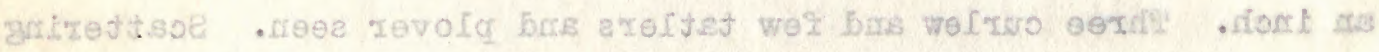

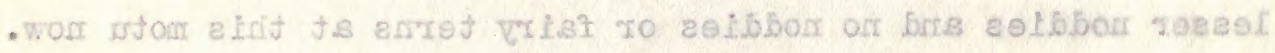

Af encert

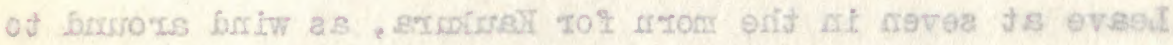

-

\section{द. बाม}

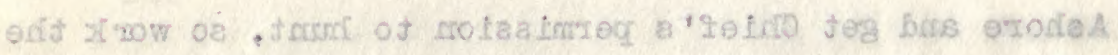

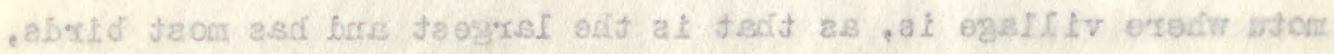

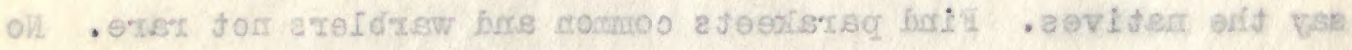

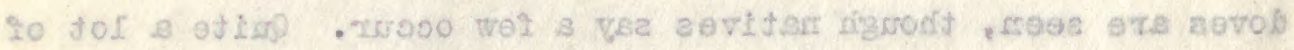

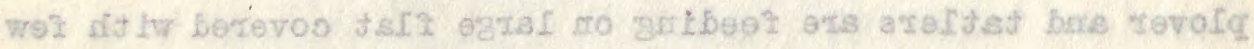

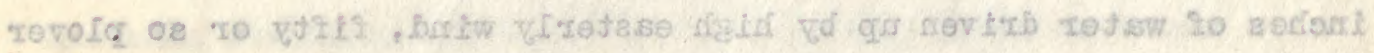

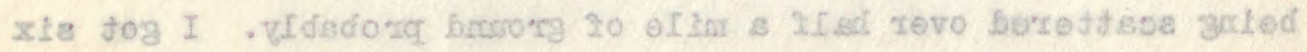


herons, though others got none. One young heron noticed in the village as a pet.

June 16

Ashore at another motu, but find birds scarcer. kail are said to be here, but we saw none in two days. In the center of the large motu is rough lava, same as Henderson and lakatea have, though not so deep cavities. Village here has fences as a mule and horse are kept for hauling copra from far parts of motu a half mile or more to sheds. Motu is well planted and about three hundred people live here. A new church of Jesus Christ has just been completed and evidently has many more adherents than the small Protestant or the weatherworn Catholic churches boast. Breadfruit and bananas seem to grow well, though probably earth from Tahiti is used to plant them in. Fences about some houses are the result of having the work animals here. Hlowers grow around some houses, and some houses are well made of lumber. Big flock of lesser noddies fishing off the island, and several seen sitting in coconut trees resting, as do the noddies on most islands; but I do not remerber seeing the lesser noddies sitting in cocont trees before.

\section{June 17}

Sunday, and head across to Rangiroa Island where we anchor inside at dark. 


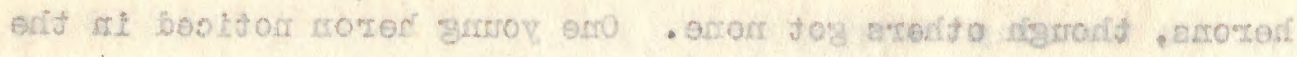
. Jog a as egelisiv

$$
\begin{aligned}
& \text { DL erest }
\end{aligned}
$$

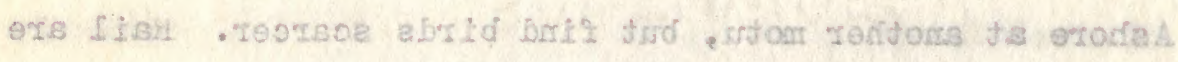

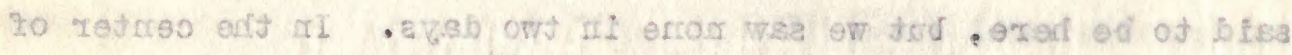

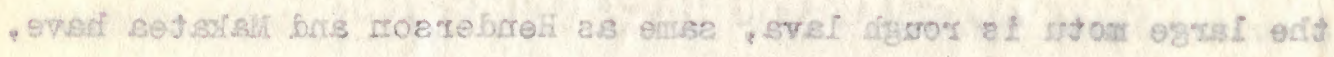

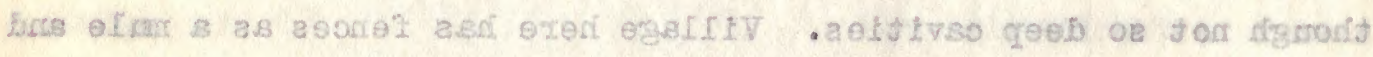

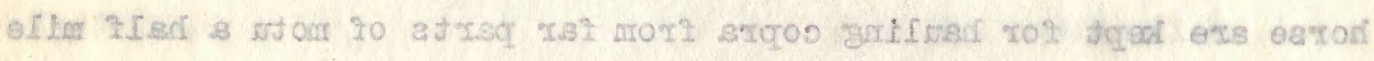

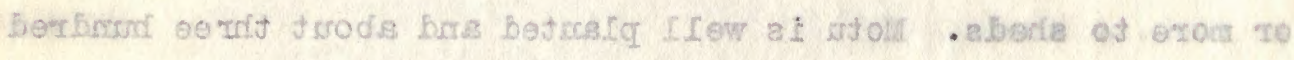

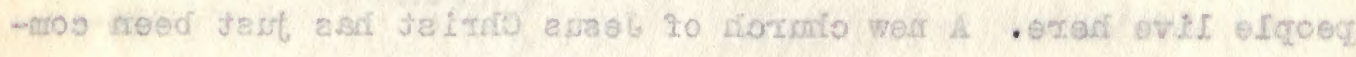

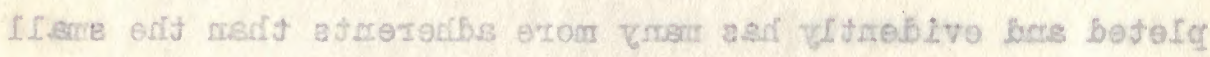

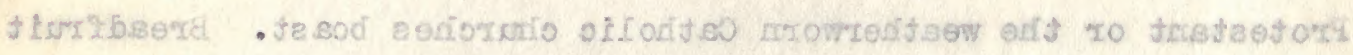

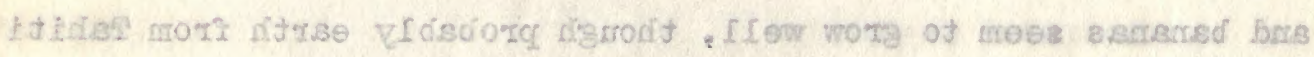

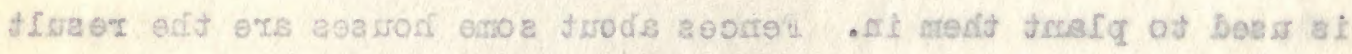

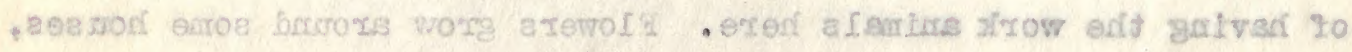

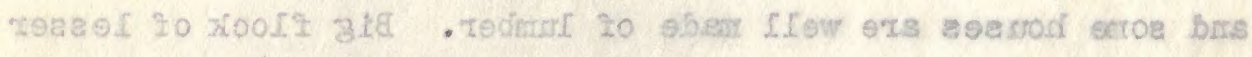

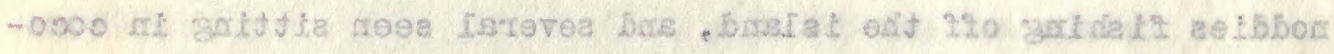

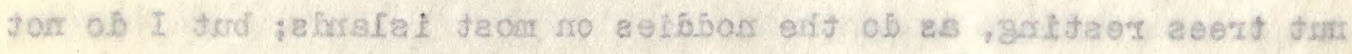

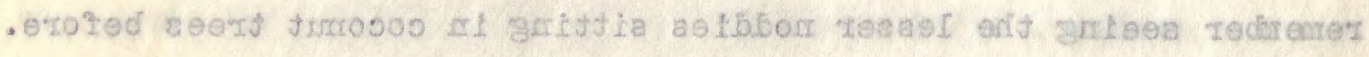

\section{PI entst}

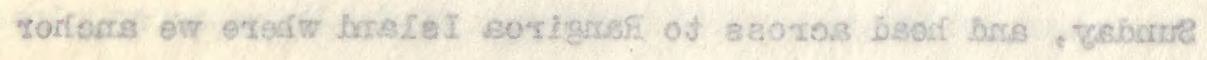


June 18

Got permission from policeman to hunt, and sailed across the lagoon to south side, where arrive at one P. M. Lesser noddies were fishing in small flocks at times, and some flocks had lunatus terns with them, and a flock of blue ternlets was also seen fishing in the lagoon. Quite a flock of lunatus (?) terms was resting on the islet in the pass when we came in last night.

Small and large motus, as well as stretches of reef, form the south side of island, while the most of north side has vegetation. About 1,200 tons of copra is the yield of this is land, each year.

\section{June 19}

As I write this before sun is up and while we wait for him to rise a little so that coral rocks beneath the lagoon surface may be better seen as we move to another motu, a glance over the lagoon shows a lunatus tern or two flying along to windward at fifty feet above the water, while a couple of lesser noddies hag the surface closely as they flap hurriedly along in the same direction.

Ashore yesterday P. M. and found birds very scarce. Four warblers for three of us and a pair of parakeets seen. Loule and Correia picked up a dozen blue ternlets on the rocks on the reef and I got one of several herons seen. Plenty of suitable ground 
8I enstrot?

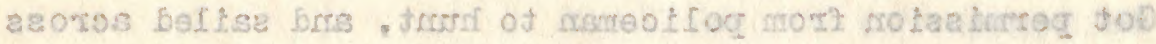

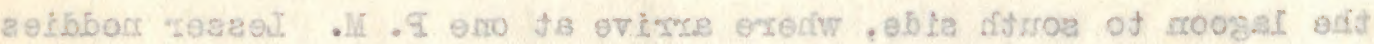

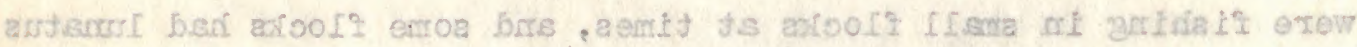

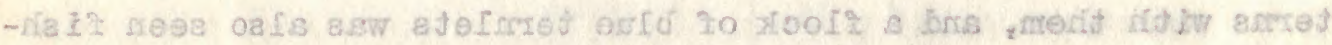

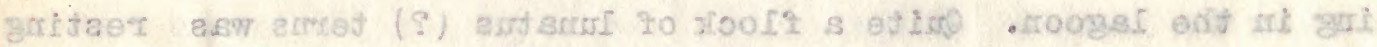

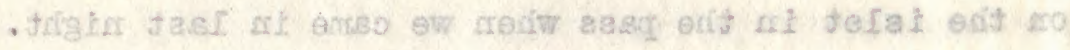

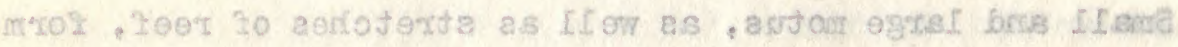

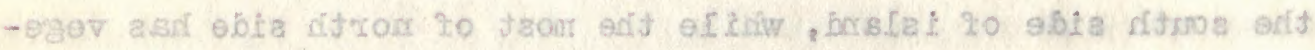

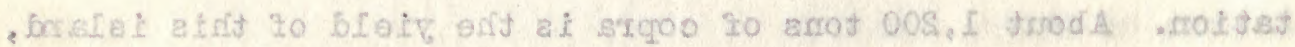
- zedr dose

\section{e.f encert}

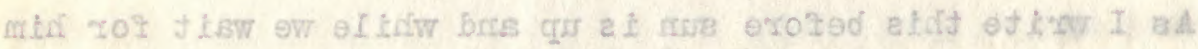

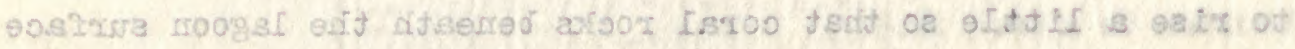

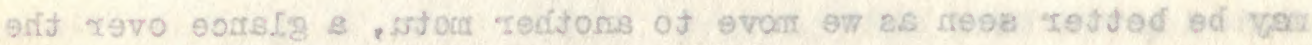

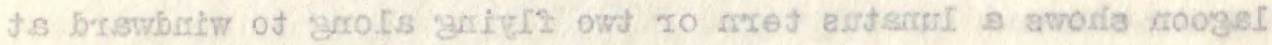

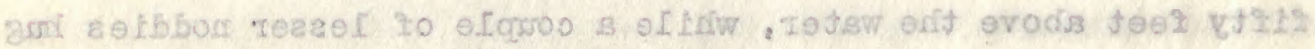

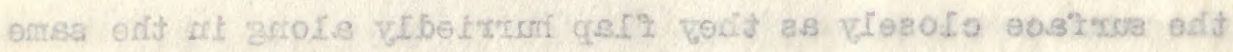
. sto lis $\operatorname{sen} 18$

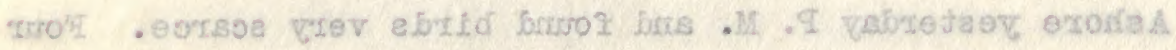

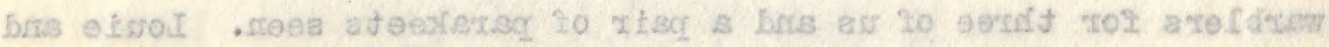

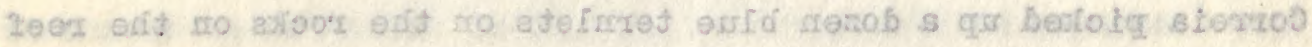

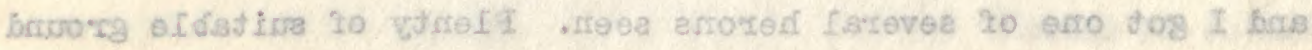


for warblers, and why they are not more plentiful is a question. Cats are common by tracks seen, but cover is dense in places. Natives say a few rail are present, but indefinite time would be required to secure specimens. Iunatus terms are frequent on the lagoon, and they probably breed on some motu, the sooties having a large colony on this side to the westward, but not a bird of that species was seen as we crossed the lagoon. A flock of a dozen was noted at the pass yesterday, bound north, and they were headed probably for fishing toward Ahi or lanihi Islands, where I often saw them.

Ashore on south side at several motus and find warblers scarce, and no doves or rail, though ground looks good. Herons are common on the reef fishing, and a heavy swell on the south side is noticeable. For miles a ledge of pinnacled coral rocks sticks up on the inner side of the reef, the edges of the rocks being so sharp that they out the fingers if touched without caution. They are waterworm into all sorts of fantastic shapes, being from one to ten or so feet high. The motus have thick brush and trees on them except where cleared for cocomts. Many cocomats are planted and bear well, and most motus have been planted, though there is mach ground for others on the same islets. A grove of high trees is roosting place of lesser noddies, and about four P. M. the birds straggle singly along to roost from the westward. I notice as I am working on that side. Several blue 


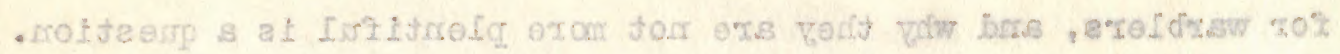

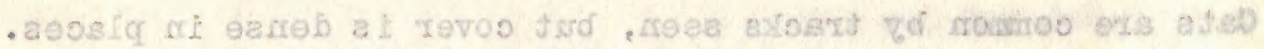

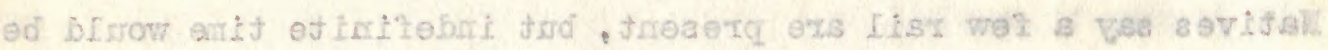

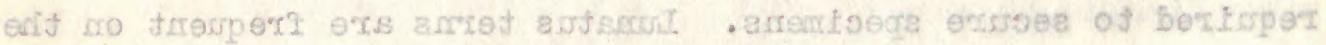

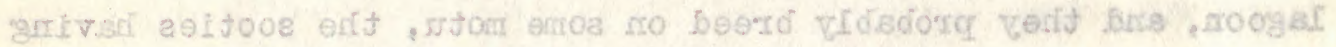

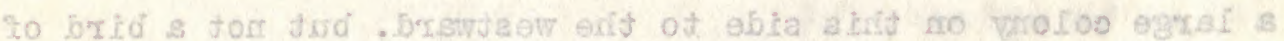

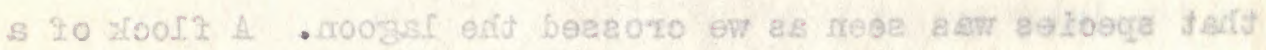

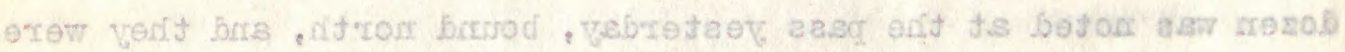

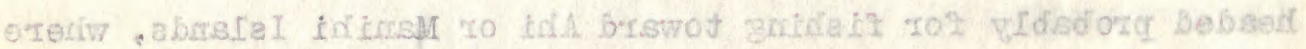
- irosid wise diot to I

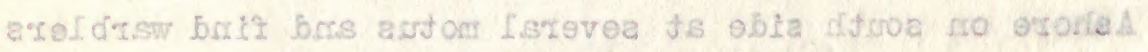

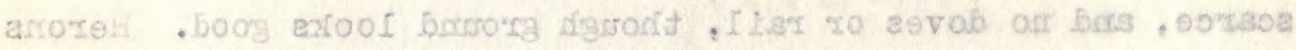

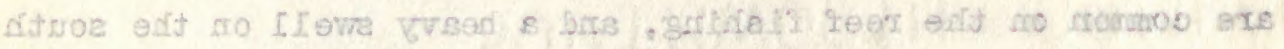

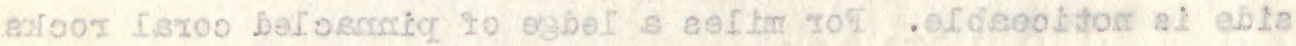

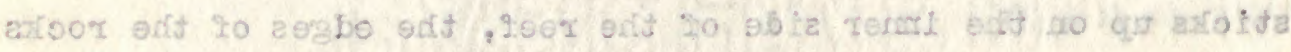

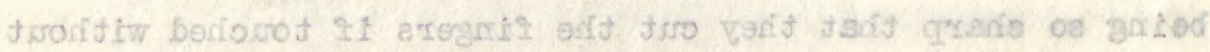

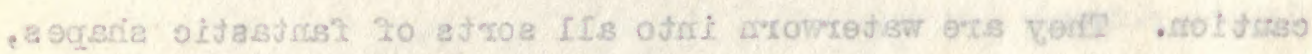

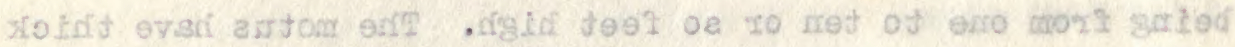

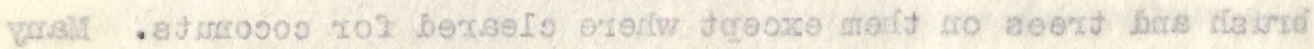

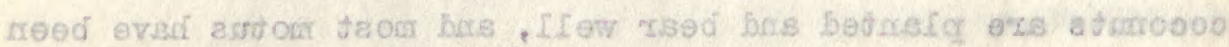

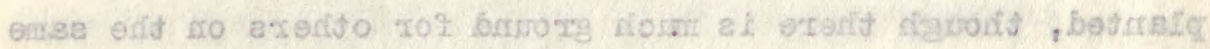

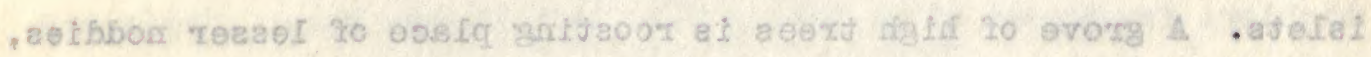

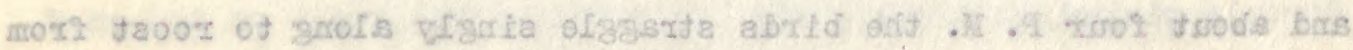

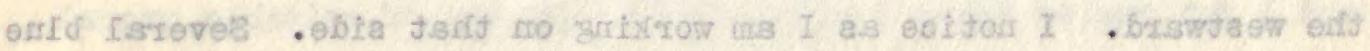


ternlets are using the coral rocks for resting and they undoubtedly nest in the hollows of the rocks as was noticed on Kauehi Island. Scattering yellowbill and Iunatus terms fish along near shore of lagoon, but noddies are scarce, and some fairy are seen on certain motus, while on others not a bird is found.

\section{June 20}

Perfectly calm, and we leave at eight for Tikehau Island.

Have but fifteen cases of gasoline left and expect to arrive at Papeete with supply gone. In lagoons usually have to steam, though here sailed in and would have sailed out had wind been present. Fishing lesser noddies are scattered over surface of water and few lunatus.

Ashore at four P. M. and find a few warblers where coconts are planted and fresh growth of bushes after a hurricane of few years back.

\section{June 21}

I work down to a long motu on east side and get one parakeet and a cuckoo and a few herons along reef. We sailed yesterday along the reef for miles on north side, but could see no place to land, as reef was high on outer edge and no break large enough to ran boat in. Golden plover are frequent here. 


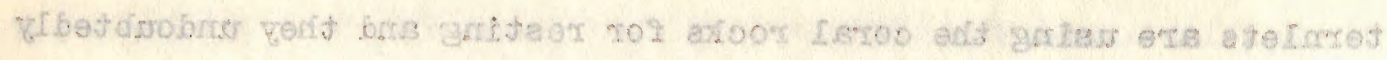

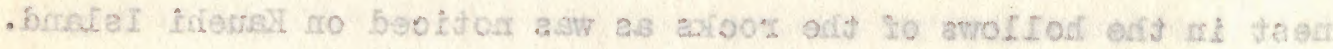

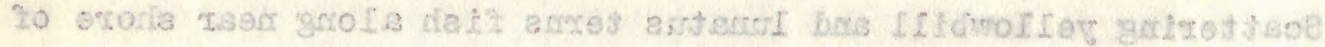

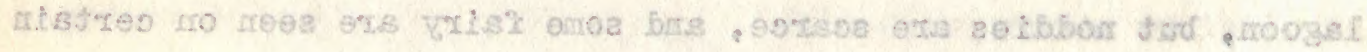

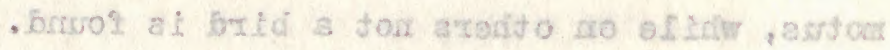

$$
\text { OS exshts }
$$

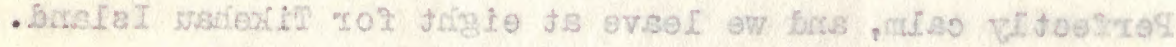

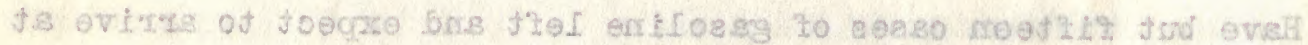

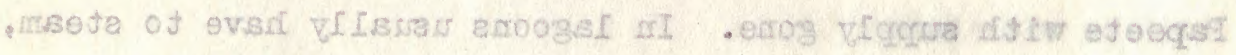

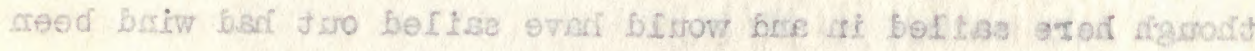

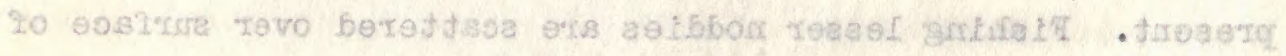

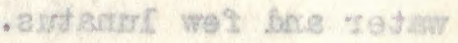

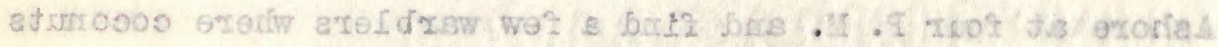

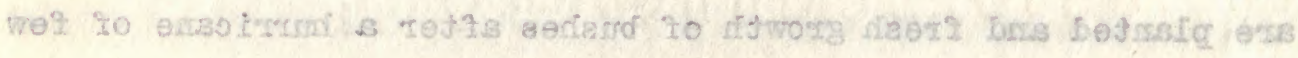
- IDad ascor

IS pirsts

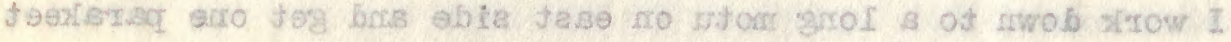

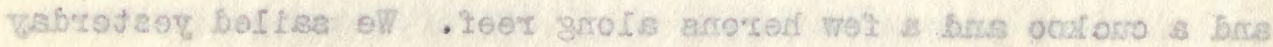

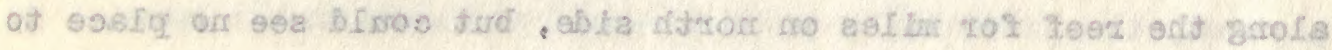

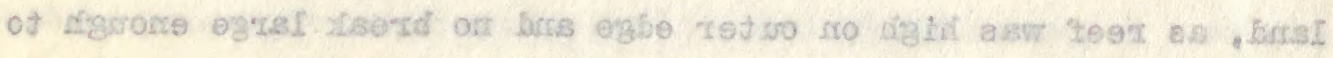

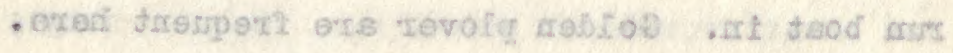


June 22

Ashore by pass, as Captain does not fancy going in as

pass is narrow. Correia gets a dozen term eggs on north side pass (noddies') and I get two dozen on south side of pass on detached pieces of brush where cats evidently do not range, for some nests are less than a foot above ground. Nests are made of small twigs from bushes and are often lined with tohunu blossoms, an occasional nest having a few small shells or bits of coral in it. Most nests are old ones, and I saw one newly built of grass largely which was picked near site. A pond of fairly fresh water near the colony was studded with rocks. The birds would sit on these, as well as in the bushes where the nests were. A scattering fairy tern or two was seen here, but they were very scarce. Inree or four lunatus terns flew along the reef. In eve about 3:30 I was walking along the outer edge of the reef and a parvirostris shearwater came flying along over the reef and was shot. Female ovaries slightly swelling. Louie got a rail near the pass, and a native said a few were found on the island and that formerly before the cyclone ground doves were common but now very scarce if present.

\section{June 23}

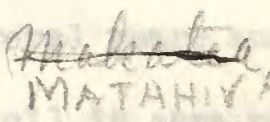

Arrived here at ten in the morn and find people here from Tikehau and 'France Austral' getting copra. The west side south of pass along the reef is tilted up in small benches, and farther 
SS emsto

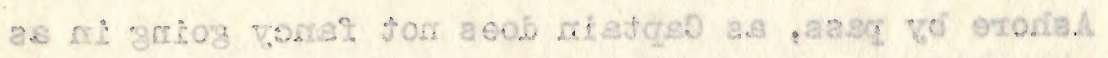

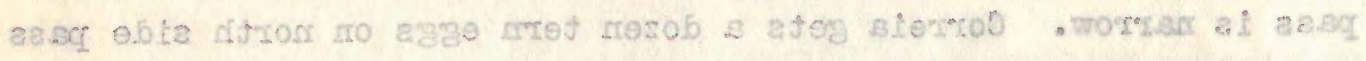

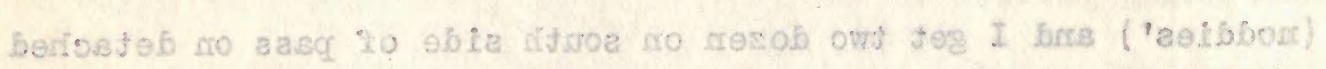

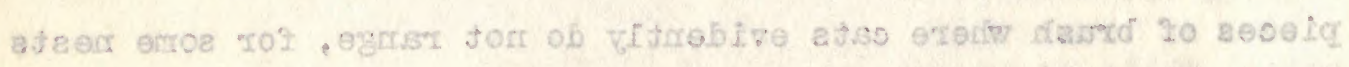

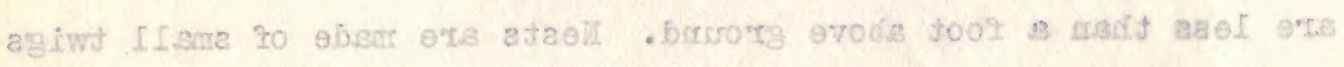

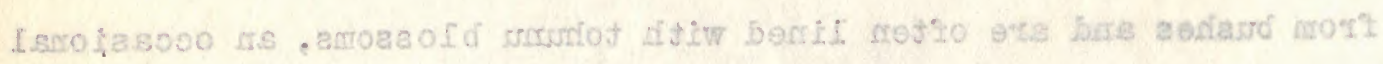

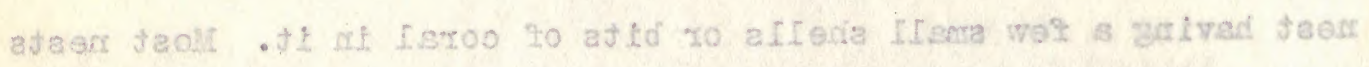

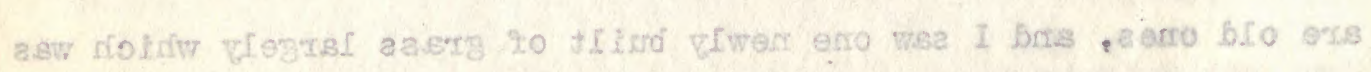

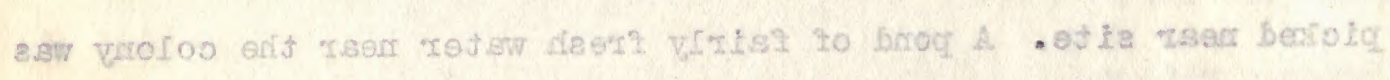

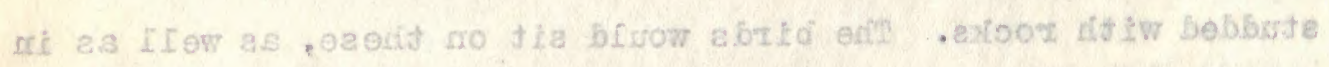

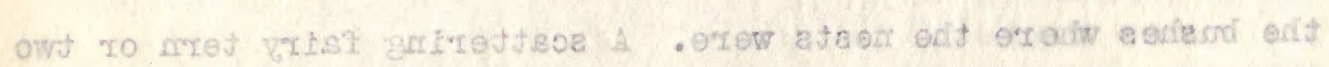

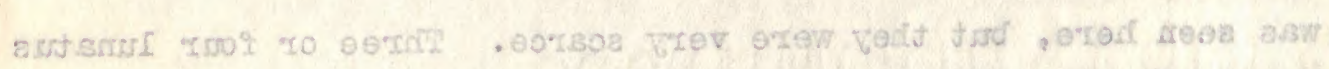

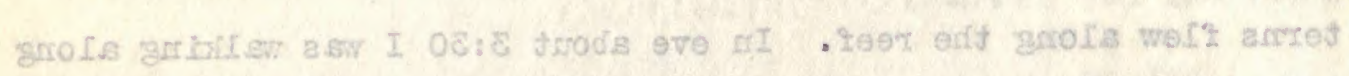

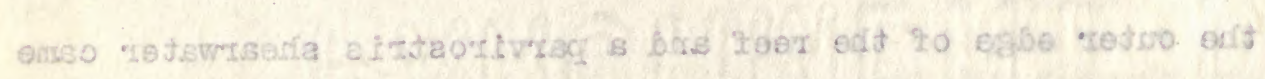

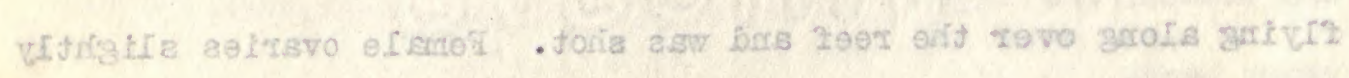

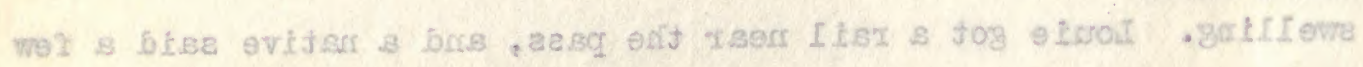

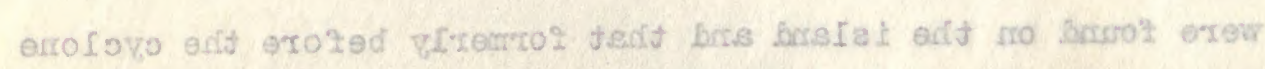

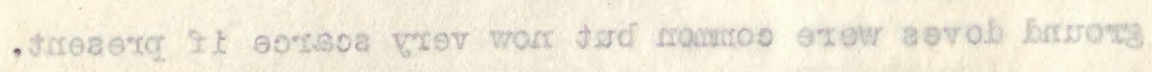

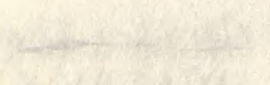

as arsert

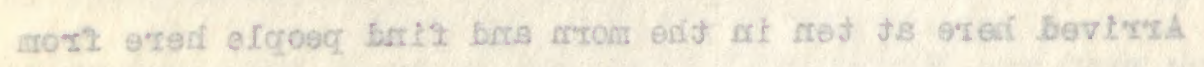

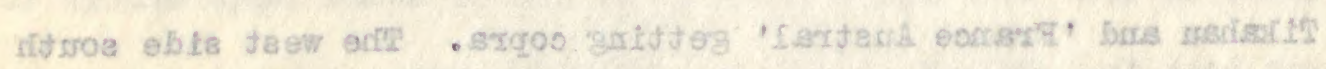

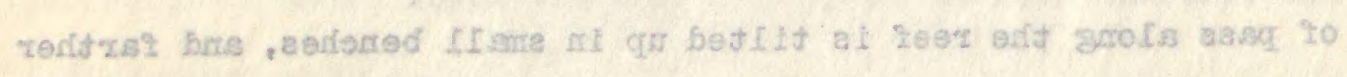


in has been tilted (?) straight up, resembling the ground on Wakatea. This is only a section a few rods in width for a short distance along the coast. Boobies (redfooted) and frigates are nesting here and several fairy terns noted. A curlew was shot and plover and tatlers common. Herons in blue and white in about equal numbers are seen. Lesser noddies probably nest on side where boobies are. Yellowbill terms are common fishing in the lagoon, and outside noddies are seen fishing, as well as sooties. An old wreck is seen on south side, the after part being thrown up back of the beach against some large trees and others pieces scattered along the reof. An iron ship, three mast ship, says a sailor. The island here is somewhat wider than most of the atolls, it seems at least on the south side where I went today, and coconuts look good, though, like all islands, mach land is not planted. The natives, however, have about all they can handle, for population does not seem to be increasing, and the work of clearing and keoping clear the land now planted is a big task. Quite a bit of cutting and reclearing is necessary after trees are planted and they begin to bear, for a strong growth is frequently seen in places where the trees have been planted several years and are ready to begin bearing. Rats take a large toll in some places and dozens of muts are seen under some trees that the rats have eaten into when they are half grown. Have on two or three occasions seen rats going up trees, and only rarely are some trees 


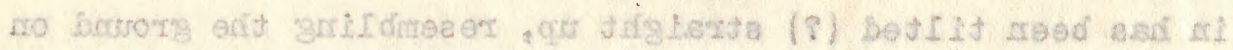

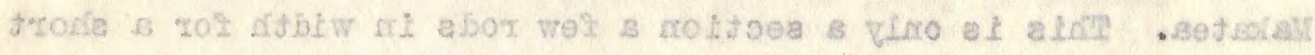

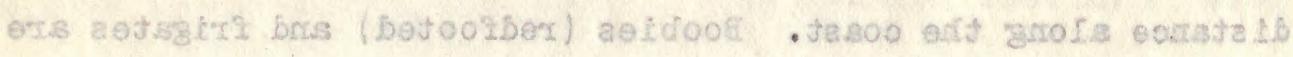

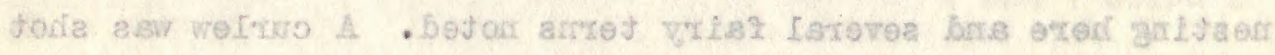

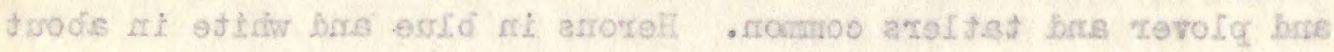
orexim ebla mo fesm VIósdorg a

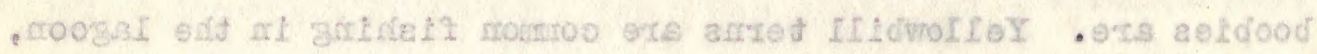

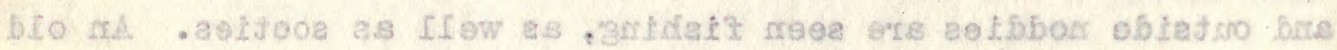

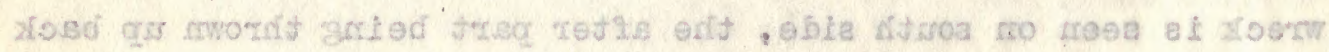

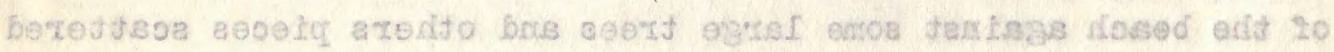

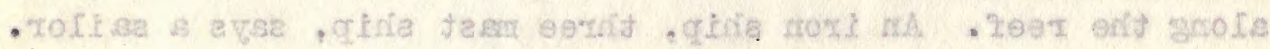

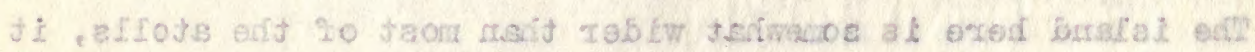

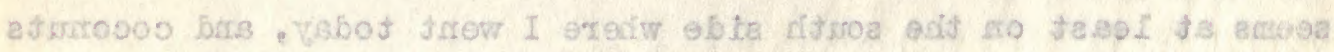

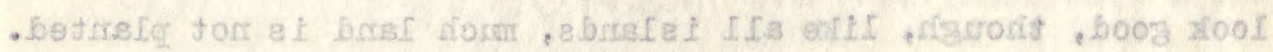

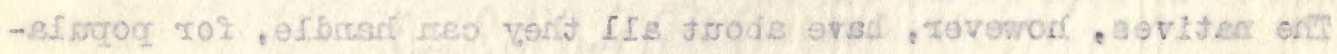

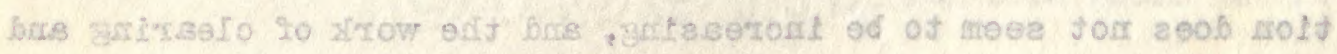

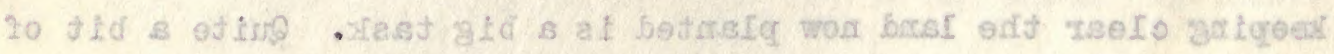

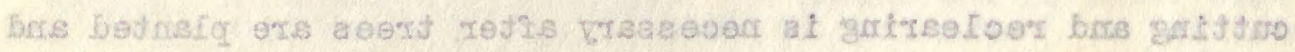

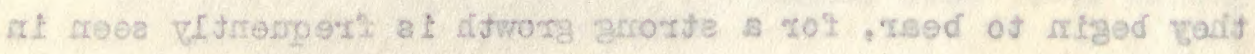

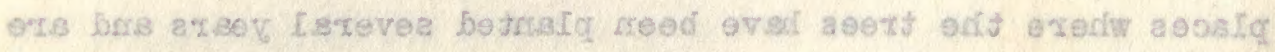

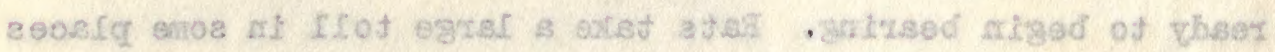

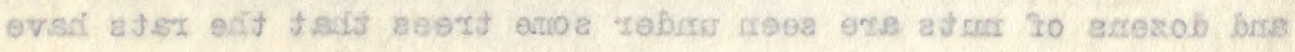

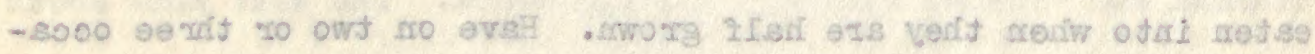

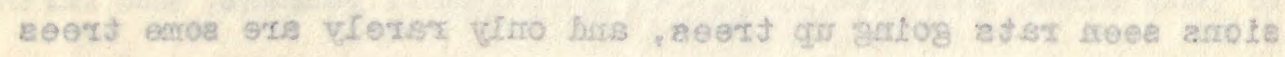


seen bound with a piece of lead or tin to keep the rats from climbing. Great many natives are in debt from the season of 1920 when traders gave long credit in hopes of big profits from pearl shell, but price dropped during season and the natives could not pay off. The Chinese merchants are now in some cases buying coconats as they come from the tree and drying them themselves,--a method that perhaps appeals to the less thrifty natives, though I cannot see much profit to the Chinaman, for he pays about a franc for four nuts and four thousand make a ton of copra, which is worth about a thousand franes at recent prices. At this island are two frame houses, the rest being made of coconut leaves. Twenty-five or so others at the pass. At Ahi Island are most of the houses mede of lumber and usrally roofed with galvanized iron. Two cutters are anchored in the shallow pass and two or three hauled up for repairs nearer the huts, the pass not being deep enough to a.llow them inside lagoon.

\section{June 25}

I work to south of pass and Correia and Loule go north to booby colony and a few boobies and frigates, getting three lesser frigates as well as a couple of big birds. I made a speciality of herons all day and picked up sixteen of the wary birds, using a trick learned from a plume bunter in Brazil. Over this same ground Saturday I couldn't get a bird. 


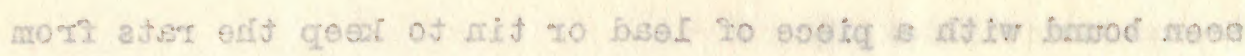

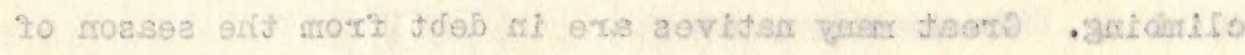

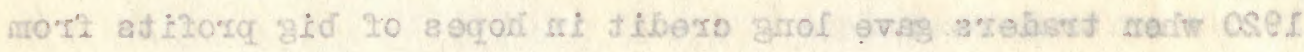

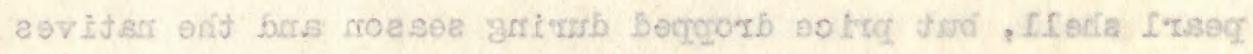

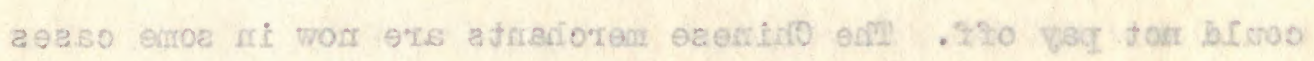

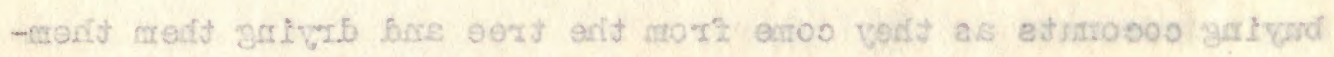

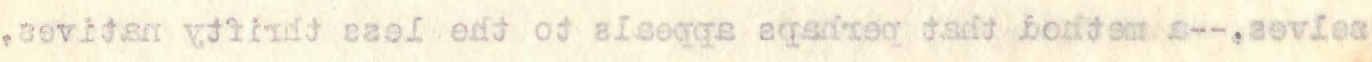

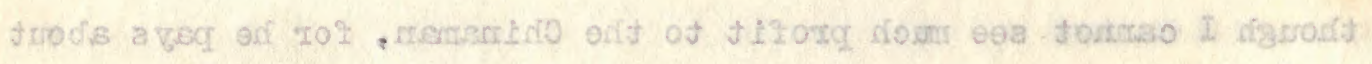

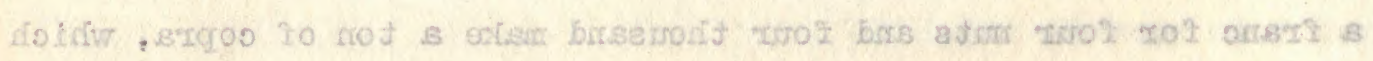

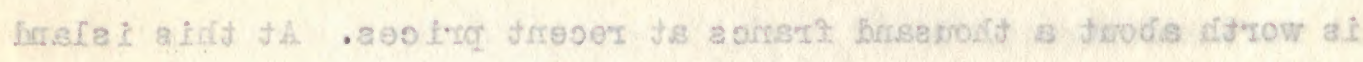

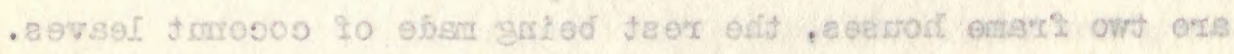

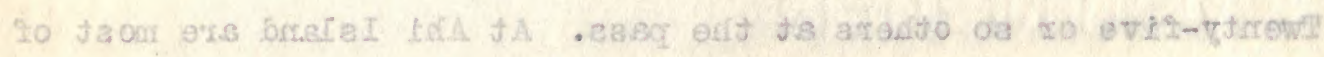

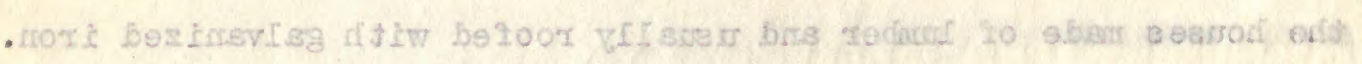

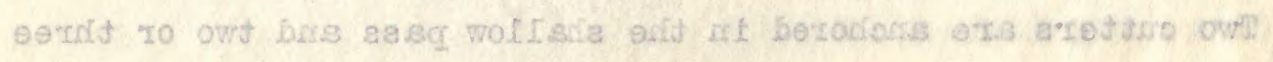

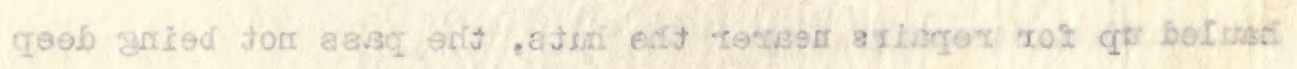

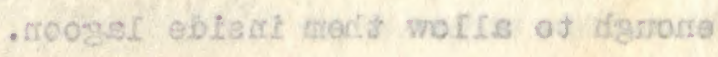

\section{as ersto}

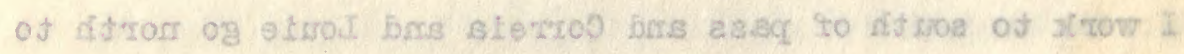

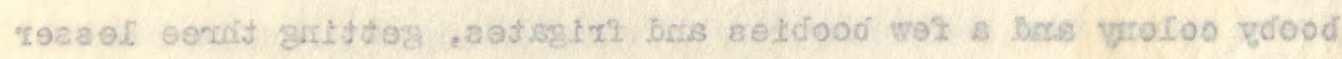

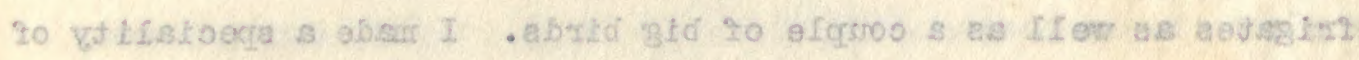

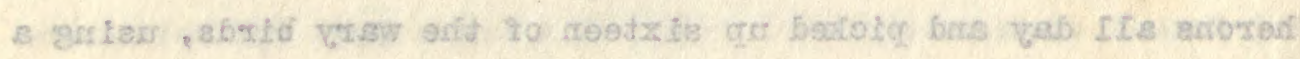

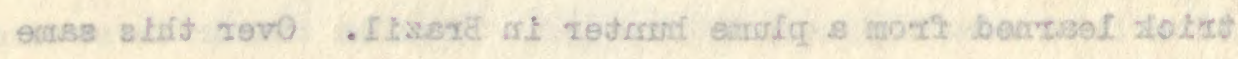

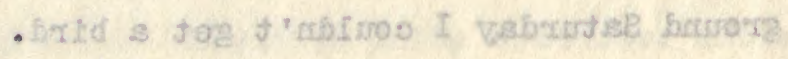


June 26

Correia goes ashore and I skin remainder of yesterday's take. Louie is sick. Correia gets a few noddy terns and finds them nesting in pandanus trees.

\section{June 27}

I go past booby colony to east end of island, and returning same way visit booby and frigate colony, finding birds nesting, and a few lesser noddies roosting with the other lind. Young birds in many nests. I get four herons, and Correla gathers one and a native gives him a redtail tropic that he found on a nest (?). Few tropics nest, as pigss destroy nests, and I saw no biras of the species. Lesser noddies are also very scarce, not a dozen being seen. We leave in eve for Papeete. Several large fat people here.

\section{June 28}

Sixty miles to go at noon, having made a hundred since yesterday at four P. M. Reach Papeete probably early tomorrow, as land in sight at one P. M. 
aS ocest,

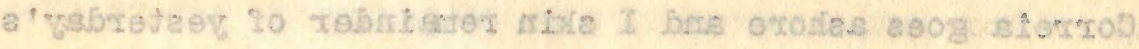

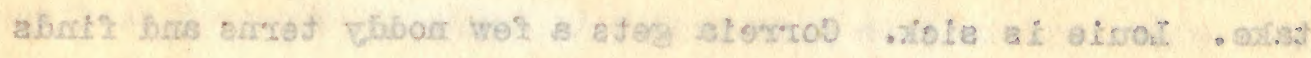

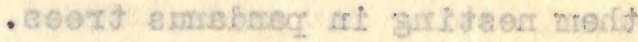

re orsti

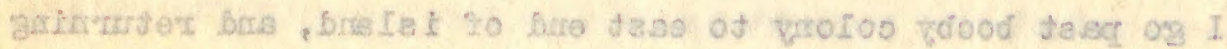

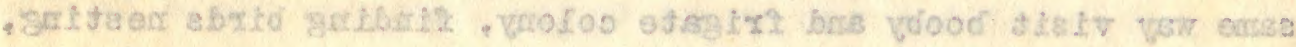

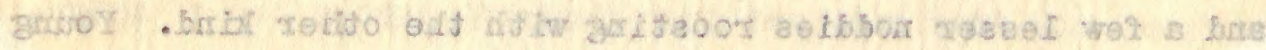

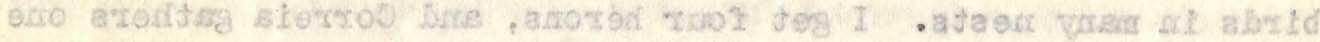

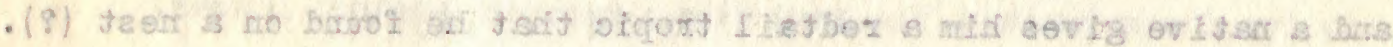

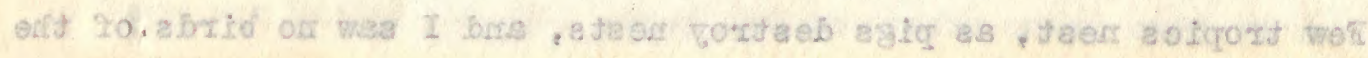

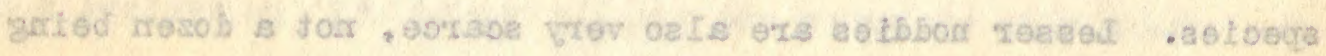

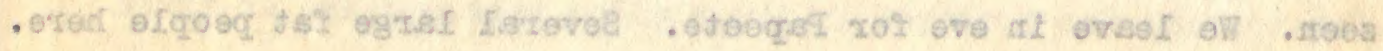

\section{ge essst}

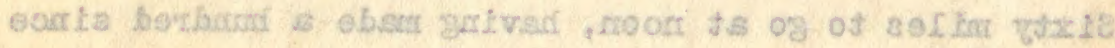

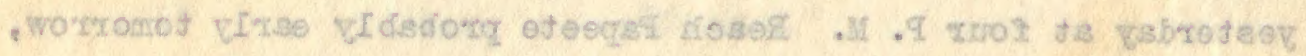

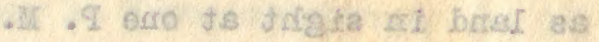


Nonderam Leland

Shelches by Ermeti if 7254
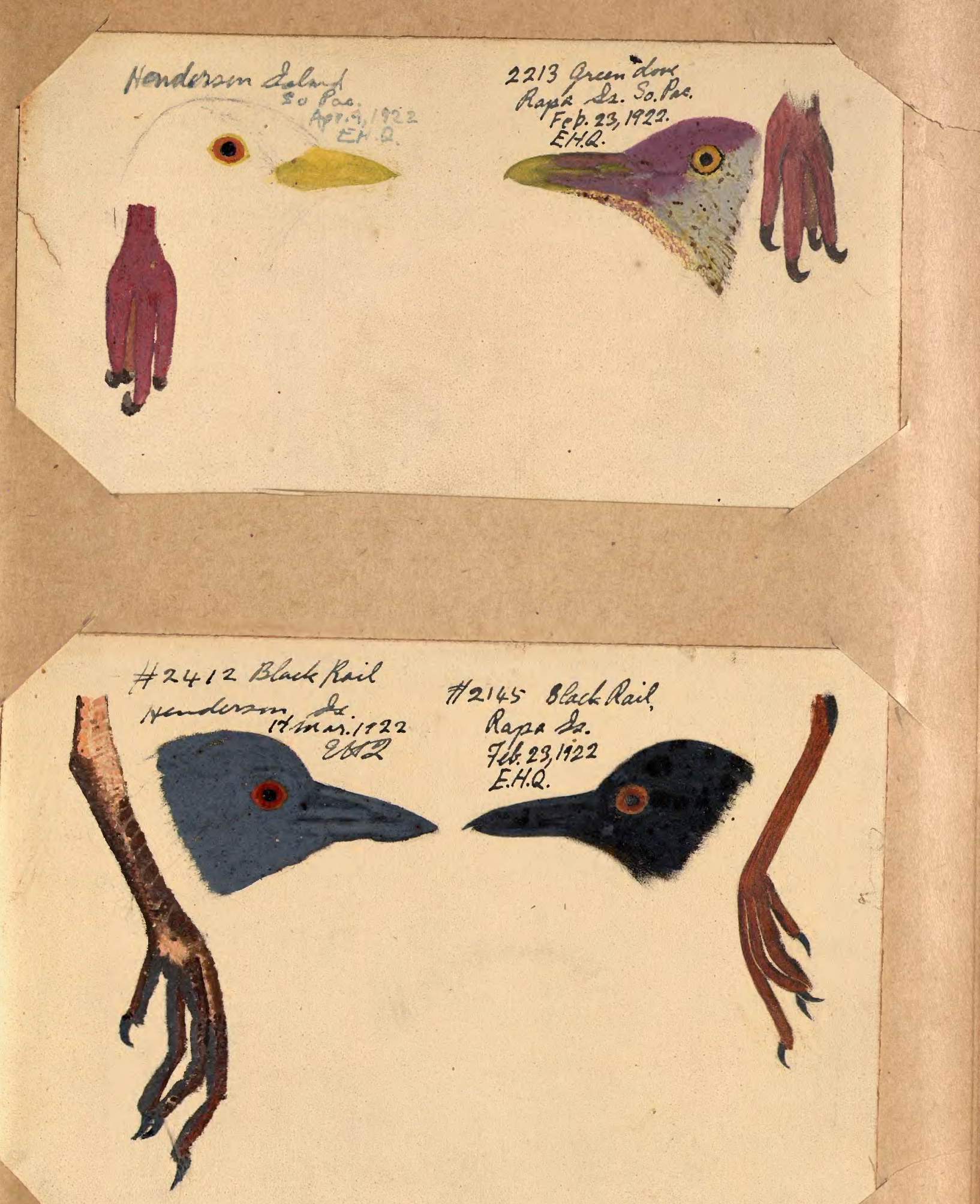

\#2145 slack Rail Rapa 2 . E.H.Q. 


* 2357 Redfrot 2eoratio (sula piscator) $\times \frac{1}{2}$ inesh 15.922

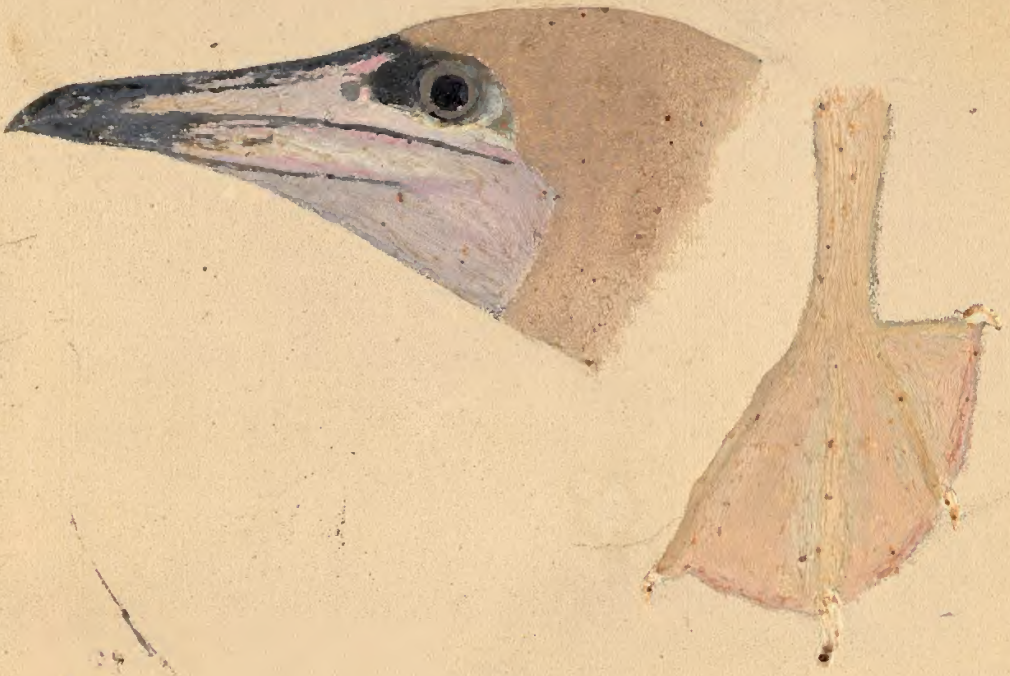

*25 82 Blmefrech Borly

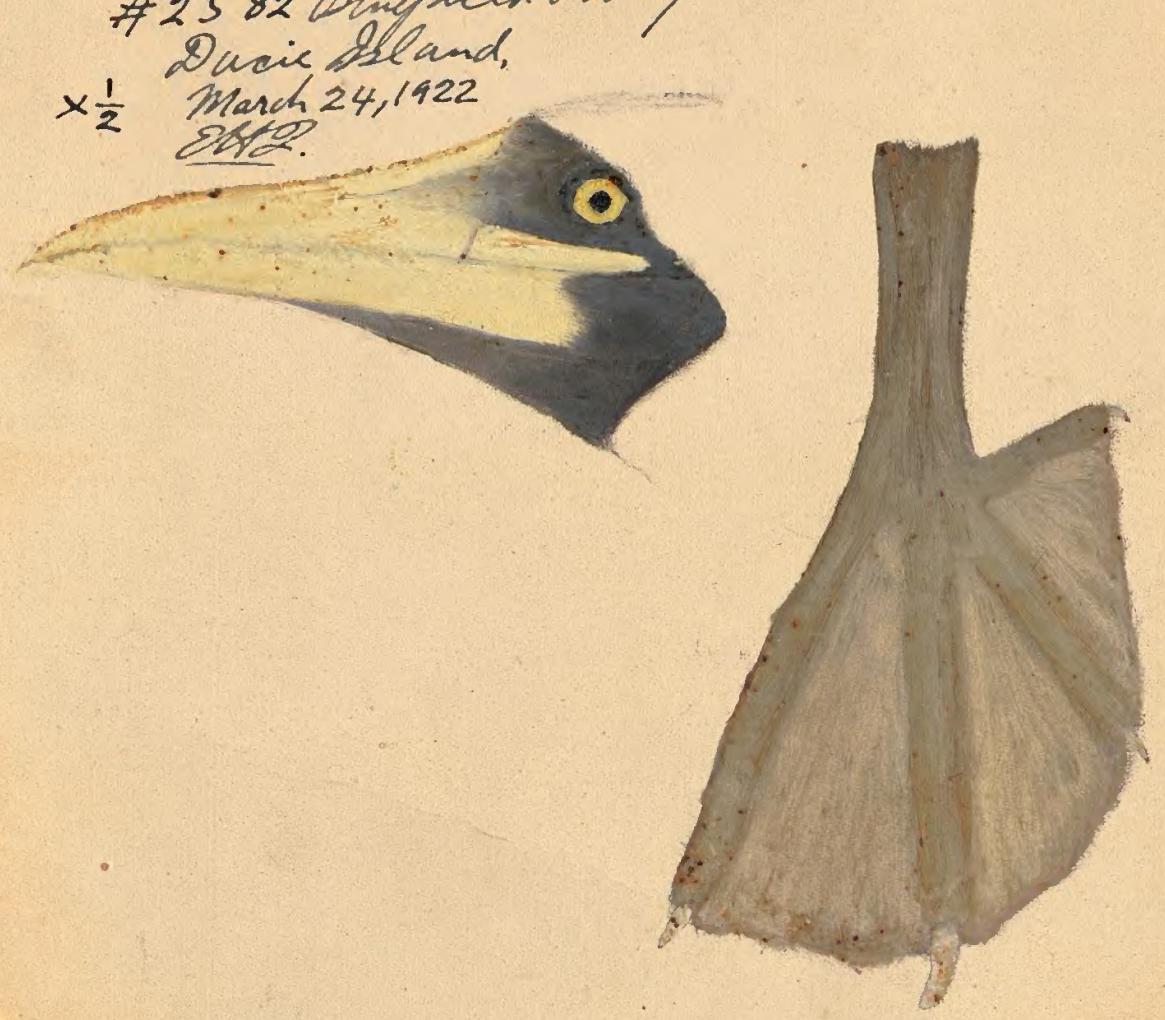



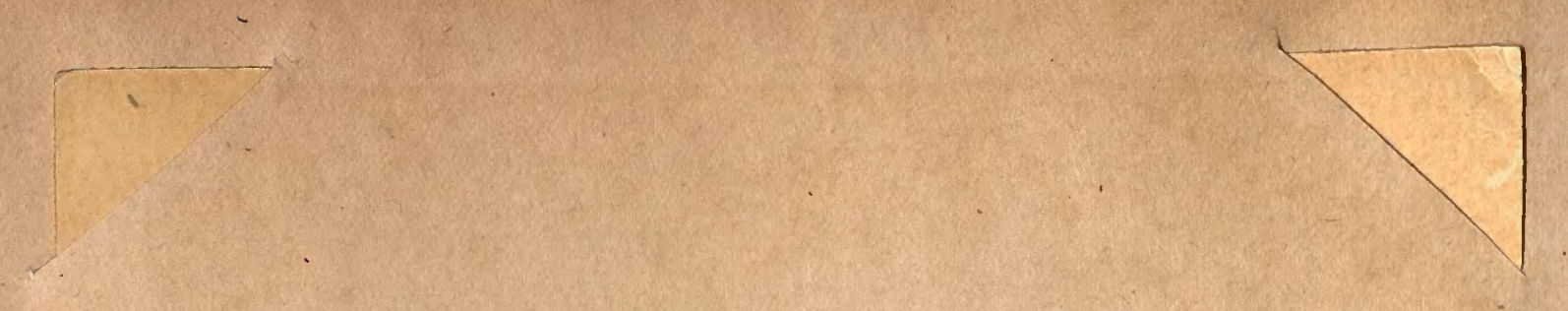

1 


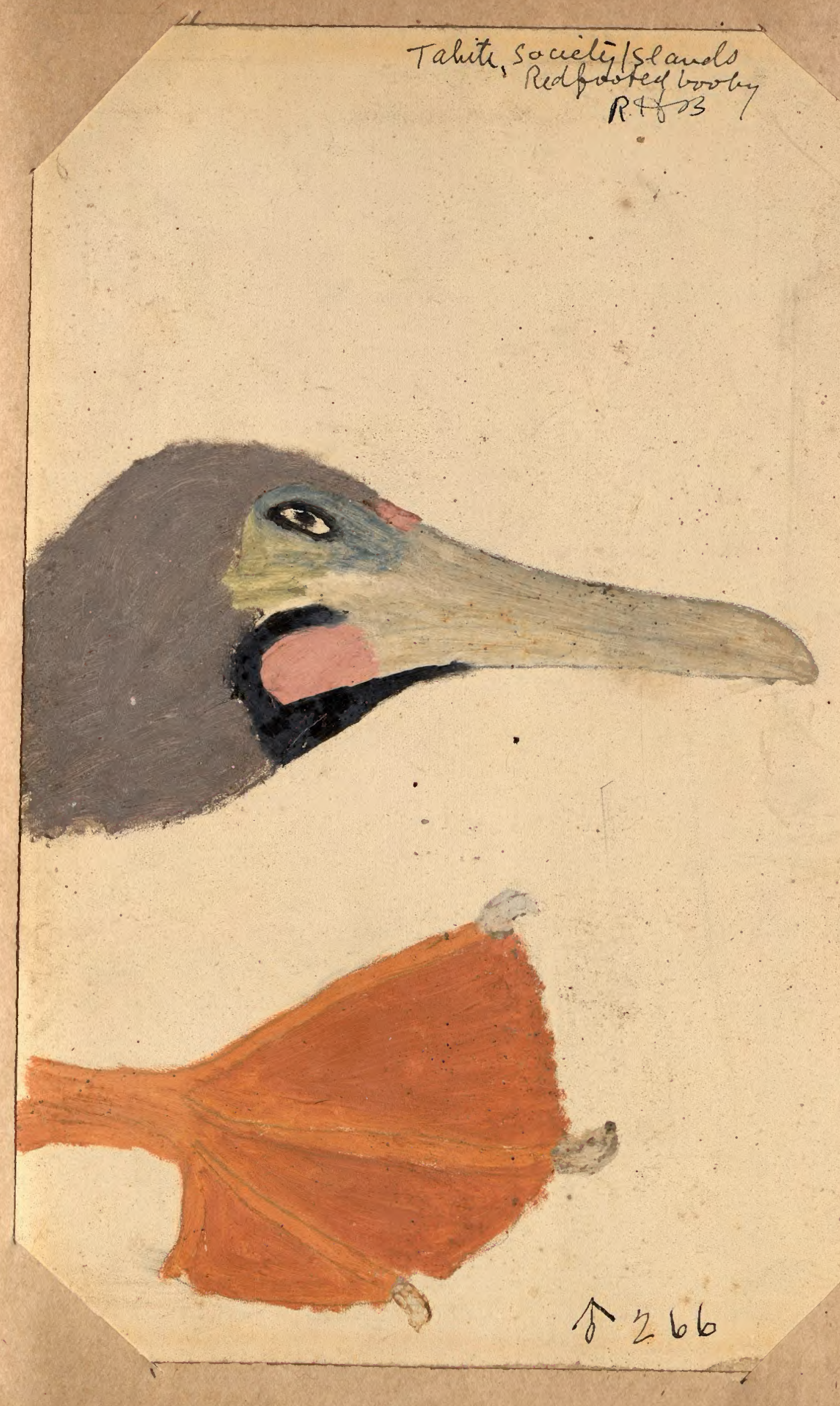



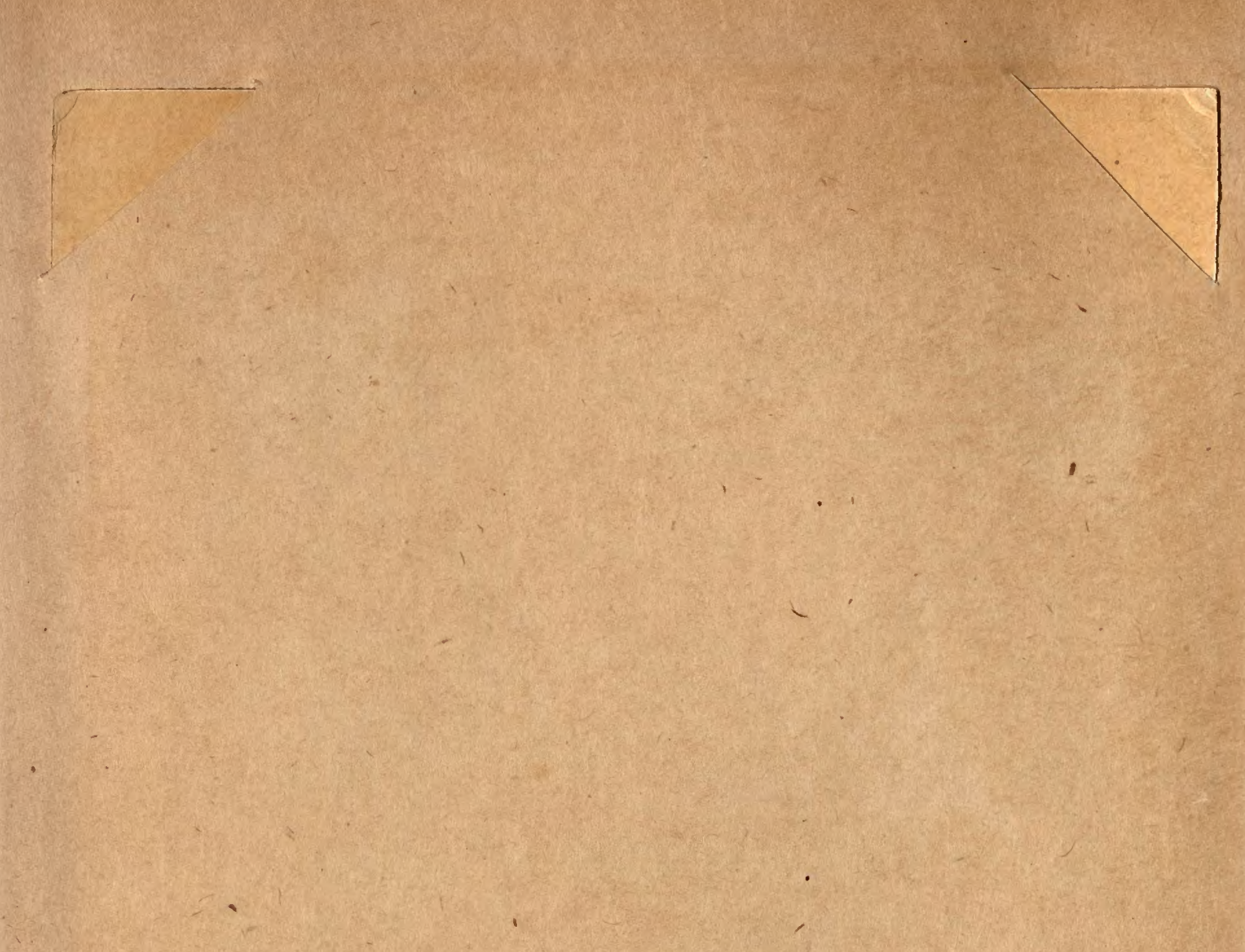

-
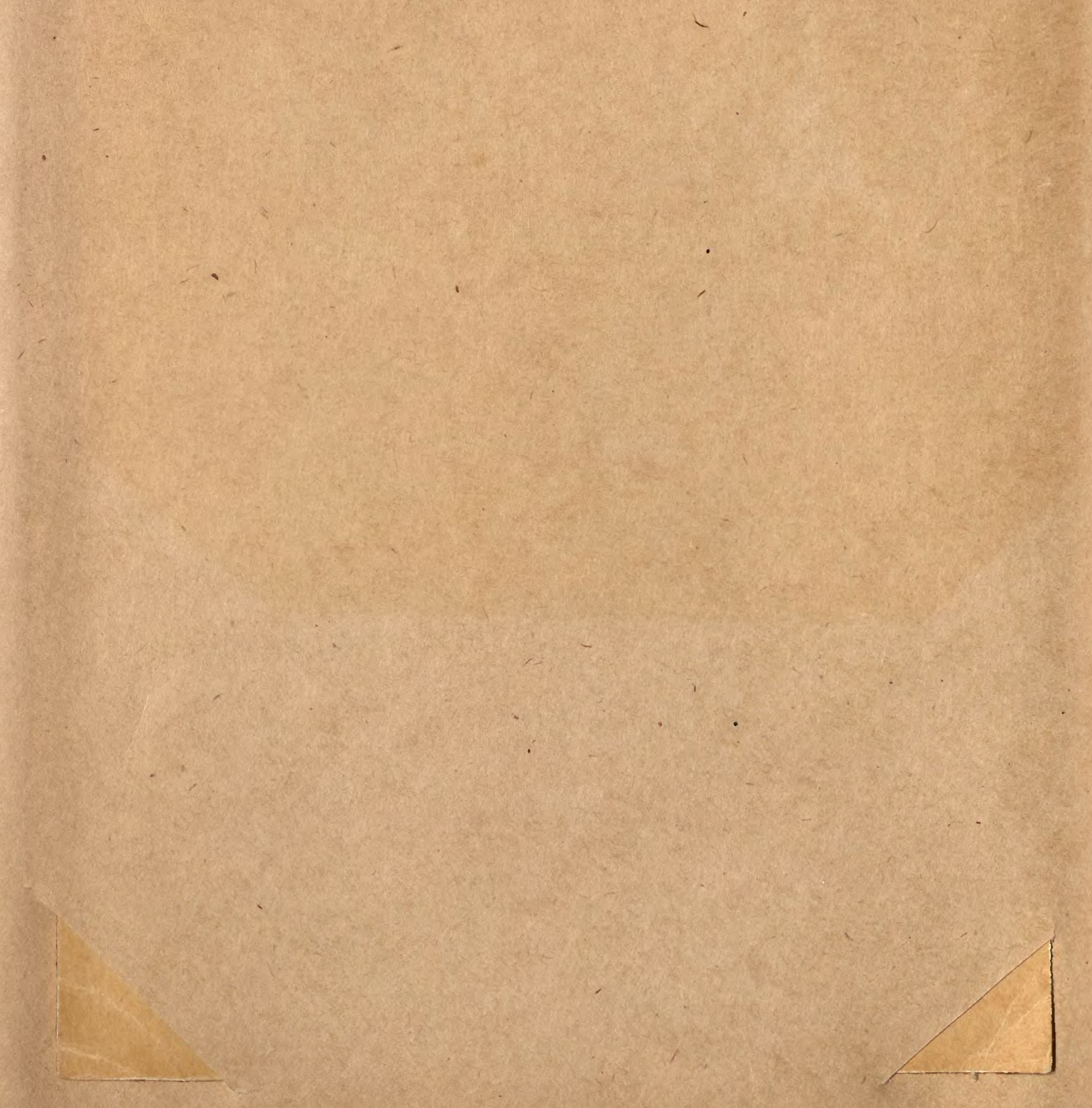
*2355- Prtite Tem Lat 25.5 . Fong 129. W.
Marchls, 1922

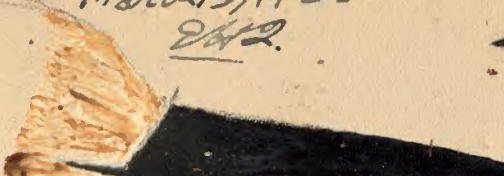

\#2231 White Tem, Bass Precha, So. Pac., Fel. 27,1922 E.H.
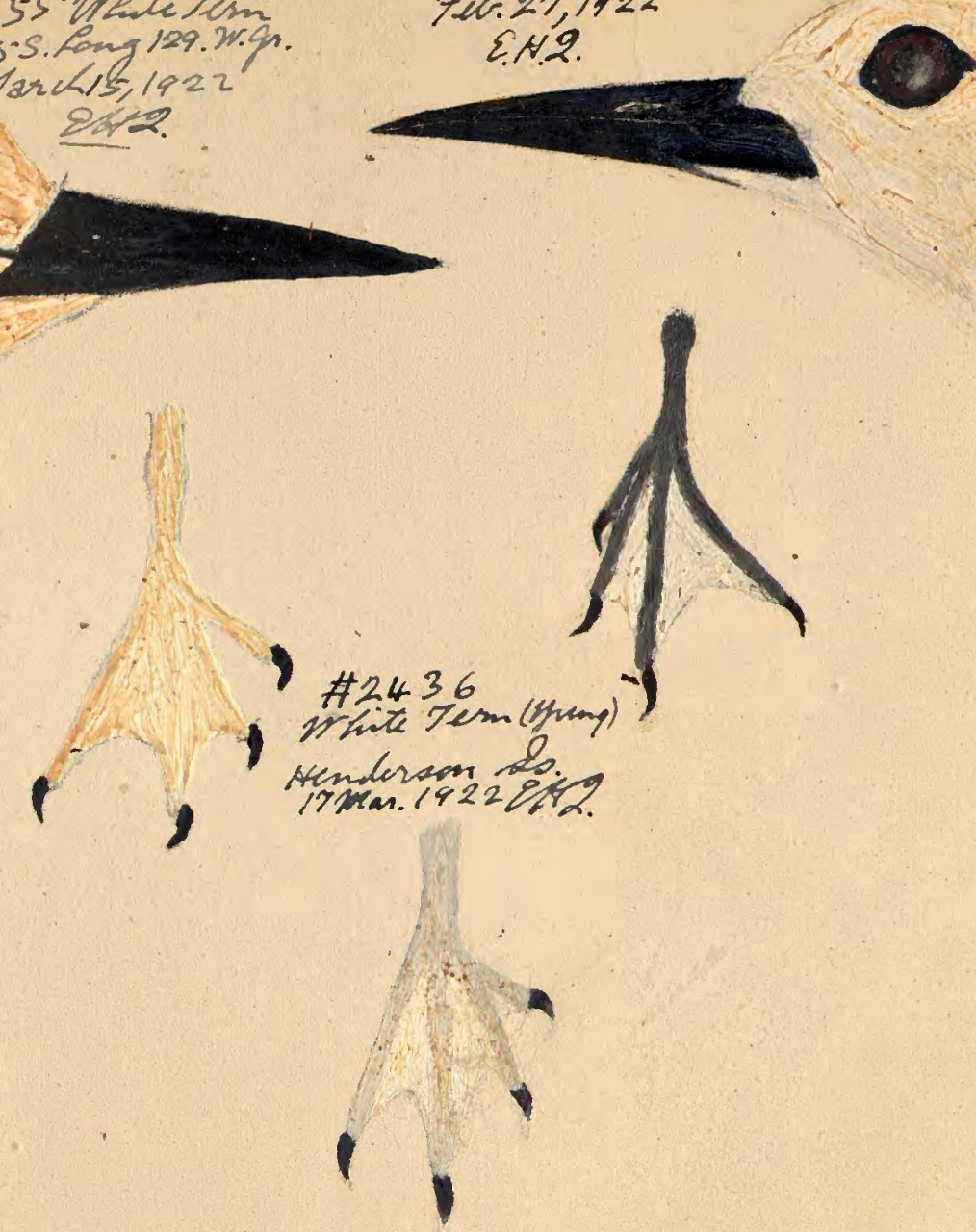



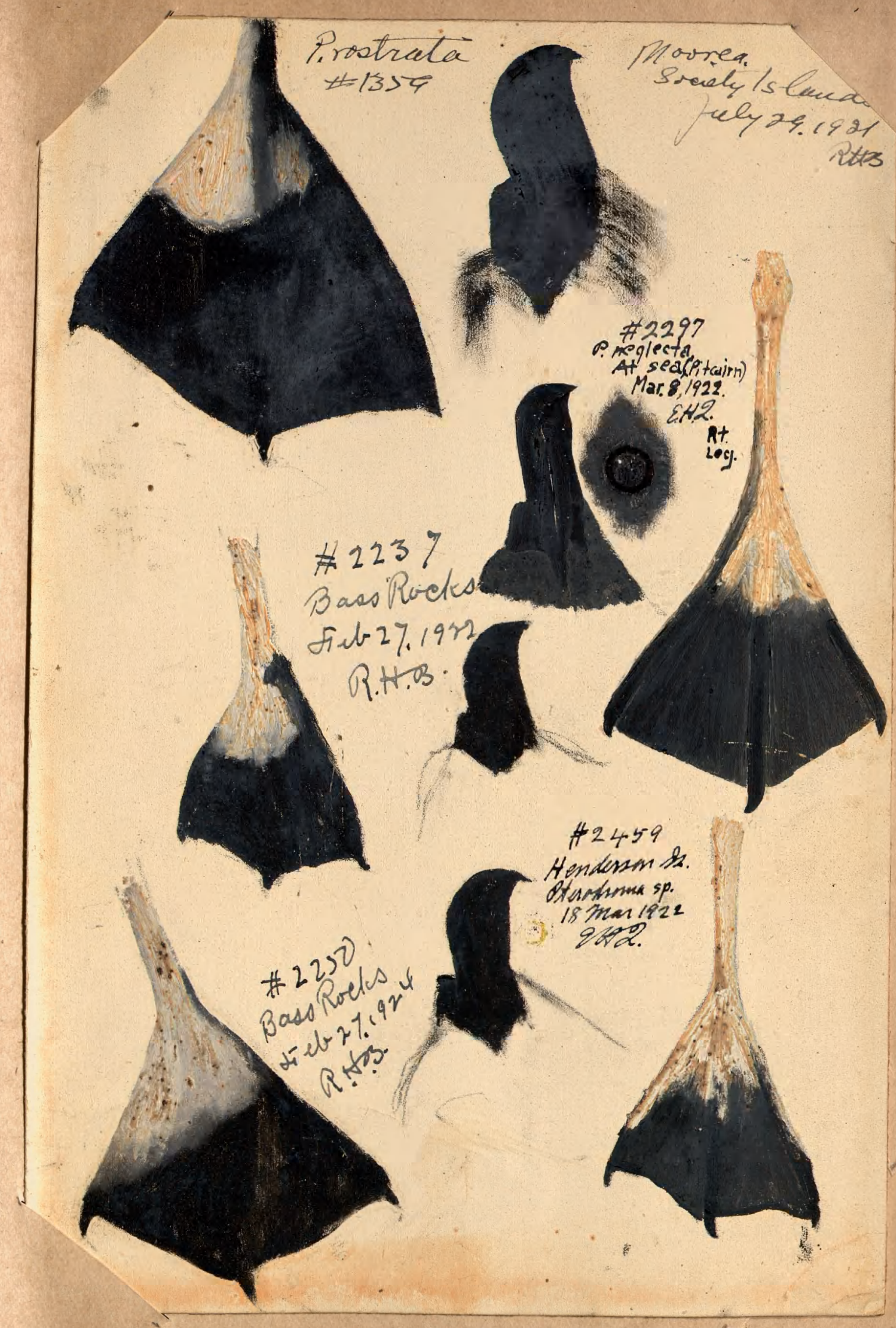



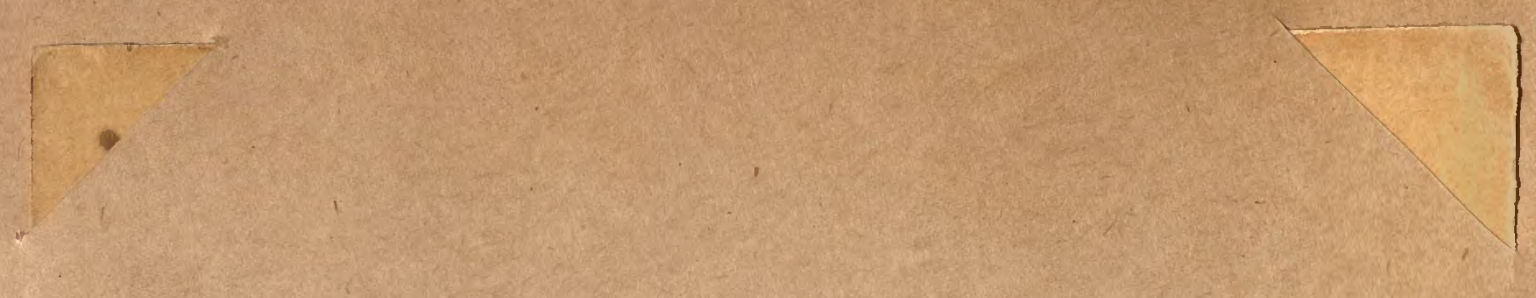

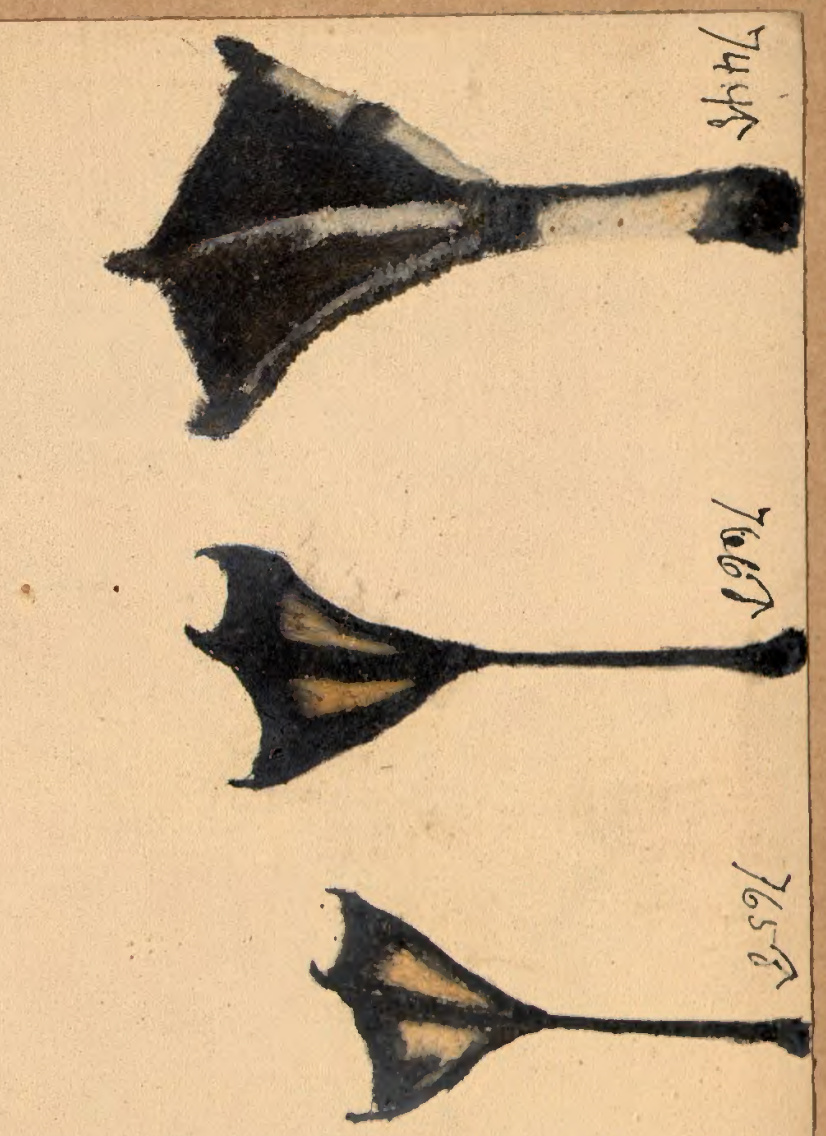

क

को 


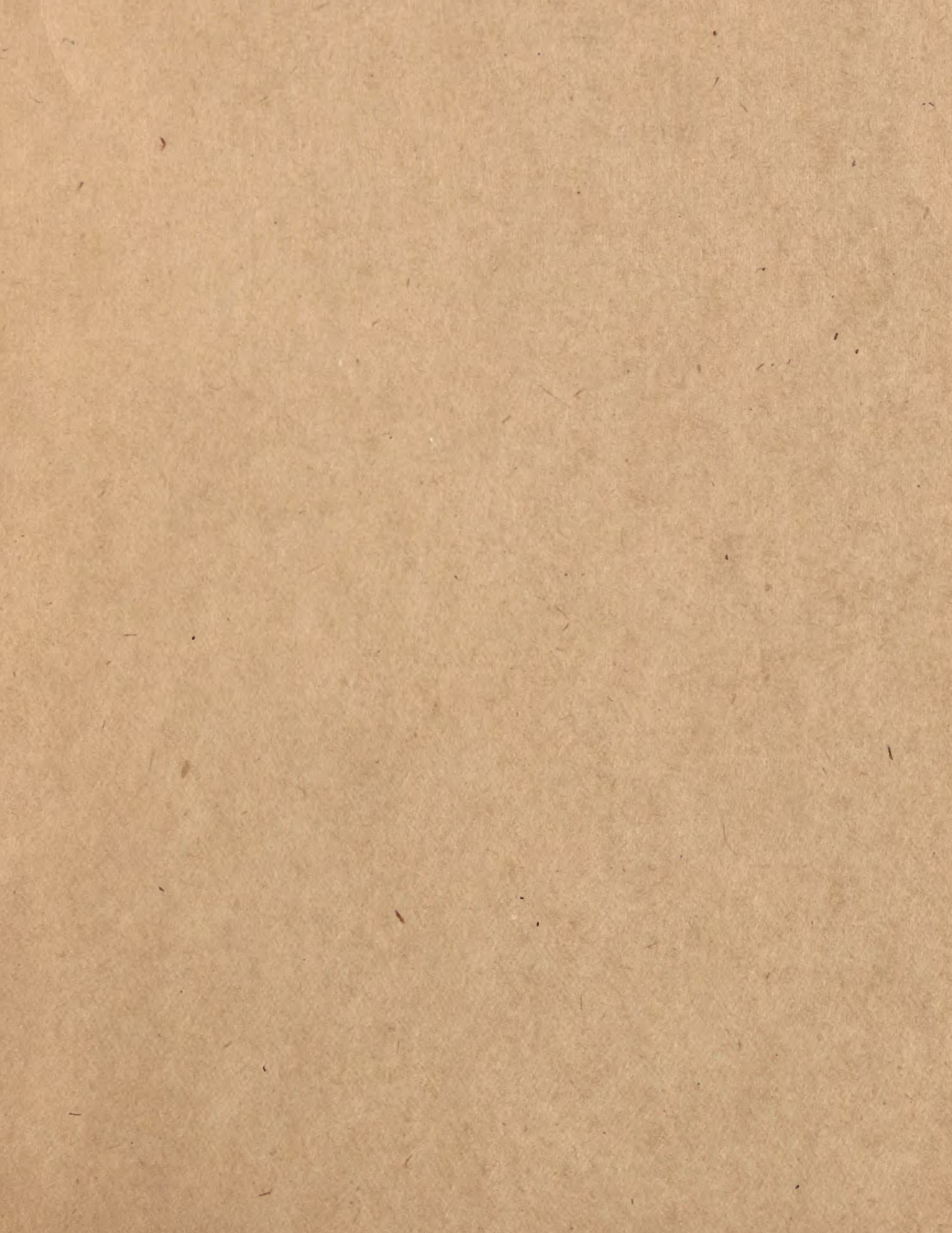

(7) 
Field Notes

of Whitney Expedition

Uapu I., Marquesas

Sept. 8, 1922

On the top of ridge about 3000 feet watching neglected shearwaters, noddy terns and occasional yellow-billed tropics swing along to windward of ridge; strong wind blowing from east as swiftly flying paroquets and doves cross from one side to another. Iittle swifts work back and forth catching small insects. Fairy terns below me sail around and around. Doves on set wings come blowing over the ridge to look for berries. Ripe guavas as large as Bartlett pears are on ridge, while lower green coconut trees grow up cañon a couple of miles. Flycatcher calls cheewee cheewee. Nest 40 feet up. Warbler nest 15 feet in willow tree.

\section{Tiau Island.}

September 22

Top of island peak has house site paepae about ten by eighteen feet. Stone weighs 200 pounds or so. Pigs about everywhere. A Hundred sheep or more in sight. Hear warblers, flycatchers, swifts, and fairy terns. Highest peak on lee side paved with rocks, flat side up; two or three terraces, twelve feet wide, sixty feet long; smaller pile 4 x 15; big natural boulders. Few flint axe heads in process of completion found. Buro trees in grove. Sooty terns below on cliffs.

Lesser noddy terns: tukak tukak

Fairy tern: creek creek creek

Sooty tern: creek cruou

Red-footed booby: cra ouuuuu

A ground dove walks around me at 20 feet distant. 


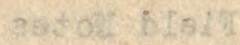

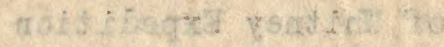

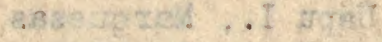

Geted 8.450

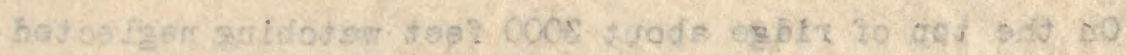

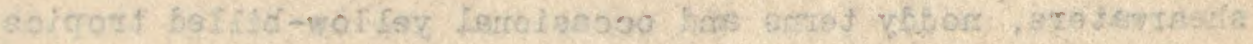

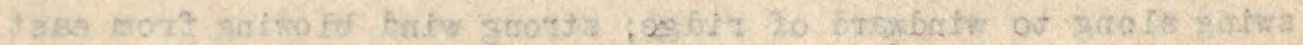

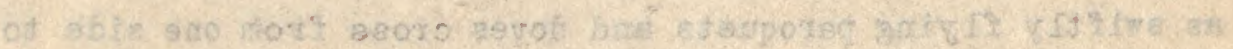

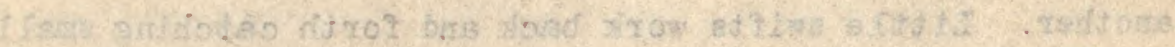

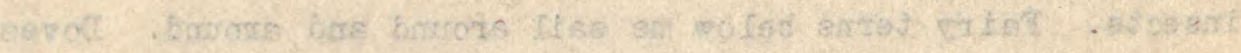

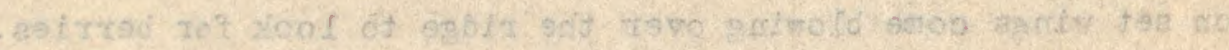

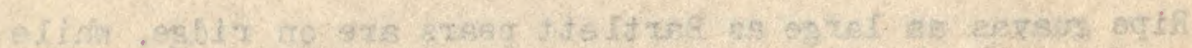

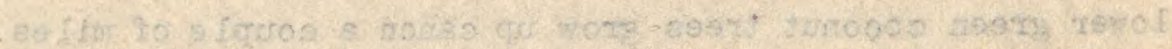

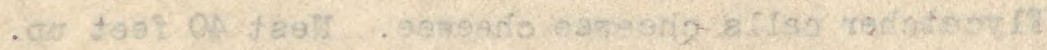

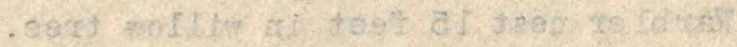

Gatefer suoth

SS rodistotoig

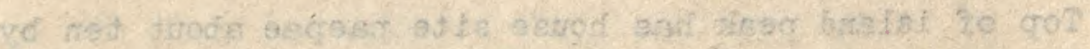

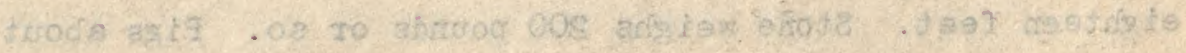

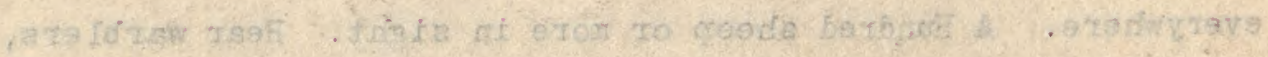

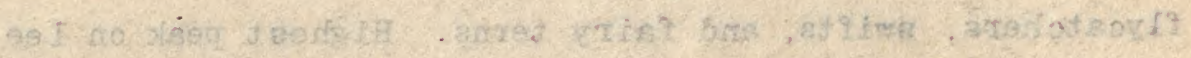

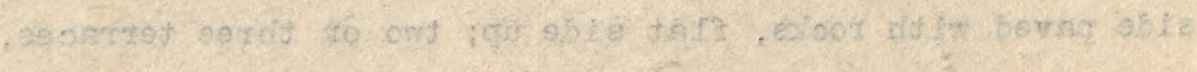

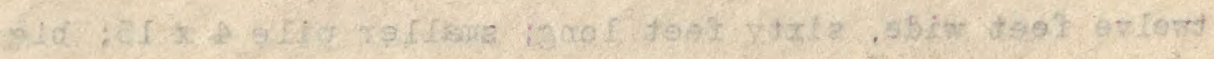

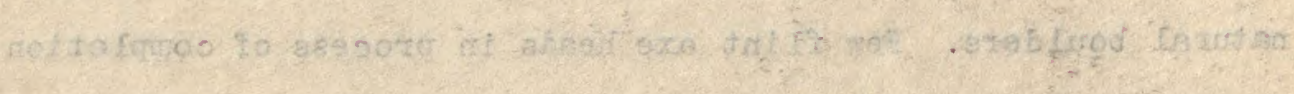

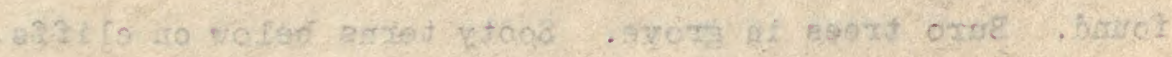

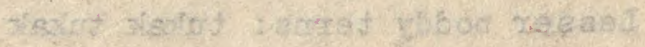

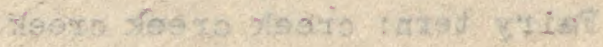

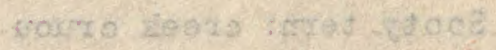

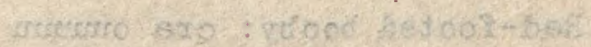

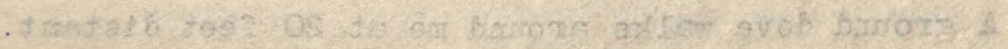




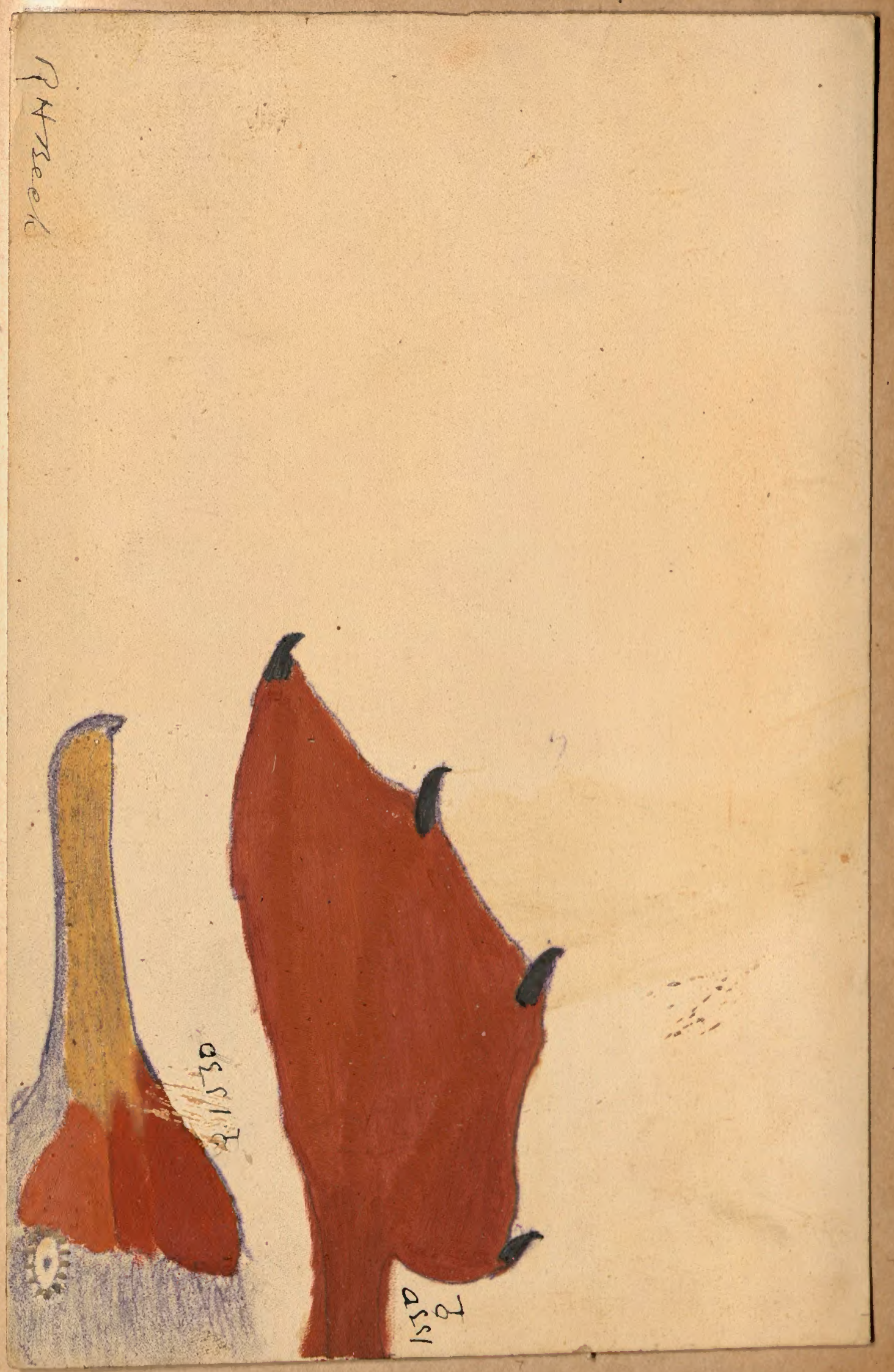



Another flies over and lights in tree, while one on ground flies up and preens itself; both fly dow and pick leaves, both in the same spot facing each other.

\section{Hatutu Island \\ October 5}

Lesser frigates, young, are near top of island on lee side, small nest of sticks, guano covered, placed on ground, weeds, or tussock grass. Most young with yellow heads, downy breast, and back feathers. They snap bills when neared. Sometimes an old one sails over, a few yards below frigates in bushes.

Many lesser noddies' nests, but no eggs, in trees with downy boobies.

\section{Uahula Island November 9}

Sooty tern island, $1 / 4$ mile $10 n g, 300$ yards wide, covered with sooty terns, young of all ages and few fresh eggs. Some nests of a few small pebbles; young crawl under small twigs. A nearby island of sandstone had I unatus terns nesting on ledges; cavac cavac is the call. They nest in red soil on lee side of island. Under tussock grass on lee side we found Bulwer and white-chinned petrels' nests. Young sooty terns flying here, while on other island birds are younger. First island was undermined along banks by waves, and we used ropes to lower specimens $1 / 2$ mile from Uahuku Island. Cree $u$ reek cree $u$ reek: call of sooty terns; young call was cruk cruk.

On small islet many fresh deserted eggs of Bulwer petrel as not enough nesting sites. Some birds when pulled from nest sit a few minutes and then walk away; others fly. 


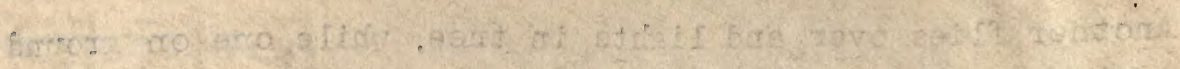

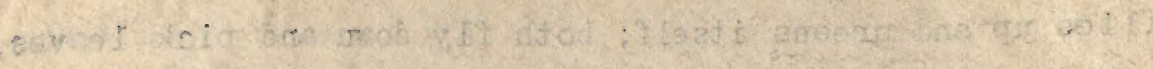

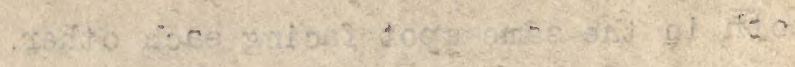

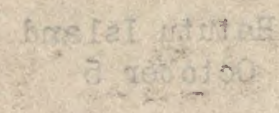

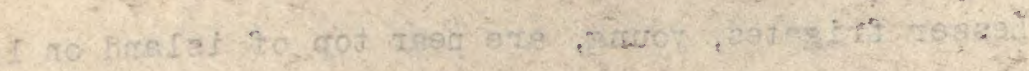

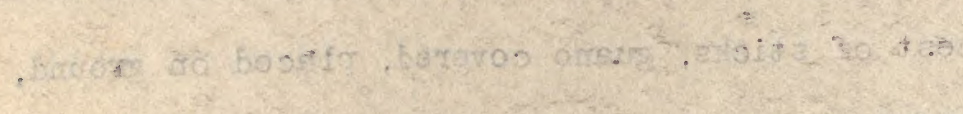

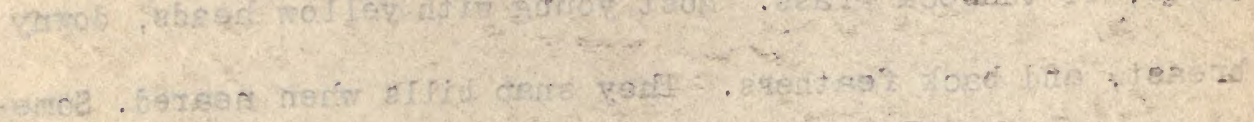

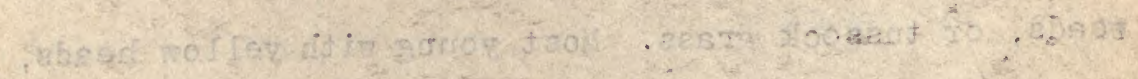

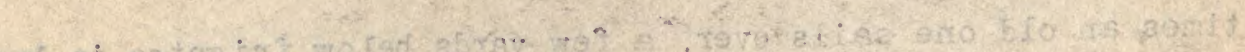
Gertings is

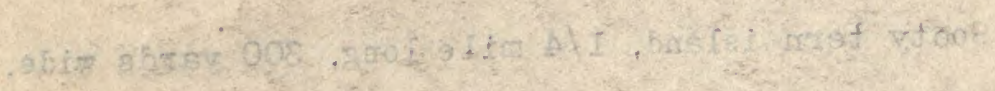

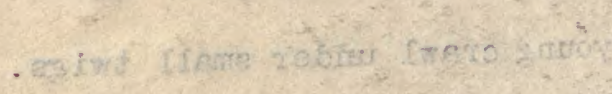

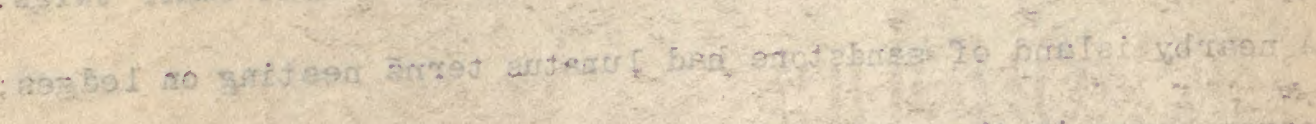

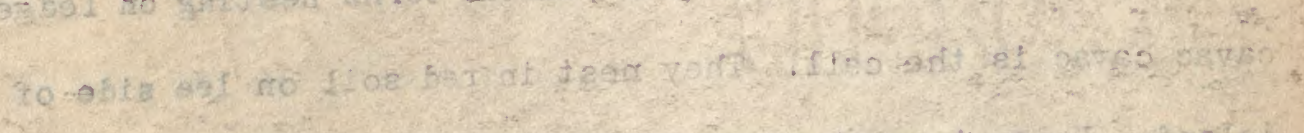

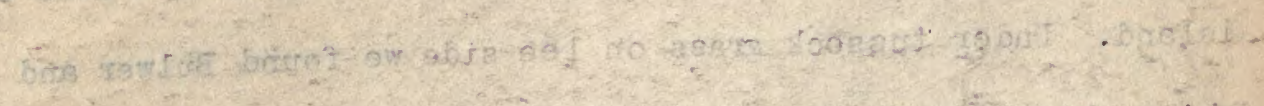

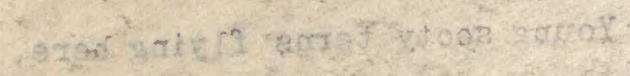

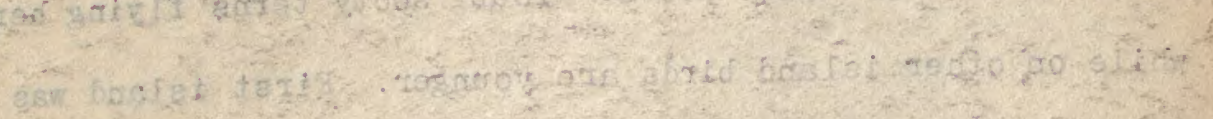

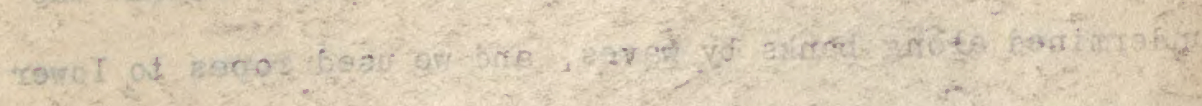

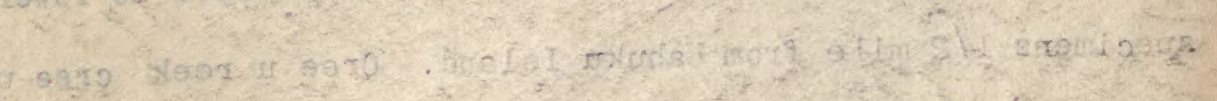

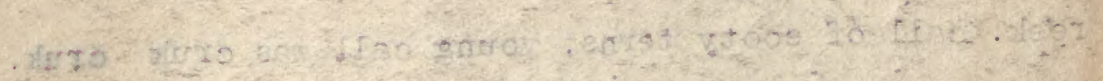

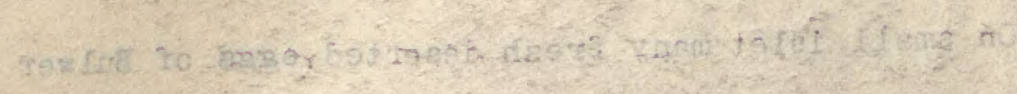

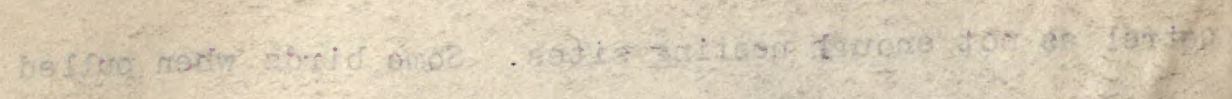




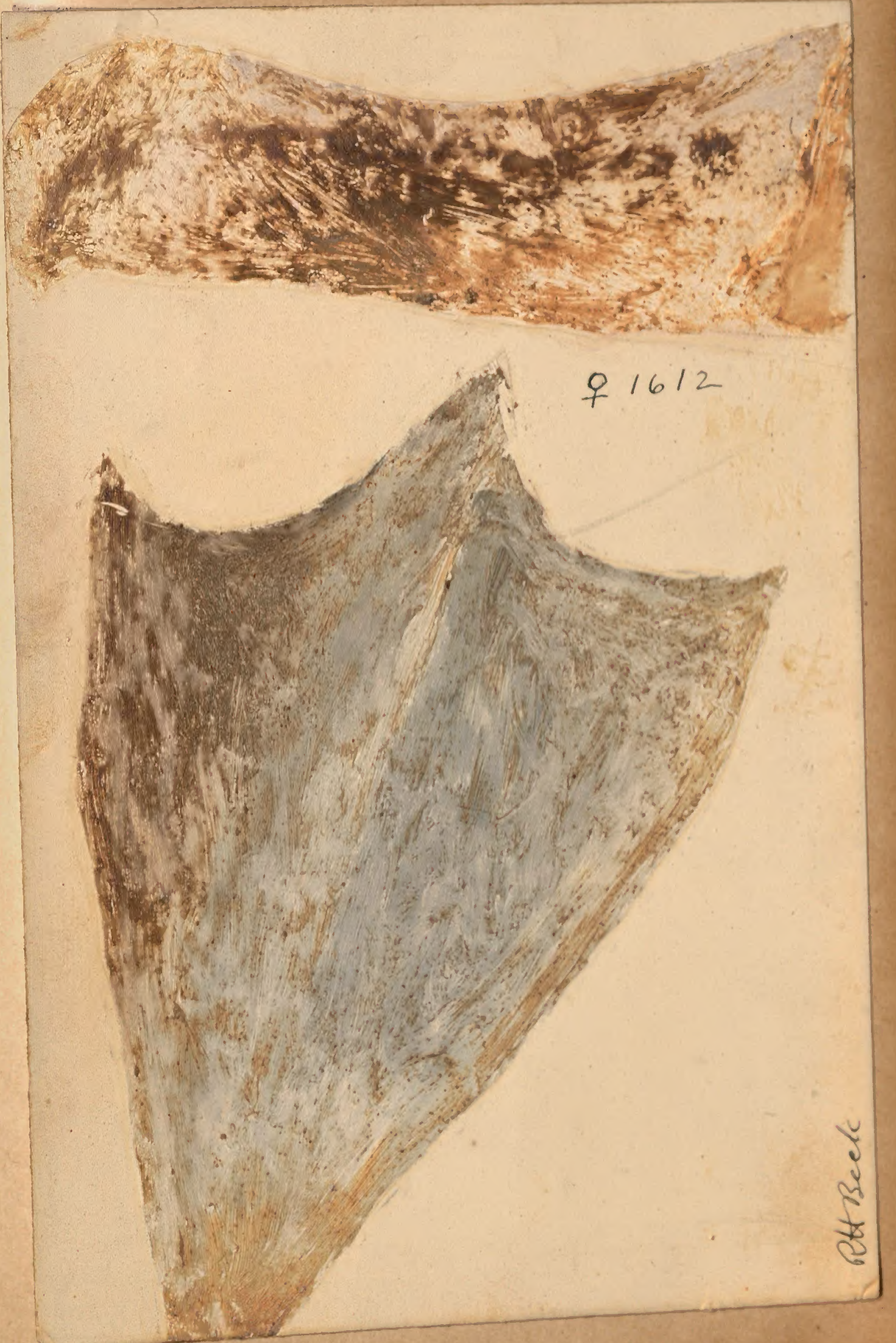



Fine, dry grass is nest of petrel usually, pulled from overhead perhaps. Island covered with sooty terns sounds like frog pond at 8:30 P.M. Dozens of dead young were noticed on rookery, cause unknown.

In morning nine red-footed boobies fly along coast, with one plotus booby flying along with them but above them; calm, fly close to water.

Blue ternlet calls soft low cre e e e

Doves circle about from banyan tree loaded with

small fruit. 000 coo c00 c00 u u

Flycatcher calls chee weu chee weu chi chi chi chi - flirts tail.

Noddy tern on ground tangled in seeds of large tree. Kingfisher: kaou kaou. Tahuata Island.

\section{Fatuhiva Island}

December 4 .

Rapid kik kik kik kik waming cry as well as call of young for food is flycatcher. Chi chi chi repeated rapidly call of young for food. Male calls cree re a reek.

Dove's nest of dozen fine twigs. Saw dove fly from nest in tree. I went over and saw both birds on nest ten feet up in fork, resting on main $1 \mathrm{imb}$, two inches in diameter. Watched five minutes; one bird flew away and then when I went under the nest one watched me from twenty feet, afterward flying away •

Rail call was whau uk whau uk trilling. 


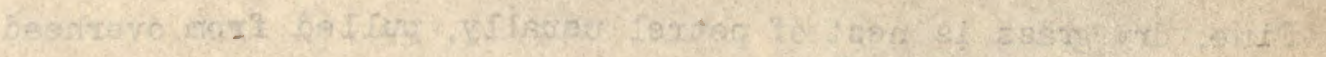

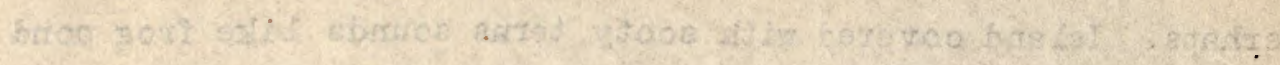

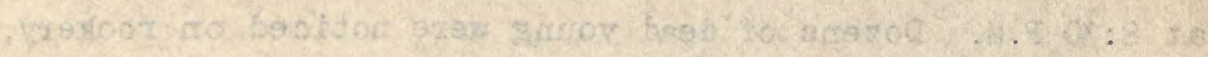

. Mros

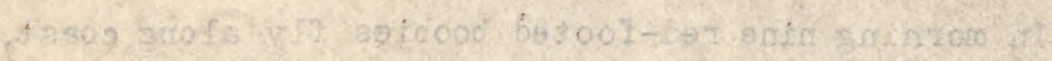

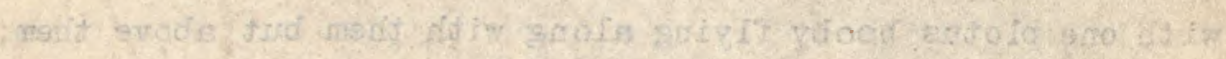

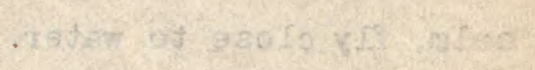

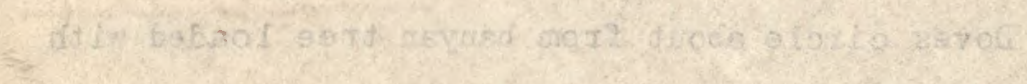

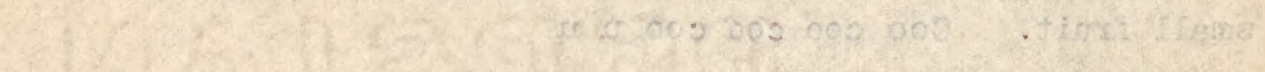

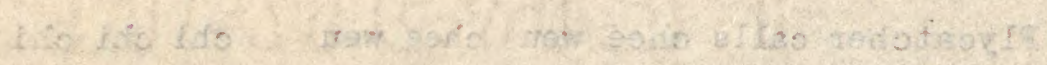

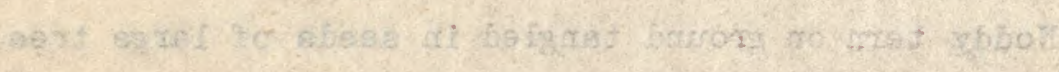

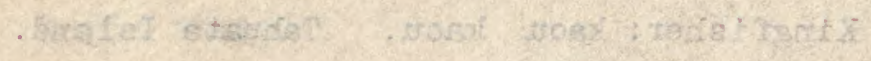

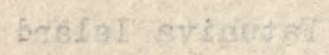

$$
\begin{aligned}
& \text {.t xevoragell }
\end{aligned}
$$

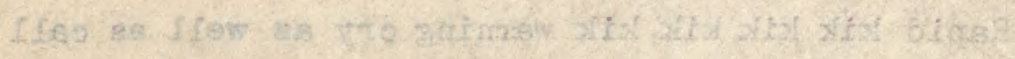

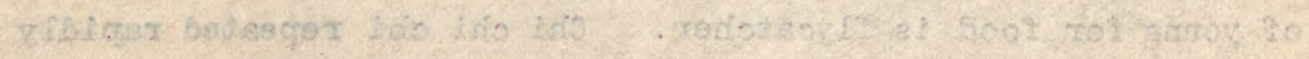

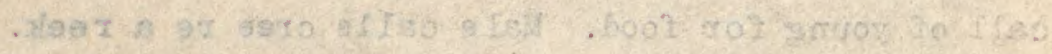

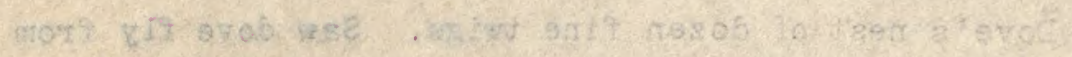

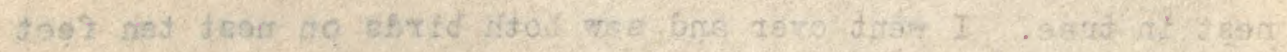

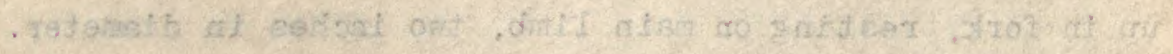

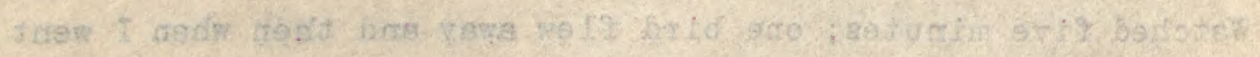

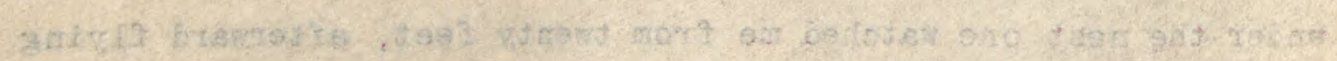

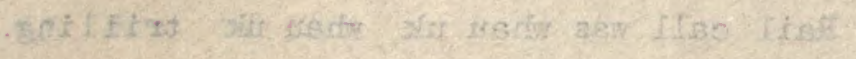

Trosiat atodet

. 3. rediss

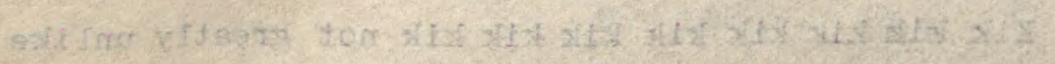




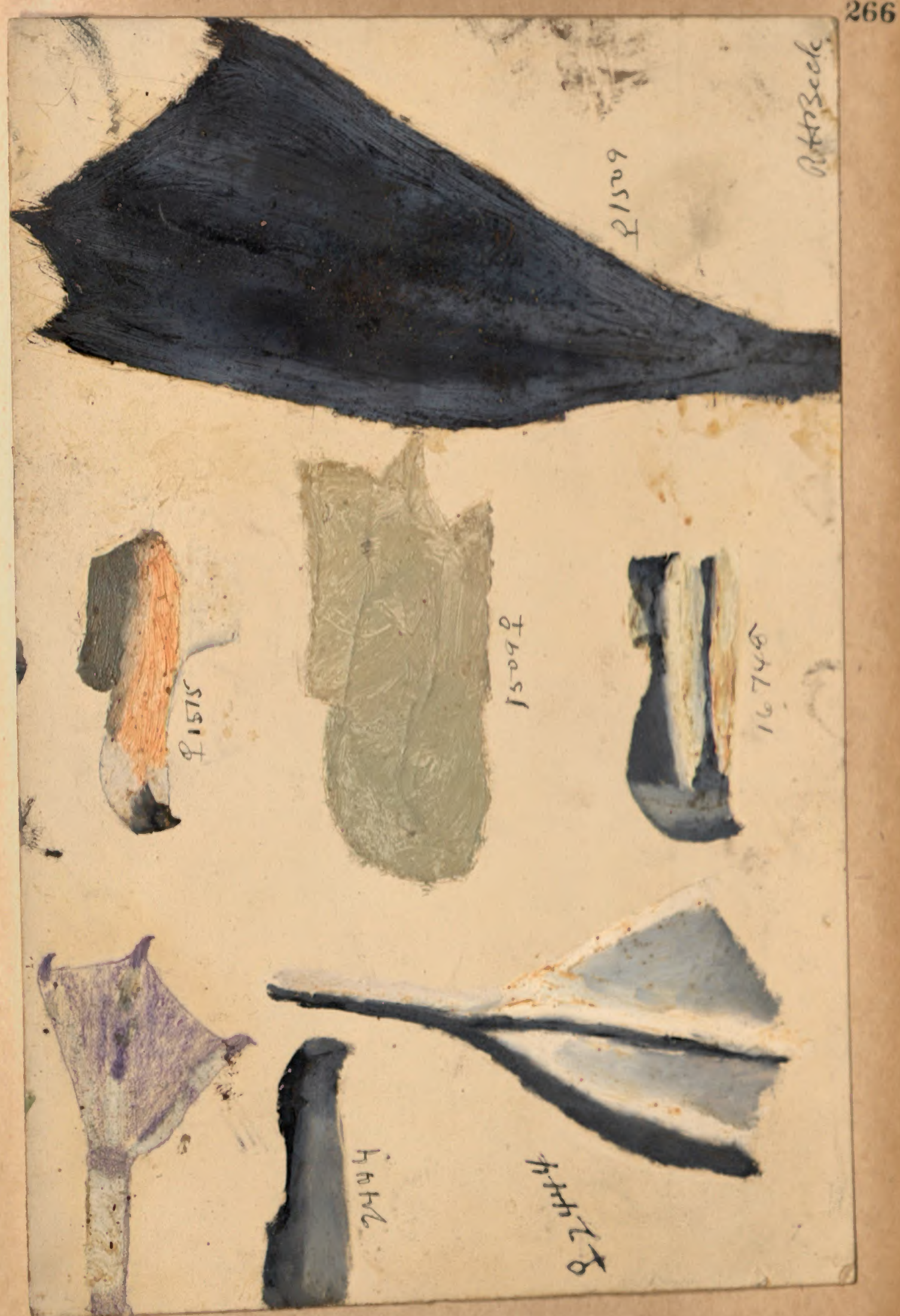




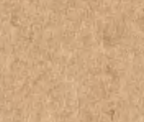

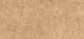


the California flicker is call of Henderson Island shearwater flying or sitting.

Tic kee ou ou ou like ou in you is call of neglected shearwater. Under trees on dead leaves eggs are laid. Birds walk well but not upright, waddle slightly. One walks out fifty feet or so to edge of trees and tries to take flight. It touched feet to ground but once lightly after springing into air. Light breeze to head into.

of twenty or so red-footed boobies nesting in trees fifteen feet up not one was white.

Fairy terns were nesting on trees and one young seen. Neglected shearwater dozed six feet from me. Gray tern called cremwww

Blue-faced booby called creeeeeeeeeeu

As a rule tarsus and upper toe were more pinkish on small shearwaters. Over dozen nests were in 60 foot radius. No big shearwaters in lot. Seven nests six feet apart. Fresh egg at base of tohunu tree was in nest of dead leaves and twigs. Cavak call of cuckoo Crok ok crok crok call of red-tailed tropic bird.

Rapa Island

February 15, 16, 1923.

Native names:

$\begin{array}{ll}\text { Rail tabuensis } & \text { Coto coto } \\ \text { Fairy tern } & \text { Taki taki } \\ \text { Petrel } & \text { Kome } \\ \text { Neglected shearwater } & \text { Kaea } \\ \text { Dove } & \text { Coco }\end{array}$

A rail's nest on islet $1 / 4$ mile off shore in tall

coarse grass on top of ridge. Hollowed out nest of dry leaves 


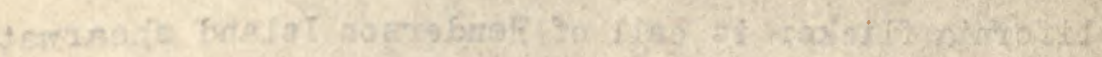

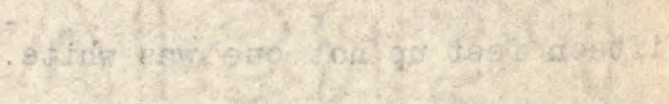

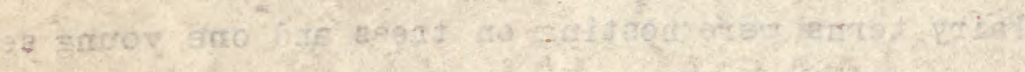

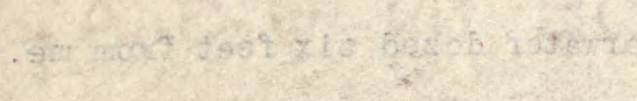

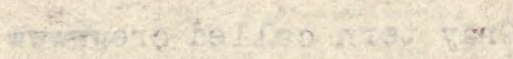

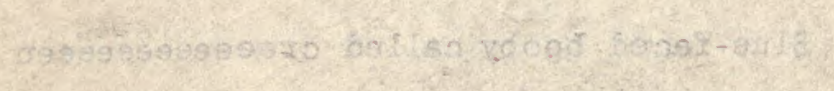

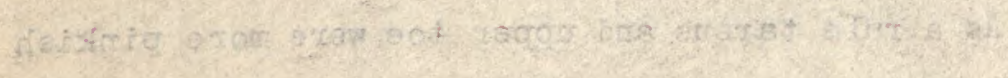

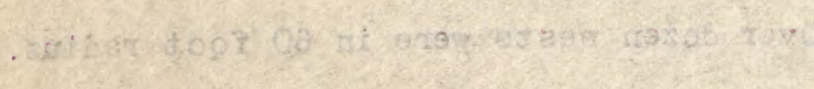

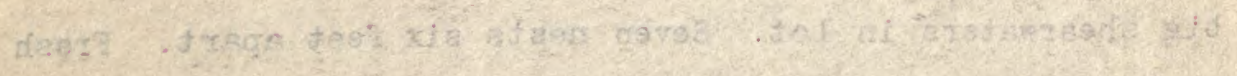

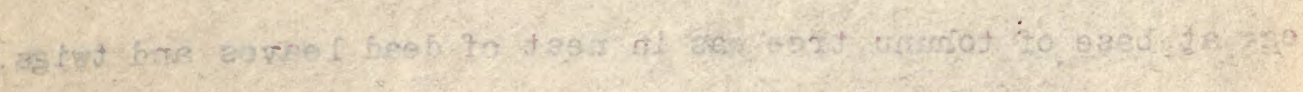

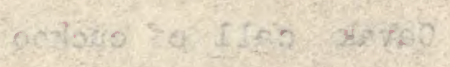

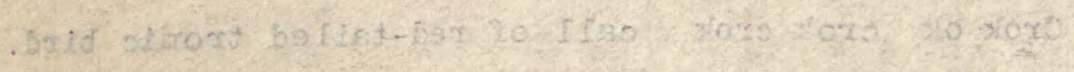

$$
\begin{aligned}
& \text { hiretal zest }
\end{aligned}
$$

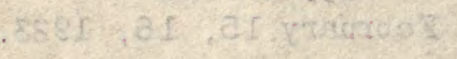

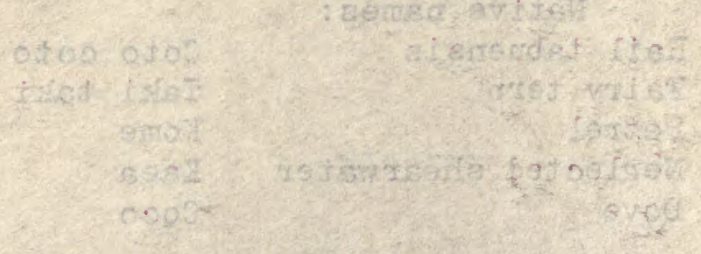

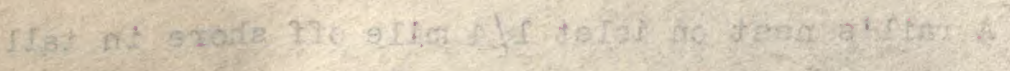

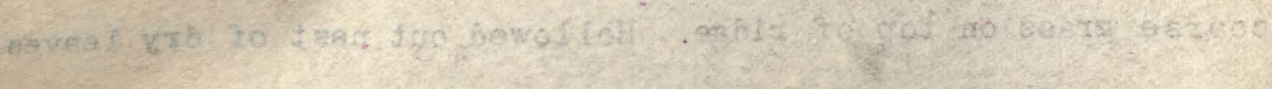




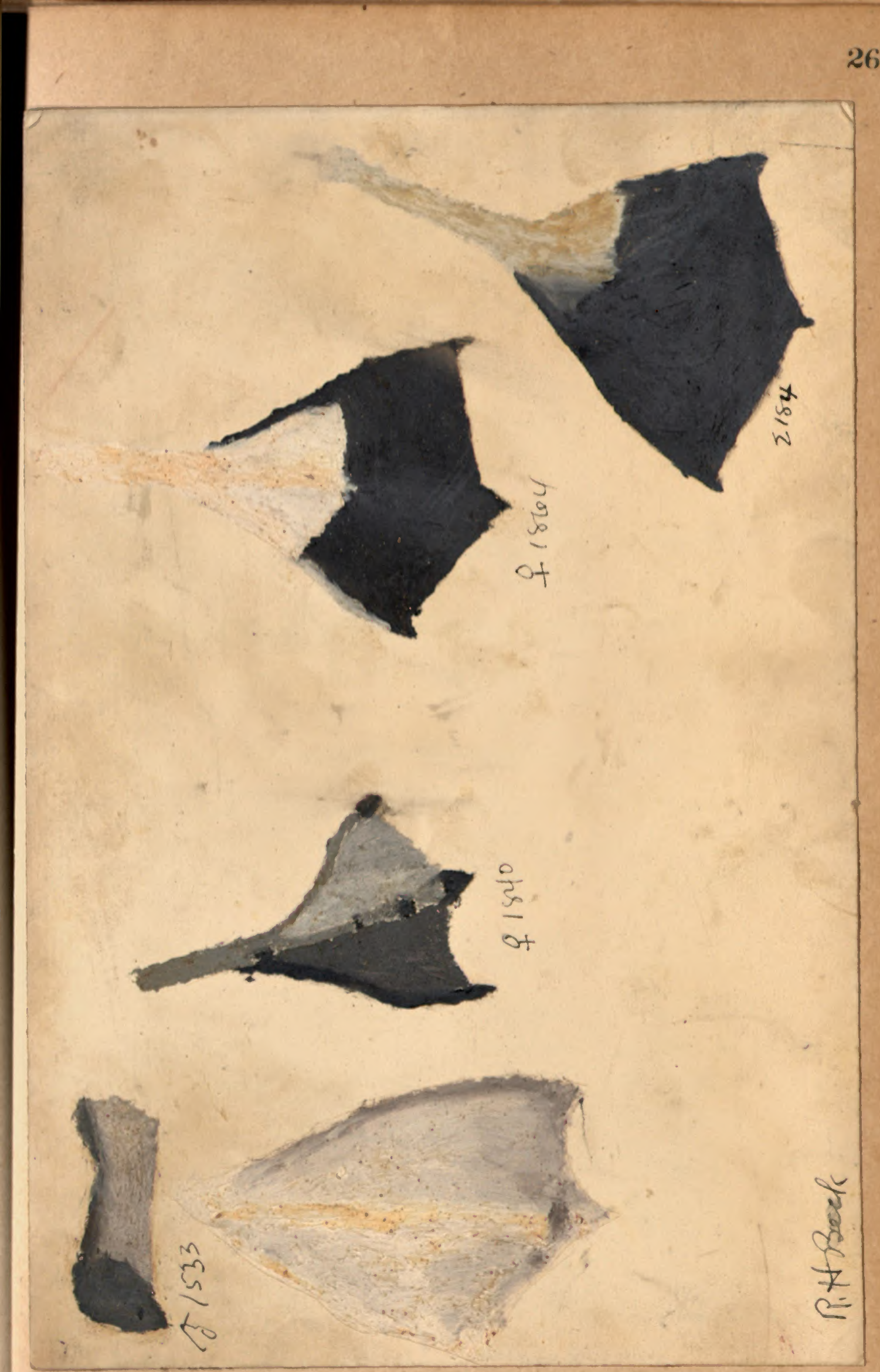



of the coarse grass, ten inches up in clump of grass.

Petrels nest under clump of grass on top of ridge, with rock just outside entrance to fly. from. Few dry leaves of $10 \mathrm{w}$ shrub in nest. Other nests under rocks.

Noddy terns, young, seen on cliffs of islet.

Boom boom is sound heard from pounders of poipoi at dark on the 22nd, as I hunt rail and listen to shearwaters sailing along cliffs.

\section{February 23.}

Weeeo0000, long drawn out, is call of neglected shearwater circling cliffs of Rapa Island. A pigeon comes flying along fifty yards below me. I drop pencil, grab gun, and drop pigeon. A little gray tern beats its way along the high cliffs to windward, as fairy terns circle over the bananas and clumps of tree ferns in the sheltered cañon.

\section{Girls in taro with torn dresses pull weeds and taro} at same time; wrap the taro in bags fashioned of grass, and carry on back over ridge and along shore to homes. The poipoi makers pound poipoi, smashing root with one pound. Women pick panful of small clams at water's edge and eat them instead of poipoi. Small boys rig canoes with sails since seeing our Fanfan work with sail. Roots are pulled from taro before being thrown onto levee. Water grass is pulled by roots. Taro plants are a foot apart and have six or eight leave like a lily; in muddy water one or two inches deep. Ducks alight in taro beds and. nest in ferns on hillside. Beds are terraced even to tops of hills. Girls pick a little long grass to form a sack and tie 



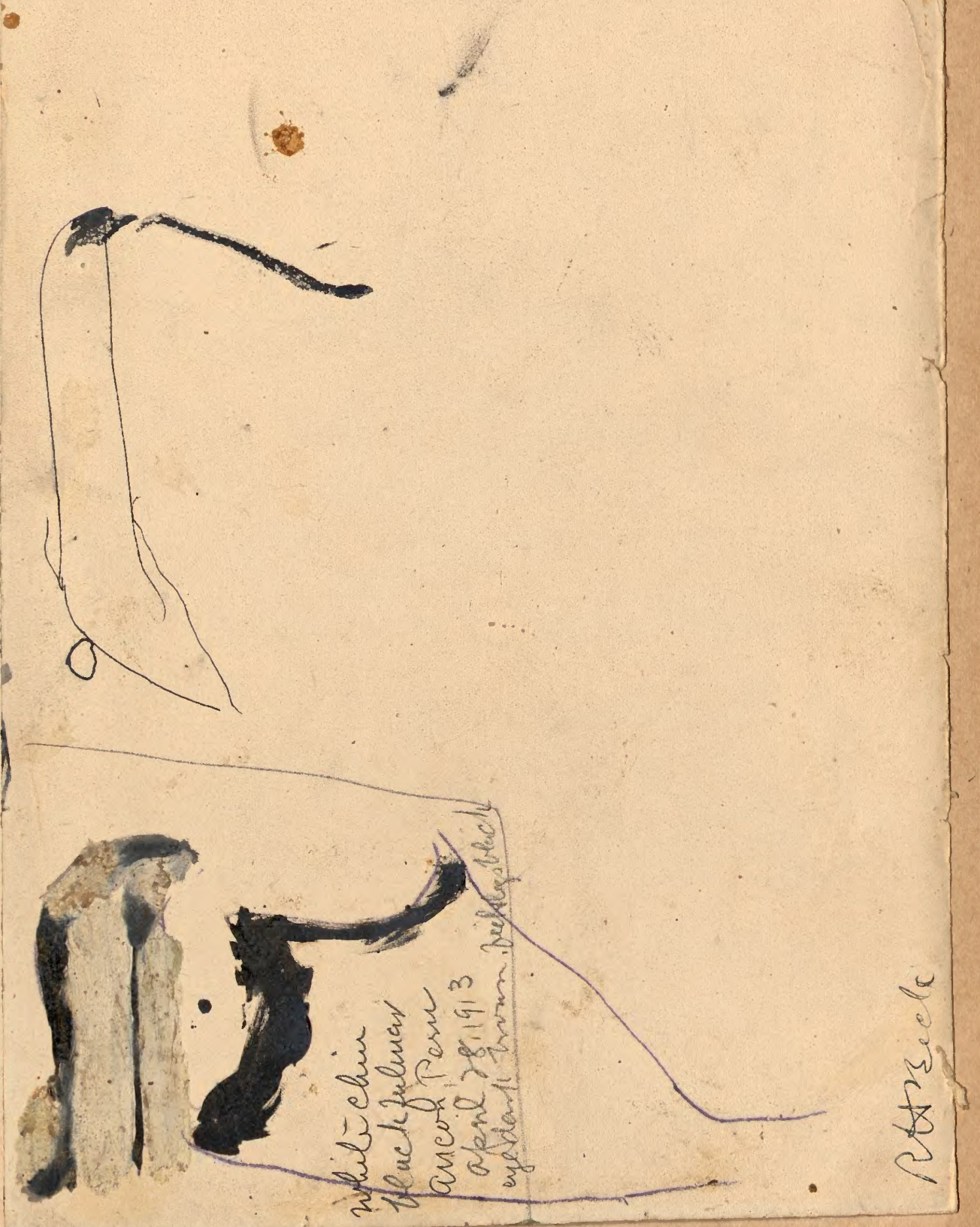




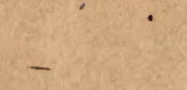


one end, spreading out top to hold taro roots. They break into song sometimes and laugh wholeheartedly at little jokes: They tie tops of grass sacks with long grass stems. Boys come along at dark with bunches of dry grass for burning and sing finely in unison. Fishing boats in good weather go outside bay in morning at 6 a.m. Bananas grow around taro beds in places.

\section{Manihi Island, Tuamotus \\ February 16.}

Fairy tern call: cauk cauk. Lesser noddy tern: crrrk crrrk; they sit in trees, some by nest or in it.

Dove nest ten feet up on shrub with red abd black berries just under dead coconut limb; bird cooed on nest while I stood twelve feet away; moved in nest to arrange twigs and tuck twig in nest; then flew in other direction.

\section{Iunatus tern: cavikavik cavacavaca}

Yellowbill tern nest just above highwater mark by small box, two eggs. Two other nests two feet apart on coral strand, with washed up coconut husks strung along shore. One egg on rocky, wind-swept coral beach; few coral pebbles placed by bird for 1 ining.

Fakarava Island April 20.

Plotus booby nest of few grass stems, pandanus leaves, and coconut husks on small motu near bushes in open. Another $1 / 2$ on islet grass and few small sticks. Nest $11 / 2$ feet wide. three other single eggs in fresh nests. Twenty birds on islet 30 yards by 50 yards in extent. 


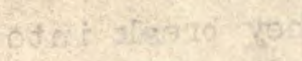

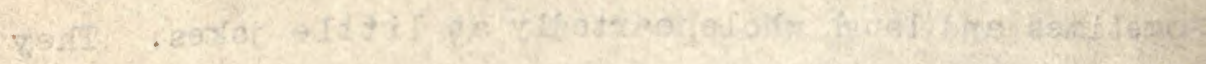

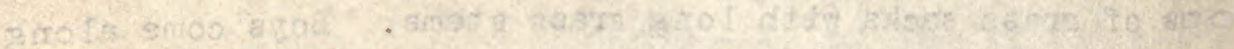

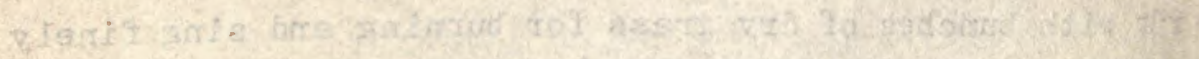

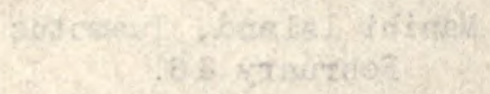

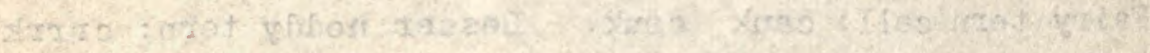

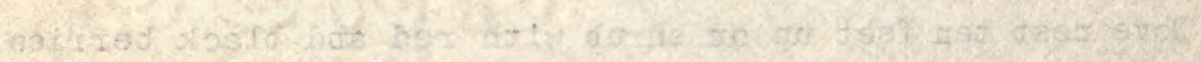

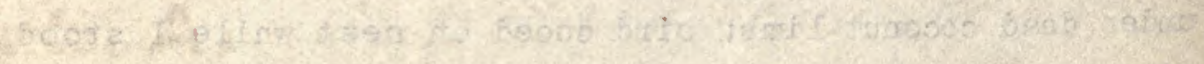

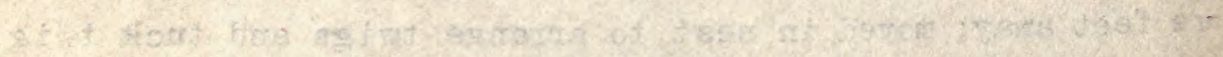

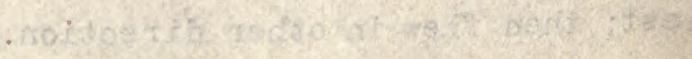

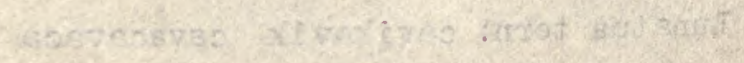

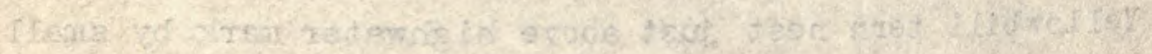

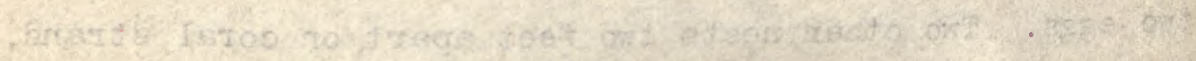

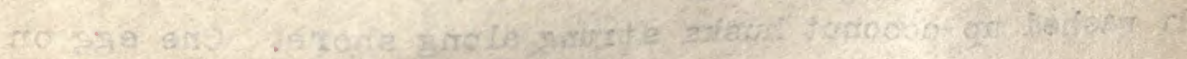

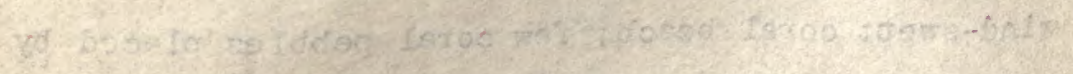

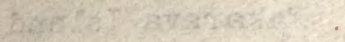

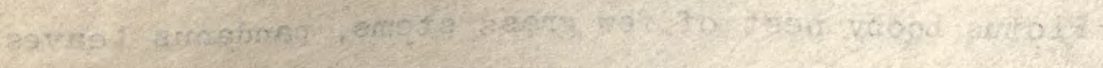

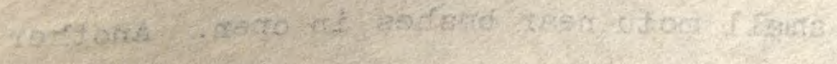

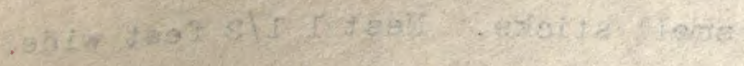

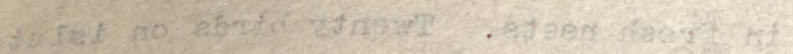




$$
1
$$


( 
Hiti Island

May 5.

Standing under mickymicky tree with camera set for lesser frigates while birds soar over and across again and again. I wait twenty minutes, then as I get ready to quit they suddely drop over nests and I pull slide and away they go.

A dove nest four feet up in mikymiky tree or bush on beach near boobies and frigates. Fossibly got out on beach to get away from rats which climb about in the thickets. A bird on but wild. Another nest was only two feet above the ground or sandy beach, incubated egg; about thirty twigs comprise nest.

\section{Tuahane Island} April 3 .

A dove in a mikymiky tree on nest allowed me to lift her off her young and look at it. She struck me several times with her wing. I rubbed and felt her wing a couple of times also. Drizzly rain. Red-footed booby nests in potea potea trees ten to twenty feet up; well built nests. Some with eggs, and some not laid in yet. Four or five nests in seve trees, some close to shore. Kick kick kick, rapid calls of red-footed booby as ready to light. Crau crau, when on nest. Frigates flying over nest call tick tick tick. Roa, name of bush that furhishes berries for doves. Kuk kuk kuk kuk, call of male frigate as it nears nest to light. Two young frigate birds in nest over booby nests. Five booby nests within ten feet of frigate bird nest, built after the frigate nest was. Many old sticks under nests; used nests seem to be of entirely new twigs. 




$$
-8-
$$

\section{Kauehi Island}

May 30.

A fairy tern nest was two feet above ground on tohunu stumo against small limb; bird on nest. Yellow-billed terns : nests in coconut, husks for lining, above high water near where we got five eges in March. Two young nearly ready to fly and six incubated eggs. Blue ternlet nest of small bits of coral and broken shells on top of big coral rock on reef. Five feet above reef. Several birds.

\section{Apataki Island}

June 8 .

Yellow-billed tern nests in depression and other in no depression alongside coral floor in sand, usually 200 yards from reef and 300 yards from lagoon. Eight eggs here and two others farther along, as natives evidently disturbed first nesting place. Two nests $11 / 2$ feet from the other, though plenty of good spots anywhere in forty feet or more. Birds leave the vicinity in few minutes. Fly over and circle long time before alighting.

June 9.

To cavaca colony and find young birds flying; good looking rail country but no birds seen. Vinis not uncommon. Warblers common. Few yellow-billed terns, young, ready to fly and most fly a few yards. Few fresh eggs found but nothing between them and the flying young. Young ones walk out to rocks on inner side reef and sit there. Few fly back and forth. 


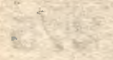

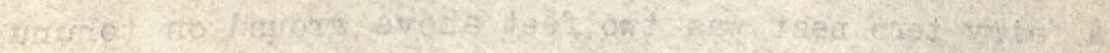

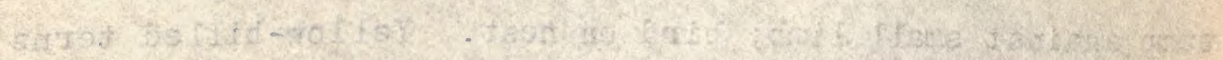

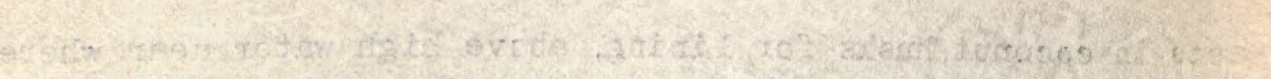

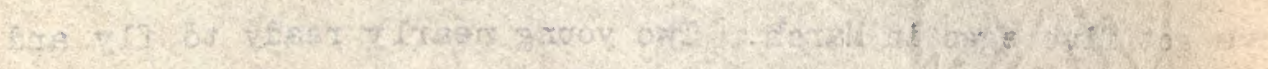

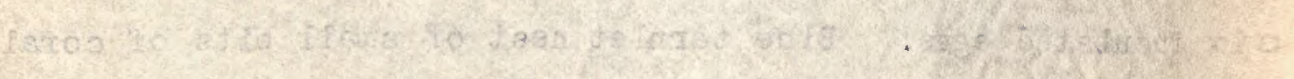

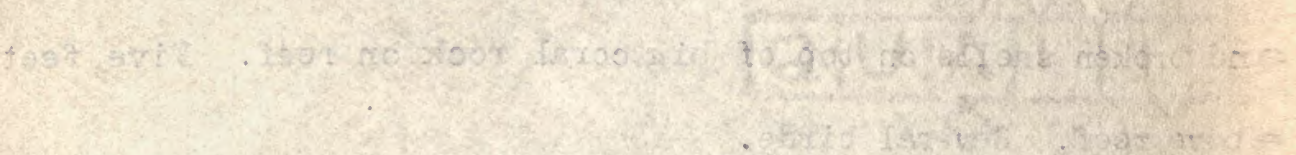

$$
\text { 4. }
$$

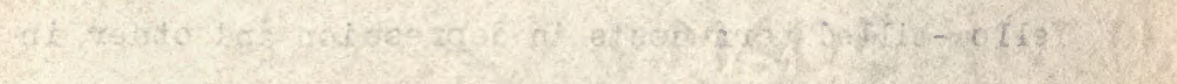

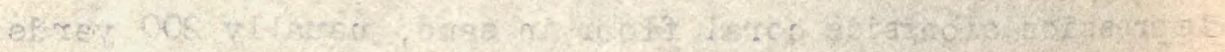

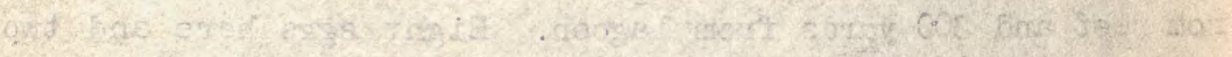

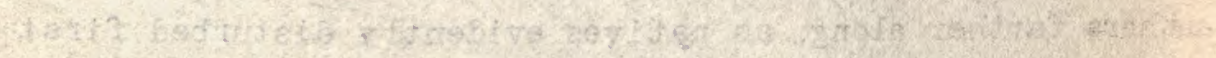

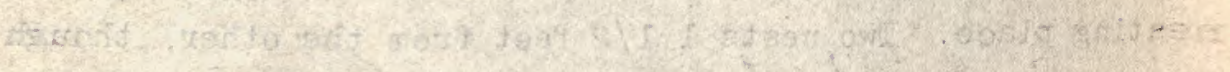

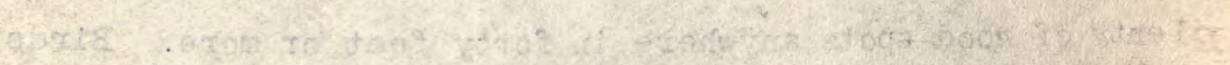

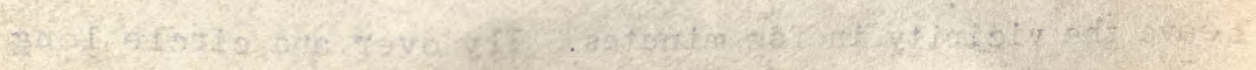

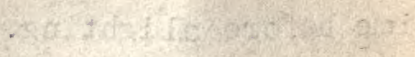

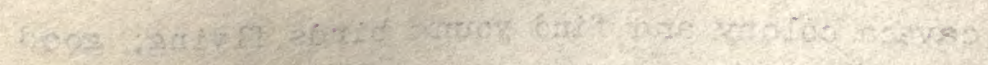

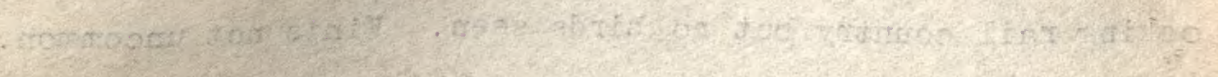

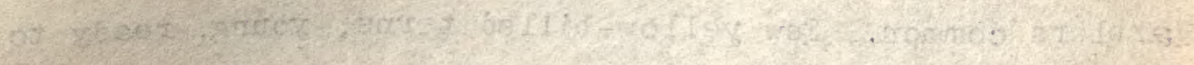

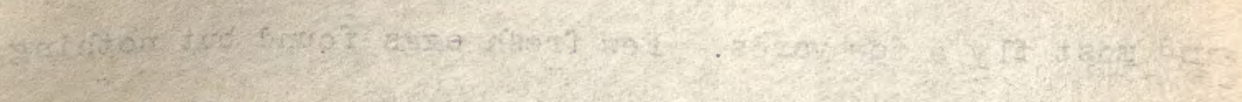

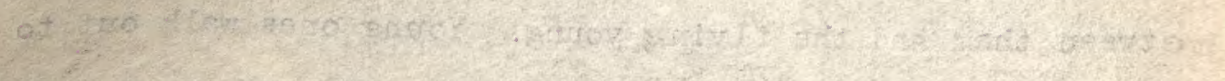

Ditrog bera 










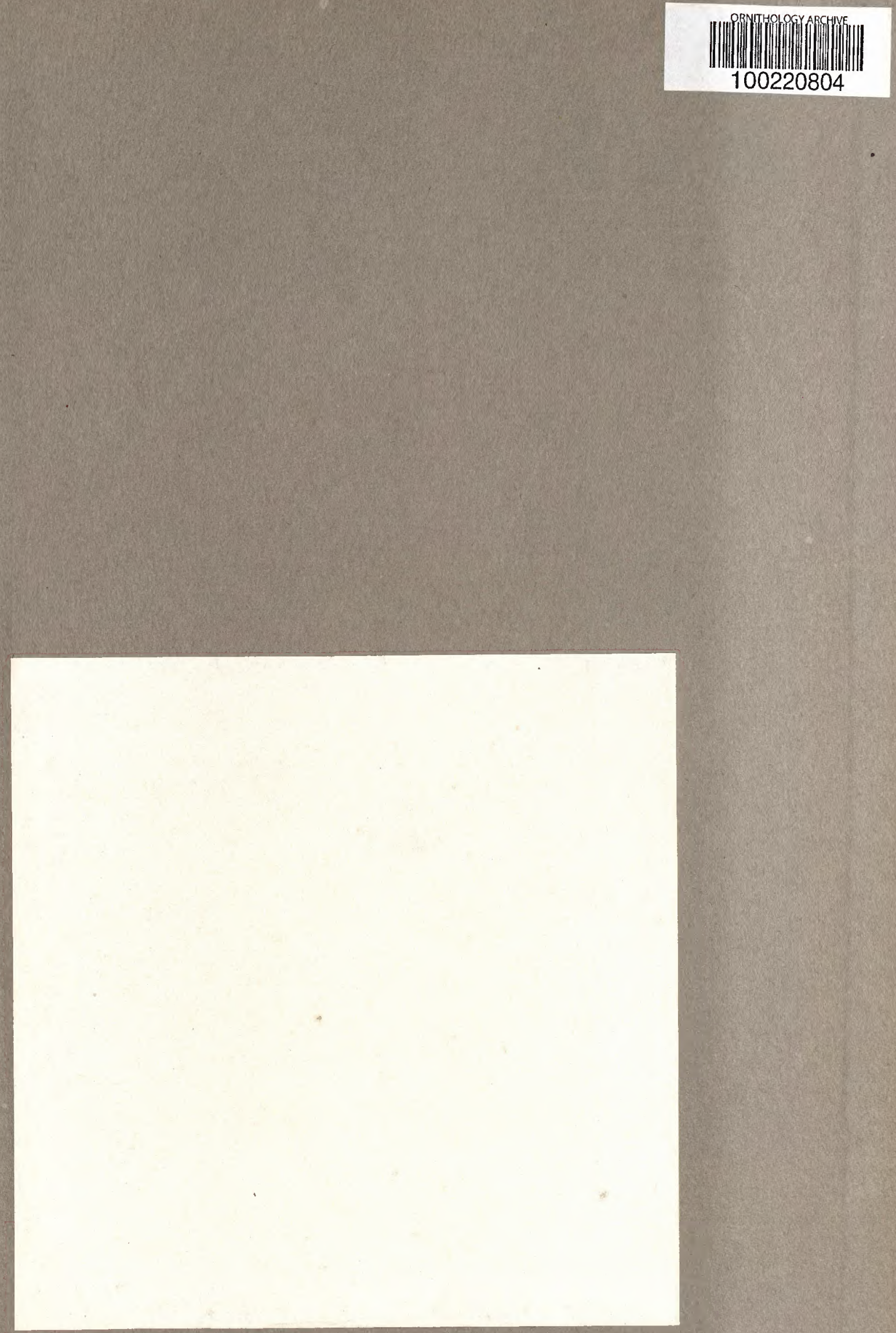


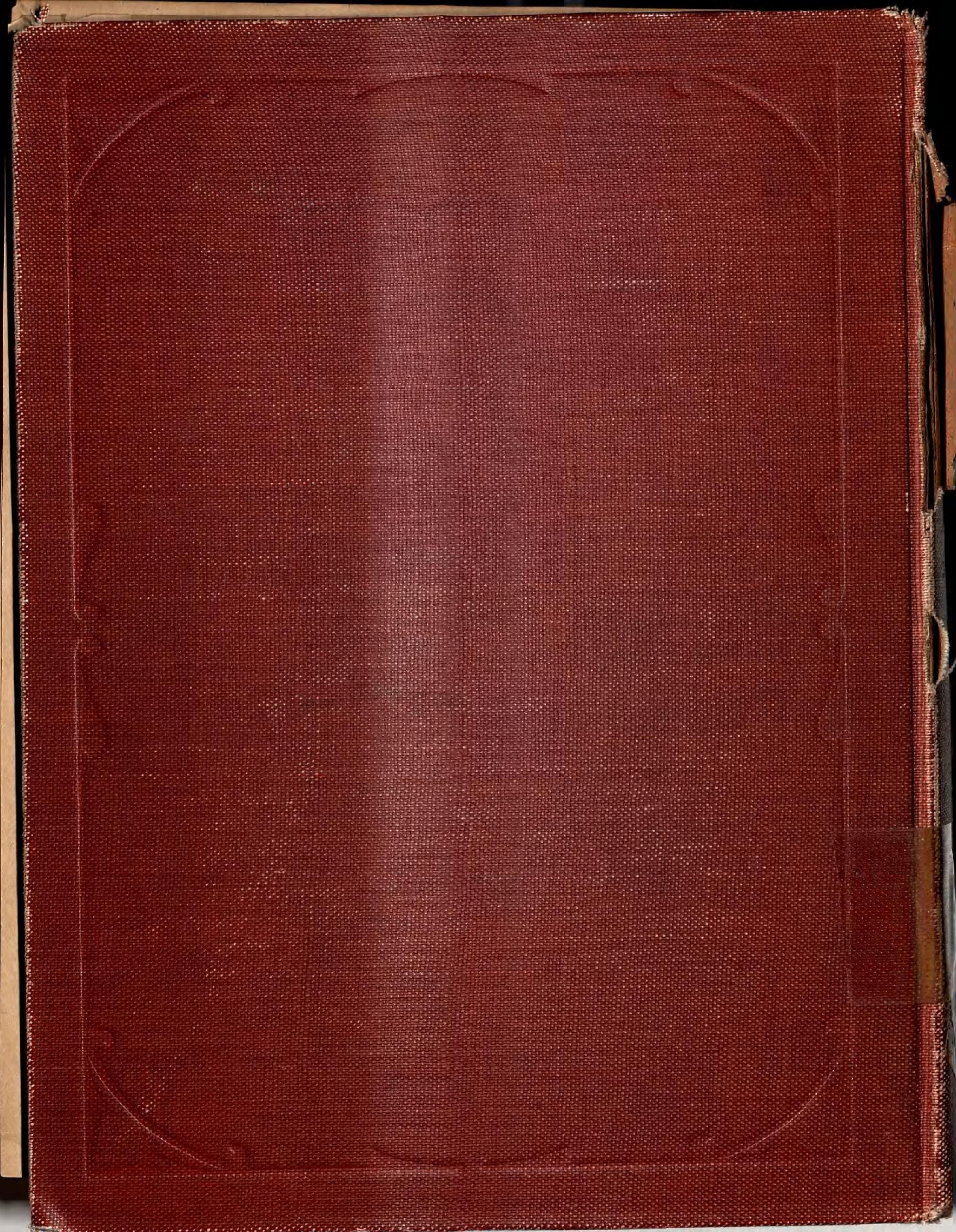

